UNIVERSIDADE DE SÃO PAULO

FACULDADE DE FILOSOFIA, LETRAS E CIÊNCIAS HUMANAS DEPARTAMENTO DE ANTROPOLOGIA

PROGRAMA DE PÓS-GRADUAÇÃo EM ANTROPOLOGIA SOCIAL

\title{
CAMILA AYA ISCHIDA
}

A EXPERIÊNCIA NIKKEI NO BRASIL:

UMA ETNOGRAFIA SOBRE IMAGINÁRIOS E IDENTIDADES

SÃo PAULO

2010 
UNIVERSIDADE DE SÃO PAULO

FACULDADE DE FILOSOFIA, LETRAS E CIÊNCIAS HUMANAS

DEPARTAMENTO DE ANTROPOLOGIA

PROGRAMA DE PÓS-GRADUAÇÃO EM ANTROPOLOGIA SOCIAL

A EXPERIÊNCIA NIKKEI NO BRASIL:

UMA ETNOGRAFIA SOBRE IMAGINÁRIOS E IDENTIDADES

\section{CAMILA AYA ISCHIDA}

Dissertação apresentada ao Programa de Pós- Graduação em Antropologia Social do Departamento de Antropologia da Faculdade de Filosofia, Letras e Ciências Humanas da Universidade de São Paulo, para a obtenção do título de Mestre em Antropologia.

Orientador: Profa. Dra. Rose Satiko Gitirana Hikiji. 


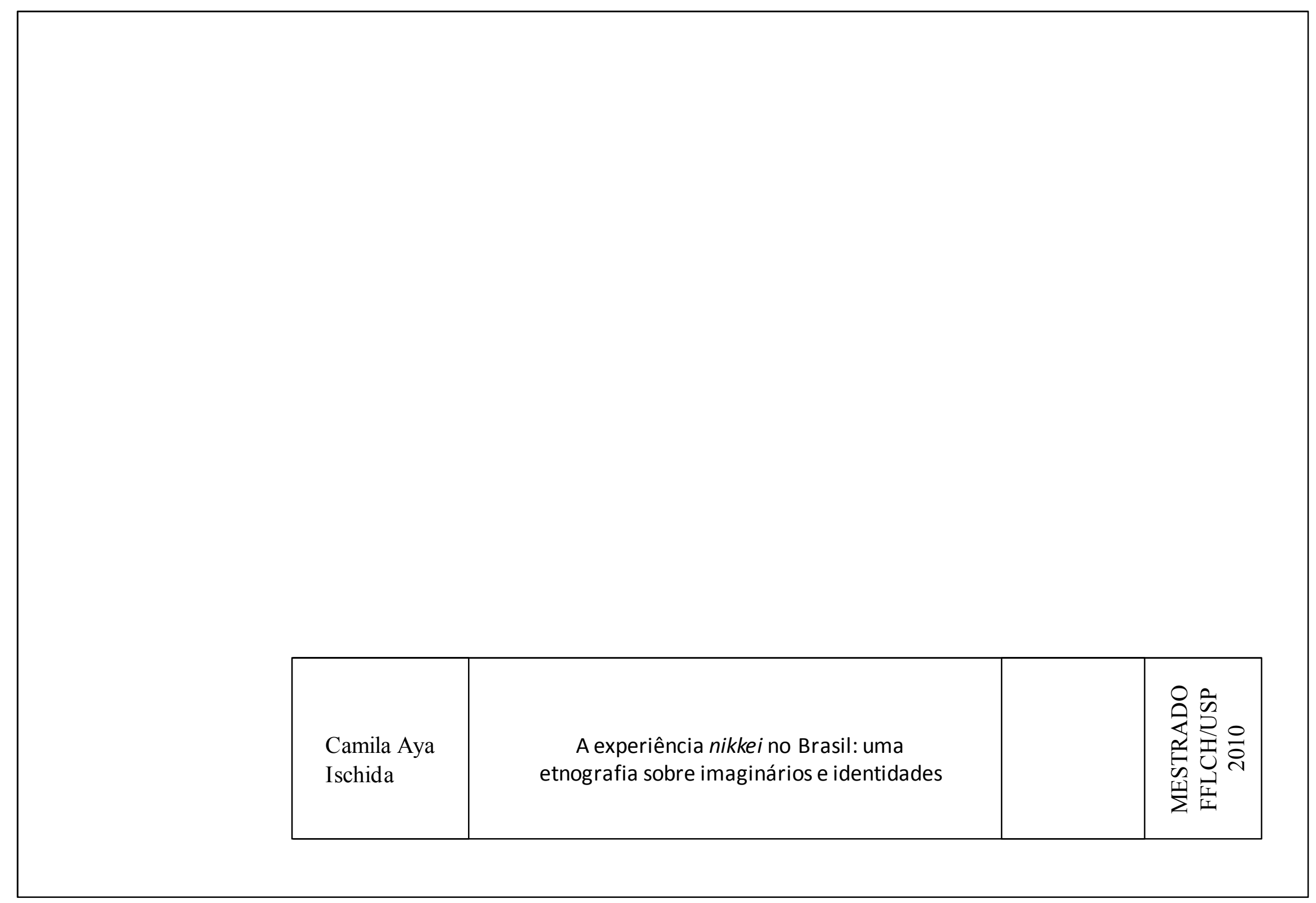




\section{CAMILA AYA ISCHIDA}

\section{A EXPERIÊNCIA NIKKEI NO BRASIL: UMA ETNOGRAFIA SOBRE IMAGINÁRIOS E IDENTIDADES}

Dissertação apresentada ao Programa de Pós-Graduação em Antropologia Social da Universidade De São Paulo, como parte dos requisitos para obtenção do título de mestre em Antropologia.

\section{BANCA EXAMINADORA}

Orientador:

Profa. Dra. Rose Satiko Gitirana Hikiji

$1^{\circ}$. Titular:

Profa. Dra. Lilia Katri Moritz Schwarcz

$2^{\circ}$. Titular:

Profa. Dra. Célia Sakurai

24 de novembro de 2010 
Aos meus avós,

Kazuto Ishida e Ritsuko Ishida, Shizuo Nishikawa e Yahoko Nishikawa, também escritores dessa história 


\section{AGRADECIMENTOS}

Gostaria primeiramente de agradecer à FAPESP, Fundação de Amparo à Pesquisa do Estado de São Paulo, pela concessão da bolsa de mestrado, suporte imprescindível para o desenvolvimento da pesquisa e para o financiamento das viagens a campo.

À minha orientadora, Profa. Dra. Rose Satiko G. Hikiji, primeiramente pela confiança depositada nessa pesquisadora aspirante, egressa do interior do Paraná, e em segundo, pela generosidade. Sua leitura sensível e o incentivo sempre constante foram fundamentais para a produção do trabalho.

Aos professores Jeffrey Lesser, historiador-antropólogo, e Lilia Moritz Schwarcz, antropóloga-historiadora, pela participação no exame de qualificação. Seus comentários, críticas e sugestões foram muito valiosos para o resultado obtido nesta dissertação.

Aos professores, colegas e funcionários da Universidade de São Paulo e ao grupo de orientandos da Rose - Magda, Alexandre, Ewelter, Fábio, Victor e Diana - obrigada pela força! Aos docentes da Universidade Estadual de Maringá, especialmente à Profa. Dra. Eide S. Azevedo Abreu e Prof. Dr. Sidnei Munhoz, grandes mestres que me guiaram nos primeiros passos da pesquisa acadêmica. Às minhas amigas, Dweyme, Cynara, Andréa, Michelle, Paula e Magda, obrigada pelos conselhos e amizade.

À minha família, os Ishida e os Nishikawa, que sempre me apoiaram. A toda família Onishi que gentilmente me "acolheu" aqui em São Paulo, especialmente aos meus tios, Flora Nishikawa Onishi e Oswaldo T. Onishi. O apoio de ambos foi muito importante, acompanhandome em todos os passos desta empreitada, desde o processo seletivo para o mestrado até a entrega desta dissertação.

Aos meus pais, Claudiner e Cecília, e aos meus irmãos, César e Cariston, pelo amor e apoio incondicional e irrestrito a todas as decisões e escolhas que fiz. Sem vocês, nada disso seria possível. E a Renato Onishi, meu companheiro de todas as horas, pelo amor, dedicação e paciência com que dividiu comigo todos os momentos dessa pesquisa.

E, finalmente, a todos os meus interlocutores que cederam seu tempo e partilharam comigo suas histórias e seus dramas, grandes protagonistas dessa "experiência nikkei no Brasil”". 


\section{RESUMO}

Comemorado o centenário da imigração japonesa no Brasil, no ano de 2008, em que termos é possível pensar a identidade nikkei? Na conjuntura social atual, esses descendentes são antes de tudo pessoas que mesmo possuindo um ancestral comum e a marca fisionômica peculiar, carregam experiências diversas no convívio e no embate com a alteridade. Não obstante assumir esse pressuposto, a hipótese que norteia a pesquisa é a de que um imaginário que associa os japoneses e seus descendentes a um ethos ligado à honestidade e ao esforço no trabalho e nos estudos foi sendo gradualmente forjado ao longo do tempo. $\mathrm{O}$ objetivo da pesquisa é investigar os processos de identificação de sujeitos nikkeis com esse imaginário, em outras palavras, buscar entender como identidades se constroem por meio da ressignificação do mesmo. O trabalho de campo foi orientado por entrevistas com descendentes de japoneses, moradores das cidades de São Paulo-SP, Maringá-PR e Astorga-PR, de diferentes perfis no que diz respeito à faixa etária, gênero, classes sociais e gerações. Metodologicamente não esteve pautado na busca por uma amostragem representativa da "comunidade nikkei" no Brasil, mas ancorado em explorar diferentes pontos de vista, biografias e narrativas. Em meio à multiplicidade das trajetórias, que elementos costuram as histórias e reflexões dos atores? Para além da esfera imaginário-discursiva, o trabalho de campo revelou também que discursos identitários podem ser modulados a partir do agenciamento de um repertório de "valores", símbolos e códigos que os nikkeis atribuem e que são atribuídos à "cultura japonesa". "Raça" e "colônia/comunidade" japonesas também foram categorias acionadas pelos interlocutores e uma breve incursão nessa questão foi realizada. A partir da perspectiva etnográfica, o objetivo consiste em mostrar como esse conjunto de valores, imagens, representações, estereótipos é conferido e auto-conferido ao nikkei e como é tematizado e vivenciado pelos sujeitos dessa pesquisa.

Palavras-chave: imaginário, nikkei, experiência, identificações, "cultura japonesa” 


\begin{abstract}
After the celebration of the Japanese immigration centenary in Brazil in 2008, how it is possible to conceive the nikkei identity? At the current social context, these Japanese-Brazilians are after all individuals who despite having the common ancestor and the peculiar physiognomic marker, they have different experiences in the relationship with alterity. Even considering this assumption, the hypothesis of this research is that an imaginary that associates the Japanese and Japanese-Brazilians with an ethos of honesty and discipline at work and studies has been gradually forged. The aim of this research is to investigate the identification process of the nikkeis (Japanese-Brazilians) with this imaginary, in other words, it intends comprehend how identities are built through the reception/rethinking of it. The fieldwork was based on interviews with Japanese-Brazilians who live at Maringá and Astorga, at Paraná State and São Paulo, capital, individuals with different profiles regarding to ages, gender, social classes and generations. Methodologically, it was not focused on searching a representative sample of the nikkei community in Brazil, but based on exploring different views, biographies and narratives. Among the multiplicities of trajectories, what elements articulate the actors' histories and reflexions? Beyond the imaginary-discursive universe, the fieldwork also revealed that identitary discourses can be built through the agency of values, symbols and codes repertory, which the nikkeis attribute to "Japanese culture". "Race" and "Japanese colony/community" also were categories used by the interlocutors and a brief approach in this issue was done. Through the ethnographic perspective, the aim consists in demonstrate how this arrangement of values, images, representations, stereotypes is perceived by the subjects of this research.
\end{abstract}

Key-Words: imaginary, Japanese-Brazilians, experiences, identifications, “Japanese culture”. 


\section{LISTA DE TABELAS}

Tabela 1 - Distribuição da população nikkei absoluta no Brasil ............................................................ 24

Tabela 2 - Cartograma: Distribuição da população nikkei no Brasil .................................................. 30

Tabela 3 - Porcentagem da produção agrícola japonesa no Estado de São Paulo .......................... 39

Tabela 4 - IDH do Brasil e grandes regiões desagregados por grupos de raça/cor, 2000.......... 69

Tabela 5 - Índice de escolaridade PNAD .................................................................................................... 71

Tabela 6 - Índice de escolaridade PNAD ............................................................................................... 71

Tabela 7 - Índice de escolaridade PNAD .............................................................................................. 73

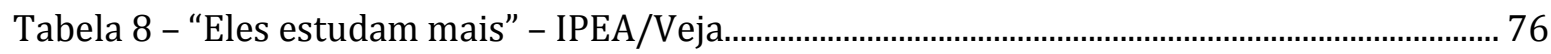

Tabela 9 - "Perfil psicológico" - Pesquisa Saito ………………................................................................. 92

\section{LISTA DE FIGURAS}

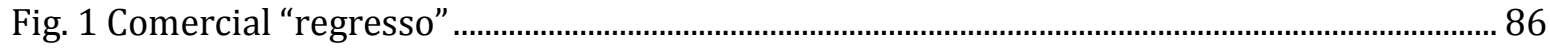

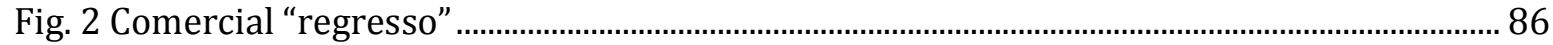

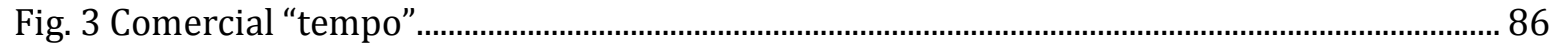

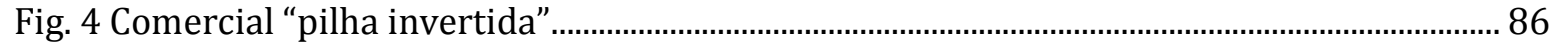

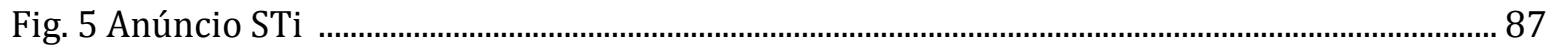

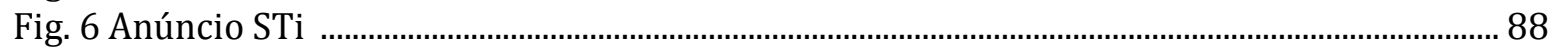

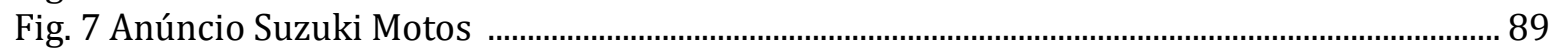

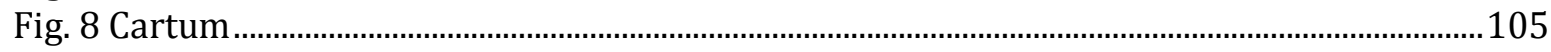

Fig. 9 Atriz Daniele Suzuki e sua personagem Yoko na novela Bang Bang ...................................112

Fig. 10 Miss Brasil e Miss Universo.......................................................................................................113

Fig. 11 Cirurgia de ocidentalização.....................................................................................................114

Fig. 12 Cirurgia de ocidentalização..............................................................................................114

Fig. 13 Miley Cyrus "puxando os olhos" ............................................................................................124

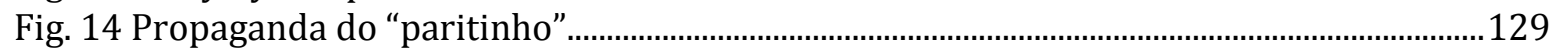

Fig. 15 Capa do CD de Lourenço \& Lourival.........................................................................................131

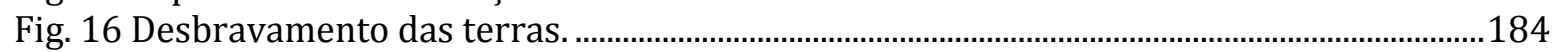

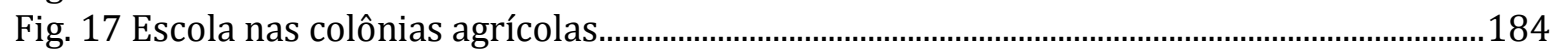

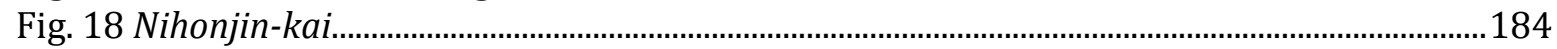

Fig. 19 Hasteamento das bandeiras..............................................................................................

Fig. 20 Início das atividades no undōkai........................................................................................192

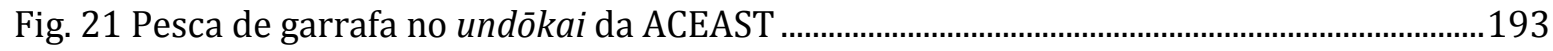

Fig. 22 Corrida de Guetá no undōkai da ACEAST ............................................................................193

Fig. 23 Voluntários fazendo sukiyaki no "chapão" ................................................................................194

Fig. 24 Apresentação do grupo de taikō da ACEAST …………….................................................194

Fig. 25 Bōnenkai na ACEAST ..................................................................................................................197

Fig. 26 Nomeação dos cargos de direção e do conselho da associação ...........................................197

Fig. 27 Mistura de sabores no bōnenkai da ACEAST: espetinho, strogonoff e nishimê ...............198

Fig. 28 Visão panorâmica do Festival Nipo-Brasileiro........................................................................199

Fig. 29 Apresentação de Bon-odori na "Nipo"..................................................................................20

Fig. 30 Cosplay do personagem Naruto …………….......................................................................213

Fig. 31 Jovens dançando o matsuri dance no Hoshi Matsuri em Maringá .......................................220

Fig. 32 Apresentação do Ryukyu Koku Matsuri Daiko ........................................................................221

Fig. 33 Vista da comemoração no Sambódromo do Anhembi ............................................................229

Fig. 34 Apresentação no Sambódromo com autoridades ao fundo..................................................2229

Fig. 35 Apresentação de bon-odori na festa do Imin-100 em Rolândia ............................................230

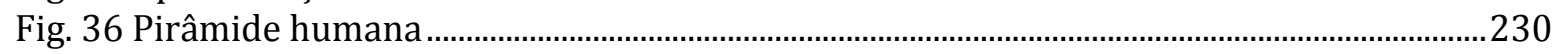

Fig. 37 Coral de mil vozes ................................................................................................................231 
Fig. 38 Capa da Revista Veja, edição 2038 …………………………………........................................232

Fig. 39 Edição especial das sandálias Havaianas em comemoração ao Centenário .....................232

Fig. 40 Desfile da Porto da Pedra com figura de Buda ao fundo........................................................232

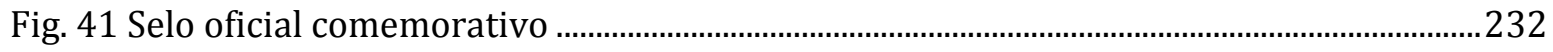

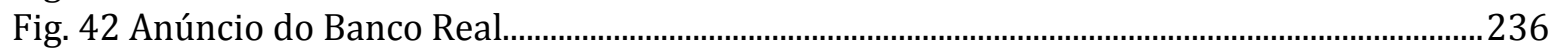

Fig. 43 Anúncio do Bradesco ......................................................................................................237 


\section{CAPÍTULO I}

UM OUTRO ORIENTALISMO? IMAGENS E DISCURSOS SOBRE O NIKKEI............................... 28

1.1 Sobre um encontro no supermercado....................................................................................... 29

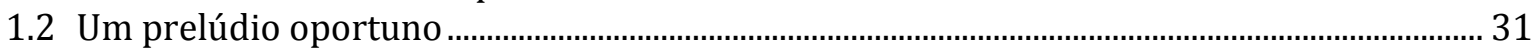

1.3 "Japonês não tem vergonha de trabalhar" ................................................................................ 35

1.4 "O respeito pela lei e pela ordem" e a produção de subjetividades .......................................... 45

1.5 Trabalho e honestidade: duas faces da mesma moeda? ............................................................... 53

1.6 "Eu vou lá, porque é japonês": o folclore................................................................................ 59

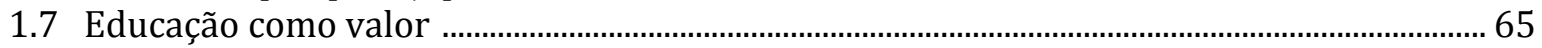

1.8 O outro lado da cobrança: "não se fazem mais japinhas como antigamente"........................ 77

1.9 "Os nossos japoneses são mais criativos que os japoneses dos outros" .................................. 80

1.10 Considerações finais .................................................................................................................. 90

\section{CAPÍTULO II}

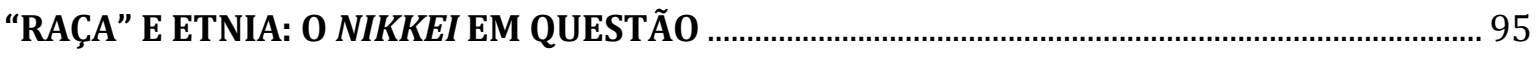

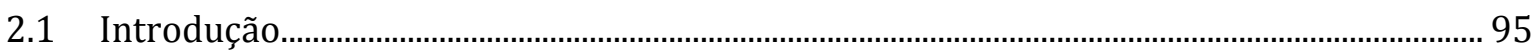

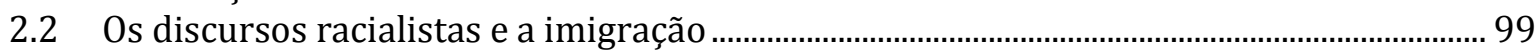

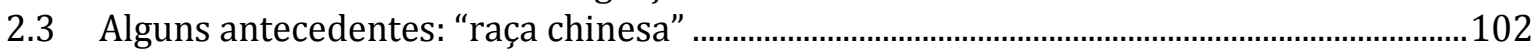

2.4 0 japonês como "imigrante indesejável" ....................................................................................103

2.5 Japonês: "O typo que está longe de se parecer com o modelo estabelecido pela santa madre... esthética!" ...................................................................................................................................110

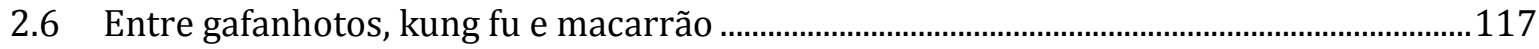

2.7 “Comê paritinho non é difícil, né?": ethnic humor? ..................................................................127

2.8 “Esse japonês tem nome!" ..........................................................................................................132

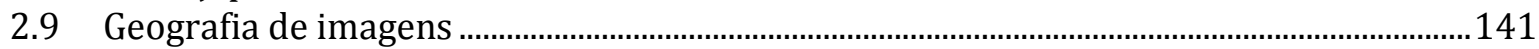

2.10 Provocações na infância .........................................................................................................144

2.11 "Raça japonesa": alguns apontamentos ......................................................................................154

\section{CAPÍTULO III}

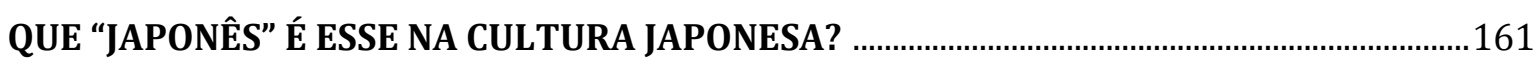

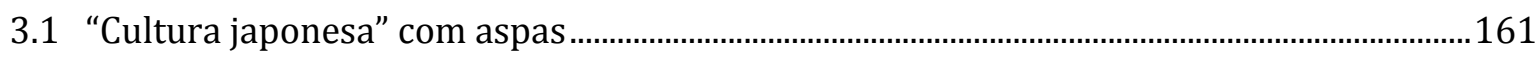

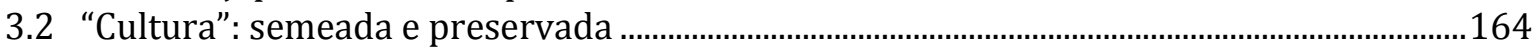

3.3 “Gambarê-nasai!" ......................................................................................................................... 166

3.4 "Cada geração tem seu tempo, cada geração tem seu momento. Não tem melhor, nem

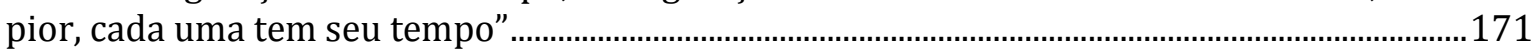

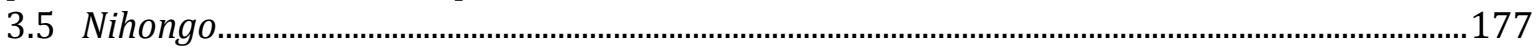

3.6 Sobre o "né?" ......................................................................................................................179

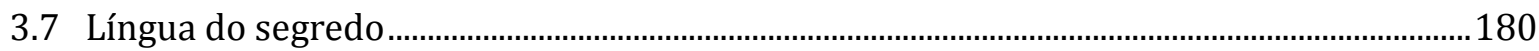

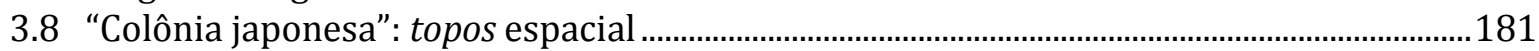


3.9 "Colônia japonesa/comunidade nikkei": topos discursivo .........................................................187

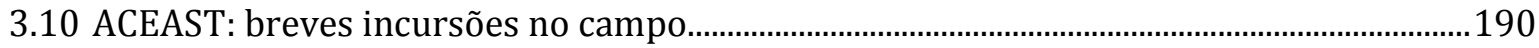

3.11 "Panelinhas" e um adendo: discursos sobre reserva e timidez...............................................200

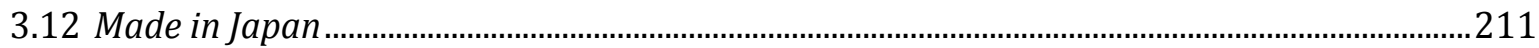

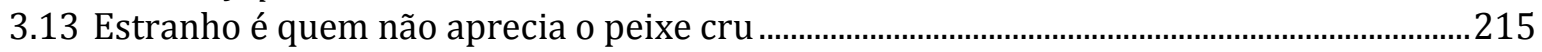

3.14 "Acho que virou moda ser japonês": o Japão é mesmo pop...................................................... 217

3.15 "Alguma coisa está acontecendo": "o resgate da cultura" ........................................................ 219

3.160 centenário da imigração japonesa no Brasil........................................................................... 228

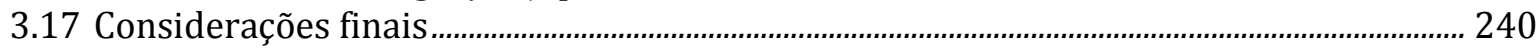

\section{CAPÍTULO IV}

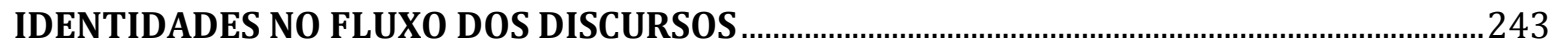

4.1 "A gente só percebe isso quando alguém fala"..................................................................................243

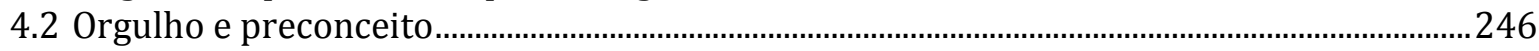

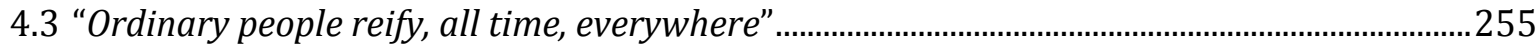

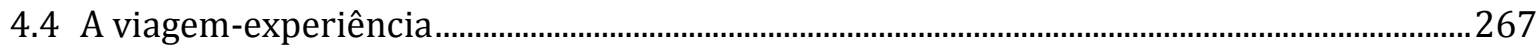

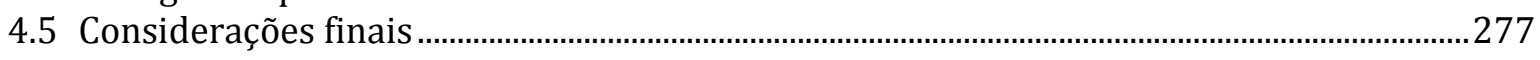

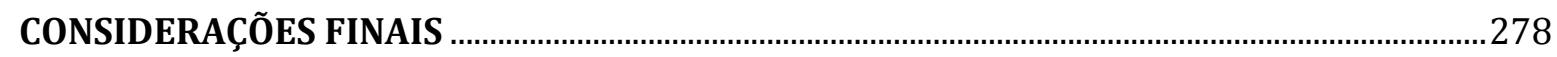

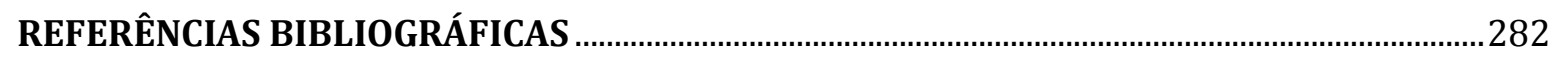

GLOSSÁRIO 


\section{INTRODUÇÃO}

\section{DIVAGAÇÕES EM TORNO DO NORI}

Peço licença para abrir a introdução deste trabalho com uma breve história sobre uma compra que fiz em uma loja de produtos japoneses em São Paulo. Como pesquisadora descendente de terceira geração, será possível observar ao longo do texto diversos parênteses, com relatos meus, que também ajudam a compor esse conjunto de experiências que diz respeito aos nikkeis ${ }^{1}$ no Brasil.

Certo dia, passava por um desses estabelecimentos comerciais hoje muito comuns na cidade de São Paulo: uma loja de produtos japoneses. Ofertando principalmente alimentos importados do Japão, essas lojas que, inicialmente se estabeleciam no bairro da Liberdade, ganharam as ruas da capital e de várias cidades do Brasil. Como eu estava com pressa nesse dia, rapidamente peguei um pacote de nori, sem me atentar para o rótulo em português no produto. Quando passei no caixa, perguntei ao senhor que me atendia se aquela alga era própria para fazer temaki ${ }^{2}$. O homem idoso, de origem nipônica, ficou na dúvida e dirigiu minha pergunta ao rapaz que estava em outro caixa, que aparentava ser seu filho. Diante da negativa, perguntei ao senhor qual era a finalidade da alga. O moço que deveria ter uns trinta anos ouviu e começou a explicar que aquele nori, o ajitsuke era servido como aperitivo e uma senhora cliente, também de origem japonesa, que se encontrava ao meu lado, comentou que seus netos adoravam quando o comiam junto com o gohan ${ }^{3}$. Já havia me recordado sobre a diferença entre as duas algas, quando o rapaz de repente disparou, com certo tom de desdém e surpresa: "Ué, mas você não é japonesa?!". Confesso que fiquei constrangida com a interpelação, dita em voz alta, e certamente ouvida por todas as pessoas na fila do caixa. No momento pensei: "Não, eu sou brasileira!”.

\footnotetext{
${ }^{1}$ A categoria analítica nikkei é uma abreviação do vocábulo japonês nikkeijin e significa "pessoas de origem japonesa, nascidas fora do Japão". Na presente pesquisa, esta será a terminologia adotada. No entanto, vale ressaltar que o senso comum e a própria categoria nativa se apropriam do termo "japonês" para se referirem aos descendentes. Uma análise sobre essas diferenças será empreendida posteriormente. Por ora, quando "japonês" estiver grafado com aspas, o termo refere-se aos descendentes de maneira geral, e quando estiver grafado sem aspas, refere-se aos japoneses nativos ou imigrantes nascidos no Japão. Atualmente, os nikkeis no Brasil compreendem os isseis (imigrantes, primeira geração), nisseis (segunda), sanseis (terceira), yonseis (quarta), gosseis (quinta), rokusseis (sexta) assim como os "mestiços” (filhos de pai ou mãe nikkei) e os dekasseguis (descendentes imigrantes residentes no Japão). Aproveito para esclarecer que neste trabalho não se buscou utilizar um padrão no emprego da forma romanizada dos termos japoneses. O rōmaji é o modo de representar a forma escrita da língua japonesa através do alfabeto latino. Algumas palavras estão grafadas de forma "aportuguesada" e em itálico, próxima à maneira como são apresentadas em escritos acadêmicos e jornalísticos, e podem estar convertidas para o plural, como por exemplo, "nikkeis".

${ }^{2}$ Temaki: espécie de sushi enrolado em formato de cone no nori, alga.

${ }^{3}$ Gohan: arroz branco.
} 
Talvez ele nem tivesse observado a quantidade de produtos japoneses que eu estava comprando junto com o ajitsuke nori: sembei, moyashi, guioza, umê, shimeji, manju e sushi. Talvez isso também nem fizesse diferença. Não era o bastante, eu precisava saber a finalidade do ajitsuke nori e a distinção com relação ao yaki nori, este próprio para o temaki. Afinal de contas, eu era "japonesa". Nada respondi ao caixa da loja, contudo sua interpelação ficara na minha cabeça. Esse episódio ilumina o problema central deste trabalho: uma das formas de se pensar a construção identitária pode ser via interpelações discursivas. Interpelações sobre "brasilidades", "japonesidades", "nikkeidades", seja lá quais forem. O indivíduo (re) cria e (re) constrói sua identidade no contexto que surge, ou melhor, a partir dos elementos dados pelo contexto. No processo reflexivo que se engendra, identificações são forjadas. Naquele momento preciso em que o caixa exclamou, “Ué, mas você não é japonesa?!", senti-me desnorteada em uma confusão de sentimentos - “eu sou brasileira, descendente de japoneses, teria eu 'obrigação' de conhecer o atijsuke nori?".

Todas essas divagações resumem a problemática deste trabalho. Em 2008, decorridos cem anos da primeira leva de imigrantes japoneses aportados em Santos no lendário navio Kasato Maru, como pensam e como se pensam os descendentes de japoneses no Brasil? É possível falarmos em grupo étnico? Em que termos podemos falar em identidade nikkei? Sobre a segunda questão, cabe ressaltar que considerar os nikkeis como constitutivos de um grupo étnico é uma premissa que se mostra consonante com a de muitos pesquisadores dos chamados "estudos japoneses" 4 . Antes de introduzir as bases e objetivos da presente pesquisa, talvez seja mais profícuo pontuar brevemente as concepções de alguns estudiosos dessa questão.

O antropólogo brasilianista Takeyuki Tsuda, em sua obra, Strangers in the ethnic homeland, a partir de uma etnografia multisituada com descendentes de japoneses no Brasil e no Japão, afirma que a despeito da "integração cultural e sócioeconômica" dos nikkeis no interior da sociedade brasileira hoje, os mesmos continuam a evocar uma identidade de "minoria étnica japonesa”. Alguns fatores presidem essa auto-afirmação, como por exemplo, o processo de inscrição "racial". De acordo com o autor,

race is the most prominent marker that differentiates the Japanese Brazilian as ethnically "Japanese" in Brazil" [...] Because of a strong consciousness of the racial, cultural and

\footnotetext{
${ }^{4}$ Grosso modo, trata-se de um domínio de pesquisa que genericamente toma como foco de análise questões referentes ao "universo japonês", seja no âmbito da cultura, língua, artes, literatura, etc; podendo dialogar com diversas áreas de conhecimento, como as Ciências Sociais, Economia, História, Artes, etc. Muitos pesquisadores utilizam o termo grupo étnico para se referirem aos nikkeis: cf. Saito, H; Maeyama, T. (1973). cf. Tsuda (2000). cf. Lesser $(2001,2007)$. Os últimos também empregam o termo "ethnic minority". No decorrer deste trabalho, também serão empregados os termos "nipo-brasileiros" ou "nipo-descendentes", sinônimos de nikkeis.
} 
social differences from others Brazilians that distinguish and define them as "Japanese", the Japanese Brazilians emphasize their minority ethnic identity despite a growing realization that they have become more brazilianized. Many of my informants privileged the Japanese side of their dual ethnic identity claiming that they feel more "Japanese" than "Brazilian" (Tsuda, 2003: 58).

Além dos traços fenotípicos, outros elementos importantes contribuiriam para essa marcação da diferença com relação aos "brasileiros": o status econômico e educacional dos nipo-descendentes e também sua filiação com o Japão, potência mundial e modelo de desenvolvimento tecnológico e econômico. A disseminação de imagens e impressões positivas sobre esta nação como país de primeiro mundo e como baluarte de uma tradição cultural regida por valores como diligência, honestidade, trabalho árduo, responsabilidade, inteligência, disciplina, e a tendência dos brasileiros de associarem os nikkeis com os japoneses do Japão ${ }^{5}$ culminou na reprodução do que Tsuda denomina de "positive minority status" entre os nipobrasileiros. De acordo com o autor, a maioria dos nikkeis "não deseja descartar sua condição de minoria étnica em favor de uma identidade nacional brasileira. De fato, sua 'niponicidade' é menos um estigma étnico a ser evitado do que uma vantagem positiva a ser mantida" (Tsuda, 2000: 7).

Tsuda assevera que as vantagens de ser "japonês" no Brasil estão associadas a um contraste entre o Primeiro Mundo (Japão) e Terceiro Mundo (Brasil) e entre as culturas "brasileira" e "japonesa" (id.: 17). Portanto, para muitos nikkeis, "o seu status de minoria étnica é uma fonte de orgulho e autoestima e, para alguns, ainda induz a um senso de superioridade em relação ao que é considerado brasileiro". É possível postular que os nikkeis enfatizem prioritariamente esse traço de niponicidade na modulação do seu discurso identitário? Seria essa construção praticamente hegemônica como assegura o autor? Haveria uma preferência pelo lado “japonês" nessa identidade étnica dual? Estariam mesmo os nikkeis totalmente "satisfeitos" em serem inscritos "racialmente" e etnicamente como "japoneses"?

Jeffrey Lesser argumenta o contrário em sua obra, A discontented diaspora. Segundo o autor, muitas pessoas no Brasil erroneamente acreditam que os nikkeis se sentem "japoneses" e que incontestavelmente possuem uma ligação emocional forte com o Japão como pátria. De acordo com o historiador, "enquanto os nipo-brasileiros raramente se vêem como diaspóricos no sentido clássico, o forte imprint (marcação) da maioria teve um impacto na construção de sua identidade" (Lesser, 2007: XXI) (tradução minha). Os sujeitos nikkeis pesquisados por Lesser

\footnotetext{
${ }^{5}$ De acordo com um informante de Tsuda (2000: 9), "para os brasileiros, japonês é japonês, não importando se ele mora no Brasil ou no Japão. Consequentemente, o que os japoneses (do Japão) fazem instantaneamente se torna um reflexo de quem nós (nipo-brasileiros) somos" (tradução minha).
} 
eram atores de filmes eróticos, militantes políticos e guerrilheiros das décadas de 1960, 1970 e 1980 que reclamavam sua brasilidade através da ocupação de papéis e participação em domínios tradicionalmente vistos como "não-nikkeis". Essa "militância étnica", exercida através da rejeição de ideias sobre a etnicidade japonesa, teve ironicamente o efeito reverso, pois concorreu para endossar a sua condição de minoria étnica, essencializando-os como "japoneses" (id., ib.).

Nas palavras de Lesser (2007: 25), “enquanto os telespectadores tendiam a ver nos personagens, confirmações para suas ideias essencialistas sobre o nikkei, atores e atrizes viam sua própria participação como uma espécie de brecha no interior das fechadas comunidades étnicas dos seus pais imigrantes". Mesmo tendo ciência de que esses sujeitos estavam inseridos em categorias profissionais e de atuação específicas, o exemplo da pesquisa do autor mostra como é problemático uniformizar o discurso daqueles sobre quem se fala.

O cuidado, que não raro resvala no receio, de se empregar certas categorias analíticas mais abrangentes, é uma medida que se insere na atual paisagem teórica marcada pelo movimento de crítica epistemológica às concepções de modernidade engendradas pela ciência ocidental, pautadas pelo recurso às polarizações conceituais. A Antropologia, disciplina tradicionalmente ancorada epistemológica e metodologicamente nos "grandes divisores", tais como, Indivíduo e Sociedade, Natureza e Cultura, Nós e Eles, se vê no centro de um grande debate teórico que procura pôr em cheque tais procedimentos de análise.

Florencia Ferrari no artigo, Como estudar nômades com um pensamento nômade? Sugestões para definir um campo em Antropologia, nos confessa certas inquietações que também são aqui compartilhadas. Ao se propor a estudar ciganos, já anuncia uma dúvida que assola pesquisadores sem "campo" definido no interior da disciplina antropológica. A autora se questiona sobre a subárea em que atua quando se depara com um formulário para pedido de bolsa: “seria 'etnologia', por estudar um 'grupo étnico'? No Brasil, etnologia, só 'indígena'. Seria antropologia urbana, caso esses ciganos vivam na cidade; ou antropologia rural caso vivam no campo?” Resignada, conclui: "parece que essas separações não fazem sentido. Só sobrou então antropologia das populações afro-brasileiras [...]" (Ferrari, 2006: 1).

Tais dúvidas também estão presentes quando pensamos na inserção da temática nikkei em um "campo" da Antropologia. Ela não se insere na etnologia pela mesma razão que a atestada por Ferrari, também não se "encaixa" nos chamados "estudos raciais", pois estes tradicionalmente se reconhecem pela abordagem da "questão negra" e nem nos estudos de 
imigração, ${ }^{6}$ pois os nikkeis fazem parte de uma população que já se encontra no país há mais de cem anos. ${ }^{7}$

A partir desse relato introdutório, Ferrari aponta duas questões: a arbitrariedade na definição dos "campos" de pesquisa em Antropologia e a problematização de certos conceitoschave da disciplina, como o de Sociedade, por vozes presentes no debate crítico epistemológico, como Bruno Latour, Marilyn Strathern, Roy Wagner, Gilles Deleuze e Félix Guattari. Tais conceitos se associam a pressupostos que até hoje balizam a disciplina, no entanto, contribuem também para provocar esses questionamentos no pesquisador como os apontados pela autora.

$\mathrm{Na}$ trilha aberta por esses autores, Ferrari chama a atenção para os problemas que envolvem o emprego da concepção de grupo social na pesquisa etnográfica, tomando como referência seu estudo sobre ciganos. Ao questionar a noção clássica de grupo social como "unidade concreta, fechada, separada do entorno e passível de descrição", a autora argumenta que a pressa no trabalho de campo em tomar o "grupo" como dado, sem levar em consideração se a noção é valida para aqueles a quem se está descrevendo é um procedimento arbitrário.

Cabe reiterar que muitos pesquisadores que transitam no "campo" de "estudos japoneses" consideram tout court os nikkeis como constitutivos de um grupo étnico a priori. Contudo, a percepção dos nipo-descendentes como pessoas de variados "perfis socioculturais", pertencentes a idades e gerações diversas, moradoras de diferentes contextos sócioespaciais, nos incita a questionar tal pressuposto, no sentido de tentar investigar como ele se revela no discurso dos mesmos e não tomá-lo como dado. Além disso, a própria categoria "etnia" precisa ser problematizada de algum modo neste caso, pois como veremos adiante, os sujeitos dessa pesquisa raramente pensam sua condição a partir dessa chave explicativa, mobilizando com maior frequência categorias como "raça" e "cultura". No capítulo 2, veremos como a questão das marcas fenotípicas se apresenta na produção de subjetividades.

É importante lembrar que na conjuntura social atual, os nikkeis são antes de tudo pessoas que mesmo possuindo um ancestral comum e a marca fisionômica peculiar, carregam experiências diversas no convívio e no embate com a alteridade. Todavia, o cuidado com a alcunha totalizadora não deve recair no imobilismo analítico da perspectiva individualizante.

\footnotetext{
6 Já o chamado "fenômeno dekassegui", fluxo migratório de trabalhadores estrangeiros em busca de melhores oportunidades no Japão, é a temática que mais rende pesquisas acadêmicas no interior dessa área híbrida de "estudos japoneses".

7 A dificuldade de inserção dessa temática em uma subárea da disciplina também vem acompanhada de uma dificuldade em conjugar a questão da "identidade nikkei" com um embasamento teórico adequado. Soma-se a isso a escassez de estudos que tomam os descendentes de japoneses na conjuntura atual como "objeto" de análise. Assim como afirma João Pacheco de Oliveira sobre os povos indígenas do Nordeste, talvez os nikkeis conformem também um "objeto de interesse residual [...] e, inteiramente deslocado dos grandes debates atuais da antropologia. Uma etnologia menor" (Oliveira, 1988: 47).
} 
Como aponta Eduardo Viveiros de Castro, o relativismo antropológico não deve ser interpretado como limite ao conhecimento, mas como estímulo a este, ou seja, não deve ser usado como pretexto para eximir o antropólogo da "indagação tendo por horizonte os universais humanos". 8 (Viveiros de Castro, 1995: 8).

A partir desse conjunto de questionamentos, a problemática da identidade foi aqui reelaborada por meio do aporte teórico discursivo. Nesse sentido, os interlocutores dessa pesquisa são agora pensados como indivíduos que podem se constituir como múltiplos sujeitos "brasileiros", “japoneses", “nipo-descendentes", "nipo-brasileiros" - quando interpelados por discursos que os mobilizam a tomar uma posição. Em linhas gerais, a pesquisa buscará compreender os processos de subjetificação, de produção discursiva do self, ou seja, os caminhos que levam os sujeitos a uma identificação com os elementos que compõe o imaginário sobre o “japonês"/nikkei.

A hipótese defendida é a de que esse imaginário sobre os japoneses e seus descendentes, pensado aqui como um corpus discursivo, sofreu alterações ao longo dos mais de cem anos da imigração: "perigo amarelo", "quinta-coluna", "inassimilável”, "trabalhador", "honesto", "inteligente", etc. Todavia, como pontua Stuart Hall (2005), "um núcleo de sentidos", esteve marcadamente presente ao qualificar um "ethos japonês" aos nikkeis, o qual, de acordo com as entrevistas realizadas, mostra-se atrelado a elementos como esforço, disciplina, ordem e honestidade.

Esse imaginário é aqui encarado como um repositório de imagens, representações e ficções e tem certo paralelo com a concepção de "formação discursiva" de Foucault, uma vez que se inscreve em um regime de verdade e assume eficácia prática sobre a realidade (Foucault, 2008). No capítulo 1, serão analisados alguns aspectos da construção desse imaginário discursivo por meio da forma como é percebido, ressignificado e reapropriado pelos interlocutores a partir de suas experiências como nikkeis. A questão que permeia a análise gravita em entender se e em que medida essa trama imaginária se constitui em um elemento importante para os processos de identificação dos sujeitos.

Entretanto, nas ricas narrativas contidas no trabalho, foi possível perceber também, em diversos momentos, a abordagem de temas que escapavam à esfera do discurso e das identificações por meio deste. Meus interlocutores frequentemente traziam à tona experiências que eram por eles repensadas em termos como "cultura", "raízes", "valores", "origens". A

\footnotetext{
${ }^{8} \mathrm{O}$ autor ironicamente afirma que o relativismo vem sendo administrado, nos cursos de Antropologia, como "um tranquilizante epistemológico, uma espécie de lexotan argumentativo que dispensa os pacientes de fazer qualquer indagação séria sobre as condições de socialidade, do simbolismo, da magia, do ritual, do parentesco" (id.; ib.: 6).
} 
relação com esse cabedal simbólico também se revelou nas falas dos sujeitos. A reboque, a pesquisa toma como desafio problematizar duas categorias que são constantemente acionadas pelos diferentes discursos em fluxo - dos nikkeis e também sobre os nikkeis - de modo assente, sem que haja uma reflexão maior sobre seus sentidos e usos. Tal como a categoria de identidade, as noções de "cultura japonesa" e "comunidade nikkei", figurando inicialmente no texto, "sob rasura" ${ }^{9}$, também serão postas em suspeição e investigadas ${ }^{10}$. Desse modo, no capítulo 3 , será possível deslindar como elas são ressignificadas e também operacionalizadas pelos sujeitos.

Sempre privilegiando o ato de fala dos mesmos, poderemos observar no capítulo 4, as tensões entre as afirmações identitárias e as manifestações de preconceito. Pelas narrativas de alguns interlocutores, veremos como na esfera prática da vida social, ou no que o antropólogo Michael Herzfeld (2004) cunha de "intimidade cultural" - domínio em que "os aspectos da identidade cultural são considerados fontes de embaraço externo" - valores, estereótipos, essencialismos e ideias reificadas sobre e si e sobre o "outro" são também mobilizados. Será possível compreender, a partir desses relatos que o recurso às generalizações também faz parte das estratégias de elaboração de fronteiras e negociação de identidades.

Um ponto que merece ser considerado refere-se à escassez de pesquisas sobre os japoneses e seus descendentes no Brasil quando inseridos na contemporaneidade. É importante lembrar, contudo, que o centenário da imigração japonesa no Brasil propiciou uma alavancada de produções discursivas - científicas, literárias, midiáticas, jornalísticas - sobre a história da imigração dos japoneses. A estrutura geral ou "núcleo" desses discursos descreve as fases do processo migratório como uma saga, iniciando com a chegada dos primeiros imigrantes no Kasato Maru, o trabalho e a vida nas fazendas, os conflitos no período da Segunda Guerra Mundial, seguido do movimento dekassegui e da apreciação da "cultura japonesa" pelos brasileiros. Essa narrativa trilha os percalços da adaptação dos japoneses ao país, concluindo com o "sucesso" e a "integração plena" dos descendentes na sociedade.

A presente pesquisa toma como desafio estender a investigação para além desse marco, a "integração". Em outras palavras, busca entender como a questão identitária se apresenta para os descendentes de japoneses na conjuntura atual, articulando a discussão com suas experiências de vida. Em que termos podemos pensar essa "integração"? Como a ideia de

\footnotetext{
${ }^{9}$ Stuart Hall, ao se propor a discutir o multiculturalismo, afirma que o termo "se encontra tão discursivamente enredado que só pode ser utilizado "sob rasura"” (Hall, 2003: 49).

${ }^{10}$ Em resenha do livro de Herzfeld, Márcio Goldman afirma que todo antropólogo: "Aceitando o caráter social de suas próprias teorias, bem como a força teórica das representações nativas, e a partir das vivências mais concretas e das experiências mais profundas, deve praticar o que Roland Barthes denominou certa vez uma etimologia às avessas: não a que busca a "verdadeira" origem oculta das palavras, mas a que tenta dissolver em seus múltiplos processos de criação aquilo, palavras e coisas, que nos é apresentado como "natural” (Goldman, 1998: 153).
} 
"raça japonesa" é mobilizada? Como preconceitos são agenciados? Como se revelam no discurso dos sujeitos e no seu cotidiano?

Cumpre observar também que protagonizamos no cenário atual a manifestação de fenômenos, como por exemplo, o intenso fluxo transnacional de pessoas e símbolos entre Brasil e Japão, o trânsito veloz de produtos culturais através da internet, a explosão do que se convencionou chamar "cultura $j$-pop" pelo mundo, a afirmação de particularismos locais e étnicos no contexto global, a grande repercussão midiática das comemorações do centenário, os quais se constituem em eventos que não podem passar ao largo da discussão. No capítulo 3, esses temas serão brevemente retomados.

Tais questões não figuram como foco principal da análise, contudo adensarão a reflexão na medida em que parecem alimentar o fenômeno de que denominamos "positivação do exótico" 11 pelos não-nikkeis. Em outras palavras, a força da difusão e do consumo, relativamente recentes, de imagens e símbolos referentes à "cultura japonesa" nos seus mais variados âmbitos - como por exemplo, culinária, religião, entretenimento, esporte, cinema, teatro, dança, música revela um fenômeno de dimensões globais, mas que possui uma especial ressonância no Brasil, país conhecido como a maior "colônia japonesa" fora do Japão. Uma das hipóteses que norteia o trabalho centra-se na ideia de que tais elementos provocam uma inflexão "positiva" sobre o imaginário discursivo em torno dos nikkeis.

Desse modo, ao mesmo tempo em que a pesquisa propõe mapear alguns discursos sobre os japoneses e seus descendentes ao longo de suas presenças no país, também buscará levar em consideração como esse conjunto de eventos imprime sua marca sobre esses mesmos discursos. Vale reiterar que o fenômeno de "positivação" não constitui o alvo principal da análise, mas não será desprezado uma vez que, verificou-se pelas entrevistas, a importância que assume para os interlocutores.

\section{SOBRE O CAMPO}

Como já explicitado, o conjunto de imagens atribuído aos descendentes de japoneses que pode lhes beneficiar com a condição de "positive minority status", na concepção de Tsuda, é aqui discutido a partir da fala dos sujeitos entrevistados. Como recurso metodológico, optei por

\footnotetext{
${ }^{11}$ Por "positivação do exótico" entendo esse fenômeno do consumo de bens culturais tangíveis e intangíveis relacionados a referenciais nipônicos, sejam eles produzidos no Japão ou no Brasil pelos seus descendentes. Processo que se principiou há cerca de três décadas, mas que ganhou maior amplitude na última, tem na aceitação da culinária um grande exemplo. Inicialmente conhecidos pelo exotismo, os pratos japoneses, como o sushi e o sashimi, caíram no gosto dos não-nikkeis e se popularizaram.
} 
abordar previamente com estes a imagem midiática/televisiva do "japonês", para em seguida entrar no domínio do imaginário social que diz respeito aos descendentes. ${ }^{12}$ A metodologia consistiu na exibição de fotografias com a imagem de figuras ou personagens televisivos "japoneses" da atualidade, ou seja, aqueles que mais obtiveram "sucesso" com o público em geral. ${ }^{13}$ Esse recurso se mostrou necessário, pois devido à escassez de produções televisivas envolvendo nikkeis, grande parte dos sujeitos pesquisados não se lembrava de tê-las visto. $\mathrm{O}$ roteiro produzido, utilizado como uma forma de guiar as conversas, foi dividido em três blocos, sendo o primeiro referente à "imagem do japonês na mídia televisiva", o segundo sobre a “imagem dos japoneses e seus descendentes na sociedade brasileira" e o último, referente à "relação do sujeito pesquisado com a chamada "cultura japonesa". 14

A princípio, essa proposta reformulada, visava se inspirar em uma metodologia aos moldes da sugerida por Miriam Moreira Leite em Retratos de Familia: leitura da fotografia histórica. Leite analisou álbuns de famílias de imigrantes que vieram para São Paulo entre os anos de 1890 a 1930. Uma parte de seu trabalho consistiu em colher depoimentos dos retratados ou de seus descendentes no momento em que reviam e contemplavam as mesmas. Nas suas palavras, é uma utilização radial da fotografia que dá “origem a um grande número de associações que levam e desdobram um acontecimento ou instituição, colocando a fotografia num contexto de experiência que respeita as leis da memória” (Leite, 1993: 104).

As fotos publicitárias dos atores e atrizes ou dos personagens em cena foram empregadas no sentido de que pudessem despertar a memória, fazendo com que esta revelasse outras imagens esquecidas e possibilitasse a compreensão dos modos como os sujeitos as recebem e as ressignificam, enfocando o paralelo por eles traçados entre "nikkei imagem" e “nikkei real". Como argumenta Leite (id.; ib.: 145), "quando olhamos uma fotografia, não é ela que vemos, mas sim outras que se desencadeiam na memória, despertadas por aquela que se tem

\footnotetext{
${ }^{12}$ Faz-se necessário esclarecer que, inicialmente, a presente dissertação esteve voltada para a análise das imagens do "japonês" na televisão, partindo da metodologia da etnografia de recepção. No decurso da pesquisa de campo, o enfoque foi direcionado para as imagens dos japoneses e seus descendentes na sociedade e os processos identitários por ela motivados. Isso não significa que a abordagem do conteúdo imagético televisivo pelos consulentes não tenha sido satisfatória, contudo, foi perdendo ao longo da pesquisa etnográfica o seu papel de destaque. Essa constatação me fez repensar a problemática do trabalho e optar por tirar as imagens televisivas do "japonês" do foco central de análise, tal como proposto pelo projeto original, reinserindo-as como importantes elementos na configuração do imaginário discursivo sobre os nikkeis.

${ }^{13}$ As personagens selecionadas foram "Miyuki" do seriado Malhação e "Yoko" da novela Bang Bang, interpretadas pela atriz Daniele Suzuki; o "Takae" da novela Belíssima, interpretado pelo ator Carlos Takeshi; a apresentadora Sabrina Sato; a atriz Cláudia Rodrigues, travestida de gueixa e a imagens de propagandas da empresa de eletroeletrônicos Semp Toshiba.

${ }^{14}$ Faz-se necessário frisar que a divisão do roteiro em três blocos serviu apenas como um mecanismo facilitador na condução das entrevistas.
} 
diante dos olhos [...] Citando John Berger, conclui: "não olhamos apenas para uma foto sempre olhamos para a relação entre nós e ela" (id.; ib.: 31 ).

As fotografias, desse modo, prestar-se-iam aqui, como "recurso catártico", método muito utilizado na obtenção de histórias de vida. De acordo com a autora, mediante o estímulo visual, os sujeitos se sentem instigados a falar sobre si mesmos ou sobre questões propostas pela imagem. O recurso às fotografias serviu, portanto, como um prelúdio para compreender como as identificações se articulam ou se tensionam com o imaginário midiático e social sobre os japoneses e seus descendentes. No limite, sua utilização poderia ajudar a elucidar questões de "como nós (nikkeis) temos sido representados" e "como essa representação afeta a forma como nós podemos representar a nós próprios" (Hall, 2007: 109). O material obtido com as entrevistas realizadas mostrou uma profunda riqueza etnográfica na segunda parte referente à "imagem dos japoneses e seus descendentes na sociedade brasileira". Nesse sentido, a abordagem do conteúdo imagético televisivo serviu como uma espécie de porta para que os pesquisados trouxessem à tona uma série de outras questões, como as impressões e reflexões acerca da experiência de ser nikkei.

Quando se fala em "nikkeis" nesta pesquisa, a referência é a segunda e a terceira gerações de nipo-descendentes, nisseis e sanseis, que atualmente concentram a maior parte da população nikkei no país (30,9\% e 41\%, respectivamente). A metodologia empregada consistiu na realização de entrevistas com pessoas de "perfis sócioculturais" diferenciados no que tange ao gênero, idade ${ }^{15}$, classe social, atividade profissional, local de residência, vinculação ou não a associações nipônicas, etc. Vinte e sete entrevistas foram realizadas com indivíduos selecionados aleatoriamente, cujas biografias diversas compunham um leque de experiências plurais: exdekasseguis, fã de animes, organizadores dos festejos do centenário da imigração japonesa no Brasil ou simplesmente pessoas que aparentemente não apresentavam um vínculo mais estreito com os "referenciais culturais nipônicos".

Como o foco da pesquisa esteve direcionado ao eixo dos valores, discursos e representações dos sujeitos e não da observação direta de contextos de interação, o emprego de entrevistas abertas se constituiu no método mais exequível e profícuo. As questões propostas visavam instigar os interlocutores a discorrer sobre como viam e percebiam a imagem dos nikkeis na sociedade brasileira, se se identificavam com a mesma e a comentar a respeito de suas relações com a "cultura japonesa", abordando aspectos como costumes, língua, filiação a entidades nipônicas, etc. Essa proposta foi pontuada pela busca da intersecção dos depoimentos

\footnotetext{
${ }^{15} \mathrm{O}$ entrevistado mais novo tinha 19 anos e o mais idoso, 73 anos.
} 
com a trajetória de vida dos interlocutores. Visando preservar o anonimato dos mesmos, seus verdadeiros nomes foram substituídos por nomes fictícios. É importante ressaltar que não foi empregada a metodologia de história de vida, pois procurei agregar diversas falas, no limite, um amplo leque de narrativas que representam alguns capítulos da história da presença japonesa e nikkei no Brasil.

Uma pergunta que tende a se interpor na leitura de cada depoimento é: "num mar de anônimos nikkeis, por que essa pessoa?". O fator que presidiu as escolhas foi a aleatoriedade. O único critério previamente definido era o de que seriam descendentes de japoneses, nisseis e sanseis, pessoas comuns do Estado do Paraná e de São Paulo. Por pessoas comuns, refiro-me aos que não possuem notável projeção pública, como intelectuais, artistas, políticos. Para isso, valime de indicações de terceiros. Ao contar o tema de minha pesquisa e do "perfil" que estava procurando no momento - com relação à idade, geração, local de residência, profissão, etc amigos, colegas e parentes me ajudaram, intermediando o contato. Felizmente, encontrei uma boa abertura e receptividade. A maior parte das entrevistas foi realizada na casa ou no local de trabalho dos depoentes. De maneira geral, estes se mostraram bastante interessados e dispostos em contribuir com a pesquisa. $\mathrm{O}$ recurso às entrevistas mostrou um resultado bastante rico, com conversas longas nas quais os sujeitos reavivaram um corpus de memória em seus testemunhos.

No que diz respeito à escolha dos sujeitos pesquisados, o procedimento metodológico consistiu em selecioná-los em três cidades reconhecidas pelo seu número significativo de habitantes nikkeis: São Paulo-SP ${ }^{16}$ (grande porte), Maringá-PR ${ }^{17}$ (médio porte) e Astorga-PR ${ }^{18}$ (pequeno porte). A princípio, tal decisão se justificou pela necessidade de se averiguar em que

\footnotetext{
${ }^{16}$ São Paulo e Paraná são os Estados com maior concentração de população nikkei no país. A cidade de São Paulo se constitui na maior cidade "japonesa” fora do Japão. De acordo com o IBGE, a população nikkei absoluta no Brasil, ano de 2000, contava com 1.405.685 habitantes no país (0,8\% da população total do país), tendo a maioria, 693.495 , concentrada no Estado de São Paulo (1,9\% da população total do Estado) (Beltrão, Sugahara et al, 2008). Em 2007, conforme levantamento do Ministério da Justiça japonês, a estimativa era a de que 316.967 os brasileiros viviam no Japão (Agência Sebrae de Notícias, 04/08/09). No entanto, em decorrência do agravamento da crise financeira mundial e da desaceleração econômica deste país no ano de 2009, cerca de 60 mil trabalhadores brasileiros retornaram do Japão, como aponta Aloysio Gomide Filho, chefe da Divisão das Comunidades Brasileiras no Exterior do Itamaraty (Fonte: “Crise traz 400 mil brasileiros de volta do exterior”. Valor Econômico, 24/05/10).

${ }^{17}$ Segundo o IBGE, a população total do Estado do Paraná no ano de 2000 era de 9.564.642, sendo a população nikkei absoluta de 143.588 (1,5\% da população do Estado) (Beltrão, Sugahara et al, 2008). Os resultados preliminares do Censo Nikkei realizado na cidade de Maringá-PR apontam 14 mil japoneses e descendentes vivendo no município (Fonte: O Diário do Norte do Paraná, 09/04/09). Sendo a estimativa populacional de 331.412 habitantes em 2008 (IBGE), o percentual é de aproximadamente 4,2\%.

${ }^{18}$ Segundo os dados censitários de Astorga-PR, o município conta com 25.164 habitantes. Situada entre as cidades de Maringá-PR (50 km de distância) e Londrina-PR (65 km de distância), reconhecidas pelo seu elevado número de habitantes nikkeis, Astorga não recebeu um fluxo tão grande de imigrantes japoneses. Uma pesquisa informal realizada junto à Associação Cultural e Esportiva de Astorga aponta que há cerca de 80 famílias associadas, perfazendo um total de aproximadamente 214 pessoas. Contudo, é importante frisar que há também na cidade muitas famílias que não são associadas e não participam das atividades promovidas pela ACEAST. O percentual estimado da população nikkei total no município é de $1,3 \%$.
} 
medida a vivência em contextos sócioespaciais diferenciados influenciava o modo de perceber as imagens e consequentemente a percepção de si mesmo. Como será visto, tal variável tem um peso significativo, mas não condicionante na determinação dessas experiências. Outro motivo para a escolha dessas cidades foi o facilitador, uma vez que atualmente moro na cidade de São Paulo, mas passei a maior parte de minha vida nesses municípios do Paraná. Tenho uma relativa rede de contatos, pois em Astorga, meus pais foram presidentes durante os anos de 2007 a 2009 da entidade nipo-brasileira, Associação Cultural e Esportiva de Astorga (ACEAST); e em Maringá, possuo muitos familiares que ali residem.

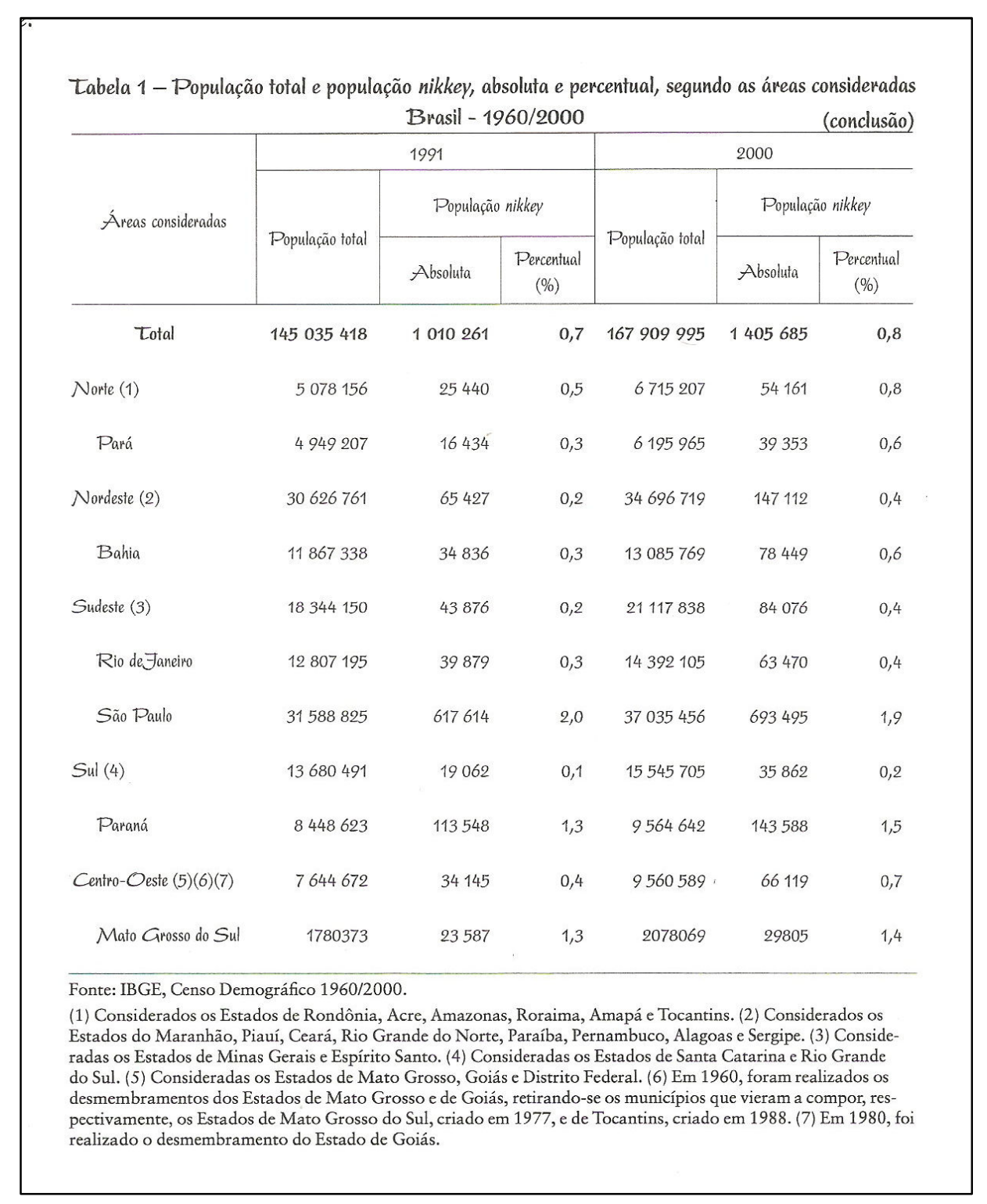

Fonte: Beltrão \& Sugahara et al, 2008. 
Para situar o leitor quanto à distribuição territorial dos nikkeis, algumas tabelas demográficas serão inseridas, entretanto, vale ressaltar que o presente estudo embora reconheça a importância das análises quantitativas, tem uma orientação diversa. O propósito de escolher participantes de perfis diversos não esteve pautado na busca por uma amostragem representativa da "comunidade nikkei" no Brasil, mas simplesmente explorar diferentes pontos de vista, biografias e narrativas. O desafio residiu em desvendar os elementos que costuram essas histórias, dando ensejo, assim, a que o depoimento de uma nissei, moradora da cidade de São Paulo-SP, ex-dekassegui, ganhe luz, por exemplo, frente ao discurso de um sansei, residente na cidade de Maringá-PR, membro de uma entidade nipônica.

É importante ressaltar que o presente trabalho pretende ser construído a partir de uma perspectiva polifônica, ou seja, atravessado por múltiplos discursos que se entrecruzam na abordagem da questão das imagens do nikkei. É na tensão entre o que é falado, publicado e impresso e imaginado que essa etnografia se situa. $O$ recurso à montagem, através da justaposição de discursos que aludem um ao outro é uma inspiração para este trabalho, na medida em que também buscarei pôr lado a lado as diferentes construções discursivas produzidas sobre os nikkeis e pelos nikkeis. Afinal, esse imaginário é alimentado pelos agentes envolvidos, descendentes e não-descendentes. $\mathrm{O}$ objetivo aqui se ancora no sentido de manter um texto aberto, entrecruzado por um conjunto multipolar de práticas, discursos, ficções e narrativas, cujas conexões de sentido não serão descritas, mas apenas sugeridas.

Como é possível perceber, a concepção de imaginário aqui adotada guarda, em alguns aspectos, um paralelo com a noção foucaultiana de discurso, com seus efeitos de verdade e poder na conformação de realidades e práticas políticas. Contudo, faz-se necessário esclarecer que esse complexo de imagens e representações será analisado na maneira como é pensado pelos meus interlocutores. Serão eles que guiarão a discussão frente ao modo como acreditam que são vistos pela sociedade e de como se vêem. A busca reside em compreender os valores, imagens, representações, estereótipos atribuídos ao descendente e de como esse conjunto de percepções é vivenciado pelos sujeitos dessa pesquisa. Articuladas com a trajetória de vida, suas narrativas também estarão acompanhadas de outros discursos - políticos, jornalísticos, acadêmicos fragmentos, perdidos em uma linha atemporal, que juntos podem constituir um mosaico "de acontecimentos e reminiscências, camadas de significado e digressões” (Taussig, 1993: 19). 


\section{QUANDO O “OUTRO” SOU EU}

Um ponto importante que merece ser levantado refere-se à minha ascendência japonesa. Mais do que meramente seguir o paradigma auto-reflexivo na prática etnográfica, fazse necessário de antemão assumir que a minha condição de descendente de japoneses, sansei por parte de mãe e yonsei por parte de pai, tem consequências diretas no resultado deste trabalho. A interlocução na abordagem de várias questões desta pesquisa poderia ser diferente caso eu não fosse nikkei. Ao longo da leitura, tal questão ficará mais clara. De início, talvez seja oportuno expor alguns dados sobre a minha biografia, que serão retomados na escritura do texto, seja para esclarecer algum ponto, seja na relação estabelecida com o entrevistado.

Embora meus pais sejam membros da ACEAST e nos últimos anos tenham exercido funções de direção na entidade, não fui uma pessoa que "cresceu dentro da colônia", usando uma expressão nativa. Quando criança e adolescente, não tive o interesse em aprender a língua japonesa, apesar de ter tido a oportunidade se quisesse. Não falávamos o idioma em casa, somente poucas palavras perdidas em uma frase. Minhas idas ao kai $k^{19}{ }^{19}$ restringiam-se ao undokai $^{20}$ e aos "jantares orientais", na condição de convidada, diga-se de passagem, e não de voluntária na organização dos eventos. Minha rede de sociabilidade era formada majoritariamente por não-nikkeis. Também nunca viajei ao Japão, fosse a trabalho ou a estudo.

$\mathrm{O}$ interesse pela temática dessa pesquisa e a curiosidade, despertada um pouco tardiamente, por alguns aspectos da chamada "cultura japonesa" foram se dando nos últimos anos da faculdade. Nesse sentido, é importante esclarecer que a relação com a pesquisa e com os pesquisados, se por um lado foi de afinidade e por que não, de identificação com algumas narrativas, por outro foi também de estranhamento. Assim, penso que categorizações como antropólogo insider ou outsider, nativo ou não-nativo só fazem sentido quando contextualmente localizadas e quando assumidas o seu caráter fluido.

Renato Rosaldo em sua obra, Culture and truth: the remaking of social analysis, desenvolve uma crítica ao "mito do distanciamento" na análise social, recuperando várias etnografias para explorar seu argumento, dentre elas, a produzida pela antropóloga nipoamericana, Dorinne Kondo. No Japão, a pesquisadora, que compartilhava os mesmos traços físicos que os japoneses, apesar de beneficiada com essa condição, como na facilidade que encontrou em se inserir em determinados grupos, sentia certa pressão no ambiente para agir

\footnotetext{
${ }^{19}$ Kai kan: sede do nihonjin-kai ou associação nipônica.

${ }^{20}$ Undō: esporte; kai: reunião. Espécie de gincana esportiva montada na sede das associações, cujo objetivo é proporcionar uma reunião e confraternização de pessoas através de brincadeiras, como cabo de guerra, corrida, etc.
} 
como uma "nativa". Segundo Rosaldo, Kondo narra uma anedota interessante sobre os "dilemas da identificação como fonte de conhecimento". Qual não foi o choque da antropóloga, quando empurrando um bebê no carrinho e fazendo compras para a casa em Tóquio, depara-se com uma típica jovem dona-de-casa japonesa, com os joelhos ligeiramente dobrados a arrastar-se nos chinelos, e a reconhece nada mais nada menos como o reflexo dela própria? Numa tentativa de se distanciar diante da perspectiva, se é que ela existe, de "going native", Kondo retorna aos Estados Unidos por um mês e quando volta ao Japão, resolve se mudar para um apartamento próprio, mas ao lado da "família" com quem havia morado durante todo o campo (Rosaldo, 1993: 180-181).

Rosaldo ressalva que Kondo poderia manter esse distanciamento até certo grau, pois ao mesmo tempo em que a condição de "near-native persona" lhe trazia vantagens, por outro, lhe era cobrada uma postura de maior delicadeza no trato de certas questões e que não era tão intensamente exigida de outros outsiders. Defendendo a ideia de que o antropólogo possui "identidades múltiplas que se entrecruzam" (multiplex social identities) e que sofrem mudanças durante o trabalho de campo, afirma que "the knowing person not only blends a range of cognitive, emotional, and ethical capabilities but her social identities also variously include being a woman, a researcher, and a Japanese-American" (id., 1993: 194).

As observações de Kondo e Rosaldo vão ao encontro de algumas apreensões e sentimentos surgidos no trabalho de campo dessa pesquisa. A expectativa de alguns de que eu fosse uma participante ativa da "colônia", falasse o nihongo, de que entendesse certos códigos, símbolos, palavras japonesas ou compartilhasse experiências como as vividas por tantos com quem dialoguei, como a ida ao Japão a trabalho, também foi sentida em alguns momentos, afinal eu era uma pesquisadora nikkei estudando "os nikkeis".

A inserção de dados sobre a minha biografia e de relatos sobre algumas experiências por mim vivenciadas, também fora do campo, não foram aqui incorporadas com a intenção de levar ao extremo a proposta auto-reflexiva e recair em uma espécie de "ego trip", um exercício narcisista de reflexão, mas sim de não ignorar que esse background tem implicações diretas na análise. A ideia de multiplex social identities de Rosaldo, estendida não somente para os sujeitos da pesquisa, mas também para os antropólogos, apresenta-se de forma muito apropriada para este trabalho, já que assume que a investigação pode ser conduzida a partir de várias posições, neste caso, além de pesquisadora, descendente de japoneses, mulher, paranaense... 


\title{
1. CAPÍTULO I - UM OUTRO ORIENTALISMO? IMAGENS E DISCURSOS SOBRE OS NIKKEIS
}

\begin{abstract}
Passados 100 anos, nossa comunidade de origem japonesa - a maior fora do Japão - é plenamente integrada e muito admirada por suas qualidades e realizações. São brasileiros orgulhosos de sua ascendência, que se destacam nos mais diversos aspectos da vida nacional. São pessoas conhecidas por sua determinação, empenho e criatividade. Gente estudiosa e trabalhadora.
\end{abstract}

Discurso do Presidente Luís Inácio Lula da Silva durante a cerimônia oficial de chegada do Príncipe herdeiro do Japão, Naruhito, no dia 19 de junho de 2008.

Tomando como mote o próprio discurso do Presidente da República, uma questão paira no ar: passados cem anos da imigração japonesa para o Brasil, como um imaginário sobre os japoneses e seus descendentes que se alimenta da associação com o trabalho e com o empenho ainda persiste na nossa sociedade? Persistência, empregada aqui no sentido de constância. Como veremos neste capítulo, esse discurso de "gente trabalhadora" permeou a passagem dos japoneses no Brasil, sendo acionado em diversos momentos históricos pela imprensa, debates públicos, relatórios políticos. A hipótese levantada é que a despeito da multiplicidade desses discursos e das transformações pelas quais os mesmos passam ao longo do tempo, um conteúdo interno que se qualifica pela atribuição de um ethos específico aos nikkeis rescaldo da ideia de esforço (gambarê), seja no trabalho ou nos estudos - ainda se mantém.

De acordo com a metodologia adotada, o propósito consiste em entrecruzar diferentes discursos em jogo sobre os japoneses e seus descendentes - históricos, jornalísticos, políticos - e também dos descendentes a respeito de como são percebidos na sociedade brasileira. Não obstante valer-se em alguns momentos das contribuições de autores como Michel Foucault, Edward Said e Homi Bhabha, é importante ressaltar que o foco deste trabalho não se centraliza em realizar uma investigação depurada, de acordo com os procedimentos teóricos do campo da linguística em análise do discurso, e nem tem a pretensão de cobrir e analisar todo o complexo processo histórico de construção do que chamamos aqui de imaginário discursivo sobre os nikkeis. Este emergirá no texto sob duas formas: pelos qualificativos que o compõe e à medida que seja trazido à tona pelos interlocutores da pesquisa. Para a maior parte deles, esse imaginário se estrutura a partir de três pilares básicos: os atributos de trabalhador, honesto e esforçado. 


\section{SOBRE UM ENCONTRO NO SUPERMERCADO}

Mais do que meramente seguir o paradigma autorreflexivo na prática etnográfica, fazse necessário assumir de antemão que a minha condição de descendente de terceira geração de japoneses tem consequências diretas no resultado deste trabalho. A interlocução na abordagem de várias questões desta pesquisa poderia ter sido diferente se eu não fosse nikkei. Ao longo da leitura, tal questão ficará mais clara. O desafio, portanto, será equilibrar no processo de escritura, a abertura para a experiência e o distanciamento necessário que a empreitada etnográfica exige. Assim, acredito que essa pesquisa não poderia passar ao largo da reflexão sobre minhas origens. Como brasileira, descendente de japoneses, minha vida foi marcada por experiências positivas e negativas que marcaram e marcam minha trajetória pessoal. Gostaria, portanto, de relatar um episódio por mim vivenciado que ilumina alguns pontos de fundamental importância para este trabalho.

Há alguns anos conheci uma senhora em um corredor de um supermercado. Era aquele atípico dia em que duas pessoas estranhas se mostram abertas para conhecer a outra sem estarem num espaço apropriado para tal, afinal, era um corredor de enlatados. Travamos uma conversa bastante longa, e naquele momento, eu estava acompanhada de um namorado que, nas classificações raciais vigentes no senso comum, era "mestiço", somente seu pai era nikkei. No meio da conversa, esta senhora dispara: "Ouvi dizer que casar com homem japonês é muito bom, pois eles são respeitadores, trabalhadores...". Logo depois, ela questionou, com um franzir na testa que me lembro muito bem: "E mulher japonesa? Será que elas são boas para casar? Acho que elas são muito submissas, não são?”. Achei engraçada a interpelação e sorrindo, afirmei que realmente os primeiros imigrantes tiveram que trabalhar muito para chegar aonde chegaram, mas quanto à submissão das mulheres, muita coisa havia mudado. Acrescentei que, em 2008, comemoraríamos o centenário da imigração japonesa, ou seja, “os japoneses já se encontram no Brasil há cem anos...”. Ela ouviu atentamente e logo se justificou: “Ah, minha filha, você me desculpe pela pergunta. É que moro no Espírito Santo, e lá tem poucos ‘japoneses””.

Essa conversa aconteceu na cidade de Maringá, local que recebeu muitos imigrantes de origem japonesa na década de 1940, no processo de venda e loteamento de terras realizado pela Companhia Melhoramentos Norte do Paraná. Não tenho dúvidas de que esta senhora tenha ficado impressionada com a grande quantidade de "japoneses" andando pelas ruas em sua visita à cidade. Uma série de imagens deve ter lhe ocorrido à cabeça, entre elas: homem trabalhador e respeitador e mulher submissa. Uma tríade de qualificativos que ela "ouvira dizer" estar 
associada aos nikkeis. Lembro que achei o episódio curioso, "bom para pensar". Estava mais "familiarizada", se assim posso dizer, com as atribuições de disciplina, honestidade, timidez, inteligência, feiura e ingenuidade aos "japoneses", mas até então acreditava que o discurso de "mulher japonesa submissa" tinha permanecido vivo somente com a primeira geração de imigrantes. Teria a mídia um papel importante na veiculação de uma imagem de “japonesa gueixa"? E o fator demográfico, apontado pela senhora? Como é possível ver no cartograma abaixo, o Estado do Espírito Santo é a sexta unidade da federação com menor índice populacional de nikkeis: 8.627 de acordo com censo do IBGE de 2000.

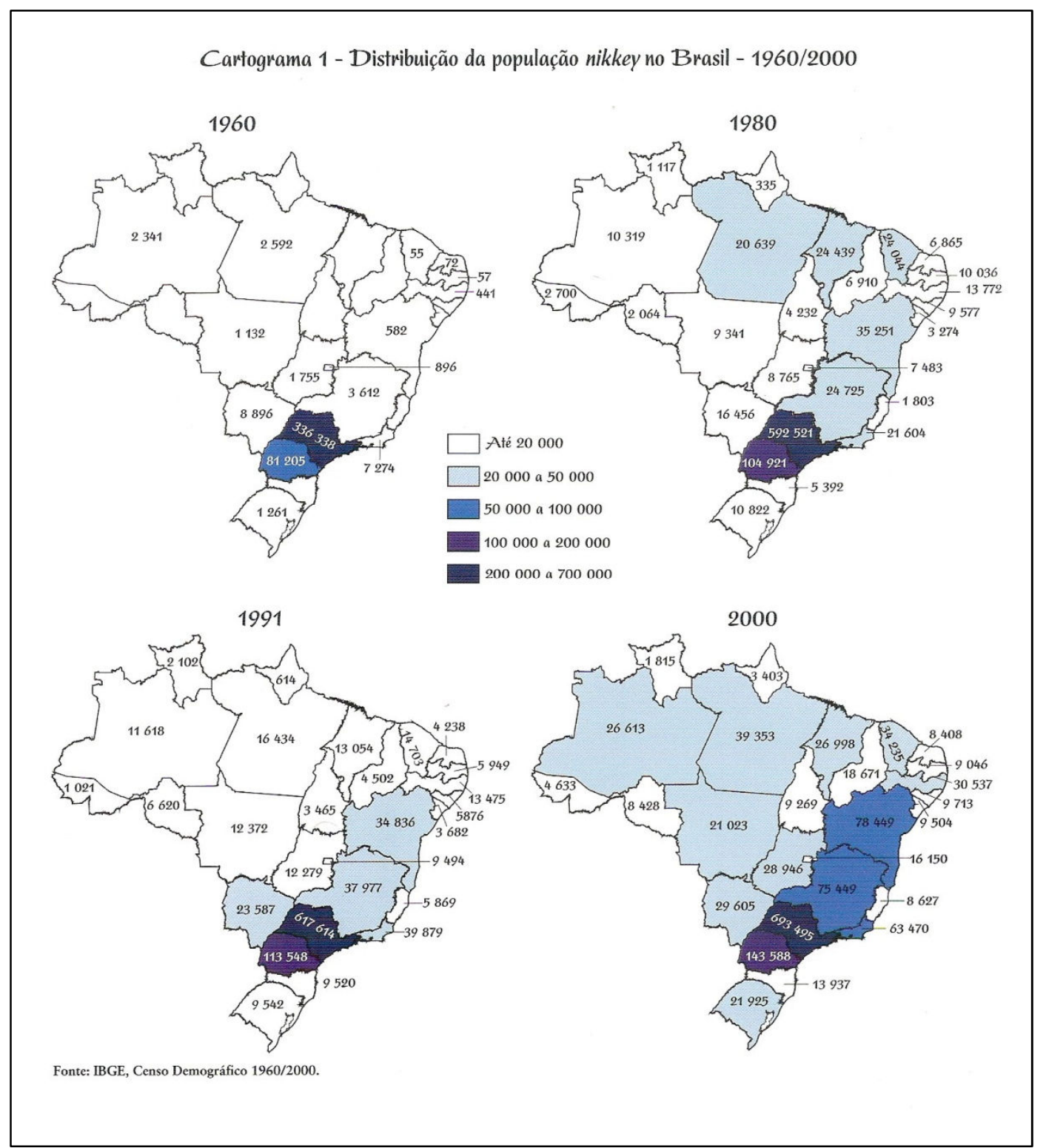

Fonte: Beltrão, Sugahara et al, 2008 
Interessante pensar como esse episódio no supermercado traz questões instigantes. Como uma cena, possibilitou visualizar uma forma de interpelação muito comum aos descendentes de japoneses e também divisar como os discursos sobre empenho, respeitabilidade e submissão, por exemplo, podem estar atravessados por marcadores como gênero, espaço e geração. Para adentrar nesse tópico de discussão, é preciso que investiguemos primeiramente um pouco sobre esse qualificativo atribuído aos nikkeis, citado por praticamente todos os entrevistados: a de trabalhador.

\section{UM PRELÚDIO OPORTUNO}

Antes um esclarecimento prévio se faz necessário. É de praxe que as pesquisas que se estendem ao que vagamente chamei no início da dissertação de "universo japonês e/ou nikkei" se iniciem com uma narrativa sobre os primórdios do movimento imigratório para o Brasil. Instituiu-se em quase cem por cento dos trabalhos quase que como uma introdução obrigatória, uma espécie de cartilha a ser seguida. Qual a razão ou justificativa para tal procedimento? Instada por essa questão, interroguei alguns colegas pesquisadores da área: "assim o fazemos, pois pouco se sabe na academia e fora dela sobre esse assunto". Não me dei por satisfeita, pois o ano de 2008, com as comemorações do centenário da imigração japonesa no Brasil, houve uma verdadeira "enxurrada" de informações divulgadas em diversos espaços - midiático, político, acadêmico - e que, também eram acometidas pelo mesmo modelo de narrativa: reportando-se inicialmente a chegada dos primeiros imigrantes japoneses no navio Kasato Maru em junho de 1908.

Pude perceber nas entrevistas realizadas que essa forma de se reportar a um passado distante como repositório de uma "cultura" ancestral, reconhecida por valores como disciplina, honestidade e respeito, repassada ou não para as próximas gerações, foi um expediente recorrentemente mobilizado pelos entrevistados em suas reflexões. O estabelecimento das diferenças entre a antiga e as novas gerações no que tange ao compartilhamento de "valores" também se mostrou um recurso comum. Júlia Suzuki Bertolli, sansei, 42 anos, da cidade de Astorga, acredita que a desonestidade seja um ato que se verifica com menos frequência entre os descendentes de japoneses, devido à herança educacional recebida dos pais e avós:

"De vez em quando você vê um assassino japonês, de vez em quando você vê um assassino
com outro japonês, de vez em quando você encontra um traficante, de vez em quando! Por
quê? Porque eu penso que a própria rigidez na educação que o japonês herdou, trouxe lá de
trás para gente aqui, fez com que os descendentes se desvirtuassem cada vez menos, né? E
pelo fato de a gente trabalhar muito, estimulado e ensinado esse lado pelos nossos pais, pelos
nossos descendentes, pelos nossos avós fez com que a gente tivesse menos necessidade, que a 
gente conseguisse se dar um pouco melhor, né? 'Japonês' tem fama de estudioso, de inteligente... Mas tudo isso foi estímulo que ele teve do pai e da mãe, que você tem que estudar, que você tem que aprender para ser alguma coisa melhor ou ser alguém melhor na sua vida! Eu penso que, de forma geral, a minha geração e a de meus amigos orientais foi educada tudo da mesma forma. Por isso não estou falando uma coisa além... estou falando de uma geração. A minha geração pelo menos... acho que a gente cresceu tudo assim".

A própria questão das imagens e discursos sobre os nikkeis na atualidade, foi bastante repensada pelos sujeitos dessa pesquisa a partir do estabelecimento de comparações com um imaginário associado aos primeiros imigrantes e a segunda geração de descendentes. Sérgio Takeda, por exemplo, nissei, 40 anos, dono de uma loja de produtos japoneses em São Paulo, acredita que a imagem do nikkei trabalhador e honesto "infelizmente" ficou no passado:

\begin{abstract}
"Na minha geração realmente ainda existia. Hoje já não sei como está. Mas tinha algumas vantagens de ser nissei, né? Principalmente na hora de procurar emprego também. Ajudava bastante [risos]. Na hora da entrevista, eles sabiam que era 'japonês', já ficavam interessados, principalmente em bancos. Hoje eles procuram muito pessoas boas na parte de exatas, engenheiros. Naquela época era nihonjin. Quem era nihonjin ${ }^{1}$ já tinha o pé dentro, né? Não era todo mundo que se dava bem, mas ajudava bastante. Hoje, acho que não tem muito disso [...] Na minha geração já estava começando a mudar essa ideia. A imagem dos japoneses já está mudando bastante. Hoje, acho que mudou completamente. Isso... de considerarem o 'japonês' honesto, trabalhador, hoje já mudou bastante... infelizmente".
\end{abstract}

Seja para afirmar ou negar, identificar-se ou rejeitar o imaginário sobre os nikkeis, a relação com a história é acionada pelos interlocutores da pesquisa. Termos como continuidade, resgate, transformação e mudança são agenciados quando o assunto “cultura japonesa" é abordado. O imaginário que associa os japoneses e seus descendentes ao esforço, honestidade, à boa conduta moral foi sendo gradualmente edificado como uma espécie de mito.

Entender as permanências de alguns componentes desse imaginário que persiste mesmo com a passagem do tempo nos remete ao conceito de "estrutura da conjuntura" cunhado por Marshall Sahlins. Sua proposta busca superar o emprego de polarizações binárias, "logicamente instáveis", frequentemente utilizadas para se pensar a cultura e a história: diacronia e sincronia, passado e presente, sistema e evento, estático e dinâmico. O autor oferece uma crítica a esse binarismo "debilitante", afirmando que "outras civilizações compreenderam melhor a sua síntese. É necessário fazer o reconhecimento teórico, encontrar o lugar conceitual do passado no presente, [...] do estático no dinâmico" (Sahlins, 2003: 19) (grifos meus).

Essa síntese entre estrutura e história de que fala o autor se revela no conceito de "estrutura da conjuntura". Se a história é ordenada culturalmente, os esquemas culturais são ordenados historicamente, pois os agentes sociais criativamente reavaliam, repensam os

\footnotetext{
${ }^{1}$ Japonês. Nihon: Japão, jin: pessoa.
} 
significados destes esquemas quando realizados na prática, "os significados são postos em risco na ação" (Sahlins, 2003: 9). O autor pensa essa ordem cultural, portanto, enquanto "convenção", constituída na sociedade e "ação", vivenciada pelos sujeitos. O destino fatal do capitão Cook/ Deus Lono nas mãos dos havaianos, discutido em Ilhas de História (2003), pode ser explicado pelos significados atribuídos pelos últimos à série de contingências históricas, "coincidências rituais" que se seguiram, de acordo com os esquemas simbólicos que ordenavam sua cosmologia. A estrutura será ressignificada em um novo contexto histórico.

Lilia Schwarcz (1995: 60) se inspira em Sahlins quando sugere que a fábula das três "raças" progenitoras da nação, com a mestiçagem como marca da identidade brasileira, é como um mito, uma estrutura que se transforma e se atualiza "no e em contexto", "sem perder certas persistências". Segundo a autora, essa mestiçagem - que da visão romântica de Karl Von Martius, passa a revestir-se de um caráter biológico e degenerativo no início do século XIX; para mais tarde nos anos 30 com a "campanha da brasilidade", tornar-se símbolo da cultura nacional; e finalmente nos anos 50 associar-se à malandragem - vai sendo reelaborada metaforicamente, ganhando novos contornos, sem deixar de manter certos "valores de permanência mental" (Schwarcz, 1995: 62).

Passados cem anos da imigração japonesa no Brasil, arrisco a pensar que o imaginário sobre os nikkeis no Brasil, que tende a associá-los a certo "ethos japonês", rescaldo da ideia de esforço (gambarê), assim como um mito, também constantemente se ressignifica de acordo com as contingências históricas sem deixar de "reproduzir velhas categorias culturais" e de revelar certas permanências. O que se pretende aqui não é buscar a verdade, nem a falsidade dessas imagens e discursos, mas a "política de sua interpretação e representação" (Taussig, 1993: 15). O propósito não é desconstruir, qualificar, julgar esse imaginário, mas apontar as recorrências de alguns elementos que o engendram (Schwarcz, 1995: 51).

Quando o ensaísta Eduardo Lourenço toma como desafio a exploração da "alma portuguesa", mergulhando na mitologia nacional de um povo que desenha sua singularidade na "saudade", sentida na relação com um passado esplendoroso, real ou imaginário, de povo marítimo, descobridor, viajante, “eleito” por Deus, messiânico - esclarece que

O nosso propósito não é o de, complacentemente, revisitando o que nos parece ser característico da imagem e dos avatares do destino português durante oito séculos, compreender a realidade desse destino, ainda em devir, mas o de insinuar que ele não só não é inseparável das ficções ativas com que os portugueses viveram ou vivem, como a sua leitura é impossível sem ter em conta essas mesmas ficções, quer dizer, a mitologia que elas configuram (Lourenço, 1999: 92). 
Para o autor, a História não é o único lugar por excelência na compreensão do "nós mesmos como passado coletivo". Só em função do imaginário, essa "massa de sombra luminosa", "rêverie humana", que qualquer tipo de autognose é possível: a "Mitologia sem História é vazia e a História sem Mitologia, cega”, afirma o autor, citando Kant (Lourenço, 1999: 93). Longe de conceber os nikkeis a partir da ideia de povo, a presente pesquisa se inspira na proposta de Lourenço no sentido de que, nunca é demais reiterar, não tem a pretensão de compreender todo o conjunto de imagens relacionadas aos japoneses e seus descendentes, mas compartilha com o autor o argumento de que esse imaginário e a leitura dele estão atrelados às "ficções ativas" com que os nikkeis viveram ou vivem.

Das dúvidas quanto à aceitação de um contingente populacional muito estranho à língua e aos costumes nacionais, que detinha, no entanto, uma ética de trabalho admirada por representantes do corpo diplomático brasileiro no Japão às narrativas gloriosas do centenário da imigração japonesa no Brasil, cujo núcleo basicamente esteve centrado no "sucesso" da mesma e nas inúmeras "contribuições" trazidas pelos nikkeis graças ao seu trabalho e empenho; este trabalho levanta a hipótese de que uma trama imaginária foi sendo forjada ao longo das circunstâncias históricas, atualizada e reatualizada pelos agentes envolvidos, brasileiros, descendentes e não-descendentes de japoneses, e consequentemente modulada por valores japoneses e brasileiros. O objetivo aqui reside em investigar como a relação dos interlocutores com essa trama diz algo sobre suas identidades.

É importante destacar dois pontos a partir dessa discussão. Primeiramente, se o caráter relacional, contextual, histórico, fluido e não essencializado do conceito de identidade não é novidade $^{2}$ e se concordamos com a ideia de "inscrição racial" que tende a vincular os nikkeis a certo "ethos japonês", é necessário que busquemos perscrutar algumas raízes de tal associação. E se é este vínculo que configura o alicerce desse imaginário sobre os nikkeis, é importante repassar brevemente por alguns momentos históricos da imigração japonesa que abrigaram esses componentes discursivos. Como sugere Eduardo Lourenço, “a sacralização das origens faz parte da história dos povos como mitologia". No caso dos japoneses, a vinda do Kasato Maru

\footnotetext{
${ }^{2}$ Conforme as clássicas contribuições de Fredrik Barth (1998) para os estudos de etnicidade, cuja obra Grupos étnicos e suas fronteiras, originalmente publicada em 1969, tornou-se uma referência ao defender uma visão dinâmica e relacional de grupo étnico. Para o autor norueguês, a existência de fronteiras étnicas não implica no isolamento social ou cultural do grupo. Em outras palavras, mesmo com as transformações culturais advindas da mobilidade e das situações de contato com outros agrupamentos, as dicotomizações entre membros e não-membros persistem quando os atores elegem e exibem traços diacríticos para se diferenciarem. Em suas palavras, "a melhor utilização do termo etnicidade é um conceito de organização social que nos permite descrever as fronteiras e as relações dos grupos sociais em termos de constrastes altamente seletivos, que são utilizados de forma emblemática para organizar as identidades e as interações” (Barth, 1984 apud Poutignat \& Streiff-Fenart, 1998:183-84).
} 
constituiu-se como uma espécie de mito de origem, marco histórico em que as imagens sobre o Japão e seu povo ganhavam contornos mais definidos.

\section{“JAPONESS NÃO TEM VERGONHA DE TRABALHAR”}

Feita essa observação, cabe destacar que relações harmoniosas, de reciprocidade, de convivência pacífica e relações conflituosas, de altercação e até mesmo armadas com a sociedade receptora permearam a passagem e o estabelecimento dos nikkeis no país. Em alguma medida, tais relações alimentaram e foram alimentadas por discursos. De diferentes “matizes", proliferaram pelos mais diversos cantos por meio de livros, imprensa, relatos de viagens, documentos policiais, debates públicos. Desde as primeiras discussões a respeito da entrada dos nipônicos no país, controvérsias entre detratores e defensores dessa questão se fizeram sentir. $\mathrm{O}$ argumento central dos primeiros consistia na ênfase da ameaça racial e política que os imperialistas "amarelos" poderiam trazer para um país já bastante "castigado" com a presença negra e mestiça. Já os defensores nutriam seus argumentos a partir do potencial de trabalho desses imigrantes que poderiam repetir no Brasil os avanços e progressos obtidos com a Restauração Meiji em $1868^{3}$ e de sua capacidade de assimilação aos modelos de desenvolvimento ocidentais.

Não obstante entender que os discursos favoráveis ou desfavoráveis, positivos ou negativos sobre o japonês tenham sido concomitantemente engendrados na arena pública, examinarei num primeiro momento as representações relacionadas a fatores laborais, ou seja, ligados ao trabalho e ao empenho, principais argumentos usados pelos defensores da entrada dos nipônicos em alguns discursos públicos e políticos que circularam no Brasil até meados da década de 1930. Será possível observar como tais discursos ganham luz frente ao modo como os interlocutores dessa pesquisa se vêem representados no imaginário nacional e ressignificam os atributos de trabalho e honestidade. Já os discursos que viam no japonês um "perigo racial” para a conformação ideal da nação serão reservados para análise no segundo capítulo.

Como é possível notar, as discussões em torno da vinda de imigrantes para o Brasil gestaram-se no âmbito dos debates concernentes à identidade nacional que figuraram em fins do século XIX e início do XX. Fundamentado nas concepções de "raça" como definidoras da nação, o ideário vigente era a de que os prejuízos advindos da mácula de um país mestiço poderiam ser atenuados com a entrada de imigrantes europeus prontos para compor o tipo nacional desejado. As medidas legais contra a escravidão que vinham se sucedendo desde 1850

\footnotetext{
${ }^{3}$ Período que marcou o fim do isolamento econômico da ilha e início do processo de modernização ou ocidentalização japonês.
} 
aceleram o fluxo migratório, ${ }^{4}$ mas por ora, não para todos os grupos: asiáticos e africanos são preteridos. Essa situação se reverterá com os subsequentes déficits imigratórios, ou seja, quando a saída total de imigrantes supera a entrada, causados, sobretudo pela insatisfação de colonos italianos com as condições de trabalho nas lavouras de café.

As pressões da elite do circuito cafeeiro que tinha no Estado de São Paulo seu grande centro levam à contratação de uma mão-de-obra alternativa ao branco desejável, mais "dócil" e "submissa": a japonesa (Lesser, 2001: 154). As negociações se iniciaram em 1894 com Sho Nemoto, enviado especial para assuntos da imigração, que na época representava um país ávido por diminuir seu excedente populacional causado pelas reformas estruturais articuladas durante a Revolução Meiji. Segundo Jeffrey Lesser, ${ }^{5}$ Nemoto, baseando-se no notável crescimento econômico que seu país vinha apresentando nas últimas décadas do século XIX, vendeu a imagem dos imigrantes japoneses como "brancos da Ásia", entretanto com a diferença de figurarem em alguns quesitos como sendo o que os europeus, sobretudo os italianos "anarquistas", não eram: "quietos, trabalhadores e ansiosos por se tornarem brasileiros" (id.; ib.: 154).

A assinatura do Tratado de Amizade, Comércio e Navegação entre Brasil e Japão em 1895 formalizará os trâmites burocráticos seguintes no interesse de ambos os países com a política migratória. Em 1897, o Japão estabelece uma legação em Petrópolis e o Brasil abre uma delegação em Tóquio e um consulado em Yokohama, tendo Henrique Lisboa como ministro plenipotenciário (Lesser, 2001: 157). Empolgado com o progresso do país, relatara em ofício diplomático: "Durante perto de dois meses de permanecer neste país, já pude convencer-me das vantagens que poderão resultar para o Brasil do estabelecimento de uma corrente de emigração japonesa e do fomento do comércio direto... o caráter desse povo é inexcedível para o aperfeiçoamento do trabalho... possui o povo japonês um espírito de iniciativa, invenção e adaptação" (id., ib.) (grifos meus).

A demanda por novos mercados para o café e por braços na lavoura aqui no Brasil e o comprometimento com a subvenção total ou parcial das passagens marítimas pelo governo do

\footnotetext{
${ }^{4}$ Medidas como a proibição do tráfico negreiro em 1850; a Lei do Ventre Livre em 1871; a Lei dos Sexagenários em 1885, e finalmente a abolição da escravatura com a Lei Áurea em 1888. A década de 1890 concentrou o maior volume de entrada de estrangeiros, sobretudo, italianos: mais de um milhão e duzentos mil indivíduos (Carneiro, 1950 apud Seyferth, 1996:49)

${ }^{5}$ Em seu livro, A negociação da identidade nacional: imigrantes, minorias e a luta pela etnicidade no Brasil, Lesser dirige sua análise para três grupos imigratórios não-europeus - chineses, sírio-libaneses e japoneses - e seus esforços nas tentativas de definir seus lugares na identidade nacional. Através de uma extensa pesquisa em inúmeras fontes, que passam por jornais, revistas, livros, relatos do corpo diplomático, debates legislativos, o historiador americano perfila vários discursos em circulação sobre esses grupos do final do século XIX à metade do século XX. Sua obra e de outros pesquisadores como Sakurai, Dezem e Takeuchi serão usadas como fonte para a apresentação de certos discursos do período, pois uma pesquisa direta em arquivos não está no escopo deste trabalho.
} 
Estado de São Paulo coincidiu com as medidas proibitivas e restritivas à imigração japonesa e com o recrudescimento dos movimentos discriminatórios nos diversos países que receberam trabalhadores nipônicos. Em 1907, a assinatura do Acordo de Cavalheiros - Gentleman's Agreement Act - entre os Estados Unidos e Japão, o qual se comprometeria a proibir a saída de seu contingente emigratório para terras americanas, dará o derradeiro estímulo para esse novo empreendimento: a contratação dos japoneses pelo regime de colonato no Brasil.

É interessante notar que, inicialmente, o discurso xenofóbico norte-americano encarnado no "yellow peril" estava atrelado a questões de ordem trabalhista. Chineses e japoneses, na condição de mão-de-obra barata, contratada, sobretudo, para a exploração da costa oeste, representavam um concorrente desleal ao trabalhador nacional. Segundo Rogério Dezem, a Chinese Exclusion Convention - liderada pela American Federal Labor, realizada no Estado da Califórnia em 1901, cujo propósito, autoexplicativo por sinal, consistiu em debater medidas de exclusão dos trabalhadores chineses e também japoneses - concluíra que: “Os japoneses [...] são mais perigosos [...] porque são mais inteligentes e civilizados [...] do que os chineses" (Dezem, 2005: 181). Ainda segundo o autor, o japonês era visto “[...] pelos brancos como grandes concorrentes, pois o espírito de sacrifício de que estavam imbuídos os levava a se sujeitarem a condições extremas, o que redundou na redução de salários de tal forma que os levou muitas vezes a furarem greve para ganhar salários extras" (Ando \& Wakisaka apud Dezem, 2005: 183).

$\mathrm{O}$ discurso antinipônico calcado na ameaça da frugalidade e do trabalho eficiente e organizado do japonês frente ao nacional também foi empregado como argumento para a proibição da imigração "amarela" no Brasil. O microbiólogo e interventor federal na Bahia, Dr. Artur Neiva, conhecido como um dos "três heróis da campanha antinipônica" no país, acreditava que o problema da importação da mão-de-obra japonesa não se encontrava na inferioridade da "raça", mas em sua operosidade que trazia uma concorrência desleal aos trabalhadores nacionais. Em pronunciamento no dia 3 de fevereiro de 1934 na Assembleia Constituinte, proferiu: “ $O s$ nipões são o milagre da organização e nós o prodígio da desorganização" (Takeuchi, 2008:84) (grifos meus).

Retomando a cronologia da imigração, é importante destacar que até 1913, chegaram ao Brasil 3.734 famílias japonesas, ano em que o governo paulista corta os subsídios aos japoneses (Sakurai, 2009: 17). As dívidas com as despesas da viagem, pagas pelo Estado, eram repassadas aos fazendeiros, que posteriormente as deduziam do pagamento aos colonos. Com as duras condições de vida nas fazendas, os conflitos, as fugas e os rompimentos de contrato eram comuns. Diante dessa situação, a partir de 1925, o governo japonês assume a subvenção da emigração e do incentivo a formação de colônias no Brasil por meio das companhias de 
colonização que passam a comprar glebas de terras virgens através de acordos com os governos estaduais, com o intuito de loteá-las e vendê-las aos imigrantes residentes ou aos que ainda estavam por vir.

A expansão de frentes pioneiras na produção de café no Oeste paulista, organizadas em moldes de empresa agrícola, leva muitos imigrantes a tentar a sorte com a compra de pequenas propriedades no entorno dessas novas fazendas e ferrovias abertas (Cardoso, 1998). Por outro lado, os que se mantiveram nas zonas de colonização mais antigas, como Vale do Paraíba, Mogiana, Paulista ou próximos à capital, encontravam-se agora em regiões urbanizadas que favoreciam o comércio e a policultura. Esse processo de mobilidade geográfica para as chamadas "bocas do sertão", definido por Hiroshi Saito como centrífugo e o último, em direção às áreas suburbanas, como centrípeto, garantiu a prosperidade para muitos ex-colonos japoneses (Saito, 1961: 145).

Esse processo de migração interna também se estendeu ao chamado Norte Novo do Paraná, regiões de Londrina e Maringá, a partir dos loteamentos e vendas de terras promovidos pela Companhia Melhoramentos Norte do Paraná. A crise cafeeira de 1929 e a proibição do plantio do café no Estado de São Paulo impulsionaram a vinda de muitas famílias para a região, local de terra fértil e não atingido pela interdição. Sr. Paulo Sasaki, nissei, maringaense de 73 anos, o entrevistado mais idoso desta pesquisa, dá o testemunho das dificuldades enfrentadas nesse processo de desbravamento de novas terras. Sua família chegou ao Brasil em 1914 e, como quase todas que aqui vieram, passou pelo trabalho nas fazendas de café no interior de São Paulo. Em 1940, Sr. Paulo e a família se mudam para um sítio próximo a Arapongas na região Norte do Paraná, "no meio do mato":

\begin{abstract}
"Quer dizer, derrubaram o mato para a gente morar. A maioria dos colonos fez isso naquela época. Com certeza, todas aquelas pessoas que vieram naquela época sofreram bastante. A língua, as tradições, os costumes eram diferentes... Não sei se você viu o filme Gaijin, ${ }^{6}$ mas é aquilo mesmo. Eles realmente sofreram muito. Eu me lembro, porque eu também passei por essa fase. Eu trabalhei na lavoura também. Plantei café, carpi, eu fiz isso aí. Só que hoje, graças a Deus, a colônia japonesa dentro da sociedade brasileira está ótima! Porque você pode ver, a soja, na realidade, naquela época lá em Arapongas, plantavam para fazer $m i s s \bar{o},{ }^{7}$ lembra? E hoje, o que é a soja!! Quem trouxe aquela soja?! Os japoneses é que trouxeram! E hoje é plantado no Brasil inteiro! Quem trouxe isso aí? Japonês! A comida, por exemplo. Hoje, sushi, sashimi, quem come mais? São os brasileiros! E são os japoneses que trouxeram!".
\end{abstract}

\footnotetext{
6 “Gaijin - Caminhos da Liberdade” (1980) é um longa-metragem produzido pela cineasta Tizuka Yamazaki que conta a história de Titoe e de outros imigrantes japoneses no duro processo de adaptação ao país.

7 Missō: ingrediente muito importante da culinária japonesa é uma espécie de pasta produzida a partir da fermentação da soja, arroz, cevada com sal e utilizada principalmente para fazer a sopa de missō, o missōshiro.
} 
Nesse curto testemunho do Sr. Paulo Sasaki é possível encontrar os principais elementos formadores da narrativa sobre os cem anos de presença japonesa e nipo-brasileira no país: o sofrimento dos primeiros imigrantes no processo de adaptação, o trabalho árduo na colonização das terras, a formação das colônias, e finalmente as contribuições dos japoneses para a "cultura brasileira", seja na culinária, seja para o próprio desenvolvimento econômico do país. Sr. Paulo lembra que, somente a partir da década de 1950, a "colônia japonesa começou a se sobressair, comprando lotes de lavoura e hoje nós estamos aí".

O papel dos núcleos agrícolas e a articulação das famílias em cooperativas foram fundamentais para esse destaque no cenário nacional mencionado pelo Sr. Paulo. Esse associativismo, que tinha na Cooperativa Agrícola de Cotia, fundada em 1927, o seu maior modelo, ensejava oportunidades de bons rendimentos a esses imigrantes. Lesser (2009: 91) aponta que em meados da década de 1930, a CAC possuía dois mil cooperados e produzia cerca de 50\% das batatas de São Paulo. Segundo Ruth Cardoso (1998: 51), em 1932, mesmo “detendo 1,8\% da área agrícola do Estado de São Paulo, a colônia japonesa já era responsável por 29,53\% da sua produção total".

PORCENTAGEM DA PRODUÇÃO AGRÍCOLA JAPONESA

NO ESTADO DE SÃO PAULO - 1931-1932

\begin{tabular}{|cc}
\hline Produtos & \% \\
\hline Café & 5 \\
Arroz & 8 \\
\hline Algodão & 46 \\
\hline Feijão & 5 \\
\hline Milho & 4 \\
Batata & 14 \\
Casulos & 57 \\
Chá & 75 \\
Banana & 11 \\
Verduras & 70 \\
Produção Total & $\mathbf{2 9 , 5 3}$ \\
\hline
\end{tabular}

Fonte: Rodrigues de Mello, 1935 apud Cardoso, 1998 
Esse quadro favorável que contava com os subsídios do governo japonês e das companhias de colonização na compra de terras, no auxílio técnico e nos financiamentos alavancarão o fluxo imigratório que acelera até o período da Segunda Guerra, quando a imigração japonesa é proibida no Brasil. Entre 1925 a 1941, quase 150 mil nipônicos entram no país, perfazendo mais de 75\% do total de emigrados antes da Guerra (Cardoso, 1998: 34).

É esse contexto de entrada maciça de japoneses no país, gestada através de uma imigração tutelada por um governo em franca expansão imperialista na Ásia, somada à alta produtividade observada nas colônias agrícolas, que dará os contornos para a consolidação de um discurso antinipônico pautado não somente no "perigo racial" que esses imigrantes traziam para a composição da nação, como também no perigo político de um projeto de invasão nipônica. $^{8}$

Ao visitar algumas colônias japonesas em 1930 e 1931, o membro do Departamento de Imigração de São Paulo, Dr. Álvaro de Oliveira Machado, afirma em documento apresentado por Lesser, que embora “"a população nordestina de origem indígena [...] [fosse] muito semelhante à raça mongólica', a produção per capita dos japoneses era quase cinco vezes maior que a dos 'brasileiros', colocando em desvantagem a mão-de-obra nacional e a de outros grupos imigrantes". Oliveira Machado ficara impressionado com o que viu e temia "um plano secreto de expansão e de infiltração" (Lesser, 2009: 90-91).

De acordo com o historiador (2001: 181), o parecer do conselho da Sociedade Geográfica do Rio de Janeiro, datado de 1923, condenava o " "preconceito de raça”, endossando com entusiasmo a 'imigração amarela', por suas 'conhecidas qualidades de... industriosidade, disciplina, asseio, respeito pela lei e pela ordem e inteligência". Ainda segundo Lesser, a ideia de que os imigrantes japoneses estavam criando o "país do futuro" que os brasileiros não eram capazes de fazer, levou um observador das forças armadas norte-americanas a opinar que "um japonês e sua família podem produzir anualmente, a partir de um determinado lote de terra, dez vezes mais que o nativo descuidado, preguiçoso e imerme, e sua família” (Lesser, 2001: 166-67) (grifos meus).

Talvez seja possível inferir que esses dois pareceres emitidos, nas décadas de 1920 e 1930, estabelecendo uma diferença entre a ética de trabalho japonesa e a nativa estejam balizados por certa "lógica da malandragem" da última. Como defende Lilia Schwarcz (1995a: 56-59), a condição "mestiça" do país, depois de recuperada como uma especificidade positiva local nos anos de 1930 é apropriada como representação oficial da nação, figurando como tema

\footnotetext{
${ }^{8}$ Uma reflexão um pouco mais detalhada sobre o período está reservada para o segundo capítulo.
} 
central das políticas culturais do Estado Novo. Feijoada, samba e capoeira são desafricanizados no sentido de serem originalmente considerados criações de pretos, escravos e mestiços - e são transformados em ícones da identidade nacional. Segundo a autora, a figura do malandro, com sua ginga e "jeitinho brasileiro", personificado na imagem irreverente do personagem da Disney Zé Carioca, avesso ao trabalho regular e afeito a expedientes não-oficiais com o intuito de "se dar bem", também compõe esse imaginário da nação:

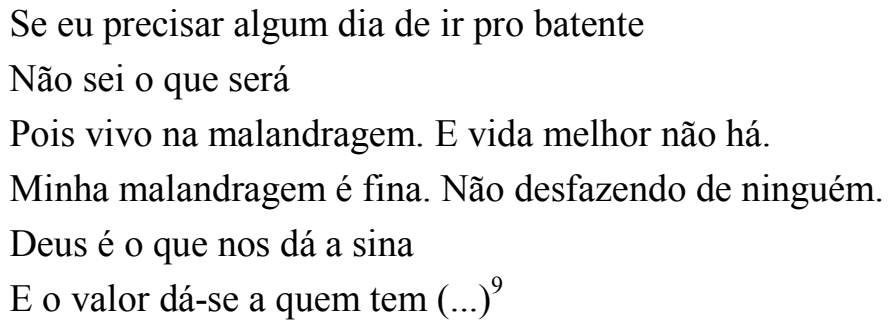

Nas entrevistas realizadas observei que as pessoas não faziam ou pelo menos buscavam não tecer comentários qualificando éticas de trabalho supostamente diferentes: a "japonesa" e a brasileira. A maioria acreditava que havia uma imagem de esforço no trabalho associada aos nikkeis, muitos se identificavam com a mesma, mas somente alguns estabeleceram diferenças com relação aos brasileiros não-nikkeis. Em duas ocasiões pude notar um discurso em que essa demarcação foi assumida.

Após a apresentação de uma comunicação em um evento cientifico, conversava com uma estudante que também havia apresentado um trabalho no mesmo dia. A moça que chamarei aqui de Márcia, não-descendente de japoneses, falava sobre sua dentista, nikkei. Pelo tom íntimo com que narrava, parecia ser também sua amiga. Márcia ficara impressionada com o pai da dentista, um senhor que no passado ocupava um cargo de direção da antiga empresa de energia elétrica Light e que hoje, aposentado, ajuda a filha consertando coisas no consultório, fazendo limpeza, varrendo o chão. Contou-me que os filhos desse senhor são todas pessoas bem sucedidas, sendo que alguns moram fora do país. Admirada com o fato de que ele fosse uma pessoa que mesmo tendo sido executivo no passado, varresse o chão da calçada do consultório da filha, Márcia disse: "Brasileiros não valorizam, desprezam esse tipo de serviço. Japonês não. Japonês é organizado, gosta das coisas certinho".

A entrevistada de Maringá-PR, Lúcia Miyamoto, nissei, 46 anos acredita que essa humildade apresentada por pessoas bem sucedidas permanece viva somente com a primeira

\footnotetext{
${ }^{9}$ Letra de "O que será de mim”, Francisco Alves, Ismael Silva e Nilton Santos, 1931 citada por Schwarcz (1995a:
} 58). 
geração de imigrantes, aquela que diante de condições precárias de vida, batalhou para conquistar o sucesso profissional. ${ }^{10}$ Já os descendentes destas pessoas não teriam a mesma disposição para encarar um trabalho braçal com o mesmo sentimento de dignidade. Dá exemplos de japoneses que, não obstante conseguirem erguer um patrimônio na cidade, atuam como voluntários nos eventos promovidos pela Associação Cultural e Esportiva de Maringá, a ACEMA:

"Então, esse pessoal que é mais antigo... as batchans e ditchans ${ }^{11}$ que trabalharam muito são
pessoas muito mais humildes. Sabe, aquelas pessoas que colocam o avental e vão servir uma
mesa, que vão cortar (verduras) e vão lavar uma louça. A geração nova é a que ficou metida!
Que só usufrui do dinheiro que os velhos ganharam! E hoje, eles estão com o narizão lá em
cima, porque podem andar de carrão, ter uma 'casona', fazer viagens para o exterior! Coisa
que ditchan e batchan, eles só trabalharam! E são pessoas humildes, muito bacanas, que você
até admira de ver a disposição que eles têm de trabalhar e de servir as pessoas, porque eu acho
uma coisa muito bonita é servir alguém! Uma coisa que eu vejo na ACEMA de positivo, são
aquelas grandes festas em que você vê pessoas ali que são muito ricas e que vão lá servir uma
pessoa que está ali, paga para comer, mas ele vai ali servir! Ele não tem nenhum orgulho de
falar, 'ah, vou servir uma mesa, ser garçom!'. Então, vai lá e serve a pessoa. Isso eu admiro. É
uma coisa que eu vi lá dentro que eu admirei. Agora a geração nova é uma geração muito
mais assim... muito mais fútil mesmo".

Tive o privilégio de realizar essa entrevista com Lúcia e com seu filho Leonardo ao mesmo tempo. O objetivo era identificar como as clivagens geracionais se interpõe na relação com esse imaginário sobre os nikkeis. Assim que a mãe terminou de falar, Leonardo lembra-se da "história da feira", ao que Lúcia confirma ter sido uma cena que presenciara e que havia deixado-a "chateada". Contou-me que nesta feira trabalhava uma família que vendia ovos: a mãe, uma obassan ${ }^{12}$ já com certa idade, o filho e a nora. Enquanto os dois primeiros trabalhavam,

"A nora toda bonitinha, com barriguinha de fora ali, só ali... com aquela cara de 'alface'! Ali do lado e cheio de gente, cliente que veio comprar, e nem para abrir o saquinho e colocar doze ovos lá dentro. Porque tem doze furos ali é só colocar doze!! A pessoa escolhe. Mas nem para isso. Ainda falei para o Léo, 'poxa, ovo é R\$ 2,50! É fácil de fazer a conta, né?'. Nem isso!”.

Até esse momento, achei que a indignação de Lúcia era com a nova geração de descendentes que segundo ela, já não dava tanto valor ao trabalho. Mas ela complementa:

\footnotetext{
${ }^{10}$ Lúcia e o marido enfrentaram dificuldades financeiras no passado, e hoje são empresários, donos de uma fábrica de sembei, biscoito japonês, cuja massa assemelha-se ao "biscoito da sorte" chinês. A história da família será contada com mais detalhes no capítulo 2 .

${ }^{11}$ Ditchan: termo japonês para avô. Batchan: Avó. Designativos de parentesco utilizados pela maioria dos nisseis e sanseis para se referirem aos pais de seus pais. Como o Brasil é um país que recebeu grandes levas imigratórias, é comum encontrar descendentes de estrangeiros chamando os antepassados pelos termos estrangeiros nativos, como nonno (avô) e nonna (avó), no caso dos italianos.

${ }^{12}$ Obassan: senhora.
} 
“Então, acho assim... essa 'mistura' também... Tem pessoas que acham que é muito fácil catar um japonês bobo...". Percebi uma certa cautela na tentativa em não parecer preconceituosa, perceptível na escolha de suas palavras, nas pausas, no seu tom de voz. Quando contou a história da feira parecia revoltada e agora falava como se medisse as palavras. Talvez não fosse cautela, mas uma dúvida, afinal ela estava qualificando negativamente a miscigenação:

\begin{abstract}
"Eu acho, né? Não sei se eu estou certa ou estou errada... Mas assim, eu acho que a pessoa... a 'mistura' ali... Depende muito da pessoa, mas tem pessoas que não acrescentam mesmo! Que não fazem a diferença. Então, é aquela história... tem a ideia de que o japonês é bobo. Por que fica ali, poxa? Vai fazer o que ali então? Não sabia que ele vendia ovo?! É por isso que eu acho que brasileiro faz japonês de bobo [risos]".
\end{abstract}

Lúcia conclui que "japonês não tem vergonha de trabalhar". Contou-me que, certa vez, fazia uma entrega de sembei em uma loja, enquanto outra senhora nikkei fazia entrega de bentō. ${ }^{13}$ Quando a observava indo embora, falou para o filho:

\begin{abstract}
“"Olha aí, Leonardo! A mulher está ali entregando bentō, mas olha o carro que ela vai embora, ela vai embora com um Civic!'. Então, tem muitos que não têm orgulho... Japonês geralmente não têm vergonha de trabalhar. Você vê pessoas assim, todas metidonas, mas realmente, trabalhadores, na maioria, eles são. São trabalhadores! Não tem vergonha. Agora vai falar para um brasileiro, ás vezes, 'vai lá varrer a calçada', se você tem loja... Eles acham humilhação. Eles não gostam disso. Eles acham que não é serviço pra eles. 'Vai lá catar o lixo, amarrar o lixo'. Não faz entendeu? Então, eu acho que essa é a grande diferença. O oriental, eu não sei se isso é cultura, ou se isso é... o que que é... Mas eles assim, na maioria das vezes não tem vergonha de trabalhar. Não acham humilhante trabalhar. Agora têm muitos eu acho que acham. Acho que a moça deve achar feio ficar vendendo ovo na feira, né? Ainda mais na feira! Que tem um monte de gente! Catando uma bandeja de ovo, onde já se viu, né? O ganha-pão é tirado dali e garanto que essas pessoas ganham muito dinheiro, ralam muito, mas ganham dinheiro! Então, eu acho que há diferença aí, né?".
\end{abstract}

Lúcia diz que os japoneses e seus descendentes conquistaram um espaço na sociedade e são muito mais respeitados do que antigamente. "O conceito de que o japonês é bobo melhorou", eles não são mais aqueles "agricultores idiotas" que vieram para cá e foram enganados, como os avós de seu marido que compraram terras alagadas aqui no Brasil. É interessante observar a semelhança nos exemplos dados por Lúcia e por Márcia e na conclusão que ambas chegaram: "Os japoneses não têm vergonha de trabalhar". Vendendo ovos na feira, andando de Honda Civic ou sendo executivo de uma empresa, esses nikkeis, sobretudo, os isseis, não acham que pegar em uma vassoura seja uma função que rebaixe o indivíduo.

\footnotetext{
${ }^{13}$ Obentō ou bentō é uma espécie de marmita servida em uma bandeja, geralmente composta por arroz (sushi ou oniguiri), carne ou peixe, legumes cozidos e conserva. Para os japoneses, a preparação do bentō é considerada também uma arte em compor pratos esteticamente aprazíveis aos olhos. Essa visão artística na preparação dos alimentos se estende ao domínio da culinária japonesa de modo geral.
} 
Leonardo Miyamoto, filho de Lúcia, de 19 anos, concorda que a geração de seus pais e avós seja trabalhadora e honesta, mas acredita que esses valores não são compartilhados pelos jovens de sua geração. Dá o exemplo de sua amiga "mestiça", cujo objetivo maior na vida é casar com o namorado rico: "Depende da pessoa, né? Mas tem muita gente que não leva isso. Tem os exemplos em casa, mas só fica folgando. Então, tem muita gente que não assimilou o objetivo de trabalhar e ser honesto na vida". Pelas entrevistas e conversas informais travadas com jovens nikkeis entre 19 e 25 anos, pude perceber que a maioria compartilha da opinião de Leonardo. Reconhecem e vêem com admiração os esforços das gerações anteriores em prover melhores condições de vida aos descendentes, mas sentem que esses dois valores, trabalho árduo e honestidade, pouco se verificam nas gerações sansei (terceira) e yonsei (quarta).

Chama a atenção na fala de Lúcia o modo como ela modula seu discurso marcando a diferença entre "japoneses" e "brasileiros" no universo do trabalho, agenciando uma espécie de ethos, que ela "não sabe se é cultura ou o que é", que explique porque a grande maioria dos nikkeis, especialmente isseis e nisseis, não "acha humilhante trabalhar" ou pelo menos não tem vergonha de fazer determinados tipos de serviços. Além disso, destaca-se em sua fala a força com que preconceitos e construções sobre o "outro" podem ser agenciados nos processos de construção identitária.

Com efeito, é importante salientar que o trabalho de campo indicou caminhos e questões importantes que "extravasavam" a esfera do imaginário discursivo sobre os nikkeis. Não obstante a pesquisa tomar como foco a relação dos sujeitos com essa trama imaginária, a "cultura japonesa" se mostrou um dispositivo fundamental na modulação do discurso identitário. Todavia, faz-se necessário frisar que este trabalho não tem a pretensão de empreender algo como uma arqueologia dos valores e costumes da chamada "cultura japonesa", buscando as raízes de práticas que muitas vezes remontam às bases religiosas do budismo, do confucionismo ou xintoísmo ou à história política do Japão. Entende-se "cultura japonesa” aqui a partir dos significados atribuídos à mesma pelos interlocutores da pesquisa. $\mathrm{O}$ capítulo 3 dedicar-se-á a explorar brevemente alguns desses sentidos, como os valores de disciplina, educação, honestidade e respeito à família.

Para além de um "ethos" de trabalho que poderia ter ligações com o princípio do "gambarê" - motivação para alcançar os objetivos através do esforço, perseverança e dignidade e que também se traduziu no trabalho árduo e nos sacrifícios em prol dos filhos (Sakurai, 1993: 59) - é importante não esquecer que não somente os imigrantes japoneses, mas outros grupos estrangeiros que aqui aportaram eram reconhecidos pelas características de produtividade e frugalidade que apresentavam. Conforme matéria do Diário Popular, em março de 1892: 
A classe média está sendo absorvida pelo elemento estrangeiro, pela considerável massa dos que emigraram para aqui e tomaram conta de toda pequena indústria, de todo o pequeno comércio, de toda a pequena propriedade e que, enriquecida porque trabalha muito e gasta pouco, tem amplo e incontestável direito de fazer imposições, em seu exclusivo proveito (Morse apud Fausto, 1998: 21) (grifos meus).

Segundo Boris Fausto, na São Paulo do início do século XX, habitada por portugueses, italianos, espanhóis, japoneses, árabes, judeus e lituanos, sentimentos os mais diversos se impunham na relação entre nacionais e estrangeiros. Os últimos, se de um lado, sentiam certa inveja pela forma como os primeiros se apresentavam, "comportando-se como 'donos da terra'; de outro, nutriam "desprezo pela sua suposta condição física doentia, pela aversão ao trabalho". Afinal, embora de etnias diferentes, partilhavam da mesma convicção: "Todos se consideravam gente devotada ao trabalho, os verdadeiros construtores de uma cidade que ia se convertendo em metrópole" (Fausto, 1998: 26).

\section{O “RESPEITO PELA LEI E PELA ORDEM” E A PRODUÇÃO DE SUBJETIVIDADES}

Interessante notar como o argumento de potencialidade do trabalho do imigrante japonês foi operacionalizado tanto pelos favoráveis, como pelos desfavoráveis a essa imigração. Enquanto os últimos mobilizavam constantemente essa eficiência como justificativa para a concorrência desleal ao trabalhador nacional, além é claro dos argumentos de cunho racialista; os primeiros expressavam sua admiração pela contribuição dos japoneses ao desenvolvimento do país, como atesta a posição do prefeito de Antonina no Paraná, João Ribeiro da Fonseca, em 1926, citada por Jair de Souza Ramos:

Embora o ideal seja a arianização de nossa raça, o japonês é o tipo do trabalhador ideal, pelo espirito de ordem, de iniciativa, de capacidade e de disciplina. Não acredito no chamado "perigo amarelo" dadas as qualidades de ordem e respeito do japonês que acatam as leis e as autoridades locais, jamais as incomodando, de modo que as estatísticas policiais só raramente registram um japonês envolvido, mesmo em simples casos correcionais. Ele é assimilável se não o deixamos isolado. Concordo que do ponto de vista estético, seja elemento que não satisfaça: mas suas grandes qualidades sobrelevam esse defeito e ele nos dá aquilo de que mais necessitamos: o esforço produtivo admirável (SNA, 1926 apud Ramos, 1966: 76) (grifos meus). ${ }^{14}$

\footnotetext{
${ }^{14}$ Embora o autor não faça referência ao contexto de produção desse discurso, acredito que esteja de algum modo relacionado à colônia de Cacatu, próxima ao porto de Antonina, uma das primeiras colônias japonesas no Paraná, formada em 1916.
} 
Esse discurso citado por Ramos figura em um inquérito realizado pela Sociedade Nacional de Agricultura, em 1925, com o intuito de "colher a média de opiniões sobre as controvérsias do projeto" apresentado pelo deputado Fidélis Reis, em 1923, de restrição da imigração japonesa no Brasil. Foram seis mil questionários enviados a institutos de pesquisa, jornais, políticos e associações rurais e comerciais de todo o país. Das 166 respostas obtidas, 92 eram contrárias à entrada desse contingente imigratório, 57 eram favoráveis e 14 foram omissas (Ramos, 1996: 74).

A apreciação do projeto de Reis feita pelo deputado federal do Rio de Janeiro, Oliveira Botelho, em 1924, mostrava um parecer positivo. Ao recolher informações a respeito dos colonos japoneses no Estado de São Paulo, o deputado se convenceu de que a imigração desse povo traria muitos benefícios ao país. ${ }^{15}$ A facilidade no aprendizado do português e a construção e doação de escolas ao Estado eram provas de sua capacidade de "assimilação". Botelho concluiu que os japoneses seriam todos eles "moralizados, bem aceitos em toda parte pelo seu ótimo comportamento”. Segundo Takeuchi (2008a: 61), “em relação à aparência física, o autor concordou que o tipo japonês não era o mais apurado, mas entendeu, como ocorrera com os indígenas, que o cruzamento do brasileiro com o japonês daria bons resultados".

Ramos observou uma lógica na estruturação das posições tomadas, tanto as de concordância como as de discordância com o projeto: a presença de três categorias nativas que balizavam a argumentação; a saber, a eugenia da raça, sua civilização e disponibilidade à assimilação. No discurso pró-japoneses, o autor destaca que embora reconhecida a sua condição eugênica inferior, e esteticamente, "seja elemento que não satisfaça", como sugere o prefeito de Antonina, o imigrante nipônico era recomendável nos quesitos civilização e assimilação. Oriundo de uma nação que despontava como potência na conjuntura mundial, o japonês era visto como "portador de atributos civilizatórios, tais como a disciplina no trabalho, o hábito de poupar e as técnicas produtivas" (Ramos, 1996: 72). Já sua predisposição à assimilação poderia ser notada pelo seu "tipo ordeiro e respeitador das leis e das autoridades" (grifos meus) (id.; ib.: 76).

No contexto do efervescente debate em torno da aprovação da Emenda Miguel Couto, de 1934 , que visava diretamente restringir a imigração nipônica ${ }^{16}$, havia também atores políticos

\footnotetext{
15 Botelho, em parecer à comissão de finanças da Câmara dos deputados, em 1925, recorrendo a números estatísticos, afirmara que nas colônias nipônicas de São Paulo e Minas Gerais, a "produção de arroz crescera em 400\%, a de algodão em 300\%, e a de cana-de-açúcar, em 100\%" (Lesser, 2001: 182).

${ }^{16}$ A Emenda Miguel Couto restringia a corrente imigratória "ao limite de $2 \%$ sobre o número total de seus respectivos nacionais aqui fixados durante os últimos cinquenta anos” (Takeuchi, 2008a: 65). Segundo Takeuchi, tal medida só foi aprovada, porque não atingia os imigrantes europeus. Já os japoneses foram os mais prejudicados,
} 
importantes que se posicionavam favoravelmente à entrada e à permanência dos japoneses no Brasil. O "trabalho árduo" e a "contribuição para o desenvolvimento do país" configuravam os principais argumentos utilizados para justificar tal posição. Cabe citar a de Assis Chautebriand, proprietário dos Diários Associados, que em 1934, ao defender os “perfeitos" imigrantes japoneses, pedia aos adversários que fossem mais cautelosos ou iriam "ferir o orgulho de uma raça que por vinte e cinco anos vem trabalhando para a grandeza do Brasil” (Lesser, 2001: 214) (grifos meus). O presidente da Sociedade Rural Brasileira, Bento de Abreu Sampaio, em discurso proferido na Câmara dos Deputados do Estado de São Paulo, em 1935, declarara:

Conheço como ninguém o valor dos japoneses. Marília, a minha querida cidade, é o maior centro dos japoneses no Brasil. É a gente mais eficiente para o trabalho, educada, culta e sóbria... Durante a noite escura, em que os fazendeiros não podiam pagar regularmente seus colonos, não se viu um colono japonês impaciente ou reclamando. Quanto à raça, não sei se os grandes médicos (os médicos antijaponeses Neiva e Couto) terão razão, porque em Marília existem entre os colonos homens e mulheres bonitos e robustos (id., ib: 220) (grifos meus).

Vale reiterar que a polarização do debate em torno da presença japonesa no país contava com ardorosos defensores e detratores, entre a classe política, empresarial e científica do país. A segunda parte do trabalho, dedicada ao traçado de discursos que qualificaram negativamente os imigrantes japoneses, em paralelo com essa primeira parte em que as atribuições positivas dominam, possibilitará visualizar, mesmo que precariamente, essa tensão. A polarização do debate já era percebida por dois observadores da época, citados por Sakurai:

\footnotetext{
"Japonês é como óleo na água: não se mistura", ou "Inteligência viva, sóbrios, dedicados ao trabalho, disciplinados desde a tenra idade", ou ainda "Os japoneses, como elementos úteis ao trabalho do nosso Estado [São Paulo] têm qualidades que nos obrigam a um trato preferencial" (Crissiuma, 1935 apud Sakurai, 2000: 201).
}

Como acontece com os pareceres acerca do trabalhador nacional, o que, neste quesito, se diz do amarelo, nomeadamente do japonês, é de gerar perplexidade: ele ora é o primor da humanidade, ora é a sua vergonha; é aqui o tipo pacífico, operoso, temente às leis por excelência; é adiante o indivíduo rusguento, apático, velhaco a mais não ser (Heitor da Nóbrega, 1926 apud Sakurai, 2000: 202) (grifos meus).

Como vimos, os discursos do prefeito de Antonina e do fazendeiro Heitor da Nóbrega, ambos datados no ano de 1926, fazem alusão à obediência às leis e ao "espírito de ordem" dos imigrantes japoneses. O primeiro ainda acrescenta que "as estatísticas policiais só raramente registram um japonês envolvido, mesmo em simples casos correcionais". Vários foram os 
discursos que associavam a disciplina no trabalho dos nipônicos com o respeito pela lei e pela ordem.

Pude observar em algumas entrevistas realizadas que esse discurso não somente persiste, mas é também agenciado, como na fala de Yumi Kawamura, 39 anos, da cidade de Astorga. Considera-se nissei, pois seu pai nasceu no Brasil, mas foi registrado no Japão. Nascida em Maringá no Paraná, Yumi participava de várias atividades da associação nipônica da cidade, Associação Cultural e Esportiva de Maringá, a ACEMA. Cursava faculdade de Direito, mas resolveu trancá-la com apenas 19 anos para ir ao Japão a trabalho. Tinha planos de ficar dois anos, ficou doze, tendo voltado definitivamente em 2004, porque estava grávida. Nutre uma grande admiração pelo Japão, “tudo é bom lá no Nihon ${ }^{17}$ ”. É casada com um descendente, também ex-dekassegui, que conheceu em uma de suas visitas ao Brasil. O namoro se firmou no Japão e hoje o filho do casal tem 4 anos. No momento, Yumi faz faculdade de Pedagogia:

\begin{abstract}
"Todo mundo me falava na faculdade, 'nunca vi japonês bêbado, nunca vi japonês na rua fazendo bagunça, é tudo certinho'. Então, elas falavam 'dá para confiar, porque Deus me livre, brasileiro...'. Não os professores, as alunas... Que japonês, você pode andar nos bares que dificilmente você vê alguém bebendo, roubando. É claro que há exceções, mas em números bem menores, né? Se você vai alugar uma casa, com certeza a imobiliária vai dar muito mais crédito para o nihonjin ${ }^{18}$. Não defendendo o nosso lado, mas que é é."

"[...] Mas é por isso que o nihonjin ainda é bem visto, porque ele ainda manteve tudo de certo que aprendeu, não é? Se a gente começasse a beber e a fazer tudo que eles (os "brasileiros") aprontam, eu acho que a credibilidade do nihonjin vai embora".
\end{abstract}

Yumi discorre sobre o conceito de pessoas “ordeiras" que os descendentes transmitem, relatando os comentários das colegas de faculdade. Enfatizando que há exceções, acredita que o pouco envolvimento dos nihonjins com bebidas, drogas e roubos assegura-lhes uma imagem de credibilidade e confiabilidade, com a qual ela se identifica:

\begin{abstract}
"Até demais! Eu sou toda certa! Tudo que você imaginar de nihonjin: não bebo, não fumo, não faço nada.. Aquela imagem de nihonjin! Às vezes, eu não gostaria de ser assim, mas eu sou certinha. Me encaixo no perfil, totalmente, $100 \%$. Por um lado sim, eu acho bom, porque a gente tem disciplina e eu sigo muito a tradição japonesa e quero que meu filho também, entendeu? Porque eu acho bom, mas por outro lado eu não queria ser assim tão rígida e ser tão certinha! Não queria ser certinha! Sou perfeccionista! Não gostaria de ser assim! Muito certo, sabe? Não gosto de dever, não gosto de nada... Me encaixo 100\% nesse perfil"'.
\end{abstract}

Sobre essa suposta sobriedade dos nikkeis, Paulo Sasaki, entrevistado já citado no início do trabalho, compartilha dessa opinião. Nissei, 73 anos, morador da cidade de Maringá,

\footnotetext{
${ }^{17}$ Nihon: Japão.

${ }^{18}$ Japonês. Nihon: Japão/ jin: pessoa.
} 
contador aposentado, atualmente é assessor político de um deputado estadual nikkei do Paraná. Nos "eventos da colônia" em que o deputado não pode estar presente, Sr. Paulo o representa. Ficamos conversando por um longo tempo em uma sala da sede do comitê de assessoria do deputado. ${ }^{19}$ O Sr. Paulo faz parte da ACEMA e da Aliança Cultural Brasil-Japão do Paraná ${ }^{20}$ há mais de 40 anos, tendo sido vice-presidente por três anos da primeira entidade. Tem um nome reconhecido na "comunidade nikkei", pois como ele próprio diz, "conheço o Paraná inteiro e todo mundo me conhece. Seu pai me conhece por causa disso". É digno de nota que meu pai, na época da entrevista, janeiro de 2009, era presidente da Associação Cultural e Esportiva de Astorga (ACEAST). Foi através dele que o contato com Sr. Paulo foi estabelecido.

Em vários momentos da entrevista, o assessor perguntava sobre minha relação com a "cultura" ou "colônia japonesa". Queria saber se eu ou minha família treinávamos o canto de música japonesa, se eu falava japonês, se já tinha ido ao Japão como dekassegui, como era a participação de jovens no nihonjin-kai ${ }^{21}$ de Astorga. Essa curiosidade partiu de várias pessoas, que legitimamente buscavam sondar não só meus interesses e intenções com a pesquisa, mas também minha biografia pessoal. Em que medida ela se cruzava com a trajetória vivida por eles? Percebia que vários depoentes, por mais estranhos que fossem a mim - vale ressaltar que fiz questão de selecionar pessoas que não eram próximas e sim amigas, conhecidas ou parentes de amigos ou parentes meus ${ }^{22}$ - em alguns momentos, identificavam-se comigo e buscavam uma espécie de confirmação ou aprovação para o que diziam, esperando um aceno na cabeça, um sorriso ou até mesmo uma história minha que fosse parecida com a deles. Será possível perceber ao longo do trabalho que as falas vêm carregadas de pronomes na $2^{\mathrm{a}}$. pessoa do plural, "nós, nosso", como as de Yumi: "Não defendendo o nosso lado, mas que é é". Frases do tipo, "você sabe do que eu estou falando", "você já deve ter passado por isso" ou "você sabe como é" permearam a experiência etnográfica desta pesquisa.

\footnotetext{
19 Tentei marcar uma entrevista com o referido deputado, mas não foi possível. Em duas tentativas, fiquei esperando nessa mesma sala durante horas para ser atendida, mas infelizmente não obtive sucesso.

${ }^{20}$ A ACBJ do Paraná (1968) e Liga Desportiva e Cultural Paranaense (1948) fundiram-se em uma única entidade, conhecida como Aliança-Liga do Paraná e agrega atualmente 76 associações nikkeis do Estado, constituindo-se como a principal entidade representativa da "comunidade nikkei" do Paraná. Segundo seu recém criado site, a entidade sem fins lucrativos funciona como uma federação, "definindo as diretrizes de todas as associações para promoção da cultura japonesa e competições esportivas”. A Aliança Cultural Brasil-Japão também possui sede em São Paulo e de acordo com seu site, foi criada em 1956, tendo por finalidade o desenvolvimento do intercâmbio entre Brasil e Japão. Seu fundador e primeiro presidente foi o poeta Guilherme de Almeida. A entidade em São Paulo oferece cursos de língua japonesa, portuguesa, de literatura e artes japonesas, como ikebana, origami, kirigami, o-shiê, washi, shodo.

${ }^{21}$ Nihonjin: japonês. Kai: associação. Associação de japoneses.

${ }^{22}$ Conheci a maior parte dos informantes no mesmo dia em que fiz a entrevista.
} 
Voltando ao Sr. Paulo, quando lhe pergunto se a imagem dos japoneses e seus descendentes na sociedade brasileira é positiva, embalado pelos elogios aos festejos do centenário da imigração japonesa que havia feito no início de nossa conversa, exclama:

"Com certeza é positiva! É um orgulho para a colônia japonesa! Eles ("brasileiros") falam que os municípios cresceram, porque a comunidade japonesa estava presente. Temos que ter orgulho disso! Eu acho que vocês (jovens nikkeis) tem que dar essa continuidade, para que a comunidade sinta orgulho até com 200 anos de imigração, quem sabe!”.

Questionado se acredita que os jovens estão dando essa continuidade. Sr. Paulo abaixa um pouco o tom de voz, agora já menos empolgado:

\begin{abstract}
"Olha, infelizmente... (pausa). Porque hoje a mistura de raças é muito grande. Hoje não se mantém aquela tradição... Só uma cidade como Maringá é que mantém, porque tem uma estrutura muito grande que é a ACEMA. Mas as cidades pequenas infelizmente não têm atividades para os jovens. Maringá tem, Londrina tem. Então, onde tem atividades, mantém-se essa tradição, participando dos eventos da colônia. E onde não tem? Os jovens não participam. A verdade é que com o passar do tempo vai mudar muito...".
\end{abstract}

"E para além das atividades culturais e esportivas das associações, há ainda uma continuidade na questão de valores transmitidos para as novas gerações?”, pergunto em seguida:

"Eu acho que essa parte vai continuar. Se bem que nós temos muita gente malandrinha, hein! [risos]. No Japão você vê os dekasseguis fazendo arte, roubando, essas coisas. Isso existe com certeza! Toda raça tem! Mas infelizmente está avançando muito. Eu acho... Aqui no Paraná ainda não se vê falar muito... muito pouco. Graças a Deus, né! Muito pouco! Tem... mas muito pouco. Acho que realmente nós temos que manter isso na cabeça dos jovens. Ainda bem que hoje os nisseis e sanseis estudam. Eles estudam bastante. Não vão atrás de drogas... Talvez tenha muito drogado, mas acho que é muito pouco com relação aos jovens que existem aqui no Paraná. Eu acho que é o costume e são os pais quem tem que ensinar as crianças. Não pode largar as crianças de qualquer jeito não. Tem que cuidar direitinho, olhar... Apesar de que no mundo de hoje todo mundo faz o que quer, né? Mas acho que a responsabilidade dos jovens da colonia japonesa ainda persiste. Eu acho, né... pelo fato de não ter esse tipo, 'ah, ouvir dizer que japonês estava drogado e roubou'. É muito raro. Tem, mas é muito difícil. Então, eu acho que vai continuar".

Os depoimentos de Yumi e do Sr. Paulo revelam inúmeras questões presentes na pauta de discussões colocadas pela pesquisa. Chama a atenção como nesse momento particular os dois mobilizam categorias diferentes para se referirem aos nikkeis: "nihonjin" e "colônia japonesa". A primeira palavra é formada pelos kanjis $^{23}$, Nihon (Japão) e jin (pessoa), significando que a pessoa referida é japonesa nascida no Japão. Brasileiros, por exemplo, são chamados de burajirujin e norte-americanos de amerikajin. Os estrangeiros são chamados pelos japoneses de

\footnotetext{
${ }^{23}$ Uma dos sistemas de escrita do nihongo, língua japonesa. Além do kanji, há o katakana, hiragana e o rōmaji.
} 
gaijin, sendo gai (fora) e jin (pessoa), incluindo nessa categoria também os nikkeis, descendentes nascidos fora do Japão. Como será possível perceber, mesmo afirmando sua brasilidade, o termo nihonjin é recorrentemente apropriado pelos nipo-descendentes, sobretudo os isseis e nisseis, em uma autorreferência com relação ao restante dos brasileiros, os gaijins. Na fala de Yumi, essa diferenciação é bem marcada. Ela diz se “encaixar totalmente no perfil de 'nihonjin', 100\%”. São termos nativos ressignificados em cada contexto. No Brasil, nihonjin e gaijin, portanto, terão uma conotação diferente daquela originalmente assumida no Japão.

Assim, é importante esclarecer que a categoria analítica nikkei, utilizada nesta pesquisa, não é nativa, mas está sendo conscientemente empregada devido a alguns fatores: primeiramente, por se tratar de uma convenção usada para definir toda pessoa de ascendência japonesa nascida fora do Japão; em segundo lugar, por constituir-se em um termo que possibilita marcar as diferenças entre japoneses e descendentes de japoneses e por fim, para melhor investigar o uso que meus interlocutores fazem dessas categorias, os contextos nos quais emergem, os sentidos a elas atribuídas, etc. Os termos "nipônico", "nipo-brasileiro" e "nipodescendente" também serão empregados. Vale ressaltar que a palavra Japão é um exônimo em português para Nippon ou Nihon, os termos nativos usados para nomear o arquipélago. O antepositivo "nipo", portanto, tem origem nessa palavra japonesa.

Já o termo "colônia japonesa" apresentou na fala do Sr. Paulo conotações diversas. Quando ele afirma que o sucesso na comemoração do centenário da imigração deve ser motivo de orgulho para a colônia/comunidade japonesa, está se referindo aos descendentes de japoneses como um todo. No momento em que discorre a respeito das atividades culturais e esportivas oferecidas pela colônia de Maringá e Londrina, faz menção às entidades nipônicas dessas cidades. O terceiro capítulo é dedicado à investigação dessas duas categorias, "colônia" e "comunidade", tão presentes nos discursos envolvendo os nikkeis. Outro ponto interessante é a mobilização do termo "raça" pelo Sr. Paulo, o que também poderá ser notado em vários relatos ao longo do texto e que merecerá uma análise no segundo capítulo.

A maioria das entrevistas foi realizada nos meses de janeiro, fevereiro e março de 2009. O período de final de janeiro coincidiu com um episódio que vale a pena ser comentado: a prisão de um estuprador que agia nos arredores dos metrôs da zona sul de São Paulo. Tal ato hediondo não chocaria tanto algumas pessoas com as quais conversei, se não fosse por um detalhe: o sobrenome do criminoso. Alexandre Filadelfo Suyama, de 29 anos, usuário de crack e réu confesso de seis estupros era "mestiço", descendente de japoneses. A repercussão na mídia foi grande, pois Suyama foi descoberto devido a um fato peculiar: seu boné. Câmeras de segurança do prédio em que fez sua última vítima gravaram a inscrição de seu apelido no boné 
que usava. Uma busca pelo site de relacionamentos Orkut levou a polícia às fotos e à identificação do estuprador.

Já para alguns nikkeis, com os quais conversei informalmente sobre o fato, o que verdadeiramente lhes chamou a atenção foi a ascendência do criminoso, "Nossa, 'japonês' fazendo isso?”. Pude perceber que por mais que enfatizem que há descendentes criminosos, "malandros", "safados", "fazendo arte", como em toda "raça", contudo casos raros; não conseguem esconder a consternação diante de acontecimentos como esse. A acusação de peculato que recaiu sobre o ex-ministro da secretaria de comunicação do governo Lula, Luiz Gushiken, no caso do mensalão em 2007, também foi paradigmática no que tange a certo abalo na imagem de integridade do nikkei. Como desabafa Júlia Suzuki Bertolli, sansei, 41 anos, de Astorga:

"É tal coisa... Quando você vê um assassinato e vê que é um sobrenome japonês, te chama mais atenção do que um Matos, um Resende... Eu penso assim, porque me sinto assim, né? Porque a gente sempre procura na gente o que a gente tem de melhor. Nós procuramos em outro ser humano o que ele tem de melhor, tá? Na nossa descendência, na nossa raça, a gente também tem que procurar o que há de melhor. Mas na nossa raça também tem bandido, na nossa raça também tem traficante, tem de tudo, mas não aparecem na mídia. Ainda bem, ainda bem... A gente sabe que tem, mas aparecem em menor quantidade. Corrupção... Quando você ouve falar em corrupção e quando passa um japa, é frustrante! É muito mais frustrante que... outro cara, outro descendente. Ele pode ser, como pode não ser. Mas o oriental... parece que mexe mais com os brios da gente, parece que está mexendo com a nossa dignidade enquanto oriental talvez".

Como pensar este depoimento um tanto que passional, diriam alguns talvez, sem levar em consideração a biografia dessa pessoa? Visto isoladamente, seu conteúdo poderia denunciar que se trata supostamente de uma descendente com um vínculo muito enraizado com a "cultura" e/ou "colônia japonesa", como Yumi e Sr. Paulo. Sansei por parte de pai e yonsei por parte de mãe, Júlia inicia nossa conversa, afirmando: "Não tivemos educação japonesa rigorosa. Eles próprios (os pais) não tiveram. Eu não falo o idioma. Aliás, acho que sou mais abrasileirada do que oriental, sabe, com questão de educação...”. Júlia nunca foi ao Japão trabalhar como dekassegui, confidenciou-me que nunca se interessou por homens japoneses, é casada com um não-nikkei "italiano" e também não participa das atividades do nihonjin-kai da cidade. Sobre o esposo que é membro da entidade (ACEAST - Associação Cultural e Esportiva de Astorga) e que participa ajudando nos eventos promocionais, afirma: "Ele é mais oriental do que eu. Eu sou meio largada".

Como se poderá observar, há regularidades nos depoimentos, mas não há modelos indutivos, enquadramento em perfis. A tarefa será atentar para os discursos em jogo, ao mesmo 
tempo em que dados sobre a vida dos sujeitos da pesquisa não se mantenham obscurecidos. $\mathrm{O}$ grande desafio deste trabalho consistirá em entrever no meio de testemunhos tão plurais, de horas de conversas sobre os mais variados assuntos, os elementos que se cruzam, as histórias que se repetem, os dramas comuns que se encenam.

\section{TRABALHO E HONESTIDADE: DUAS FACES DA MESMA MOEDA?}

Como bem sintetiza o comerciante astorguense Cláudio Shimada, sansei, 41 anos: “A visão primeira, primordial que o ocidental tem do japonês é essa: honesto, trabalhador, esforçado. Talvez porque boa parte dela ainda se mantenha íntegra. A gente não vê tanto índice de coisas negativas. Então, ajuda também, ajuda em fatos, né?”. Ele credita essa integridade à educação recebida dos pais. Cláudio acrescenta que a transformação do Japão em potência econômica refletiu positivamente na imagem dos descendentes de japoneses no Brasil: "Existe um respeito maior, um tratar diferente, sutil, mas existe. No subconsciente há essa coisa”.

A honestidade e a integridade foram um dos qualificativos atribuídos aos nikkeis mais apontados pelos meus interlocutores. Para algumas pessoas, como Cláudio Shimada, Júlia Suzuki Bertolli e Daniel Kobayashi essa imagem se encontra atrelada à atividade profissional a que se dedicam: o comércio. Seus testemunhos mostram, com exemplos vivenciados, como sentem as sutilezas desse "tratamento diferenciado".

Cláudio é nascido e criado em Astorga. É formado em Administração pela Universidade Estadual de Londrina e nesta cidade trabalhou no antigo Banco América do Sul, ${ }^{24}$ cuja clientela e corpo de funcionários era na época formado, segundo ele, "emintemente por descendentes de japoneses". Viaja para o Japão como dekassegui e por lá fica durante um período de três anos. Conhece Maria, sua esposa, natural de Mogi das Cruzes-SP, que também trilhou um caminho semelhante ao seu: trabalhou no Banco América do Sul e depois viajou ao Japão a trabalho. Cláudio retorna à Astorga e dedica-se a trabalhar juntamente com o pai na loja de artigos para presentes e utilidades domésticas da família. O casal tem dois filhos, um menino

\footnotetext{
${ }^{24}$ O Banco América do Sul foi fundado em 1940 a partir da iniciativa da companhia de colonização, Bratac Sociedade Colonizadora do Brasil - sua principal acionista. O banco atuava principalmente nas operações de crédito agrícola e industrial para membros da "comunidade japonesa". Em 1941, com a Segunda Guerra, sofre intervenção federal e somente em 1948 a administração é retomada pela antiga diretoria, composta majoritariamente por isseis e nisseis. Em 1998, devido à política do Banco Central de exigir reserva de provisão para créditos de liquidação duvidosa, o Banco América do Sul foi forçado a se associar a outro banco, o Sudameris, que por sua vez passou pelo controle do ABN Amro Real em 2007 e recentemente foi incorporado ao Santander (Toyama, 2009). O Banco Real foi um dos principais patrocinadores dos eventos promovidos no ano do centenário da imigração japonesa. No portal do site, há um link "comunidade nipo-brasileira", criado com vista a atrair, sobretudo, uma clientela que envia grandes remessas de capital do Japão para o Brasil: os dekasseguis.
} 
de 11 e uma garota de 14 anos. Frequentam a ACEAST e atuam como voluntários nas promoções desenvolvidas pela mesma, desde que os filhos se interessaram pela prática de taik $\bar{o}^{25}$. Cláudio também passou a frequentar um templo budista sediado em Maringá, já que Maria era adepta da religião. Indagado se já se sentiu de alguma forma beneficiado com essa "visão primeira que o ocidental tem do japonês", o comerciante afirma:

"Tudo isso é muito sutil. Eu penso que, talvez você não perceba, nós não percebamos, mas
quando você vai no comércio de uma outra cidade e vai soltar um cheque, o grau de
desconfiança talvez de quem está recebendo o cheque, se for um descendente, é menor. Talvez
você não observe isso. Ele vai seguir todos os protocolos, vai pedir telefone, endereço, mas lá
no fundo, no inconsciente dele, ele está fazendo pelo protocolo. Mas eu penso que talvez ele
pense que tenha menos problemas. Agora não chega a ser nada muito, "ah, você é japonês,
não tem problema!'. Hoje em dia, acho que como foi falado, não é todo japonês que é 100\%".

Sobre essa imagem de integridade, a qual, segundo ele, vaga no subconsciente ou inconsciente das pessoas, aliada com a credibilidade no comércio, Cláudio pondera, "Mais importante do que ser japonês, é fazer o dever de casa, tratar bem o cliente, ouvi-lo, respeitá-lo, fazer o trabalho bem feito", até porque "hoje em dia, não é todo japonês que é 100\%”. Já Júlia credita à honestidade e à confiabilidade os principais elementos que traduzem o discurso positivo sobre o nikkei. Elogiando as promoções de jantares realizadas pela ACEAST, e encarando-as como uma forma de "revitalização da cultura", afirma:

\begin{abstract}
"Não sei se você compartilha da minha opinião. Subentende-se que por ser de uma cultura oriental, subentende-se, entre aspas, que 'são boa gente'. Dá uma confiabilidade maior... que não é falsa, que não é de todo falsa. É claro que no meio de frutos bons, tem sempre aqueles que apodrecem, sempre tem! Mas todo evento que é promovido pela raça oriental tem uma confiabilidade maior, pelo menos da minha parte. Eu acredito que por parte dos ocidentais também. Eles põem muita fé na nossa raça".
\end{abstract}

Ela "acredita e constata, com certeza" que a confiabilidade que o seu comércio transmite está diretamente relacionada com o fato de se tratar de um estabelecimento de propriedade de uma família oriental. Júlia é formada em Comunicação Social pela Universidade Estadual de Londrina, mas não exerce a profissão. Talvez sua formação explique a maneira segura e expansiva com a qual se comunica. Já a conhecia de vista, pois sua mãe é amiga de minha mãe e depois desse encontro, sempre que me vê, pergunta sobre o andamento da pesquisa.

\footnotetext{
${ }^{25}$ A entrevista foi realizada na sede da ACEAST, no dia anterior a um jantar oriental promovido na entidade com o objetivo de arrecadar dinheiro para a compra de taikōs, tambores japoneses. Nesse dia, os pais dos praticantes estavam organizando os preparativos da festa, cortando as verduras, arrumando o salão, enquanto, as crianças e jovens ensaiavam para tocarem no dia seguinte. Insisti bastante para que Maria, a esposa de Cláudio, participasse da conversa. Relutante, ela aceitou, mas pouco falou.
} 
Nossa conversa durou algumas horas e foi realizada no escritório de sua relojoaria, empreendimento familiar herdado dos pais e que existe na cidade há quase cinquenta anos.

\begin{abstract}
"Eu já cansei, cansei de atender clientes meus que falam que só compram aqui e são fiéis a nós e não vão comprar em outro lugar, porque eles confiam em família japonesa! Na experiência deles, que conviveram, de vários clientes que conviveram com famílias orientais... e dos elogios que se dão a essa família... Eu tenho um cliente que diz, 'O oriental é muito fechado, mas se ele se torna seu amigo, ele é seu amigo, até debaixo d' água!!'. Então, são coisas assim que fortalecem cada vez mais a imagem que a gente tem. É muito, muito comum, eles chegarem aqui e perguntarem, 'Cadê aquele japonês que trabalhava ali? Não! Porque eu só conserto com ele! Eu não confio meu relógio em mais ninguém que não seja ele!' [tom de voz bastante enfático]. Olham os meninos trocando pilha e ficam olhando meio torto. Por quê? Porque não é o 'japonês' que está trocando! Quantas vezes chegam clientes e dizem, 'Eu quero falar com a 'japonesa'!'. Por quê? Porque a gente sente que é um fator de confiabilidade. E eu tenho certeza que é por tudo de bom que nossa raça proporcionou para os ocidentais. Eu tenho certeza, porque os relatos que eu escuto, sabe, de como eles gostam... Claro que quem não gosta, não fala nada! Mas quem gosta, gosta mesmo! É incondicional! Incondicional... Na minha vida... Acho que a época em que eu menos senti o peso [risos] talvez de ser oriental... foi na minha época de faculdade. Mas sempre teve, antes disso, e depois disso, no próprio mercado de trabalho... Existe uma certa diferença de tratamento sim, tá? Graças a Deus, nós temos uma boa imagem! Eu penso que sempre foi muito positiva. A partir do momento em que a gente foi conquistando os espaços, porque antigamente nós tínhamos o nosso pequeno espaço. A gente era assim, como diz meu cliente, muito fechado! $\mathrm{Na}$ nossa, né! Mas fomos conquistando os espaços e a gente foi se abrindo para os ocidentais também, né? Mas com certeza nós tiramos vantagem dessa imagem boa que nós temos... os orientais".
\end{abstract}

"Então, você acha que os descendentes tiram vantagem dessa imagem, um benefício talvez?", pergunto em seguida.

\begin{abstract}
"Ah, é um reflexo, não é? Um benefício, exatamente! Você plantou aquilo, você está colhendo aquilo! Se você sempre teve uma vida de paz, você vai colher paz no seu futuro! É mais ou menos isso! A gente está colhendo os frutos do que já se produziu lá trás!"
\end{abstract}

Esse relato de Júlia traz uma reflexão rica em detalhes a respeito do que ela mesma denomina "fator de confiabilidade" que envolve os "japoneses" ou "orientais", seja no comércio, - “eu não confio meu relógio em mais ninguém que não seja ele!”; seja nas relações pessoais, "o oriental é muito fechado, mas se ele se torna seu amigo, ele é seu amigo, até debaixo d' água!!; seja na faculdade, - "existe uma certa diferença de tratamento sim, tá? Graças a Deus, nós temos uma boa imagem". Sua fala que foi reproduzida aqui integralmente, sem cortes, marca a diferenciação entre nikkeis e não-nikkeis por meio da chave "oriental" e "ocidental", além de mobilizar o termo "raça japonesa".

O depoimento de Júlia também registra duas temporalidades, a de sua geração e a de seus pais e avós, mas ela o faz agenciando a $2^{\mathrm{a}}$. pessoa do plural, como se construísse os elos de 
uma história comum, "a gente foi conquistando os espaços, porque antigamente nós tínhamos o nosso pequeno espaço. A gente era assim, como diz meu cliente, muito fechado! Na nossa, né! Mas fomos conquistando os espaços e a gente foi se abrindo para os ocidentais". Em outro momento de sua fala, Júlia afirma que a "timidez" e a falta de "entrosamento" da primeira geração cederam lugar a uma "adaptação" à sociedade, pois as responsabilidades, o cuidado com os negócios e o sustento da família sobrevieram e atualmente, "eles não são mais aquelas coisinhas deslocadas, que não cabiam em lugar nenhum. Todos eles têm seu lugar na sociedade". Traçando um paralelo entre a sua geração e a de sua filha, de 18 anos, Júlia conclui que os jovens de hoje não precisaram passar pelo "trauma da adaptação" e nem pela experiência de preconceito como ela vivenciara.

Daniel Kobayashi tem uma trajetória de vida semelhante às de muitos descendentes de sua faixa etária. Sansei, 35 anos, nascido e criado na cidade de Astorga, resolveu ir para o Japão em 1992, sem terminar a faculdade. Lá conheceu sua esposa, Ana e depois de casados, retornam ao Brasil em 2004. O casal tem dois filhos, um garoto de 4 e uma menina de 2 anos. Não conhecia Daniel pessoalmente. Foi novamente meu pai que intermediou esse encontro, pois pedi a ele que me indicasse uma pessoa na faixa dos 30 anos, "perfil" até então ausente na pesquisa. A única informação que detinha era a de que ele e a família eram adeptos da Igreja Messiânica, ${ }^{26}$ são membros da ACEAST, porém não atuam como voluntários nos eventos promovidos. Fui recebida em sua casa e logo que entrei, chamaram-me atenção alguns objetos que eu sabia serem provenientes do Japão, como aqueles grandes relógios que tocam uma música a cada hora que passa. "Ex-dekassegui", logo pensei. A esposa e os filhos de Daniel se encontravam na casa, pois era final da tarde. Adotando a estratégia de conversar com mais de um entrevistado ao mesmo tempo, convidei e insisti para que Ana participasse da conversa, ao que ela não aceitou. Parecia ser bastante tímida.

Depois de confirmada a condição de ex-dekassegui de Daniel, seguiu-se um bate-papo a respeito de sua experiência no Japão. Ele contou-me que no início não sabia ao certo como empregar o dinheiro acumulado em oito anos de trabalho e resolveu, no final, dar continuidade aos negócios da família. O empreendimento erguido pelo avô há 48 anos e levado adiante pelo pai de Daniel, leva o sobrenome da família e era do tipo "secos e molhados", comércio muito

\footnotetext{
${ }^{26}$ Conforme consta em seu site, a Igreja Messiânica foi instituída no Japão em 1935 por Mokiti Okada (MeishuSama) e foi introduzida no Brasil em 1955, e conta atualmente com três milhões de adeptos e simpatizantes. Sua doutrina tem influências do budismo e cristianismo e tem como objetivo maior construir o Paraíso Terrestre, conciliando "ciência material" com "ciência espiritual". A religião é conhecida pela prática do johrei, "processo purificador", que tem como objetivo "eliminar as máculas do espírito" (http://www.messianica.org.br/doutrina.htm Acesso: 27/07/20). A Luz divina é canalizada sobre o corpo da pessoa por meio das mãos de um ministrante, purificando-a de males físicos e espirituais.
} 
comum em cidades pequenas e mais tarde se tornou um mercado, graças aos investimentos do ex-dekassegui. Sobre a imagem do nikkei na sociedade brasileira, Daniel discorre a respeito das atribuições de honestidade, esforço no trabalho e reserva:

\begin{abstract}
"Eu sinto que tem um certo respeito, porque sempre o pessoal mais antigo transmitiu isso para a sociedade brasileira. Um povo trabalhador, honesto. No comércio, quando a gente é cobrado de um cheque ou coisa assim, a gente até brinca, 'Cuidado, que esse cheque aqui não tem fundo'. Na maioria das vezes, usando essa brincadeira com a pessoa, eles dizem, 'Não, onde já se viu! Eu nunca vi um japonês ser caloteiro!' ou coisas assim. Então, essa questão da honestidade está bem estampada na sociedade. Depois só de ver isso, a gente acredita na gente. Dá uma vontade de manter isso, de ser honesto, de estar sempre cumprindo, pagando as contas em dias, ser transparente nesse sentido. Então, eu acho que tem o outro lado de falar que o povo japonês é assim mais reservado e tal. Mas a própria colonia de Astorga, a ACEAST com as festas... o ano passado teve o Imin- $100,{ }^{27}$ então foi bem abrangente. $\mathrm{O}$ povo brasileiro pôde sentir que o povo japonês não é tão fechado assim. Já está bem aberto para miscigenar, para misturar, para mostrar a cultura japonesa. Eu acho que eles estão vendo com bons olhos. Não é mais aquela rigorosidade".
\end{abstract}

A partir de suas experiências profissionais, mais especificamente, no comércio, Cláudio, Júlia e Daniel expuseram como acreditam que os japoneses e seus descendentes são vistos na sociedade brasileira e de como essa imagem afeta suas vidas. A credibilidade, confiabilidade e transparência são atributos que permeiam as narrativas, cujos pontos em comum poderiam ser explicados pelas peculiaridades de uma lógica de mercado local. A cidade de Astorga, com seus quase 26 mil habitantes, reconhecida como município em 1952, conta com a loja de Cláudio, a relojoaria de Júlia e o mercado de Daniel há pelo menos algumas décadas. Esses estabelecimentos de cunho familiar praticamente se desenvolveram junto com a cidade. $\mathrm{O}$ pioneirismo, portanto, também lhes assegura uma imagem positiva já que se constituíram em referências comerciais do município. Cumpre observar que esses empreendimentos se modificaram, passaram por reformas e se modernizaram depois que os filhos assumiram a direção.

Contudo, para além do pioneirismo e das reformas, outros elementos foram apresentados pelos informantes como explicativos para a respeitabilidade de seus comércios: valores transmitidos pelos pais e avós através da educação. Será possível perceber nessas e em outras falas que os sujeitos dessa pesquisa fazem muitas referências ao passado familiar, como assegura Júlia quando diz que as gerações do presente estão "colhendo os frutos" do que foi produzido pelas gerações passadas ou como revela, de forma emocionada, Daniel, que se inspira nas atitudes do pai e do avô como um modelo de vida a ser seguido e transmitido a seus filhos.

\footnotetext{
${ }^{27}$ Imin é o termo japonês para migração/imigração. O Imin-100 foi o nome escolhido no Paraná para nomear as comemorações do centenário da imigração japonesa no Brasil.
} 
Retomando sua fala a respeito da "vontade de manter a questão da honestidade que está bem estampada na sociedade", indago se ele sente existir certa expectativa para agir de acordo com essa imagem positiva do nikkei:

"Como já tem essa coisa pré-montada, eu me espelho muito naquilo. Então, eu procuro ser, dentro desse caráter de honestidade, de estar cumprindo minhas tarefas e ajudar de uma forma geral. Eu tento me enquadrar nisso. E tem a questão das raizes também. Eu vejo assim, o jeito que meu ditchan foi, o jeito que meu pai é. Tem coisas assim que, poxa vida, são tão certas, né? Eles procuram estar sempre dentro da lei. Então, eu falo, eu também tenho que ser sempre assim, para tentar passar para os meus filhos, os meus netos essa qualidade, porque muito se perdeu ao longo do tempo, a nível de caráter, honestidade, de todas as etnias. Mas, assim, devemos tentar buscar esses termos, porque é uma forma de a gente estar bem com a gente mesmo e estar com uma imagem boa para as outras pessoas, para a sociedade".

Um ponto muito revelante a observar é que Daniel indica duas questões diferentes, mas igualmente importantes: a imagem ou discurso sobre os japoneses e seus descendentes, fundamentada na ideia de honestidade e trabalho, que ele considera como uma "coisa prémontada", um estereótipo, mas que o estimula a cumprir suas tarefas de forma correta e transparente; e finalmente, a questão das "raízes", a base, o substrato cultural e emocional, provido pelo pai e avô, que atuaram no seu desenvolvimento, sustentam suas ações e inspiram a educação de seus filhos. Narrativas como as de Daniel e várias outras que se seguirão atentam para elementos que escapam à esfera do discurso e das identificações por meio deste e que são traduzidos em termos como "raízes", "valores", "origens". Nos capítulos 3 e 4, tais questões serão retomadas.

Uma observação que se faz necessária diz respeito às considerações positivas que os informantes fizeram a respeito dos eventos e atividades promovidas pelo nihonjin-kai de Astorga, a ACEAST, na época presidida pelos meus pais. Embora nenhuma questão tenha abordado a gestão da entidade, não se pode descartar a possibilidade de que essas pessoas tenham se sentido um pouco "coagidas" pela própria situação de pesquisa, a tecer elogios à associação, pelo fato da pesquisadora ser filha dos presidentes em exercício. Contudo, é importante destacar que os anos de 2007, 2008 e 2009 foram de muita agitação nas diversas entidades nipo-brasileiras no país, pois os preparativos para as comemorações do centenário da imigração japonesa exigiram grandes esforços das diretorias e de seus membros. A "revitalização" da entidade, comentada por algumas pessoas, foi um fenômeno verificado em várias associações.

Como já adiantei na introdução do trabalho, apesar de meus pais estarem bastante engajados em suas funções, era de conhecimento de todos que os filhos de ambos, incluindo a 
minha pessoa, nunca participaram como membros do Kai, fosse como voluntários nas organizações dos eventos, fosse na prática de atividades culturais, como o karaokê e taikō, por exemplo. A maioria de seus filiados apenas me conhecia de vista, e foi somente depois, com o desenvolvimento da pesquisa e com algumas observações de campo na ACEAST, é que aos poucos as pessoas foram se familiarizando comigo e com as minhas intenções como pesquisadora.

\section{“EU VOU LÁ, PORQUE É JAPONÊS”: O FOLCLORE}

Diante dos depoimentos de Júlia, Cláudio e Daniel, inferir que a imagem de trabalho e honestidade que estes interlocutores conferem a seus estabelecimentos seja explicada somente pela clivagem espacial, ou seja, como decorrente exclusivamente da dinâmica do comércio local é um raciocínio unilateral. A paisagista Sueli Takahashi, de São Paulo, dá um testemunho que se assemelha em muitos aspectos aos dos paranaenses.

Sueli é nissei, tem 52 anos e é natural de Poá, região metropolitana de São Paulo. Afirma que devido a pouca convivência com japoneses e seus descendentes nesta região, não tinha muitos laços com os referenciais da "cultura japonesa". Sueli conta que sua mãe "levou um sabão" da professora dos dois filhos mais velhos quando estes estavam no primeiro ano da escola brasileira, pois não sabiam se comunicar em português e ficavam sem entender nada na sala de aula. A partir desse momento, sua mãe concluiu, "Já que estamos aqui no Brasil, temos que saber o português!", e assim evitou-se a falar o japonês em casa. O pouco contato com outros descendentes, segundo ela, também facilitou a não preservação da língua e de hábitos japoneses dentro de casa.

Após a mudança para o centro de São Paulo e, sobretudo, depois que passa a trabalhar na Cooperativa Agrícola de Cotia como assistente social em 1981, acaba por desenvolver um estreito contato com os cooperados japoneses e descendentes, alguns dos quais não sabiam falar o português. Conta que teve que aprender "na marra algumas coisas", pois tinha dificuldade até para memorizar os nomes japoneses, devido à estranheza do som e pronúncia. Com o tempo, entretanto, essa situação muda:

"Mas depois eu me identifiquei tanto! [...] Aí fui descobrindo, 'nossa eu sou japonesa mesmo!'. Sabe assim? Em termos de gosto, cultura, tudo isso. Foi aí que eu comecei a valorizar, né? Porque antes, não que eu não valorizasse, mas como eu não tinha contato... Também em casa quase não se falava japonês... Mas depois a gente vê como a raiz é uma coisa forte... Então, a gente vai se descobrindo, né?”. 
Ao se casar, com um descendente, muda-se para uma região da cidade com alta concentração de nikkeis e intensa atividade nas associações culturais, Parelheiros. A manutenção da "tradição" é tão forte que Sueli atesta que, mesmo conhecendo muitas "coisas da cultura" no tempo em que trabalhava na CAC, viu "tipos de manifestações, danças, festas ali que a maioria do pessoal da cidade desconhece". ${ }^{28}$ Ela já não sabe se os jovens darão "continuidade", mas acha que "no tempo que a gente tem para preservar, tem mais que preservar mesmo! Acho que cada um tem sua identidade. Não pode querer imitar os outros. A gente tem a cara de nihonjin, então tem mais é que valorizar o que a gente é, né?’. Ao discorrer sobre a imagem do nikkei perante a sociedade brasileira, Sueli argumenta:

\begin{abstract}
“Se você pega um médico 'japonês', um dentista 'japonês'... Na Medicina, o 'japonês' é hipervalorizado, principalmente na Medicina. Não tem para ninguém, né? [...] Acho que eles se aplicam mais. Também tem isso, de acharem que o 'japonês' é muito disciplinado, muito estudioso, inteligente. Esse negócio de inteligente não tem nada a ver [risos]. É porque é esforçado. Então... mas eu acho que é mais por isso. Eu acho que vai mais atrás, vai mais a fundo na questão. Isso com certeza! Eu sei que é, eu sei que é assim... E mesmo até na minha própria profissão... Mas é mesmo! [risos]. Não é para querer me vangloriar não, mas é verdade! O pessoal vê... vai passar o trabalho para mim ou para uma outra pessoa não descendente... Ah, claro, vai saber que eu sei mais do que a outra pessoa. Eu posso até não saber, mas eles acham que eu sei mais pelo fato de ser descendente [risos]. Então, tem um lado bom, tem um lado muito bom, é claro [risos] [...] Eu mesma quando vou procurar um profissional, que é na área médica, até talvez em engenharia ou alguma coisa assim... Eu acho que a gente... confia. A gente acha que ele é o cara que está mais preparado, porque tenta se aprofundar mais, né? Vai mais a fundo na questão. Eu acho que, em geral, o pessoal pensa dessa forma". ${ }^{29}$
\end{abstract}

Sueli sente que sua ascendência traz vantagens para o seu ofício como paisagista, pois passa uma imagem de confiança e de ser depositária de um conhecimento maior que ela pode até não ter. Foi a única entrevistada que estabeleceu a associação da competência na área de Medicina com a ascendência japonesa e que afirmou procurar profissionais nikkeis nessa área. Júlia Suzuki Bertolli, por exemplo, não pensa como Sueli, mas acredita que o sobrenome japonês pode ter um significado diferente, sobretudo para as pessoas mais velhas, por inspirar confiabilidade:

\footnotetext{
${ }^{28}$ Sueli acredita que a diferença na intensidade das atividades nas diversas associações na cidade de São Paulo está relacionada à falta de opções de lazer em algumas regiões. Segundo ela, "quem mora, por exemplo, no bairro da Saúde ou qualquer outro bairro mais próximo do centro, tem muito mais opção. Não vai querer ficar só entre eles, né?"

${ }^{29}$ Sueli ressalta que essa imagem positiva depende da área de atuação profissional e da questão geracional. Ela dá o exemplo da Arquitetura e das Artes, ao afirmar que é mais difícil encontrar nikkeis mais criativos nessas áreas. Sueli complementa que essa ausência é notada na geração mais velha, que possui raras exceções como a artista plástica Tomie Ohtake.
} 
“Ah, mas isso já é lenda, né? Essa história de que é médico, é japonês! É lenda! Eu não me atenho muito a esse detalhe, tá? Isso é uma coisa de vivência. Os mais antigos respeitam muito médico japonês, você está entendendo? O sobrenome japonês traz respeito sim! Eu não nego!”.

Instada por essas questões, resolvi fazer uma entrevista com um médico nikkei. Tinha o interesse em saber se realmente ainda existiam muitas pessoas que o procuravam com base nesse "critério". Dr. Luís Yamamoto, nissei, médico de Londrina-PR, docente e coordenador do curso de Medicina da Universidade Estadual de Londrina acredita que isso é "puro folclore": "É aquilo que eu falo para os meus alunos: "Não é porque tem cara de 'japonês' que é bom. Tem paciente que pensa assim, 'Eu vou lá, porque é japonês'. Mas não funciona não! Tem muito cara ruim!”.

Nossa conversa foi realizada no consultório que ele possui em Astorga, depois da última consulta agendada do dia. Era um sábado à tarde, sua secretária me ligou e fui imediatamente atendida. Não o conhecia pessoalmente, contudo ele se mostrou muito solícito em contribuir para a pesquisa. Falei sobre a temática do projeto e da minha motivação em entrevistálo: as altas taxas de aprovação de nikkeis nos cursos de Medicina, além do relato já citado de Sueli Takahashi. Dr. Luís utilizou sua experiência como professor para desconstruir a imagem que associa o médico descendente de japoneses a uma suposta competência ou credibilidade:

"Então, a qualidade... Não é porque é nipônico, porque é descendente que deve ser bom não, viu? Isso ai é muito relativo. Passar no vestibular é uma coisa, ser bom profissional é outra. Passar no vestibular é questão de disciplina, né? Você vai bem, você passa. Mas a maioria que você vê lá não é essas coisas não, viu? Isso aí [a imagem] é uma coisa folclórica na verdade. Isso é coisa do passado! Aquilo que eu falo para eles, 'Vocês, de garantias vocês não tem nada!'. Eu ferro eles! [risos]. Então, antigamente japonês era sinônimo de competência e credibilidade, né? Hoje em dia não. Tem muito japonês 'tabajara' aí, sabe? [risos]. É um ou outro que é bom mesmo. Dentro de um bolo, se você tem uma amostragem x, ali você vai ter alguém que preste, isso você vai ter que ter...”.

A perda de valores, as mudanças geracionais e a miscigenação são os fatores apontados pelo médico para a não correspondência entre imagem e realidade:

“Isso aí independe da raça, tá? Já foi aquela época em que o 'japonês' era realmente considerado, tinha credibilidade. Hoje em dia, você pode ver em todas as áreas, seja aqui, ou seja, como dekassegui, seja como médico... tem muita tranqueira, muita tranqueira, muito bagulho. Não tem aquela questão ética mais, não tem mais aquela questão cultural. Então, já se miscigenou tanto, se abrasileirou tanto o negócio que já se perdeu certo tipo de coisa. Mesmo no Japão também. A japonesada é tranqueira, né? A sociedade moderna japonesa também é muito tranqueira, já perdeu seus valores. Não se tem mais os valores que se tinha antigamente". 
Dr. Luís, que morou e fez especialização no Japão por um ano e meio, acredita que a "perda das raízes" também se verifica no país do sol nascente: "a tendência agora é decair". Segundo ele, todo o esforço de superação do pós-guerra da geração anterior, a "mentalidade" em reconstruir a nação, a "cultura de esforço e competência" acabou com a "ocidentalização/americanização" do Japão. Segundo ele, no Brasil, esse processo segue o mesmo curso:

"Hoje em dia essa questão da tradição está acabando. As coisas vão se diluindo, se dispersando e você não tem a preservação da sua cultura. O negócio vai desaparecendo, porque com 'abrasileiração' da cultura, a tendência é cada vez mais diluir e acabar. Até o japonês que é japonês, não é tão japonês assim. É diferente. Não tem nada a ver com aquele japonês de antigamente que veio aqui para o Brasil. Não tem nada a ver, nada a ver. Eu morei lá, fiz minha pós-graduação lá e olha não tem nada a ver. Influência totalmente americana... são totalmente americanizados. Dependência americana total, não tem seus valores".

É interessante observar como sua análise é balizada por um conceito de "cultura japonesa" que tem um sentido de "cultura autêntica original", como se as mudanças históricas e os contatos com outros povos tivessem o efeito de "diluir" totalmente os alicerces e o conteúdo da mesma. Fato observável no próprio termo que o médico emprega para definir muitos "japoneses", "tabajara" - etnônimo que ganhou um significativo pejorativo no senso comum, ao fazer referência a coisas falsas, não originais ou de má qualidade. Sua fala, é importante frisar, não é isolada, muito pelo contrário, tem ressonância em vários discursos, inclusive acadêmicos.

Segundo Elisa Sasaki, o Nihonjinron, por exemplo, traduzido como "teorias da japonicidade", é um gênero literário e acadêmico produzido pelas Ciências Humanas do Japão, que toma como foco estudos sobre a identidade cultural e nacional japonesa, buscando enfatizar as singularidades, "essências" do "ser japonês". O argumento central dessa produção discursiva baseia-se na apresentação de um Japão homogêneo, no que tange à desconsideração de suas diferenciações internas e da "tendência pronunciada de negar pontos em que a experiência japonesa apresenta interseção com as experiências compartilhadas por outras pessoas e sociedades" (Sasaki, 2009: 112). A partir dessa discussão, vale ressaltar que esta dissertação, se por um lado, toma como desafio refletir sobre as fronteiras fluidas e o dinamismo que envolvem o conceito de "cultura japonesa", assim como o de identidade nikkei; de outro, dedica atenção às formas de agenciamento, muitas vezes essencializadas, desses termos pelos sujeitos.

Comentei com Dr. Luís que sua opinião em diversos aspectos divergia bastante daquelas que eu colhera até o momento, pois apesar de vários entrevistados acharem que muitos valores tinham se "perdido" com o avançar das gerações; o respeito à família, a honestidade e o 
esforço foram mencionados como elementos que, em alguma medida, ainda não estavam completamente ausentes da experiência de vida dessas pessoas. O médico, então, enfatiza o seu ponto de vista relativista:

"Isso é questão de berço. É questão de berço! Depende da família. Então, isso é muito relativo. Depende da educação que o indivíduo tem na família, porque não é só porque tem descendência nipônica aí que vai ser... Depende da educação".

Retomando sua fala sobre a imagem do "bom médico japonês" que ficou no passado, indago-lhe se, na época da faculdade, ele sentira que havia essa associação de ascendência com qualidade no serviço prestado. Dr. Luís, que aparenta ter cerca de 45 anos, afirma:

\begin{abstract}
"Naquela época ainda era, faz quase uns 20 anos. Mas agora nem tanto, né? Mas mesmo assim, ainda passa bastante descendente. Passa bastante... Na UEL, agora tem esse negócio de cotas, para 'raça' negra, para escola pública... Mas é aquela coisa, ainda não está totalmente perdido o negócio [risos]. Ainda tem uma credibilidade, né? Ainda tem uma credibilidade".
\end{abstract}

O médico conta, então, que em média, a cada 80 alunos ingressantes no curso de Medicina da universidade, 25 são descendentes de japoneses, cerca de 30\%. Embora Londrina seja uma cidade com grande concentração de nikkeis, a taxa é bastante alta. "É, querendo ou não querendo, japonês ainda é esforçado, né? É esforçado. Não quer dizer que vai ser o mais inteligente. Você vê que é esforçado, tem disciplina", conclui o médico. "Como descendente, você não se identifica com a imagem de credibilidade?" - pergunto em seguida:

"Eu tenho minha formação, minha educação é a educação tradicional, né? É aquela coisa, eu sou 'japonês', eu sou' japonês'. Eu tenho disciplina, tudo. É aquela coisa, eu sou dos antigos. Agora dos meus alunos, eu não posso falar. Dos meus alunos eu não posso falar isso... Você vê o esforçado e você vê o desleixado, né? Então, o desleixado, você larga mão. Esses aí não vão ser nada mesmo. Agora a maioria dos descendentes ainda se esforça. Pode não estudar muito, mas se esforça, né? Na parte do esforço, a dedicação compensa. Agora a parte de estudar, estudar não é essas coisas não...".

Dr. Luís, ao mesmo tempo em que busca reforçar que a educação é um valor cultivado pela família que não tem relação com a origem cultural do sujeito, considera que a determinação e a disciplina ainda se constituem em valores partilhados pela maioria dos nikkeis. Todavia, esse desempenho ou a suposta imagem construída sobre esse desempenho não redundam em vantagens para o profissional descendente:

"O que você conseguiu é consequência do seu esforço! Não tem nada a ver com você ser descendente ou não descendente. Isso aí não tem benefício nenhum! Você não tem privilégios por ser descendente, isso não existe aqui no Brasil, não existe. [...] Antigamente sim. Eu trabalho com um médico lá em Londrina, é um médico antigo, tradicional, que antigamente 
toda a 'japonesada' ia com ele. Agora não. Pode ver que estão muito diluídas as coisas. Por exemplo, na minha área, (Ginecologia) a mulher não vai procurar só porque é da minha raça, está entendendo? Não vai por isso. Vai pela sua competência, não vai se você é descendente ou não. Isso não quer dizer nada hoje em dia! Isso não influencia em nada na escolha do paciente. Então, não tem vantagem nenhuma! Você tem que mostrar competência".

Ao final da conversa, pergunto ao médico se ser descendente de japoneses tinha algum significado em sua vida. Ele que não possui nenhum vínculo com qualquer entidade nikkei "Eu não sou muito chegado não. $\mathrm{ACEL}^{30}$, essas coisas não tem nada a ver" - afirma com veemência: "Não faz diferença, você não tem vantagem nenhuma em ser nikkei, viu? Falar a verdade, você não tem vantagem nenhuma, nenhuma! Não tem benefício nenhum! O governo te ajuda? Não te ajuda. Você não tem nenhum beneficio em si”. Sobre as comemorações do centenário da imigração japonesa em Rolândia-PR - cidade que recebeu o Príncipe Naruhito, no dia 22 de junho de 2008 - Dr. Luís disse ter sido obrigado a integrar a equipe médica que dava assistência no local e, bastante insatisfeito, disse:

"Perdi um dia inteiro naquele negócio lá! Perdi o dia inteiro naquelas festividades de cem
anos. Não ganhei nada, perdi meu dia. Poderia estar dando plantão e ganhando dinheiro. E eu
lá dando assistência de graça, você está entendendo? E nem recebi um 'obrigado' da
organização! Então, perdi meu tempo [...] Não querem saber quem ajudou e quem não ajudou
depois [...] Não tem porquê. Besteira, né? Porque não é o que você vai ganhar com isso, mas
pelo menos o mínimo de respeito, né? A gente não é estudante, para ficar ali perdendo tempo,
certo? Sem ganhar nada. Mas aquela coisa, só participando, por participar mesmo, porque na
verdade eu não queria, mas fui obrigado a participar por causa do meu amigo que era chefe da
parte médica lá. Perda de tempo. Perdi meu tempo lá. O que me acrescentou? Com a vinda do
Príncipe? Não mudou nada na minha vida". Ao final da entrevista, confusa quanto à sua insistente afirmação e negação de que há uma valorização dos estudos nas famílias de origem japonesa, pergunto se sua trajetória pessoal e seu esforço em construir a carreira tiveram em alguma medida relação com esses valores:

“Agora eu não fujo da regra. Meu negócio é disciplina mesmo! Tudo que eu consegui foi por disciplina e educação. Disciplina, educação e esforço, né? O que você quer, você consegue. Você tem que ir atrás das coisas. 'Japonês' é persistente, né? 'Japonês' é aquele cara persistente, que persevera, que chega lá. Chega lá pelo seu próprio trabalho, pelo seu próprio esforço. Mas a tendência é que ainda que exista... uma boa parte dos 'japoneses' ainda tem isso, mas uma boa parte está se perdendo".

Dr. Luís julga-se um "japonês, japonês das antigas”, por ter tido uma educação tradicional, embora atribua suas conquistas unicamente ao esforço pessoal. A partir das elevadas

\footnotetext{
${ }^{30}$ Associação Cultural e Esportiva de Londrina.
} 
taxas de aprovação de nikkeis no vestibular de Medicina na UEL, admite que "a maioria ainda se esforça", mas acredita que a "tendência é a coisa ir se diluindo" com a miscigenação.

Os depoimentos do médico e da paisagista Sueli, em suas divergências e concordâncias mostram a dificuldade em se criar "tipologias", quando se trata de uma reflexão sobre os descendentes de japoneses no Brasil. O que se percebe é que as pessoas que participam intensamente de atividades da "colônia", como Sueli, cuja rede de sociabilidade é majoritariamente formada pelos amigos que fez na associação, têm uma preocupação maior na "preservação" de referenciais da "cultura japonesa" pela própria relação de proximidade que desenvolvem com esses referenciais nesses espaços. Contudo, isso também não se apresenta como "regra geral”, pois há pessoas como Júlia, que nunca mantiveram vínculos estreitos com entidades nipo-brasileiras, mas demonstram apreço e preocupação semelhante com esses referenciais.

Em que pese a multiplicidade das narrativas e das trajetórias pessoais aqui brevemente introduzidas, regularidades podem ser apontadas. Dr. Luís, por exemplo, discorda inteiramente da visão que Sueli possui dos médicos descendentes de japoneses considerando-a folclórica, adjetivo empregado no sentido de lenda ou crendice que não condiz com a realidade - "tem muito japonês ‘tabajara' aí.”. Mas ambos mencionam, cada qual ao seu modo, o esforço e a disciplina no trabalho e nos estudos como aspectos importantes da experiência nikkei.

\section{EDUCAÇÃO COMO VALOR}

No contexto da Segunda Guerra Mundial, em que Brasil e Japão se mantiveram em lados opostos no conflito, nos discursos em voga na época, a ênfase nos aspectos negativos da presença japonesa no país foi muito mais acentuada. Em 1946, ano em que se discutia novamente a aprovação de dispositivos constitucionais contra a entrada de imigrantes japoneses, algumas vozes insurgentes despontaram contra a "injusta apreciação de toda colônia japonesa radicada no Brasil", como a do jornalista Wladimir de Toledo Piza, do Correio Paulistano, que em 18 de abril de 1946, argumentava:

Se, porém, é plenamente justificável a revolta contra os sicários estrangeiros, que escolheram nossa terra para a satisfação dos seus instintos primitivos e sanguinários ${ }^{31}$, a extensão desse

\footnotetext{
31 Piza se refere à Shindo Renmei. No contexto da Segunda Guerra Mundial e da instilação da campanha antinipônica no Brasil, alguns japoneses e seus descendentes fundaram sociedades secretas, cujo lema geral residia na lealdade ao Japão e no culto ao Imperador. A mais famosa delas, Shindo Renmei, surgiu em 1945, e sua mais destacada atuação consistiu em pregar a vitória do Japão na Guerra através das ações, recorrentemente violentas, dos kachigumi (vitoristas) contra os makegumi (derrotistas), japoneses considerados pelos primeiros como traidores por acreditarem e aceitarem a derrota do Japão imperial. As atividades da Shindo Renmei,que incluíram ataques e
} 
sentimento a todos os componentes de um grupo humano, ordeiro e trabalhador, disciplinado e obediente, não deixa de ser uma clamorosa injustiça [...] Mas todos eles, ou quase todos, muitos anos passados, ainda se dedicam ao trabalho agrícola. Por esse aspecto, nenhum outro colono é mais vantajoso para o nosso Estado, pois, se temos falta de braços na atualidade, essa falta se faz sentir, preferentemente para o cultivo da terra. [...] Tem mesmo o japonês a preocupação de fazer com que o filho se instrua, nesse particular oferecendo um exemplo sadio e benéfico ao nosso caboclo, rotineiro e renitente ante as vantagens de alfabetização. Se o Estado the oferecer escola brasileira, jamais organiza ensino próprio [...] Totalmente desconhecidos da grande massa brasileira, os japoneses mantiveram-se aos nossos olhos, durante muito tempo, envoltos numa aura de mistério e de lenda. Mas, à proporção que a lenda se desfaz e o mistério desaparece, podemos ver, sem juizos preconcebidos, um povo laborioso e bom, com defeitos e qualidades como todos os demais, mas com grande predominância de excelentes qualidades (CEHIJB, 1993: 298) (grifos meus).

É possível perceber nesse discurso o gérmen para a gradual mudança no imaginário sobre os japoneses e seus descendentes, no que concerne ao arrefecimento do antijaponismo. Contudo a resistência à entrada de imigrantes dessa origem perdurará até 1952, quando a necessidade econômica sobreveio. O Japão, novamente precisava escoar o seu excedente populacional, inchado com os 6,3 milhões de repatriados que retornaram antes e durante a Segunda Guerra. ${ }^{32} \mathrm{O}$ governo brasileiro cede, então, às pressões da "colônia" para o recebimento de imigrantes que pudessem acrescentar conhecimentos técnicos para o desenvolvimento de culturas agrícolas nas regiões Norte, Nordeste e Centro-Oeste.

O desfecho da Segunda Guerra Mundial com a derrota do Japão significou para muitos imigrantes o fim do sonho de retorno, uma vez que a emigração temporária fazia parte do plano inicial destes. De acordo com Ruth Cardoso (1973: 322), a devastação do país no pós-guerra estimula o processo de radicação de muitas famílias e se torna um marco divisor para a conscientização da ligação do nissei com o Brasil. Inspirada nas contribuições da chamada escola culturalista norte-americana e no uso de concepções como "padrões culturais" e "familiares", a antropóloga produz uma clássica obra, Estrutura familiar e mobilidade social: estudo dos japoneses no Estado de São Paulo, na qual situa o processo de urbanização como um momento importante do movimento de ascensão social dos imigrantes japoneses, justificado pelo desejo de maior escolarização do nissei. A abordagem, mesmo inserida na chave da "integração" e "assimilação" cultural, fornece importantes pistas para a reflexão que proponho aqui.

\footnotetext{
assassinatos de vários makegumis, vieram a corroborar as teses de que os imigrantes e seus descendentes eram "inassimiláveis".

${ }^{32}$ Com a ocupação de Okinawa pelos EUA no final da Guerra, cerca de 54 mil pequenos proprietários e agricultores entram no país entre 1952 e 1988, sendo que 43\% eram parentes de pessoas que haviam imigrado antes do conflito (Lesser, 2001: 295).
} 
Através do uso de entrevistas, ${ }^{33}$ a autora aponta que " $76 \%$ dos chefes de família vindos antes da guerra têm uma história ocupacional onde as mudanças de status são contínuas e progressivas. Apenas 11\% deles não mudaram suas condições de trabalho e 13\% desceram na escala ocupacional" (Cardoso, 1973: 54). A continuidade do processo de "mobilidade social" é assegurada pela entrada dos nisseis nos cursos universitários e em sua inserção nas carreiras profissionais liberais.

A trajetória do entrevistado Sr. Paulo Sasaki e de sua família é comum a de muitos nisseis participantes da pesquisa quantitativa de Ruth Cardoso. Como vimos, oriundo de uma família de agricultores que saiu do interior do Estado de São Paulo para desbravar terras no Norte do Paraná, Sr. Paulo, com apenas 11 anos de idade, por volta do ano de 1947, foi mandado pelos pais à cidade de São Paulo para estudar. Morando na casa de parentes, completou o ginásio, o colegial e se formou em uma escola técnica de contabilidade. Em 1960, mudou-se para Maringá, trabalhando como contador em empresas durante vários anos e depois viajou para o Japão três vezes a trabalho, como dekassegui. Atualmente, é assessor de um deputado estadual.

Para o imigrante issei, a educação do nissei se conformava como um processo de autorrealização através do sucesso dos filhos e como uma forma de evitar que estes sofressem os reveses dos obstáculos econômicos e culturais enfrentados pelos pais (Tsukamoto, 1973: 27). O estudo, portanto, era um meio eficaz de emancipar os filhos do mundo camponês. Frequentemente muitos pais restringiam os seus investimentos complementares na agricultura para enviarem os filhos às escolas da cidade (Ono, 1973: 151). A educação do nissei também se apresentava como uma forma de trazer o prestígio social à família, através de um representante junto à sociedade brasileira (Maeyama, 1973: 266). Segundo Tsukamoto (id.; ib.: 27), “a obsessão pela educação e a luta pela ascensão social constituem, por assim dizer, duas forças motoras que sustentaram a vida cheia de vicissitudes dos japoneses residentes tanto na América do Norte como na do Sul". 34

O investimento na educação foi considerado pelos líderes da Era Meiji como um passo fundamental para a modernização do país. De acordo com Elisa Sasaki, a alfabetização em massa também foi usada como arma para consolidar o nacionalismo por meio da doutrinação política. O Decreto Imperial da Educação, editado em 1890, conjugava valores do confucionismo e da "ética samurai" a uma moralidade baseada na sacralização e na lealdade ao Imperador:

\footnotetext{
${ }^{33}$ Cardoso partiu de uma mostra de 75 famílias de origem japonesa selecionadas por meio dos dados e informações levantados pela Comissão de Recenseamento da Colônia Japonesa em 1958.

${ }^{34}$ Essa valorização da educação do nissei também foi perceptível em outros países que receberam os imigrantes japoneses, como os Estados Unidos (cf. Yamamoto, 1986) e Peru (cf. Fukumoto, 1986).
} 
Vós, Meus súditos, sede filiais aos seus pais, sede afetuosos com seus pais e irmãs; sede harmoniosos como marido e mulher, como verdadeiros amigos; levai convosco a modéstia e a moderação; estendei a vossa benevolência a todos; prossegui o aprendizado e cultivai as artes; desenvolvei as faculdades intelectuais e os poderes da perfeita moral; além disso, levai adiante o bem público e promoveis interesses em comum; sempre respeitai a Constituição e observai as leis; quando surgir emergência devei vos oferecer corajosamente ao Estado; e assim guardar e manter a prosperidade do Nosso Trono Imperial coevo com o Céu e a Terra. Assim vós deveis ser os Nossos bons e fiéis súditos, transmitir as melhores tradições de vossos antepassados (Sasaki, 2009: 31).

O Édito clama pelo cultivo de certas virtudes como a observância das leis, a piedade filial, o desenvolvimento do intelecto e a lealdade ao Império, valores que muitos emigrantes japoneses carregaram consigo para os países de destino. Aqueles que buscavam conquistar a todo custo o sucesso material no menor tempo possível visando o retorno ao Japão tinham sérias preocupações quanto ao futuro dos filhos. O medo de que os mesmos se tornassem "caboclos brasileiros" e ao regressarem, não conseguissem se comunicar e se portar em conformidade com os preceitos do "espírito japonês" (Yamatodamashii), como apropriado e pregado pela ideologia nacionalista, levou muitos colonos que viviam em localidades distantes a se mobilizarem para erguerem escolas com suas próprias mãos. ${ }^{35}$ Depois de levantadas, as mesmas eram oferecidas ao governo do Estado, que enviava um professor e as franqueava para todas as crianças da área e não somente para os filhos dos imigrantes nipônicos. A autorização para o ensino do japonês era então requisitada, sendo as despesas pagas pela colônia ou associação de japoneses.

Essa preocupação com a educação pode ser observada na edição de 31 de julho de 1925 do jornal Nippak Shimbun, que ao discorrer sobre as escolas primárias e o ensino da língua japonesa, noticiava:

Não existe ninguém entre os imigrantes estrangeiros mais preocupado do que o japonês em relação à educação dos filhos. Pessoas que até há pouco, vivendo no meio da mata virgem, na ânsia de ganhar dinheiro, não se incomodavam em sacrificar mulher e filhos, uma vez conquistada certa margem de segurança em sua vida, têm de enfrentar o problema da educação da prole. E decidem então construir uma escola primária. Trata-se de uma característica peculiar dos japoneses, que quase não se observa em outros imigrantes. É uma atitude que merece apoio. [...] (CEHIJB, 1993: 99-100). ${ }^{36}$

\footnotetext{
${ }^{35}$ Para os japoneses, a educação tinha um sentido amplo de instrução e formação pessoal, pois havia grande receio de que os filhos se tornassem "furyō" (desviados) (Os nikkeis e a sociedade brasileira nos próximos 20 anos, 2003 : $35)$.

${ }^{36}$ A partir desse editorial, presume-se como os decretos referentes à política oficial de nacionalização, anos mais tarde, proibindo a comunicação e o ensino da língua japonesa e fechando escolas afetaram diretamente as aspirações dos imigrantes isseis, cerceando-lhes o direito de educar seus filhos como bem lhes aprouvesse. Em 1938, cerca de 300 escolas nipônicas são fechadas (CEHIJB, 1993: 128). Essas medidas, no entanto, não coibiram o ensino clandestino da língua japonesa, que passou a ser realizado em casebres no meio das plantações, porões ou com professor particular.
} 
Passados exatos oitenta anos dessa publicação, a "peculiaridade" do imigrante japonês frente a outros grupos estrangeiros e nacionais no que tange à valorização da educação continua sendo tema de discussão. Os dados apresentados pelo pesquisador Marcelo Paixão, em reportagem da Folha de São Paulo no ano de 2005, revelam, a partir do Censo 2000 do IBGE, que o Índice de Desenvolvimento Humano dos orientais (raça amarela), no Brasil é 0,937, quase o mesmo que do Japão, 0,938. ${ }^{37} \mathrm{O}$ IDH é calculado a partir dos índices de escolaridade, renda e expectativa de vida. O Brasil, cujo índice é de 0,790 ocupa a 62a . posição do ranking de 177 países pesquisados. Na região Sudeste, que responde pela maior concentração de orientais no Brasil, o IDH é de 0,958 entre os orientais, maior até mesmo que o da Noruega, 0,959, país com melhor índice do mundo.

ÍNDICE DE DESENVOLVIMENTO HUMANO DO BRASIL E GRANDES REGIÕES DESAGREGADOS POR GRUPOS DE RAÇA/COR, 2000

\begin{tabular}{|c|c|c|c|c|c|c|c|c|c|c|c|c|}
\hline Região & $\mathrm{RAÇA} / \mathrm{COR}$ & $\begin{array}{l}\text { Renda per } \\
\text { Capita (R\$) }\end{array}$ & $\begin{array}{c}\text { Indicador } \\
\text { Rendimento }\end{array}$ & $\begin{array}{c}\text { Esperança } \\
\text { de Vida }\end{array}$ & $\begin{array}{c}\text { Indicador } \\
\text { Longevidade }\end{array}$ & $\begin{array}{c}\text { Indicador de } \\
\text { Alfabetização }\end{array}$ & $\begin{array}{l}\text { Indicador de } \\
\text { Escolaridade }\end{array}$ & $\begin{array}{l}\text { Indicador } \\
\text { Educação }\end{array}$ & Valor IDH & $\mathrm{IDH}$ & $\begin{array}{c}\text { Ranking } \\
\text { Mundo } \\
(2000)\end{array}$ & País/Referência \\
\hline \multirow{7}{*}{ Sudeste } & BRANCA & 550,87 & 0,808 & 74,61 & 0,827 & 0,942 & 1,015 & 0,967 & 0,867 & Alto & $31-32$ & Barbados/Brunei \\
\hline & PRETA & 271,65 & 0,692 & 67,53 & 0,709 & 0,863 & 0,815 & 0,847 & 0,749 & Médio & $79-80$ & Cazaquistão/Ucrânia \\
\hline & PARDA & 248,67 & 0,678 & 68,64 & 0,727 & 0,894 & 0,856 & 0,881 & 0,762 & Quase-Alto & 70 & Tailândia \\
\hline & NEGRA & 252,85 & 0,681 & 68,36 & 0,723 & 0,888 & 0,849 & 0,875 & 0,760 & Quase-Alto & $70-71$ & Tailândia/Arábia Saudita \\
\hline & AMARELA & 1215,19 & 0,937 & 75,28 & 0,838 & 0,97 & 1,355 & 1,098 & 0,958 & Alto & 1 & Noruega \\
\hline & INDÍGENA & 348,67 & 0,733 & 66,57 & 0,693 & 0,872 & 0,821 & 0,855 & 0,760 & Quase-Alto & $69-70$ & Venezuela/Tailândia \\
\hline & Total & 446,02 & 0,773 & 71,14 & 0,769 & 0,923 & 0,951 & 0,932 & 0,825 & Alto & $42-43$ & Estônia/Costa Rica \\
\hline \multirow{7}{*}{ Sul } & BRANCA & 423,6 & 0,765 & 75,33 & 0,839 & 0,94 & 0,982 & 0,954 & 0,853 & Alto & $33-34$ & Rep Tcheca/Argentina \\
\hline & PRETA & 238,09 & 0,671 & 69,14 & 0,736 & 0,855 & 0,795 & 0,835 & 0,747 & Médio & $82-83$ & Peru/Granada \\
\hline & PARDA & 210,8 & 0,651 & 69,89 & 0,748 & 0,861 & 0,806 & 0,843 & 0,747 & Médio & $82-83$ & Peru/Granada \\
\hline & NEGRA & 217,52 & 0,656 & 69,75 & 0,746 & 0,859 & 0,804 & 0,841 & 0,748 & Médio & $81-82$ & Geórgia/Peru \\
\hline & AMARELA & 883,22 & 0,885 & 75,85 & 0,848 & 0,958 & 1,337 & 1,085 & 0,939 & Alto & $4-5$ & Bélgica/Austrália \\
\hline & INDÍGENA & 226,71 & 0,663 & 66,57 & 0,693 & 0,801 & 0,711 & 0,771 & 0,709 & Médio & 103-104 & Guiana/El Salvador \\
\hline & Total & 392,78 & 0,753 & 72,62 & 0,794 & 0,928 & 0,953 & 0,936 & 0,827 & Alto & \begin{tabular}{|l|}
$40-41$ \\
\end{tabular} & Uruguai/Bahamas \\
\hline \multirow{7}{*}{ Brasil } & BRANCA & 460,38 & 0,779 & 73,99 & 0,817 & 0,917 & 0,983 & 0,939 & 0,845 & Alto & $33-34$ & Rep Tcheca/Argentina \\
\hline & PRETA & 215,13 & 0,654 & 67,64 & 0,711 & 0,785 & 0,792 & 0,787 & 0,717 & Médio & 99 & Jordânia \\
\hline & PARDA & 190,51 & 0,635 & 68,03 & 0,717 & 0,818 & 0,836 & 0,824 & 0,725 & Médio & $96-97$ & China/Tunísia \\
\hline & \begin{tabular}{|l|} 
NEGRA \\
\end{tabular} & 193,93 & 0,637 & 67,87 & 0,715 & 0,813 & 0,83 & 0,819 & 0,724 & Médio & $96-97$ & China/Tunísia \\
\hline & AMARELA & 1052,46 & 0,913 & 75,75 & 0,846 & 0,951 & 1,257 & 1,053 & 0,937 & Alto & $6-7$ & Estados Unidos/Islândia \\
\hline & INDÍGENA & 187,46 & 0,632 & 66,57 & 0,693 & 0,739 & 0,692 & 0,724 & 0,683 & Médio-Baixo & $110-111$ & Indonésia/Guiné \\
\hline & Total & 341,11 & 0,73 & 70,4 & 0,757 & 0,871 & 0,907 & 0,883 & 0,790 & Quase-Alto & $55-56$ & Cuba/Bielorússia \\
\hline
\end{tabular}

Fonte: Microdados da Amostra do Censo Demográfico de 2000. In: Paixão (2005)

Entre os orientais e seus descendentes, a educação como valor é apontada como a principal razão para os altos indicadores sociais. Gilberto Dimenstein, em referência à reportagem, discute essa questão em coluna da Folha, fazendo referência também aos judeus no

\footnotetext{
37 “Índice de desenvolvimento de índio é o da Bolívia” e "IDH de orientais é quase igual ao do Japão". Folha de São Paulo, 19/04/05.
} 
Brasil. ${ }^{38}$ Assim como os imigrantes japoneses, chineses e coreanos, os judeus prosperaram não obstante as adversidades econômicas e culturais enfrentadas. No caso dos primeiros, os valores do confucionismo, como a disciplina, a meritocracia e a reverência à educação, ajudariam a entender o alto IDH. No caso dos judeus, o "bar-mitzvá", ritual de passagem para a vida adulta condicionado à leitura da Torá, explicaria os índices irrisórios de analfabetismo e a alta taxa de escolaridade: acima dos 25 anos, 63\% deles cursaram ou estão cursando o Ensino Superior. O jornalista conclui: "Não existe superioridade étnica ou racial. O que existe é a combinação de valorização do saber e capital social. [...] Compartilhar responsabilidades com a escola é uma medida de capital social”. Como reforça Dimenstein, os professores não devem ser encarados como os únicos educadores: família, escola e comunidade precisam atuar juntas nesse domínio.

Em 1977, segundo dados apresentados por Sussumu Miyao, a população nikkei representava pouco mais de $2 \%$ da população do Estado de São Paulo, no entanto, ocupava cerca de $10 \%$ das vagas nas universidades. Os percentuais mais elevados correspondiam às matrículas no Instituto Tecnológico de Aeronáutica (15,9\%); na Fundação Getúlio Vargas $(12,5 \%)$ e na Universidade de São Paulo (12,9\%). O ingresso nos cursos de ciências exatas tinha uma taxa bastante alta (14,6\%), seguida pelas áreas biomédicas (12,2\%) e por fim, pelas ciências humanas (7,4\%) (Miyao, 1980: 95). Segundo levantamento de Ferreira e Asari (1986: 215), na Universidade Estadual de Londrina, verificou-se que em 1979, cerca de 19,21\% dos estudantes matriculados e em 1978, 10\% de seus docentes, eram de origem japonesa.

Dados da Pesquisa Nacional por Amostra de Domicílio - PNAD de 1987 e 1988, apresentados por Luiz Cláudio Barcelos, ${ }^{39}$ mostram como os índices de escolaridade dos "amarelos" superam todos os demais grupos raciais:

\footnotetext{
38 “Judeus e japoneses são mais inteligentes?”. Folha de São Paulo, 24/04/05.

$39 \mathrm{O}$ autor busca mostrar a desigualdade racial no quadro educacional brasileiro. Embora o desempenho de "amarelos" tenha sido usado como parâmetro para tal discussão, nenhuma menção é feita a possíveis fatores culturais explicativos para a alta taxa de escolaridade dos mesmos, como o valor à educação, por exemplo.
} 


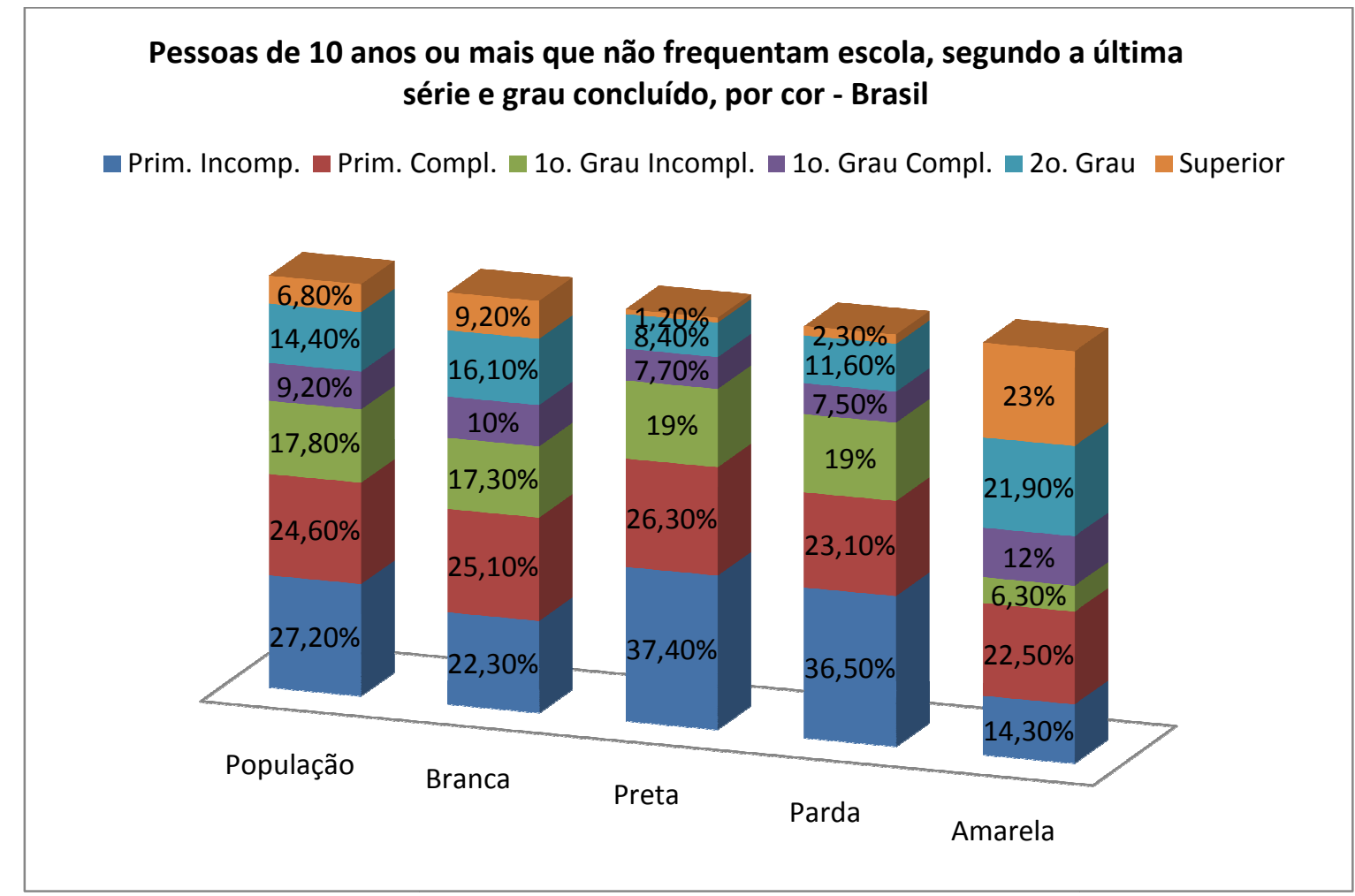

Fonte: PNAD - 1987. Barcelos (1992)

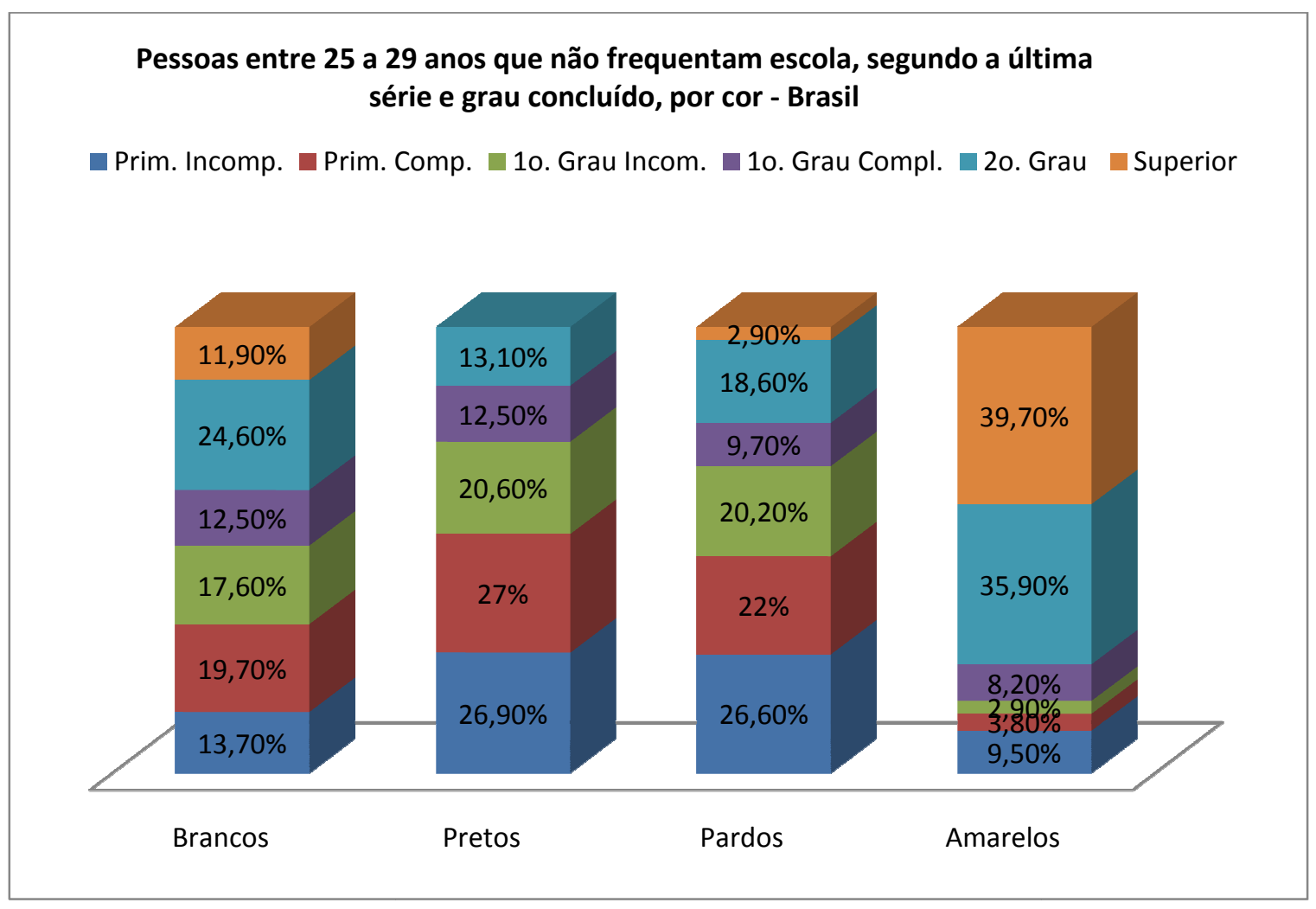

Fonte: PNAD - 1987. Barcelos (1992) 
Quase todos, se não todos os sujeitos pesquisados no presente trabalho, afirmaram que embora a inteligência seja um atributo associado aos descendentes de japoneses, acreditavam ser o esforço e a disciplina os reais fatores que explicavam a aprovação nos vestibulares e a inserção nos cursos universitários. Faz-se necessário enfatizar que muitos mencionaram que as taxas de aprovação dos descendentes caíram muito desde a entrada maciça dos nisseis nas faculdades. A principal razão apontada pelos entrevistados para essa queda foi o enfraquecimento do valor dado tradicionalmente à educação pelas novas gerações. Embora não sejam considerados fenômenos negativos pelos sujeitos dessa pesquisa, a miscigenação e o movimento dekassegui que atraiu muitos jovens, sem formação superior ou sem intenção de completá-lo, ao Japão foram as principais razões apontadas para essa queda. Essas questões serão retomadas posteriormente.

No entanto, uma pesquisa do Datafolha de 19/10/95 mostrava que a inserção universitária ainda é significativa quando comparada com a representação demográfica dos nipobrasileiros na sociedade brasileira. O estudo mostrou que 53\% dos adultos nikkeis tinham educação superior, comparado com apenas 9\% da população adulta total (Lesser, 2001: 301). Nesse mesmo ano, na Universidade de São Paulo, 15\% dos alunos e 8\% dos professores eram nipo-descendentes (Os nikkeis e a sociedade brasileira nos próximos 20 anos, 2003: 43). Além disso, levando-se em consideração os dados recentemente apresentados pelo pesquisador Marcelo Paixão (2005), é possível inferir que a situação sócioeconômica da população oriental e nikkei se mantém em um patamar favorável e bastante acima do restante dos brasileiros.

"Compartilhar responsabilidades com a escola", medida apontada por Dimenstein como meio para a obtenção de capital social foi bastante comentada pelos entrevistados. A valorização da educação se mostrou atrelada à cobrança de resultados pelos pais. A nissei Clarice Nakashima, paulistana de 39 anos, que atualmente trabalha na área de gestão educacional em uma faculdade afirma:

\footnotetext{
"Engraçado, porque todo mundo pensa que japonês é inteligente. Você já deve ter passado por isso... Você pode estar no cursinho ou qualquer lugar, eles acham que você vai tirar o lugar deles. Eu não sei por quê. Não é estranho isso? [risos]. Mas eu não acho que realmente seja mais inteligente. Eu acho que, é isso que eu estou te falando, pelo fato dos pais cobrarem mais, por serem mais cobrados, eles focam nisso. E eu quero que meu filho foque nisso, porque isso é um diferencial na sociedade, a educação. Não é porque eu sou japonesa! É porque eu lido com educação, eu trabalho com gestão acadêmica. Eu acredito nisso, como ideologia mesmo! Eu gosto de estudar. Mas eu acho também que japonês tem essa tendência, essa coisa".
} 
Clarice ao mesmo tempo em que desassocia a importância que atribui ao estudo da sua ascendência, afirmando que a explicação residiria em sua atuação profissional na área da Educação, reconhece a "tendência" dos nikkeis em "focar" os estudos, por conta de uma cobrança dos pais. A menção a minha origem também pôde ser notada em sua fala: "você já deve ter passado por isso...". Lembro que sim, ouvia comentários de colegas, "tinha que ser japonesa!". Mas um episódio que me recordo em detalhes aconteceu na primeira aula como estudante de Ciências Sociais na Universidade Estadual de Maringá. Uma colega sentada na carteira da frente olhou para trás e se assustou: "Nossa, japonesa fazendo Ciências Sociais?! Você não deveria estar fazendo curso de Biologia, Engenharia ou Medicina?!”. Eu não sabia no momento, mas já estava conhecendo o conceito de alteridade.

A questão do "foco" a que se refere Clarice também esteve presente no discurso do dentista de Londrina, Rodrigo Suzuki, sansei, 22 anos. Indagado sobre como achava que os descendentes de japoneses são vistos na sociedade, responde:

"Acredito que, embora na sociedade, tenha piadinha de japonês, de negro, piadinha de pobre e
homossexual, acredito que, de modo geral, ele é respeitado na sociedade, desde que não tenha
acontecido nada de grave. Ele é visto como trabalhador, todo mundo também acha que japonês
tem dinheiro, não sei por quê. Mas eu acredito, de certo modo, que o japonês é trabalhador,
eles sabem focar... Também acredito que, quase na totalidade, sempre enfocam o estudo
primeiro. Não deixam isso escapar. Tudo que está ao alcance para bancar os estudos dos
filhos e netos, eles vão fazer o possível. Eles acham e eu também acho que é o jeito mais fácil
para uma pessoa conseguir renda ou conseguir respeito, conseguir algo que a sociedade, se não
respeite, no mínimo ela espelhe". O gráfico a seguir ilustra essa preocupação em prover educação de qualidade aos filhos, comentada por Rodrigo. Segundo Barcelos (1992: 53), quanto maior o aumento da escolaridade do chefe de família, maior será a participação da criança em colégios particulares:

Pessoas de 7 a 14 anos de idade que frequentam escola, segundo a cor e o tipo de rede escolar - Brasil

\section{População}

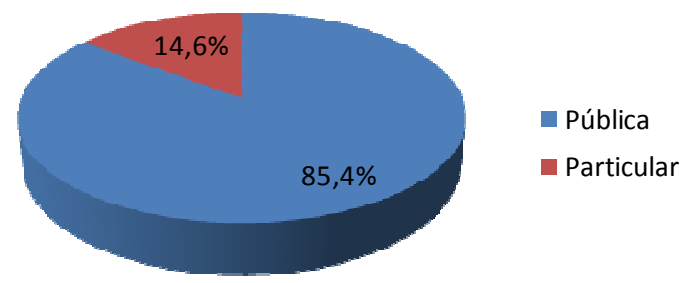


Branca

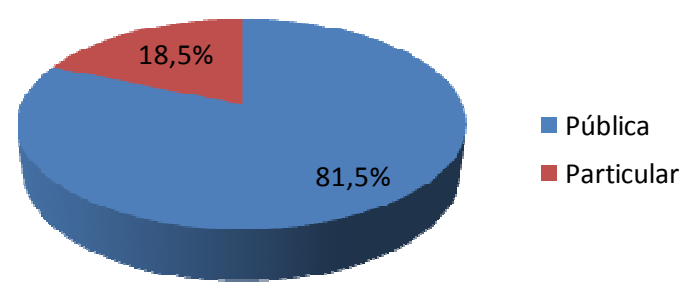

Parda

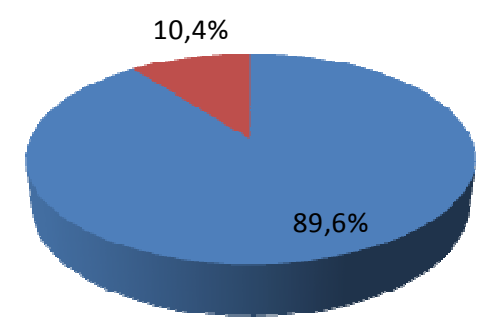

Preta

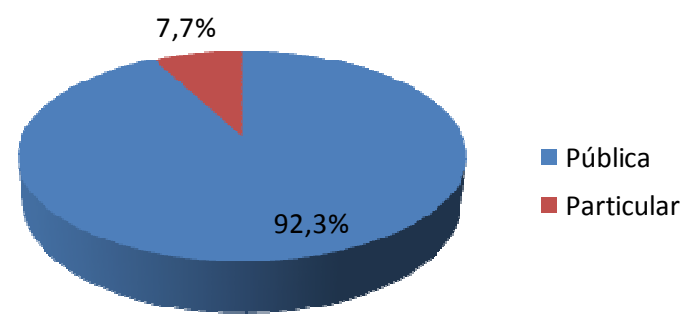

Amarela

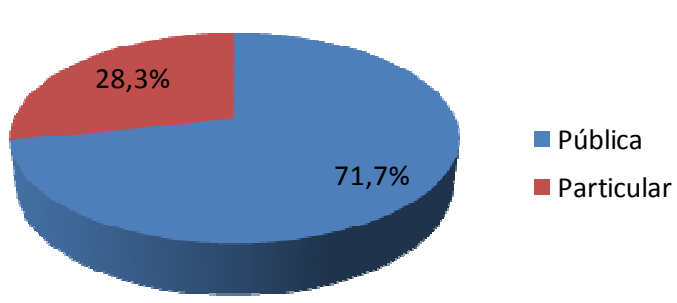

Fonte: PNAD - 1988. In: Barcelos (1992).

A conversa com Rodrigo foi realizada em uma manhã de sábado na casa de seus pais em Astorga. Nascido nesta cidade, o rapaz conseguiu a aprovação no concorrido vestibular de Odontologia da Universidade Estadual de Londrina assim que terminou o Ensino Médio. Atualmente, continua morando em Londrina e lá trabalha em um consultório. Filho de professora e de um contador, Rodrigo afirma que a educação em sua casa foi bastante rígida no que dizia respeito à cobrança de resultados. Segundo ele, o desejo de muitos avós e pais de origem japonesa de que o filho tenha um cargo de prestígio, em áreas como Medicina, Engenharia, Direito ou Odontologia, esteve presente em sua formação. Acredita que é por isso que são poucos os descendentes que atuam em domínios como Artes, Letras ou Ciências Humanas. Rodrigo tinha interesse em fazer Letras e Gastronomia, mas se o fizesse, diz que seu pai "surtaria". Escolheu Odonto, um curso que gostava e que "dava orgulho" para o pai. 


\begin{abstract}
"A grande parcela que está nesses cursos concorridos, tem capacidade? Tem. Graças a Deus a gente não precisa de cota para nipônicos. Eu acho o sistema de cotas bem preconceituoso. Não sou contra negros, pelo contrário. Gostaria que tivessem mais negros na universidade para dar uma balançada. Mas se você estabelece cotas, você está julgando que essa etnia não é capaz de competir com as outras, mas não é assim. Acredito que todos tenham a mesma capacidade, embora nem sempre as mesmas armas para entrar no vestibular. Na minha sala de uns sessenta, não digo metade, mas um terço, um quarto já eram japoneses ou descendentes. E assim nossos calouros, nossos veteranos. Acho que Londrina tem bastante japoneses também".
\end{abstract}

Rodrigo reconhece que atualmente existe uma dificuldade muito maior dos pais em educar os filhos: "Há mais rebeldia no mundo, fazem-se coisas que há vinte, trinta anos eram inconcebíveis". Além disso, afirma que a preocupação principal dos pais é trazer dinheiro para casa e a educação acaba ficando em segundo plano. Mesmo com essas mudanças no processo educacional, acredita que a inserção dos nikkeis no mercado de trabalho ainda é considerável, devido ao investimento da educação: "Não quer dizer que todo japonês seja inteligente, mas no mínimo, a grande maioria é esforçada". Acrescenta que

“A educação do 'japonês' é mais rígida, dos 'brasileiros', não. O pai é mais ditador, manda, e
você, obedece. Pais 'brasileiros', a criança negocia, 'ah, pai se eu fizer isso, vou ganhar o
quê?'. Pelo menos na minha casa nunca foi assim. Você faz e pronto! Não tem que reclamar".

De acordo com a orientadora educacional Isabel Nishida, nissei, 53 anos, 36 de profissão atuando como funcionária do Estado, existe um "diferencial” entre as famílias nikkeis, no que diz respeito ao valor atribuído à educação, e que justamente se revela na cobrança por resultados:

"Eu, como professora, como orientadora de uma escola de 1300 alunos eu vejo esse
diferencial sim, porque ainda a gente nota que, em questão de educação, nós temos esse
diferencial sim. É mais fácil, as famílias são pais mais presentes, ou mesmo não indo à escola,
cobram em casa. Eu vejo que os filhos de nikkeis, os pais procuram dar o máximo para eles,
mas cobram resultado. Eles investem nos filhos sim, que em sua grande maioria
correspondem sendo bons alunos. Tanto é que a gente vê nos vestibulares sempre estão nas
primeiras classificações. A gente vê que ainda existe essa cobrança, porque eu sempre digo: a
única herança que os pais podem deixar para o filho é o estudo. Porque o estudo é uma
herança que ninguém tira da gente, cultura ninguém tira da gente... Então, se for valores

\footnotetext{
${ }^{40}$ Londrina, assim como Maringá, foi uma cidade que recebeu fortes levas de imigrantes japoneses com os loteamentos e vendas de terras da Companhia Melhoramentos Norte do Paraná. Conforme reportagem da Folha de Londrina, de 21/06/2008, "Contabilidade é uma área fértil para nikkeis: números confirmam que os descendentes de japoneses conquistaram boa parte das vagas da UEL", em 1987, 60\% das vagas do curso de Odontologia da UEL foram ocupadas por descendentes de japoneses. No mesmo ano, estes conquistaram $40 \%$ das vagas de contabilidade, $55 \%$ das vagas de Enfermagem, 41,1\% das de Engenharia Civil e 24\% das vagas de Medicina. Como bem mostra os dados apresentados por Rodrigo, passados vinte anos, essa estatística já não mais se apresenta com números tão elevados.
} 
materiais e não souber administrar, em questão de dias, semanas, meses, a gente perde, mas o saber não. Esse é para sempre! Eu vejo que os pais cobram, principalmente aqueles que a gente conhece aqui do grupo (taikō) são bem cobrados. ${ }^{41}$ No Japão, eles são tão cobrados, a educação ainda é tão rígida que tem um grande índice de suicídio, né? Aqui graças a Deus não existe isso! Mas a gente sabe que não é essa cobrança. Mas tem cobrança...”.

A Revista Veja publicou uma matéria em 23/05/07 intitulada “"Cultura do sucesso' pesquisa mostra que jovens de origem asiática vão mais longe nos estudos e estão deixando os brasileiros para trás" (grifos meus). Em muitas passagens da reportagem, é possível perceber a clara distinção estabelecida entre asiáticos e brasileiros através do recurso à nominação. Os primeiros foram chamados, quase em toda a matéria, simplesmente de asiáticos e não de brasileiros de origem asiática. Na condição de estudantes "superiores" foram citados por uma especialista americana como tendo "o estudo no DNA" e foram colocados sempre em oposição aos (verdadeiros) brasileiros.

Embora a matéria recaia em algumas essencializações, os aspectos culturais são ressaltados. O senso de competição alimentado em casa e incentivado nas escolas, a meritocracia e a participação dos pais na vida escolar são indicados como os principais motivos para o "sucesso" dos alunos de origem asiática nos estudos. A reportagem também cita dados do Instituto de Pesquisa Econômica Aplicada (IPEA) que mostra que 37\% deles concluem a universidade, taxa quatro vezes maior que a média dos brasileiros. A dedicação por horas de estudo também é maior: enquanto o "típico" aluno brasileiro passa 5 horas por dia estudando, o aluno de origem asiática passa 8 horas.

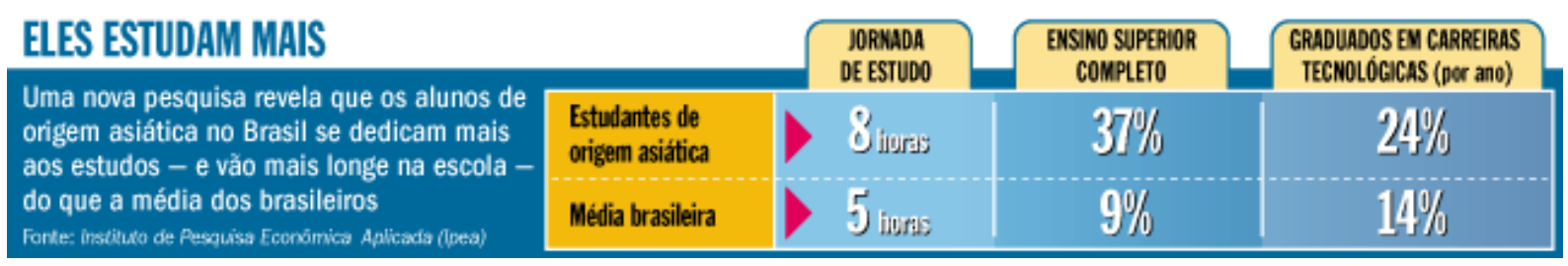

Fonte: IPEA - Revista Veja

O estudante Clinton Shin, de origem coreana, 14 anos, o melhor de sua turma, considera-se nerd: "Entre meus amigos de família asiática, isso é sinal de prestígio, e não de vergonha". A matéria fecha com a fala do economista Claudio de Moura Castro, "As famílias asiáticas entenderam há muito tempo que o sucesso depende de sacrifícios e paciência para esperar pelos resultados", concluindo: “Os brasileiros ainda não".

\footnotetext{
${ }^{41}$ Isabel é coordenadora do grupo de taikō, Seishun Daiko, da Associação Cultural e Esportiva de Astorga.
} 
O OUTRO LADO DA COBRANÇA: "NÃO SE FAZEM MAIS JAPINHAS COMO ANTIGAMENTE"

Além da cobrança por resultados feita em casa pelos pais, de que falam Isabel, Rodrigo, Clarice e as matérias da Veja e da Folha, existe também um outro lado da cobrança mencionado por alguns entrevistados: aquele que se reveste às vezes de uma expectativa ou até mesmo pressão para que o sujeito aja, comporte-se, produza de acordo com o que é supostamente esperado de um "japonês" ou descendente. Essa cobrança pode partir de um nikkei, como de um não-nikkei.

"Por ser nihonjin, eles esperam sempre o melhor", diz a entrevistada Yumi Kawamura $^{42}$. Ela conta a história do irmão que estava fazendo um curso agrícola, junto com dois amigos também descendentes. O professor aplicara uma prova ao final e quando divulgou as notas, disse: "Nós temos três alunos 'japoneses', dois agiram como 'japoneses', um fugiu totalmente". O rapaz tirara oito. "Você não é ‘japonês', não! Porque você não conseguiu a nota máxima!”, continuou o professor. “Tiraram o maior sarro do rapaz”. Yumi acrescenta:

"Para 'japonês', ele teria que ter tirado dez, como meu irmão e o outro tiraram dez. Então,
existe uma pressão, porque por você ser nihonjin todo mundo acha que você é inteligente. Aí
falam, 'Esse não é japonês, não!'. Eu era cobrada por isso pelos professores. Acho que se eu
tirasse nota baixa, eles ficariam decepcionados. A minha professora falava, 'Ah, não precisa
nem falar a nota, né?'. Aliás, todo mundo da sala já sabia. Existe uma cobrança sim, por mais
que você fale que não, tem. E a gente sofre sim, porque sempre esperam o melhor da gente."

O comerciante Daniel Kobayashi ${ }^{43}$ também já havia mencionado essa vontade de corresponder em ações, na prática, no dia-a-dia, à imagem esperada de honestidade do nikkei, que, segundo ele, “está bem estampada na sociedade”. Já a narrativa de Yumi mostra como a "brincadeira" do professor teve o efeito de chamar a atenção para a ascendência do amigo de seu irmão e teve força de um discurso que adjetiva quem se enquadra ou quem foge do que é esperado de um "legítimo" "japonês".

A cobrança por parte dos professores, sentida também por Yumi, apareceu em uma conversa que tive com um grupo de amigos, membros da diretoria do seinen-kai ${ }^{44}$ da Seicho-No-

\footnotetext{
${ }^{42}$ As narrativas dos sujeitos da pesquisa estarão dispersos ao longo do trabalho, como fragmentos discursivos, assim como sugere a proposta metodológica adotada. Quando a fala de um depoente aparecer em um outro capítulo ou em um momento distante de sua apresentação inicial, notas serão empregadas com informações básicas para facilitar a identificação da autoria da fala. Como no exemplo, Yumi Kawamura, nissei, 39 anos, de Astorga, estudante de Pedagogia.

${ }^{43}$ Sansei, 35 anos, ex-dekassegui, dono de um mercado em Astorga.

${ }^{44}$ Seinen: jovem; Kai: associação. O seinen-kai, em linhas gerais, constitui-se em um departamento de jovens, com diretoria própria, dentro das entidades nikkeis.
} 
$I e^{45}$ de Maringá. Esta foi a única conversa que pude travar com um grupo relativamente numeroso de pessoas, ao todo foram seis, sendo cinco nikkeis e um não-descendente. Este, o único rapaz do grupo, William, tem 19 anos e é ativo participante das atividades promovidas pelo seinen. Disse que seu interesse pela "cultura japonesa" começou quando entrou para o departamento. Esteve o tempo todo acompanhando a conversa, que se estendeu pela tarde de um domingo de janeiro, muito interessado nas discussões levantadas. Quando perguntei ao grupo sobre como achavam que os nikkeis eram vistos na sociedade brasileira, qual a imagem que os não-descendentes tinham deles, William se adiantou:

\begin{abstract}
“Então, né... começa comigo [risos]? A imagem que nós temos é que os 'japoneses' são praticamente o pessoal perfeito. Tem sempre aquela comparação com a gente. São sempre melhores, a gente tem que estar sempre correndo atrás. São sempre mais honestos e são sempre mais inteligentes, tem mais disciplina, tem mais tudo. Depois que a gente entra no meio... [risos] e fala, 'ué, cadê?' [Todos riem]. Quando entrei no seinen, o pessoal falava, 'Mas por que você está no seinen? Seinen não é só japonês?' É, o pessoal ficava espantado. 'Ué, você não é japonês!'. Eu falava, 'Você não está vendo direito, abra os olhos!" ${ }^{46}$ [risos]."
\end{abstract}

Reproduzo agora inteiramente a conversa que se estendeu entre William, Fernanda, Juliana e Cíntia ${ }^{47}$ :

"É mesmo. A imagem é essa: enquanto você está festando, o japonês está estudando. É a imagem de quem não conhece. Mas a gente festa, a gente é normal [risos]. Normal entre aspas, mas é igual. Nós tivemos um professor que nos odiava, porque ele achava que nós não seguíamos o padrão. Ele achava que nós éramos comportados, inteligentes. Por causa dessa imagem dele, ele acabou com a gente...”. (Fernanda, sansei, 21 anos, estudante de Pedagogia)

“ [Essa imagem] Mudou bastante... acho que já não está mais assim...” (Cíntia, sansei, 23 anos).

"Mas é a imagem que o pessoal tem, de quem não conhece". (William e Fernanda)

“A nossa geração é que não está mais desse jeito, já está distorcida. Esse professor dizia, 'Não se fazem mais japinhas como antigamente'. (Cíntia)

"É isso mesmo, os professores ficam prestando mais atenção no 'japonês"! Sei lá, eles cobram.. Se não é como esperado, eles... dá uma diferença. Eles falavam: 'Mas você não é 'japonesa'!?'. (Juliana, sansei, 17 anos, vestibulanda de Medicina).

\footnotetext{
${ }^{45}$ Segundo seu site, a Seicho-No-Ie pode ser considerada uma filosofia de vida ou uma religião - "não há rigidez de conceito nesse sentido" - que "transcende o sectarismo religioso, pois acredita que todas as religiões são luzes de salvação que emanam de um único Deus". Fundada pelo japonês Masaharu Taniguchi, em 1930, possui vários ensinamentos, cerimônias e práticas de culto e meditação. Bastante difundida no Brasil, a Seicho-No-Ie possui adeptos nikkeis e muitos não-nikkeis (www.sni.org.br acesso: 23/03/2010).

${ }^{46}$ Existem dois departamentos de jovens na Seicho, o seinen-kai e a Força Jovem. Ambos têm a mesmas funções quanto ao público visado: jovens a partir dos 15 e 20 anos, respectivamente. Segundo os entrevistados, a diferença é que o primeiro está voltado para os interessados em "cultura japonesa", descendentes de japoneses ou não. Além disso, nas reuniões, algumas orações e cânticos são feitas em japonês.

${ }^{47}$ No capítulo 2, encontram-se mais detalhes sobre a trajetória de vida das garotas.
} 
“Tem pai que fala, 'Ah, faz amizade com aquele 'japonês' mais inteligente da sala!'. No vestibular também foi engraçado. Lembro que na nossa sala tinha dois 'japoneses', e um pessoal falou: 'Duas vagas que a gente perdeu'. Eu falei: 'Isso nao tem nada a ver gente, só porque ele é 'japonês' não quer dizer que ele já passou!'. O pessoal tem um medo muito grande, uma imagem que quem não conhece ainda tem. (William, 19 anos, não-descendente)

"Elogiou um monte a gente, hein!” (risos). (Fernanda)

"Então, né? Depois que a gente começa a conviver... a gente vê que eles são iguais a gente..." (William).

Esse rica interação que aconteceu entre os participantes revela como a confusão e o entrelaçamento entre representação e realidade é entendida por eles e como a representação/imagem é compreendida como não conhecimento sobre o outro ou como conhecimento pouco aprofundado sobre o outro. O "padrão" de crianças e jovens inteligentes e bem-comportados é desconstruído na fala do grupo. Essa referência mudou, pois as novas gerações "já estão mais distorcidas", "não se fazem mais japinhas como antigamente". Provavelmente, o professor de Fernanda e Cíntia estivesse tomando como paramêtro para sua análise, os nisseis, cuja elevada inserção nos vestibulares mais concorridos do país, como visto nas taxas apresentadas por Miyao (1980), ajudou a difundir a piada: "Garanta sua vaga na USP, mate um japonês".

De acordo com Luiz Cláudio Barcelos, as expectativas de um professor podem ter efeitos sobre o desempenho do estudante - "a origem racial do aluno, juntamente com o rendimento escolar anterior e nível sócioeconômico, figura entre as variáveis mais frequentemente identificadas como relevantes para a formação de expectativas" (Alves et al apud Barcelos, 1992: 39). No caso dos alunos de origem japonesa, estas podem assumir a forma de uma espécie de cobrança para que o estudante corresponda aos estereótipos e imagens associadas a um desempenho positivo.

A fala dos entrevistados aponta também para a "normalidade", para a "igualdade" e não para a "diferença" com relação aos jovens não-descendentes, nesse sentido, oferecendo uma outra visão àquela imagem de "nihonjin" definida por Yumi: "Sou toda certa, não bebo, não fumo, não faço nada... Aquela imagem de nihonjin!”. Outros jovens com quem conversei disseram que a representação de pessoas recatadas, que não sabem se divertir e ficam o tempo todo estudando não condiz em nada com a realidade.

Diante do debate entre os membros da diretoria do Seinen sobre todas essas questões, indago logo em seguida: “Então, vocês se identificam com essas imagens?”. Fernanda diz: 


\begin{abstract}
"Uma porcertagem sim. Como com a questão do respeitar os mais velhos sim, mas com a questão de ser santinho, de não fazer baderna, aí não. Nós somos adolescentes, jovens, normais! Nessa parte sim, mas em outras, não. Nós vivemos no Brasil, então a porcentagem maior será brasileira e não japonesa. Na parte japonesa, nós convivemos com a família e mesmo assim, a família ainda perdeu um pouquinho conforme as gerações. A gente tem respeito pelos antepassados, pelas nossas raizes. Damos um valor bem grande. Mas no resto a gente é normal, nós somos todos iguais. Questão de inteligência é tudo a mesma coisa".
\end{abstract}

Em seguida, William chama a atenção para um aspecto até então não mencionado, “Ah, mas deixa eu só falar uma coisa. Acho que uma coisa que vocês cultuam bastante e que não tem tanto na sociedade é a disciplina. Vocês tem uma disciplina bem grande. E um respeito à família que não tem tanto por ai". Todos concordam, "Isso aí acho que continua tendo", dizem algumas garotas.

Múltiplas e plurais são as experiências com relação à educação, diversas são as vozes que ajudam a compor a imagem que associa os descendentes de japoneses à disciplina, à inteligência, ao bom-comportamento, ao sucesso nos estudos. Profissionais na área de educação, um dentista recém-formado e um grupo de jovens falam sobre valores, tradição, cobranças, imagem, realidade... O objetivo deste capítulo e dos outros também, não é fazer um cálculo sobre "manutenção" ou "perda" de valores, como por exemplo, saber estatisticamente se a aprovação de nikkeis nos vestibulares concorridos do país ainda se mantém no mesmo patamar que nos anos de 1980. Provavelmente não, e embora acreditando que este seja um tipo de dado relevante, o propósito aqui é entender a relação dos interlocutores dessa pesquisa com o imaginário sobre os japoneses e seus descendentes. Em que momentos há identificação? Quais as bases fundantes desse complexo imaginário? Discursos, meramente? Aspectos da "cultura japonesa"? Ambos?

\title{
“OS NOSSOS JAPONESES SÃO MAIS CRIATIVOS QUE OS JAPONESES DOS OUTROS”
}

Como o fim da Segunda Guerra Mundial e a suspensão da imigração japonesa para o Brasil, a política emigratória só será retomada no começo da década de 1950 e se estenderá até meados dos anos 60 e 70, com o envio de técnicos japoneses para atuarem nas cooperativas ou mesmo através da imigração livre com as "chamadas de parentes próximos". Neste período, o desenvolvimento econômico e industrial do Japão passa a absorver o excedente populacional do arquipélago que estivera inflado com os repatriados que retornaram antes e durante o conflito mundial.

A confluência de fatores como a ascensão social dos nikkeis e o aumento do número de casamentos com não-descendentes de japoneses, encarados sob alguns aspectos como indícios 
de "assimilação" e "integração", a visibilidade internacional do poderio tecnológico e econômico demonstrado pelo Japão, o fortalecimento das relações comerciais entre este país e o Brasil pode ter provocado uma gradual inflexão no imaginário sobre os nikkeis, no sentido de atribuir um maior destaque para os aspectos positivos e não negativos de sua presença em terras brasileiras.

Jeffrey Lesser argumenta em sua obra, Uma diáspora descontente (2008), que nas décadas de 1960 a 1980, em pleno regime militar, as idéias de nação brasileira ainda estavam ancoradas na adesão à ideologia cultural da modernização. A explosão demográfica e o crescimento econômico de São Paulo cristalizaram sua posição como centro industrial, financeiro, político e cultural do país, garantindo a atração de milhares de migrantes de outras regiões e emigrantes de diversos países para o seu território. ${ }^{48}$ As definições de identidade nacional, portanto, eram agora perpassadas pela identidade regional. Como caldeirão étnico, São Paulo, além de ter se tornado modelo de "democracia racial”, figurava também como modelo de desenvolvimento econômico, ou seja, um espelho para o país.

Como bem-sucedidos moradores da cidade e como sujeitos imediatamente associados aos japoneses do Japão - nação que despontou como potência mundial nesse período - os nikkeis eram figuras importantes na construção desse imaginário. De acordo com o autor, o rápido crescimento econômico do país do sol nascente levou a elite paulistana a tomá-lo como meta e os nikkeis como "the best brazilians", protagonistas interlocutores na consecução desse objetivo. Lesser menciona a propaganda do Banco Bamerindus, com sede em São Paulo, na década de 1970, “precisamos de mais brasileiros como os japoneses" (Lesser, 2008: 22).

O historiador americano defende que os anos de 1960 e 1970 foram no Brasil, sobretudo em São Paulo, as "décadas da diáspora", pois à medida que capitais estrangeiros adentravam no país, os paulistanos descendentes de imigrantes buscavam ressignificar e renegociar suas identidades a fim de se beneficiar dessa expansão econômica. ${ }^{49}$ De acordo com o autor, "a solução para o avanço do Brasil era importar uma população estrangeira que trazia produtos estrangeiros, tecnologias estrangeiras e uma ética de trabalho estrangeira" (id.; ib.: 25).

\footnotetext{
${ }^{48}$ Entre 1960 e 1980, a população de São Paulo saltou de 4,7 milhões para 12,5 milhões de habitantes. A cidade também constitui a maior cidade "japonesa" fora do Japão. Em 1987, a população nikkei contava com 1,2 milhões de habitantes no país, tendo a maioria, 887 mil, concentrada no Estado de São Paulo. Desse número, 326 mil viviam na capital São Paulo e 170 mil nas regiões imediatamente adjacentes (Lesser, 2008: 38).

${ }^{49}$ Os investimentos japoneses no Brasil começaram com a política de industrialização do governo de Kubitschek. A presença desse capital podia ser notada nos empreendimentos conjuntos como a usina siderúrgica Usiminas e o estaleiro Ishibrás, nas empresas japonesas instaladas na Zona Franca de Manaus e no fluxo comercial de produtos travado entre os dois países. Em 1960, 45 empresas japonesas operavam no país. Em 1976, esse número saltou para 537. Na década de 70, o Japão se tornou o terceiro maior investidor direto no Brasil, perfazendo um total aplicado de quase 2,9 bilhões de dólares (id., ib.: 48).
} 
Como "forasteiros fisionômicos", a visibilidade de seus traços tornava a população nikkei alvo de essencializações, como a de "minoria-modelo", produtiva, operosa e disciplinada. Nas décadas de 1960 e 1970, o nikkei representava a concretização do que a elite no período préguerra imaginava para o futuro do país. Efetivamente presentificavam naquele momento os "brasileiros do futuro", acepção tão preconizada nos discursos políticos daquela época. Lesser chega até a atribuir o termo "commodity étnica" para mostrar como o Japão e os nikkeis se prestaram para compor essa geografia imaginada.

A qualificação dos nipo-brasileiros nas cidades, angariada através da inserção dos nisseis nas universidades públicas e na sua colocação em categorias profissionais liberais, foi possível devido ao abandono do "espírito" dekassegui de seus pais, ou seja, a de trabalhador temporário no Brasil. Fenômeno, portanto, que foi gestado concomitantemente com o processo de fixação na terra, que por sua vez, esteve alinhado com a substituição da lavoura predatória pela introdução de novas tecnologias no campo, como a produção e distribuição a partir das cooperativas agrícolas, a agricultura intensiva, os planos de desenvolvimento do cerrado e a grande produção de hortifrutigranjeiros no país. Uma matéria do jornal britânico The Observer ilustra bem essa nova condição dos citadinos nikkeis: “Os escritórios parecem totalmente povoados por eles... [Na] horticultura, eles são brilhantes... [Em] certos dias, eles parecem tomar metade do aeroporto, carregando suas pastas idênticas, fumando seus cigarros no estilo rígido dos principiantes, posando para fotografias" (Lesser, 2008: 45).

Se, como vimos, a expansão na agricultura brasileira gerada em partes pelas inovações introduzidas pelos imigrantes japoneses era um elemento presente nos discursos favoráveis à imigração nos anos de 1920 e 1930, será reforçada no contexto discursivo dos anos 60, reverberando até os dias de hoje. Uma breve reflexão sobre alguns discursos presentes nas comemorações do centenário da imigração japonesa no Brasil será feita no capítulo 3. De modo geral, é possível perceber a modulação de uma narrativa que busca enfatizar o "sucesso" da presença nikkei no país, não obstante as diversidades enfrentadas e sua "integração" plena à sociedade brasileira.

Esse "sucesso" é na maior parte das vezes pensado a partir do viés econômico. Vimos pelos dados apresentados por Marcelo Paixão (2005) como o IDH dos "amarelos/orientais" no Brasil é quase igual ao do Japão. Sobre o grupo dos brasileiros de origem japonesa - sem levar em consideração outros grupos de origem asiática - a já mencionada pesquisa Datafolha de 19/10/95, que mostrou que 53\% dos adultos nikkeis tinham educação universitária comparado com apenas $9 \%$ da população adulta total, também revelou que $80 \%$ das famílias nikkeis em São Paulo tinham renda de pelo menos dez salários mínimos, sendo que no total da população, 
apenas 30\% tinham salários tão altos (Lesser, 1995: 301). A imagem de que o "japonês é rico" forjou-se, portanto, no contexto de inserção dos nikkeis nas camadas médias da sociedade. A entrevistada Fernanda Saito, do seinen-kai da Seicho-No-Ie, sansei, 21 anos, estudante de Maringá, narra um episódio interessante sobre esse discurso:

\begin{abstract}
"Antigamente, a gente (ela e a família) morava numa casa de madeira. Era bem velhinha mesmo. Daí, foram bater palma lá em casa, pedir dinheiro. Nossa, foi super engraçado! Aí apareci na porta e eles começaram a dar risada [risos]. Falaram: 'Japonês! 'Japonês' nessa casa?! Ué, mas vocês não são ricos?!'. E começaram a questionar a gente por morar lá na casa de madeira e falar que a gente não tinha dinheiro para dar para eles. Falaram que a gente era mentiroso, que era tudo fachada [risos]. Eles se assustaram com 'japonês' morando em uma casa de madeira e não tendo dinheiro para dar para eles".
\end{abstract}

O retorno financeiro, contudo, é encarado como resultado de um conjunto de conquistas obtidas em vários campos de atuação: na agricultura, no comércio, na prestação de serviços, nas universidades. Além de figurarem na mídia de informação como "cultura do sucesso", os nikkeis passam a ser requisitados para a mídia publicitária com o intuito de vender uma imagem de eficiência do produto. Seja em propagandas de cursinhos pré-vestibulares, seja nas associadas à tecnologia japonesa, o objetivo se constitui em promover a associação da mercadoria com a alta produtividade.

Como vimos, nas décadas que se seguiram ao fim da Segunda Guerra Mundial, o Japão conseguiu se reerguer economicamente de forma significativa. De acordo com Elisa Sasaki, com a ocupação militar americana entre os anos de 1945 a 1952 e com a Guerra da Coreia, o Japão se tornou um aliado importante dos Estados Unidos no contexto da Guerra Fria. $\mathrm{O}$ investimento em capital e a transferência de tecnologia americana para o arquipélago aumentou rapidamente, alavancando seu comércio exterior nos setores têxteis, eletrônico, naval, provocando o renascimento econômico do país (Sasaki, 2009: 141-142).

Entre as décadas de 1960 e 1980, as altas taxas de crescimento provocaram o "milagre econômico" japonês que o levou ao posto de segunda maior potência econômica do mundo. A inundação de produtos de alta tecnologia no mercado internacional colocou o Japão e seus robôs, computadores, máquinas, carros e videogames, como uma das principais referências mundiais no campo da produção tecnológica e científica. O Brasil não ficou imune ao consumo dos produtos japoneses: Sony, Nintendo, Mitsubishi, Toyota, Kawasaki, Honda, Canon, Panasonic invadiram também os lares brasileiros e as imagens que remetiam tais marcas e mercadorias ao universo da tecnologia japonesa de alta qualidade começavam a se consolidar. 
É nesse contexto que os brasileiros de origem japonesa passam a fazer parte desse imaginário. O famoso slogan, produzido pela agência de publicidade Talent para a marca de eletroeletrônicos, Semp Toshiba, "os nossos japoneses são mais criativos que os japoneses dos outros" ou "os nossos japoneses estão ainda mais criativos que os japoneses dos outros", é amplamente conhecido pelos consumidores. A campanha para a linha de computadores em que personagens travestidos de japoneses buscam mostrar que entendem de tecnologia e tentam vender produtos que não são da Semp Toshiba, também garantiu sucesso à marca com a assinatura "fingir que é japonês é fácil, difícil é fazer um computador com tanta tecnologia". A parceria entre a agência e a marca já dura 22 anos. Segundo o sócio-diretor da Talent, José Eustachio, "As campanhas agregaram modernidade à marca, uma atitude mais contemporânea”. Além disso, “A Semp Toshiba faz uma simbiose perfeita da junção da cultura japonesa com a brasileira, que possui mais humor", completa. ${ }^{51}$

O que não falta é "humor" nas peças publicitárias da empresa quando protagonizadas por personagens "japoneses": a fala carregada com forte sotaque, a dificuldade na comunicação, a postura abobalhada, além de elementos da "cultura japonesa" são parodiados na transposição para a linguagem midiática. Por que "os nossos japoneses seriam mais criativos que os japoneses dos outros?". Parafraseando Eustachio, assim como a Semp Toshiba, os nikkeis, "japoneses" do Brasil, são melhores porque conjugam a "marca", perdoem o duplo sentido, e a qualidade japonesa com o "jeitinho brasileiro", bem humorado, divertido e criativo. Essa estratégia pode ser observada nos comerciais da campanha, "os nossos japoneses estão ainda mais criativos que os japoneses dos outros", que inclusive faturou o prêmio de melhor campanha nacional no $27^{\circ}$. Profissionais do Ano de 2005, evento considerado "a maior festa da propaganda brasileira". 52

No comercial "pilha invertida", por exemplo, uma mulher "brasileira" chega em uma loja de eletroeletrônicos e diz que está trazendo sua TV quebrada para consertar. O rapaz da loja, um "japonês" se assusta e fala com sotaque: "É uma Semp Toshiba!!”. Ele grita: "Pessoal vem ver! Akira! Massao! Uma Semp Toshiba quebrada!”. “Ohh!”, exclamam. Eis que aparecem várias pessoas "japonesas", um odissan com hashi e tchawan ${ }^{53}$ na mão, uma mãe com um bebê no colo, “chama vô, chama vizinho!", enchendo a loja, deixando a mulher atônita. Todas curiosas com o inesperado, ou melhor, o impossível: uma Semp Toshiba quebrada. Até que o

\footnotetext{
50 Em 1977, a SEMP (Sociedade Eletro Mercantil Paulista) fechou um acordo de participação acionária e tecnológica com a empresa japonesa Toshiba Corporation, passando a atuar como Semp Toshiba.

51 "Um casamento de culturas na publicidade". Conforme http://www.adnews.com.br/publicidade/72809.html Acesso: 29/04/2010.

52 "AlmapBBDO, Talent e Escala vencem a etapa nacional do Profissionais do Ano. Conforme: http://www.portaldapropaganda.com/noticias_dia/2005/11/09/0001 Acesso: 08/11/2005

${ }^{53}$ Odissan: senhor. Hashi: pauzinhos. Tchawan: espécie de vasilha
} 
funcionário pega o controle remoto da TV e diz: “Oh! Queburô non! Píria tá ao conturário!”. Em uníssono, todos dizem "ahh", dando de ombros e levantando a mão como se dissessem: "que estúpida! Duvidando da qualidade de uma Semp Toshiba!”. Uma senhora, obassan, baixinha, com bengala em riste, chama, então, sua atenção: "Se riga cabeçon!”. Corta a cena e entra música de fundo oriental com voz em off narrando: "Só a Semp Toshiba dá até 50 meses de garantia em TV's, sem cobrar mais por isso. Nossos japoneses estão ainda mais criativos que os outros".

No comercial "regresso", uma mulher japonesa, vestida de quimono, abre a porta de uma típica e tradicional casa do Japão e se depara com o marido japonês, Yoshiro, vestido de terno. Assustada, leva a mão à boca. Diz, com o sotaque bastante forte, que o mesmo foi embora há 50 meses, e apresenta duas crianças gêmeas, Hiroshi e Toshio, nascidas depois que ele a havia deixado, grávida. O pai esboça um sorriso, e em seguida toma um susto quando surge uma criança menor, japonesa e com os cabelos bem loiros em forma de "tigela". A mulher o apresenta como Ricardinho, filho de Ricardón, e encabulada, olhando para o chão, diz: "50 meses... muito tempo né, Yoshiro?”. Corta a cena e entra música de fundo oriental com a voz em off: “50 meses é uma eternidade. Só a Semp Toshiba dá tanta garantia em TV's, sem cobrar mais por isso". Entra a logomarca com televisões ao fundo e quatro japoneses, de jaleco branco, em forma de escada, confirmando em coro, com um sonoro "hai" (sim). 

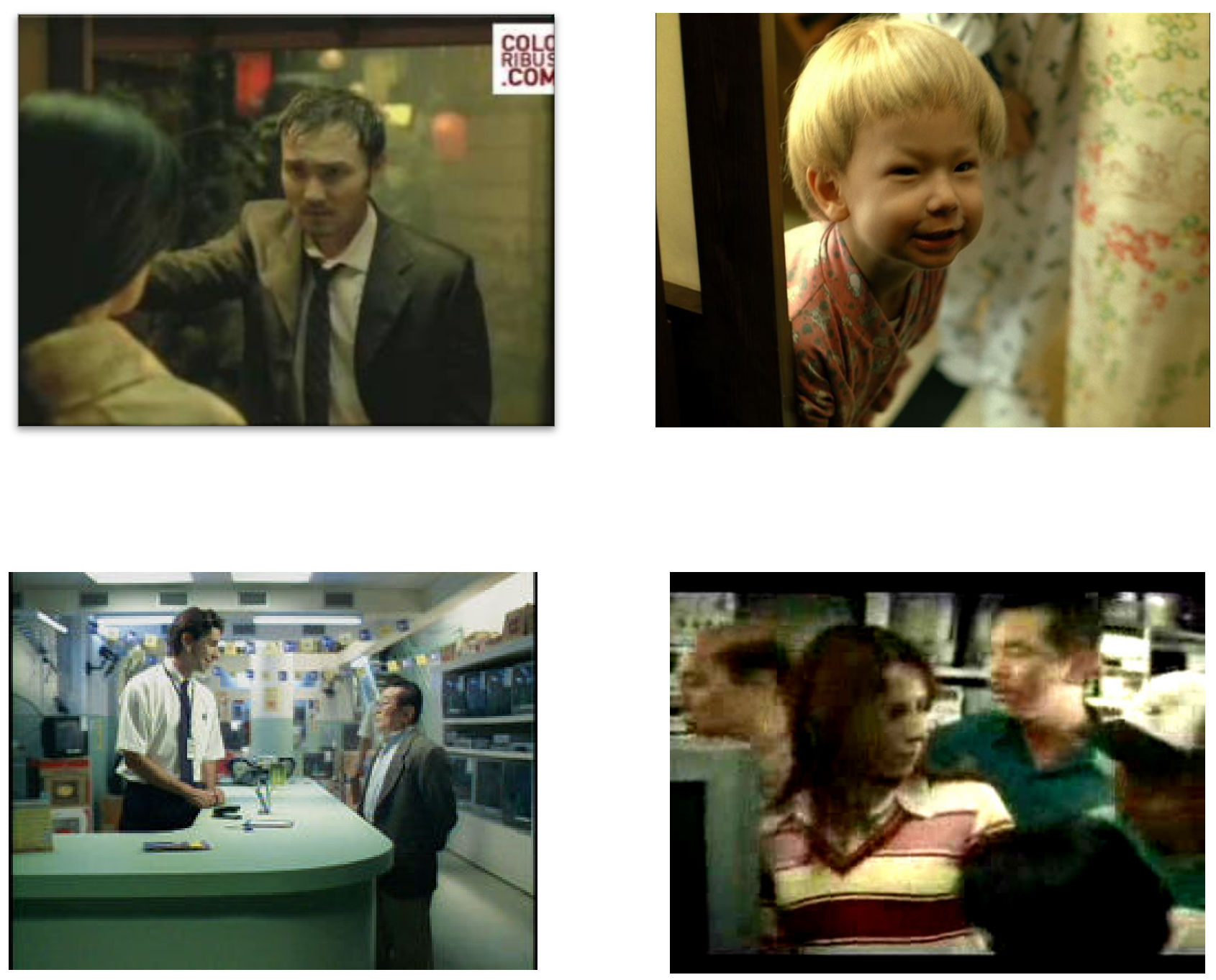

ertida"

Depois de cinco anos sem propagandas com a temática dos "nossos japoneses", a Talent os "resgata" em 2010, como consta no próprio site da agência. ${ }^{54}$ A Semp Toshiba que lidera a venda de aparelhos televisores desde 1997 aposta no marketing na tentativa de dobrar seu faturamento até 2012: em média US\$ 15 milhões por ano são usados para esse fim. ${ }^{55}$ A linha STi (Semp Toshiba Informática) que reúne desktops, notebooks e servidores é um filão que vem sendo explorado nas campanhas publicitárias de 2010. Nada como recorrer aos velhos

\footnotetext{
54 “Talent resgata japoneses para STi”. Conforme: http://www.talent.com.br/blog/?p=1562 Acesso: 29/04/2010

55 "Um casamento de culturas na publicidade". Conforme: http://www.adnews.com.br/publicidade/72809.html $14 / 07 / 2008$.
} 
"japoneses": "As peças trazem de volta os japoneses que já fizeram sucesso nas campanhas da Semp Toshiba para reforçar a qualidade dos produtos da marca", anuncia o site da Talent. ${ }^{56}$

O conteúdo-chave dessa nova campanha consiste em enfatizar a qualidade e o diferencial não somente dos produtos da $S T i$, mas de seus criadores "japoneses". Atributos tão notáveis que poderiam colocar em dúvida até mesmo a autoria de grandes invenções e conquistas, como a roda, o rock \& roll e a viagem à Lua. A edição de janeiro de 2010 da revista Rolling Stones teve um anúncio da STi na contracapa, com um "japonês" vestido de Elvis Presley usando o crachá da companhia e a seguinte questão: “O Rei do Rock seria um dos japoneses da Semp Toshiba?"

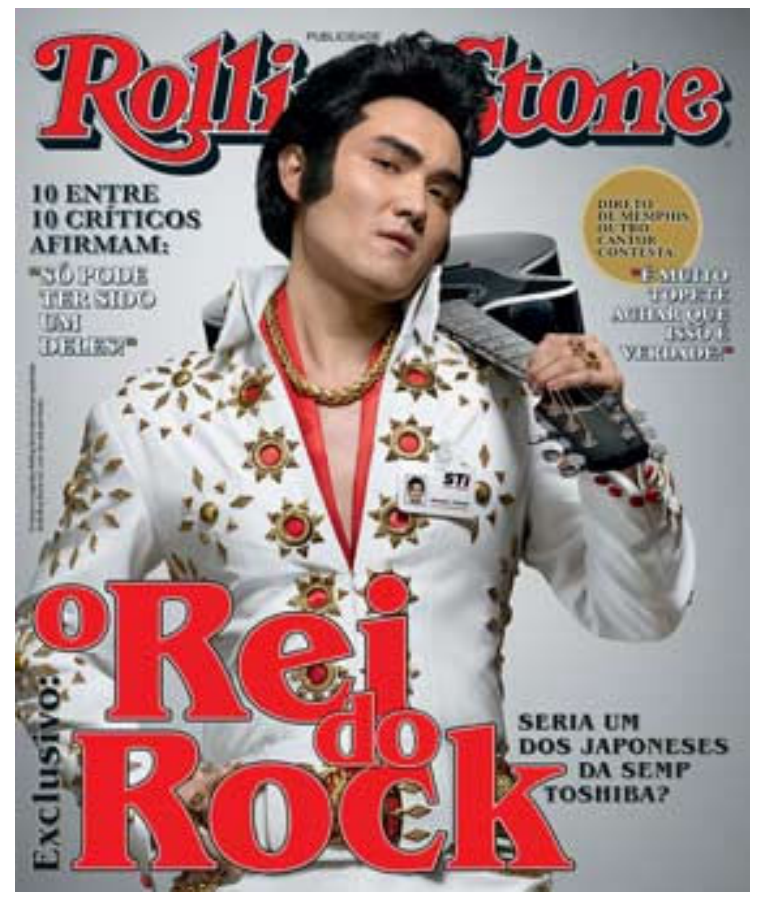

Fig.5 Anúncio STi

Conforme o site da agência, essa hipótese se justificaria pelo conceito da comunicação: "Se eles foram capazes de desenvolver uma linha tão avançada de computadores como os da $S T i$, eles poderiam ter sido responsáveis por qualquer grande invenção ou realização, inclusive o rock' $n$ roll. A assinatura resume: 'STi é Semp Toshiba. Uma grande marca faz toda a diferença",.

\footnotetext{
${ }^{56}$ http://www.talent.com.br/blog/?p=1562 Acesso: 29/04/2010
} 


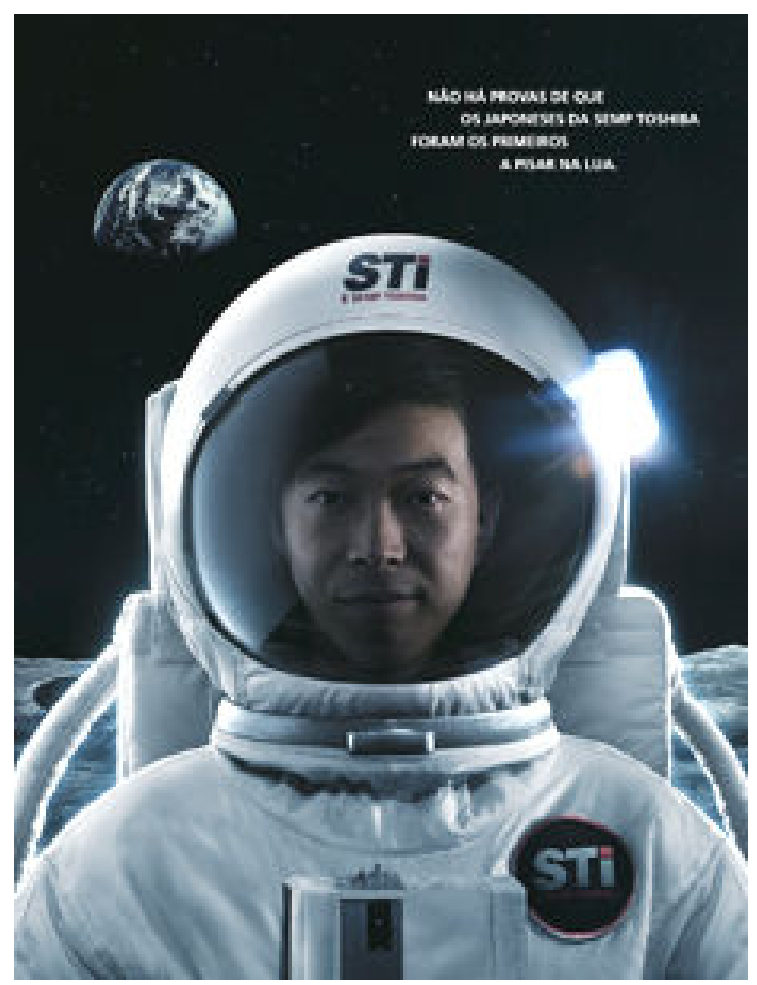

Fig. 6 Anúncio STi

O comercial "Lua" também mantém o mesmo conceito. A peça inicia com imagens antigas reproduzindo o momento em que Neil Armstrong pisa na Lua, proferindo a famosa frase: "That's one small step for a man, one giant leap for mankind" 57 . Em seguida, o astronauta que está de costas é chamado por um assobio e ouve-se: “Ei, cabeção!”. Ele vira-se lentamente, a respiração ofegante no interior do capacete. A imagem que se vê é a de um ofurō de madeira, ${ }^{58}$ do qual emerge um japonês que diz "buuu!", tentando dar-lhe um susto. "Demorou, né? Hahaha", ri o japonês mergulhando na banheira, a roupa de astronauta posta ao lado. A música de fundo oriental não deixaria de aparecer também neste momento. $\mathrm{O}$ americano fica de boca aberta, atônito com a cena. Entra voz do narrador em off: "Não há provas que os japoneses da Semp Toshiba foram os primeiros a pisar na Lua”. Imagens de notebooks e computadores aparecem e a música muda para um arranjo de guitarra, criando uma atmosfera de modernidade para o que ele anunciará: "Mas se eles criaram computadores tão avançados como os da $S T i$, quem duvida? STi é Semp Toshiba. Uma grande marca faz toda diferença".

De acordo com Lesser (2008: 55), essa tática de mercado tem início nas décadas de 1960 e 70, quando os anúncios passam a se dividir em três categorias: "empresas japonesas no Brasil que enfocavam a 'brasilidade' dos nikkeis; empresas nipo-brasileiras que promoviam a

\footnotetext{
57 "Este é um pequeno passo para um homem, mas um grande salto para a humanidade".

${ }^{58}$ Banheira originária do Japão com formato mais profundo e curto que a banheira ocidental. A prática de imersão em água mantida em alta temperatura possibilita o relaxamento do corpo e da mente, possuindo também um caráter ritual. No Brasil, o banho de ofurō é atualmente muito utilizado em spas.
} 
'capacidade natural' dos nikkeis de melhorar o Brasil; e empresas não-nikkeis que usavam, em sua estratégia de marketing, a inteligência e alta produtividade associada ao Japão e aos nikkeis". Misto de todas essas categorias, a Semp Toshiba soube explorar esse imaginário que associa os "japoneses" do Brasil com os japoneses do Japão, a partir da chave tecnologia e eficiência, ao mesmo tempo em que o lado criativo do brasileiro se impõe como elemento importante na composição do diferencial da marca. A Suzuki motos também fez uso dessa referência ao contratar a apresentadora Sabrina Sato como garota-propaganda da marca: "A Sabrina é como a Suzuki, fabricada no Brasil com tecnologia japonesa".

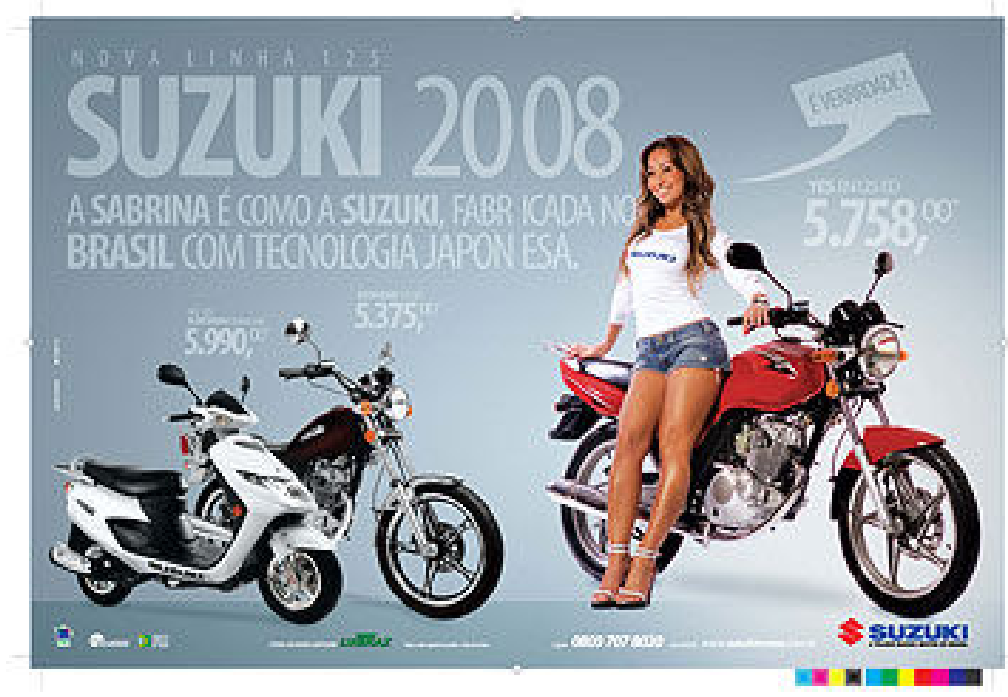

Fig. 7 Anúncio Suzuki Motos

Carmen Rial, ao discutir os estereótipos étnicos e raciais na propaganda brasileira à época das Copas do Mundo de 1994 e 1998, atenta para o repertório de signos presentes no imaginário coletivo que conotam diferentes valores para determinados grupos étnicos. A autora afirma que os negros e mulatos frequentemente se mostram associados ao trabalho físico, sendo o corpo a principal marca que os distinguem. Sua visibilidade, portanto, é particularmente percebida nas arenas "ideologicamente consideradas de seu domínio - esportes, música, dança, comida e bebida" (Rial, 2001: 9) (trad. minha).

Por oposição a essa representação, Rial aponta a presença dos homens japoneses nas propagandas como estandarte da razão e do trabalho intelectual e como contraponto ao trabalho físico. A associação com a alta tecnologia e garantia de qualidade nos produtos remete ao imaginário de que os japoneses são dedicados, esforçados, trabalhadores capazes de repetir a mesma tarefa centenas de vezes até que esteja bem cumprida. A cabeça, portanto, seria um símbolo que os diferencia. A autora ilustra essa afirmação com o comercial da Sharp de julho de 
1995 que mostrava cinco cabeças de japoneses que exaltavam a marca em diferentes línguas. Seus corpos permaneciam invisíveis, sendo que somente as cabeças se movimentavam (Rial, 2001: 12).

Nas propagandas da Semp Toshiba, por trás da fala com sotaque e da postura abobalhada dos personagens há uma pessoa esperta e inventiva. Embora a apelação à comicidade seja o principal mote das peças, a intenção é valorizar os "japoneses" da Semp Toshiba, através da veiculação de uma imagem de eficiência e confiabilidade aos produtos por eles criados. Afinal, são "made in Brazil", mas a tecnologia é japonesa, sinônimo de modernidade e durabilidade. As imagens sobre o Japão como o principal polo high tech do mundo inundam os televisores brasileiros com informações sobre os avanços do país em diversos campos de produção tecnológica, como por exemplo, robótica, eletroeletrônica, satélite, sistema digital de TV, nanotecnologia, uso de energia solar, etc. Como já pontuaram Lesser e Tsuda, a associação dos "japoneses" no Brasil com os "japoneses" do Japão, recurso, como vimos, muito explorado pela publicidade abre caminho para que essas imagens também alimentem discursos positivos sobre os nikkeis. Como afirma a entrevistada Yumi Kawamura, "a televisão mostra que coisa que é de japonês é coisa boa! Principalmente a Semp Toshiba, que dá para confiar!”.

\section{CONSIDERAÇÕES FINAIS}

José Murilo de Carvalho (1998) nos brinda com uma reflexão muito oportuna sobre o imaginário social brasileiro e que levanta algumas questões importantes para essa pesquisa. $\mathrm{O}$ autor defende que a visão paradisíaca do Brasil como país de grandezas naturais existente desde os tempos da presença europeia, criou raízes profundas no imaginário nacional, sobrevivendo até os dias de hoje. O historiador mostra como a exaltação das belezas naturais foi documentada desde a carta de Caminha, passando pelos registros de cronistas do século XVI, pela obra História da América Portuguesa (1730) de Rocha Pita, pela "Canção do exílio" de Gonçalves Dias até a letra do hino nacional.

A "sobrevivência do edenismo", segundo o autor, poderia ser verificada por duas pesquisas de opinião pública por ele mencionadas ${ }^{59}$ que tematizavam dentre outros assuntos, a questão do orgulho nacional. Com uma das taxas mais altas do mundo, de acordo com os dados do World Values Survey de 1990, 87\% das pessoas consultadas sentiam orgulho de serem brasileiros, sendo a natureza o motivo mais recorrentemente apontado para tal. Carvalho

\footnotetext{
${ }^{59}$ VP/Veja e Cpdoc/ISER.
} 
questiona as razões para esse patriotismo que não está condicionado às conquistas políticas nacionais, mas a "fatores sobre os quais não se tem controle", que em tese se situam fora do domínio das ações humanas. O autor sugere em seguida que a persistência do "motivo edênico" poderia estar relacionada à "inadequação do elemento humano que habita o país", inadequação que ele chama, por oposição à razão edênica, de "razão satânica" (Carvalho, 1998: 13).

Na pesquisa de opinião mencionada, o "caráter do povo" aparece em terceiro lugar como motivo para se ter orgulho do país e a autoimagem dos brasileiros foi caracterizada pelos consulentes a partir dos seguintes atributos, nesta ordem: sofredor, trabalhador, alegre e conformado (id., ib.: 14). A aparente contradição entre o sofrimento e a alegria é diagnosticada pelo autor a partir da falta de consciência cívica dos brasileiros: o "não-cidadão" que se vê como vítima e não como agente da história. Sobre a confiabilidade nos concidadãos, considerada segundo alguns estudiosos, elemento central para o bom funcionamento e exercício da democracia, nada menos que 60\% dos entrevistados julgam os brasileiros pouco ou nada confiáveis - a taxa mais baixa entre 43 países pesquisados segundo o World Values Survey de 1990 (id.; ib.: 16) (grifos meus).

Embora o historiador mencione o dado, sem entrar em maiores explicações, de que africanos e asiáticos são "vistos como tendo tido influência mais negativa que positiva" na autoavaliação dos brasileiros (VP/Veja) (id.; ib.: 13); o trabalho e a honestidade foram um dos elementos mais apontados pelos meus interlocutores como sustentáculos da imagem dos descendentes de japoneses na sociedade brasileira. Ao contrário da "razão satânica", presente na visão negativa sobre o "povo" brasileiro, o imaginário sobre os nikkeis se qualificaria mais por atributos considerados positivos e a confiabilidade transmitida pelos mesmos aos seus concidadãos seria encarada como reflexo, como consequência justamente desse trabalho e honestidade.

Em um estudo publicado em 1986, Toshiaki Saito desenvolve uma pesquisa quantitativa na área de Psicologia Social com o intuito de verificar em que medida os estereótipos construídos sobre os japoneses nas décadas anteriores ainda continuavam a influenciar as percepções das novas gerações de brasileiros descendentes de japoneses e nãodescendentes. O pesquisador adotou o público universitário da Universidade Federal do Paraná como objeto de pesquisa e o dividiu em dois grupos: A) descendente de japoneses e B) nãodescendentes. O grupo A teve a participação de 113 sujeitos, sendo 53\% do sexo feminino e 47\% do sexo masculino, com média de idade de 23 anos. O grupo B teve a participação de 106 sujeitos, sendo $55 \%$ do sexo feminino e $45 \%$ do sexo masculino, com média de idade também de 23 anos. Saito formulou uma lista com 99 adjetivos que pudessem caracterizar estereótipos e 
pediu para que o respondente selecionasse 10 adjetivos, pela ordem decrescente de valores, que se aproximassem da percepção que se tinha em relação ao outro grupo. Partindo da ideia de "perfil psicológico", o autor concluiu que os grupos se percebem da seguinte forma: ${ }^{60}$

\begin{tabular}{|c|c|}
\hline $\begin{array}{l}\text { PERFIL DO HOMEM } \\
\text { JAPONÊS }^{61}\end{array}$ & \\
\hline 1. Estudioso & $66 \%$ \\
\hline 2. Trabalhador & $59 \%$ \\
\hline 3. Responsável & $54 \%$ \\
\hline 4. Dedicado & $54 \%$ \\
\hline 5. Inteligente & $51 \%$ \\
\hline 6. Reservado & $39 \%$ \\
\hline 7. Fechado & $38 \%$ \\
\hline 8. Competente & $38 \%$ \\
\hline 9. Educado & $35 \%$ \\
\hline 10. Tímido & $30 \%$ \\
\hline 11. Intelectual & $30 \%$ \\
\hline 12. Compenetrado & $30 \%$ \\
\hline 13. Observador & $29 \%$ \\
\hline 14. Calmo & $26 \%$ \\
\hline 15. Culto & $24 \%$ \\
\hline 16. Individualista & $23 \%$ \\
\hline 17. Equilibrado & $21 \%$ \\
\hline 18. Econômico & $21 \%$ \\
\hline 19. Isolado & $21 \%$ \\
\hline 20. Formal & $20 \%$ \\
\hline
\end{tabular}

\begin{tabular}{|ll|}
\hline $\begin{array}{l}\text { PERFIL DO HOMEM } \\
\text { BRASILEIRO }\end{array}$ \\
\begin{tabular}{|l} 
1. Comunicativo \\
2. Carnavalesco
\end{tabular} \\
3. Gozador & $55 \%$ \\
4. Machão & $48 \%$ \\
5. Alegre & $39 \%$ \\
6. Paquerador & $36 \%$ \\
7. Sociável & $32 \%$ \\
8. Religioso & $32 \%$ \\
9. Humano & $31 \%$ \\
10. "Boa gente” & $30 \%$ \\
11. Ambicioso & $30 \%$ \\
12. Oportunista & $29 \%$ \\
13. Individualista & $26 \%$ \\
14. Mulherengo & $23 \%$ \\
15. Simpático & $21 \%$ \\
16. Indisciplinado & $21 \%$ \\
17. Imaturo & $20 \%$ \\
18. Irresponsável & $18 \%$ \\
19. Afetivo & $17 \%$ \\
20. Fanfarrão & $16 \%$ \\
\hline
\end{tabular}

\begin{tabular}{|c|c|}
\hline $\begin{array}{l}\text { PERFIL DA MULHER } \\
\text { JAPONESA }\end{array}$ & \\
\hline 1. Responsável & $53 \%$ \\
\hline 2. Estudiosa & $49 \%$ \\
\hline 3. Inteligente & $47 \%$ \\
\hline 4. Tímida & $41 \%$ \\
\hline 5. Reservada & $41 \%$ \\
\hline 6. Dedicada & $41 \%$ \\
\hline 7. Educada & $39 \%$ \\
\hline 8. Trabalhadora & $38 \%$ \\
\hline 9. Humilde & $29 \%$ \\
\hline 10. Fechada & $29 \%$ \\
\hline 11. Calma & $29 \%$ \\
\hline 12. Fiel & $27 \%$ \\
\hline 13. Acanhada & $25 \%$ \\
\hline 14. Simpática & $23 \%$ \\
\hline 15. Prática & $23 \%$ \\
\hline 16. Competente & $21 \%$ \\
\hline 17. Observadora & $21 \%$ \\
\hline 18. Submissa & $20 \%$ \\
\hline 19. Individualista & $19 \%$ \\
\hline 20. Formal & $18 \%$ \\
\hline
\end{tabular}

\begin{tabular}{|c|c|}
\hline $\begin{array}{l}\text { PERFIL DA MULHER } \\
\text { BRASILEIRA }\end{array}$ & \\
\hline 1. Romântica & $47 \%$ \\
\hline 2. Comunicativa & $45 \%$ \\
\hline 3. Religiosa & $45 \%$ \\
\hline 4. Sensual & $44 \%$ \\
\hline 5. Sociável & $35 \%$ \\
\hline 6. Carnavalesca & $35 \%$ \\
\hline 7. Fofoqueira & $34 \%$ \\
\hline 8. Humana & $32 \%$ \\
\hline 9. Afetiva & $32 \%$ \\
\hline 10. Curiosa & $31 \%$ \\
\hline 11. Carinhosa & $30 \%$ \\
\hline 12. Supersticiosa & $26 \%$ \\
\hline 13. Alegre & $22 \%$ \\
\hline 14. Observadora & $19 \%$ \\
\hline 15. Preconceituosa & $18 \%$ \\
\hline 16. Ambiciosa & $17 \%$ \\
\hline 17. Individualista & $17 \%$ \\
\hline 18. Oportunista & $17 \%$ \\
\hline 19. Sexual & $16 \%$ \\
\hline 20. Paqueradora & $16 \%$ \\
\hline
\end{tabular}

\footnotetext{
${ }^{60}$ Aqui foram recortadas as primeiras 20 atribuições de um total de 99.

${ }^{61}$ Perfil do homem "japonês" e mulher "japonesa", segundo os não-descendentes.

${ }^{62}$ Perfil do homem "brasileiro" e mulher "brasileira", segundo os descendentes de japoneses.
} 
Como é possível observar, embora tenha feito a pesquisa com brasileiros descendentes de japoneses, Saito nomeou os perfis de "japonês" e "brasileiro". É importante considerar que a análise de cunho quantitativo facilmente pode recair num reducionismo de significados, ainda mais quando se trata de uma temática tão complexa como essa. Entretanto, quando cotejamos os dados de Saito com alguns dos depoimentos da presente pesquisa, que se pretende qualitativa, observamos que há elementos comuns.

Os jovens consultados pelo autor, geração universitária da década de 80 , tem hoje cerca de 50 anos, assim como os entrevistados Júlia Suzuki, Yumi Kawamura, Lúcia Miyamoto, Sueli Takahashi e Luís Yamamoto. A geração posterior, dos filhos destes, de modo geral, afirma que esses qualificativos não mais se verificam na realidade. Contudo, os estereótipos e adjetivos mais citados pelos meus interlocutores, independentemente da clivagem geracional, como formadores do imaginário sobre os nikkeis ainda são os mesmos encontrados na pesquisa de Saito: trabalhador, responsável, estudioso.

Como declarado na introdução do capítulo, a hipótese aqui defendida é a de que essa trama imaginária, como um mito, é constantemente ressignificada e reatualizada de acordo com as circunstâncias históricas, sem deixar de reproduzir certas permanências. Ao longo da presença japonesa e nipo-brasileira no país, vimos como a ideia de esforço se constituiu em um elemento constante nas narrativas e discursos em fluxo.

Cumpre esclarecer que essa pesquisa não tem a pretensão de enveredar para qualquer tipo de exercício de futurologia no que tange à sobrevida desse imaginário, à "preservação da cultura" ou à "perda de valores". O que se buscou e se busca trazer à mostra é o agenciamento desses termos pelos sujeitos da pesquisa e a reflexão que tais questões incitam nos mesmos a partir de suas experiências de vida. O foco deste capítulo, precisamente, incidiu sobre o conjunto de imagens que foi sendo construído sobre e pelos japoneses e seus descendentes no Brasil. Como pretendemos mostrar, esse imaginário pode se constituir em uma das chaves, não a única é preciso lembrar, para os processos de construção identitária do sujeito.

O propósito deste capítulo, portanto, consistiu em trazer à tona partes dessa malha discursivo-imaginária que toma a força de trabalho, a disciplina e a organização como atributos relacionados a eles. Uma investigação historiográfica que cubra o período esteve e está longe de se constituir nos objetivos do trabalho. Por isso, discursos políticos, charges, textos jornalísticos, acadêmicos, propagandas, comerciais foram aqui mobilizados. Vale ressaltar que a apresentação desse mosaico de discursos e imagens - que apesar de seguir uma cronologia, não deixa de 
resultar num panorama mais superficial sobre o imaginário em questão - foi uma estratégia adotada para mostrar um pouco do repertório semântico utilizado nas representações e autorepresentações positivas sobre os nikkeis. 


\section{CAPÍTULO II - "RAÇA" E ETNIA: O NIKKEI EM QUESTÃO}

\section{INTRODUÇÃO}

Como já pontuado, no período entre as décadas de 1960 e 1970 - marcado pela ascensão sócioeconômica dos nisseis e pelo aumento do número de "casamentos interétnicos" a questão da "assimilação" e "integração" se impõe como elemento central da produção de discursos sobre os japoneses e seus descendentes. A Revista Veja, em dezembro de 1969, publicava: "Levou quase trezentos anos para os portugueses do Brasil se considerarem brasileiros... Para os 'japoneses do Brasil', demorou muito menos". A reportagem era ilustrada com fotos de famílias de "casais interétnicos" e de um "japonês louro" representando o "Brasil" (Lesser, 2001: 47).

Por conta das comemorações dos 70 anos da imigração japonesa ao Brasil, o ministro das Relações Exteriores, Antônio F. Azeredo da Silveira, proferiu um discurso, no qual usou os dados relativos ao número de alunos e professores da Universidade de São Paulo para elogiar o "poder de assimilação dos nikkeis": "Já se disse que o japonês é capaz de fazer pérolas como a natureza, relógios como os suíços e uísque como o escocês. No Brasil, o imigrante japonês se fez brasileiro como os brasileiros!" (Lesser, 2008: 46). O tom desse discurso não mudou decorridos trinta anos, com as comemorações dos cem anos da imigração, como pôde ser observado na proliferação de eventos, publicações, exposições e no conteúdo dos discursos políticos em todo o ano de 2008.

Em 11/06/97, a matéria na Revista Veja, "Discretos e suaves: visita sem pirotecnia do casal imperial do Japão atesta sucesso da integração", revelava que "considerando que a imigração acabou, não é apenas a cultura nipônica que corre o risco de desaparecer, mas os próprios traços fisionômicos orientais". Quase quarenta anos depois da matéria citada de 1969, a edição especial comemorativa do centenário da mesma revista ${ }^{63}$, "Imigração japonesa: 100 anos depois", concluía: "O fato de os próprios yonseis já terem, em sua maioria, um não-japonês na árvore genealógica (caso de $61 \%$ deles) leva a crer que os olhinhos puxados podem estar com os dias contados. Eles deverão ficar mais e mais redondos nas próximas décadas".

O discurso da "assimilação e integração" frequentemente vem acompanhado da afirmação de ausência de conflitos étnico-raciais no país. No livro, Uma Epopéia Moderna: 80

\footnotetext{
${ }^{63}$ Edição especial da Revista Veja, "O Brasil do sol nascente: os 100 anos da imigração japonesa”, edição 2038 $(12 / 12 / 07)$.
} 
anos da imigração japonesa no Brasil, Masuji Kiyotani e o jornalista José Yamashiro afirmam que essa "assimilação" do japonês deve-se em parte à "natureza generosa e hospitalidade inata" do povo brasileiro, que "como um todo tinha um espírito magnânimo e generoso, praticamente sem preconceito de raça. [...] Essas virtudes do povo brasileiro permitiram que o imigrante nipônico - que não tinha necessariamente a mesma largueza de espírito - desenvolvesse toda a sua potencialidade de trabalho e produção, algo inimaginável em outros ambientes sociais" (CEHIJB, 1993: 114) (grifos meus). São discursos das mais variadas ordens - jornalísticos, políticos, literários e até acadêmicos - que buscam reforçar o imaginário harmônico da “democracia racial" vigente no país.

Priscila Nucci (2000), em sua pesquisa a respeito do silêncio sobre o tema do racismo contra os japoneses no Brasil na produção científica-intelectual entre as décadas de 1940 e 70 , defende que o ideário assimilacionista - traduzido nas preocupações da elite do início do século XIX com a disposição dos povos imigrados à miscigenação - foi ressignificado a partir da década de 1940, em alguns estudos de sociologia e antropologia. Termos como "assimilação", "integração", "aculturação", agora matizados, já que despojados da retórica racialista, continuaram a ser utilizados nos estudos acadêmicos sobre os grupos imigrantes, contudo a ênfase passara a recair sobre os aspectos sociais e culturais e não biologizantes de tais termos. ${ }^{64}$

De acordo com a autora, com relação aos japoneses, o objetivo da maioria dessas pesquisas era mostrar as especificidades culturais do grupo e o seu grau de inserção e integração na sociedade brasileira, sendo que quaisquer atitudes discriminatórias contra o mesmo eram ignoradas ou minimizadas. Nucci conclui que a desqualificação do conceito de raça nessas análises em favor de um enfoque nos aspectos culturais parece ter provocado um silêncio sobre a discussão do racismo contra as populações estrangeiras imigradas (Nucci, 2000: 137).

Jeffrey Lesser defende que depois que os nikkeis "haviam se tornado cidadãos brasileiros" pela perspectiva do Estado na década de 1960, deixaram de assumir a mesma importância que tinham como elementos de investigação e pesquisa. Em outros termos, se nas primeiras décadas posteriores à imigração, o japonês foi alvo de análise pela intelligentsia nacional e pelos agentes políticos da época - tendo em vista os questionamentos em torno de seu papel como possível ameaça ou como ator desejável para a formação e desenvolvimento da

\footnotetext{
${ }^{64}$ De acordo com Nucci, os conceitos de assimilação e aculturação se desenvolveram no Brasil sob a influência de estudiosos como Emílio Willems, que ao lado de outros como Schaden, Baldus e Pierson, buscava introduzir um novo paradigma científico nos estudos de sociologia e antropologia em instituições como a Universidade de São Paulo e a Escola Livre de Sociologia e Política. Willems buscava dissociar a miscigenação, que entendia como processo biológico, da assimilação, que encarava como processo social, sendo o último definido por ele como referente a "processos de modificação, substituição e perda de traços psíquicos adquiridos" (Nucci, 2000: 120).
} 
nação - no período decorrente que coincidiu com a ditadura militar, os nikkeis foram sendo afastados dos estudos de raça e etnicidade.

O autor argumenta que no Brasil, a ascensão social tende a acarretar mudanças nas categorizações étnicas e raciais. Na década de 1930, era comum que os nikkeis fossem deslocados da categoria amarela para a branca. O discurso proferido pelo deputado federal Acylino de Leão em 1935 atesta essa mudança: “Os colonos japoneses... são até mais brancos que os portugueses". A brancura ou europeidade, portanto, era um requisito importante para a inclusão na "raça brasileira", mas o que significava ser "branco" sofreu alterações ao longo do tempo (Lesser, 2008: 25).

Segundo o historiador, tal fato deveu-se ao peso no país da concepção acadêmica de raça e etnicidade subsumida à noção de classe. Sendo assim, as ideias de "minoria", "opressão" e "pobreza" faziam parte da mesma equação. O autor assevera que o fato de os nikkeis não serem encarados como "verdadeiras" minorias, devido à sua ascensão econômica, permitiu que uma série de estereótipos fossem construídos sobre eles impunemente, concluindo que "apesar das ressalvas acadêmicas apontando para o fato de o Brasil ser, por excelência, um lugar de transitoriedade racial, os nipo-brasileiros, nos raros casos em que figuram nas discussões acadêmicas, costumam ser tratados como uma comunidade monolítica” (Lesser, 2008: 58).

Passados cem anos da imigração japonesa no Brasil, "integração e assimilação" continuam a ser as palavras de ordem dos discursos que cobriram o marco histórico. Kokei Uehara, livre-docente da Escola Politécnica da Universidade de São Paulo, presidente do Bunkyo em 2008 e da Associação para a Comemoração do Centenário da Imigração Japonesa no Brasil, discursara na abertura do evento do Anhembi:

Sou também um humilde imigrante que ainda criança para cá veio, com as mesmas esperanças e sonhos que embalaram a todos os imigrantes. Vivi e testemunhei uma boa parte desses cem anos de história, do sofrido início até a plena integração de nossa comunidade à sociedade brasileira. Essa conquista foi uma luta travada desde os primeiros dias pelos pioneiros e sustentada depois pelas gerações seguintes de nipo-brasileiros. Tivemos de superar as barreiras da língua, de usos e costumes diferentes. Vivemos as agruras da Segunda Guerra Mundial, mas nunca, nunca esmorecemos e muito construímos!

Como notou o entrevistado Pedro Higa, sansei, paulistano, 22 anos, pouco se comentou nos eventos comemorativos e na cobertura da mídia televisiva sobre o centenário, a relação conflituosa envolvendo brasileiros e japoneses no duro processo de adaptação dos últimos à nova realidade que se apresentava. Houvera realmente uma tentativa de “esquecimento", por parte da elite política e intelectual do país, nikkei e não-nikkei, do passado 
de racismo científico, oficial e nas práticas cotidianas? Teria tal "esquecimento" alguma ligação com as dúvidas de vários entrevistados a respeito de terem sido ou não vítimas de preconceito?

A edição comemorativa da Folha de São Paulo a respeito do centenário da imigração japonesa no Brasil ${ }^{65}$, conta com uma matéria que apresenta o dado de que "após cem anos de convivência, $44 \%$ dos japoneses e descendentes que moram em São Paulo afirmam que há preconceito de nikkeis contra brasileiros" e 36\% afirmam que existe o preconceito inverso, ou seja, o dos brasileiros contra os nikkeis. ${ }^{66}$ De acordo com os entrevistados ouvidos pela Folha ${ }^{67}$, o segundo tipo figura, principalmente, por meio das piadas com relação ao físico: aos olhos "fechados" (9\%) e ao tamanho dos órgãos genitais masculinos $(15 \%)$.

Uma das hipóteses dessa pesquisa é a de que as piadas, "brincadeiras" com relação à aparência física do "japonês" tem ligação com o peso com que a concepção de "raça", historicamente construída, ainda se faz sentir na representação da nação brasileira e com a força com que as marcas fenotípicas presidem as classificações raciais vigentes no país. Discursos sobre o caráter antiestético da figura do nipônico estiveram presentes em charges, jornais, declarações políticas, principalmente até o fimm da Segunda Guerra Mundial.

Voltando aos depoimentos, chama a atenção a maneira como a maioria dos interlocutores desta pesquisa agencia certos termos para se referirem aos nikkeis e não-nikkeis: “japoneses”, “orientais", "povo japonês”, "raça japonesa”, "raça oriental”, "povo brasileiro", "ocidentais". Já o conceito de etnia, como notado ao longo do trabalho, foi pouco acionado nos depoimentos. Um dos propósitos da pesquisa consiste em levantar alguns questionamentos a respeito da mobilização dessas categorias. Para tanto, faz-se necessário realizar uma breve recuperação de como a ideia de "raça japonesa" foi sendo forjada no imaginário brasileiro, lançando mão da análise de alguns discursos. O objetivo não consiste em empreender uma espécie de exegese da categoria, mas simplesmente entender algumas de suas representações e usos. Além disso, faz-se necessário dirigirmos o olhar para outro lado da questão: os discursos contrários ao recebimento e a presença dos japoneses no país. Na representação desse "outro", imagens positivas e negativas conviveram lado a lado, interpondo-se na experiência dos japoneses e seus descendentes no país.

Vale reiterar que não cabe aos objetivos da pesquisa, cotejar as diferentes análises sobre o período, contestar fontes, cruzar dados históricos e muito menos empreender uma investigação em arquivos. O que se busca aqui é produzir uma montagem de discursos que

\footnotetext{
${ }^{65}$ Folha de São Paulo, "100 anos de imigração japonesa: Retrato dos nossos japoneses”, 18/06/2008.

${ }^{66}$ Folha de São Paulo, "Convívio mantém algumas arestas: Lado a lado. Pouco mais de um terço vê preconceito contra e de "brasileiros", 18/06/2008.

${ }^{67}$ Folha de São Paulo, "Piadas sobre o físico estão entre as que mais irritam", 18/06/2008.
} 
tomaram como foco a indesejabilidade do imigrante japonês, a partir, sobretudo, de considerações de ordem racial.

\section{OS DISCURSOS RACIALISTAS E A IMIGRAÇÃO}

No final do século XIX, nações passaram a ser identificadas, especialmente, através da ideia de raça e não mais pela língua nacional, critério assim elaborado pelo nacionalismo cultural do romantismo (Seyferth, 1996: 42). Como vimos, os debates concernentes à introdução da mãode-obra imigrante no Brasil foram forjados no bojo das nascentes discussões acerca da identidade nacional. Acalentados pelo discurso eugenista, os pressupostos de homogeneidade racial eram frequentemente mobilizados para justificar ideologicamente as políticas de "branqueamento" do país. As negociações que antecederam a entrada oficial dos japoneses no Brasil em 1908 estiveram pautadas numa visão ambígua que ora os via como ameaça racial e política, ora os encarava como elementos que poderiam repetir aqui a rápida modernização econômica e militar conquistada pelo Japão com a Restauração Meiji.

As controvérsias em torno da vinda dos imigrantes japoneses, portanto, coincidiram com um momento histórico em que o Brasil respirava os ares da Belle Époque (1870-1914) e as renovações tecnológicas e culturais que esse período adiantou na Europa. O clima intelectual que grassava no país e, que buscava atrelar progresso e ciência, tinha no social-darwinismo, no evolucionismo social, no positivismo e no naturalismo a vanguarda teórica para se pensar o futuro da nação. ${ }^{68}$ Mas foram os modelos racialistas os alvos de maior atenção pela intelligentsia nacional.

Como analisa Lilia Schwarcz em $O$ espetáculo das raças: cientistas, instituições e questão racial no Brasil (1870-1930), tais modelos foram seletivamente apropriados pelas instituições de saber e centros de pesquisa com seus influentes "homens de sciencia", os quais ao se apresentarem como portadores do discurso científico e, consequentemente, como porta-vozes legítimos das discussões sobre os impasses e futuro da nação, garantiam força e autoridade aos seus argumentos racialistas. De acordo com a autora, "era a partir da ciência que se reconheciam diferenças e se determinavam inferioridades" (Schwarcz, 1993: 28).

As diferentes teorias que buscavam compreender a origem do homem congregavam-se em dois pólos: o monogenista e o poligenista. O primeiro partia da premissa de que a

\footnotetext{
${ }^{68}$ Como observa Giralda Seyferth, para a elite política brasileira tal progresso era incompatível com a composição étnica de uma população constituída majoritariamente por tipos inferiores, como negros, mestiços e índios. Foi neste contexto que o projeto imigratório aparece como uma saída para alavancar o desenvolvimento do país (Seyferth, 1996: 56).
} 
humanidade era una, sendo os diferentes tipos humanos produtos "da maior degeneração ou perfeição do Éden", mas sujeitos a estágios semelhantes de desenvolvimento. Já o segundo, ancorava-se na ideia de que as diferentes raças humanas constituíam espécies diversas que não se reduziam a uma única humanidade. Apesar das divergências, ambas se assentavam nos pressupostos de hierarquização racial (Schwarcz, 1993).

A publicação de $A$ origem das espécies em 1859 por Charles Darwin torna-se um marco divisor para a consolidação de teorias como o evolucionismo social e cultural e o darwinismo social. Grosso modo, a primeira escudada no modelo monogenista fiava-se na hipótese do "aprimoramento evolutivo das raças", e a segunda, de vertente poligenista, defendia que o cruzamento de raças diferentes, entendidas como espécies ontologicamente diversas, conduzia à degeneração não somente racial, mas também social. De acordo com um dos expoentes desse modelo, conde Arthur de Gobineau, a hibridação era maléfica, pois o mestiço carregava somente os defeitos ou "características ruins" de seus progenitores. A eugenia - eu: boa; genus: geração - como movimento que buscava a preservação dos "tipos puros" e o "aprimoramento das populações", constitui-se como um braço importante do darwinismo social (Schwarcz, 1993).

Schwarcz observa que a percepção das "diferenças" é antiga, contudo sua "naturalização" decorreu de um processo recente, iniciado no século XIX no bojo dessas teorias, e que se transformou em um "projeto teórico de pretensão universal e globalizante" que previa a atribuição de qualificativos morais a partir das características físicas apresentadas. Em suas palavras, "em meio a esse projeto grandioso, que pretendia retirar a diversidade humana do reino incerto da cultura para localizá-la na moradia segura da ciência determinista do século XIX, pouco espaço sobrava para o arbítrio do indivíduo" (id; ib.: 65).

O pressuposto da hierarquização racial era defendido por teóricos poligenistas, como Ernest Renan e Gustave Le Bon, que classificavam as raças como que sobrepostas em uma pirâmide: a raça branca, considerada superior, encontrava-se no ápice; seguida da raça amarela, intermediária; e abaixo, as raças negra e dos aborígenes australianos, consideradas inferiores. $\mathrm{Na}$ concepção de Gobineau, a raça ariana detinha o monopólio da civilidade e da beleza - "era a mais nobre de todas, perdida para sempre em razão dos casamentos com asiáticos e negros". Modelo de feiura, a raça amarela era descrita pelo conde francês como "fraca", um "esboço" de raça (Dezem, 2005: 210).

Gobineau, considerado pai do racismo científico, em sua clássica obra, Essai sur L'inégalité des Races Humaines, grande inspiradora do pensamento racialista brasileiro, atribuía a decadência das civilizações aos "excessos de mestiçagem" (Seyferth, 1996: 4). Sua estadia de 
um ano e dois meses no Brasil como diplomata, no final do século XIX, deixou-lhe com uma impressão tão negativa, a ponto de decretar o "nosso" fim em 270 anos, devido aos excessos de “negros" e "mestiços" na população (Moutinho, 2004: 23).

Schwarcz nos mostra como a intelectualidade nacional soube filtrar e acomodar as doutrinas racistas europeias, como as de Gobineau, na elaboração do que considerava um projeto de nação viável a uma realidade já muito miscigenada. O branqueamento, como medida para sanar o atraso do país, foi a arma-chave propagada pela elite intelectual e sua defesa encontrava coro em vozes como a do diretor do Museu Nacional do Rio de Janeiro, João Batista Lacerda, "O Brasil mestiço de hoje tem no branqueamento em um século sua perspectiva, saída e solução" ${ }^{69}$

Logo, o paradoxo da mestiçagem como mal e solução residia no seu caráter dúbio, uma vez que ao mesmo tempo em que trazia consequências maléficas para o progresso da civilização, poderia, através de medidas de seleção, criar as condições para a formação de um tipo nacional superior. Neste contexto, a imigração surge como uma questão candente, pois se apresenta como possibilidade de “depuração da raça negra”. De acordo com Seyferth (1996: 49), "os imigrantes tinham um papel adicional a exercer: contribuir para o branqueamento e, ao mesmo tempo, submergir na cultura brasileira através de um processo de assimilação”.

Segundo Laura Moutinho, o principal teórico defensor da "arianização do povo brasileiro" foi Oliveira Vianna, cuja análise da problemática da mestiçagem estava circunscrita à política institucional da imigração, não de toda e qualquer imigração, é preciso esclarecer, mas a europeia. A injeção de sangue ariano em uma população mestiça - estimulada por um "conjunto de condições favoráveis", como o clima e o "fato" de que os colonos europeus se casam mais com brasileiras do que com suas compatriotas - simbolizava a "boa mistura", caminho viável para a conformação da "boa nação" (Moutinho, 2004:73).

A "boa nação", portanto, era a que conseguia aliar a unidade nacional e cultural com uma população homogeneamente formada por "elementos civilizados". Nas palavras de Seyferth (1996: 55), "tudo o que pode ameaçar esta unidade e a formação do tipo nacional especificamente brasileiro é criticado: a homogeneidade das 'colônias alemãs', a imigração asiática, a exclusividade da imigração portuguesa”. É nessa conjuntura histórica que as diferenças de raça, costumes e língua constituir-se-ão no alicerce que sustentará os discursos que enxergavam no japonês um perigo racial e político para a nação.

O ofício do diplomata, Luís Guimarães Filho, encarregado de negócios do Brasil em Tóquio, ao Barão do Rio Branco em 1907, sintetiza o tom dessas preocupações na época:

\footnotetext{
${ }^{69}$ Tese apresentada no I Congresso Internacional das Raças, realizado em julho de 1911 (Schwarcz, 1993: 11).
} 
"parece-me que a fisionomia e a força de uma nação dependam principalmente da unidade da raça: injetar sangue asiático em um organismo ainda etnicamente balbuciante entravar-lhe-á a marcha para a homogeneidade de um tipo nacional... perderá a coesão que necessita para ser um grande país, uma nação de brasileiros" 70 (Lesser, 2001: 160) (grifos meus).

\section{ALGUNS ANTECEDENTES: "RAÇA CHINESA"}

Dezem, em sua análise sobre a gênese dos discursos filo e antinipônicos no Brasil (1878-1908), argumenta que os debates em torno da "Questão Chinesa" (1979) e que envolviam as possibilidades do emprego dos chins como mão-de-obra na lavoura foram permeados por discursos que contribuíram para alimentar o imaginário sobre os imigrantes "amarelos" e sobre os "perigos" racial e político que a vinda dos mesmos trazia para os projetos de modernização do país. No contexto da campanha abolicionista e do consumo das doutrinas racialistas europeias, os chineses, como pertencentes à "raça intermediária", eram encarados pelos favoráveis à imigração meramente como "instrumentos transitórios de trabalho a baixo custo", uma solução temporária para a falta de braços na lavoura.

“Indolentes”, “fracos”, “depravados”, "narcotizados pelo ópio”, "ladrões de galinhas", "de aspecto físico feio", "viciados em jogos" foram alguns dos qualificativos atribuídos aos chineses e arregimentados como argumento pelos que se posicionavam contrariamente à vinda dessa população. ${ }^{71}$ Os temores da degenerescência racial e moral da sociedade brasileira também subsidiavam os discursos como o do estudioso do Brasil e das demais colônias portuguesas, Oliveira Martins, "Um Brasil chinês - a substituição de um dos focos europeus na América por uma nação mestiça e abastardada é uma perspectiva repugnante” (Dezem, 2005: 59).

O abolicionista Joaquim Nabuco, por exemplo, acreditava que além de se constituir em uma tentativa de mongolização do país, a imigração chinesa não traria uma transição completa ao trabalho livre, mas sim um prolongamento da escravidão. Em um pronunciamento na câmara em 03 de setembro de 1879, o deputado deixa clara a inconveniência do projeto enumerando os motivos: "etnológicamente, porque vêm criar um conflito de raças e degradar as existentes no país; econômicamente, porque não resolvem o problema da falta de braços;

\footnotetext{
${ }^{70}$ Nesses ofícios datados de 1907, o diplomata antecipará uma discussão que se agravará anos depois com a Segunda Guerra, "o japonês é espião de nascença e nosso inimigo pelo sangue" (Lesser, 2001: 160).

${ }^{71}$ Esses argumentos eram retirados principalmente dos discursos veiculados pela mídia dos países que receberam levas de imigrantes chineses, como os Estados Unidos e Peru. O que ficava de fora do discurso oficial era a situação de miséria e semi-escravidão a que estes eram relegados. De acordo com Dezem, maus tratos, discriminação e salários insuficientes levavam muitos chineses a uma resistência à dominação fosse através do vício em ópio, suicídio, práticas de pequenos delitos como o roubo de galinhas ou até mesmo a reações mais violentas sob a forma de rebeliões.
} 
moralmente porque vêm introduzir em nossa sociedade essa lepra de vícios que infesta todas as cidades onde a imigração chinesa se estabelece" (Dezem, 2005: 92).

Segundo Dezem (id.; ib.: 59), no panfleto de Quintino Bocaiúva, A crise da lavoura de 1868, o republicano expõe que a imigração chinesa era a mais economicamente viável para suprir a mão-de-obra nas lavouras cafeeiras por ser menos onerosa aos fazendeiros no pagamento dos salários. De acordo com Bocaiúva, "a questão da necessidade sobrepõe-se ao preconceito". Não foi o que aconteceu. Como conclui Dezem (id., ib.: 101), "o projeto acabou não vingando. Deixou apenas rastros de uma mentalidade preconceituosa moldada por teorias intolerantes".

Essa situação se reverterá anos depois com a grande demanda de mão-de-obra nas lavouras cafeeiras. A produção de café em São Paulo que chegara em 1885 a representar 34\% do total do país, após a Abolição, em 1900, alcançava 69\% (Tajiri \& Yamashiro, 1996: 25). À alta dos preços do café no mercado internacional, seguiram-se os subsequentes déficits imigratórios, ou seja, quando a saída total de imigrantes supera a entrada, nos anos de 1900, 1903, 1904 e 1907, causados, principalmente, pelos descontentamentos dos imigrantes europeus que se sentiram enganados pelas promessas de enriquecimento e pela consequente suspensão da política italiana que subsidiava as passagens de seus emigrados em 1902 (Decreto Prinetti).

Esse conjunto de fatores "flexibilizou" a resistência na contratação de trabalhadores não-brancos. A demanda por mão-de-obra na lavoura precisou contornar até mesmo as restrições postas em prática pelo governo provisório republicano: o Decreto no. 528, de 28 de junho de 1890, editava que era “[...] inteiramente livre a entrada, nos portos da República, dos indivíduos válidos e aptos para o trabalho, que não se acharem sujeitos à ação criminal do seu país, excetuados os indígenas da Ásia, ou da África que sòmente mediante autorização do Congresso Nacional poderão ser admitidos de acordo com as condições que forem estipuladas" (id., ib.: 109).

\section{O JAPONÊS COMO "IMIGRANTE INDESEJÁVEL”}

Jair de Souza Ramos sugere que no contexto das migrações internacionais para o Brasil, dois personagens centrais, ou melhor, duas representações se interpuseram na definição das políticas públicas e na tomada de posições: o "imigrante desejável” ou "ideal” e o "imigrante indesejável". Ao primeiro, "branco, camponês, resignado", contrastava o segundo, "raças atrasadas, não civilizadas, inferiores” (Seyferth, 1991 apud Ramos, 1996). É sob essa última pecha que alguns discursos enquadraram os imigrantes japoneses. 
Ao analisar os discursos presentes na nascente imprensa ilustrada no Brasil, representada pelas revistas $O$ Malho e Revista da Semana, Rogério Dezem observa que houve uma mudança conceitual nos discursos sobre o japonês e divide o período que cobre essa redefinição do imaginário em três fases: 1) anterior à Guerra Russo-Japonesa (1903-1904); 2) durante o conflito (1904 e 1905); e 3) posterior ao conflito (1906 a 1908).

A primeira fase foi pontilhada pelos reflexos do chamado "japonismo", que em linhas gerais, referia-se ao entusiasmo pelo "caráter estético da cultura japonesa" no final do século XIX pela Europa e Estados Unidos. A mitificação do exótico e distante país das gueixas, samurais e cerejeiras, sintetizava uma visão de Japão "feminino" e "inofensivo". Já durante a Guerra Russo-Japonesa, os jornais brasileiros, que reproduziam grande parte do material a partir da imprensa inglesa e francesa, idealizavam a valentia dos "pequenos japoneses" contra o "colosso branco russo", buscando ressaltar os valores morais da honra e da força do nacionalismo no país. A vitória contra a Rússia foi decisiva para o Japão se tornar além de uma potência na Ásia, um ator político, econômico e militarmente reconhecido no cenário geopolítico mundial. Dezem afirma que essa "inversão do discurso" alimentou um imaginário calcado em um Japão "masculino", "forte”, "guerreiro", "heróico" e que anos mais tarde, no contexto da Segunda Guerra, seria substituído pela tríade representativa do "perigo amarelo": "fanático", "desleal" e "traiçoeiro" (Dezem, 2005: 270).

Márcia Takeuchi, ao analisar as formas de representação dos japoneses no imaginário político dos anos de 1920 a 1945, recupera como o "mito político" do "perigo amarelo" se construiu e legitimou práticas nacionalistas repressivas por parte do governo. No contexto em que o cientificismo retórico se desdobrava na implementação de programas de higienização e saneamento e os projetos de cunho eugênico se tornavam armas profiláticas contra os males da nação; o japonês, como um elemento "estranho", figurou como alvo importante nos discursos que temiam a mistura de raças inferiores na população brasileira. Manuel de Oliveira Lima, ${ }^{72}$ ministro plenipotenciário do Brasil no Japão, em ofício encaminhado ao Itamaraty em 1901, posicionou-se contrariamente à imigração alegando diferenças na educação, costumes e, sobretudo, na "natureza psicológica e objetivo social que separa a raça ariana da mongólica" (Leão apud Takeuchi, 2008a: 57).

Segundo Dezem, quando os japoneses aqui aportam e deixam de ser concebidos como elementos "imaginados" pela intelectualidade, políticos e imprensa, para se apresentarem como "partícipes do cotidiano nacional", a ideia de "perigo amarelo" se corporifica resgatando os

\footnotetext{
${ }^{72}$ Escritor e diplomata, cuja função exercida no Japão investia-lhe de autoridade para falar em nome desse oriente. Também publicou o livro No Japão: impressões da terra e da gente em 1903.
} 
estigmas atribuídos aos chineses nos debates realizados trinta anos antes. Os conflitos envolvendo questões trabalhistas, uma vez que os japoneses passam a aparecer como concorrentes do trabalhador nacional devido à sua produtividade e frugalidade, como vimos no primeiro capítulo, parecem reavivar as polêmicas discussões sobre a "Questão Chinesa" de 1879 (Dezem, 2005: 285).

No início do século XIX, os discursos sobre as abissais diferenças raciais, culturais e religiosas passam a aflorar na mídia. A revista $O$ Malho que, durante os anos de 1904 a 1907 , continha inúmeras propagandas e charges que mobilizavam os signos de força e coragem do povo japonês, publica em dezembro de 1908 um cartum intitulado "Immigração Japoneza", que além de apresentar caricaturas do nipônico, estava acompanhado das seguintes legendas:

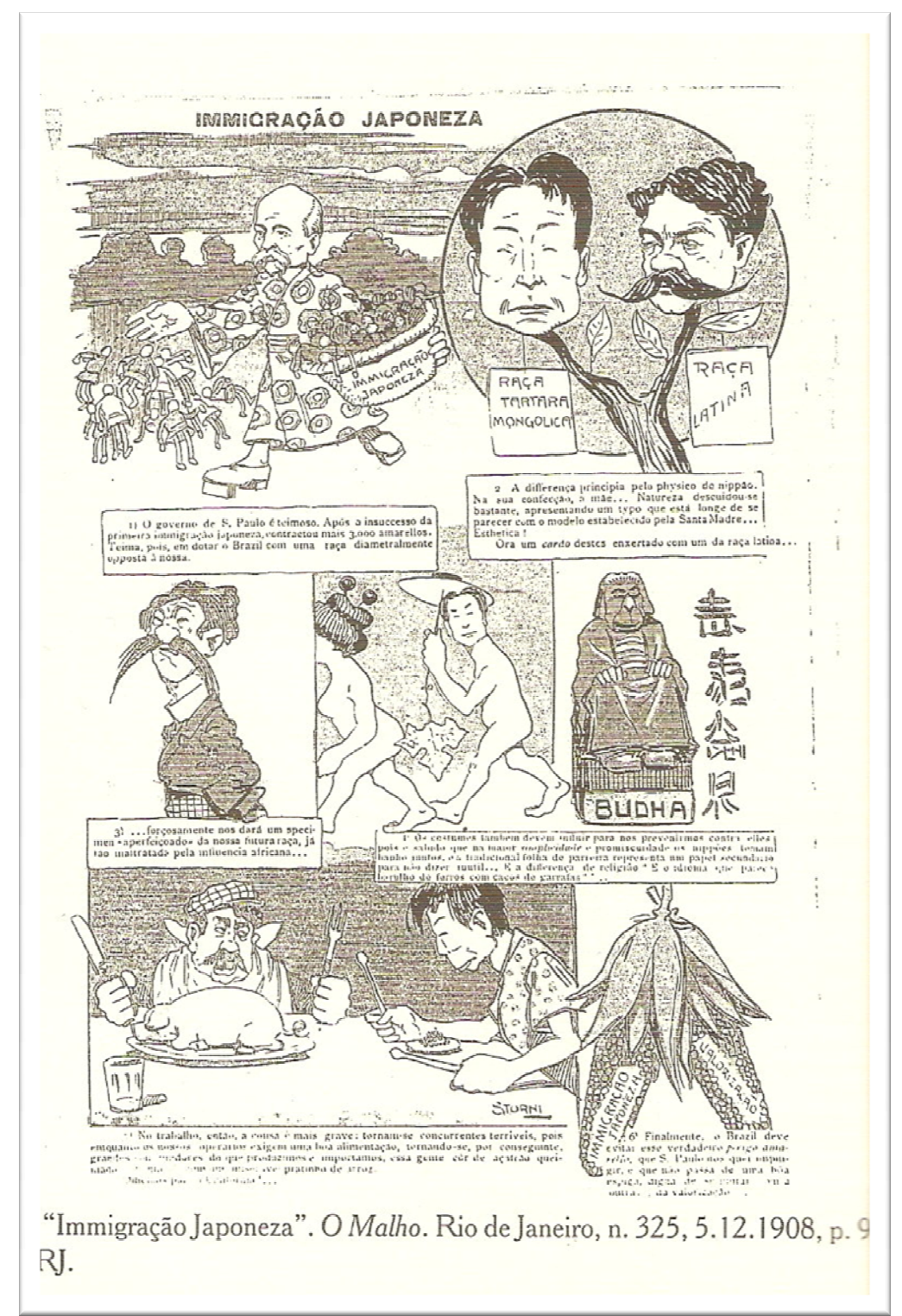

Fig. 8 Cartum “Immigração Japoneza” (Dezem, 2005) 
O governo de São Paulo é teimoso. Após o insucesso da primeira immigração japoneza ${ }^{73}$, contractou mais 3000 amarellos. Teima, pois em dotar o Brazil com uma raça diametralmente opposta à nossa. A differença principia pelo physico do nippão. Na sua confecção, a mãe... Natureza descuidou-se bastante, apresentando um typo que está longe de se parecer com o modelo estabelecido pela Santa Madre... Esthética! Ora um carão desses enxertado com um de raça latina... forçosamente nos dará um specimen 'aperfeiçoado' da nossa futura raça, já tão maltratada pela influência africana... [...] Finalmente, o Brazil deve evitar esse verdadeiro perigo amarello, que São Paulo nos quer impingir... (Dezem, 2005: 288).

No inquérito promovido pela Secretaria Nacional de Agricultura, citado no capítulo 1, sobre o projeto de restrição à imigração nipônica, a posição do seu relator, o deputado federal por São Paulo, João de Faria, reunia alguns dos argumentos acima descritos:

Imigrante caro, devido à distância de seu país natal, o japonês não agradou o fazendeiro paulista. A sua língua nos é incompreensível, os costumes são muito diferentes dos nossos, com um aspecto fisico pouco atraente, dotado de uma moral que a nosso ver, é estranhável $\mathrm{e}$ se caracteriza pela falta de cumprimento de seus contratos, o colono japonês, em regra, quando recebe o pagamento, deserta em massa da fazenda durante a noite [...] (SNA, 1926 apud Ramos, 1996: 76-77) (grifos meus).

O referido projeto de lei, datado de 1923, foi apresentado pelo deputado e membro da Sociedade Nacional de Agricultura (SNA), Fidélis Reis, e propunha estímulos à imigração europeia, a proibição da entrada de imigrantes negros e a restrição da imigração japonesa. Alegou ser a questão da composição racial da nação objeto de maior importância do que as necessidades econômicas, pois a inserção de um elemento inassimilável pela sua moral e cultura representava um grande risco para a integridade do país. A este argumento, acrescentou que "além das razões de ordem étnica, moral, política e social, e talvez mesmo econômica que nos levam a repelir in limine a entrada do amarelo e do preto, $[. .$.$] outra porventura existe, a ser$ considerada, que é do ponto de vista estético e a nossa concepção helênica de beleza jamais se harmonizaria com os tipos provindos de uma semelhante fusão racial" (Takeuchi, 2008a: 60).

Lesser menciona que a conexão biológica entre japoneses e indígenas, devido a uma suposta origem racial comum, foi tomada como argumento de autoridade pela elite defensora da entrada dos nipônicos. O discurso racialista, portanto, também foi mobilizado para justificar uma

\footnotetext{
${ }^{73} \mathrm{O}$ insucesso da primeira imigração japonesa a que se refere o autor do cartum, diz respeito ao que o sociólogo Hiroshi Saito (1961) denominou de "período experimental" da imigração japonesa no Brasil, que perdurou de 1908 até a suspensão da concessão de subsídios por parte do governo paulista, em 1922. As justificativas para o corte eram as de que os japoneses não cumpriam os contratos, fugiam ou se rebelavam com as condições de trabalho nas fazendas (Sakurai, 2009: 17); ou ali permaneciam por pouco tempo, já que aqui chegavam munidos de recursos financeiros, o que lhes possibilitava tornar-se independentes cerca de um ano depois (Saito, 1961: 33). Além disso, com o fim da Primeira Guerra Mundial, as expectativas se voltavam para a retomada da vinda de trabalhadores europeus, os imigrantes preferencialmente "desejáveis".
} 
posição favorável à imigração asiática, a partir do pressuposto de que a integração e assimilação dos japoneses seriam mera consequência dessa gênese comum. Logo, podemos aventar que as teorias raciais eram arregimentadas de acordo com os interesses em jogo.

Edgar Roquette-Pinto, antropólogo e professor do Museu Nacional, que em 1918, observou que "os japoneses eram tão 'feios' que 'considerações estéticas levavam-no a se opor à sua entrada em massa" (Lesser, 2001: 168); muda sua posição dez anos depois na ocasião do I Congresso Brasileiro de Eugenia, realizado em 1929, em "razão da 'maravilhosa transformação dos japoneses', que agora 'agiam' como ocidentais" (id., ib.: 180). Contrariando as fortes posições racistas vigentes no evento, argumentou que o "problema brasileiro seria uma questão de higiene e não de raça" (Schwarcz, 1993: 96). Apropriando-se também do pressuposto da origem racial comum entre japoneses e indígenas, defenderá em sua obra Ensaios de Antropologia Brasiliana (1933) o caráter assimilacionista dos primeiros, os quais, produtos da miscigenação dos brancos (ainus) com os amarelos (mongóis) e pretos (indonésios) refletiam o desenvolvimento "racial do Brasil" (Lesser, 2001: 183).

A polêmica entre defensores e críticos do movimento imigratório não arrefeceu com a instalação dos japoneses nas fazendas e posteriormente nas colônias agrícolas, pelo contrário, ganhou novos ares na arena pública a partir das décadas de vinte e trinta. O sucesso econômico das colônias e sua articulação nas cooperativas agrícolas geraram pareceres elogiosos, como vimos na primeira parte da pesquisa, mas também alimentaram controvérsias. A elite política e acadêmica se dividia entre conclamar que os braços japoneses traziam o desenvolvimento econômico para o país e a mais nativista, em antever os riscos de um projeto secreto de expansionismo e invasão nipônica, por conta do caráter bélico e não-assimilacionista do imigrante, enquistado que estava em suas colônias e nihonjin-kais.

A política expansionista do Japão intensificada após as vitórias nas guerras sinojaponesa (1894-1895) e russo-japonesa (1904-1905) amplifica-se com as posses da Coreia (1910), Manchúria (1931) e com a retomada do conflito com a China (1937). De acordo com Takeuchi, a divulgação neste país de um documento apócrifo, que circulou pelo mundo, denominado Memorando Tanaka, cuja falsidade foi comprovada mais tarde pelo Tribunal de Tóquio instaurado pelos Aliados, constituiu-se como uma das peças-chave para a consolidação do discurso antinipônico no Brasil. ${ }^{74}$

\footnotetext{
${ }^{74}$ Supostamente escrito pelo primeiro-ministro japonês Giichi Tanaka, o documento, encaminhado ao Imperador Hiroíto em 25 de julho de 1927, continha um plano conspiratório de dominação do mundo. Em linhas gerais, iniciava-se com a ocupação de territórios vitais no Pacífico, como Manchúria, Mongólia, Coreia e China, mediante uma política de colonização controlada pelo Departamento de Negócios Coloniais. Previa também o domínio de
} 
A comparação do suposto plano de dominação contido no memorando com a emigração para o Brasil foi inevitável e o mito do "perigo amarelo" ganhou foros de verdade, uma vez que a imigração tutelada pelo governo japonês aliada às iniciativas das companhias de colonização - responsáveis pela auto-suficiência das colônias a partir do provimento de instalações, como escolas, ambulatórios, máquinas de beneficiamento de grãos - corroborava a tese do "complô japonês" no país (Takeuchi, 2008a: 191-200). O ataque a Pearl Harbor em 1941 veio a agravar a materialização do "yellow peril".

Tais acusações de complô partiam, sobretudo, do trio que ficou conhecido como "os três heróis da campanha antinipônica": o microbiólogo e interventor federal na Bahia, Dr. Artur Neiva; o deputado e médico eugenista, Miguel de Oliveira Couto, e o psiquiatra, professor e deputado, Xavier de Oliveira. As discussões provocadas pelo trio tinham ampla divulgação no Jornal do Commercio do Rio de Janeiro, de propriedade de José Félix Alves Pacheco. O apelido coletivo era condizente com a atuação e investimento desses reconhecidos atores políticos na luta contra os "nipões", que se "infiltravam sorrateiramente como, serpentes a tomar as riquezas da pátria" (Takeuchi, 2008b: 178).

Miguel Couto, autor da Emenda ${ }^{75}$ que leva o seu nome, caracterizava os imigrantes como "gente versuta, ambiciosa, guerreira e mística" (Lesser, 2001: 178). Segundo Márcia Takeuchi (2008b: 178), nos debates empreendidos pelo médico, por Neiva e o psiquiatra Xavier de Oliveira, "os japoneses e seus descendentes foram qualificados como indivíduos feios, hipócritas, portadores do eterno sorriso, que obedeciam tão somente às ordens de seus chefes". A não-assimilação, os enquistamentos raciais e os planos de expansionismo imperial nipônico configuravam a tríade acusatória que recaía sobre os mesmos. Em um pronunciamento a época da Assembleia Nacional Constituinte, Couto justificando seu discurso como pura manifestação de amor à pátria, afirmara: “Chego a achar belo o olho mongol. Já estou prelibando a volúpia intelectual do soneto com que o nosso querido Olegário Mariano há de cantar os olhos oblíquos e empapuçados das nossas netas. [...] Não se trata, porém - repito - de imigração, trata-se da

fontes naturais de energia e a instalação de escolas e hospitais a fím de criar um ambiente favorável à conquista, e finalmente, anunciava o derradeiro conflito armado contra os EUA.

${ }^{75}$ A Emenda Miguel Couto restringia a corrente imigratória "ao limite de $2 \%$ sobre o número total de seus respectivos nacionais aqui fixados durante os últimos cinquenta anos" (Takeuchi, 2008a: 65). De acordo com Takeuchi, embora alegando não possuir preconceito de raça, "sentimento antipático e desumano", Couto havia formulado originalmente o projeto visando somente à população africana e asiática, pois não desejava que a imigração europeia e, consequentemente, "a formação eugenética do povo brasileiro" fosse prejudicada. Ao verificar que nenhum país europeu havia alcançado o número que seria estabelecido pela cota, o relator estendeu a restrição aos imigrantes de todas as origens. Tal mudança garantiu a aprovação por 171 votos contra 26 na sessão de 24 de maio de 1934 (id.; ib.). 
própria existência nacional [...]" (Takeuchi, 2008a: 78). Como veremos, o olho do "oriental" constitui-se na região do corpo onde mais se incide a localização da diferença.

Xavier de Oliveira - que também engrossava o coro dos "desprovidos de preconceito de raça", como Couto e Neiva - chamava a atenção para a predisposição do nipônico às doenças mentais devido ao seu "misticismo religioso, mesclado com o fanatismo patriótico, que é uma das mais notáveis das suas qualidades intrínsecas" (Takeuchi, 2008a: 82). Já Artur Neiva, não desconsiderou o caráter estético da questão, afirmando em sessão plenária de fevereiro de 1934, “agora do ponto de vista antropoestético, positivamente, o japonês não nos serve. Ninguém me convencerá que seja Adônis ou Diana caçadora" (id.; ib.).

De acordo com Takeuchi, era comum nesses discursos a associação do japonês com toda sorte de animais, como serpentes, abutres, aves de rapina, víboras, macacos, polvos, ratos, os quais conformavam um verdadeiro " "bestiário do complô: a animalização do personagem da conspiração" (Takeuchi, 2008a: 80). A formação do Shin-Nihon (Novo Japão) se desenvolveria por etapas: invasão e infiltração através da imigração; esfera de influência juntamente com a ocupação; e finalmente, a absorção, através da posse ou japonização. O mito valia-se de metáforas que identificavam a conspiração "com tudo que rasteja, se esconde, se infiltra, ou seja, a associação com animais imundos, símbolos da sujeira e da infecção" (Takeuchi, 2008a: 80). A autora afirma ser possível encontrar na narrativa de Couto, "o simbolismo da serpente para descrever as etapas da dominação amarela: o bote, a constrição e, finalmente, a deglutição" (id., ib.).

Lesser aponta que um levantamento dos jornais brasileiros que cobriam os anos de 1934 e 1935 mostrava que os artigos sobre a imigração japonesa eram contínuos, sendo que "dos 27 jornais existentes nas cidades do Rio de Janeiro, São Paulo, Santos e Campinas, treze eram a favor da entrada dos japoneses e sete eram militantemente contrários". Sobre a instituição da cota imigratória, o jornal Gazeta de Notícias, do Rio de Janeiro, publicou em novembro de 1935, "os nossos eugenistas e patrioteiros estão de parabéns. A nação, porém, está de pêsames" (Lesser, 2001: 220). Veremos que os discursos contrários à presença nipônica no país se estenderão até o contexto da Segunda Guerra Mundial.

Os discursos públicos, políticos e científicos trazidos à tona até agora são uma pequena mostra das imagens controversas construídas em torno dos imigrantes japoneses. Refletir sobre as experiências, status, identidades, discursos do nikkei na sociedade brasileira hoje implica dirigir o olhar também para o passado, pois esse imaginário foi se engendrando de forma gradual, ao curso das mudanças históricas e das transformações nas concepções de raça, nação, etnia. 
Tais discursos, cujos árbitros, com suas visões positivas ou negativas, valeram-se, frequentemente, de polarizações do tipo, "nós", brancos, ocidentais, de um lado e "eles", amarelos, orientais, de outro. Nesse processo, é possível observar como os discursos se configuram como lócus em que relações de poder e saber, (o conhecimento do outro) imbricamse (Said, 2007; Foucault, 2007, 2008). Seus "efeitos de verdade" ganharam um desdobramento prático sobre a realidade, ou seja, funcionaram como argumentos de autoridade para a legitimação de políticas efetivas de contenção do chamado "perigo amarelo" e também para a justificação de práticas discriminatórias contra a população nikkei.

Cumpre reiterar que não cabe aos propósitos deste trabalho realizar uma análise historiográfica que cubra o período, nem passar em revista as muitas obras já produzidas na literatura sobre a imigração japonesa no Brasil. No presente capítulo, a intenção residiu em mostrar a força com que a categoria "raça" era catalisada pelos discursos, tanto filo como antinipônicos, mas, sobretudo, pelos últimos, em quase meio século de presença dos imigrantes japoneses no Brasil, ou seja, até meados do fim da Segunda Guerra Mundial, momento em que o conceito de "raça" passa por uma revisão.

Sobre essa questão, este trabalho se assenta sob a hipótese de que o agenciamento da categoria "raça japonesa" no universo privado das relações cotidianas se deve em parte ao imaginário "racial" da nação, definido pela sua mistura de cores e povos e também ao intenso uso político que se fez dessa categoria em vários momentos da construção discursiva sobre o "japonês", através da imprensa, livros, debates públicos, cartuns. Assim, para muitos entrevistados dessa pesquisa, a experiência de preconceito vivenciada pelas primeiras gerações se apresenta como um parâmetro para a reflexão sobre as formas e possibilidades de preconceito contra as gerações mais novas. Em outras palavras, a construção da ideia de "perigo racial" e político em torno do "japonês" e as políticas restritivas direcionadas a essa população foram consideradas por muitos entrevistados como medidas efetivas e diretas de preconceito e discriminação, ao passo que ser alvo de "piadas" devido à condição étnica não o foi.

\section{JAPONÊS: “O TYPO QUE ESTÁ LONGE DE SE PARECER COM O MODELO ESTABELECIDO PELA SANTA MADRE... ESTHÉTICA!".}

Interessante notar no discurso antinipônico as constantes preocupações de ordem estética que a entrada dos "pequenos" e "feios" japoneses implicava para a composição racial da nação. Como vimos, até mesmo os defensores desse fluxo migratório lamentavam o "defeito" de o japonês "não ser o tipo mais apurado", como ponderaram João Ribeiro da Fonseca e Oliveira 
Botelho. Concluir que as pessoas de ascendência oriental, indígena ou africana não se inserem no "padrão estético universal" - branco, alto, com traços finos - não é algo novo. Na conjuntura atual, em nichos específicos, como o mundo da moda e da TV, guardadas as diferenças quanto ao gênero, comumente atribui-se a essas pessoas a beleza "exótica", misteriosa para as primeiras, animalesca, sensual para as segundas.

No caso dos japoneses, os olhos oblíquos, o rosto arredondado, o nariz achatado, a baixa estatura, o torso "reto" são as principais características fenotípicas aglutinadas em seu corpo, lócus de produção de uma série de discursos sobre a diferença, como a que Isabel Nishida, 53 anos, costumava ouvir quando criança, "Japonês calabrês, foi o diabo quem te fez!" ou "Japonês cara chata, come queijo com barata!". Considerações de ordem estética apareceram muito pouco e de formas esparsas nas entrevistas realizadas. Experiências como as de Isabel são comuns a muitos nisseis, porém a maioria limitou-se a dizer que, motivo de revolta na infância, tais "brincadeiras" foram sofridas somente no passado.

Não poderia deixar de mencionar um episódio sobre esse tópico em especial e que na época havia me deixado aborrecida. Há cerca de cinco anos, em 2004, uma colega de Maringá havia voltado de uma experiência de trabalho temporária no Estado do Pará, em uma cidade próxima a Belém. Embora tenha apreciado a vivência no local, começou a discorrer como lá era um lugar que concentrava "gente feia". Querendo mudar de assunto, perguntei se havia muitos descendentes de japoneses que residiam no Estado, pois tinha uma vaga noção sobre os núcleos coloniais japoneses voltados para a produção de pimenta em Tomé-Açu no Pará. Ao que minha colega responde, claramente não querendo mudar de assunto, "Tem bastante sim! Mas olha, o povo do Pará é tão feio que até o japonês é mais bonito!”. No momento, ela nem percebera o que tinha falado, ou melhor, para quem tinha falado e continuou sua "análise estética comparativa" entre Paraná e Pará, que já nem me recordo mais. Suas palavras ressoavam em minha cabeça e o sentimento de repulsão contido em seu discurso contra a população paraense e contra os japoneses, eu nunca esqueci.

"Por ser japonês, fulano até que é bonito" são frases ditas espontaneamente que eu mesma já ouvi diversas vezes. Uma professora de inglês certa vez perguntou se eu era "mestiça", ao que diante da negativa, estranhou, "nossa, mas você é bonita...”. Durante o trabalho de campo, enquanto mostrava fotos de alguns personagens japoneses da televisão para um grupo de três jovens sanseis na faixa dos 19 anos, um amigo não-descendente dos garotos, que também participava do papo, diante da figura da atriz Daniele Suzuki, comentou: "Essa aqui é bonita...", não sem deixar de complementar, "por ser japonesa...”. São interpelações que sugerem "exceções" ou "compensações". 


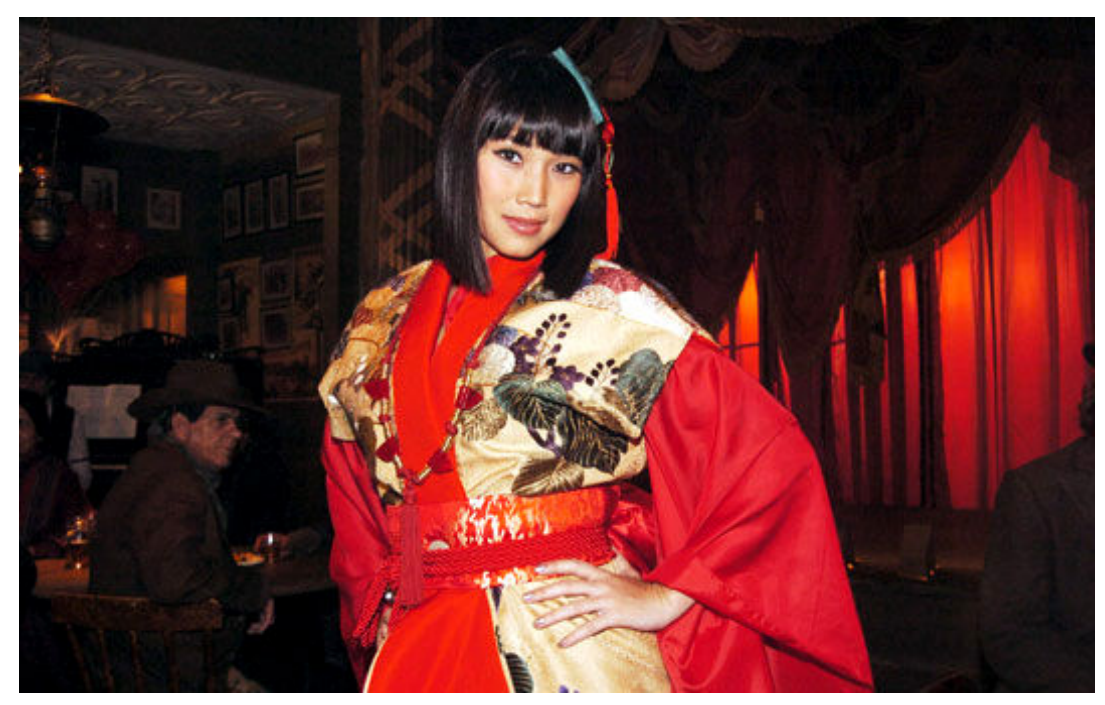

Fig. 9 Atriz Daniele Suzuki e sua personagem Yoko na novela Bang Bang

A eleição de Riyo Mori para o título de Miss Universo em 2007 ganhou uma ampla repercussão no país. Talvez tal vitória não merecesse tanta visibilidade midiática se a japonesa não tivesse desbancado a curvilínea Miss Brasil 2007, Natália Guimarães, segunda colocada na competição. A indignação reinante era alimentada pela tentativa de encontrar explicações plausíveis para a vitória de uma jovem "bonitinha", porém "reta", frente à beleza exuberante e cheia de "curvas" de Natália: o júri era formado por dois orientais. ${ }^{76} \mathrm{O}$ apresentador da $T V$ Globo, Fausto Silva, ao apresentar a mineira Natália no quadro "Dança no Gelo", no seu programa Domingão do Faustão, no dia 26/08/07, disse: “Com vocês a Miss Brasil que só perdeu para uma japinha feia por injustiça". 77

Um ano depois, na cerimônia que coroou a Miss Brasil 2008, a homenageada da vez, Adalgisa Colombo, Miss Brasil 1958, declarou no palco sua revolta pela derrota de Natália Guimarães, presente no evento, no concurso Miss Universo 2007, "Perdeu para uma japonesa feia demais". ${ }^{78}$ Sem entrar nas discussões sobre o mérito das candidatas ou as possibilidades de favorecimento ou lobby no concurso, o que está em jogo aqui são as construções discursivas sobre os signos de beleza e feiura inscritos no corpo do japonês. É importante frisar que essas declarações públicas não foram isoladas e sim estiveram acompanhadas de manifestações de

\footnotetext{
${ }^{76}$ Os dois orientais que participaram do júri na final televisionada no dia 28/05/07 eram americanos: o ator de ascendência coreana, James Kyson Lee e a campeã olímpica de patinação artística pelos EUA, de origem chinesa, Michelle Kwan.

77 Segundo consta no site Terra: http://exclusivo.terra.com.br/interna/0,OI1857080-EI1118,00.html Acesso: $23 / 03 / 10$.

78 Segundo consta no site Terra: http://exclusivo.terra.com.br/interna/0,0I2742442-EI1118,00.html Acesso: $23 / 10 / 10$.
} 
indignação na internet, em $b \log s$, fóruns, comunidades virtuais como o Orkut $^{79}$ e também em rodas de conversas informais. A reflexão sobre a veiculação na grande mídia de discursos como as do apresentador Fausto Silva num país que conta com a maior população nikkei do mundo é particularmente instigante.

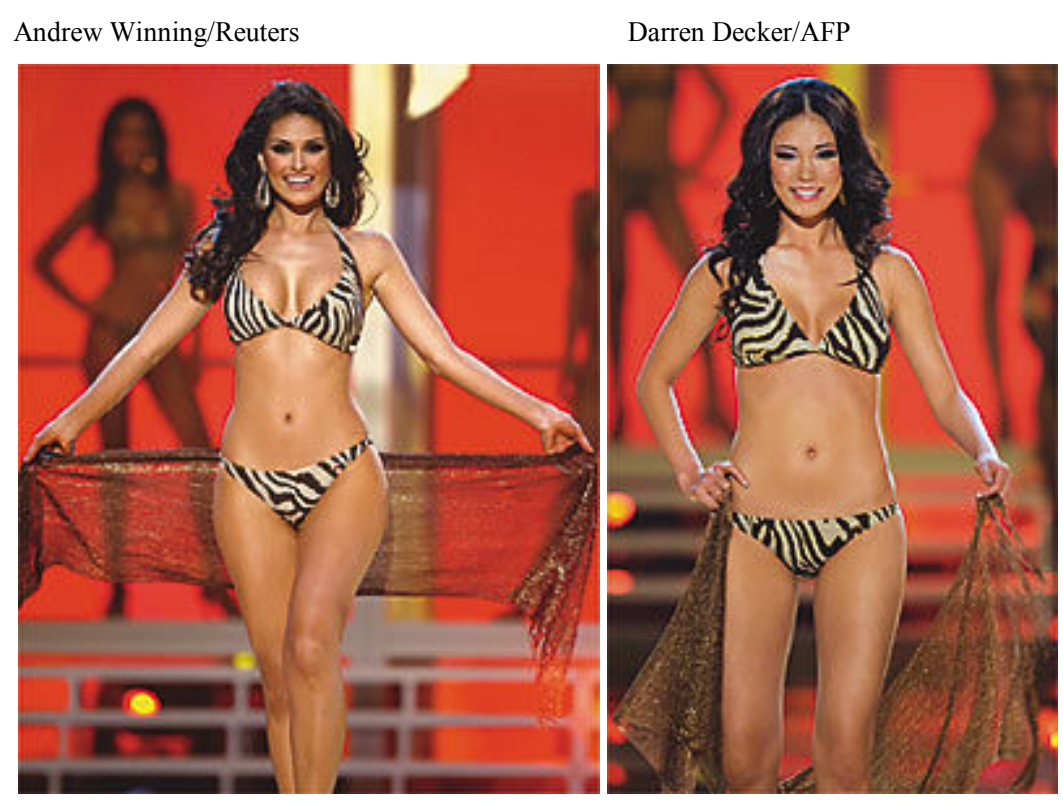

Fig. 10 Miss Brasil e Miss Universo. Fonte: Revista Veja ${ }^{80}$

A polêmica no resultado do concurso levanta algumas questões sobre o cânone de beleza nacional. Seios fartos, quadris volumosos e cintura fina são atributos valorizados no Brasil e no mundo e raramente perceptíveis em pessoas de origem oriental, a não ser mediante intervenção cirúrgica. Os olhos, lócus denunciante por excelência dessa origem, no sentido de imediatamente servir como marcador de diferença e de identificação, têm suas peculiaridades. De acordo com a cirurgiã plástica, Edith Horibe, “Cerca de 50\% [dos orientais] nascem com ausência do chamado sulco ósseo palpebral, ou popularmente as dobrinhas nas pálpebras”. ${ }^{81}$

"Com finalidade de se obter um toque mais harmonioso à face" ${ }^{82}$, surgiu em 1970 a cirurgia de "ocidentalização dos olhos", procedimento estético relativamente simples, com anestesia local e que consiste em retirar os excesso de gordura e pele existente nas pálpebras

\footnotetext{
${ }^{79}$ Ver matérias "Fãs de brasileira lançam 'teoria da conspiração' do Miss Universo", 29/05/07, disponível em http://g1.globo.com/Noticias/Mundo/0, MUL43863-5602,00.html. "Miss Brasil volta ao país e critica lobby japonês" 01/06/07. Disponível em http://noticias.bol.uol.com.br/brasil/2007/06/01/ult4469u4700.jhtm. Acesso: 23/03/10.

80 "Praticamente campeã moral" - "Natália e Riyo fazem demonstração do choque cultural: a brasileira ficou em segundo e a japonesa ganhou". Revista Veja, edição 2011, 06/03/07.

81 “À la ocidentais". Revista Plástica \& Beleza, edição 108, março de 2010.

${ }^{82}$ Conforme home page de uma clínica de cirurgia plástica, http://www.perfect.com.br/cirurgia.asp?cir=58\&offset= Acesso: 23/03/10.
} 
superiores, sobre a qual é feita a dobra. Segundo matéria da Revista Veja de 2002, com título bem sugestivo, aliás, "De olhos bem abertos", 83 "estima-se que 14.000 pessoas, sobretudo nos Estados de São Paulo e Paraná, submetam-se a cirurgias de ocidentalização a cada ano, o dobro do que acontecia no início dos anos 90”. Além desse tipo de intervenção cirúrgica, as mais procuradas pelos descendentes de orientais são o implante de silicone nos seios e glúteos, a rinoplastia para o aumento do dorso do nariz e a lipoescultura para aumento das curvas. ${ }^{84}$
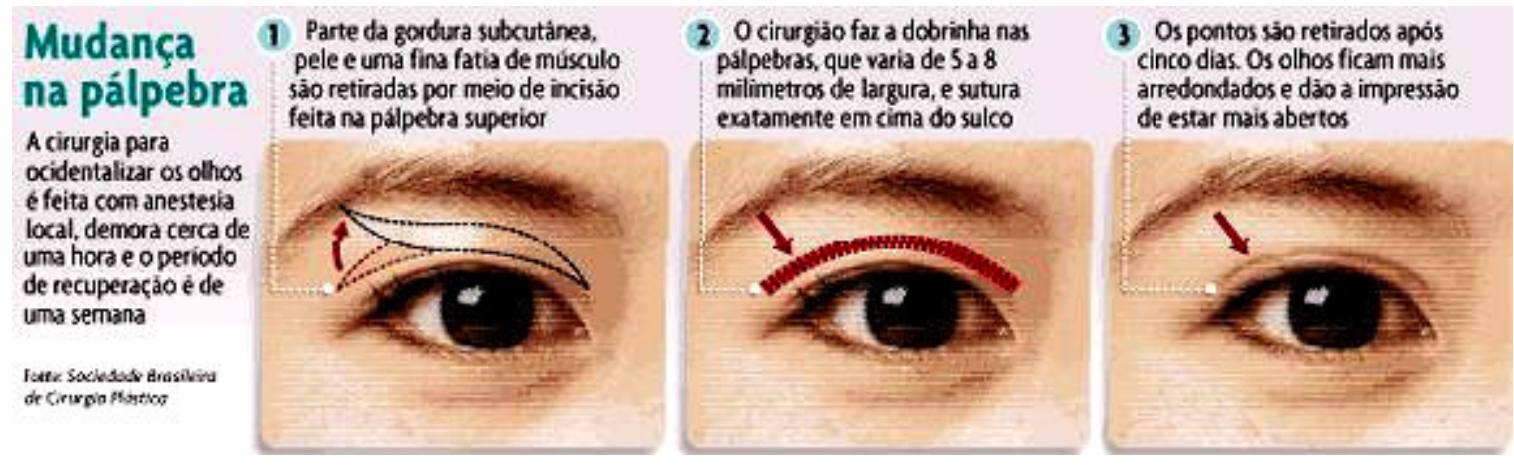

Fig. 11 Cirurgia de ocidentalização. Fonte: Revista Veja
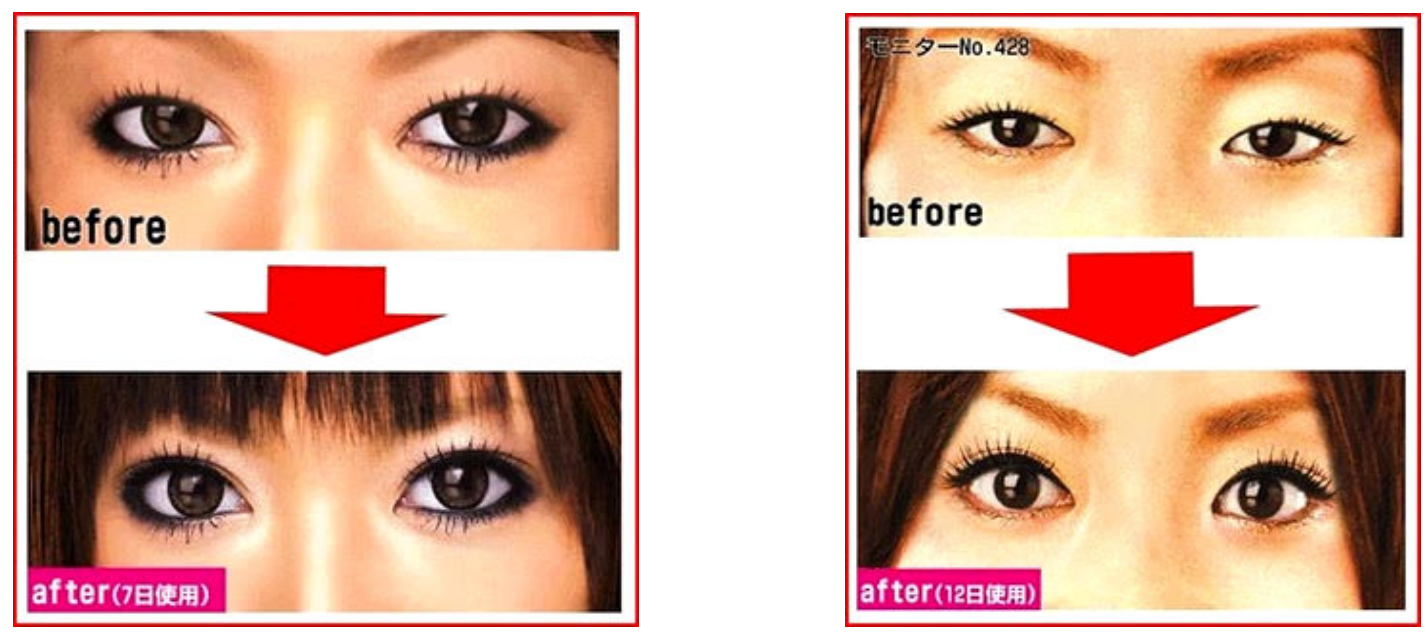

Fig. 12 Cirurgia de ocidentalização.

Interessada na questão das cirurgias de "ocidentalização dos olhos”, Mônica Raisa Schpun realizou um estudo em que buscava entender as motivações que levam descendentes de japoneses a se submeterem a esse tipo de intervenção estética. Considerando os olhos como "traço físico em que mais incide esta tendência tão culturalmente enraizada no Brasil, a identificar - e discriminar - um grupo social pelas características fenotípicas", Schpun aponta

\footnotetext{
83 "De olhos bem abertos: criar dobrinha na pálpebra é a moda entre os descendentes de orientais no Brasil". Revista Veja, edição 1763, 07/08/02.

${ }^{84}$ Conforme matéria “À la ocidentais”. Revista Plástica \& Beleza, edição 108, março de 2010.
} 
que vários entrevistados disseram ter sido alvos de provocações na infância. Sem precisarem os episódios vividos, mencionaram expressões como, “abre o olho, japonês!”, que através do seu duplo sentido, constitui-se em uma advertência para que o sujeito preste atenção (Schpun, 2007: $3)$.

O termo, bastante controverso, "ocidentalização" poderia sugerir uma tentativa de "passing" ou "impostura", um "fazer se passar" como ocidental (cf. Gilman, 1999 apud Edmonds, 2002). Todavia, Schpun conclui que a principal motivação é a busca pela beleza. Uma entrevistada sua lembrou que "entre nós, descendentes de orientais, quando íamos descrever um japonês (esa) que achávamos bonito (a), fazíamos uma referência aos olhos, se tinha a dobra ou não" (Schpun, 2007: 6). Alexander Edmonds, em sua pesquisa sobre as cirurgias estéticas e o universo da beleza no Rio de Janeiro, argumenta que o conceito de impostura é inadequado para se pensar essas questões, "porque evoca apenas o desejo de normalidade e não de perfeição [...] e porque insinua que a paciente está tentando passivamente, amoldar-se a um grupo ou juntar-se a ele" (Edmonds, 2002: 219).

De acordo com Schpun, a cirurgia de "ocidentalização" não significa para os pacientes um desejo de "normalização" ou de desaparecimento dos seus traços originais, mas puramente a satisfação de se sentirem mais belos e de se destacarem. "Meus/minhas entrevistado(a)s mostram-se todo(a)s, independentemente da geração a que pertencem orgulhoso(a)s de sua ascendência" (grifos meus), afirma a autora, que analisa essas intervenções cirúrgicas como uma "reinvenção", uma construção identitária (Schpun, 2007: 8). A "ocidentalização dos olhos" significaria um investimento "que não nega as origens", mas que se assume como uma "adesão a uma nova identidade nipo-brasileira". A reinvenção e exibição das novas marcas corporais tornar-se-iam um "trunfo e não mais um handicap social", especialmente para os mais jovens, testemunhas da conjuntura atual de valorização de imagens do Japão. Schpun conclui que a cirurgia ao tornar "maiores os olhos dos nipo-brasileiros, mostra entre outras coisas que eles os têm bem abertos" (id.; ib.: 10).

Fora o trocadilho totalmente dispensável feito pela autora, diga-se de passagem, muito recorrente nos discursos jornalísticos, sua pesquisa aborda um fenômeno que vêm crescendo com intensidade e trata de duas questões muitos importantes: de como a "niponidade é legível nos corpos" e da centralidade do corpo na produção de subjetividades. Contudo, a associação imediata que a autora estabelece entre as transformações das marcas corporais, no caso, os olhos, local onde, segundo ela, se incide o "racismo de marca" 85 e o que ela denomina vagamente de

\footnotetext{
${ }^{85}$ Conforme termo cunhado por Oracy Nogueira (1998).
} 
"nova identidade nipo-brasileira" não é muito clara. ${ }^{86}$ A exibição dessa "nova beleza" teria um caráter público, diferente do sofrimento privado, discreto e silencioso vivido pelas primeiras gerações diante da discriminação.

No que tange às possibilidades de "negação das raízes" com o procedimento estético, para o presidente da Sociedade Brasileira de Cirurgia Plástica, José Tariki, "Metade dos orientais têm a 'dobrinha'. A cirurgia não descaracteriza os que não têm". ${ }^{87}$ De acordo com o argumento de Edmonds: no Brasil, diferentemente dos Estados Unidos, "a beleza não é politizada" (Edmonds, 2002: 244). No último, país que ainda respira a herança do movimento de "políticas da identidade" e do multiculturalismo dos anos de 1960 e 70 como expressões de uma nova sensibilidade com relação à diversidade, como o black is beautiful, a cirurgia plástica pode ser encarada como um desejo de se adequar às normas racistas vigentes.

Segundo o antropólogo, no Brasil, a aparência tende a ser considerada um problema estético individual e não coletivo, como as marcas de uma identidade racial (id., ib.: 243). Reina aqui uma hierarquia estética abertamente assumida, com a brancura e especialmente a "lourice", ocupando o nível mais elevado da pirâmide. Todavia, sob o abrigo da "democracia racial", tal hierarquia dificilmente é percebida como racista, já que a beleza não é uma questão política. "No Brasil, cosméticos podem ser 'apenas' cosméticos; cabelos louros, narizes finos, seios reduzidos - ou aumentados - são considerados 'coisas da beleza', não da raça”, assevera Edmonds (id.: 244).

É importante salientar que a cirurgia de "ocidentalização" tem se tornado uma prática comum não somente no Brasil - país campeão no número de cirurgias plásticas por habitante no mundo, superando até mesmo os Estados Unidos ${ }^{88}$ - mas também nos países asiáticos, como China, Japão e Coreia. ${ }^{89}$ A intensificação do fluxo de bens, pessoas e símbolos com o chamado "Ocidente" pode ter provocado mudanças em alguns valores estéticos desses países. No portal da internet "Plástica hoje", a matéria "ocidentalização, uma plástica exclusiva para os orientais", informa:

\footnotetext{
${ }^{86}$ De acordo com Schpun: "Assim temos, por um lado, os homens nascidos após a guerra, que ainda hesitam em assumir sua adesão a uma nova identidade nipo-brasileira, identidade que requer um investimento singular sobre a aparência e a valorização de uma estética própria, a qual já aderem, discretamente. E, por outro, os jovens do grupo, que já trazem a público, ao lado das mulheres, mais ou menos jovens, a marca desta adesão" (Schpun, 2007: 11) (grifos meus).

87 “Cirurgia plástica nos olhos é moda entre os orientais de São Paulo: 'ocidentalização' é feita por descendentes de japoneses, chineses e coreanos”. Revista Época São Paulo, edição 597, 26/10/09.

88 "Brasil, império do bisturi", Revista Veja, edição 1683, 17/01/01.

89 Conforme matéria publicada no jornal O Globo, 30/06/07 "Chinesas fazem cirurgia para se ocidentalizar". Disponível em: http://oglobo.globo.com/mundo/mat/2007/06/30/296589906.asp Acesso: 25/03/10.
} 
Cada vez mais as mulheres com descendência asiática estão tentando amenizar os traços especificamente orientais, mas sem perder sua essência original. [Sobre o corpo com poucas "formas"] Isso e outros "incômodos" hoje podem ser resolvidos na sala de cirurgia estética. [...] Claro que a sociedade e a história têm uma parcela de culpa nessa "exigência" de se ocidentalizar, porque até bem pouco tempo não tinha problema algum ser um descendente oriental, era até considerado exótico e charmoso. ${ }^{90}$ (grifos meus)

É interessante observar como os "traços orientais", "essência" do ser oriental, são pensados como "incômodos", "problemas" que podem ou devem (já que o autor usa o termo "exigência") ser "resolvidos", "amenizados" com a cirurgia. É um discurso que faz lembrar a força da estratégia discursiva que no passado associou os japoneses aos signos da feiura. Foram décadas de construção de imagens caricaturais, charges, debates políticos que tomavam o "físico do nipão" como alvo de crítica ou chacota. Também nos remete à defesa dos projetos eugênicos de "melhoramento da raça" através da miscigenação no início do século XIX. Se a mistura com o branco era capaz de diluir certos traços das "raças inferiores", a cirurgia estética hoje pode se ocupar desse objetivo.

No Brasil, as dobras nos olhos e os "traços mais finos" são associados aos "mestiçoo", categoria nativa para designar filhos de nikkeis "puros" com não-nikkeis; assim como a cor menos escura e os "traços mais finos" são associados aos "mulatos". Se o significante antiestético da diferença para o negro está relacionado principalmente à cor, para o "oriental" está relacionado aos "olhos rasgados". Alisar o cabelo, afinar o nariz, "ocidentalizar" os olhos consistem em "práticas cosméticas" que não são vinculadas a "formas de opressão sexual ou racial" (cf. Edmonds, 2002: 246), mas são vistas como uma busca individual de "melhora da aparência", cuja finalidade consiste em simplesmente "obter um toque mais harmonioso à face". 91

No país que conclama o posto de paraíso da diversidade, da beleza de suas cores, impossível não se lembrar da máxima "quanto mais branco melhor", na idealização do modelo de beleza vigente no país. Segundo Schwarcz, “A cultura, sobretudo para efeito de exportação é negra; ou melhor, mestiça. Já a moda interna é branca, assim como boa parte da cultura que se pretende divulgar" (Schwarcz, 2000: 122).

\section{ENTRE GAFANHOTOS, KUNG FU E MACARR AOO}

\footnotetext{
${ }^{90}$ Disponível em http://www.plasticahoje.com.br/2010/01/ocidentaliza\%C3\%A7\%C3\%A3o-umapl\%C3\%A1sticaexclusiva-para-os-orientais.html Acesso: 25/03/10.

${ }^{91}$ Conforme home page de uma clínica de cirurgia plástica, http://www.perfect.com.br/cirurgia.asp?cir=58\&offset= Acesso: 25/03/10.
} 
Uma das questões propostas aos entrevistados se resumia a indagar se eles já tinham passado por experiências de preconceito. Termo aqui entendido não somente como préjulgamento sem exame crítico, mas como discriminação, atitude ou sentimento hostil frente às características pessoais do portador. As respostas foram as mais variadas. Assim como na pesquisa de Schpun, a maioria não soube precisar um evento específico relacionado à experiência do preconceito. Tanto para aqueles que se viam, como para aqueles que não se viam como vítimas, a percepção geral é a de que essa experiência se revela nas "brincadeiras" e nas "piadas" e não em atitudes de hostilidade e intolerância, como a sofrida pelos negros. Isso não significa que para algumas pessoas, tais "brincadeiras" não sejam consideradas racistas.

A ridicularização se concentra, sobretudo, nos elementos antiestéticos do "corpo japonês" e em aspectos da "cultura japonesa". No primeiro caso, ao "olho rasgado", ao órgão genital masculino - "pinto pequeno" -, ao "corpo tábua" da "japonesa" são atribuídos significados de feiura e zombaria. No segundo, o sotaque, as palavras hai e arigatô $^{92}$ tão amplamente conhecidas, o curvar-se como sinal de deferência, as lutas marciais, os sobrenomes japoneses são ressignificados pelo autor da "brincadeira" em outro contexto, ganhando ares de teatralidade cômica.

Júlia Suzuki Bertolli ${ }^{93}$ me relatou sua experiência, traçando um percurso narrativo da época de colégio até hoje. Afirmou ter sofrido "duplamente" o preconceito, porque "além de ser japonesa, era canhota":

“Nossa, o que as crianças falavam! Que eu não ia para o céu, que eu não ia para quinta-série,
sabe? As brincadeiras eram sempre assim: 'Ô, 'vamo' pegar a japonesa!'. Na quinta-série
tinha uma 'negona' deste tamanho (sinaliza com as mãos), ai de quem mexesse comigo! Foi a
minha sorte, sabia? Ela me protegia! Vizinhos... que tinham preconceito da raça. Isso foi...
quer ver? Levando em consideração que eu sou de $67 \ldots$ Até 80 e pouco, o negócio era
piorzinho, hein! $85 . .$. quando eu fui para faculdade. Exatamente! Até meados de 80 , da década
de 80 , existia muito preconceito em relação a nossa raça. Ao menos assim, vividos por mim!
Agora, talvez, o meu pai e minha mãe não encarassem isso como preconceito. Talvez isso
fosse algo da cabeça de uma criança, porque eu era uma criança naquela época. Talvez, para
eles, sabe? Mas 'ai, não vá andar com ela, porque ela é japonesa!', isso eu já escutei! Isso eu
já escutei! Você está entendendo? Na escola, eu nunca tive nenhum tipo de problema de
preconceito em relação aos professores, tá? Muito pelo contrário! Eu lembro uma vez que teve
revista de cabelo para ver se tinha piolho, né? Aquilo tremia todo mundo da cabeça aos pés,
porque olha o mico que seria ter uma lêndea na cabeça! Aí, a professora olhou o meu cabelo e
falou assim: 'ah, imagina que ela ia ter piolho!'. Você está entendendo? Ah, eu fiquei muito
contente, né? Talvez, não pela minha raça, mas por quem eu era, né? Então, por parte dos
professores, não! Mas por parte dos amiguinhos, sempre rolava uma brincadeira! Assim como
hoje! Acho que até hoje ainda rola né? Alguma coisa... Que nem, assim...O negão, você
chama de negão! O japonês, você chama de japonês! 'Ô, japonês, vem cá... não sei o quê!'

\footnotetext{
${ }^{92}$ Hai: sim; Arigatô: obrigado.

${ }^{93}$ Astorguense, dona de uma relojoaria, sansei, 41 anos.
} 
Não tem outra! Agora, o italiano, o espanhol, o turco, o árabe? Se não tiver uma coisa assim muito... como é que você vai chamar ele? Não tem! Talvez falte uma identidade para eles! Mas os negros, os japoneses e os indios têm uma boa identidade, né? Mas teve sim! Eu acho que... No fundo, no fundo ainda existe um pouco. Mas talvez lá com as pessoas mais antigas né?"

Pergunto a Júlia se houve algum episódio marcante de preconceito por ela vivido, fazendo menção ao que ela escutara quando criança "não vá andar com ela, porque ela é japonesa!":

\begin{abstract}
"Bom, realmente... Em relação ao preconceito, isso marcou minha infância sim! Eu estava subindo para missa... Eu era 'pequetitita', devia ter uns 9 anos, no máximo. Aí, na frente vinha uma coleguinha minha com a mãe dela... meia quadra na frente. Aí, a menina falou assim: 'Mãe, vamos alcançar ...'. Ah, não, elas estavam atrás! ‘Mãe, vamos alcançar a Júlia?' A mãe: 'Ah, menina deixa ela ir na frente, você não vê que ela é japonesa?'. Aquilo me ofendeu tremendamente. Não me ofendeu, porque se tivesse me ofendido, eu teria voado no pescoço dela. Me magoou tremendamente... Mas eu não sabia, eu não entendia o peso do que é ser japonesa para essa mulher. Mas eu sabia que alguma coisa de errado comigo tinha, né? A gente acaba se sentido inferiorizado numa situação dessa. Não sei se me marcou drasticamente, mas deve de ter marcado, porque eu nunca esqueci. Eu nunca esqueci desse fato! Eu conheço a dona hoje. Ela vem aqui no meu estabelecimento comercial, você está entendendo? Então, o que eu posso falar para você?”
\end{abstract}

"Era como se naquele momento, você tivesse se dado conta de que era 'japonesa'?”, indago-lhe em seguida. "Exatamente! Mas nada assim... nada marcante. Eu simplesmente vivi normalmente até hoje...". Júlia conta sua experiência com muita vivacidade, mas observa que tais episódios não lhe causaram feridas abertas, traumas que ela carregou, embora tenham deixado marcas em sua vida que ela nunca esquecera. Sobre o famoso recurso à nominação, "ô, japonês!", vivido e comentado por quase cem por cento dos entrevistados, Júlia afirma que se sente incomodada:

"Mas é tal coisa, né...Você não pode chamar o negro de preto, porque é racismo, né? Realmente é chato você chamar uma pessoa, 'ô, pretinho vem cá!'. Não é a mesma coisa? 'Ô japonês, vem cá!'. Como se a pessoa não tivesse uma identidade. Talvez me incomodasse... tanto com o negro, quanto com o japonês... Talvez me incomodasse... Me soa, o falar dessa pessoa, um sentimento de superioridade em relação a pessoa que está sendo chamada. Isso me incomoda sim, me incomoda sim! No fundo, no fundo me incomoda.

Essa fala de Júlia, estabelecendo uma comparação entre o uso desse expediente para com o "japonês" e para com o "negro" e considerando as diferentes consequências para cada caso, também é compartilhada por outros informantes. Será possível notar ao longo do texto que o recurso comparativo - relacionando os nikkeis ora com os "negros", ora com outros imigrantes 
que para o Brasil vieram, nos mais diversos assuntos, como preconceito, imagem midiática, associações culturais, centenário - foi bastante arregimentado pelos meus interlocutores. A própria Júlia no depoimento anterior busca uma resposta para os motivos de se chamarem o "negão" de "negão", o "japonês" de "japonês", mas não o italiano, o espanhol, o turco, o árabe como tais. "Talvez falte uma identidade para eles! Mas os negros, os japoneses e os indios têm uma boa identidade, né?", conclui.

O que seria essa "boa identidade" de que fala Júlia? Seria talvez uma identidade mais bem marcada pelo aspecto físico, pela "raça"? Por que faltaria uma identidade para o italiano? Conceito caro à Antropologia, é interessante observar como ele é apropriado por Júlia em outro momento. Chamar a pessoa de "pretinho" e "japonês", além de desagradável, "chato" em suas palavras, e denotar uma posição de superioridade de quem interpela, soa como se o interpelado "não tivesse uma identidade". Neste caso, Júlia refere-se ao conceito pessoal de identidade, aquele que promove a identificação do sujeito, como um ser único e particularizado. ${ }^{94}$

Júlia questiona por que a utilização de epítetos raciais, como "pretinho" é considerado racismo no Brasil e no caso dos nikkeis, o epíteto "japonês" ou "japa", não o é. No fórum da comunidade do Orkut, "arigatô, o c...”, que conta com cerca de oito mil membros, há dois tópicos que geraram bastante debate: "Pq as pessoas pensam que zoar japa não é racismo?”, com 156 comentários e "Principais leis nacionais sobre o racismo", com 65 comentários. Um dos argumentos centrais utilizados pelos defensores de que a zombaria deveria ser considerada racismo, era o de que se a injúria que mobiliza elementos pejorativos contra o negro constitui crime, tal observância da lei também deveria ser estendida com relação aos nikkeis ou “orientais". A Constituição prevê o estatuto jurídico de igualdade para todos os cidadãos, condenando preconceitos de raça, etnia, religião, origem, mas de acordo com alguns de meus informantes e com comentários postados no fórum; ofensas dirigidas aos japoneses e "orientais", não são consideradas e não figuram como práticas racistas nem pela lei, nem pelas suas vítimas.

Com o objetivo de explorar essa questão do preconceito, tomaremos como ponto de partida um acontecimento público televisionado envolvendo uma importante figura política no Estado do Paraná: seu atual Governador ${ }^{95}$, Roberto Requião (PMDB). A Paraná Educativa é uma emissora pertencente ao Estado paranaense e que transmite parcialmente a programação da TV Brasil por meio do sinal de parabólica. A emissora tem sido utilizada por Requião como um

\footnotetext{
94 "Pessoa" próxima a ideia de "persona" latina, que como Mauss pontuou, deu o sentido primitivo ao que veio a ser o nosso. Assim como discutido em seu clássico texto sobre a noção de pessoa e de eu: "A 'pessoa' é mais do que um elemento de organização, mais do que um nome ou o direito a um personagem e a uma máscara ritual, ela é um fato fundamentado do direito" (Mauss, 2003: 385).

95 Gestão 2006-2010.
} 
canal para veicular conteúdos políticos relacionados ao governo e também como um instrumento para fins eleitorais, seja através de propagandas de sua gestão e promoção pessoal, seja através de ataques a adversários políticos, imprensa e instituições, como bem explicam as multas constantemente aplicadas pela Justiça ao controverso representante do Estado. ${ }^{96}$

O principal veículo empregado pelo Governador para esses fins é o programa "Escola de Governo", mais conhecido como "Escolinha do Requião", transmitido pela Paraná Educativa ao vivo do Museu Oscar Niemeyer, todas as terças-feiras. O programa consiste em uma espécie de reunião entre o Governador, secretários e funcionários públicos estaduais de primeiro escalão. No dia 6 de outubro de 2009, o pesquisador da área de Ecofisiologia do Instituto Agronômico do Paraná (Iapar), Lauro Akio Okuyama - que acompanhava a exposição do presidente do referido Instituto, José Augusto Picheth - ao falar sobre o desenvolvimento das pesquisas na área de trigo, criticou o governo estadual, afirmando que o grande problema encontrado era a falta de técnicos, "Nós não temos gente para dar continuidade à pesquisa".

Requião, reconhecido por não aceitar manifestações críticas ao seu governo, dirigindose ao presidente do Instituto, disse: "Picheth, está demitido o japonês! Diminuiu o pessoal em mais um pesquisador!". "Mas sou só eu, então acabou o programa do trigo", retrucou o funcionário. Visivelmente irritado com a resposta do pesquisador, o governador afirmou que as contratações para o Instituto já haviam sido realizadas, o que faltava era vontade de trabalhar de algumas pessoas. Em seguida, revogou a demissão de Okuyama, o qual ainda falou mais um pouco. Foi interrompido: “Gafanhoto, você perdeu uma grande oportunidade de ficar quieto. Tudo bem. É isso, Picheth? [...]. Deixe claro pro Kung Fu que o que a Secretaria de Agricultura reivindicou ao Estado e o que o Iapar pediu foram viabilizados. E se não tem pesquisador é porque a direção do Iapar achou desnecessário. Provavelmente, $K u n g F u$, eles acharam que você sozinho resolveria esse problema todo". E, diante do riso da plateia do Museu, encerrou a discussão "punindo" Okuyama pela audácia e reclamação infundada: “O japonês fica, então, sem macarrão durante quinze dias!".

Essas informações não foram retiradas da "grande mídia" no Paraná e sim de três articulistas de jornais da $w e b .^{97} \mathrm{O}$ acontecimento mereceu pequena nota em alguns jornais impressos regionais. Muitos elementos chamam a atenção nesse episódio, especialmente os personagens e as circunstâncias. Primeiramente envolveu a figura política mais importante do

\footnotetext{
96 Conforme matéria, "TV Educativa: Requião multado por uso eleitoral”, 02/10/2006. Disponível em: http://www.observatoriodaimprensa.com.br/artigos.asp?cod=401TVQ003 Acesso: 25/03/2010.

${ }^{97} \mathrm{http}: / /$ www.parana-online.com.br/colunistas/231/71094/?postagem=O+FRACOTE Acesso: 28/03/2010. http://www.paranaonline.com.br/editoria/politica/news/401591/?noticia=PESQUISADOR+CRITICA+ADMINIST RACAO+ESTADUAL+NA+ESCOLA+DE+GOVERNO Acesso: 28/03/2010. http://jornale.com.br/zebeto/2009/10/06/o-dia-do-gafanhoto-na-escola-do-requiao/ Acesso: 28/03/2010.
} 
Estado, o seu Governador e em segundo lugar, teve um caráter público, afinal, mesmo não sendo um canal da TV aberta, foi televisionado para todo o Paraná. O fato mostra a maneira grosseira com que Requião, na autoridade máxima que seu posto representa, atacou publicamente Okuyama, que simplesmente exercia ali o seu direito de cidadão e servidor público, cobrando melhores condições de trabalho. O Governador acionou três categorias para se referir ao pesquisador, cujo nome ele nem ao menos se deu o trabalho de saber: japonês, Kung $F u$ e Gafanhoto.

Em sua "piada", Requião faz menção à famosa série de TV do início dos anos de 1970, “Kung Fu”, que tinha o ator americano David Carradine como o protagonista Kwai Chang Caine, monge shaolin, mestre em wushu, arte marcial chinesa conhecida no Ocidente como kung $f u$. Gafanhoto era o apelido que o personagem tinha quando criança. ${ }^{98}$ A confusão de referências “orientais" é uma prática comum no Brasil, e geralmente pessoas, coisas e símbolos chineses, coreanos, taiwaneses são tomados por japoneses e vice-versa. À máxima "japonês é tudo igual" soma-se a ideia de que o "oriental" ou o "asiático" são todos iguais também.

Dois elementos causam surpresa nesse evento: o desfecho "cômico" que se seguiu risadas que ecoaram pelo Museu Oscar Niemeyer, legitimando os comentários pejorativos do Governador que tinha clara intenção de humilhar Okuyama - e a baixa ou quase invisível repercussão midiática do acontecido num Estado que possui a segunda maior "colônia japonesa" no Brasil. As consequências políticas do ato não passaram completamente despercebidas pelo Ministério Público Federal que estava investigando o caso. ${ }^{99}$

É digno de nota, entretanto, que só tive conhecimento desse episódio envolvendo o pesquisador do Iapar, após outra declaração polêmica de Requião, tendo esta recebido considerável destaque na "grande mídia". Três semanas depois do "caso Okuyama”, no dia 27 de outubro de 2009, novamente em seu programa "Escola de Governo", ao anunciar as ações para o controle do câncer de mama no Paraná, Requião quis aproveitar o espaço para novamente "fazer graça”: “A ação do governo não é só em defesa do interesse público. É da saúde da mulher também. Embora hoje o câncer de mama seja uma doença masculina também. Deve ser consequência dessas passeatas gay”. Dessa vez, a plateia não riu.

A repercussão dessa declaração foi imediata. A Associação Brasileira de Lésbicas, Gays, Bissexuais, Travestis e Transexuais (ABGLT) agiu solicitando uma audiência a

\footnotetext{
${ }^{98}$ De acordo com Linda Lee Cadwell, esposa de Bruce Lee, a ideia da série foi concebida pelo ator sino-americano, que na época ainda não era mundialmente conhecido e que foi preterido para o papel, pois os produtores acreditavam que o público americano não aceitaria uma série de TV criada e protagonizada por um "chinês". Disponível em: http://www.imdb.com/title/tt0068823/trivia Acesso: 15/04/2010.

${ }_{99}$ Segundo nota, "Requião é investigado após fazer piada de pesquisador". Disponível em: http://www.bonde.com.br/bonde.php?id_bonde=1-3--803-20091027 Acesso: 28/03/2010.
} 
Requião. ${ }^{100} \mathrm{O}$ vídeo contendo as imagens de sua declaração circulou pela internet em sites de notícias e grandes jornais deram cobertura ao fato. ${ }^{101} \mathrm{O}$ crítico Arnaldo Jabor, no Jornal da Globo, no dia 28 de outubro de 2009, ao comentar sobre a "súbita homofobia" que andava acometendo a classe política no Brasil, já que "agora os políticos deram para chamar uns aos outros de gays, em vez de denunciar corruptos, mentirosos e chefes de oligarquias"; finaliza seu argumento fazendo menção a Requião: "Eu acho que o que incomoda políticos é a não-caretice dos gays, sua liberdade corajosa. Será que é semelhante à raiva contra a imprensa livre? O Requião, um homem com lindos olhos verdes, não precisava dar uma dessas. Só falta agora dizerem que não há gays no Paraná". ${ }^{102}$

Quase um mês depois do ocorrido, no dia 24 de novembro de 2009, o Ministério Público Federal solicitou à Justiça Federal que aplicasse multa de R 250 mil ao Governador do Estado em razão das duas declarações proferidas pelo mesmo na "Escolinha". Segundo o MPF, Requião usou a TV para constranger e ridicularizar Lauro Akio, chamando-o de "Gafanhoto" e "Kung Fu" e depois a utilizou para as "manifestações absolutamente preconceituosas contras os homossexuais, com nítido caráter homofóbico, ao relacionar a ocorrência de câncer de mama em homens à opção sexual". Desde a proibição da Justiça obrigando o Governador a não fazer uso indevido da Rádio e Televisão Educativa do Paraná (RTVE), ele já acumula quatro multas aplicadas no valor total de R \$ 850 mil por descumprimento de decisão judicial. ${ }^{103}$

Essa decisão junto à Justiça Federal de multar o governador pelo uso ilegal da RTVE se baseou, portanto, nas duas declarações dadas pelo mesmo nesse breve intervalo de três semanas. Isoladamente, o caso de Okuyama não resultou em nenhum processo legal contra Requião, mas de acordo com reportagem citada, estava sob investigação do órgão público. Segundo as fontes jornalísticas aqui utilizadas, o parecer do MPF concluiu que o governador lançou mão do canal público para causar "constrangimento" e "ridicularizar" o pesquisador do

\footnotetext{
${ }^{100}$ A ABGLT divulgou nota em que afirma que piadas desse tipo reforçam o preconceito e a discriminação e ainda lembrou que 19 gays e travestis foram assassinados em 2009 no Paraná. Nos últimos anos, foram 160 mortos. Disponível em: $\quad$ http://jornalnacional.globo.com/Telejornais/JN/0,,MUL1357250-10406,00GOVERNADOR+DO+PR+FAZ+DECLARACAO+PRECONCEITUOSA.html Acesso: 31/03/2010.

${ }^{101}$ A matéria divulgada pela Agência Estado, "Requião atribui câncer de mama em homem a gays" circulou em vários sites de notícias, como no Estadão: http://www.estadao.com.br/noticias/nacional,requiao-atribui-cancer-demama-em-homem-a-gays,457357,0.htm e portal Globo G1: http://g1.globo.com/Noticias/Politica/0,,MUL13572815601,00-REQUIAO+ATRIBUI+CANCER+DE+MAMA+EM+HOMEM+A+GAYS.html. Acesso: 28/03/2010. A notícia também foi veiculada nos principais telejornais do país, como o Jornal Nacional.

$102 \mathrm{http}: / /$ jaborando.blogspot.com/ Acesso: 28/03/2010.

103 Conforme matéria da Agência Estado, "MPF pede multa de R\$ 850 mil para Requião", disponível em: http://portalimprensa.uol.com.br/portal/ultimas_noticias/2009/11/25/imprensa32306.shtml. Acesso: 28/03/2010 e http://veja.abril.com.br/agencias/ae/brasil/detail/2009-11-24-608810.shtml. Acesso: 28/03/2010. A última polêmica protagonizada por Roberto Requião na "Escolinha" foi no dia 23 de fevereiro de 2010 e consiste nas acusações ao Ministro do Planejamento, Paulo Bernardo, de superfaturamento da obra de um ramal ferroviário no interior do Paraná. Diante da acusação, o Ministro entrou com ação cível por danos morais contra Requião. O MPF está pedindo na Justiça a suspensão do programa "Escola de Governo", diante da representação de Bernardo.
} 
Iapar, chamando-o de "Gafanhoto" e "Kung Fu". O termo "japonês" não é mencionado e nenhuma alusão ao "preconceito étnico" ou "racial" é feita. Já a relação entre homossexualidade e desenvolvimento de câncer de mama em homens, estabelecida por Requião, comprovadamente inadmissível em termos científicos e proferida em tom de chacota, é considerada "manifestação nítida de preconceito e homofobia".

O recurso comparativo sempre se mostra como um meio profícuo para incitar a reflexão sobre alguma questão. De modo geral, as discussões sobre "raça" e etnicidade no Brasil, historicamente se mostraram atreladas a análises sobre o contexto norte-americano ou sulafricano, países onde predomina o "preconceito de origem". ${ }^{104}$ Tomaremos como efeito de comparação, a acusação de racismo que recaiu sobre a estrela teen americana, Miley Cyrus, intérprete de Hannah Montana, na série homônima da Disney. Mundialmente conhecida, a cantora e atriz, com apenas 16 anos foi eleita em 2008 uma das cem pessoas mais influentes do mundo pela Time, figurando na capa da revista. ${ }^{105}$ A polêmica envolvendo a adolescente aconteceu devido à circulação desta foto, com ela ao centro, junto com seu namorado e grupo de amigos:

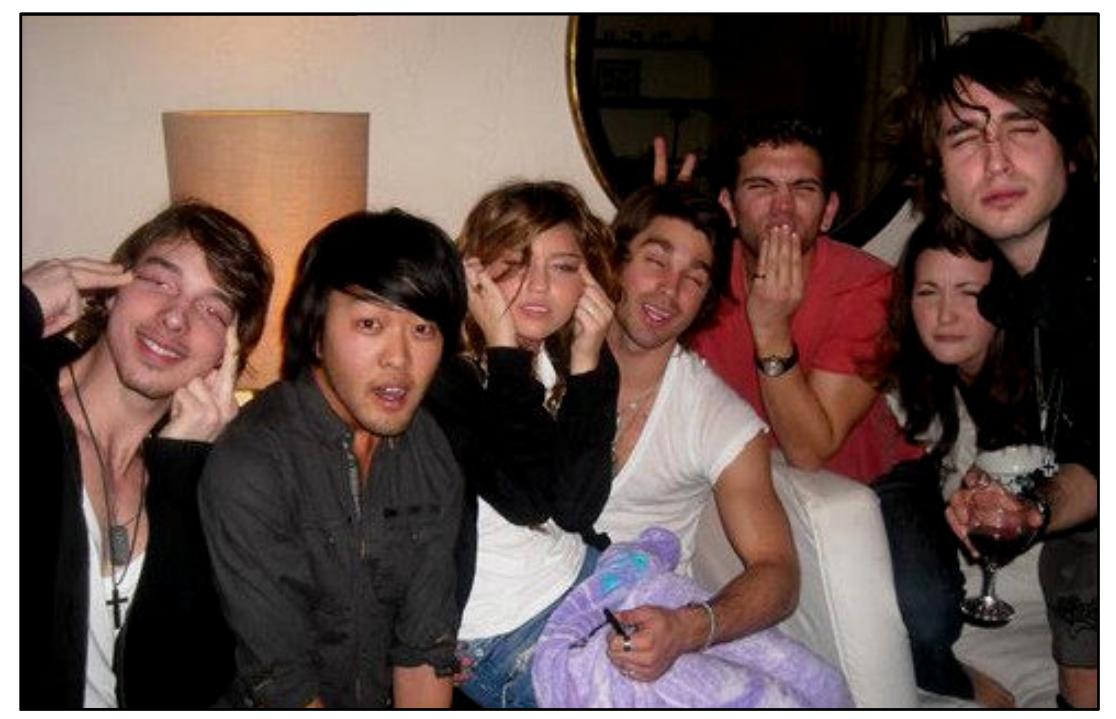

Fig. 13 Miley Cyrus "puxando" os olhos Fonte: TMZ

Segundo consta na matéria da Revista $T M Z,{ }^{106}$ a OCA, "a group dedicated to advancing the social, political and economic well-being of Asian Pacific Americans" condenou o

\footnotetext{
104 Conforme Nogueira (1998). As categorias empregadas pelo autor, "preconceito de marca" e "preconceito de origem" serão discutidas mais adiante.

${ }_{105}$ Disponível em: http://www1.folha.uol.com.br/folha/mundo/ult94u397713.shtml. Acesso: 28/03/2010.

106 "Asian Group not mad at one of these people", 03/02/09. Disponível em : http://www.tmz.com/2009/02/02/asiangroup-not-mad-at-one-of-these-people/ Acesso: 16/04/2010.
} 
gesto de Miley, considerando-o ofensivo para a comunidade americana de descendentes de asiáticos. Segundo a declaração do diretor executivo da organização, George $\mathrm{Wu}$, publicada na revista:

\begin{abstract}
"The photograph of Miley Cyrus and other individuals slanting their eyes currently circulating the Internet is offensive to the Asian Pacific American community and sets a terrible example for her many young fans. This image falls within a long and unfortunate history of people mocking and denigrating individuals of Asian descent... ...Not only has Miley Cyrus and the other individuals in the photograph encouraged and legitimized the taunting and mocking of people of Asian descent, she has also insulted her many Asian Pacific American fans[...]. The inclusion of an Asian Pacific American individual in the photo does not make it acceptable.[...] OCA hopes that Miley Cyrus will apologize to her fans and the APA community for this lapse in judgment and takes the opportunity to better understand why the gesture is offensive".
\end{abstract}

A atriz se defendeu das acusações em seu $b \log$, afirmando que estava somente fazendo uma "cara de pateta". Além disso, criticou a mídia por valer-se da foto para difamá-la, tentando transformá-la em uma "garota má":

"I've also been told there are some people upset about some pictures taken of me with friends making goofy faces! Well, I'm sorry if those people looked at those pics and took them wrong and out of context!". "In NO way was I making fun of any ethnicity! I was simply making a goofy face. When did that become newsworthy? It seems someone is trying to make something out of nothing to me. If that would of been anyone else, it would of been overlooked! I definitely feel like the press is trying to make me out as the new 'BAD GIRL'!'

"I feel like now that Britney is back on top of her game again, they need someone to pick on! Lucky me! haha Anyway, I just wanted to let you guys know what is on my heart. You guys know me and have been by my side every step of the way! You guys know my heart and know the most important things to me are my friends, family, fans, and GOD! In NOWAY do I want to disappoint any of you! But, when I have made mistakes in the past, I feel like I've owned up to them and apologized." 107

A resposta de Miley parece estar mais dirigida para a imprensa do que propriamente para a OCA ou para os descendentes de asiáticos em geral. Dias depois, a estrela finalmente se desculpou pela foto em seu website: "I really wanted to stress how sorry I am if the photo of me with my friends offended anyone. I have learned a valuable lesson from this and know that sometimes my actions can be unintentionally hurtful". ${ }^{108}$ Mas a desculpa não acalmou Lucie J. Kim, moradora de Los Angeles, que entrou com um processo judicial contra Miley, em nome da comunidade asiática que vive nos Estados Unidos, cerca de um milhão de pessoas. Kim alegou

\footnotetext{
107 "Miley Cyrus racist photo response”. 05/02/09. Disponível em : http://www.popcrunch.com/miley-cyrus-racistphoto-response/ Acesso: 16/04/2010.

108 "Miley apologizes: take two". 09/02/09. Disponível em : http://www.tmz.com/2009/02/10/miley-apologizes-taketwo/ Acesso: 16/04/2010.
} 
que Miley tinha consciência de que a imagem, ofensiva e racista a seu ver, poderia ser publicamente disseminada pela internet. De acordo com a TMZ, "Kim says in the suit, filed Wednesday in L.A. County Superior Court, that each Asian Pacific Islander is entitled to the minimum damages for a civil rights violation -- \$4,000", totalizando a indenização, portanto, em 4 bilhões de dólares. ${ }^{109}$ Miley venceu a batalha judicial, pois o juiz entendeu que a atitude, embora ofensiva, não violava nenhuma lei. Nas enquetes promovidas pela $T M Z$ nas matérias já citadas, a maioria dos leitores não considerou a atitude racista e nem concordava com a indenização requerida. ${ }^{110}$

Em que pesem as diferenças no contexto e circunstâncias, no conteúdo da gozação, nos personagens envolvidos, trata-se aqui da apresentação de dois casos envolvendo pessoas públicas. Miley Cyrus, que durante a polêmica das fotos foi apelidada pela mídia de "Hanoi Montana", foi flagrada junto com os amigos, "puxando os olhos" ao lado de um rapaz de origem asiática, único a não fazer o gesto. Sem querer minimizar o caráter ofensivo da atitude da garota, ídolo de milhares de crianças e adolescentes no mundo todo, é importante lembrar que a imagem foi originalmente tirada em um contexto privado. $\mathrm{O}$ caso de Requião é bem mais problemático, pois autoridade máxima do Poder Executivo do Estado, que supostamente deveria zelar pelo tratamento igualitário de seus cidadãos, teve clara intenção de ofender publicamente Lauro Okuyama, descambando para ataques pessoais diretos à condição étnica do pesquisador.

Se Miley Cyrus fosse brasileira, seu gesto teria provocado pouca ou nenhuma repercussão por aqui. Nem é preciso dizer que um processo judicial contra tal atitude provavelmente jamais se verificaria. País que supostamente não possui conflitos étnico-raciais tão historicamente marcados como os Estados Unidos, ${ }^{111}$ o Brasil é visto como a nação da tolerância racial e da boa convivência entre os povos. Afinal, as ofensas desferidas por Requião não tiveram o objetivo de excluir ou segregar a vítima, mas de provocar o riso da plateia com uma "brincadeira" apenas. Luís Carlos Sant'anna ao analisar a representação do negro em humorísticos televisivos argumenta: “sob a licença cômica, abre-se um incrível e 'lícito' espaço de atuação do preconceito, que flui livre e, o mais importante, com um desgaste mínimo ao mito da democracia racial. Afinal, tudo não passa de brincadeira" (Sant'anna, 1984: 8).

\footnotetext{
109 “Asians want \$4 billions from Miley Cyrus". 11/02/09. Disponível em : http://www.tmz.com/2009/02/12/asianswant-4-billion-from-miley/ Acesso: 16/04/2010.

110 "Hanoi Montana...": 1) Who cares? (69\%); 2) Over the line (31\%)

"Should Miley pay?": 1) No way (81\%); 2) Definitely (19\%).

${ }^{111}$ Vale lembrar que após o ataque à Pearl Harbor, os Estados Unidos confinaram seus cidadãos de origem japonesa em campos de concentração, alegando constituir-se em uma medida de segurança.
} 
No site do jornalista Fábio Campana, o artigo postado de autoria de Roger Pereira do jornal Paraná Online, "Pesquisador critica administração estadual na Escola de Governo"112 rendeu 69 comentários que, de maneira geral, condenavam a atitude de Requião, considerada ora racista, ora manifestação de sua contumaz arrogância, ora ambos. Por que aos olhos do MPF, da grande imprensa, e até mesmo de muitos nikkeis, a ofensa de Requião não é pensada como preconceito ou injúria étnica ou racial? Quais seriam as implicações se o personagem dessa história fosse "outro"? Em tom de chacota, um indígena chamado publicamente de "PapaCapim"113 ou "Macunaíma"114 ou quem sabe um negro chamado de "Pelé" ou "Mussum"?

\section{“COMÊ PARITINHO NON É DIFÍCIL, NÉ?”: ETHNIC HUMOR?”}

Introduzi esse questionamento como uma maneira de provocar alguma reflexão e não de estabelecer comparações. Há claramente especificidades, como o longo e terrível processo de séculos de escravização e exploração da população indígena e negra no Brasil. A luta dos movimentos sociais que os representam no combate ao preconceito e ao racismo felizmente tem mostrado um grande esforço na tentativa de coibir a intolerância racial, as representações depreciativas na mídia, as práticas discriminatórias, sejam públicas ou privadas. No caso de Okuyama, o que também está em jogo é a percepção da diferença a partir das marcas fenotípicas e a desqualificação desse sujeito, não por meio de perseguição ou exclusão, mas através da ridicularização.

As percepções e opiniões sobre o preconceito contra os nikkeis por parte dos entrevistados foram bastante relativas. A grande questão que alguns se colocavam é se essas "brincadeiras", que geralmente envolvem o gracejo das características fenotípico-corporais e culturais do "japonês" constituem formas de preconceito étnico-racial. Muitos deles concluem que mesmo ofensivas, tais atitudes não "chegam ao ponto" de serem qualificadas como discriminação. Quando discutia sobre a imagem do japonês na televisão, o entrevistado Rodrigo Suzuki, 22 anos, sansei, dentista de Londrina-PR, expressou a opinião de que a mesma constituise num "modo jocoso de brincar" e embora não aprecie esse tipo de representação - "Acho que tem outras formas de deixar uma coisa engraçada sem brincar com a etnia das pessoas" acredita que o "povo quer ver esculhambação na mídia":

\footnotetext{
${ }^{112}$ Disponível em: http://www.fabiocampana.com.br/2009/10/requiao-nao-engole-pesquisador-que-o-criticounaescolinha/comment-page-2/\#comment-143779 Acesso: 28/03/10.

${ }^{113}$ Menino índio, personagem da "Turma da Mônica", criado pelo desenhista Maurício de Souza.

${ }^{114} \mathrm{O}$ anti-herói, personagem-título do romance de Mário de Andrade.
} 
"Não digo que isso seja preconceito, mas eles vêem graça em tudo, querem brincar com tudo. Não acho que apesar de imagens assim, eles chegam a manchar uma característica nossa, porque aonde a gente vai... Assim para um povo de pouca cultura, nós somos bem respeitados, nós somos um povo trabalhador, honesto... Apesar de ter um monte de japonês safado aí também, na política, acredito que essa imagem por enquanto ainda não está manchada".

Rodrigo conclui que a jocosidade na representação midiática do japonês não chega a afetar negativamente, a "manchar" certas "características" dos nikkeis, como a imagem de trabalho e honestidade a eles associada e o respeito adquirido na sociedade. Arrisco a pensar que essas avaliações sobre as possibilidades de preconceito contra os japoneses e seus descendentes na atualidade estejam balizadas por dois parâmetros. Um deles, como disse anteriormente, são as experiências discriminatórias sofridas pelas primeiras gerações de imigrantes que não sabiam a língua e que viveram sob o contexto da guerra. Afinal, hoje as matérias que estampam os jornais não mais acusam os japoneses e seus descendentes de "perigo amarelo", e sim de "legítimos brasileiros", "de olhos puxados e corações abertos"115. A hipótese é que também atuam nessa balança, os sentidos atribuídos à discriminação social e racial sofrida, sobretudo pelos negros. Diferentemente dos últimos, a imagem positiva dos nikkeis na sociedade lhes favoreceria, pois lhes possibilitaria passar ao largo de experiências de segregação, exclusão e intolerância.

Novamente o recurso comparativo sobrevém, mas agora não para indicar uma semelhança ou paralelo na experiência com o negro, como o fez Júlia - "Mas é tal coisa...Você não pode chamar o negro de preto, porque é racismo, né? Realmente é chato você chamar uma pessoa, 'Ô, pretinho vem cá!'. Não é a mesma coisa? ‘Ô japonês, vem cá!” - mas para demarcar a diferença. Como atesta Thiago, "mestiço", sansei, 17 anos, "Preconceito mesmo, assim, nunca senti... Ninguém nunca fez assim, virado a cara e falado pra mim, 'Ah, você é japonês!' [...] Agora alvo de gozação sim...". ${ }^{116}$ Yumi Kawamura ${ }^{117}$ também comparou a imagem positiva dos nikkeis com a imagem negativa atribuída aos negros e de como isso influi na discriminação sofrida:

\footnotetext{
"Eu acho que na sociedade brasileira, japonês é bem visto, é bem aceito. Não tem aquela discriminação, assim tanto, como os negros no caso. 'Negro, ih é pobre'. Japonês quando chega, 'Ih, é rico'. Por exemplo, aqui na faculdade, quando eu estudava, todo mundo falava, 'a única rica da sala'. Eu acho que é esse lado. Falam assim, 'nunca vi japonês pobre e burro!'. Todo mundo fala. Agora no nosso dia a dia, eu acho que a gente leva uma vantagem, um pouquinho, mas leva".
}

\footnotetext{
${ }^{115}$ Conforme reportagem especial do Jornal Nacional sobre o centenário da imigração japonesa, veiculado no dia 20/06/08. Disponível em: http://jornalnacional.globo.com/Telejornais/JN/0,,MUL609085-10406,00BRASILEIROS+DE+OLHOS+PUXADOS+E+CORACOES+ABERTOS.html Acesso: 31/03/10.

${ }^{116}$ Entrevista realizada em 2005 para o trabalho de conclusão de curso, Clowns mascarados: estereótipos do nikkei na mídia televisiva.

${ }^{117}$ Astorguense, nissei, 39 anos, estudante de Pedagogia.
} 
Yumi estabeleceu essa comparação quando conversávamos sobre as imagens dos japoneses na televisão, as quais ela acredita que estejam adquirindo maior seriedade, sobretudo com a atuação da atriz Daniele Suzuki e não mais focando na comicidade como antigamente. Dá o exemplo da propaganda do salgadinho Stiksy da Elma Chips, provavelmente veiculada no início da década de 1990, em que um japonês vestido de quimono diz que vai ensinar os "brasileiros" a comerem palitinho. ${ }^{118} \mathrm{Na}$ cena, a câmera está enquadrada no ator, mas é possível perceber o cenário: ele se encontra em uma típica casa tradicional japonesa, à frente do shōji, aquelas portas corrediças ou divisórias forradas com papel translúcido e sustentadas por grades de bambu. Por trás do shōji, é possível observar que há uma planta de bambu e um mensageiro do vento que balançam no decorrer da cena. Uma lanterna oriental branca e uma luminária também feita de bambu compõem o interior da casa. Todos os elementos, portanto, fazem referência ao Japão ou ao "Oriente”.

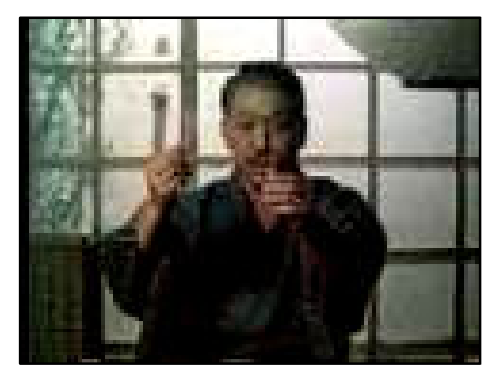

Fig. 14 Propaganda do "paritinho"

A cena começa com o ator - um senhor japonês na faixa dos 50 anos, com um ralo bigode e um dente um pouco "avantajado", talvez postiço, vestido de quimono - curvado em forma de reverência, provavelmente sobre um tatami. Levanta a cabeça e diz de forma séria, carregando no sotaque japonês: "Com ricença. Eu vai ensinar brasireiro como comer paritinho. Non é difícil, né? É só pegar um partitinho Stikys assim e outro paritinho Stikys assim (coloca os palitos nas mãos como se fossem hashis) e..."

Close-up no rosto do ator, que posicionado lateralmente para a câmera, come rapidamente os palitos. Nesse movimento, a câmera acelera, em quick motion, e o som dos palitinhos sendo rapidamente devorados se faz ouvir. Recurso utilizado em todas as propagandas da empresa: o apelo sensorial evocado pela crocância do salgadinho que estaleja ao ser mordido.

\footnotetext{
${ }^{118}$ http://www.youtube.com/watch?v=81yAFeOas4g Acesso: 01/04/2010.
} 
O japonês solta uma gargalhada, "Há, há, há, há" e fala com a boca cheia e com os olhos bem abertos: “Torradinho!”. Rindo e pegando um pacote de Stikys, diz: "Com Stikys, muito fácil comer... paritinho, né?”. E logo, enfia mais dois palitinhos rapidamente na boca como se fosse um roedor. Novamente se ouve o som da comilança. A câmera repete o movimento do ator de colocar o palito na boca três vezes em quick motion. A propaganda termina com a voz do narrador, em off, "Stikys, impossível comer um só", slogan que ainda se mantém como carrochefe da imagem da marca Elma Chips. "Propaganda só para tirar sarro!", indigna-se Yumi:

"Eu lembro mesmo quando eu ia pra escola e o pessoal ficava falando assim, 'come paritinho, né?' E ficava dando risada, sabe? Sem falar daquela música sertaneja que teve, 'Tanaka não sei o que lá, tocando vaca'. Não podia andar na rua que o pessoal já dava risada. Quando eu estudava, ah, todo mundo dava risada! Eu tinha um ódio!! Eu detestava! Hoje já esta melhorando!"

A música sertaneja a que Yumi se refere é "Os três boiadeiros japoneses", composta pela dupla de Ribeirão Preto, Lourenço \& Lourival. A música-título do álbum de 1997, que é uma paródia da clássica canção caipira, "Os três boiadeiros", de Anacleto Rosas Júnior, é inteiramente cantada, macaqueando-se o sotaque japonês:

"Essa é história de três japoneses que trabalhavam no serviço de tocar gado

Toshiro, Okuda e Tanaka"

Viajando... Pela estrada

Okuda na frente. Tocava berrante

Chamando o vaca

E Tanaka, sempre do lado

Distraindo os vacas

Tomando cuidado com as encruzilhadas

E nós três vivia... Tocando vaca

E nós três vivia... Tocando vaca

"Nós corria, corria atrás dos vacas

Outra vez, era os vacas

Que corria atrás de japonês"

Mas um dia na invernada

Deu uma trovoada, uma aterrisada

$\mathrm{O}$ vaca estorou

Nesse dia... Morreu Okuda

Caiu do cavalo. Foi dentro da vara. E o vaca pisou

Fica eu e o Tanaka... Tocando vaca 
Fica eu e o Tanaka... Tocando vaca

"Tanaka, segura o vaca, Tanaka! Se não cê vorta prantá repoio!

Ô, japonês medroso, Tanaka!!!”

No domingo, de rodeio

Tanaka bebeu, encheu o cara de saquê

E pulou na picadeiro

No relance, atirei no vaca

A chifruda tremeu, e no pulo que deu

Matou o companheiro Tanaka

Eu ficar sozinho... Tocando vaca

Eu ficar sozinho... Tocando vaca

"Uuhh que baita furo deu o Tanaka. Cê atrapalhou tudo, cabou debaixo de vaca"

Viajando... Pela estrada

Não toca berrante, nem vejo lá adiante Okuda e Tanaka

Neste trio, fica eu, Toshiro

Em toda cidade, todo mundo pergunta

Dos três japoneses

Eu ficar sozinho... Tocando vaca

Eu ficar sozinho... Empurrando vaca

“Agora japonês aborreceu, tá!

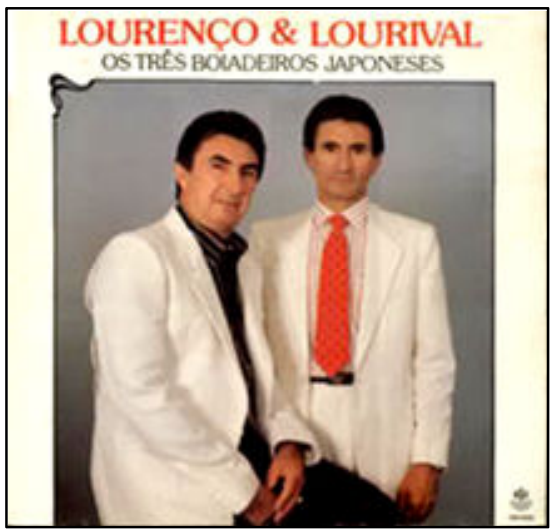

Não vai mais trabalhar com vaca

Japonês vai montar quitanda

Não vai mais esquentar a muringa com vaca não

Vai mandar repoio, birinjela nabo

Em todo mundo, falô!?!"

Yumi que se mostrou visivelmente irritada com essas paródias do japonês as encara como uma forma de "tirar sarro" e não como preconceito, pois as imagens positivas dos nipobrasileiros na sociedade sobrelevam as negativas. Já no caso dos negros, as representações negativas relacionadas à "raça", como a pobreza, são indicadores da discriminação sofrida. Segundo ela, a visibilidade de personagens nikkeis na mídia tem aumentado e o desempenho de artistas como Daniele Suzuki e Sabrina Sato ajudam a "melhorar a imagem do japonês na televisão". Propagandas da Semp Toshiba, por exemplo, "mostram que coisa que é de japonês é coisa boa, dá para confiar".

O antropólogo norte-americano Takeyuki Tsuda (2000) também compartilha, em alguns aspectos, da opinião de Yumi. Para o autor, "a insistência dos brasileiros em inscrever racialmente os japoneses é um simples reconhecimento da diferença, e não uma reação 
prejudicial, na qual a diferença é negativamente percebida. Na pior das hipóteses, mesmo que haja um conteúdo de zombaria ou brincadeira, não há aversão ou denigration (sic)”. Relatando sua experiência no Brasil, em que foi designado como "japonês", Tsuda afirma que, no geral, considerou essa experiência mais divertida do que ofensiva, e ainda complementou que, depois de um tempo, aquilo se tornou algo esperado, uma rotina. Seus informantes, assim como ele, não se sentem ofendidos. Tsuda também acredita que o gesto de alguns brasileiros, de "puxar os olhos" para se referir a coisas ou pessoas japonesas, não tem a pretensão de ofender os nikkeis, mas é simplesmente um "comentário divertido" sobre a diferença fisionômica destes - atitude que o autor denomina de ethnic humor (Tsuda, 2000: 6).

Diferentemente do que registrou o autor, alguns entrevistados nesta pesquisa anunciaram terem sido vítimas de preconceito pelo fato de serem “japoneses”, e aqueles que não consideraram a sátira da ascendência como uma forma de preconceito, como Yumi, não necessariamente mostraram-se indiferentes ou viram uma positivação ou divertimento nessa "inscrição racial". Yumi "detestava" que fizessem piada com ela e acredita que o uso do apelativo “ô, japonês!” é sinal da falta de educação de quem chama.

A noção de ethnic humor é, no mínimo, problemática, pois o divertimento aqui se encontra na referência aos traços fenotípicos do indivíduo. É importante levar em consideração que o tal do "ô, japonês", “ô, japa!" não configura uma interpelação provida de um único sentido. Dependendo de quem fala e como se fala, muitos entrevistados disseram que não se incomodam de serem chamados assim. Desse modo, o grau de familiaridade, amizade e intimidade e o tom usado pelo interpelante definem se a interpelação foi ou não ofensiva. O caráter relativo do sentimento de preconceito verifica-se na fala de Rodrigo Suzuki:

"É mais brincadeirinha, ser excluído, não. É de mau gosto... mas nada que me faça perder o sono. Quando é amizade, tudo bem. Negro fazer piada de negro é engraçado. Agora vai um branco fazer piada de negro é racismo. É a mesma coisa... [risos]".

\section{“ESSE JAPONÊS TEM NOME!”}

Essa ideia de relatividade também aparece na narrativa de Alice Ohara, astorguense de 46 anos, sansei, mãe de um menino de 5 anos. É formada em Psicologia, mas atualmente possui uma escola franqueada do sistema Kumon ${ }^{119}$ de ensino e atua no estabelecimento como

\footnotetext{
${ }^{119}$ Segundo consta no site da empresa, o Kumon é um método de ensino criado no Japão em 1958, pelo professor de matemática, Toru Kumon. Através de um "material didático autoinstrutivo" e de uma rotina diária de estudos, o
} 
orientadora. Nossa primeira conversa foi realizada depois do término das aulas, ali mesmo na escola. Discutíamos sobre a existência ou não de preconceito nas imagens dos japoneses da televisão. Alice não se lembrava dos personagens, mas disse que a "raça nikkei está aparecendo bastante agora" e a "imagem é bem melhor do que antigamente", quando a ironia e a comicidade faziam-na "se sentir inferiorizada". Logo em seguida, Alice compartilha comigo o desconforto que seu filho de apenas 5 anos sente quando chamado de "japonesinho":

\begin{abstract}
"Meu filho não gosta que falem que ele é 'japonês'. Só que a gente (ela e o marido) nunca passou esse tipo de coisa para ele, de preconceito, nada. Desde pequenino, se alguém chamava assim de 'ô, japonesinho', ele falava que não gostava. Eu falo para ele, 'Não, filho, tem que gostar! Não porque te chamaram de japonesinho. Está certo que tem que chamar pelo nome. Fale: 'Meu nome é tal e me chame pelo nome'. Mas assim... porque eu acho que tem que ter orgulho da descendência. Falo para ele, 'tanta gente fala que japonês é inteligente, japonês é isso, japonês é aquilo'. Eu falo que tem que ter orgulho e não ficar com vergonha. Mas é que algumas pessoas ainda falam de 'japonês'... Às vezes dá um ar de preconceito, eu acho. Tem outros que não. Às vezes, as pessoas chamam. É igual falar de negro, né? É a mesma coisa eu acho. Tem uns que não gostam... Mas agora eu acho que tem que ter orgulho, né? A maioria eu acho que esta enobrecendo a raça e não está diminuindo".
\end{abstract}

Para Alice Ohara, Yumi Kawamura e vários informantes, a abordagem inicial do tema da imagem televisiva do japonês operou como um gatilho que disparou questões outras, de ordem mais geral, como a representação do nikkei na sociedade brasileira ou de ordem particular, como o conflito vivido pelo filho de Alice, Gabriel, ou as lembranças da época da escola de Yumi.

Alice toca em uma questão muito importante, crucial no entendimento da identidade para algumas pessoas: o orgulho da descendência. É curiosa a forma como ela desenvolve seu argumento na tentativa de dissuadir o filho, descontente em ser chamado de "japonesinho": mesmo tendo um "ar de preconceito", afinal "é igual falar de negro", o apelativo está vinculado a um imaginário "enobrecedor" da "raça" que a associa à inteligência e a outras atribuições positivas. Num quadro em que tantas pessoas falam que "japonês é isso, japonês é aquilo", o filho deve sentir orgulho e não vergonha de sua descendência. Pergunto à Alice se Gabriel, está passando por essa experiência na escolinha ou na rua:

'Na escolinha, acho que não. A maioria o chama pelo nome. Mas aí ele foi à catequese, em
uma Igreja perto de nossa casa e como são várias crianças de outros lugares, do bairro e
ninguém conhecia ele, todo mundo começou a chamá-lo de japonesinho, 'ô japonesinho'. Aí
ele chegou em casa e eu perguntei, 'Você gostou da catequese?'. 'Ah, mãe eu gostei, mas não método consiste em proporcionar uma orientação individualizada que forme alunos capazes de aprender de maneira independente e disciplinada. No Brasil, são 1700 unidades franqueadas que oferecem cursos de matemática, japonês, inglês e português. Disponível em: www.kumon.com.br, acesso: 29/05/2010. 
quero mais ir'. 'Por quê?'. 'Ah, todo mundo me chama de japonesinho e eu não gosto', ele falou. 'Mas filho, então fala para professora, ou para quem te chamar de japonês: 'Meu nome é Gabriel, me chamem pelo nome'". Até conversei com a professora e falei, 'Olha, ele não gosta que chamem ele assim, gosta de ser chamado pelo nome'. Ela falou: 'Ah, tá agora que eu sei vou falar para os amiguinhos'. Até a professora falava 'japonesinho'! 'Até eu falei, não sabia que ele não gostava', ela disse. Falei: 'Ele tem nome, chamem pelo nome'. É a mesma coisa se chegasse um loirinho e eles chamassem, 'ô, polaco!'. Ele tem nome, né? Aí eles começaram a chamá-lo pelo nome, mas ele parou de ir [risos]. Até mesmo na rua, ele ficava na babá e alguém dizia 'ô, japonesinho!'. Ele falava, 'Ai, não gosto que me chamem assim! Eu tenho nome!'. Então, depende de como chama. Mesmo ele sendo pequeno, a gente nunca falou esse tipo de coisa para ele. Ele está com 5 anos, mas desde os 3, 4 anos já falava isso. A gente nunca passou esse tipo de coisa. Tanto é que meu marido não liga se chamam ele de japonês. Não sei de onde ele tirou isso, mas nunca gostou".

“E você, já passou por essa experiência?” - questiono em seguida.

“De falarem, 'Ô, japonesa?'. Ah, sim! Até aqui na escola, tinha um aluno que chegava, 'Ô, japa', não sei o quê. Cheguei nele e falei: 'Olha, eu não gosto que você me chame dessa forma. Meu nome você sabe, então me chame pelo meu nome'. Ele falou: 'Por que?'. Eu falei, 'É a mesma coisa se eu...'. Porque ele é negro, né? Aí falei, 'É a mesma coisa se eu chamasse você assim (de negro). Você não iria gostar'. ${ }^{120}$ Aí ele falou, 'É... Tudo bem'. Aí ele parou. Depende a forma, né? Mas ele chegava, 'Ô, japa, ô japonesa, não sei o quê'. Então, começou assim. Eu acho que é um jeito pejorativo você chamar alguém assim. Falei, 'não gosto' e até falei para a mãe dele, aí ele parou. Eu acho que depende como ele chega e fala. Agora, de repente... Eu já ouvi menininhas falarem: 'Ai, que japonesinho bonitinho'. Não é? [risos] Aí, eu acho que não é por maldade. Depende como chama, né?"

No dia seguinte à entrevista com Alice, seu marido, Jorge, concordou em me receber em sua casa para uma entrevista. A ideia inicial era conversar individualmente com cada um. Contudo, o papo foi ficando bem mais descontraído depois que Alice se juntou a nós. É importante ressaltar que eu também não conhecia o casal pessoalmente, e dessa vez, foi minha mãe que havia intermediado o contato. Na conversa conjunta, o casal ficou mais à vontade para discutir sobre algumas questões. Um complementava a fala do outro, relembrava detalhes que o outro já não se lembrava, entravam em concordância ou discordância em alguns pontos. Foi a partir desse dia que a metodologia de entrevistar mais de uma pessoa ao mesmo tempo foi adotada. Assim como Alice já comentara, Jorge, nissei, 52 anos, não se incomoda de ser chamado de "japonês". Como é feirante, deve ouvir muito esse designativo, mas ressalva:

"Eu não me incomodo! Mas o pessoal mais de idade não gosta. Não gostam nem que chamem de japonês. O pessoal me cumprimenta, 'ô, japonês!'. Eu não ligo! Eu não ligo, sabe? Agora depende esse ligar ou não ligar. Depende se o pessoal está querendo tirar sarro ou está

\footnotetext{
${ }^{120}$ Novamente é possível perceber o uso do recurso comparativo com relação ao negro e ao "polaco", termo usado para designar geralmente as pessoas de ascendência polonesa. Todavia, frequentemente a apresentação de certas características físicas, como a pele branca, os cabelos loiros e os olhos claros, independentemente da origem, já bastam para o uso da alcunha.
} 
querendo fazer gozação, esse tipo de coisa. Se você vê isso, você já corta, né? Agora, se chega pessoa estranha querendo tirar onda, aí você tem que cortar, né? É aquele negócio... Meu pai sempre falava: nihonjin é bakataré. ${ }^{121}$ Ele falava isso aí. Realmente... Meu pai sempre falava, 'você vê que estão querendo fazer você de bobo, querendo te rebaixar, não deixa'. Desde pequeno, ele falava isso aí. E realmente, esse pessoal mais de idade passou muita dificuldade. Então, eles não gostavam, né? Tem parente da Alice que não gosta de ser chamado de japonês (Jorge diz que é um tio dela de 70 anos). 'Eu sou japonês, mas eu tenho nome!'. Quando dizem, 'Ô, japonês!' (voz mais grossa). Ele fala: ‘Esse japonês tem nome!’”.

Jorge relaciona as dificuldades enfrentadas pela geração mais velha - referindo-se, provavelmente, ao desconhecimento da língua e ao preconceito sofrido - com a não apreciação do apelativo “ô, japonês!". Uma crônica publicada no jornal Paraná Shimbum ${ }^{122}$ de um nissei, Toshio Icizuca, que quando criança passou pela experiência da hostilidade e da humilhação na época da Segunda Guerra, dá a tom de como essa interpelação ganha outra dimensão dependendo do contexto:

A palavra "ja-po-nês", dita com misto de ódio e desprezo pelas pessoas que queriam nos intimidar, marcou-nos profundamente como se pertencêssemos a uma raça inferior, diferente dos brasileiros em geral. Confesso que, em certos momentos, sentia vergonha de ser japonês, queria ter feição que não pudesse ser identificado como oriental. Esse tipo de sentimento de revolta era estritamente pessoal, não revelava a ninguém, nem aos meus pais. Com o fim da Guerra, as manifestações de hostilidade começaram a diminuir e, consequentemente, a intensidade da minha revolta interna também ia perdendo a força. Porém, ao ser chamado de japonês, mesmo sem nenhuma conotação de maldade ou ofensa, tudo voltava à estaca zero.

Uma breve incursão sobre o passado se faz necessária para compreender esse sentimento de repúdio de Icizuca não só com relação à situação vivenciada por ele na época, mas com relação à sua própria condição étnica. A campanha antinipônica, que como vimos no início do capítulo se iniciara já nos primórdios do movimento imigratório, continuou a todo vapor durante a década de 1930 - período em que o nacionalismo foi arregimentado para sustentar as bases de um regime político centralizador - culminando, como já apontado, no controle da imigração através da Constituição de 1934, que estabelecia uma cota anual de $2 \%$ sobre o número de imigrantes de cada nação que haviam entrado no país nos últimos cinquenta anos. Além dessa medida que visava diretamente restringir a imigração japonesa, a política de nacionalização de caráter discriminatório levada a cabo posteriormente pelo Estado Novo, conhecida como "campanha da brasilidade", instituiu que 30\% dos habitantes das colônias deveriam ser brasileiros, fechou escolas japonesas (nihongakos), associações, jornais, proibiu reuniões e a comunicação em língua estrangeira em público.

\footnotetext{
${ }^{121}$ Bakataré: idiota, bobo, ingênuo.

122 “Orgulho de ser japonês". Crônicas Nikkei. Paraná Shimbum. 21 a 27/11/09.
} 
Vale reiterar que a política do racismo oficial articulada pelo Estado Novo esteve escudada nos polêmicos debates políticos da época. Declarações como a do jurista e intelectual Oliveira Vianna, ${ }^{123}$ "o japonês é o como enxofre, insolúvel”, ocupavam lugar especial no arsenal ideológico do período e contribuíam para a conformação de diretrizes políticas do regime. De acordo com Márcia Takeuchi, a construção do nipônico como “inimigo-objetivo”, pois enquistado e inassimilável, satisfazia as aspirações centralizadoras do regime varguista que justificava suas ações autoritárias sob o argumento da necessidade de integração da nação. ${ }^{124}$

A deflagração da Guerra e o rompimento das relações diplomáticas do Brasil com os países do Eixo em 1942 intensificaram a retórica nacionalista e sua contrapartida xenófoba, que se desdobrou em uma série de manifestações discriminatórias pelo país e medidas governamentais, como o confisco de bens e propriedades de empresas e indivíduos oriundos desses países como forma de ressarcimento por danos de guerra; transferência ao Banco do Brasil de um porcentual sobre as contas bancárias superiores a dois contos de réis, cujos titulares fossem dessas nacionalidades e expulsão de residentes japoneses, italianos e alemães de áreas consideradas estratégicas, como o litoral. ${ }^{125}$ Devido à visibilidade de seus traços fisionômicos, a população nikkei foi a que mais sofreu com a situação de guerra, pois eram vistos como “etnicamente perigosos" (Takeuchi, 2008a: 189).

Notícias da existência de supostos espiões japoneses disfarçados de lavradores pululavam na grande imprensa e as cooperativas agrícolas, ora vistas como modelos de produtividade, passaram a serem tachadas de "centros de sabotagem econômica" e "quintacolunas da alimentação". Além disso, a estrita vigilância da polícia política, prisões sob acusações de ameaça à segurança nacional, torturas, apreensão de bens, cerceamento da comunicação, censura, pressões psicológicas, perseguição e discriminação, passaram a fazer parte do cotidiano de muitos nikkeis. A resistência se deu de forma silenciosa, sem confrontos diretos, permeada pelo desejo remoto de repatriação ou pela maior valorização de tradições

\footnotetext{
123 Vianna atuou como consultor jurídico do Itamaraty e do Ministério do Trabalho nas décadas de 1930 e 1940 . Em 1934, presidiu a Comissão Especial de Imigração que deveria discutir a viabilidade da imigração assíria e que, posteriormente, foi incumbida de estudar as possibilidades de se adotar medidas restritivas contra a entrada de elementos indesejáveis ao país, como os japoneses.

${ }^{124}$ Já Jeffrey Lesser chama a atenção para a postura conciliatória de Vargas no período posterior a elaboração da Constituição de 1934, a qual instituiu a cota dos 2\%. O presidente que, em 1933 em visita ao Pará, afirmara que os “japoneses prenunciavam um brilhante futuro para a Bacia Amazônica quase deserta" (Lesser, 2001: 194), três anos depois buscava aplacar a ira dos nativistas ao mesmo tempo em que sofria pressão do governo japonês para aumentar a cota, uma vez que este condicionava a compra de algodão brasileiro à política de imigração (id. ib.: 227). ${ }^{125}$ Essa medida de evacuação foi tomada depois do torpedeamento de cinco cargueiros brasileiros por submarinos alemães em 1943. Cerca de dez mil famílias foram removidas para o interior do Estado do dia para a noite. O deslocamento e locomoção destes colonos pelo país também foram prejudicados pela perda das carteiras de habilitação e condicionados à apresentação de salvo-condutos.
} 
culturais, fosse pela simples persistência em falar a língua japonesa, o nihongo, e em manter o funcionamento das escolas de forma clandestina, fosse pela participação em sociedades secretas.

O livro do escritor e jornalista Vivaldo Coaracy, O perigo japonês, publicado em 1942, o qual reunia artigos de sua autoria como colaborador do Jornal do Commercio, também se prestou como um efetivo discurso da campanha antinipônica. Mobilizando a simbologia da nação como corpo, estratégia linguística comum à época, o autor associava o nipônico ao "vírus" e ao "quisto", ou seja, a elementos estranhos entranhados no tecido social. ${ }^{126}$ Tal infiltração pérfida seria possibilitada pela inerente hipocrisia desses "homenzinhos pequeninos e amarelos que se insinuam, sorridentes e humildes, numa penetração insidiosa, até o momento em que possam dominar" (Takeuchi, 2008a: 129). Como enfatiza Takeuchi, a imprensa e as charges políticas serviram muitas vezes como complemento a teses racistas, como as de Coaracy. A autora cita uma matéria publicada pelo jornalista David Nasser na revista O Cruzeiro, em 1945, intitulada, "Japs and chins":

Eis o japonês. Fisicamente, ele é de aspecto repulsivo, míope, insignificante. Se trabalha no campo, sorri muito e fala pouco. Se é diplomata, fala pouco e sorri muito [...] A expressão dos olhos é nula, sob o ponto de vista de análise, e indecifrável. O sorriso é baço, opaco e apenas é sorriso por uma convenção qualquer. Ele vos estenderá a mão. Não esconderá um punhal na manga do casaco. Convidar-vos-á a uma chávena de legítimo javanês. Não porá veneno no bule de porcelana. Saireis encantados certos de que tudo quanto se diz ou se escreve sobre as atrocidades do japonês é mera publicidade. Isto é o que ele deseja (id.; ib.: 144).

A cortesia do japonês e a dificuldade em se comunicar em português valeram-lhe a pecha de "traidor", "falso", "covarde", portador do "sorriso amarelo", "espião". Coaracy também utilizava o argumento vigente no discurso antinipônico americano de concorrência ao trabalhador nacional:

Satisfazendo-se com salários vis,... inferiores ao padrão de vida mínimo do branco, o japonês promove uma concorrência mortífera ao operário nacional dos países onde é admitido e lança assim os gérmens de gravíssimos problemas sociais... Sob esse ponto de vista, o japonês é um criador de pobreza nos países que o recebem (Nucci, 2000: 53).

Como observa Priscila Nucci, o discurso inflamado de Coaracy a favor do "esmagamento do inimigo" em defesa da soberania nacional, incitando as nações "civilizadas" a tomar uma atitude contra o "perigo japonês", nos lembra as justificativas do governo norte-

\footnotetext{
${ }^{126}$ Em outra passagem, o autor opta por utilizar uma analogia que julga mais adequada para a questão, a do "câncer prolífero, que se desdobra e desenvolve, estendendo raízes, transformando a natureza dos tecidos através dos quais progride fatal para o organismo em que implanta" (Takeuchi, 2008a: 125).
} 
americano para o bombardeio de Hiroshima e Nagasaki na Segunda Guerra ${ }^{127}$. Sobre essa questão, um dos "três heróis da campanha antinipônica", o psiquiatra e deputado Xavier de Oliveira, em número da Revista de Imigração e Colonização de 1945, é bem enfático em seu apoio à medida:

Agora mesmo, lá no Extremo Oriente, um exército de 10 milhões de homens, a estas horas, estará depondo as armas, sem contudo ter sido vencido, ou antes, destruído em campo de batalha. Com o Japão, entretanto, o problema, para a humanidade, não é vencer uma guerra, mas destruir um povo, inimigo do gênero humano. Certamente, a bomba atômica, neste momento, senão há mais tempo, já não é segredo para as suas e para as universidades germânicas (Nucci, 2000: 73) (grifos meus).

No contexto do imediato pós-guerra, o sentimento antinipônico ganha força junto à opinião pública com as atividades da Shindo Renmei. ${ }^{128}$ Os mais nativistas - como o deputado Miguel Couto Filho, levando adiante a campanha preconizada pelo pai - passam a associar a colônia com a posição dos "vitoristas", estendendo a pecha de "fanáticos" para todos os seus descendentes. O deputado declarou ao Diário de São Paulo, em 18 de abril de 1946: "Temos o dever de combater arduamente os nipônicos e a sua entrada no Brasil. De minha parte, não pouparei esforços para mostrar, da tribuna da Constituinte, que os daninhos e antipatrióticos objetivos desses perigosos amarelos revelando os seus intuitos e manobras, merecem a nossa mais veemente repulsa" (CEHIJB, 1993: 299) (grifos meus).

Esses acontecimentos serão usados como alicerce para a tentativa de aprovar dispositivos constitucionais contra a entrada de japoneses no país na Assembleia Nacional Constituinte de 1946, através da emenda redigida por Miguel Couto Filho e José Augusto: “É proibida a entrada no país de imigrantes japoneses de qualquer idade e de qualquer procedência". A contagem dos votos resultou num empate, 99 deputados a favor e 99 contra. O Presidente da Constituinte, Mello Vianna, dá o voto de Minerva, posicionando-se contrariamente à emenda, que é, por fim, rejeitada. Como mencionam Miyao \& Yamashiro (CEHIJB, 1993: 308), a

\footnotetext{
${ }^{127}$ Sobre o destino que deveria ser dado aos imigrantes japoneses residentes no Brasil, o autor sugere medidas de profilaxia social: "Para esses a solução é intuitiva: destruir-lhes os núcleos de segregação, como quem ma sua horta destrói uma casa de marimbondos; disseminá-los, distribuí-los, espargidos... pela vastidão do território, dando-lhes terras em compensação das que hajam adquirido, e meio à população nacional, para que nessa se diluam". (Nucci, 2000: 64).

${ }^{128}$ O incidente na cidade de Oswaldo Cruz em julho de 1946, na Alta Paulista, é mencionado como o mais grave conflito surgido no contexto das ações da Shindo Renmei, pois envolveu o confronto direto entre brasileiros e japoneses. A morte de um motorista brasileiro por um japonês durante uma discussão, coincidiu com um período de intensos incidentes entre "vitoristas" e "derrotistas" na região. A população da cidade saiu em fúria pelas ruas sob os clamores de "matem o shindô!" e "acabem com os japoneses!", linchando os que encontrassem pela frente, invadindo suas residências e comércios, trazendo-os à força para as ruas, espancando-os e até puxando-os pelo laço. Os distúrbios continuaram por mais dois dias, sendo necessária a ação das tropas do exército da cidade vizinha, Tupã (CEHIJB, 1993: 291).
} 
maioria dos deputados que votou contra não era favorável à imigração japonesa, apenas não concordava com a inclusão de tal dispositivo na carta constitucional.

Como já discutido no primeiro capítulo, em meados das décadas de 1950 e 1960, o enfraquecimento das atividades da Shindo Renmei, o fortalecimento do processo de radicação dos imigrantes e seus descendentes no país e a inserção dos nikkeis nas camadas médias urbanas da sociedade provocaram uma gradual inflexão no imaginário, no que concerne ao arrefecimento do antijaponismo. Vimos como a partir das décadas de 1970 e 1980, os discursos que tematizavam os nikkeis passaram a celebrar o sucesso econômico dos mesmos e sua integração à sociedade brasileira.

Voltando aos depoimentos após essa breve contextualização, cumpre salientar que o entrevistado Jorge Ohara acredita que nos dias de hoje já não há muito preconceito contra os japoneses e descendentes como antigamente. Mas quando era criança, conta que ele e seu pai passavam de carro na periferia da região de Umuarama-PR, onde residiam, e a "molecada jogava pedra, tijolo, faziam gestos". Segundo ele, esse tipo de atitude parte de "pessoas sem instrução, de classes mais baixas ou moradores de periferia”. Afinal, “hoje está diferente. Não tem ninguém que não tenha televisão em casa. Cara de japonês todo mundo conhece, né? Talvez no Nordeste, existam cidades que algumas pessoas nunca viram japonês, que japonês é novidade, né?”. Jorge também acha que esse preconceito parta de pessoas invejosas, com "dor de cotovelo" quando vêem um japonês bem sucedido, pois "o japonês que veio de fora (do Japão), tem carro, casa, loja, propriedades e a gente que é do Brasil não tem nada. Eu acho que pensam assim. Muitos falam, 'Ah, por que você não volta para lá? (Japão)"'. Contou-me, então, a história de um bêbado que veio pedir dinheiro para ele, ao que ele respondeu que não tinha. O bêbado gritou:

\footnotetext{
"Por que você não volta para o Japão?" (voz grossa). Do jeito que ele gritou, já parti para cima e falei: 'O que é que você falou aí?! O que é que você falou á́?! (tom de ameaça). Eu sou tão brasileiro quanto você!!'. 'Desculpa, desculpa!'. Então, você vê que é um pessoal lá de Sergipe, uma coisa assim que ele disse. Ele falou dos problemas que tinha, é um pessoal que está na miséria. Mas é um caso isolado, não é todo dia que você vê essas coisas. Pessoal bem instruido não fala esse tipo de coisa".
}

É interessante notar como a "brasilidade" de Jorge foi despertada com a interpelação do homem bêbado, "Eu sou tão brasileiro quanto você!". É digno de nota que muitos informantes também disseram que as atitudes desrespeitosas para com os nikkeis, partem, sobretudo, mas não exclusivamente, de pessoas com nível de escolaridade baixo. É possível notar também o próprio preconceito de Jorge contra os nordestinos e contra os moradores da periferia, considerados por ele como pessoas mais ignorantes, devido à falta de instrução. Alice pondera 
que mais do que riqueza ou pobreza, tudo depende da educação dada em casa. Conta que um dia estava em uma esquina junto com o filho, Gabriel, esperando para atravessar a rua e um grupo de crianças estava passando em um ônibus escolar. Um deles gritou algo como "japonesa, cara de bolacha" ou "japonesa cara chata, come queijo com barata". Alice não se lembrava da expressão exata e disse que não se sentiu ofendida. Mas uma senhora que se encontrava por perto, repreendeu a criança na frente de todos. "Aquilo era uma falta de educação e ele não deveria falar assim com ninguém!". Alice se impressionou com a senhora que ao colocar-se em seu lugar, sentira-se ofendida por ela.

Desperta atenção na fala de Jorge e Alice a maneira como associam o apelativo “japonês" a um estado de anonimato, como se a falta do nome, da identidade revelassem também a falta de importância e pessoalidade conferidas ao sujeito interpelado, algo também notado por Júlia Suzuki, “'Ô, japonês, vem cá!’. Como se a pessoa não tivesse uma identidade...”. Segundo João de Pina-Cabral (2005), uma das origens da ideia de pessoa se encontra na concepção dramática de per sonae, máscara, "aquilo pelo qual passa o som”, como já discutido por Mauss. A per sonae constitui-se em uma "entidade à qual pode ser atribuída voz", um sujeito autoidentificado plenamente, dotado de responsabilidades (Rorty, apud Pina-Cabral, 2005: 5). O autor salienta que:

A etimologia per sonae deverá alertar-nos para o facto de o conceito de pessoa implicar chamar e ser chamado - a ideia de "apelo", que tem tão fortes ressonâncias legais. Trata-se essencialmente da ideia de que, convocando e sendo sujeito a convocação, eu sou reconhecido como actor no todo social. Sou, pois, chamado a agir e decidir no interior da socialidade através do meu nome, já que, se quiser abstrair-me das responsabilidades dessa pertença, sou obrigado a assumir o anonimato; isto é, tenho que recusar o uso do meu nome.

No contexto em que a existência social está intimamente amarrada à nomeação, o apelo ao "japonês" e suas variações pode soar como uma convocação a uma espécie de sujeito coletivo e o reconhecimento social e legal do indivíduo singular em sua unicidade, ou seja, pelo nome próprio, fica comprometido, afinal como diz o tio de Alice e o filho dela, Gabriel, mas de uma outra maneira: "Esse japonês tem nome!". No entanto, como bem esclareceu o casal Ohara, tudo depende da maneira com que o apelativo é evocado, “depende esse ligar ou não ligar”, que por sua vez está relacionado às intenções do autor: se utilizado de forma mais amistosa, não há problemas; mas se utilizado de forma ofensiva, "tem que cortar".

Jorge destaca a questão geracional na ressignificação e resposta aos designativos "japonês", "japa": para os japoneses mais velhos que sofreram os reveses do processo de adaptação ao novo país, os termos têm um sentido, talvez de fardo ou ofensa pessoal; para Jorge 
que nasceu depois da Segunda Guerra e que não testemunhou a campanha antinipônica vivenciada pelos seus pais há outro, já que ele não se incomoda em ser assim chamado desde que não haja um conteúdo de zombaria na interpelação; e para seu pequeno filho que "não entende porque é chamado de japonês, sendo brasileiro" existe outro sentido, talvez de conflito interno.

Segundo Alice, o descontentamento de Gabriel não se restringia somente à interpelação "ô, japonesinho". O filho também se questionava por que "era daquele jeito, com olhos puxados, diferente". Dizia que não gostava de ter nascido "japonês". A "diferença" a que se refere o menino foi sentida quando percebeu ser o único descendente de japoneses de sua turma da escola. Alice e o marido "tiveram que fazer um trabalho" em mostrar a Gabriel que as diferenças existem, há "os mais claros, os mais morenos, os descendentes de italianos, alemães e japoneses, todos são diferentes, mas brasileiros".

\section{GEOGRAFIA DE IMAGENS}

No que concerne à variável geográfica, a narrativa de Jorge e da senhora "capixaba" que conheci no supermercado revelam indícios de que os discursos e imagens sobre os nikkeis podem se apresentar e serem sentidos de modos diversos nos diferentes pontos do país. No depoimento de Mariana Yoshida, a percepção da diferença está associada ao tempo, momento da infância e ao lugar, a cidade do Rio de Janeiro. Sansei, 36 anos, Mariana tem uma interessante história de deslocamentos. Nasceu em Kobe, no Japão, por causa de um trabalho temporário exercido pelo pai. Retorna ao Brasil com nove meses, e passa a residir no Rio de Janeiro até a adolescência. Neste ínterim, aos 9 anos, permanece na França por dois anos devido à outra transferência de trabalho do pai. Volta a morar no Rio até entrar no curso de Engenharia da Computação na Universidade Estadual de Campinas. Depois de formada, sai de Campinas e muda-se para a cidade de São Paulo para trabalhar. Há dez anos reside na capital e atualmente está no segundo ano do curso de Ciências Sociais da Universidade de São Paulo, local onde marcamos nossa conversa. ${ }^{129}$ Quando the peço para comentar se a experiência de ser nikkei mudou ou muda em algo na sua vida, Mariana relata:

"Na infância, tenho lembranças, talvez de 4 anos até talvez entrar na faculdade... Como eu morava no Rio, eu sentia bastante assim... gozação de criança... de adulto, não. Mais na escola ou quando você saía... Eu sentia, às vezes, não sempre, que tinha uma diferença, que eu era percebida como diferente. Às vezes, não era nem por maldade e tal. Era mais por ser diferente mesmo. Mas tinha uma certa... gozação assim, né? De ficar tirando sarro e tal, que eu não

\footnotetext{
${ }^{129}$ Conheci Mariana quando atuava como monitora para sua turma através do Programa de Aperfeiçoamento de Ensino.
} 
gostava, lógico. Mas também eu não sabia reagir, quer dizer, para brigar ou algo assim. Minha reação normalmente era ficar fechada, ficava triste, ficava assim na minha. Então, eu sentia uma certa discriminação. Depois com o tempo, a gente vai crescendo e vai aprendendo a se afirmar, a reagir. Eu acho que foi melhorando e talvez eu não mais percebesse tanto. $\mathrm{E}$ depois, aqui em São Paulo, nunca percebi nada, nem em Campinas, na UNICAMP, porque era muito eclético lá, né? Aqui em São Paulo, na verdade a gente é mais discriminado por ser carioca do que por ser "japonês'! [risos]".

A fala de Mariana revela que a vivência em contextos sócioespaciais diversos pode acarretar experiências diversas na relação com a alteridade. Num lugar como o Rio, com pouca concentração da população nikkei, ela se sentia "diferente" e alguns momentos "discriminada". Sua fala assemelha-se muito com o depoimento de uma entrevistada de Maringá-PR que passou parte da infância e adolescência na cidade de Barreiras-BA. Cíntia Ito ${ }^{130}, 22$ anos, sansei, nasceu em Arapongas-PR e aos 7 anos muda-se para a cidade baiana, permanecendo ali por 10 anos, quando viaja para o Japão como dekassegui junto com a família. Retorna para Barreiras e atualmente cursa faculdade de Administração e trabalha em um banco em Maringá. Acredita que os descendentes de japoneses são "meio discriminados" no Brasil por causa das "brincadeirinhas", cuja nocividade depende da intenção do autor. Ela se incomoda com aquelas que são feitas "por maldade mesmo", diferente das promovidas pelos amigos, quando "colocam apelidos carinhosos”, “aí tudo bem”. Afirma que já passou por isso, mas não foi algo que tenha deixado marcas fortes:

"É mais na Bahia, porque quando a gente chegou lá, não tinha muitos descendentes. Então, para o pessoal lá era diferente. Então, lá a gente sofreu mais preconceito. Aqui (em Maringá) já é normal, tem bastante (descendentes de japoneses). Mas lá na Bahia, no começo foi bem, bem difícil para a gente, pelo menos para mim... Eu era criança também, então, criança... [risos]. Na minha idade já não falam mais... mas era bem chato. [...] Eles estranham mesmo. Quando encontra, quer perguntar, quer saber um monte de coisa. Então, foi lá que a gente sentiu mais essa diferença. Aqui não tanto".

Cíntia revela como o "estranho" desperta uma curiosidade quase antropológica nas pessoas. Tanto na Bahia, quanto no Japão, ela sentiu a diferença. No Japão, os japoneses queriam saber o que os brasileiros comiam, faziam, como "as coisas funcionavam". Na Bahia, os baianos queriam saber o que esses "japoneses" no Brasil faziam, comiam, se era sushi e sashimi usando "pauzinhos". "Comemos sim, mas comemos no dia a dia o arroz com feijão, como vocês", ela respondia.

\footnotetext{
${ }^{130}$ Cíntia é parente de familiares meus. Foi minha prima que marcou essa entrevista e ofereceu sua casa para que pudéssemos conversar.
} 
Yumi Kawamura ${ }^{131}$ conta a história de seu irmão, funcionário do Banco do Brasil, que foi transferido para uma cidade em Goiás, tornando-se o centro das atenções do local. "Só faltava ficarem lá na frente do banco para verem meu irmão! Por onde passava, falavam: 'ô japonês, ô japonês!"”, disse. Apelidado de "o japonês do banco", levava tudo na brincadeira, porque segundo ela, "Quanto mais você ficar com raiva, é pior. Se eles falarem alguma coisa, você dá uma resposta à altura. Leva na brincadeira e vai”. Atualmente o irmão trabalha em uma agência em Naviraí, no Mato Grosso do Sul, cidade que recebeu muitos imigrantes japoneses. Nas palavras de Yumi:

"Lá nessa agência tem (descendentes de japoneses), então o pessoal já está mais acostumado. Na outra cidade (em Goiás), ele havia sido o primeiro. Minha irmã que o acompanhou até lá falou: 'Coitado dele, vai sofrer!'. Mas não, o pessoal tratou super bem. Adoraram! Então, ele já passou uma imagem assim de japonês... O próximo que chegar, já vai ter a confiança. E ele falou mesmo, 'Nossa, a confiança que eles têm em nihonjin!'. Em Naviraí, não faz nem um mês que ele está lá, e já ofereceram o curso de caixa para ele! E o rapaz que já está lá há seis meses, passaram por cima! Não sei se é pelo fato de ser nihonjin... Mas, ah, japonês é bem visto! É claro que tem os malandros da vida, mas dificilmente você vê, não é? Japonês metido em escândalo, em roubo. É claro que toda regra tem exceção! Mas é muito difícil, né? Geralmente quando sai alguma notícia de nihonjin é coisa boa. É o que a gente está acostumado e eu pretendo que isso continue por muito, muito tempo! É claro que hoje nihonjin geralmente não está mais casando com nihonjin, está casando com gaijin. E aí já vai perdendo, né?".

Na narrativa de Yumi sobre a presença do irmão em Goiás, é possível perceber dois momentos, o estranhamento inicial que a chegada de um "japonês" causa em um local onde os habitantes não estão "acostumados" com pessoas tão "diferentes" e, posteriormente, a marca de confiança que ele imprimiu na imagem do "japonês", como que preparando o caminho para "o próximo que chegar". Yumi fica na dúvida se a rápida promoção do irmão está relacionada com sua ascendência, mas conclui com um discurso compartilhado por vários informantes: a imagem do "japonês" ainda é positiva perante a sociedade, sendo uma "minoria" - as "exceções" envolvida com "malandragem", criminalidade ou "coisas erradas, eticamente ditas erradas", como apontara Cláudio Shimada. ${ }^{132}$ Imagem esta que se encontra "ameaçada" pelos processos de miscigenação em curso, suscitadores da "perda de valores".

Nos três depoimentos citados, as interlocutoras Mariana, Cíntia e Yumi, estabelecem uma comparação entre a vivência nas cidades de São Paulo-SP, Maringá-PR e Naviraí-MS, com relativa concentração de nikkeis, e a vivência nos municípios e regiões que historicamente não receberam grandes levas de imigrantes japoneses, como Barreiras-BA, Rio de Janeiro-RJ e o

\footnotetext{
${ }^{131}$ Nissei, 39 anos, de Astorga, estudante de Pedagogia.

${ }^{132}$ Sansei, 41 anos, de Astorga, ex-dekassegui, dono de uma loja para presentes e utilidades domésticas. Citado no capítulo 1.
} 
interior do Estado de Goiás. Vivência e convivência marcadas pela percepção e autopercepção da diferença, sentida aqui através de modos diversos: pelas "brincadeirinhas", gozação, curiosidade, discriminação, admiração, confiança.

\section{PROVOCAÇÕES NA INFÂNCIA}

Antes de iniciar o trabalho de campo com as entrevistas, tinha uma ideia primeira de que ouviria histórias de discriminação sofridas principalmente por isseis e nisseis. Como previsto, alguns disseram que as verdadeiras vítimas foram os antepassados, que como vimos, tornaram-se objeto de críticas abertas nos jornais e debates públicos, promovidos, literalmente, por uma campanha antinipônica que varreu o país em certos momentos de tensão. Alvo das políticas restritivas à imigração, essas pessoas sentiram o fechamento do cerco no contexto da Segunda Guerra. No entanto, percebi que quase todos os entrevistados se limitaram a dizer somente isso. Há certo silêncio na memória deste conflito, encarado por muitos autores como evento-chave, de um lado para a fixação dos japoneses e seus descendentes no país, e de outro, para a "cisão da colônia" entre "vitoristas" e "derrotistas".

Para os imigrantes japoneses, parece não haver propósito em manter vivo para as gerações futuras seu passado de luta e sofrimento. Sobre a discriminação contra os japoneses na época da Guerra, soube há pouco tempo pela minha avó, nissei de 78 anos, que sua família enterrara no quintal de casa, bandeiras japonesas, livros em japonês, retratos do Imperador, ou seja, todos os símbolos que estivessem relacionados ao Japão, devido ao medo de represálias por parte da polícia. Era a primeira vez que eu e meus pais ouvíamos isso.

As narrativas sobre preconceito que figuram neste trabalho partiram, em sua maior parte, de sanseis, jovens de terceira geração que sentem ou sentiram há pouco tempo as provocações na infância e na adolescência. Mas como dito e repetido, as percepções de preconceito são relativas, as experiências diversas e as narrativas únicas. Quem o diria, o maringaense Leonardo Miyamoto, 19 anos, sansei, estudante universitário. Conheci Leonardo, por intermédio de uma tia minha. Perguntei a ela se poderia me indicar duas pessoas, mãe e filho, que eu pudesse entrevistar ao mesmo tempo. A intenção era investigar o possível conflito de gerações na conversa. Minha tia, sempre muito interessada no andamento da pesquisa, logo se prontificou a apresentar sua amiga, Lúcia, mãe de Leonardo. ${ }^{133}$ Não somente me levou até a casa dos dois, como acompanhou o bate-papo que se estendeu por quase toda a tarde de um sábado.

\footnotetext{
${ }^{133}$ Mãe e filho já foram citados no capítulo 1 contando a "história da feira", no tópico "japonês não tem vergonha de trabalhar".
} 
A sala era espaçosa e acomodava muito bem minha tia, eu, Leonardo, o gravador, Lúcia e sua mãe que também residia na casa, uma batchan sorridente que acompanhou toda a conversa com olhinhos e ouvidos atentos. Era bastante calada, mas de vez em quando, balançava a cabeça em sinal de aprovação frente a algum comentário. Num primeiro momento, lancei perguntas a todos, esperando que a batchan falasse algo, mas senti que a comunicação teria que ser travada em japonês, ou melhor, burajiru-go, ${ }^{134}$ novamente um empecilho para a pesquisadora. Quase não se ouvia sua voz, mas ela permaneceu ali, sentada conosco a todo tempo. Em alguns momentos da conversa, observei que ela se dirigia a minha tia, que se encontrava ao seu lado no sofá, para trocar algumas palavras.

O jeito de Lúcia imediatamente me fez lembrar a entrevistada Júlia Suzuki, pela energia e vivacidade com que se comunicava. Sua voz era clara e sua risada ecoava pela casa. Assim que sentamos, ela foi buscar refrigerantes e petiscos e um tom descontraído se fez sentir no ambiente com a presença de minha tia. Lúcia Miyamoto tem 46 anos, nasceu em Maringá, já morou no município de Umuarama-PR, e há 16 anos retornou para a cidade natal. Seu marido, também descendente, trabalhou no Japão como dekassegui por um ano e oito meses. Depois que voltou, trabalharam no setor de construção civil, "construindo e vendendo", mas não tiveram sucesso. Um parente em São Paulo que possuía uma fábrica de $s e m b e i^{135}$ concordou em lhes ensinar como produzir em grande escala. Já são “doze anos nessa luta, e graças a Deus, progredindo", acrescenta Lúcia.

Leonardo chegou à sala logo depois que sua mãe havia se apresentado. Um rapaz jovem de estatura baixa e mais econômico com as palavras do que Lúcia. "Deve ser tímido", foi minha impressão inicial, que aos poucos ia se desfazendo à medida que a abordagem de certos assuntos, seu diálogo com a mãe e o ganho de confiança na pesquisadora gradualmente se sucediam. Mãe zelosa, a preocupação de Lúcia com seu filho único é perceptível em quase todas as suas falas. Quando discutia a respeito de quão fechadas são as "panelinhas" formadas nas associações nipônicas, Leonardo comenta sobre o medo de dizer algo e ser criticado dentro desses grupos, abertamente ou pelas costas, ao que Lúcia faz uma observação:

\footnotetext{
"Na verdade, o tal do bullying que existe e acho que sempre existiu e sempre vai existir... Porque você sofre na escola por você ser oriental, né? O Leonardo mesmo falou, 'Eu sofro, porque eu sou menor que os outros'. Como ele faz aniversário em novembro, eu o coloquei um ano antes. Então, ele entrou numa turma grande. Os brasileiros já são enormes, normalmente, né? Ele sofria e eu não percebia. Eu achava que estava ganhando um ano para
}

\footnotetext{
${ }^{134}$ Burajiru: brasileiro. Go: língua. O termo é utilizado na realidade com referência à língua portuguesa.

135 Biscoito japonês que possui textura semelhante ao biscoito da sorte chinês. É facilmente encontrado em supermercados e lojas de produtos japoneses.
} 
ele, mas não. Eu acho que ele foi prejudicado. Eu me arrependo muito de ter colocado ele mais cedo".

Nas palavras de Leonardo, "Sofri preconceito pra caramba! Sempre... na época da escola inteira. Porque é japonês ou porque é baixo”.

“Ou porque tira a nota mais alta!”, lembra Lúcia.

"Por qualquer coisa...", lamenta Leonardo.

"Isso te incomodava, incomoda?", questiono-lhe em seguida.

“Chega uma hora que até já acostuma, né?” [risos]

Pergunto-lhe se há algum episódio mais marcante, de experiência de preconceito, que tenha ficado guardado na lembrança:

\begin{abstract}
"Ah, lembro na sétima série. Chegavam os meninos de Ângulo ${ }^{136}$... Tava sentado na carteira e eles puxavam pelo pé e eu caía de cabeça no chão... Pegavam aquelas carteirinhas e jogavam em cima de mim com a parte pontuda. Baixavam minhas calças na frente da turma inteira... Teve outra vez lá dentro da ACEMA (Associação Cultural e Esportiva de Maringá), quando eu tinha acabado de entrar e tinha um menino lá que era meu amigo. E como eu era novo, você queria atenção, né? E aí, ele virava as costas. E se dizia bem amigo, né? Aí, eu cheguei e cutuquei ele, 'não, eu só quero sua atenção...'. 'Fica longe de mim'. Aí, me empurrou no meio da roda, 'gente, ele quer atenção! Vamos dar atenção para ele!'. Nossa, aquilo lá doeu...”.
\end{abstract}

“São coisas até difíceis de acreditar...”, diz Lúcia.

"Realmente... É comum ouvirmos histórias de xingamentos na rua, humilhação, mas não de agressão desse nível dentro da escola”, afirmo em seguida. Ao que Lúcia desabafa:

"Isso exatamente! Você coloca em colégio particular! Léo sempre estudou em colégio particular! Então, você pensa que esse tipo de coisa de repente não vai acontecer, mas acontece. Daí, eu falei assim, 'Então, meu filho você tem que enfrentar, não tem jeito...'. Eu acho assim... É muito difícil para uma criança enfrentar o mundo real mesmo. Quando você está dentro de casa é uma coisa, hora que você solta para fora, você não sabe o que vai acontecer. É que nem o filho de um amigo nosso que vai voltar (do Japão). Eu acho que aquele vai penar! Ele estava num colégio japonês lá, agora ele está estudando num colégio brasileiro. Aí, diz que ele sofria muito. Eu acho que é o bullying ${ }^{137}$ mesmo que ele sofria! E ele batia! Ele batia e os pais eram chamados direto. Porque ele não é considerado japonês. Para ele, ele é gaijin, ele é brasileiro, né? E ele sofria... Só que a vida inteira dele foi lá. Ele tem oito anos. Ele vai voltar agora, porque a situação do Japão está difícil e ele vai entrar num colégio público, numa escola brasileira. Ele vai sofrer o processo inverso! Ele não vai ser brasileiro! Ele vai ser considerado japonês!".

\footnotetext{
$136 \mathrm{Na}$ busca por ensino particular de melhor qualidade, muitos estudantes da região, caso da pequena cidade de Ângulo, matriculam-se em colégios de Maringá.

${ }^{137}$ No Japão, o bullying é conhecido como ijime. As crianças e adolescentes estrangeiros são vítimas potenciais do assédio moral, caracterizado por atitudes como maus tratos, intimidação, constrangimento, exclusão.
} 
“Ele só fala japonês?”, desejo saber.

\begin{abstract}
"Ah, eu acho que fala bastante. Os pais usam o português. Ele sabe falar o português, mas só que tem coisa que mistura sabe? Vai falar português e coloca nihongo no meio. E ele bate, bate muito, porque eu acho que ele é muito ofendido, né? Nossa, de repente, o dinheiro que o pessoal ganha, se é que ganha, no Japão, e volta para cá, eles vão gastar tudo em recuperar a criança, o psicológico da criança, porque eu acho que ele vai ter muito problema psicológico! $\mathrm{Eu}$ acho assim, que na realidade foi uma agressão à família... Eu acho que foram atrás de dinheiro, mas eu acho que o estrago foi muito maior! Dinheiro nenhum recupera o estrago de famílias desfeitas, casamentos que se acabaram, sabe? Porque eles estão sofrendo muita coisa... Mas só que assim, os japoneses sofrem e vão continuar sofrendo. Eu acho que assim como qualquer outra... que nem os portugueses, alemães, todos que são imigrantes, acho que todos penaram muito. Hoje em dia, eu acho que existe um pouco mais de conscientização. Até mesmo o próprio bullying que eles mostram na televisão que existe, e os pais não sabem que isso existe, né? Acho que isso existe em qualquer religião, qualquer etnia. Tudo é motivo para as pessoas... Acho que o ser humano é mais ou menos complicado mesmo...".
\end{abstract}

Imediatamente minha memória se voltou para a época de colégio em Astorga, quando eu estava na sétima ou oitava série. Durante alguns meses, dois novos alunos ganharam atenção especial não somente em suas salas de aula, mas na escola inteira. Recém chegados do Japão, os pequenos irmãos, que deveriam ter 7 e 9 anos na época, eram brasileiros, e estavam sendo mandados de volta para o Brasil pelos pais, com o propósito de receberem uma educação brasileira. Passariam despercebidos pela escola, não fosse um pequeno detalhe: mal sabiam falar o português. Drama de muitas famílias dekasseguis, como bem narra Lúcia. Não cursava a mesma série que os irmãos, mas imagino que ambos tenham sofrido bastante. Lembro-me de um episódio particular que me fez chegar a essa conclusão.

Era intervalo das aulas de um dia qualquer e, como de praxe, todos os alunos se encontravam no pátio da escola, quando várias risadas e uma certa movimentação me chamaram a atenção. Uma rodinha de curiosos se formava ao redor das duas crianças "japonesas". Alguns alunos, bem mais velhos do que os dois, estavam importunando-os, fazendo comentários e perguntas maldosas, ora em português, ora macaqueando-as em japonês, pois era sabido que os meninos tinham um conhecimento precário do português. De qualquer forma, não é preciso ser fluente no idioma para saber quando você está sendo insultado. Não me recordo exatamente do conteúdo das provocações, mas lembro que o irmão mais velho se posicionava na frente do irmão mais novo, como que tentando lhe proteger da humilhação pública. De repente, ele exclama: "Dioro-no-kô!!". Gargalhadas ecoavam pelo pátio. "Dio o quê, japa?”. A direção da escola dispersa o tumulto. Depois da aula descubro o significado daquela palavra: filho da puta. Durante muito tempo, esse xingamento em japonês virou moda na escola e não saiu da boca dos alunos. 
Pelas minhas contas, o irmão mais velho, protagonista da história que narrei deve ter hoje quase a mesma idade de Leonardo. Na época em que os três passaram por essas experiências, o problema do bullying na escola já existia, só não era conhecido por esse termo e não tinha tanta repercussão nos fóruns pedagógicos e na mídia. Afinal, a violência, seja física, simbólica, virtual, infelizmente não é nenhuma novidade no ambiente escolar. Segundo Lopes Neto (2005: 165), “o bullying diz respeito a uma forma de afirmação de poder interpessoal através da agressão". O termo em inglês caracteriza atitudes ofensivas, repetidas e intencionais que envolvem uma assimetria de poder. No caso dos irmãos, a ascendência japonesa e o não domínio do idioma português os deixaram vulneráveis à agressão coletiva. No caso de Leonardo, a ascendência japonesa, a baixa estatura e a timidez, funcionaram como uma espécie de catalisadores da relação desigual de poder entre ele e os outros meninos, os de Ângulo e o que se dizia seu amigo da ACEMA. Indagado se sentia que as maldades que sofrera aconteciam devido à origem japonesa, Léo ressalta:

\footnotetext{
"Eu acho que sim. Ou também porque eu era bem quieto. Tinha medo de falar. Não me destacava, ficava bem na minha... só estudando. Tinha aqueles amigos excluídos juntos... Daí, acho que era por causa disso também. Mas também ser 'japonês' ajuda. Eu sempre fui o menor da turma...".
}

Os estudantes excluídos das "rodinhas" principais são as vítimas preferenciais do bullying. Na tentativa de encontrar justificativas para o que, na realidade, não se justifica, Leonardo também atribui à sua amizade com os "excluídos" um dos possíveis motivadores para a violência sofrida: “Ah, mas não tem só o japonês. Tem o magrinho, tem o que usa óculos... Tem o albino...". "O estranho [risos], o negro... Ele (Léo) era do grupo dos excluídos...", complementa Lúcia. Como assevera Lopes Neto (2006: 167), “a rejeição às diferenças é um fato descrito como de grande importância na ocorrência de bullying" (grifos meus).

Atualmente, Léo é um estudante universitário como outro qualquer. Estuda Música, dá aulas particulares de contrabaixo e também leciona para deficientes visuais, além de tocar em uma banda bastante requisitada para se apresentar em bares e festas da cidade. Pergunto a ele se agora que está mais velho, cursando a faculdade, ainda sente um certo "peso" em ser "japonês"?

\footnotetext{
“Ah, sente, né? O povo ainda me zoa um pouco, ‘ô, japonesinho!' [risos]. Não tem jeito! (risos). O jeito é entrar nessa também, né? Você acha o defeito do outro... Não o defeito, alguma coisa do outro para encher o saco. Ainda que as brincadeira são bem clichês, então, é a mesma em qualquer lugar...".
} 
Lúcia, que se mostrou arrependida de ter "adiantado" Leonardo na escola, revela como se fez presente na educação do filho, tentando motivá-lo a enfrentar todas essas situações adversas:

\begin{abstract}
"Na verdade, eu sempre falei para o Léo, 'Você que sofreu todos esses tipos de problemas, você sempre tem que se esforçar ao máximo para ganhar de outra forma. Ou você ganhar pela inteligência ou você ganhar pelo talento. Você tem que se esforçar, porque, de certa forma, as pessoas vão ter que te aceitar'. (Ela dá o exemplo de uma competição musical no colégio, na qual Léo participou tocando baixo). Ele se destacou. Conseguiram o $1^{\circ}$. lugar. As pessoas começaram a respeitá-lo mais. Foi ótimo ter sido mais bem aceito, do que ser só um a mais, né?".
\end{abstract}

Os estudiosos do bullying advertem que a exposição continuada à violência escolar pode ter implicações emocionais sérias na vítima. Leonardo e Lúcia não mencionam palavras como "trauma", "consequências psicológicas", "depressão", mas falam de "dor" e "sofrimento". É instigante observar como algumas ideias e posicionamentos de Leonardo são fortemente informados por essas experiências de preconceito. Em outro momento da conversa, comento como tinha ficado impressionada com a grande participação de jovens nikkeis em eventos relacionados à comemoração do centenário da imigração japonesa, como o Hoshi Matsuri, festa gastronômica com atrativos culturais, realizada em 2008, organizada exclusivamente por jovens de entidades nipônicas da cidade de Maringá. "O que explicaria tamanha participação, passados cem anos da imigração?", lanço a pergunta. Lúcia é a primeira a responder. "Discriminação", "união" e "orgulho" são as palavras-chave de seu discurso:

"Eu acho que no fundo, no fundo os orientais acabam se unindo de certa forma... Mas é porque, assim, eu acho que sente discriminação. Então, eu acho que nessas horas, eles sentem um pouco de orgulho de ficar todo mundo junto, de fazer uma grande festa como quando faz aquela Nipo. ${ }^{138}$ Então, eu acho que um pouco, é porque eles sentem orgulho ainda de serem orientais. Então, o 'japonês' tem aquela... O pessoal tem o conceito delas, que elas são unidas, né? Que fazem uma coisa bem feita. Então, acho que é por isso que... Que fazem tanto sucesso ainda... E os jovens talvez estejam procurando isso".

Leonardo menciona que participou neste evento como voluntário do grupo de jovens da Igreja São Francisco Xavier. Questiono se ele concorda com sua mãe e se acredita que ainda exista certo orgulho da descendência, mesmo entre jovens sanseis e yonseis:

“Eu acho que 'japonês', sempre na escola, sofreu muito com o preconceito. Então, acho que eles se juntam, para ficarem um pouco mais fortes. Eles acabam descontando nos da mesma descendência, né? Porque são menores... Eu acho que é isso [risos]. Isso é união...”.

\footnotetext{
${ }^{138}$ Festival Nipo-Brasileiro, realizado na ACEMA, em Maringá.
} 
Esse sofrimento com o preconceito na escola de que fala Leonardo, presente também nas narrativas de Júlia, do filho de Alice, Gabriel, de Mariana e de Cíntia é associado por estes a uma experiência sofrida na infầncia. As histórias contadas pelo grupo de amigos, membros da diretoria do seinen-kai da Seicho-No-Ie de Maringá, sobre essa questão também merecem ser aqui relatadas. Como mencionei no primeiro capítulo, esta foi a única conversa que pude travar com um grupo relativamente numeroso de pessoas. Novamente por intermédio de minha tia, adepta da Seicho-No-Ie, o bate-papo aconteceu após a reunião da diretoria ali mesmo na sede. Era um ensolarado domingo de fevereiro e os jovens discutiam sobre algumas pendências como organização de rifas e festas, vendas de potes de sorvete, tudo com vistas à arrecadação de dinheiro para uma viagem a um seminário de "treinamento espiritual", oportunidade que vêem não apenas de praticar os ensinamentos da doutrina, mas de conhecer pessoas de outras regiões do país.

Fernanda Saito é maringaense, tem 21 anos, é estudante do curso de Pedagogia e também trabalha como secretária na sede da Seicho. Seu pai tem dupla nacionalidade, e ele e sua mãe atuam como preletores ${ }^{139}$ e os avós são pioneiros da regional da Seicho-No-Ie em Maringá. Em sua casa, "a cultura japonesa e a Seicho-No-Ie sempre estiveram ligadas. A nossa educação sempre teve aquela parte japonesa, com aquelas características, por exemplo, timidez, fazer 'enryō', ${ }^{, 40}$. E da igreja, de gratidão aos antepassados. A gente tem isso da cultura japonesa também, mas é da igreja".

Juliana Sayuri Watanabe tem 17 anos e nasceu no Japão. Vai entrar no cursinho e quer prestar vestibular para Medicina. Voltou para o Brasil aos sete anos com a mãe e na época só sabia falar japonês. Estudou mais alguns anos o nihongo, diz que esqueceu muitas coisas, mas entende e fala um pouco, não com tanta fluência. Afirma que foi "horrível, terrível aprender o português". Logo que chegou, entrou na escola e não sabia falar nada. O processo foi muito difícil, "Eu era bem nihonjin mesmo, bem aquele tipo de menininha japonesa". Sua trajetória deve ser semelhante à dos irmãos, alvos de gozação no colégio de Astorga. Histórias comuns que se desenrolam no contexto migratório de idas e vindas de famílias brasileiras para o Japão. A separação dos membros de uma mesma família, os problemas de aprendizagem e as dificuldades na adaptação são alguns dos obstáculos enfrentados pelas crianças e jovens nos deslocamentos entre os dois países.

\footnotetext{
${ }^{139}$ Preletor, também chamado de Líder da iluminação, é aquele apto a divulgar a doutrina da Seicho-No-Ie.

${ }^{140}$.A expressão enryō shimasu é uma maneira polida de recusar alguma oferta. No Brasil, "fazer enryō, engyō ou enjyō” significa fazer cerimônia, demonstrar acanhamento ou reserva diante de uma situação.
} 
Nascida em São Paulo, Milena Teruya, sansei, tem 23 anos e como disse logo no início da entrevista, fez "bastante peregrinação". Aos 4 anos, viaja com a família para o Japão, onde permanece até os 11 anos. Volta para São Paulo, e meses depois muda-se para Maringá, e por lá fica durante um período de 8 anos, quando novamente parte para o Japão, agora a trabalho. Afirma que sofreu discriminação quando estudante na escola japonesa, pois além de conhecer pouco o idioma, "o preconceito já começava pelo meu sobrenome okinawano”. Como ela mesma diz, vistos como "um pouco mais escuros, peludos e com gênio ruim", "o pessoal considera a gente como se fosse um semi-japonês". ${ }^{141} \mathrm{O}$ testemunho de Milena, cuja família continua mantendo algumas "tradições okinawanas", mostra como a própria categoria "japonês", no sentido de abarcar o que seja relativo ao Japão ou quem seja seu natural ou seu habitante, não é homogênea, carregando uma grande diversidade interna e até mesmo tensões.

A jovem que passou a maior parte de sua vida no Nihon, na condição de estudante e dekassegui, assegura que muitos japoneses, "não nos discriminam somente pelo fato de sermos brasileiros, mas mais pelo fato de sermos pessoas que abandonaram o país (Japão), estarmos voltando para lá só por interesse e não termos nenhum amor à pátria”.

Reproduzo aqui o diálogo das três quando indagadas sobre experiências de preconceito.

Fernanda: "Nunca sofri por parte dos 'brasileiros', mas acho que o fato de ser tímida atrapalhou... É diferente mesmo. Os não-descendentes falam mais, são mais dinâmicos [risos], são diferentes mesmo. Eu lembro do pré...Para me acostumar foi mais complicado, porque até então era em casa que a gente vivia. Era a cultura japonesa que era forte. Esse impacto foi maior por causa de nós mesmas (se refere a ela e à irmã). Não porque nos receberam mal".

Sayuri: "Quando eu era mais novinha, estava no pré... Nossa, eu odiava os brasileiros, não gostava... Porque no Nihon, eu só conhecia japonês, né? Eu só falava nihongo, não sabia nada. Minha mãe falava um pouco, mas eu não sabia nada (português). Quando viemos para cá, entrei no pré e não gostei... É estranho que a primeira vez que eu vi um não-descendente...A gente morava numa casa e do outro lado da rua, foi a primeira vez que vi um negro! Fiquei assustada... Nossa, eu nunca tinha visto! [risos]. Eu lembro até hoje, fiquei tão assustada! Nunca tinha visto, né? ${ }^{142}$ Mas isso foi fase, porque depois também... Porque eles tiravam sarro, porque eu não sabia falar (português)... Mas depois que eu aprendi a falar, aprendi a me defender [risos]. Agora..."

\footnotetext{
${ }^{141}$ Okinawa é uma província, formada por um arquipélago, que fica ao Sul do Japão. Fazia parte de um reino independente, Ryukyu, e devido às relações comerciais travadas com a China, mantinha com este país uma intensa troca cultural. No século XVI, perdeu sua independência e foi anexado ao Japão. O termo Uchinanchu é utilizado pelos okinawanos para se distinguirem dos japoneses do continente, mainland japaneses, os Yamatonchu. Essa questão será retomada no capítulo 4.

${ }^{142}$ Esse episódio narrado por Sayuri é elucidativo para se pensar a questão da alteridade. A experiência do choque com a diferença, traduzida aqui no "susto" que ela sentira ao avistar uma pessoa negra pela primeira vez na vida, pode ser comparada ao "susto" ou curiosidade que um "japonês" pode provocar em locais como Bahia, Rio de Janeiro e Goiás, como explorada nas falas de Yumi, Mariana e Cíntia.
} 
Fernanda: "Ah, sim! Eles se aproveitavam um pouco da nossa timidez, porque eu lembro que uma vez eles esconderam meu material [risos]. Eles faziam essas brincadeiras, para gente não ir lá e reclamar com o professor. Não ficar abrindo berreiro, então eles se aproveitavam um pouco nessa parte. Pegavam os lápis, os nossos materiais... Pegar não, roubar! Eu não reclamava, fica quietinha".

Sayuri: "Você não reclamava!? Deram uma 'lapiserada' nas minhas costas uma vez, eu fiz um berreiro enorme! [risos]".

Milena: "Pelo fato de nós fazermos esse negócio de enryō, sermos educados e não conseguirmos falar não, eles abusavam...".

Sayuri: "Faz aqui meu trabalho, faz aqui, copia isso...".

Fernanda: “Ah, questão de trabalho também! Sempre caía na parte do 'japonês'...”.

Sayuri: "E eu não tinha coragem de falar não...".

$[\ldots]$

Fernanda: "Minha irmã e eu também, a gente era vista bastante como mascote. As meninas sempre queriam carregar a gente. Ficavam carregando no colo...Meninas da nossa idade! Pegavam no colo, ficavam puxando para ir junto, 'ah, cabelo liso', puxavam o cabelo, achavam que a gente era bonequinha". [Outras duas meninas participantes da conversa, concordam, dizendo que também passaram por experiências semelhantes].

"Mas até que tinha coisas boas, porque eu era protegida até. Parecia que eu era bonequinha, frágil. Tinha uns que protegiam, tinham uns que abusavam, mas tinha outros que protegiam. Mas tratavam como bonequinha, chaveirinho [risos], porque é menor e tudo".

A transcrição das falas das garotas a partir da forma como a conversa foi se desenrolando possibilita divisar como as narrativas se entrecruzam e repercutem uma sobre a outra, como a história de Sayuri que despertou lembranças em Fernanda, as quais também eram partilhadas pelas outras meninas. A falta de domínio do português, a timidez e o enryō aparecem como possíveis explicações para a ausência de algo que todas sentiram nos momentos em que eram provocadas ou quando outras crianças "abusavam" ou se "aproveitavam" delas: habilidade para se defender.

Habilidade essa, também notada pela carioca Mariana Yoshida, conquistada com o tempo, “Depois com o tempo, a gente vai crescendo e vai aprendendo a se afirmar, a reagir”, ou mesmo com a malícia, como resigna-se Leonardo Miyamoto, "Não tem jeito! O jeito é entrar nessa também, né? Você acha o defeito do outro... Não o defeito, mas alguma coisa do outro para encher o saco". Outro ponto que chama a atenção é a ênfase que os entrevistados dão para os principais autores das "brincadeiras", as crianças. O dar de ombros que presenciei ou o "você sabe como criança é terrível" que escutei, parecia demonstrar que a condição de "ser em 
formação" possibilitava uma avaliação mais escusável de suas atitudes e uma postura mais tolerante para com elas. Essas duas questões também aparecem na fala de Yumi Kawamura.

Yumi, estudante de Pedagogia, acredita que "esse negócio de ficar gritando, quando você passa na rua, 'ô, japonesa!', é falta de educação!’. Comparando com a vivência no Japão, afirma, "No Nihon, jamais! O meu marido que fala, 'Ah, brasileiro é sem educação mesmo! Pequenininho já sabe xingar, já sabe fazer isso!' Passa na rua, 'Ô, japonesa e não sei o quê! Se meu filho fala uma coisa dessas, na hora eu vou corrigir, não é Camila?!”. Sua experiência como estagiária no Ensino Fundamental lhe mostrou que as famílias desestruturadas não conseguem prover a educação necessária para as crianças:

"Você vê a molecada na escola e dá até dó. Não tem pai, não tem mãe. A mãe não está nem aí. É criado pelo tio, é criado pela avó. Que educação que essa criança vai ter?! Até mesmo quando vou fazer estágio, elas perguntam, 'Professora, professora, você veio do Japão?! Até você explicar... Mas assim mesmo fica difícil para eles entenderem também. Mas eu sofri também com essa bestagem! Nossa, eles começam a perguntar um monte de coisa. Mas aí você vai explicando. Eles questionam bastante... Tipo assim, fala uma palavra em japonês!'.

[E de adulto, também?] - pergunto.

Já de adulto, não. Fiz estágio no Ensino Médio e adorei! Porque adulto, quando pergunta é por curiosidade. O 'brasileiro', às vezes, sabe... É que criança... tsc... ainda mais... é terrível! Tudo para eles é motivo de gozação! Se a pessoa é gorda, dá risada! Se a pessoa é magra, dá risada! Então, você sabe como é! Então, se aparece um nihonjin ali, vai ser!”

Assim como Lúcia Miyamoto, Yumi me pareceu uma mãe muito zelosa com o filho único, Bruno, de 4 anos, sendo a timidez da criança seu motivo de maior preocupação. Acredita que o menino é "comportado até demais" e até "bobinho" em algumas situações e pode não saber se defender de possíveis ofensas. Ela mesma diz que nunca sofreu preconceito, pois

"sofre aquela pessoa bem quietinha, que não sabe se defender. É isso que eu não quero que meu filho seja, sabe? Eu acho que tudo tem que levar na brincadeira. Tipo assim, dar uma resposta a altura, mas levando na brincadeira. Por isso acho que não sofri. Mas eu já vi. Eu estudei com um menininho, que era de Itambé-PR, no Ensino Médio. E ele era quieto, quieto, quieto! E ele sofria hein, nossa! Porque eu acho que a pessoa não pode ser quieta, tem que saber se defender. E é isso que eu quero, que vou tentar passar para o meu filho".

Segundo a mãe, "Bruno foi perceber essa diferença de que ele é 'japonês' na escola. Como o pessoal chama 'ô, japonês!', ele fala: 'Eu sou japonês, não é, mamãe?'. Aí eu falo: 'Claro que você é, o papai é, a mamãe é. Você é nascido aqui no Brasil, mas você é descendentes de japoneses!'”. Conflito vivido, como vimos, com o pequeno Gabriel Ohara, também de 5 anos, que na tenra idade já questiona o fato de ser chamado de "japonês", pois afinal, nasceu no Brasil e tem um nome como qualquer pessoa. A postura dos pais de ambos os garotos diante dessa 
situação se assemelha no sentido de tentar passar certo "orgulho" da descendência para os filhos. Como espera Jorge Ohara, "quando crescer, ele vai entender melhor".

\title{
"RAÇA JAPONESA": ALGUNS APONTAMENTOS
}

No final da conversa com o Sr. Paulo Sasaki ${ }^{143}$, perguntei-lhe se ele já havia sofrido algum tipo de discriminação ou preconceito pelo fato de ser nikkei, ao que ele afirma que antigamente sim, pois tudo era “ô, japonês!". Segundo ele, atualmente o que ainda se observa são notícias no jornal do tipo: “japonês matou fulano de tal”. Complementa, "Por acaso, você fala, o alemão, ou o italiano matou não sei quem? Agora japonês quando faz uma coisa errada, sobressai. Dá mais ibope, né? (risos)". Em seguida, afirma que no dia anterior à entrevista, estava tendo uma discussão com outra pessoa, que vale a pena ser relatada:

\begin{abstract}
“Ontem mesmo estávamos conversando... Por que um 'japonês' quando casa com brasileira, você fala que o filho é 'mestiço'? Se um italiano casa com alemão, você fala que é 'mestiço'? Ninguém... Só 'japonês' você fala que é 'mestiço'. É por causa da raça, né? Agora não sei se isso é preconceito, mas por que isso aí? Por exemplo, casa um alemão e italiano, vou perguntar se você é 'mestiço'? Ou preto com não sei quem, você é 'mestiço'? Agora se casa um 'preto' com 'japonesa', falam que é 'mestiço', que está na cara! Por quê? Isso não existe. Eu não sei por quê...".
\end{abstract}

É interessante notar que o Sr. Paulo se questiona sobre o emprego da categoria "mestiço" no senso comum para definir o filho de nikkeis com não-nikkeis, mas mobiliza o termo "raça" várias vezes em nossa conversa. Afirma com pesar que na atualidade, "não se mantém aquela tradição", "porque hoje a mistura de raças é muito grande”. E quando discorre sobre a transmissão de valores para as gerações mais novas, acredita que "essa parte vai continuar", mas observa: "Se bem que nós temos muita gente malandrinha, hein! [risos]. No Japão você vê os dekasseguis fazendo arte, roubando, essas coisas. Isso existe com certeza! Toda raça tem!”. A fala do Sr. Paulo é emblemática para se pensar as peculiaridades da imigração japonesa no Brasil. Para além das dificuldades advindas das diferenças de língua, costumes e nacionalidade que perpassaram a vida dos imigrantes que aqui chegaram, os japoneses tinham uma característica singular, a marca fenotípica, que para alguns entrevistados dessa pesquisa, foi subsumida pelo termo "raça".

O presente trabalho não tem a pretensão de "resolver" essa questão, mas somente mostrar a força com que essa categoria ainda é agenciada nas relações cotidianas. O termo

\footnotetext{
${ }^{143}$ Nissei, assessor político, maringaense, 73 anos. Citado no início do capítulo 1.
} 
"mestiço", que segundo o dicionário Houaiss - 1. diz-se de ou pessoa que provém do cruzamento de pais de raças diferentes; 2 . diz-se de ou animal nascido do cruzamento de espécies diferentes é apropriado no Brasil, nas relações cotidianas, quase que exclusivamente para definir o filho do japonês ou seu descendente com um não-descendente. No senso comum, para o filho de "negros" com não-"negros", por exemplo, comumente utiliza-se termos, como "mulato" ou "pardo". Nesse cenário, o marcador "nacionalidade", pouco conta.

Descendente, no Brasil, é uma categoria muitas vezes agenciada como um termo isolado sem a preposição "de”, que relaciona a origem à descendência. Isso pode ser observado em várias falas dos sujeitos dessa pesquisa. Em outras palavras, no caso dos nikkeis, é comum o emprego de frases do tipo, "fulano é descendente". Já as pessoas com descendência espanhola, italiana ou alemã, com exceção talvez da última, são marcadas como brasileiras, sem a ênfase à progênie.

É importante considerar que o termo "raça amarela" não foi utilizado por nenhum entrevistado. Como foi possível observar, a partir do panorama histórico traçado anteriormente, nos discursos antinipônicos do passado, a cor era constantemente agenciada para estabelecer os limites de quem era e de quem não era brasileiro. O epíteto "perigo amarelo" traduzia com eficácia a diferença. Na fala dos entrevistados, "raça" se encontra conjugada com a nacionalidade, "raça japonesa". Arrisco a pensar que atualmente a categoria cor, que no caso dos "amarelos", agrega pessoas de origem mongólica, asiática, se faz presente na vida dos interlocutores dessa pesquisa somente nos recenseamentos.

Questionamentos como os do Sr. Paulo são muito comuns. Frequentemente, algumas pessoas têm receio de empregar em sua fala categorias como "raça", pois detém o conhecimento de que biologicamente falando não existem raças ou espécies diferentes, mas uma única raça humana. Com muito constrangimento, baixando o tom de voz, olhando para os lados, pondo a mão à boca, medindo as palavras certas, são reações e expressões gestuais possíveis de serem observadas quando o assunto "raça" é tematizado.

Certa vez, na apresentação de uma comunicação em um evento na universidade, estávamos eu e mais dois pós-graduandos à espera do professor coordenador da mesa, aproveitando o tempo para conversarmos sobre nossos trabalhos. Um deles que chamarei aqui de Carlos, descendente de japoneses, ficou bastante interessado em minha comunicação que era uma espécie de resumo de minha pesquisa em andamento. ${ }^{144}$ Visivelmente empolgado, dissera

\footnotetext{
${ }^{144}$ Durante a exposição de meu trabalho, percebi em vários momentos que Carlos baixava a cabeça em sinal de concordância. Posteriormente, quando abrimos para a sessão de debates, foi o primeiro a se manifestar dizendo que se identificou com as experiências contadas por meus interlocutores, sobretudo, as relacionadas ao bullying escolar.
} 
que iria contar um episódio vivenciado por dois amigos nikkeis, e depois, refletindo por um momento, acha melhor ficar calado. Eu e outro colega insistimos, então, para que ele contasse, pois já havia nos deixado curiosos. “A história é pesada!”, anuncia, tentando nos prevenir.

Segundo Carlos, seus dois amigos andavam pela rua, quando um deles esbarrou em outra pessoa, que disse nervosa: “Ah, eu falo, mas japonês é tudo igual mesmo!!”. O amigo pensou: “O que esse __ está falando?”. Nesse momento, Carlos tapou a boca e disse uma palavra em japonês que não consegui entender. Pedi duas vezes para que ele repetisse a palavra, ao que ele se negou. Ficou sem graça, olhou para os lados e falou baixo, "ele era uma pessoa de cor", apontando a pele com o dedo. Com essa história, Carlos queria chamar a atenção para o paradoxo na postura da pessoa que sofrera o esbarrão, pois a mesma dirigiu-se de maneira preconceituosa aos descendentes, sendo que fazia parte de um grupo também estereotipado e discriminado.

Esse episódio contém inúmeras questões "boas para pensar". Primeiramente, a maneira reticente com que Carlos resolve narrar o acontecimento. Diante de minha insistência e a do colega, afirma que o fará, mas avisando que a história era pesada, pois se tratava de um termo pejorativo com que seu amigo, mesmo em pensamento, dirigiu-se a "pessoa de cor". Termo este, "pesado", que Carlos disse com a mão na boca, em tom baixo e que se recusou a repetir. A fala da pessoa esbarrada, “japonês é tudo igual”, também se constitui em um discurso que ainda se faz sentir por muitos nikkeis, e que, em certos casos, é até corroborado por alguns. A dificuldade em distinguir os descendentes, talvez resida na vivência em um país, cujo "padrão de identidade recorrentemente veiculado" (Oliveira, 2008), funda-se no mito das três "raças" progenitoras da nação, o branco civilizador, o índio nativo e o negro escravo.

A hesitação de Carlos residia em narrar a história e demonstrar sua concordância com o que pensaram os amigos diante da situação, sem soar racista. Afinal, como estudante de pósgraduação da área de Ciências Humanas, ele precisava ter cuidado com o que dizia e como dizia. No capítulo 4, essas questões serão retomadas e outros depoimentos, como o de Clarice Nakashima e seu constrangimento em abordar a temática da "raça" serão explorados. Momento que abordaremos um assunto igualmente delicado, o outro lado da questão do preconceito, aquele contra os não-descendentes, os gaijins.

Confidenciou a todos que era um menino de estatura baixa, que demorou a crescer e que sofreu muito com isso. Afirmou ter sido vítima de agressões físicas e verbais na escola que o deixaram muito "traumatizado". "Fizeram de tudo comigo, batiam, enchiam o saco". Quanto à expectativa de notas altas, "os meninos pegavam meu boletim e diziam: 'Mas como não tirou dez?!'. 'Judiavam' mesmo!’. De acordo com ele, essas experiências deixaram várias marcas que ele superou não faz muito tempo. A julgar pela aparência, dificilmente imaginaríamos que Carlos tenha passado por isso. Hoje é um homem alto, com cerca de 1,85m, e está com 34 anos. 
O argumento racial utilizado para pensar o Brasil como nação é antigo. Partiu de estabelecimentos científicos e alcançou com força o domínio do senso comum. Antiga também é a constatação da realidade miscigenada no país. Singularidade que, como vimos, no início do século XIX era traduzida como um grande mal para o desenvolvimento da nação, será repensada na década de 1930 por Gilberto Freyre, no clássico Casa Grande \& Senzala, a partir da positivação da composição racial da nação. A mistura harmoniosa das três raças formadoras, defendida pelo autor, se transformará na marca de nossa identidade nacional. Resolvendo o "impasse" da nação, fadada ao fracasso desde o berço pela presença de "elementos inferiores" em seu seio, o modelo de inspiração boasiana de Freyre retomará a contribuição cultural da população negra no país. Com o autor, a exaltação romântica da tolerância racial e da comunhão das diferenças se consagrará no Brasil.

Com o fim da Segunda Guerra Mundial, momento em que o horror do holocausto e as doutrinas raciais nazistas que o embasavam tornaram-se publicamente condenadas no mundo todo, a comunidade científica buscou repensar o conceito de "raça", desmistificando seu aspecto biológico e natural. A concepção de que a raça é uma construção sócio-histórica e que seu conteúdo é cultural e político se firmou desde então e o conceitos de etnicidade e grupo étnico para definir em linhas gerais pessoas ligadas por traços e heranças comuns - língua, território, cultura, descendência - vão ganhando espaço (Stolcke, 1991: 106). A ideia de "etnia japonesa" ou "etnia nipo-brasileira" também se fortalece nesse contexto, deslocando aos poucos a categoria "raça amarela" nos discursos produzidos na época.

Mas somente desconstruir ou substituir o conceito não é o bastante. Segundo Lilia Schwarcz (1998: 236), “demonstrar as falácias do mito da democracia racial talvez seja menos importante do que refletir sobre sua eficácia e permanência, para além de seu descrédito teórico, que data de finais dos anos 50". Essa permanência se faz sentir por toda parte. O Brasil ainda se faz pensar pelas "raças" que o compõe, sendo a "raça japonesa" um dos elementos do variado leque de cores e culturas que o define. A utilização do termo "grupo étnico" para designar os nikkeis deve ser assumida, portanto, como categoria analítica do pesquisador e não como categoria nativa. O agenciamento da ideia de "raça japonesa" não deve ser desconsiderado como um importante elemento na produção de subjetividades.

Ainda de acordo com Schwarcz, a teoria da diferença racial como subdivisão da espécie humana, mesmo deslegitimada como argumento científico, persiste sob a capa de uma "filosofia racista", fazendo-se presente no domínio das relações pessoais e das vivências do cotidiano. Nas palavras da autora, "sua base é uma certa experiência vivida, de onde retira sua 
eficácia, já que se combate mais facilmente um argumento teórico do que uma emoção ou uma experiência sensível" (Schwarcz, 1995b: 189).

No universo do senso comum, admite-se que o Brasil é um país onde o preconceito de cor se faz sentir, todavia ele se revelaria de forma muito mais branda do que em outros países. A própria mistura racial serviria como prova dessa tolerância com os diversos povos. Com efeito, as dúvidas e controvérsias quanto às possibilidades de existência do preconceito contra os descendentes de japoneses talvez esbarrem nesse mito. "O Brasil criou seu racismo com base na negação do mesmo", afirma Kabengele Munanga (2005: 53). Vimos como nas comemorações do centenário da imigração japonesa no Brasil, o discurso da comunhão fraterna e da ausência de quaisquer tipos de conflitos étnicos foi revitalizado. As imagens positivas associadas aos descendentes de japoneses e a "marcação da diferença" através da "brincadeira" e não da exclusão social também contribuem para descaracterizar as possibilidades de preconceito contra o grupo.

Em sua clássica obra, produzida em 1954, Preconceito de marca: as relações raciais em Itapetininga (1998), Oracy Nogueira desvenda a ambivalência da ideologia das relações raciais no Brasil, que propagada pelo seu conteúdo "assimilacionista e miscigenacionista", encobre um tipo perverso de preconceito, o de "cor" ou de "marca racial". Ao contrário do "preconceito de origem", encontrado nos Estados Unidos, instituidor de uma forma de classificação racial calcada no critério da ascendência de um antepassado negro, por mais remoto que seja, e gerador de uma segregação incondicional dos membros do grupo discriminador e discriminado; o "preconceito de marca", vigente no Brasil, varia de acordo com "o número e evidência das marcas raciais" apresentadas pelo indivíduo, contrabalançados pela presença ou ausência de outros critérios de classificação, como características pessoais, situação de classe, status social. Segundo Oracy Nogueira, "a cor escura implica antes uma preterição social que uma exclusão incondicional de seu portador” (Nogueira, 1998: 167)

Na pesquisa, realizada na cidade de Itapetininga na década de 1950, o autor faz breve menção à presença dos japoneses e seus descendentes no município, em seus densos dados estatísticos, documentais e observações de campo. Considerados ora como grupo imigrante, estrangeiro ora como "grupo amarelo", Oracy quando analisa a "diluição dos estrangeiros entre os nacionais", afirma que, no Brasil, a identificação com a nacionalidade de origem geralmente não ultrapassa a segunda geração de descendentes, ressalvando o caso dos japoneses que "constituem um grupo à parte, tanto devido às diferenças culturais como à sua maior 'visibilidade', sob o ponto de vista físico, agravados esses dois fatores pela circunstância de ser 
tão recente sua penetração no país, e especialmente, na comunidade em estudo" (Nogueira, 1998: 186).

Sobre essa "visibilidade, sob o ponto de vista físico" a que se refere o autor, podemos concluir tratar-se dos caracteres fenotípicos peculiares da "população amarela" ou "grupo amarelo", marcadores da ascendência do indivíduo. Adriana Capuano de Oliveira (1997) se inspira na obra de Oracy e afirma que a lógica da aparência e do fenótipo que preside as classificações raciais no Brasil também atua no caso dos japoneses e seus descendentes. Quanto mais acentuada a "marca" do portador, incidente sobre os "olhos puxados", mais ele é reconhecido e se autorreconhece como "japonês".

A autora defende seu argumento a partir de sua pesquisa com descendentes de japoneses, frutos de casamentos mistos, os "mestiços". Assim como o "mulato", dependendo da "atenuação" dos traços "negroides" apresentados, o "mestiço" que possuir os "traços orientais" menos evidentes, pode se identificar e ser identificado como pertencente ao grupo branco, caso contrário poderá "carregar o estigma de japonês" (Oliveira, 1997: 23). Embora discorde da ênfase quase exclusiva ao aspecto físico como definidor da identidade "japonesa" no Brasil, penso que a autora apresenta uma proposta importante, que será retomada no capítulo 4.

A reflexão de Oracy Nogueira para esta pesquisa desvela uma contribuição valiosa. No caso dos nikkeis, o "preconceito de marca", cujo grau de incidência varia em função dos "traços raciais" apresentados, opera por meio da mobilização de um conjunto de imagens, discursos e estereótipos que são acionados no instante em que a "visibilidade" do seu "físico" se faz imediatamente notar. Como afirma a entrevistada nissei, "mestiça", Isabel Nishida, 53 anos, coordenadora do grupo de taikō da Associação Cultural e Esportiva de Astorga, não é possível esconder os traços:

“Porque onde a gente for, a gente é sempre 'japonês', por causa dos nossos traços [risos]... Denuncia, né? Então, não tem como não falar que não é descendente. Eu acho que como nós temos esses caracteres e essa tradição e cultura tão ricas, nós não podemos deixar perder no tempo. Então, o que puder fazer para resgatar, para manter eu acho que a gente tem obrigação de fazer".

Contudo, diferentemente da preterição social que a marca dos "negros", a cor escura, impinge aos seus portadores, uma vez que levanta de acordo com Nogueira uma série de "estereótipos" e "representações coletivas" negativas; aos "olhos puxados" podem ser atribuídos dois repertórios com conteúdos diferentes, um que denota zombaria, piada e outro atrelado a um imaginário considerado positivo em muitos aspectos, causando uma valorização do portador, e em alguns casos, podendo trazer algumas vantagens no mercado de trabalho, no comércio, por 
exemplo, como já discutido anteriormente. Não obstante as experiências serem as mais diversas, para a maioria dos entrevistados, as gozações e brincadeiras sobre o físico do "japonês" até podem constituir formas de preconceito, mas não é algo que "lhes tire o sono", que cause “traumas", pois a imagem positiva do nikkei perante à sociedade sobreleva esse aborrecimento.

O médico de Londrina-PR, Luís Yamamoto, citado no primeiro capítulo, que diferentemente da professora Isabel não mantém qualquer tipo de vínculo com entidades nipônicas e acredita que a imagem de credibilidade e competência associada aos nikkeis é "puro folclore", atesta que a mesma ainda surge em alguns domínios do mercado de trabalho. Não na sua área, já que como "profissional autônomo, que não se submete à avaliação de alguém superior", o sucesso depende somente do esforço pessoal. Mas na concorrência a um posto de trabalho entre um nikkei e um não-nikkei, o empregador pode pensar da seguinte maneira:

\footnotetext{
“"O japonês é mais dedicado, é mais trabalhador”". É óbvio que o cara tem uma tendência a escolher entre, por exemplo, um descendente de japoneses, um da 'raça negra' e um outro ali. Ele vai pender para o lado do 'japonês', é óbvio, porque o pensamento dele está embasado que o 'japonês' geralmente é disciplinado. É uma imagem que foi criada. Às vezes, o cara quebra a cara! [risos]”.
}

De acordo com o médico, entre um negro, um branco e um "japonês", a marca é passível de gerar preterição e predileção e forja um preconceito, no sentido primeiro que a palavra possui. Segundo o dicionário Houaiss: 1. "qualquer opinião ou sentimento, quer favorável, ou desfavorável, concebido sem exame crítico”. O objetivo deste capítulo consistiu em lançar algumas questões frente ao agenciamento do termo "raça japonesa", seja nos discursos oficiais no início do século XIX, seja no cotidiano dos nikkeis desta pesquisa. Também buscou levar em consideração como a questão do corpo e do preconceito, e não somente a "cultura japonesa" são peças importantes na produção de subjetividades. Marca, traço, fenótipo e físico são sinônimos para um fenômeno comum aqui descrito: são demarcadores da diferença em inúmeras experiências aqui narradas. Marca atribuidora dos mais variados sentidos: estéticos, positivos, negativos, pejorativos, vantajosos, dolorosos. Marca traduzida pelos interlocutores dessa pesquisa como "raça japonesa". Termo, cujo uso social na atualidade guarda ressonâncias com a construção discursiva da ideia de raça e sua intensa utilização no passado e também com a maneira histórica com que o Brasil se reconhece como nação pelo seu caldeirão de "raças" e culturas. 


\section{CAPÍTULO III - QUE "JAPONÊS" É ESSE NA "CULTURA JAPONESA"?}

\section{"CULTURA JAPONESA" COM ASPAS}

Abrimos esse terceiro capítulo nos apropriando, para os propósitos dessa pesquisa, do sugestivo título do artigo de Stuart Hall (2003), “Que 'negro' é esse na cultura negra?”. Neste texto, o autor discute a questão da cultura popular negra no âmbito da hegemonia cultural e no terreno das políticas culturais da diferença. A noção de "cultura japonesa" não é encarada sob os auspícios do "popular", no sentido que Hall o confere como espaço de luta, contestação e resistência. Contudo, sua leitura somada à de Marshall Sahlins e Adam Kuper, trazem apontamentos interessantes para problematizar o que é, afinal, essa "cultura japonesa", categoria quase "obrigatoriamente" agenciada quando o assunto em questão é o nikkei. Para começar, seria possível defini-la?

Certo desconforto paira nas tentativas de problematizar, revisar, definir o conceito de cultura, este tradicional "objeto" de investigação antropológica, sobretudo após as críticas desconstrucionistas contemporâneas. Não cabe aos objetivos do capítulo repassar as controversas formulações e críticas referentes às formas em que a cultura foi pensada: sistema, estrutura, texto, ficção, discurso, invenção, ideologia, etc. Tomamos como premissa de que a mesma, como um arranjo que organiza a experiência por meios simbólicos, não é “um 'objeto' em vias de extinção" (Sahlins, 1997).

Concepção que também se ancora em não considerar a cultura como um todo coeso, orgânico, permanente, mas como um conjunto simbólico híbrido, com fronteiras porosas, em fluxo constante e sujeita à negociação e à contestação. Como argumenta Kuper, "a razão pela qual ainda precisamos de uma noção de cultura é de ordem moral ou política. O conceito de cultura nos fornece a única forma que conhecemos para falar sobre as diferenças entre os povos do mundo, diferenças que persistem a despeito do processo de homogeneização" (Kuper, 2002: 272).

O autor propõe que a compreensão da cultura só é possível quando não tentamos explicá-la "em seus próprios termos", ou seja, quando não a encaramos como um sistema único. Kuper salienta que a cultura deve ser entendida a partir da fragmentação de seus elementos, tais como valores morais, rituais, conhecimentos, produtos, arte. O olhar deve se deslocar para "os 
processos que constroem, reconstroem e desmantelam materiais culturais, em resposta a determinantes identificáveis" (Wolf, 1982, apud Kuper, 2002: 310).

A partir dessa inspiração, esse capítulo também buscará dar atenção às "peças" da "cultura japonesa", direcionando a análise, sobretudo, às práticas e valores, recorrentemente mobilizados nas falas dos sujeitos entrevistados e sobre a expansão na divulgação e consumo de produtos e símbolos relacionados a referenciais nipônicos. O objetivo se fia em explorar brevemente alguns dos fundamentos que embasam esses valores, como unidade familiar e disciplina, ainda muito associados pelos interlocutores da pesquisa a uma herança ancestral. Porém, como já anunciado, compreender como esses valores filiam-se às tradições religiosas do budismo, xintoísmo ou aos códigos de conduta e moralidade do confucionismo está longe da alçada deste trabalho. Busca-se aqui refletir sobre as maneiras com que alguns desses códigos se interpuseram e se interpõem na experiência de vida dos imigrantes japoneses e seus descendentes no Brasil.

Como já mencionado no capítulo 1, foi possível perceber nas narrativas de muitos interlocutores a modulação de discursos identitários que extrapolavam a esfera do imaginário discursivo sobre os nikkeis. "Cultura japonesa" se mostrou um operador significativo para o processo de construção de identidades. A relação de distanciamento e/ou aproximação estabelecida pelos entrevistados com o que entendem por "cultura japonesa", em boa medida foi um componente importante na reflexão desses sujeitos sobre diversos temas tratados, incluindo a questão da identidade.

De acordo com Koichi Mori, não existe cultura japonesa no Brasil, mas sim cultura brasileira de origem japonesa. A cultura japonesa deslocada, que migra de um contexto para outro, não configura cultura japonesa, pois inevitavelmente sofrerá intervenções locais. Os nikkeis no Brasil criaram uma "cultura étnica com referências japonesas e brasileiras". O autor dá o exemplo da festa Tanabata Matsuri, ${ }^{145}$ realizada em Sendai, no Japão e que também acontece no bairro da Liberdade, em São Paulo. Um dos atrativos do evento é o tanzaku, papéis onde as pessoas escrevem pedidos e os amarram em bambus e que são queimados no final da festa para que os desejos cheguem ao céu. Enquanto no Japão, o papel é branco; no Brasil, há sete cores diferentes, cada qual carregando sua própria simbologia - como o amarelo, que representa o dinheiro; o rosa, o amor. A lógica empregada seria a mesma que a atribuída às cores das roupas usadas no Revéillon. Mori pontua como outros elementos da "cultura japonesa",

\footnotetext{
${ }^{145}$ Festa muito popular e tradicional no Japão, realizada no mês de julho, há mais de 1150 anos. Celebra a história de amor entre Orihime e Kengyu, casal que pode se encontrar uma única vez no ano, no sétimo dia, do sétimo mês do ano.
} 
língua, alimentação, religião, danças, foram recriadas no processo de adaptação dos imigrantes ao país (Mori apud Manfrinnato, 2008).

Segundo o autor, frequentemente os nikkeis percebem essa "cultura híbrida como a cultura japonesa autêntica", utilizando-a como meio de "manter a identidade japonesa" (id.; ib.: 2008). Não obstante alguns de meus entrevistados reconhecerem que muitos descendentes de japoneses conseguiram manter certas tradições e práticas culturais japonesas no Brasil, que já não mais encontram tantos praticantes ativos ou apreciadores no Japão, como por exemplo, o taikō e o shamisen ${ }^{146}$, tenho dúvidas quanto a afirmação do autor. Com exceção talvez do depoimento do médico Luís Yamamoto, não me pareceu que os entrevistados tivessem uma concepção tão estática e a-histórica de "cultura japonesa", como se a entendessem como mera reprodução de uma cultura original do Japão. Yumi Kawamura, nissei, 39 anos, que como vimos afirmou se encaixar cem por cento no "perfil de nihonjin", quando discorre sobre sua preocupação com a educação de seu filho, diz:

\begin{abstract}
"Quero educar ao máximo meu filho dentro da cultura, dentro da nossa tradição e preparar o bichinho para o mundo. Esse negócio de dizer só 'hai, hai, hai' ${ }^{147}$ já era, não vai a lugar nenhum! [...]. Porque o 'japonês' tem que mostrar que ele não é só certinho, certinho, que ele também sabe se divertir, não é?Aquele 'japonês' que só fica quietinho, pelo amor de Deus! Isso daí não! Eu acho que tudo vai mudando mesmo. Não pode ficar só no 'tradicionalzão'. Por que já pensou se não tivesse mudado? A gente ainda estaria casando com aqueles que os pais escolheram para gente ${ }^{148}$ ! Graças a Deus que mudou, né!? E tem que mudar! Deus me livre se nada mudasse! Eu acho que a gente não teria sobrevivido não. A gente ficaria rebelde e iria fazer tudo ao contrário".
\end{abstract}

Tendo em vista essa discussão, "cultura japonesa” aqui é grafada com aspas, e referese à diferenciação que Manuela Carneiro da Cunha emprega entre cultura, categoria analítica de "ida y vuelta" - "fabricada no centro e exportada para o resto do mundo" - e que tem o sentido antropológico de esquema simbólico que organiza a ação e percepção humanas; e "cultura", importada, performatizada e celebrada pelos nativos (Cunha, 2009). A última se inscreve em um regime de etnicidade, uma vez que é mobilizada em contextos de afirmação de identidades. É esse "metadiscurso reflexivo sobre a cultura" que aqui nos interessa (id.; ib.: 373).

Para os interlocutores dessa pesquisa, de modo geral, "cultura japonesa" é uma categoria que se refere a um complexo sistema de valores e práticas de origem japonesa,

\footnotetext{
${ }^{146}$ Taikō: tambor japonês. Shamisen: instrumento de três cordas.

${ }^{147}$ Acredito que com esse "hai, hai, hai", (sim), Yumi faça menção ao valor de obediência à hierarquia presente no Japão e também trazido ao Brasil com os imigrantes.

${ }^{148} \mathrm{O}$ miai ou "casamento arranjado" pelos pais através de um intermediário, o nakōdo, constituiu-se em uma prática tradicional que ganhou força na Era Meiji (1868-1914). Somente após a Segunda Guerra Mundial, o Código Civil japonês institucionalizou o casamento como escolha individual. Tal prática também foi adotada por muitas famílias imigrantes de primeira e segunda geração no Brasil.
} 
transmitidos pelos antepassados aos seus descendentes. Assim como sucede com os termos nikkei e nipo-brasileiro, recorrentemente subsumidos na fala pelo simples japonês, "cultura japonesa" pode ter relação com dois universos diferentes: com o que entendem hoje como "cultura" do Japão, híbrido que combina um arranjo de valores, imagens, produtos e pessoas, como as relações de hierarquia, o corporativismo nas empresas, as conquistas tecnológicas, a "americanização" do arquipélago, a "frieza" de seus habitantes, o J-Pop; e também com o sistema, igualmente híbrido, de valores, crenças, costumes e práticas culturais repassados pelos antepassados imigrantes aos seus descendentes no Brasil.

Com relação a esse último universo, alguns elementos que foram muito comentados pelos interlocutores, como as comemorações do centenário da imigração japonesa no Brasil, a ampla divulgação e interesse de não-nikkeis pela "cultura japonesa", sobretudo a culinária e a ideia de "resgate" de práticas culturais pelas novas gerações de descendentes serão aqui brevemente discutidos.

\section{"CULTURA": SEMEADA E PRESERVADA}

"Sinto muito orgulho de ser descendente de japoneses. Agradeço minha família. Se sou o que sou hoje é graças à família que me educou dentro dos costumes, dos padrões da colônia japonesa. Então, eu tenho só a agradecer, porque eu vejo que isso fez o diferencial para mim. [...] Meu marido é 'brasileiro', mas... [risos]. Acho que vivo muito dentro dos padrões, dentro dos costumes...”.

"Por favor, Isabel, defina o que você entende por padrões...", peço a ela.

"Eu vejo assim muita importância na educação, nos costumes. Sabe, esse é o diferencial. É isso que dou muito valor, porque os japoneses, o descendente, ele faz a diferença pela responsabilidade, disciplina, pontualidade. São valores que... Isso é uma marca registrada da colônia japonesa. Isso a gente adquiriu através de nossos pais, nossos avós. A gente está tentando passar isso para os nossos tocadores de taikō, às crianças que frequentam a associação, nós estamos tentando passar esses valores, porque tocar qualquer um toca, agora o diferencial são esses valores que a gente tem que desenvolver nas crianças e adolescentes. Esse é o diferencial, porque eu vejo que a colonia japonesa... Quando se fala em japonês, a gente tem um certo... como fala? A gente tem um diferencial, né? Porque falam isso: a gente não vê nenhum, muito raro, quase impossível, a gente ver um descendente de japoneses, um nikkei pedindo esmola, vagabundo, marginal. Quer dizer não é que não exista, mas é muito difícil. Agora se tiver, o que acontece? A própria colônia se encarrega também de ajudar, não é? Então, são esses valores que eu acho muito importantes. Isso não é orgulho, são valores que a gente é educada para viver, dentro desses padrões. Porque coisa mais bonita que eu vejo assim, a gente tem credibilidade e tem pessoas que realmente falam assim, 'japonês é certo mesmo'. Então, a gente se sente bem quando ouve isso, para nós é um elogio. E a gente espera que as futuras gerações continuem mantendo a tradição. Esses valores não podem acabar. Então a gente procura pelo menos...lançar uma sementinha para o futuro. Vamos ver, né? 
(risos). Espero, tenho certeza, que vai brotar, crescer e dar bons frutos. Pelo menos estamos tentando".

Esse longo depoimento é de Isabel Nishida, nissei, 53 anos, orientadora educacional da rede estadual de ensino em Astorga e coordenadora do grupo de taikō, Seishun Daiko, da ACEAST, Associação Cultural e Esportiva de Astorga. Isabel esteve à frente de sua criação em 2007. Conta como se empenhou para que a associação conseguisse os instrumentos que possuem um alto custo, junto à Aliança Cultural Brasil-Japão do Paraná. "Foi um trabalho de formiguinha", já que Isabel ia às reuniões da entidade e deixava um bilhete para os coordenadores demonstrando seu interesse em abrir uma turma de taikō, até que sua insistência garantiu a conquista de cinco tambores. ${ }^{149}$ Nos festejos do centenário na cidade de Rolândia-PR, município que recebeu o Príncipe herdeiro do trono imperial, Naruhito, o grupo Seishun Daiko foi selecionado para fazer parte dos 140 tocadores que se apresentaram no evento. Para os ensaios e para outras apresentações em Astorga, os cinco instrumentos que a ACEAST detinha não eram suficientes. A associação do município vizinho, Arapongas, distante $36 \mathrm{~km}$ de Astorga, prontificou-se a emprestar alguns. Isabel se locomovia toda semana para buscar e levar os taikōs, “eu ajudo, me empenho, largo marido e tudo, porque as crianças se empenham também”, afirma.

De acordo com Isabel, como Astorga é uma cidade pequena, não possui empresas que possam financiar o grupo. Em Maringá e Londrina, por exemplo, os grupos de taikō recebem patrocínio do Banco Real. "Lá as empresas bancam tudo, é só administrar o trabalho e aqui nós temos que ser tudo. Conforme a criança, nós temos que levar e buscar. Cidade pequena é assim, é um trabalho de conquista". Outro problema que o grupo enfrenta é a evasão dos jovens quando são aprovados nos vestibulares fora da cidade. Segundo Isabel, isso é um fator que explica a pequena participação de descendentes de japoneses na prática do instrumento: o grupo II possui catorze tocadores, sendo que somente três são nikkeis. "Nós estamos dando essa abertura para os 'brasileiros', porque primeiro a colônia é pequena, então não tem tanto adolescente e criança. Além disso, é um projeto cultural, tem que ser abrangente".

A inserção desse fragmento com o depoimento de Isabel e com um pouco da história de formação do grupo Seishun Daiko revela inúmeras e valiosas questões: o trabalho voluntário nas associações, a vontade e dedicação em “manter" certas tradições, como o taikō e o interesse

\footnotetext{
${ }^{149}$ Com a verba recebida pelo Governo Federal para as comemorações do centenário da imigração japonesa, a Aliança adquiriu os instrumentos e os emprestou às entidades interessadas, através de um contrato próximo ao de comodato. Se a entidade não desse continuidade ao projeto, deveria restituir os tambores à Aliança. Um professor, sensei, também foi contratado para ensinar as crianças e os jovens. A ACEAST, conta hoje com dois grupos de tocadores de taikōs, um total de 21 praticantes.
} 
de não-descendentes por essas práticas. Isabel, sem dúvida, uma das entrevistadas que mais visivelmente demonstrou seu apego e admiração pela "cultura japonesa", tem um envolvimento emocional muito grande com a questão, perceptível em sua fala, em seu engajamento na associação. Entrevistei Isabel durante um ensaio do Seishun Daiko. Como o som dos tambores era muito alto, ficamos do lado de fora do kai kan ${ }^{150}$, um pouco afastadas, num campo aberto, sentadas em duas cadeiras, às nove horas da noite. Na escuridão, com o braço engessado, picada pelos mosquitos, Isabel ainda se mostrou muito solícita em responder às questões, falar sobre os projetos do grupo - como a vez em que fizeram e venderam cinco mil coxinhas para custear uma viagem até Castro-PR para participarem do Festival Paranaense de Taikô - e até se prontificou a me emprestar o acervo que estava organizando com material sobre os festejos do centenário da imigração japonesa.

"Orgulhosa" e agradecida por ter sido educada dentro dos "padrões" da cultura, Isabel tem uma reflexão própria sobre o que entende por esse conceito: um complexo de valores, herdado dos pais e avós, como responsabilidade e disciplina, que ela pretende repassar para seus jovens tocadores, já que tocar qualquer um toca, o diferencial são os valores. "Diferencial” é a palavra de ordem de seu discurso, ela o repete quatro vezes. Diferencial que imprime uma marca sobre a "colônia": a imagem de credibilidade, motivo de grande satisfação para ela. É interessante observar como Isabel constrói uma visão quase orgânica de cultura. Num outro momento da conversa, afirma que a preocupação dos nikkeis mais velhos é que a "cultura japonesa não morra, porque se não dermos continuidade, ela morrerá”. É por isso que vê o seu trabalho e de outros voluntários na associação como o de semeadores do futuro, dispersadores da importância dos valores da "cultura". Como uma planta, a "cultura japonesa" deve ser regada, preservada para que gere "bons frutos" - uma geração que passe adiante a semente recebida.

\section{“GAMBARE-NASAI!”}

Luísa Sato nasceu em 1961 na cidade de Sorocaba-SP. Mudou-se para Atibaia-SP e depois para a capital, São Paulo, onde juntamente com o marido, a irmã e o cunhado, tornou-se proprietária de uma loja de produtos japoneses. Foi neste local que a nossa conversa aconteceu. Diferentemente de Astorga e Maringá, cidades em que passei a maior parte de minha vida, tinha poucos contatos na capital paulistana. A ida a campo em uma loja de produtos japoneses parecia uma boa oportunidade para obtê-los. Luísa e seu cunhado Sérgio Takeda, gentilmente aceitaram

\footnotetext{
${ }^{150}$ Sede, espaço físico do nihonjin-kai, da associação.
} 
o convite e as entrevistas aconteceram ali mesmo no balcão da loja para não atrapalhar o trabalho deles.

Tendo mãe issei, Luísa conta que teve uma educação muito rígida em casa, devido às imposições de se falar japonês e não se relacionar com "gaijins". Motivo de revolta durante a juventude, hoje, "mais madura", ela se sente "privilegiada" e entende o quanto o aprendizado da língua e de outros costumes foram importante para sua formação e para o próprio trabalho a que hoje se dedica. Através deste, Luísa me disse que ela foi aos poucos "resgatando, aprendendo a gostar e dar valor para aquilo que tinha aprendido durante a infância”. Quando conversávamos sobre as possibilidades de se pensar a identidade nikkei na atualidade, Luísa revelou-me uma experiência e uma fala comoventes:

"Eu acredito que sim. Por exemplo, outro dia mesmo eu estava comentando com minha irmã.
Estávamos assistindo a uns DVD's. Aí tinha umas frases em japonês... faladas em japonês.
Você entende e você sente como é bonita uma determinada frase e a gente quer traduzir para o
português. Você tenta traduzir e sabe quando parece que perdeu alguma coisa, um sentido
mesmo? Por mais que você tente traduzir... Aí minha irmã tava falando: 'será que é isso que é
ser... você sentir na pele que é nihonjin, sabe? Você conseguir sentir o sentido da palavra real
e se sentir sensibilizado?'. Porque se você traduz para o português, perde... A gente sente que
perde. Não é a mesma coisa. Então, de repente tem um amigo ou alguém que você gosta muito
que está meio para baixo, aí você diz 'gambarê-nasai!'. O que é 'gambarê'? É dar o melhor
de si. Mas se você diz 'dar o melhor de si' ou 'gambarê', olha a diferença! Entendeu? É
diferente... Parece que perde, né? É isso".

No momento em que discutimos sobre a imagem de trabalhador dos japoneses e seus descendentes, Luísa reforça que:

"É uma cobrança. Sempre é uma cobrança, né? Eu vejo assim. Porque os ocidentais já têm um pré-... Falam: 'Ah, porque são japoneses são mais inteligentes, são trabalhadores!'. Isso parece uma cobrança. Não é que a gente não será ou não seja. Eu acho assim... a gente é gente, né? (risos). Tem de tudo. Eu acho que não é bem assim! Então, eles acabam vendo o todo como se fosse... isso é uma cobrança. É como na escola... Você mesma já deve ter sentido isso... 'Ah, é japonesa! Tem que ser japonesa para ter tirado um dez!'. É uma cobrança muito grande. Não é assim! A gente precisa dar uma relaxada também! [risos]”.

Quando questiono se ela se identifica com essa imagem, retomando sua afirmação, "não é que a gente não seja”, a comerciante reflete por um momento e responde:

"Eu acho que... É mais esforçado? É mais esforçado! Eu acho que são mais esforçados, concorda? Talvez por essa cobrança mesmo, não sei. A gente acaba se esforçando mesmo, dando o melhor da gente mesmo, né!?" [risos]. 
Luísa menciona duas vezes a ideia de "dar o melhor de si". Na primeira, analisa como a tentativa de tradução da noção de "gambarê" esvazia o conceito, culminando na perda de seu real significado, na beleza de seu significado. Na segunda vez, assim como o entrevistado Daniel Kobayashi ${ }^{151}$ relatara, afirma que a própria imagem de esforçado do descendente de japoneses opera como uma cobrança para que o mesmo busque suprir as expectativas lançadas sobre ele. Luísa também não deixa passar despercebida nossa ascendência comum: "Você mesma já deve ter sentido isso". Sua fala revela que a pré-concepção sobre os japoneses e seus descendentes nem de todo falsa, nem de todo verdadeira, a seu ver - não é observada e sentida somente por ela. A comerciante pressupõe que eu também tenha passado por essa experiência - sua fala é de afirmação e não de questionamento - concluindo que a "gente precisa dar uma relaxada", embora acredite que "a gente acaba se esforçando mesmo".

Célia Sakurai, em seu livro Romanceiro da imigração japonesa (1993), analisa alguns romances, autobiográficos ou não, publicados a partir da década de 1980, que buscam resgatar a memória da imigração japonesa no Brasil. Coincidindo com os oitenta anos da chegada dos japoneses ao país, "a data era propícia para uma recordação do passado" (Sakurai, 1993: 23). Privilegiando o olhar feminino nessa literatura, são muitos os pontos em comum encontrados nessas narrativas: as dificuldades de adaptação ao país, as diferenças culturais, a submissão das mulheres às decisões do pai, chefe de família, a mobilidade espacial das famílias, a preocupação com a educação dos filhos, os dilemas de ser japonês e brasileiro. Elementos constituintes de uma narrativa que continua a ser contada sob a forma de saga. Passados cem anos da imigração japonesa no Brasil, esses elementos são reatualizados nos diferentes discursos - literários, políticos, jornalísticos - conservando-se a proposta de prestar uma homenagem aos antepassados. Aos reveses sofridos pelos últimos, seguiu-se a conquista do sucesso econômico, através do esforço e determinação.

Célia Sakurai mostra como essa ideia de superação, de vencer na vida, de gambarê, é a linha que costura as narrativas. A autora define esse princípio derivado do confucionismo como uma disposição para suportar as adversidades com coragem e resignação. Aceitar o "destino" é sinal de maturidade, é a busca pela harmonia ( $w a$ ), mas que não se traduz em imobilidade. Vencer os desafios colocados pelo destino, aprimorando as virtudes pessoais constitui o verdadeiro "espírito do gambarê", (Sakurai, 1993: 52-53).

A autora investiga como essa questão é trazida pela perspectiva das narradoras dos romances. Tradicionalmente, à mulher japonesa cabia o apoio ao marido, este responsável pelo

\footnotetext{
${ }^{151}$ Sansei, 35 anos, ex-dekassegui, dono de um mercado em Astorga. Citado no capítulo 1.
} 
sustento material da casa, e a educação dos filhos dentro de certos padrões de moralidade, mantendo intactos a honra e a dignidade do nome da família. Segundo Sakurai, sob a ótica dessas mulheres isseis e nisseis, "vencer na vida não significa necessariamente o acúmulo de riquezas, mas é interpretado como a manutenção de uma conduta moral reta sem, entretanto, deixar de procurar as oportunidades que possam conduzir à ascensão social, por menor que esta seja" (Sakurai, 1993: 28).

Teria o caráter de honestidade e esforço no trabalho e nos estudos, discutidos por vários entrevistados como valores repassados pelas antigas gerações, uma relação com essa ideia de gambarê? Muitas mudanças foram gestadas no processo de permanência dos japoneses no país, a começar pela divisão nos papéis de gênero e a submissão calada da mulher às exigências do marido ou da família, embora haja alguns grupos familiares que ainda se estruturem a partir de certos elementos desse modelo de hierarquia.

Nenhum entrevistado para essa pesquisa fez alusão às raízes confucionistas do gambarê. É importante ressaltar que a grande maioria quando falava de "cultura" e valores, apenas limitava-se a dizer que os mesmos foram repassados pelos pais e avós, assim como no discurso de Isabel Nishida. Quase todos os entrevistados eram cristãos, apenas um era budista. A maior parte não sabia precisar as influências históricas, políticas, religiosas que pesaram sobre a vigência de tais valores no Japão, os quais também foram compartilhados no Brasil com o processo imigratório. Nesse sentido, apesar dos sujeitos da pesquisa não terem explicitado diretamente a questão do gambarê, com a exceção de Luísa, talvez seja possível inferir que esse ethos de trabalho e honestidade agenciado pelos discursos dos e sobre os nikkeis esteja relacionado em alguns aspectos com esse ideal.

Na discussão sobre essa questão dos "valores", é importante mencionar alguns pontos. O período de maior fluxo na entrada de imigrantes japoneses no Brasil - que se estendeu entre os anos de 1925 a 1941 - coincidiu com o fortalecimento da política nacionalista no Japão. Com o fim do xogunato e com o processo de "ocidentalização" do arquipélago pós-Revolução Meiji, entrou em curso, a partir de 1880, um movimento, de valorização das "origens" e das "tradições", com vista a garantir a legitimidade política do imperador. Os códigos de moralidade baseados no confucionismo e xintoísmo, como o devotamento filial e preservação da honra, lealdade e hierarquia ajudaram a conformar a noção de Estado-Família e de obediência inquestionável ao imperador (Sasaki, 2009). 
A ideologia nacionalista, suporte do regime imperialista e expansionista no final do século XIX, foi, portanto, galvanizada pelo ideal do bushido ${ }^{152}$. Segundo Dezem (2003), a ideia de yamatodamashii (espírito japonês), difundida pela primeira vez em uma obra do século XI, será reelaborada no contexto de expansão militarista do Japão. Com a conquista de territórios na Ásia e a importação de doutrinas racialistas europeias em voga na época, “a ideologia racial será rearticulada para responder aos imperativos situacionais", e uma identidade ancorada no pressuposto de pureza de sangue, superioridade racial e homogeneidade japonesa será gradualmente gestada (Sasaki, 2009: 42).

Como já mencionado no primeiro capítulo, o programa de alfabetização implantado pelo Decreto Imperial de 1872 serviu como arma de propaganda dos feitos militares e dos ideais da "ética nacional". Escola e imprensa, segundo Benedict Anderson, contribuíram para "criar a impressão geral de que a oligarquia conservadora era uma representante autêntica da nação, enquanto os japoneses começavam a se imaginar membros dela" (Anderson, 2008: 144).

De acordo com Rogério Dezem (2003: 133-134), nesse período, o Japão passou a pleitear o posto de "potência racial" não só na Ásia, como no resto do mundo. Diante da preocupação em consolidar uma imagem positiva do povo japonês junto aos países ocidentais, o governo imperial incumbia aos imigrantes a responsabilidade, ou melhor, o dever nacional de manter as tradições culturais e morais em terras estrangeiras, associando-os a "pequenos embaixadores no Japão". ${ }^{153}$ Sob os auspícios desse ideário nacionalista, muitos imigrantes que aportaram no Brasil mantiveram essa incumbência, ora por lealdade ao imperador ou simplesmente por seguir as tradições de seu país de origem. É importante levar em conta que, como vimos, as diferentes relações dos emigrados com a ideologia nacionalista nipônica, que variou da devoção ao distanciamento, provocou a cisão da "colônia" entre kachigumis e makegumis.

Chamar a atenção para essa questão não implica sugerir que valores como devotamento filial, responsabilidade, conduta moral reta e respeito à família foram compartilhados devido exclusivamente aos ditames da política nacionalista. O que importa é não ignorar os contextos de referência de discursos como os de Isabel Nishida. Valores ou "padrões culturais", como ela diz, presentes em sua formação e na de tantos outros sujeitos dessa pesquisa,

\footnotetext{
152 Expressão que significa "caminho do guerreiro" ou "caminho ético dos samurais" (Dezem, 2005: 123). Espécie de código de honra dos samurais, o bushido teve influência do xintoísmo, confucionismo e budismo, pregando valores como lealdade, justiça, benevolência, reverência aos antepassados, honestidade.

${ }^{153}$ A imigração tutelada também tinha como objetivo diferenciar-se do "tráfico amarelo" - que arregimentava trabalhadores, sobretudo chineses, subjugando-os através da violência ou ludibriando-os - ao mostrar o "controle de qualidade" de seus emigrados japoneses.
} 
são estreitamente vinculados por eles a uma herança recebida dos antepassados. A intensidade dos laços e do apego desses antepassados com esse conjunto de valores japoneses, relação inteiramente subjetiva, motivada por fatores vários, pode dizer muito sobre seus descendentes.

Como afirma Stuart Hall, laços sociais, simbólicos e idealizados com as culturas de origem continuam a existir na definição de um "senso de comunidade", mas operam conjuntamente com as interações cotidianas da vida social como um todo. Segundo o autor, "as tradições variam de acordo com a pessoa, ou mesmo dentro de uma mesma pessoa, e constantemente são revisadas e transformadas em resposta às experiências migratórias" (Hall 2003: 63). Os "termos de compromisso" com a comunidade variam dentro de uma mesma família, sendo que cada membro, nas renegociações e definições de seus padrões de relacionamentos, "chega às suas próprias conclusões experimentais" (Parekh 1991 apud Hall 2003: 64).

“CADA GERAÇÃO TEM SEU TEMPO, CADA GERAÇÃO TEM SEU MOMENTO”... “NÃO TEM MELHOR, NEM PIOR, CADA UMA TEM O SEU TEMPO”

Quando Júlia Suzuki Bertolli, sansei, 42 anos comentava que além do estímulo e incentivo dados aos estudos, "a própria rigidez na educação que o japonês herdou fez com que ele se desvirtuasse cada vez menos", pergunto-lhe se ela busca repassar esses valores aos seus filhos:

\footnotetext{
"Eu tento, mas as coisas vão se banalizando. Vai se quebrando, vai se quebrando! A própria mistura de raças faz com que as coisas se banalizem. É o que eu falei para você, você não vê, mas acontece... Você vê um caso assim, caso assado, por causa dessa própria banalização, por causa dessa própria junção, que não é maléfica, não é maléfica! A minha filha é 'mestiça', meu filho é 'mestiço'. Meu marido é 'italiano' (descendente), não é maléfica... Eu vivo numa terra de ocidentais, eu é que tenho que me adaptar aqui e me adaptei. É claro que essa troca cultural ocasiona também essa perda de valores. E eu acredito piamente que se perdem cada vez mais os valores. Quer dizer, as famílias vão se misturando cada vez mais. Então, aquela educação da avó, da bisavó não existe mais [...] Aquela educação dela com os filhos, que deviam obediência à mãe não existe mais. Hoje minha filha me peita, de ponta de dedo com ponta de dedo, tá? Hoje meu filho de um ano e dois meses tenta me dominar. Talvez eu não tivesse o mesmo poder de educar que meu pai e minha mãe tiveram...”.
}

Indago-lhe se essa dificuldade em educar os filhos não seria uma preocupação geral da sociedade, não somente dos descendentes de japoneses. Júlia concorda, "Com certeza... uma pena, não é? Antigamente, bastava meu pai dar uma olhadinha... Hoje você pode olhar, torcer, 
fazer o que você quiser que não resolve não! Concordo que não seja uma coisa só da raça, é uma coisa global, né? Mas perdeu-se muito nessa globalização... em questão de raizes, né?”.

Como já comentado, os "casamentos interétnicos" e o movimento dekassegui, mesmo não tendo sido considerados fenômenos por si negativos pelos entrevistados, foram encarados como uma espécie de "ameaça" às transmissões de valores da "cultura japonesa". O primeiro como consequência do processo de "integração" dos descendentes à sociedade, poderia gerar o "abrasileiramento" e esquecimento das "raízes". Na visão dessas pessoas, a união com o nãodescendente pode significar uma dificuldade maior em "seguir as tradições". Assim, a "mistura de raças" diversas significaria também a "mistura" de valores diversos. Teria essa ideia de "perda", "quebra" e "diluição" dos valores uma relação com o preconceito contra os "casamentos interétnicos" existente de ambas as partes, brasileiros e japoneses, descendentes e nãodescendentes? Embora a aceitação desse tipo de casamento, atualmente, seja muito maior do que em meados da década de 1950 e 1970, o preconceito ainda se faz sentir em algumas pessoas, como será discutido no capítulo 4.

Já com relação ao movimento dekassegui, a busca por melhores oportunidades de trabalho no Japão poderia ocasionar o desinteresse pelos estudos e pela qualificação profissional, algo conquistado com muito esforço pela geração nissei. Além disso, os filhos que se separam dos pais, permanecendo no Brasil, poderiam encontrar dificuldades na educação escolar devido à falta de acompanhamento pelos pais. O entrevistado Yoshio Hasegawa, sansei, 57 anos, dentista de Maringá, disse que nos últimos anos o número de estudantes com sobrenome japonês diminuiu bastante na lista de aprovados no vestibular. $\mathrm{O}$ dentista que mora ao lado de um tradicional colégio público de Maringá afirma ter bastante contato com educadores e profissionais da escola:

\footnotetext{
“Antes era difícil ver 'japonês' balconista. Ele estava na escola, estava estudando. O pai era pasteleiro, feirante, mas estava fazendo com que o filho estudasse. Atualmente, a gente sente uma diferença muito grande. Tem tantos jovens aí que estão voltando [do Japão] e não tem outro serviço, e tem que se sujeitar a ser balconista... É o que acontece mesmo. No colégio aqui do lado, 20\% eram descendentes... Eram alunos modelos. Depois com esse negócio de dekassegui, o filho fica sozinho, fica aos cuidados da batchan e ditchan (avós). Nossa, agora tem aluno que precisaram expulsar do colégio. O pessoal falava, 'o que aconteceu? Antes era o melhor aluno e agora é o pior aluno da classe?'. Tudo é educação. Infelizmente os pais deixaram os filhos e batchan e ditchan não tem pulso para cobrar".
} 
Já o comerciante de Astorga, Cláudio Shimada ${ }^{154}$, acredita que "esse grau de dificuldade em educar os filhos não é só dos nikkeis":

“É uma dificuldade da sociedade em geral. É uma geração hoje que é bombardeada por informações, informações muitas vezes desnecessárias. Na realidade, a gente vê muitos problemas de violência. Então, nós estamos em uma época em que a sociedade como um todo está em um dilema: a dificuldade em educar os filhos. [...] Muitas vezes só falando a gente não consegue dobrá-los Se a gente fala 'A', eles falam 'B'. Eu penso que nós devemos procurar dar exemplos no dia a dia. Nós não podemos cobrar uma coisa que a gente está fazendo de errado, falar para não brigar com os outros, se ele vê a gente brigando. [...] A partir do momento que o 'japonês' trabalha, você não o vê muito envolvido com coisas erradas, eticamente ditas erradas. O próprio exemplo que um pai dá para um filho, ajuda muito na manutenção desse status. Por isso é que eu penso sim que, aparentemente, uma boa parte é um povo sim um pouco mais coerente, um pouco mais sensato nas suas atitudes".

Henrique Nagata, sansei, 26 anos, é formado em Nutrição. Embora afirme que exista uma imagem de esforçado e nerd associada aos descendentes de japoneses, acredita que, na realidade, trata-se de um "pessoal normal”. Reconhece que o investimento na educação também seja um "foco" dos pais, dando como exemplo sua experiência pessoal. Seus pais sempre o incentivaram a estudar: "faz inglês, se quiser fazer aula de espanhol pode fazer". Henrique também estudou no Kumon por cinco anos, e hoje se arrepende de não ter dado continuidade ao curso. Oriundo de uma família de classe média, imagino que esse incentivo foi considerado um investimento na formação do rapaz. Quando realizei a entrevista em sua casa, como uma completa estranha, fui muito bem recebida por ele e por seus pais. ${ }^{155} \mathrm{Na}$ pausa para tomarmos um suco, o pai de Henrique pediu licença por interromper a conversa, fez algumas perguntas sobre meu projeto e depois começou a discorrer sobre o mestrado da filha na área de Turismo. $\mathrm{O}$ orgulho era perceptível na voz e na empolgação com que falava. Henrique acredita que esse incentivo na educação é "de certa forma um diferencial, mas se for ver bem não é tão relevante":

"Tem outras culturas que também incentivam a estudar. Tanto é que você vai na faculdade,
você não vê só 'japonês'. Se fosse assim, só teria 'japonês' na faculdade. Não teria 'japonês'
fazendo faculdade particular. ${ }^{156} \mathrm{O}$ pessoal ia para estadual. Minha turma tinha quatro
'japoneses', mas o melhor da turma não era 'japonês'. Eu sempre fui um aluno mediano, para
quê tirar nota máxima? Eu tenho muito isso de 'brasileiro', o pessoal estuda só para passar
de ano. O certo mesmo é ser o melhor. Hoje eu tenho outra visão".

“Você não se identifica com essa imagem de esforçado?", pergunto-lhe em seguida.

\footnotetext{
${ }^{154}$ Sansei, 41 anos, dono de uma loja de produtos de presentes e utilidades domésticas. Citado no capítulo 1.

${ }^{155}$ Henrique é amigo de uma prima minha. Ela intermediou o contato e a entrevista foi marcada na casa dele.

${ }^{156}$ Henrique estudou em faculdade particular.
} 


\begin{abstract}
"Não. Por isso que, às vezes, eu olho os animes e eles passam muitas coisas da cultura japonesa. Os animes ${ }^{157}$ de escola, eu leio e penso, 'Nossa, se o Brasil fosse assim, qual seria a qualidade do ensino aqui?'. Toda a disciplina e tal. Mas vendo assim, se eu estudasse em uma escola japonesa, se tivesse tido essa disciplina, eu seria uma pessoa diferente hoje. Mas tem uma coisa também que eu levo em conta, que eu acho que é até melhor do que ser um japonês, por exemplo, o japonês (do Japão) tem muita confiança no outro. Então, chegam aqui no Brasil e acabam quebrando a cara, porque lá no Japão a ingenuidade é muito grande. Você chega aqui no Brasil, o pessoal é mais esperto, tem aquela percepção melhor das coisas assim... da ótica da malandragem. Você tem uma percepção... Como você convive nesse meio, você acaba pegando essas coisas, que eu vejo que minha prima e meu primo não tem lá no Japão. A ingenuidade deles é muita, é demais! Eles têm uma educação muito boa, tanto educação de inteligência, como educação de pessoa para pessoa. Mas às vezes fica muito na ingenuidade...”.
\end{abstract}

$\mathrm{Na}$ primeira fala de Henrique, "japonês" é um termo referente ao brasileiro descendente de japoneses e na continuação de seu discurso, a categoria refere-se ao japonês do Japão. É interessante observar como Henrique faz essa transição na ressignificação dos termos e como constrói sua identificação. Ao mesmo tempo em que afirma que a imagem de esforço nos estudos associada aos nikkeis não é condizente com a realidade, já que o valor da educação não tem tamanha "relevância" que justifique a configuração dessa imagem; reconhece que seus pais não mediram esforços para complementar sua formação e considerando-se um aluno "mediano", diz que "tem muito isso de brasileiro, o pessoal estuda só para passar de ano".

Em seguida, mostra sua admiração pela disciplina presente no sistema escolar japonês, mas enfatiza um ponto a seu ver importante. A partir do acompanhamento dos mangás ${ }^{158} \mathrm{e}$ animes e do contato que mantém com seus primos brasileiros que moram no Japão desde a infância, Henrique contrapõe a "esperteza", a percepção aguda das coisas e a "malandragem" do brasileiro com a ingenuidade do japonês, fruto da excessiva confiança depositada em outras pessoas. Henrique, diferentemente do dentista de Londrina, Rodrigo Suzuki, ${ }^{159}$ atribui um caráter positivo à "malandragem", contudo enquanto o segundo ressalta o aspecto nela presente de enganar os outros, furando uma fila, por exemplo; o primeiro destaca a "percepção", o "feeling" em não ser enganado e a postura de esperteza frente às situações que se apresentam. Em sua fala, esperteza é sinônimo de não-ingenuidade e perspicácia, não de ação desonesta. Indícios do que os jovens entrevistados consideram signos de brasilidade, sendo construídos e desconstruídos em contexto.

\footnotetext{
${ }^{157}$ Desenhos animados japoneses. Muitos animes tem a sua versão em quadrinhos, os mangás.

${ }^{158}$ Histórias em quadrinhos japoneses.

${ }^{159}$ Sansei, 22 anos, dentista de Londrina. Citado nos capítulos 1 e 2.
} 
Quando conversávamos sobre as "brincadeiras" dirigidas aos "japoneses”, tema já discutido no capítulo 2, Henrique diz: "se você se incomodar com isso, você não vive...":

\begin{abstract}
"Deixa eles imitarem, não sabem nem imitar direito! A gente tem uma cultura muito mais elevada do que a deles. O que eu gosto muito, o que eu peguei muito da minha família de ser oriental, como se diz, é a educação, o tratamento. Eu vejo com muitos amigos meus que não são 'japoneses', eu vejo muito assim... familias desestruturadas. Vejo minha família, nossa dou graças a Deus pela família que eu tenho! A convivência que a gente tem... Entre família de japoneses tem uma convivência muito mais unida do que muitas por aí. Claro que tem exceções, mas pais separados assim por besteira ou que brigam... Tudo bem que tem 'japonês' que tem isso, mas são poucos. Eu vejo em muita família que a união é muito maior e a educação também. De respeitar o próximo. Eu vejo muito a falta disso em outras culturas, do que em relação a nós. Eu acho que temos que agradecer por termos essa cultura, esse jeito, né? Meu avô é muito educado, nunca vi ele brigar sem motivo, muito educado, muito cortês quando alguém vai na casa dele. Aqui em casa mesmo, quando alguém vem aqui em casa é outra coisa. É outro tratamento".
\end{abstract}

Assim como o entrevistado Cláudio Shimada, Henrique chama a atenção para a estruturação e convivência mais unida das famílias de descendentes de japoneses e da educação recebida em casa - esta até mais baseada em ações e exemplos do que palavras - são elementos que, segundo eles, ainda se mostram presentes na maior parte das famílias nikkeis. "Maioria" e "exceção", como foi possível observar em vários discursos ao longo do trabalho, foram termos frequentemente acionados na reflexão dos interlocutores. Como pesos de uma balança, um equilibrava o outro: "a maioria dos nikkeis corresponde à imagem de esforço e honestidade, embora haja exceções, é claro".

A gratidão à família, aos pais e aos antepassados, também foi perceptível na fala de muitos entrevistados. Haveria alguma relação com o on, reconhecimento do débito que o indivíduo tem para com os pais pela formação e educação recebidas? (Benedict, 1997). Como já esclarecido, este trabalho não tem como objetivo fazer um exame descritivo sobre o conjunto de valores mencionados pelos sujeitos da pesquisa. Uma empreitada desse tipo está fora do escopo do trabalho, pois demandaria recuperar todo o processo histórico envolvente na relação desses valores com os empréstimos culturais feitos pelo Japão, como à China, por exemplo. Implicaria adentrar no domínio dos mitos nipônicos, da história milenar do Japão, dos pressupostos éticos do budismo, xintoísmo, confucionismo. O objetivo deste capítulo é apontar que para além do imaginário sobre os nikkeis, o agenciamento de três categorias - "valores", "cultura" e "colônia" japonesa/nikkei - também opera como definidor de identidades.

Como já analisado no capítulo 1, muitos entrevistados, sobretudo, jovens sanseis como Henrique, afirmaram que a percepção geral de que os descendentes de japoneses sejam esforçados no trabalho e no estudo vai se enfraquecendo a cada nova geração que surge. 
Contudo, alguns mencionaram a unidade e a estruturação familiar como elementos da "cultura japonesa" que "persistem". Ruth Cardoso (1998) mostrou como esses "padrões" foram importantes no processo de mobilidade social dos isseis e nisseis no Estado de São Paulo. Não se trata aqui de "sobrevivência cultural". Evidentemente, o modelo familiar de unidade cooperativa de trabalho e a hierarquia que submete o indivíduo aos interesses da coletividade já não mais se sustentam da mesma maneira como no passado.

Esse conjunto de valores herdados sofre transformações tanto no Brasil, quanto no Japão, países que já possuem uma diversidade interna, ganhando novos significados de acordo com as contingências históricas, mudanças geracionais e contextuais, inter-relacionamentos com outras culturas. Afirmar que os sujeitos dessa pesquisa não possuem essa percepção seria subestimar sua capacidade reflexiva. Como Yumi Kawamura, que pretende educar o filho "dentro da cultura, dentro da tradição", muitos afirmam que são outros tempos, outras "culturas", afinal, "a cultura é historicamente reproduzida na ação" ${ }^{160}$ : "Eu acho que tudo vai mudando mesmo. Não pode ficar só no 'tradicionalzão'. Por que já pensou se não tivesse mudado? Graças a Deus que mudou, né!? E tem que mudar! Deus me livre se nada mudasse! Eu acho que a gente não teria sobrevivido não”.

Yumi falava sobre o miai, a prática do casamento arranjado pelos pais, costume que estava atrelado ao devotamento filial e ao sistema de linhagem familiar ie, o qual implicava não somente a residência comum, mas também a divisão dos papéis sociais dos membros da família (Sakurai, 1993: 51). O pai, como chefe, é o centralizador das decisões e responsável pelo sustento e continuidade do nome da família (Cardoso, 1995: 84). Ao primogênito, como futuro chefe, cabia à herança e a obrigação de manter a linhagem. A escolha dos cônjuges dos filhos, portanto, era uma decisão dos pais e a submissão à vontade dos mais velhos era condizente com a noção de devotamento filial. A solidariedade no lar, o respeito aos mais velhos e a gratidão aos antepassados são elementos que claramente sofreram transformações com as novas gerações, alguns aspectos se mantiveram, mas o devotamento é já de outra ordem.

Essa configuração ie, unidade básica do Direito japonês perdurou até o fim da Segunda Guerra Mundial, mas a prática do miai foi seguida por muitas famílias isseis e nisseis no Brasil. As mudanças com a introdução de novos valores, segundo Yumi, são necessárias e positivas. Como assegura a personagem, Naoko, do romance Ipê e Sakura, analisado por Sakurai, sobre a forma de encarar a autoridade dos pais, distinta do passado, "Não é falta de

\footnotetext{
${ }^{160}$ Cf. Sahlins (2003).
} 
reconhecimento dos filhos com os pais. Não é desprezo. São por pensamentos distintos. Já imaginaram se os filhos fossem robôs?"' (Sakurai, 1993: 92).

Rodrigo Suzuki, que assim como Henrique e Cláudio, chama a atenção para a educação expressa não-verbalmente também recebida por ele, aquela codificada em ações, gestos e exemplos. Associando sua trajetória pessoal com esses valores, conclui:

\footnotetext{
"Valores são repassados pelos avós, tios, pais. Se os valores da etnia que eles passaram estão comigo até hoje? Grande parte sim. Mas por ações também. Se a gente vê desde pequeno, meu avô, por exemplo, fazendo a coisa certa, pagando certo, devolvendo o troco se deram a mais, a gente acaba incorporando sim. Carrega a maior parte dos valores sim".
}

Passados cem anos da imigração japonesa no Brasil, como pensar a relação dos jovens sanseis e yonseis com esses "valores"? Rodrigo analisa os processos de mudança, atentando para os preconceitos, resquícios de valores passados, como a submissão da mulher japonesa e a crença na suposta superioridade do "povo japonês":

\begin{abstract}
"Se essa nova geração vai seguir os cem anos, não vai. Se deveria seguir, acho que não. Cada geração tem seu tempo, cada geração tem seu momento. Alguns valores serão perdidos, mas outros serão adquiridos. Acredito muito que haverá uma igualdade daqui cinco, dez anos, vinte anos em relação a esse machismo doentio que tem hoje. Talvez isso desapareça. Uma maior aceitação de minorias, que não existe. Japonês é uma pessoa bem preconceituosa com relação a negros, a homossexuais, até hoje. Imin-200 vai ser como o 100? Não vai. Vai ser diferente. Vai ser melhor ou pior? Não sei, não tem melhor, nem pior, cada um tem seu tempo. Só não pode perder o caráter e o bom senso".
\end{abstract}

\title{
NIHONGO
}

Quando se fala em "peças" da "cultura" (Kuper, 2002), um dos itens mais mencionados, se não o mais mencionado, é a língua. Poucos foram os entrevistados que possuíam o domínio do nihongo, a língua japonesa. Os nisseis Paulo Sasaki e Isabel Nishida e o sansei Yoshio Hasegawa, entrevistados que ocupam cargos diretivos em associações nipônicas são fluentes na língua. Os dekasseguis retornados geralmente detêm um conhecimento básico ou intermediário. A grande maioria dos interlocutores só possuía uma vaga noção de algumas palavras ou termos usados, sobretudo, pelos avós, no universo doméstico.

Contudo, o desejo de aprender o idioma foi manifestado por quase todos. O dentista Rodrigo Suzuki, que já foi professor de inglês e já concluiu o curso de francês, não domina o japonês, mas diz: 'Não conheço nenhum ‘japonês' que no fundo, no fundo, não gostaria de saber o japonês. Ah, deve ser legal. Conheço ‘japonês' que não gosta de 'japonês', só quer namorar 
'brasileiro'. Mas querer aprender, todo mundo quer”. Isabel Nishida compartilha da mesma opinião, "Não conheço ninguém que fale que não gostaria de aprender a língua. A gente só vê a importância da 'cultura japonesa' quando está adulto. Só dá valor quando precisa de trabalho, de emprego". 161

Esse desejo de aprender a língua, portanto, é postergado, e na maioria dos casos será concretizado em uma idade mais madura, já que a prioridade é o aprendizado de línguas, como o inglês, e depois o espanhol e o francês, por conta das próprias necessidades do mercado de trabalho. Esse cenário tem sofrido uma gradual mudança no que concerne ao idioma japonês. Segundo uma conversa informal travada com uma das secretárias da Aliança Cultural BrasilJapão em São Paulo, entidade que oferece o curso de nihongo, a procura por cursos de língua japonesa cresceu com a ida de trabalhadores dekasseguis para o Japão, e entre os jovens, devido ao aumento das possibilidades de obtenção de bolsas de estudo e estágios em universidades japonesas e da abertura de vagas de trabalho no Brasil que tomam como pré-requisito o conhecimento do idioma.

Outro fator explicativo para a procura está no interesse de apreciadores, descendentes e não-descendentes de japoneses, pela "cultura japonesa”, principalmente pelos mangás e animes. Tais produtos culturais despertariam nos jovens a vontade de acessar o conteúdo, ou partes do conteúdo dos desenhos na língua original. Para o entrevistado Henrique Nagata, que se julga fã e não fanático por esses produtos - já que os obtém fazendo downloads pela internet e não gasta dinheiro comprando revistas, jogos, bonecos, fantasias de cosplayers $^{162}$ - sua vontade em aprender o idioma japonês tem uma relação com o gosto pelos animes e mangás:

\begin{abstract}
"Uma coisa que me fez apaixonar foi pela música. Não aquelas músicas japonesas, tipo enka. ${ }^{163}$ Mas eu gostei mais por causa das músicas, dos animes. Como não tem a tradução nesses shows, você acaba não se interessando. Já no anime, tem. Você vê a qualidade das letras das músicas. Você procura até a tradução das músicas na internet. Nossa, é estonteante, porque a linguagem, a música e a tradução são muito bonitas, são muito bem feitas, muito bem elaboradas, não é igual a esses 'tchans' da vida. O que me motivou bastante foi isso".
\end{abstract}

\footnotetext{
${ }^{161}$ A professora conta que quando seu pai teve um derrame cerebral, precisou de uma fonoaudióloga que falasse o japonês, mas não conseguiu achar um profissional qualificado na região. Isabel teve que aprender os exercícios para poder repassá-los para o pai.

162 Abreviação de "costume player", (costume = roupa / traje / fantasia e play = atuar), atividade que teve origem nos Estados Unidos, mas que se popularizou no Japão e que diz respeito à caracterização de personagens de séries, quadrinhos, mangás, animes, livros, videogames. Os cosplayers se reúnem em convenções, concursos e encontros que atingem hoje várias partes do mundo.

${ }^{163}$ Enka é um estilo musical japonês que tem origem na Era Meiji e mescla arranjos tradicionais japoneses com ocidentais, como instrumentos orquestrais, violão, guitarra. Inicialmente utilizado como meio para o ativismo político, tornou-se um gênero musical popular no Japão.
} 
O interesse pelos animes e mangás não foi a única motivação para Henrique desejar se matricular num curso de nihongo. A vontade de se comunicar com seus avós japoneses tem um peso muito mais forte. A admiração e o carinho que Henrique demonstrou ter pelos pais de seus pais foram perceptíveis já no início de nossa conversa. Nos primeiros trinta minutos, ele se dedicou a falar sobre a vida que os avós levaram no Brasil: a chegada ao interior de São Paulo, a mudança para o Paraná, e já idosos a viagem turística para conhecer a província de origem da família no Japão. Henrique disse que também tem muita vontade de conhecer o arquipélago, mas antes gostaria de aprender um pouco o japonês:

\begin{abstract}
"Esse ano quero começar o nihongo. Eu tenho interesse de ir ao Japão. Não quero ir à toa, porque eu acho que se você vai para um lugar e não souber se comunicar, metade do aprendizado, do aproveitamento é a conversação, é você aprender. Se você não conversar, não se comunicar, como você vai aprender? Você só vai ficar no visual, no paladar, no toque... Então, tem que saber alguma coisa, tem que aprender alguma coisa".
\end{abstract}

\title{
SOBRE O "NÉ?"
}

Um parêntese merece ser posto a respeito de um expediente que infelizmente me vi obrigada a adotar na transcrição das entrevistas. Alguns interlocutores utilizavam a contração “né?" da forma interrogativa, "não é?", no final das frases com tanta frequência que a própria compreensão do que diziam ficava um pouco prejudicada. Desse modo, em alguns momentos tal contração foi cortada das falas com o intuito de conservar uma melhor fluidez na leitura.

Um episódio particular por mim vivenciado começou a chamar minha atenção para esse detalhe que até então não tinha me atentado. Com a mudança para São Paulo, resolvi comprar uma televisão usada através de um anúncio pela internet. Fiz a negociação por telefone com uma senhora e quando estava tudo acertado, fui até sua casa para fechar a compra. Assim que me apresentei, ela disse: "Eu tinha certeza que você era japonesa!". "Nossa, como a senhora soube?", afinal era a primeira vez que nos encontrávamos pessoalmente. "Você falava muito 'né?' no telefone!', ela disse, rindo. Aquela conversa foi uma espécie de momento-revelação de duas coisas: a primeira, de como eu fazia uso constante dessa contração quase de forma inconsciente, e que acabou tornando-se até um vício de linguagem; e segundo, de como esse recurso e a maneira de utilizá-lo estão relacionados aos “japoneses". As caricaturas do japonês na mídia, por exemplo, comumente valem-se do emprego em demasia da contração "né?" na fala e na reverência na composição cômica de sua figura. 
Uma possível explicação para essa associação se deve a uma das formas de utilização da partícula japonesa ね (ne), sem acento agudo, em frases interrogativas: quando se espera a concordância do ouvinte ou quando se espera uma confirmação. ${ }^{164}$ Nesse caso, o emprego é semelhante ao do português, "não é?". Coincidentemente o som e o sentido das partículas em japonês e português são semelhantes. Mas não há comprovação de que essa contração tenha sido incorporada ao léxico japonês no período da chegada e estadia dos portugueses no arquipélago. Além disso, no idioma japonês, a partícula também pode ser utilizada no início das frases, mas com outro sentido.

Toda essa discussão levantada foi aqui brevemente introduzida para incitar alguns questionamentos. Em que medida a língua pode ser uma "peça" importante na construção identitária? O que dizer da língua falada, com seus regionalismos, contrações, particularidades, que como um discurso cria "nichos" de identificação? Esse episódio mostra como a língua e a fala podem "denunciar" elementos da biografia do sujeito, como a classe, a origem social, a naturalidade e até mesmo a ascendência. Como esse discurso, "eu sabia que você era japonesa!" pode provocar uma tomada de posição, seja de identificação ou não-identificação? Essas experiências vivenciadas por mim, seja na compra da televisão, seja em alguns cortes propositais do "né?" na transcrição das falas, atentam para a existência de elementos não exclusivamente visuais - como o fenótipo que imediatamente evidencia a ascendência - mas de outra ordem, na interpelação e na identificação do sujeito: “Você falava muito 'né?' no telefone!”.

\section{LÍNGUA DO SEGREDO}

Relembrando aquele episódio que relatei com mais detalhes no capítulo 2, protagonizado por Carlos, o colega que apresentou um trabalho num evento acadêmico junto comigo, e que fez uso de uma palavra japonesa para definir "pessoa de cor", cabe um último ponto a ser comentado. Imagino que ele deve ter presumido o seguinte: uma pesquisadora, descendente de japoneses, estudando os descendentes de japoneses no Brasil, certamente detém um conhecimento da língua japonesa. Se ele estivesse correto em sua suposição, o uso do termo em japonês poderia operar como uma linguagem cifrada, no tratamento de um assunto delicado, compreensível somente para nós dois. Como afirma Boris Fausto sobre o papel da língua no universo privado dos imigrantes no Brasil:

\footnotetext{
${ }^{164}$ Como no exemplo: "Ii keshiki desu ne" (Que bela paisagem, não é?).
} 
Para os pais, a língua de origem possibilitava a comunicação cifrada. Desse modo, ela servia de veículo para as conversas íntimas entre marido e mulher, longe do alcance de terceiros, especialmente das empregadas domésticas, no caso das famílias de classe média e alta, consistindo na língua do segredo, na feliz expressão de Castaldi (Fausto, 1998: 56-57).

Hoje, na maior parte das famílias nikkeis, os sanseis e yonseis conhecem algumas palavras em nihongo e dificilmente entenderão uma comunicação falada exclusivamente em japonês entre seus bisavós, avós e pais. Até o "exclusivamente" fica aqui comprometido, pois o que notamos nessas conversas é uma mistura de língua japonesa com portuguesa e dialetos das diferentes províncias do Japão, resultando em uma verdadeira amálgama linguística, que bem poderia ser sintetizada naquilo que os isseis e nisseis chamam de burajiru-go, "língua brasileira". ${ }^{165}$ Categoria nativa usada na realidade para nomear a língua portuguesa, o burajirugo é falado sim nas conversas íntimas longe do alcance de terceiros, mas aparece também naqueles almoços de domingo com batchan e ditchan. Preparados com carinho e regados à macarronada, churrasco e sushi, mistura de influências e sabores, são nessas ocasiões que ela espera ouvir: "tá oishii, batchan!". ${ }^{166}$

\section{“COLÔNIA JAPONESA": TOPOS ESPACIAL}

Além dos valores e da língua japonesa, a participação em entidades ou associações nipo-brasileiras constitui-se em um aspecto de importância significativa quando o assunto é "cultura japonesa". "Colônia japonesa" e "comunidade japonesa/nikkei" são categorias que continuamente surgem nos discursos que envolvem os japoneses e seus descendentes no Brasil. Uma das hipóteses deste trabalho é a de que a "colônia japonesa" - inicialmente caracterizada como uma configuração sócioespacial localizada territorialmente em zonas agrícolas no começo da imigração - vai aos poucos perdendo sua "materialidade" com a urbanização dos nikkeis, sobretudo os de segunda geração, os nisseis, até se transfigurar numa categoria, empregada para se referir às associações nipônicas, os nihonjin-kais, mas também mobilizada para aludir-se aos descendentes de japoneses como um todo. Nesse sentido, "colônia japonesa" é traduzida nessa pesquisa como um topos, um lugar espacial e discursivo.

Como visto no capítulo 1, a imigração japonesa no Brasil foi um empreendimento tutelado e subvencionado pelos governos japonês e paulista (Sakurai, 2000). A configuração das colônias agrícolas foi o resultado da política de investimento de capital do governo imperial nas

\footnotetext{
${ }^{165}$ Língua portuguesa, porutogaru-go, é um termo pouco utilizado nas relações cotidianas.

166 “Tá gostoso, vó!”.
} 
companhias de emigração ${ }^{167}$. A década de 1910 marca o início da formação das colônias de caráter oficial, apoiadas pelo governo japonês, como a de Iguape, Três Barras e Nova Aliança.

No processo de mobilidade geográfica e de constituição das colônias muitos imigrantes padeceram diante das extenuantes condições de trabalho nos processos de desbravamento e exploração das matas virgens. Epidemias de malária, subnutrição, esgotamento, tuberculose e outras doenças tiraram a vida de muitas pessoas. ${ }^{168}$ Kiyotani \& Yamashiro afirmam que foi o enfrentamento dessa dura realidade imposta aos primeiros imigrantes, isseis, a matriz geradora da idéia de "colônia japonesa" (CEHIJB, 1993: 78). Talvez seja possível aventar que essa seja uma das razões para que assim que uma colônia agrícola se instalasse, uma associação de japoneses fosse imediatamente organizada.

Segundo os autores, os nihonjin-kais eram entidades que funcionavam como uma forma de "estreitar as relações entre os patrícios e cuidar de assuntos coletivos" (CEHIJB, 1993: 93). De acordo com Yamashiro (id.; ib.: 205), os imigrantes japoneses destacavam-se como "maníacos" do associativismo, "reunindo-se três japoneses organiza-se uma associação", costumavam eles próprios dizer, à guisa de autocrítica"”. Tomoo Handa observou que "os imigrantes japoneses se reuniam e uniam como as folhas caídas se juntavam quando sopradas pelo vento" (id.; ib.: 440).

Essas associações eram inspiradas no modelo de aldeia rural no Japão (mura). Havia a eleição do presidente e de outros cargos diretivos, como tesoureiros, secretários responsáveis pelos assuntos culturais, esportivos, conselheiros, etc. Cabia a esses líderes a deliberação e resolução de assuntos de interesse geral, como organização de eventos, festas e edificação de instalações, ${ }^{169}$ com destaque para as escolas. Como visto no capítulo 1, os imigrantes japoneses

\footnotetext{
${ }^{167}$ Com destaque para a Kaigai Kogyo Kabushiki-Kaisha, mais conhecida como KKKK ou Kaikô (Companhia de Fomento Industrial do Ultramar S.A) e a Brasil Takushoku Kumiai - BRATAC (Corporação de Colonização do Brasil).

${ }^{168}$ A colônia Brejão localizada no município de Álvares Machado-SP conserva até hoje o único cemitério japonês no Brasil, onde se encontram sepultadas 784 pessoas, entre japoneses e descendentes e um único não-descendente que faleceu defendendo uma família de nipônicos. Todo segundo domingo de julho, é realizado ali um culto em homenagem aos mortos, o Shokonsai, termo que significa "convite às almas para a missa", celebração que tive a oportunidade de presenciar no seu $89^{\circ}$. ano, em 2009. Depois da missa, os participantes do evento, que em média reúne três mil pessoas segundo os organizadores, oriundas, sobretudo do Estado de São Paulo, encontram-se na antiga sede da associação que fica ao lado do cemitério, local tombado pelo CONDEPHAAT (Conselho de Defesa do Patrimônio Histórico, Arqueológico, Artístico e Turístico) do Estado de São Paulo. Pude perceber que além de cultuar os antepassados, o evento que conta também com a venda de comidas típicas e apresentação de espetáculos de canto e dança, como o karaokê e taikō, acaba sendo um ponto de encontro entre os antigos moradores da cidade de Álvares Machado e região de Presidente Prudente-SP que não mais residem ali. Algumas caravanas, que saem, sobretudo da capital, São Paulo, são organizadas exclusivamente para as pessoas passarem o dia no local, oportunidade para rever os amigos e rememorar os tempos da infância e juventude.

${ }^{169}$ Kiyotani \& Yamashiro chamam a atenção para um anúncio de Shuhei Uetsuka, presidente da Associação de Japoneses do Noroeste, em 10 de maio de 1924, no Notícias de São Paulo, pedindo o comparecimento dos representantes de entidades locais a uma reunião para discutir a respeito da construção de um hospital. Os autores
} 
as construíam e depois as doavam para o Estado. O propósito consistia em enfrentar os problemas através do cooperativismo e união de forças. Esse ideal ainda persiste até os dias de hoje como modelo na organização estrutural dessas entidades. Cardoso afirma que os nihonjinkais constituíram-se em "um dos caminhos pelos quais se ganhou consistência a ideia de colônia japonesa" (Cardoso, 1998: 125).

O desbravamento de zonas pioneiras e a consequente mobilidade espacial que o mesmo implicava, a facilidade no financiamento dos lotes e a orientação técnica no plantio oferecidas pelas companhias de emigração e colonização e o esforço cooperativo entre os membros da família que perfaziam uma unidade de trabalho são os principais fatores que Ruth Cardoso aponta para a ascensão econômica dos imigrantes japoneses no Brasil. ${ }^{170}$ As redes de cooperação se estendiam também aos vários grupos domésticos, os quais se uniam em formas associativas que exerciam um grande controle sobre os membros dos isolados núcleos, obtendo satisfatórios resultados econômicos. ${ }^{171}$ Nas palavras da autora:

Em primeiro lugar é preciso lembrar que o colono não se torna arrendatário ou pequeno proprietário exclusivamente por sua capacidade de poupança. Insistimos nos aspectos positivos e específicos da centralização de recursos e decisões, porque isso tem sua importância, mas é preciso agregar outro fator atuante nesse processo: a solidariedade nacional, em outras palavras, o aparecimento da noção de Colônia Japonesa (Cardoso, 1998: 121) (grifos da autora).

Por solidariedade, Cardoso denomina essa rede de relações extra-familiares composta por parentes e amigos que os imigrantes contavam quando decidiam arrendar ou comprar um sítio em outra região. Conselhos, ajuda, orientação, empréstimos ${ }^{172}$ também vinham acompanhados muitas vezes da compra de propriedades contíguas a essas outras famílias, permitindo constituir núcleos "etnicamente homogêneos", fundamentais para a organização da produção em outros moldes.

pontuam que o anúncio, ao demarcar a existência de uma associação regional, já era um indício da difusão da ideia de "comunidade japonesa" (CEHIJB, 1993: 97).

${ }^{170}$ Cardoso (1998) analisa como a flexibilidade na composição do grupo doméstico japonês facilitou o ajustamento às condições de trabalho nos países imigrantes e, consequentemente, a mobilidade social dos nikkeis.

${ }^{171}$ Esse modelo de cooperação também deita suas raízes nas unidades cooperativas compulsórias formadas pela reunião de grupos domésticos no Japão e lideradas pelos seus chefes de famílias.

${ }^{172}$ Talvez seja possível afirmar que o tanomoshi ou sistema de financiamento mútuo tenha sido um elemento importante como fator de aliança da "colônia". Existente no Japão desde o século XIII, essa prática mediada não por aparatos legais, mas pela confiança e compromisso moral, previa a organização de um fundo comum obtido através das contribuições do grupo, sendo que, regra geral, os mais necessitados eram os primeiros a receberem o valor reunido. Tal sistema foi empregado, sobretudo nos casos de necessidades de remessas de dinheiro ao Japão. Posteriormente, acabou por se estender ao financiamento das atividades agrícolas (CEHIJB, 1993). 


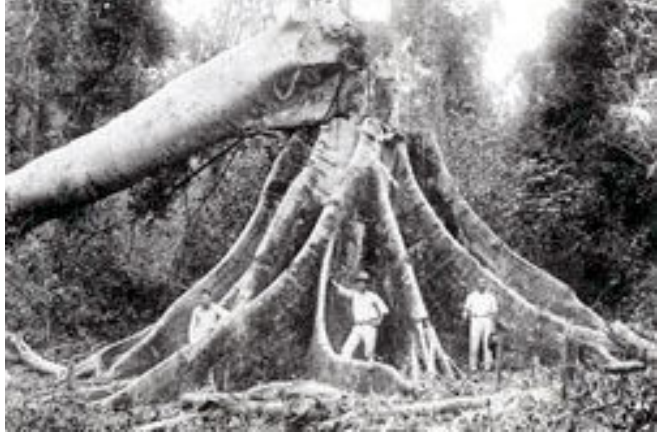

Fig. 16 Desbravamento de terras. Fonte: Museu Histórico da Imigração Japonesa no Brasil

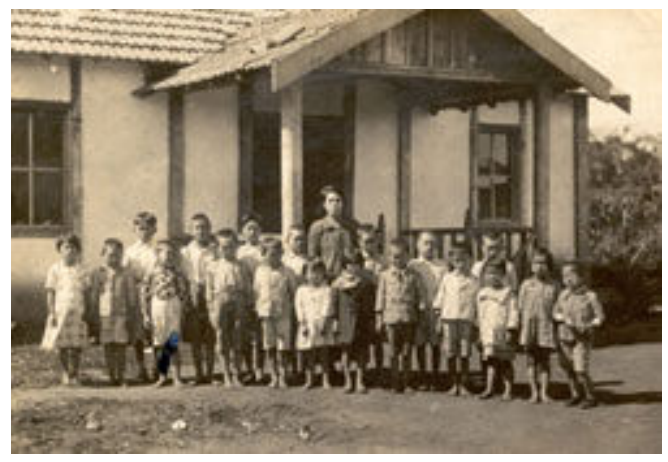

Fig. 17 Escola nas colônias agrícolas. Fonte: MHIJB.

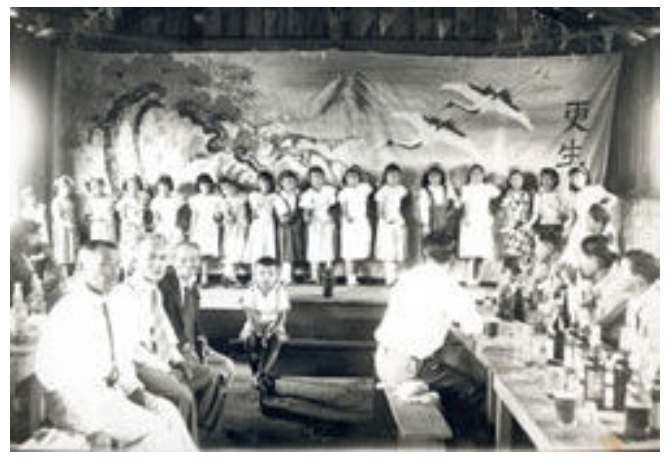

Fig. 18 Nihonjin-kai. Fonte: MHIJB.

Esse trabalho associativo estará atrelado à futura organização das cooperativas agrícolas, que passarão a se configurar como importantes polos aglutinadores da colônia. Forjadas em meados da década de 1920, constituem-se hoje como associação de produtores, cujo objetivo consiste em satisfazer as necessidades econômicas comuns, prestando serviços como elaboração de contratos, pesquisa de terras, compra e venda coletivas, financiamento de capital, etc. O Nippak Shinbun, em 3 de dezembro de 1926, adiantava que

o desenvolvimento das colônias e o próprio progresso dos imigrantes japoneses em geral, dependerá de uma organização alicerçada em bases econômicas. Que organização seria essa? Não é outra senão a cooperativa agrícola. Em vez de começar com associação de japoneses, deve-se iniciar com a organização de cooperativa agrícola. ${ }^{173}$ (CEHIJB, 1993: 104).

Como vimos no capítulo 1 , a preocupação com a educação do nissei norteou a passagem dos imigrantes japoneses nos diversos países que os receberam. O desejo de que ele

\footnotetext{
${ }^{173}$ Kiyotani \& Yamashiro chamam a atenção para a importância dos jornais japoneses como veículos de informação sobre os acontecimentos da colônia, do Brasil e do Japão. Creditam aos mesmos um papel de destaque no desenvolvimento das cooperativas ao colocarem os anúncios por elas propagados e ao fornecerem comentários esclarecedores a respeito do funcionamento das mesmas. Anos depois, esses jornais serão diretamente atingidos pela política de nacionalização getulista que proibirá a circulação de publicações em língua estrangeira (CEHIJB, 1993).
} 
dominasse a língua japonesa e portuguesa e recebesse uma educação dentro dos princípios da tradição cultural e moral nipônica também se verifica na edição do Nippak Shimbum de 1925, que já prenunciava a permanência definitiva dos imigrantes no Brasil:

Seja qual for a forma da emigração, a maioria terá que morrer na terra para onde emigrou, logo a educação do dainissei (nissei) deve ser a local, ou seja, brasileira. Não há necessidade de impor o espírito de reverência ao imperador e amor à pátria (japonesa). Será perfeito se formar cidadãos conscientes de seus deveres, corajosos e honestos; então teremos uma segunda geração (filhos de japoneses) dos quais não precisamos nos envergonhar. Só uma coisa: é preciso ensinar bem a língua japonesa. Alertamos para que não se confunda essa orientação com a educação de cidadãos brasileiros; não se deve colocar o carro diante dos bois. (CEHIJB, 1993: 99-100).

Muitos autores como Jeffrey Lesser e Tomoo Handa apontam o chamado "incidente crisântemo" como um episódio representativo das tensões identitárias do nissei envolvendo as nacionalidades brasileira e japonesa. Tal incidente deveu-se à publicação do artigo "A nossa mentalidade" em 1935 pelo estudante de Direito, Cássio Kenro Shinomoto, no jornal O Gakusei (O Estudante) da Liga Estudantina Nipo-Brasileira. Em linhas gerais, o artigo exortava a brasilidade dos filhos dos imigrantes, criticando as correntes acusações de enquistamento e nãoassimilação: "como poderemos amar a terra de nossos antepassados? Se nem a conhecemos? Podemos ter quando muito um sentimento de respeito pela pátria de nossos pais, mas nunca a idéia de patriotismo pela terra dos crisântemos" (id.; ib.; 1993: 171). Outro artigo conclamava: "sua pátria é esta terra (e você é) o filho desta terra, o Brasil" (Lesser, 2001: 223).

A política doutrinária militarista e ultranacionalista desenvolvida pelo governo imperial japonês tinha fortes reverberações entre os imigrantes, leitores dos jornais que reproduziam essas diretrizes. A repercussão do polêmico artigo forçou o desligamento de Shinomoto do jornal e da LENB. No entanto, o episódio foi um marco nos nascentes debates sobre identidade. O jornal Transição, também publicado pela Liga, em 1939, em substituição ao extinto Gakusei, apresentava sua proposta: "nós, brasileiros, filhos de japoneses, somos uma transição. Transição entre aquilo que foi e aquilo que será. Transição entre o Oriente e o Ocidente. Representamos o traço de união entre dois extremos. Por paradoxal que pareça, unimos os antípodas [...]" (Lesser, 2001: 176).

Esse debate configurar-se-á no contexto do processo de radicação dos imigrantes japoneses no Brasil, o qual pode ser verificado com a aquisição de propriedades. Se em 1912, 91,9\% dos imigrantes viviam sob a condição de colonos, trinta anos depois, em 1942, 59,7\% eram proprietários de suas terras (Cardoso, 1998). Contudo, grande parte desses imigrantes desejava que os filhos ascendessem socialmente e o estudo era considerado o principal meio para 
essa conquista. A mudança para as cidades foi um passo para a consecução desse objetivo, além de ter sido motivada também por fatores como a crise do café e a oportunidade de dedicação à atividade comercial conquistada após a acumulação de capital na lavoura.

Essa mudança abala o fechamento na colônia e o isolamento familiar de muitos imigrantes e descendentes, cujo esforço na capitalização de recursos através da terra, restringira muito seus contatos com os não-nikkeis. Entretanto, a urbanização como uma etapa no processo de ascensão também foi favorecida pelos laços de família e amizade, a partir de uma solidariedade mais vaga, porém ainda definida em termos da "colônia japonesa". Nesse processo, a colônia vai perdendo as características de agrupamento homogêneo dotado de uma referência espacial rural, passando a conformar um "campo de relações potenciais" na cidade, que se delineou por meio das marcas diferenciais - fenotípicas e culturais - como a língua japonesa, por exemplo, que permitiam uma identificação e apoio mútuo entre os nikkeis (Cardoso, 1998: 139). ${ }^{174}$

A mudança para as cidades não significou o fim das associações. Ao contrário, inúmeros nihonjin-kais foram criados ao longo da permanência dos nikkeis no país, como os kenjin-kais, ${ }^{175}$ associações dos imigrantes e descendentes de uma província do Japão. Atualmente são ao todo 46 entidades sediadas no país, coordenadas pelo Kenren, Federação das Associações de Províncias do Japão no Brasil. O intercâmbio cultural, social e assistencial entre Brasil e Japão, a promoção de eventos culturais e a intermediação na concessão de bolsas de estudos no Japão para jovens descendentes de suas províncias são uma das principais atividades dos kenjin-kais.

Com o fim da Segunda Guerra, a participação da "colônia" nos festejos do IV Centenário de São Paulo em 1954 é entendida por Nakasumi \& Yamashiro (CEHIJB, 1993: 398) como uma tentativa de superar a crise interna envolvendo a cisão entre "derrotistas" e "vitoristas" no conflito da Shindo Renmei. Segundo os autores, a mobilização para os festejos consistiu na "maior atuação coletiva e unificada da colônia nikkei do Brasil em toda sua história até então, compreendendo o período anterior e posterior da guerra". A partir desse marco, entidades de caráter nacional são criadas, como a Sociedade Brasileira de Cultura Japonesa (Bunka Kyokai - Bunkyō) em 1955, representativa da "comunidade nikkei”, pois integradora das diversas associações de japoneses e a Aliança Cultural Brasil-Japão em 1956, que visava o

\footnotetext{
${ }^{174}$ Cardoso aponta que no interior de ocupações que não exigiam qualificação profissional, como os feirantes, os iniciantes sempre esperavam contar com facilidades no contato com as firmas atacadistas japonesas. A autora atribui a essa rede de solidariedade, a concentração dos imigrantes em certos ramos de atividade, como tinturarias, oficinas, floriculturas, quitandas (id., ib.).

${ }^{175}$ Ken: Província/ jin: pessoa/ kai: associação.
} 
intercâmbio cultural entre os dois países. O Enkyō, Beneficiência Nipo-Brasileira de São Paulo é fundado em 1959. ${ }^{176}$

\section{“COLÔNIA JAPONESA/COMUNIDADE NIKKEI”: TOPOS DISCURSIVO}

A atuação conjunta da "colônia" nesse festejo, portanto, é considerada por alguns estudiosos da imigração japonesa como um marco simbólico para o entendimento da ideia de comunidade nikkei. Soma-se a esse fato, a urbanização dos nisseis e a sua inserção nas carreiras profissionais liberais, as quais conduzem a um inevitável enfraquecimento das organizações de produção fundadas nos moldes das colônias. Em outras palavras, a noção de Burajiru Nikkei Koronia (comunidade nikkei) ganha espaço, deslocando a categoria colônia japonesa no sentido que originalmente possuía de configuração sócioespacial, próxima da ideia de Zaihaku Hōjin Shakai (Comunidade dos Irmãos Residentes). ${ }^{177}$

Jeffrey Lesser afirma que se até a década de 1920, os imigrantes e seus descendentes se autodefiniam como japoneses, a partir dos anos 30 e 40, tendo em vista as impossibilidades de retorno ao Japão, passam a questionar o seu lugar no interior da nação e cultura brasileiras. O autor aponta que o termo "nikkei" passou a ser reivindicado a partir da década de 40 para distinguir os nipo-brasileiros tanto da geração imigrante quanto dos nipo-americanos (dos Estados Unidos). Mas foi, em 1985, no Congresso Pan-Americano Nikkei, que o termo foi formalmente adotado como designativo das pessoas com ascendência japonesa nas Américas (Lesser, 2001: 226).

Como é possível observar ao longo do trabalho, os sujeitos dessa pesquisa pouco utilizam a categoria nikkei quando falam de si. O termo "japonês" é o mais comumente mobilizado. Isso não significa que essas pessoas não se sintam ou não se pensem como brasileiras. Os conflitos internos decorrentes das "crises de identidade" são mais comuns em indivíduos que se encontram em contextos de trânsito, como os sofridos pela primeira e segunda geração de imigrantes no Brasil, e no Japão, com os brasileiros dekasseguis.

Uma das hipóteses deste trabalho é a de que a noção de colônia japonesa/comunidade nikkei, assim como a ideia de "cultura japonesa" constituem-se como peças, dispositivos

\footnotetext{
${ }^{176}$ Originalmente chamado de Associação de Assistência aos Imigrantes tinha como função prestar atendimento e assistência aos novos imigrantes japoneses que entravam no país com a reabertura do fluxo migratório em 1952. Em 1963, a Enkyō é reconhecida como entidade de utilidade pública pelo governo do Estado de São Paulo (CEHIJB, 1993: 407).

${ }^{177}$ Cumpre ressaltar que a manutenção de certos hábitos e práticas culturais do país de origem nessas experiências coloniais não significa assumir aqui o pressuposto da existência de comunidades homogêneas e unificadas, com fronteiras bem definidas com relação à sociedade majoritária.
} 
agenciados pelos sujeitos nos contextos de construção identitária. Como vimos, as colônias japonesas eram configurações espaciais e simbólicas que abarcavam de modo geral, as propriedades dos colonos japoneses, as cooperativas e os nihonjin-kais. Com o processo de urbanização dos nikkeis, "colônia" e "comunidade" passam a ser utilizadas também para se referir aos nikkeis como um todo. Cumpre observar que essa acepção sempre carregava as conotações ora positivas, ora negativas, de acordo com os discursos em fluxo. A palavra "colônia" ou "comunidade" japonesa como "fenômeno ideológico por excelência", signo "móvel, vivo, plurivalente", adquiria novos sentidos dependendo do contexto em que estava inserida (Bakhtin, 2002).

Como visto nos dois primeiros capítulos, essa estratégia linguística pôde ser observada nos discursos favoráveis a essa imigração, que faziam uso da ideia de colônia para mostrá-la como exemplo de produtividade, industriosidade e prosperidade, destacando o papel das cooperativas como centros de produção e dando ênfase ao crescimento econômico do país obtido com a expansão das lavouras dos imigrantes. Já os discursos contrários primavam pela associação da colônia a um elemento estranho do corpo social. Em um primeiro momento, referindo-se a ela como "quisto racial", "núcleo etnicamente perigoso" para a formação eugenética da nação com sua propagada feiura e costumes bárbaros. Em um segundo momento, a colônia passou a ser sinônimo de "quinta-coluna", "ninho de serpentes", preparada para seguir às ordens imperiais e iniciar uma ocupação de todo o país. ${ }^{178}$ Já nos discursos do centenário da imigração, a "comunidade nikkei" é vista como um exemplo de sucesso e de integração à sociedade.

Vale lembrar que a categoria "colônia japonesa" também continua a ser empregada para se referir às associações nipônicas. "Crescer dentro da colônia" ou "viver em colônia" significa partilhar não somente o espaço das entidades, mas um conjunto de tradições, práticas, valores, códigos da "cultura japonesa". Estas associações sediadas em várias cidades do Brasil e geralmente constituídas por núcleos internos, como as associações de senhoras (fujin-kai) e de jovens (seinen-kai), desenvolveram-se nos moldes das primeiras redes de cooperação. Os seinenkais, por exemplo, que tradicionalmente, visavam o aprendizado do português e aperfeiçoamento do japonês, também eram importantes meios de divulgação de tradições culturais e modalidades esportivas japonesas, representando interessantes vias para o estreitamento de relações entre os jovens de várias localidades.

\footnotetext{
${ }^{178}$ Conforme os discursos presentes nas obras de Dezem (2005), Lesser (2001; 2008), Nucci (2000), Takeuchi (2008a).
} 
Nos dias de hoje, a participação nesses espaços ainda é muito recorrente nas cidades de Astorga ${ }^{179}$, Maringá ${ }^{180}$ e São Paulo ${ }^{181}$ e também exerce um importante papel na configuração de teias de sociabilidade, que como veremos, dizem muito sobre a negociação de identidades de seus membros. Contudo, é possível perceber a relativa diminuição da participação dos nikkeis, sobretudo dos jovens, nesses espaços. Nas entrevistas realizadas, a falta de tempo, interesse ou vontade de se engajar em atividades voluntárias e, sobretudo, a não-participação dos demais membros da família são os principais fatores apontados para justificar a ausência de vínculo com tais entidades. Nesse caso, o pai apresenta um papel importante na "criação da família dentro da colônia". Muitos alegaram que não participavam, porque o pai não fazia questão, como Mariana Yoshida, sansei, 36 anos, engenheira da computação que atualmente mora em São Paulo, mas que passou a infância e adolescência no Rio de Janeiro:

\begin{abstract}
"Meus pais nunca fizeram questão de manter essa coisa de colônia, de comunidade, de formar um grupo só de amigos descendentes [...] nunca fizeram uma seleção... Porque eu vejo aqui em São Paulo que tem gente que faz isso mesmo, essa distinção, de procurar se aproximar, de ter um círculo de amigos só de descendentes. Aqui eu percebo com alguns colegas que conheci no trabalho que eles... que os amigos próximos que eles fazem os programas de final de semana... sempre é japonês. Aí mandam filhos para a escola que é de predominantemente de japoneses, até fazem nihongako ${ }^{182}$ [...]. São pessoas mais apegadas à tradição, à cultura, que só falam japonês em casa com a filha, que querem manter... [...] Então, lá no Rio não tem nada disso. Não tivemos isso, lá não é uma coisa forte. Se você quiser ir atrás, você até consegue, mas dá muito mais trabalho do que aqui em São Paulo, né? Meu pai nunca foi esse 'japonês, japonês' que gosta de manter essa coisa da comunidade fechada. Sempre foi totalmente aberto com relacionamentos, tanto que hoje no círculo próximo de amizades tem pouquíssimos amigos descendentes, que são do dia a dia. E o meu também, para falar a verdade, muito pouco. ${ }^{183}$ Alguns que são 'mestiços', né? Mas assim, eu nunca procurei me aproximar... e acho até estranho quando você de repente está num grupo que só tem 'japonês', só descendente! No trabalho, eu vejo acontecer, porque aqui em São Paulo tem bastante... Às vezes, você acabava juntando e o pessoal olhava, 'olha a reunião da colônia!' [risos]. Mas assim, para mim, é totalmente sem ser intencional”.
\end{abstract}

\footnotetext{
${ }^{179}$ Associação Cultural e Esportiva de Astorga (ACEAST) foi fundada em 1948, sob o nome original de Associação Desportiva de Astorga - Associação Manguetsu-Kai (Lua cheia). O nome teve origem na marcação das reuniões nas noites de lua cheia, pois a luminosidade facilitava a vinda dos moradores que percorriam a pé a distância de suas propriedades até a sede. Conta atualmente com 80 famílias associadas.

${ }_{180}$ A Associação Cultural e Esportiva de Maringá (ACEMA) surgiu em 18 de junho de 1947, originalmente com o nome de Nihonjin-Kai (Associação dos Japoneses de Maringá), representando 65 famílias de imigrantes. No mesmo ano, os jovens nikkeis criaram a SOCEMA (Sociedade Cultural e Esportiva de Maringá). A fusão das duas entidades em 1972 gerou a atual ACEMA que hoje agrega aproximadamente 2 mil associados.

181 São Paulo conta com inúmeras associações, como as representativas de seus bairros e as relacionadas às províncias do Japão (Kenjin-kais). Segundo Koichi Mori (2007: 227), os japoneses que vieram das ilhas principais do Japão constituíram grupos que se estabeleceram principalmente ao longo da atual linha norte-sul do metrô. Já os provincianos de Okinawa organizavam suas associações a partir dos vínculos entre conterrâneos e relacionamentos familiares, concentrando-se, principalmente, na região leste da cidade.

${ }^{182}$ Nihon: japonês. Gako: escola. Como vimos, os nihongakos, escolas de língua japonesa, proliferaram nas fazendas e colônias agrícolas no início da imigração, contudo foram proibidas a partir de 1941, funcionando somente de forma clandestina. Atualmente é um termo usado também para se referir a cursos dedicados ao ensino do nihongo, língua japonesa.

${ }^{183}$ Mariana é casada com um não-descendente.
} 
De modo geral, essas associações preconizam o objetivo de "representar a comunidade nipo-brasileira e promover a preservação e divulgação da cultura japonesa no Brasil e da brasileira no Japão, bem como incentivar e apoiar as iniciativas voltadas a esta finalidade" ${ }^{~} 184$. Desse modo, a divulgação de atividades culturais e esportivas, assim como no passado, ainda representa o eixo dessas associações, que contam especialmente com o trabalho voluntário de seus membros na organização dos eventos. Faz-se necessário enfatizar que esse modelo de associativismo, voluntarismo e departamentalização também se faz presente na estrutura de outras entidades nikkeis, como as religiosas, por exemplo.

\section{ACEAST: BREVES INCURSÕES NO CAMPO}

Como já discutido, quando o tema em questão é a "cultura japonesa", as associações nipônicas ou nipo-brasileiras são "peças" fundamentais para o entendimento da categoria. São consideradas pelos seus membros como locais propícios para o desenvolvimento de práticas e atividades culturais, ligadas ao universo do esporte, música, culinária, dança, língua, artes japonesas. Encaradas como espaços de "preservação" e "divulgação" da "cultura japonesa", ali essa tradição é reinventada: aspectos do passado são mantidos, outros são (re) elaborados. A presença de elementos de outras culturas é sentida no resultado final, o arranjo criativo que mistura tendências, sabores, sons, pessoas.

Essas associações são geralmente mantidas por meio das mensalidades cobradas dos associados e de eventos culturais promovidos com o intuito de arrecadar fundos. Na Associação Cultural e Esportiva de Astorga (ACEAST), por exemplo, jantares com típica comida oriental, yakissoba, sukiyaki, yakimeshi ${ }^{185}$ e frango xadrez, são promovidos algumas vezes durante o ano. Promoções do mais famoso típico prato brasileiro, a feijoada, também são feitas. O dinheiro arrecadado é utilizado para conservação do espaço físico da entidade e para organização de festas para os associados, como a do dia dos pais, das mães, das crianças, dos idosos, o undōkai ${ }^{186}$ e o

\footnotetext{
184 Retirado do site do Bunkyo (Sociedade Brasileira de Cultura Japonesa e de Assistência Social). http://bunkyo.bunkyonet.org.br/ Acesso: 07/06/2010.

${ }^{185}$ Yakissoba: tradicional prato de origem chinesa a base de macarrão tipo lámen, carne e legumes. Sukiyaki: prato japonês composto por carne, tofu, vegetais, cogumelos temperados com shoyu e sakê. Yakimeshi: espécie de risoto preparado com cenoura, cebolinha, omelete e presunto.

${ }^{186}$ Undō: movimento/esporte. Kai: associação/reunião. Espécie de gincana esportiva com direito a "prêmios", como produtos escolares, de cozinha, de limpeza, doces. Há diversas brincadeiras, como corrida, revezamento, pesca de garrafas, cabo de guerra. Realizada uma vez durante o ano e mais do que incitar a competição, visa a confraternização dos participantes.
} 
bōnenkai. ${ }^{187}$ Nesses eventos todos os membros são convidados e as despesas necessárias ficam por conta da entidade. As atividades culturais oferecidas são o nihongako, karaokê, taikō e dança de salão, cobradas com mensalidade à parte para o pagamento dos professores. Essas atividades são abertas para a comunidade em geral, não somente para os associados. No caso do taikō e dança de salão, a maioria dos praticantes não é descendente de japoneses.

A manutenção dessas associações pequenas é encarada sob muitos aspectos como uma verdadeira luta. No caso da ACEAST, além da "colônia" ser bastante reduzida, ${ }^{188}$ a evasão de seus membros, sobretudo dos mais jovens, que se mudam para cidades maiores, como Maringá, Londrina e Curitiba para estudar e frequentemente acabam não retornando à cidade de origem, é apontada como a principal razão para as preocupações quanto à sobrevivência da mesma. Em Astorga, esses jovens que retornam somente nos finais de semana para o município, geralmente participam dos eventos promovidos pela entidade, como jantares, festas, undōkai, mas não atuam como voluntários. Não há um departamento de jovens, seinen-kai, na entidade. Outro ponto importante é a falta de tempo das pessoas em se dedicar às atividades demandadas pela associação. No caso do "jantar oriental” da ACEAST e também do Festival Nipo-Brasileiro, festa mais importante organizada pela Associação Cultural e Esportiva de Maringá (ACEMA), o voluntariado é o principal motor para a organização e existência desses eventos.

Cortando verduras, cozinhando macarrão, servindo mesas, essas pessoas muitas vezes passam o dia inteiro no kai kan. Na ACEAST, o trabalho dispensado não é remunerado. Nem mesmo o jantar sai por conta da casa. Assim como qualquer convidado, o voluntário deve pagar o cartão que dá direito à refeição. No final do evento, a comida e as verduras que não foram consumidas são repartidas entre aqueles que ajudaram na organização do jantar. Além da satisfação em colaborar, é a única coisa que levam para casa.

\footnotetext{
${ }^{187}$ Bōnen: despedida do ano. Kai: associação/reunião. Espécie de confraternização de final de ano realizada pelas entidades.

${ }^{188}$ De acordo com os dados censitários da cidade, Astorga possui 25.164 habitantes. Como consta na nota 19, Astorga não recebeu um fluxo tão grande de imigrantes japoneses como as cidades interioranas Maringá, Uraí, Assaí e Londrina no Paraná ou Álvares Machado, Marília e Presidente Prudente em São Paulo. Uma pesquisa informal realizada junto à ACEAST aponta que há cerca de 80 famílias associadas, perfazendo um total de aproximadamente 214 pessoas. Contudo, é importante frisar que há também na cidade muitas famílias nikkeis que não são associadas e não participam das atividades promovidas pela ACEAST. O percentual estimado da população nikkei total no município é de $1,3 \%$.
} 


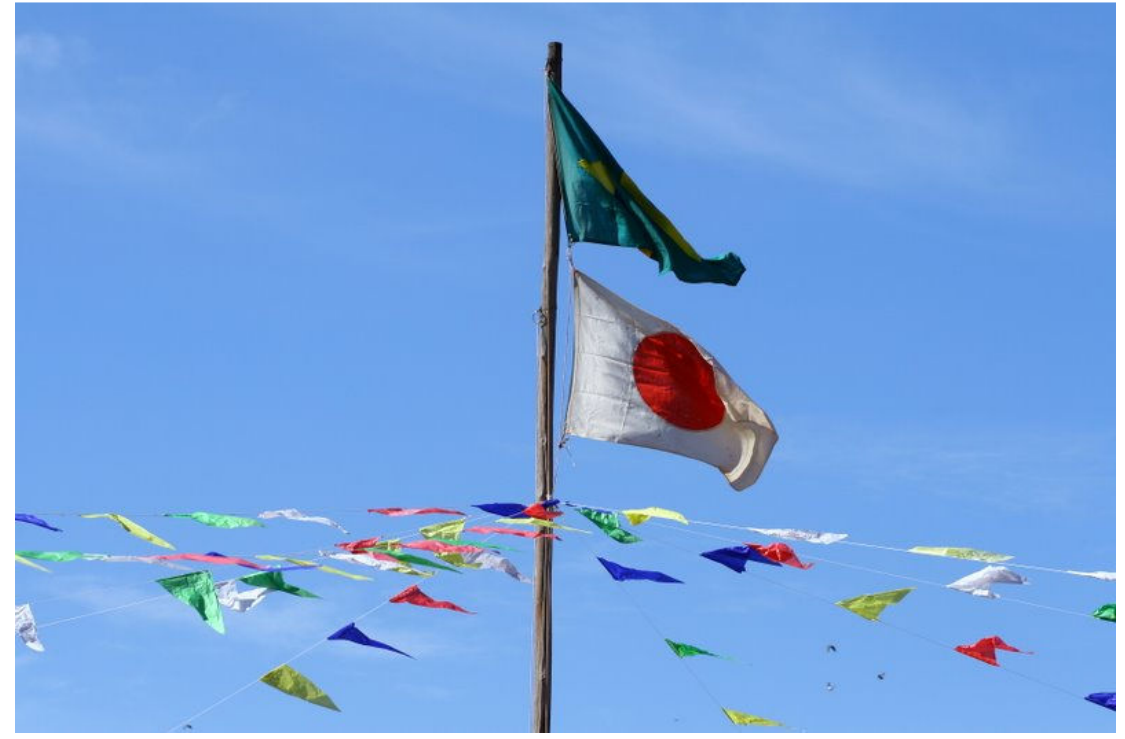

Fig. 19 Hasteamento das bandeiras brasileira e japonesa no undōkai da ACEAST. Maio/2008. Foto: Leandro Monteiro.

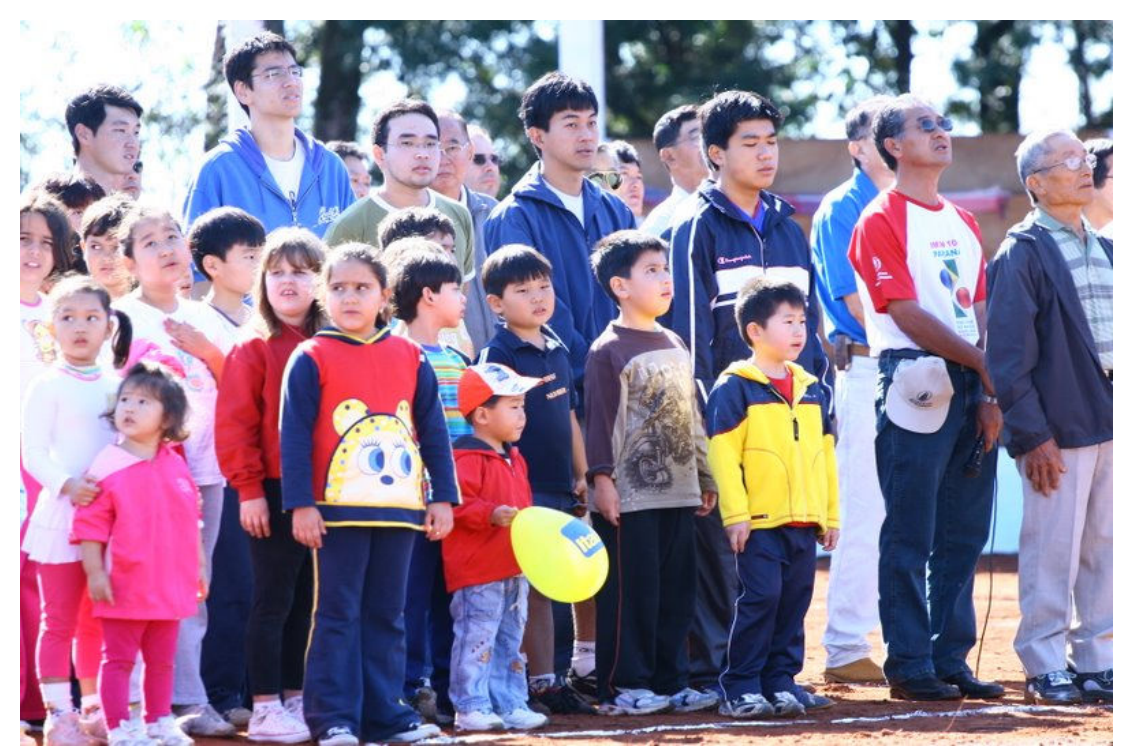

Fig. 20 Início das atividades no undōkai é precedido pelo canto dos hinos brasileiro e japonês. Detalhe para as diferentes gerações presentes. Maio/2008. Foto: Leandro Monteiro. 


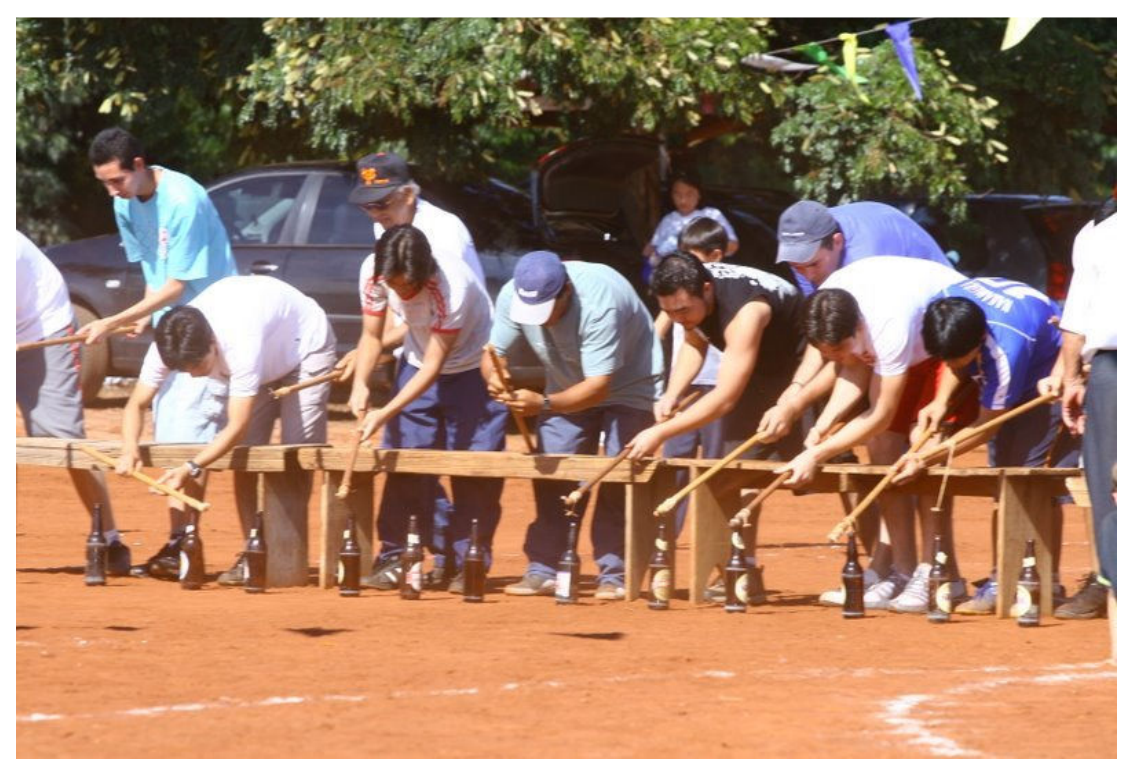

Fig. 21 Pesca de garrafa. Jovens costumam participar somente desses eventos. Foto: Leandro Monteiro.

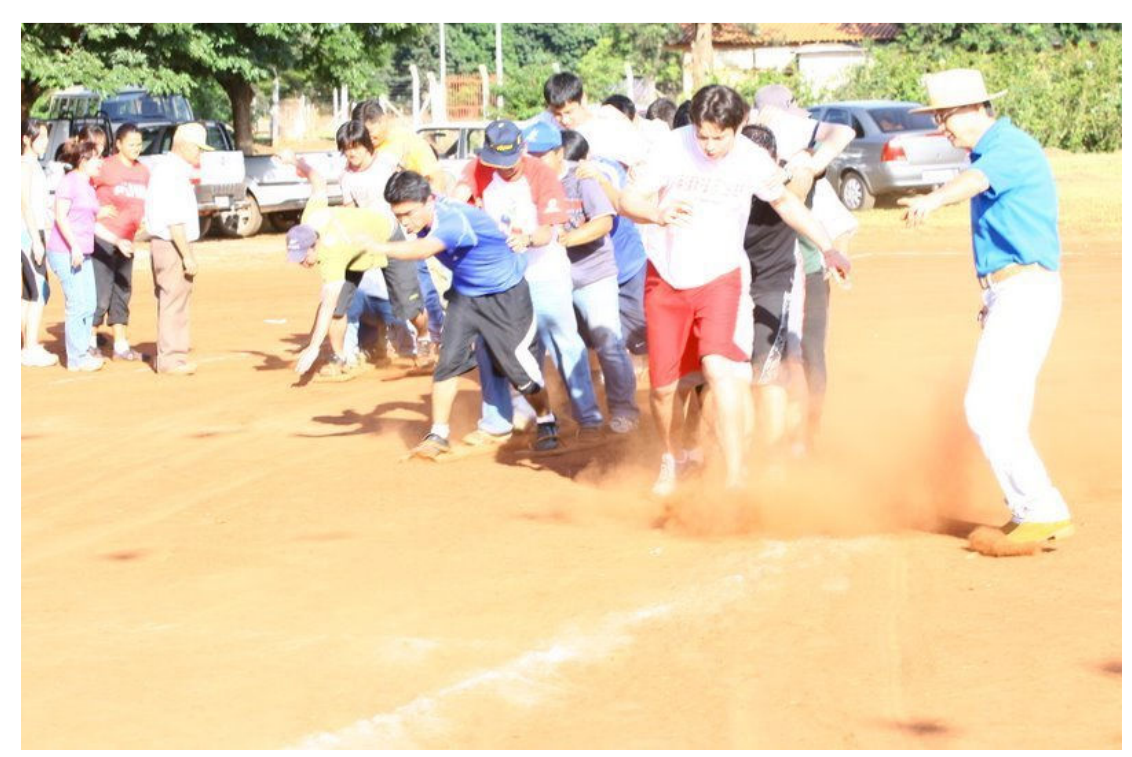

Fig. 22 Corrida de guetá ${ }^{189}$. Foto: Leandro Monteiro.

\footnotetext{
${ }^{189}$ Guetá: tradicional tamanco de dedo japonês feito de madeira e usado com meias. A brincadeira realizada em grupo, muito tradicional nos undōkais, consiste em uma corrida de guetá. O objetivo é tentar sincronizar os passos do grupo sobre o guetá, da maneira mais rápida possível. Duas tábuas com cinco barbantes, imitando as tiras bifurcadas do tamanco, que se estendem entre o dedão e o indicador do pé até as laterais, são posicionadas uma ao lado da outra. O grupo que conseguir atingir primeiro a linha de chegada é o vencedor. Como é possível observar na foto 22 , a brincadeira levanta uma nuvem de terra vermelha que se mistura aos tombos e gargalhadas dos participantes e do público que assiste a tudo.
} 


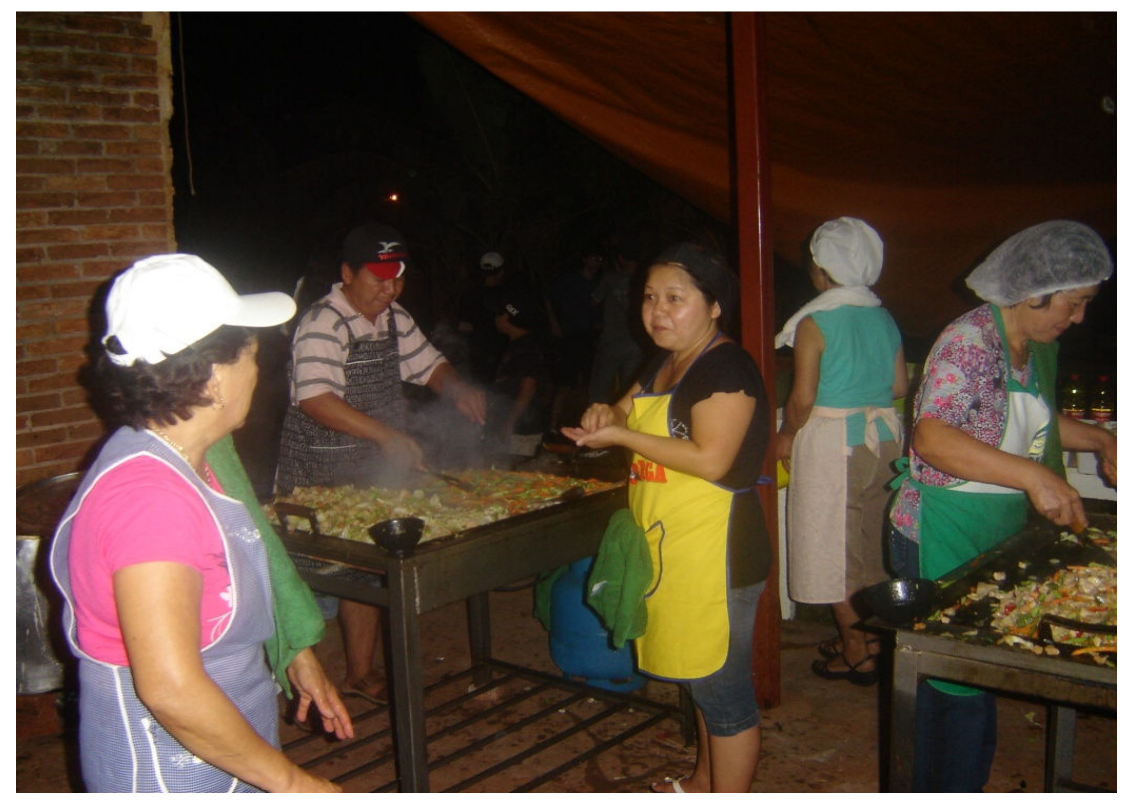

Fig. 23 Voluntários fazendo sukiyaki no "chapão". Abril/2009. Foto: Camila Ischida.

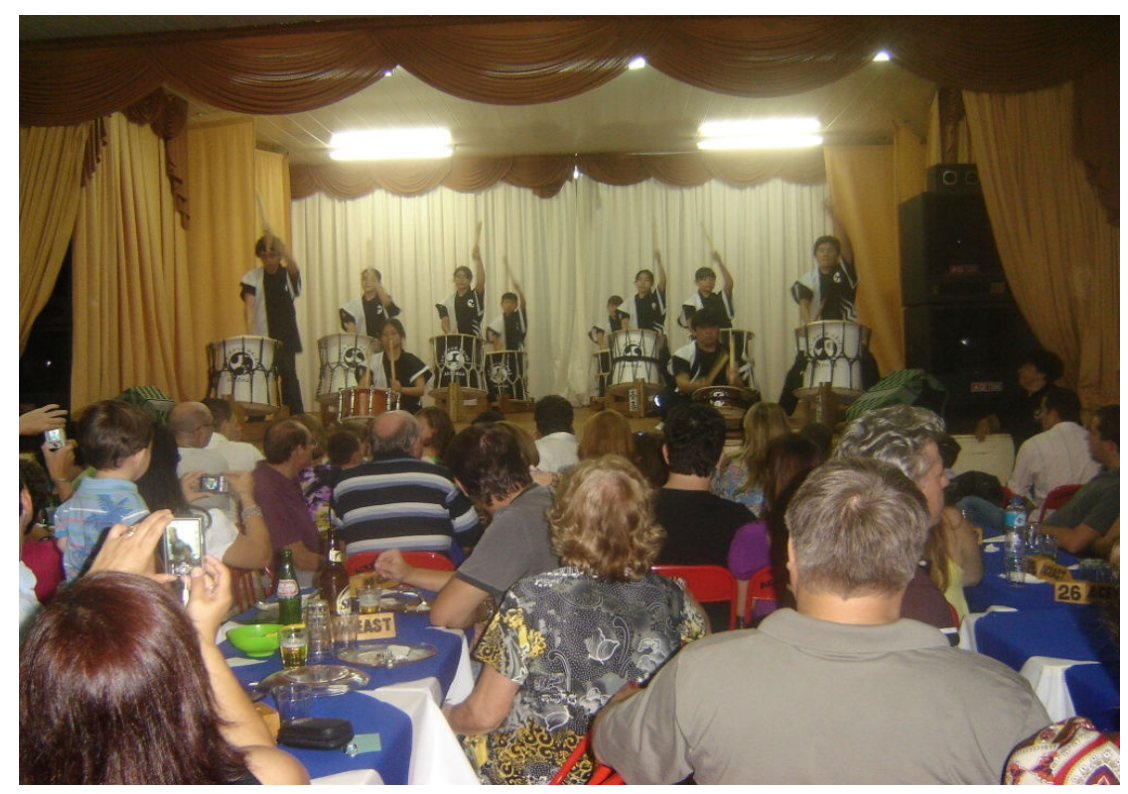

Fig. 24 Apresentação do grupo de taikō da ACEAST, Seishun Daiko, no "Jantar Oriental". Abril/2009. Foto: Camila Ischida.

Uma vez por mês ou a cada dois meses em média, a associação promove o "Jantar oriental". Realizado sempre aos sábados, os preparativos começam na noite de sexta-feira e se estendem até o fim do evento, por volta da uma hora da manhã de domingo. Muitos voluntários fazem revezamento, dedicando-se a um dos períodos do dia, mas há também os incansáveis que passam a maior parte do tempo na entidade. Tive a oportunidade de acompanhar um dia de trabalho dessas pessoas em um sábado à tarde. Até então, nunca tinha me aventurado nos 
"bastidores" do evento, ou seja, na cozinha. Simplesmente chegava à noite, jantava e logo ia embora. Muitos ali devem ter estranhado minha presença, ajudando com pratos e panelas, limpando mesas, cortando cebolas. É um trabalho árduo. Quilos e mais quilos de carne, legumes, macarrão, panelas imensas, tachos enormes. Pessoas de diferentes gerações e idades reunidas, com prevalência de pessoas mais velhas, nenhum jovem com menos de trinta anos à vista, todas juntas, ninguém parado.

Nas tarefas assumidas, há uma espécie de divisão nos papéis de gênero. Homens cuidam da salada, carne e bebidas e mulheres das verduras e da preparação dos pratos. Geralmente há dentro das entidades nikkeis o "departamento/associação de senhoras", o fujinkai. O trabalho das mulheres é entremeado por conversas, risadas, fofocas, na maior parte das vezes em português mesmo e em algumas "rodinhas", sobretudo das senhoras mais idosas, na "língua do segredo", o nihongo. A maioria dos homens fica do lado de fora, cortando, temperando e fritando a carne para os pratos e bebendo cerveja. Predomina uma divisão de gênero no trabalho e também no espaço.

O jantar tipo buffet inicia, geralmente, a partir das 19:30 horas, com um grande balcão central onde são dispostos os pratos "orientais", yakissoba, yakimeshi e frango xadrez. ${ }^{190}$ As pessoas sentadas nas mesas ao redor se servem à vontade. Logo na entrada, podem comprar uma espécie de carnê com diferentes valores, usado para comprar bebidas e sorvetes. Alguns homens e mulheres da associação atuam como garçons e garçonetes atendendo as mesas, levando os pedidos. ${ }^{191}$ Outras mulheres também se colocam a postos para repor as travessas que se esvaziam na mesa central. Ainda que levem os pedidos e tragam as bebidas, as mulheres nunca entram no bar.

Esse "modelo" ainda se encontra firmemente arraigado no passado. No caso da ACEAST, as mulheres não ocupam cargos diretivos e nem participam do conselho geral da entidade, assumindo a gestão somente do "departamento de senhoras", o fujin-kai. Embora suas opiniões e ideias sejam reconhecidas ali, formalmente não fazem parte da "diretoria". O cargo de presidente deste departamento feminino é automaticamente ocupado pela esposa do presidente em exercício na associação. Portanto, é sempre um casal que toma a frente da direção da entidade. Somente a coordenação do grupo de taikō é encabeçada por mulheres, como a

\footnotetext{
${ }^{190}$ Há também eventos nos quais se serve o sukiyaki.

${ }^{191}$ No capítulo 1 a entrevistada Lúcia Miyamoto mostrou sua admiração com alguns voluntários da ACEMA que mesmo tendo uma boa situação financeira não têm vergonha de servir uma mesa: "Uma coisa que eu vejo na ACEMA de positivo, são aquelas grandes festas em que você vê pessoas ali que são muito ricas e que vão lá servir uma pessoa que está ali, paga para comer, mas ele vai ali servir! Ele não tem nenhum orgulho de falar, 'Ah, vou servir uma mesa, ser garçom!'. Então, vai lá e serve a pessoa. Isso eu admiro. É uma coisa que eu vi lá dentro que eu admirei”.
} 
entrevistada Isabel Nishida. Percebe-se um conservadorismo na dupla resistência em aceitar novos modelos de organização, com mulheres e também não-descendentes de japoneses, casados com nikkeis, nos cargos de direção.

São esses vínculos com o passado que alimentam a crítica do entrevistado Rodrigo Suzuki ${ }^{192}$ com relação ao "machismo doentio" e ao preconceito de alguns japoneses e descendentes contra "brasileiros". Sua esperança é a de que haja uma maior "igualdade" nos próximos dez ou quinze anos. Algumas mudanças pouco a pouco entram em curso na ACEAST. O ano de 2012 será o primeiro desde a criação da entidade em 1948, que uma não-descendente poderá assumir a presidência do fujin-kai, uma vez que é casada com um nikkei, atual vicepresidente da gestão de 2010-2011.

Isso acontece porque na ACEAST, pela regra geral, o mandato do presidente é de dois anos e no biênio seguinte, o vice-presidente assume o posto do presidente. Com o fim da gestão 2007-2008 assumida pelos meus pais, houve uma espécie de “crise sucessória”, pois o vicepresidente não queria dar continuidade ao mandato e nenhum outro membro da associação quis se candidatar. Diante da situação, meus pais assumiram a administração da entidade por mais um ano. A responsabilidade e exposição que o cargo implica, o tempo e a dedicação demandados e a sujeição às críticas afastam muitos pretendentes: "ninguém quer ter dor de cabeça, muito menos de graça ainda", disse um associado. A figura 26 a seguir mostra os representantes escolhidos pelo presidente em exercício no ano de 2010, para os cargos de tesoureiro, secretários, coordenadores de departamentos ${ }^{193}$, conselheiros, avisadores ${ }^{194}$.

\footnotetext{
${ }^{192}$ Sansei, 22 anos, dentista de Londrina.

${ }^{193}$ Os departamentos da ACEAST são somente três: social, de canto, de língua japonesa.

${ }^{194}$ Esse cargo consiste em cobrar as mensalidades dos associados e também avisá-los de eventuais acontecimentos, como festas, promoções, reuniões e até falecimento de membros da associação. Os avisadores são divididos por zonas e ficam responsáveis pela cobertura de uma determinada área.
} 


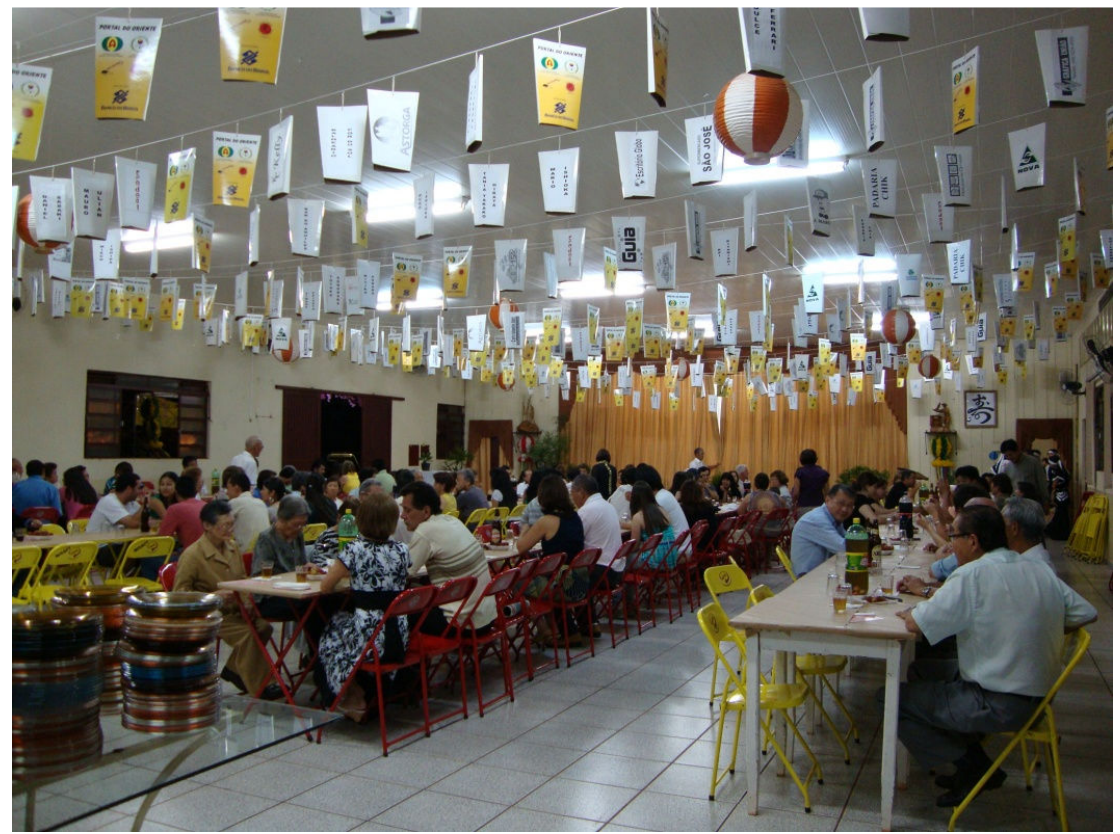

Fig. 25 Bōnenkai na ACEAST. Dezembro/2009. Foto: Camila Ischida.

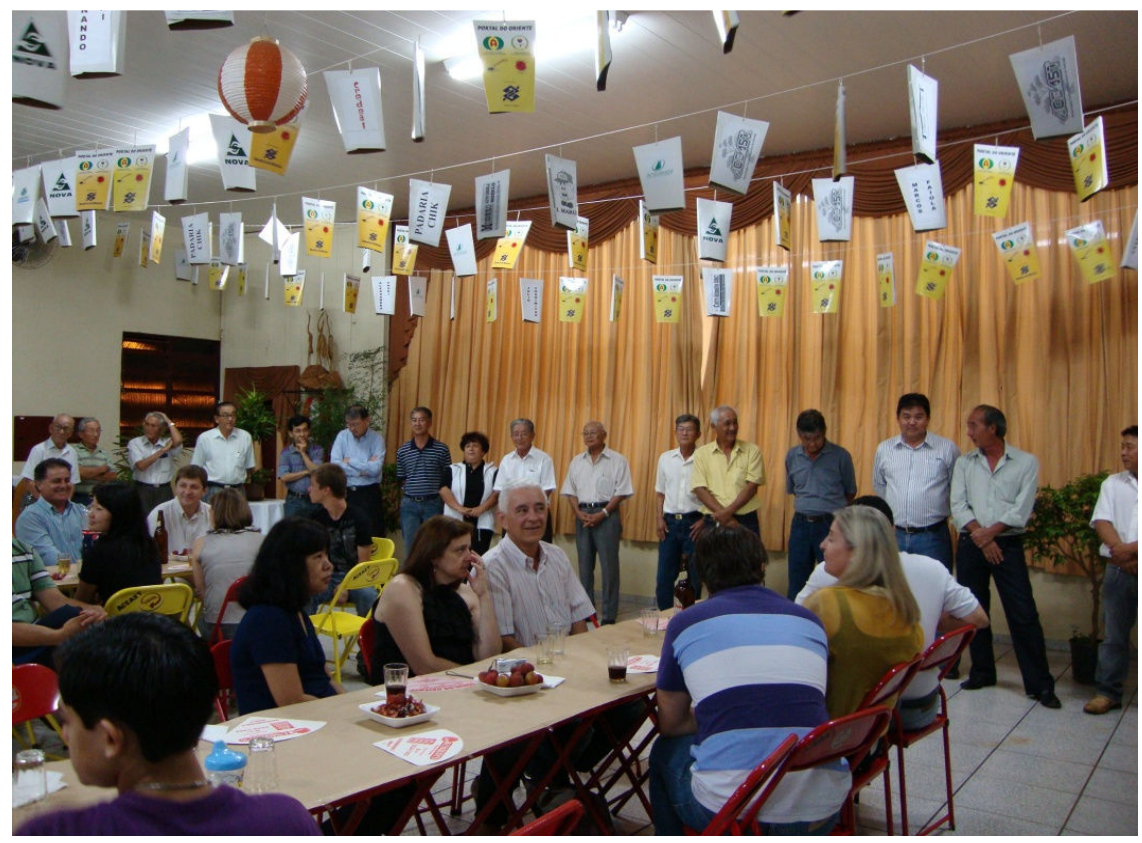

Fig. 26 Nomeação dos cargos de direção e do conselho da associação. Detalhe para a predominância dos homens. Foto: Camila Ischida. 


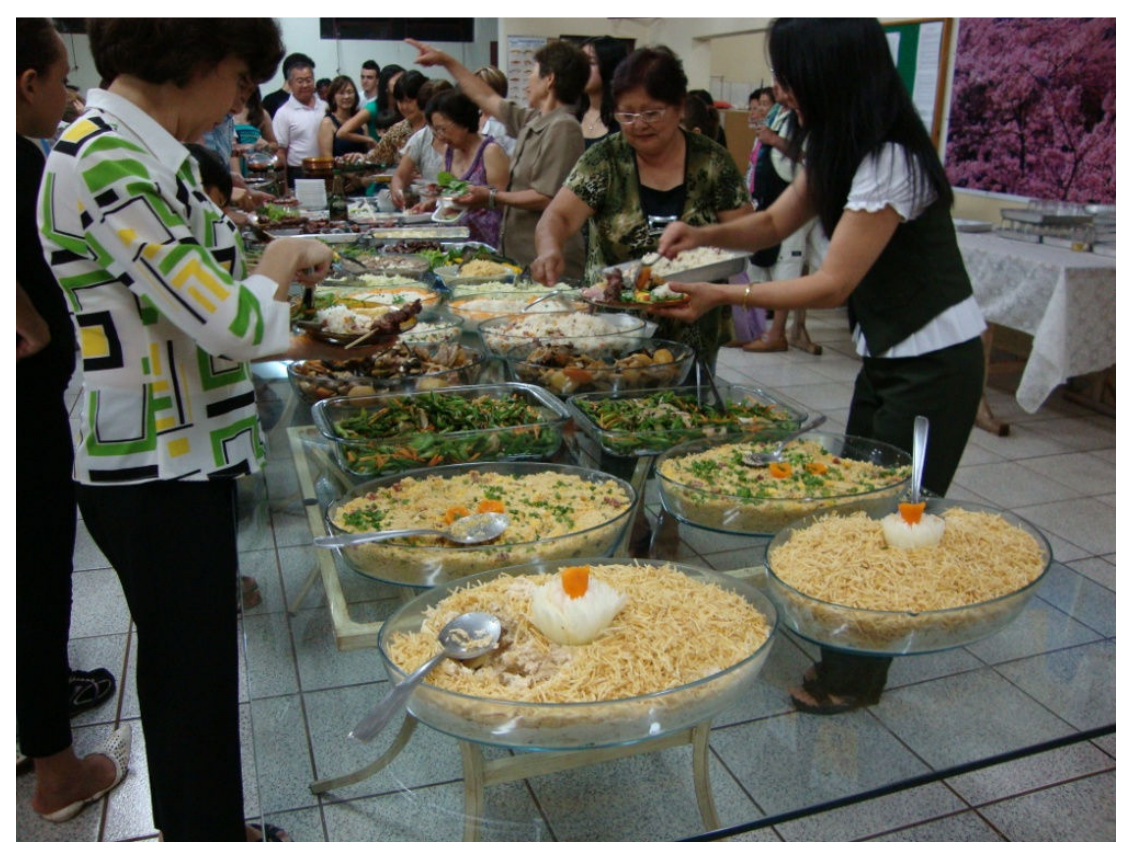

Fig. 27 Mistura de sabores no bōnenkai da ACEAST: espetinho, strogonoff e nishimê $\hat{e}^{195}$ Foto: Camila Ischida.

O que leva esses voluntários a assumir todos os anos um compromisso com a ACEAST? "Não deixar morrer a cultura japonesa", como diz Isabel Nishida? A módica mensalidade de cinquenta reais por semestre para cada família não é suficiente para manter a associação. ${ }^{196} \mathrm{O}$ trabalho voluntário e cooperativo nas promoções realizadas é fundamental para esse propósito. Mas não é só de trabalho que se ocupam essas pessoas empenhadas nessa tarefa. Nas conversas travadas informalmente com algumas, pude perceber que existe sim uma motivação para divulgar e preservar a "cultura japonesa". Esses associados-voluntários sentemse satisfeitos com a apreciação da culinária oriental e com os elogios feitos às promoções por eles realizadas na cidade. No entanto, mais do que isso, a vontade de rever os colegas e amigos, passar uma tarde jogando conversa fora, enfim, estreitar os laços de sociabilidade parece ser a principal razão para se dedicarem a passar parte ou até mesmo um sábado inteiro ajudando nos preparativos do jantar. "Eu acho que é um ambiente agradável, saudável. Você vem para se encontrar com as pessoas, revê-las. Descontrair simplesmente", disse uma informante. Há certo consenso que, sem esse trabalho e união de todos, a entidade fechará as portas. Yumi Kawamura gosta de colaborar nas promoções:

\footnotetext{
${ }^{195}$ Nishimê: cozido japonês feito com raiz de lótus, cenoura, broto de bambu, bardana, inhame, shiitake, konhaku, alga kombu,

${ }^{196}$ Esse valor corresponde à família nuclear composta por pai, mãe e filhos. Os idosos com mais de 70 anos pagam um valor menor, quarenta reais.
} 
“Tem pessoas que falam, 'você é boba, ficar o dia inteiro trabalhando de graça?!'. Mas se não tivesse, que graça teria também? Se não tivesse o kai kan aqui, a nossa cultura, ninguém conheceria o sukiyaki, yakissoba que todo mundo gosta, não é?". ${ }^{197}$ [...] Lá as obassans trabalham. Tem umas que até brigam, mas no final todo mundo acaba rindo. É um ponto em que todo mundo vai para se encontrar, conversar. Está trabalhando, mas também está se divertindo. Eles levam a sério. Meu sogro e minha sogra, se a gente [ela e o marido] fala que não vai, eles ficam bravos. E tem que ir, sabe? É um compromisso para eles. E tem obassan que fica brigando, 'não está cortando certo!', é bem 'crica'. Mas a gente tem que respeitar, né? O que eles falam, a gente... Mas é gostoso. Por isso que eu gosto de Astorga, porque é uma cidade pequena. Aqui a gente é unido, né? Lá na ACEMA é diferente. Lá é tudo cobra, um querendo engolir o outro! Um querendo aparecer mais do que o outro. Um tem mais dinheiro que o outro! Na ACEMA, é maravilhoso, tem nome, tem tudo! Mas só que lá tem umas cobras! Panelinha lá é feio... Nossa, terrível!".

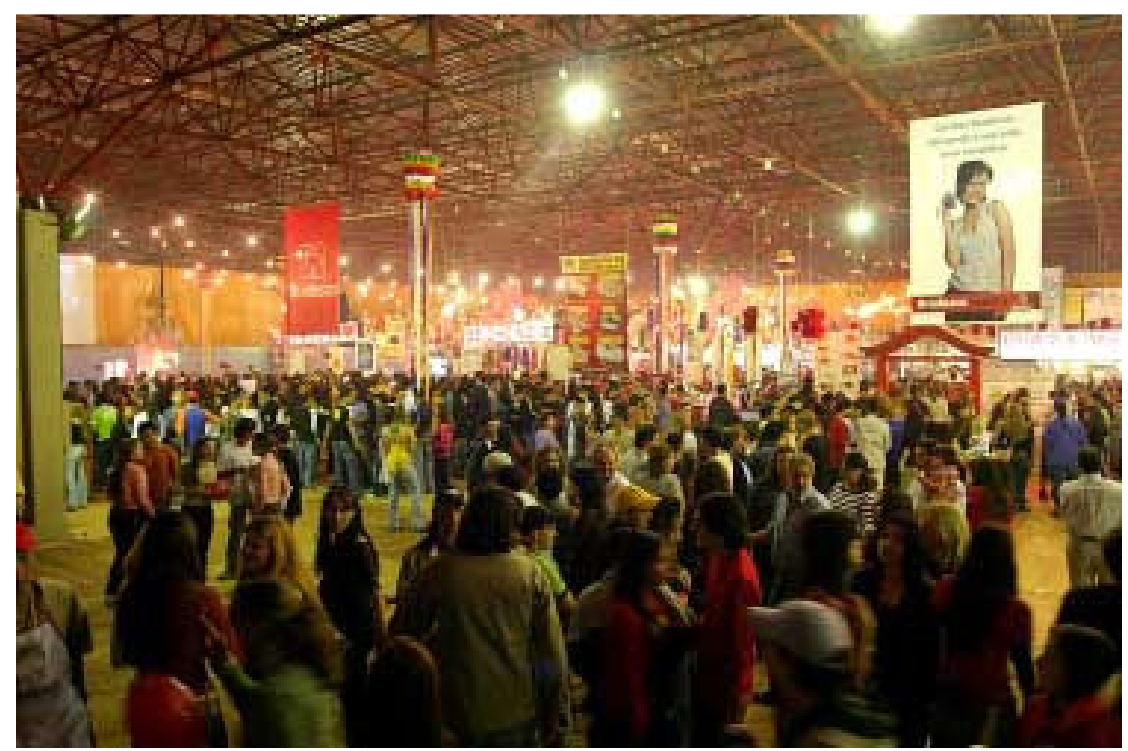

Fig. 28 Visão panorâmica do Festival Nipo-Brasileiro em Maringá, conhecido como “Nipo”.

\footnotetext{
${ }^{197}$ A pequena cidade de Astorga não possui restaurante japonês. O “jantar oriental” é realizado há 14 anos na sede da ACEAST, e contava, no início, principalmente com um público formado pelas famílias dos associados. Atualmente, a maioria dos apreciadores é não-nikkei. Como relatado pelo presidente da associação, os próprios nikkeis não-associados não compram os convites. No jantar do dia 4 de abril de 2009, a pequena entidade quase não comportou o número de convidados. Pela figura 24 é possível notar a lotação do lugar. Mesas tiveram que ser postas do lado de fora da sede.
} 


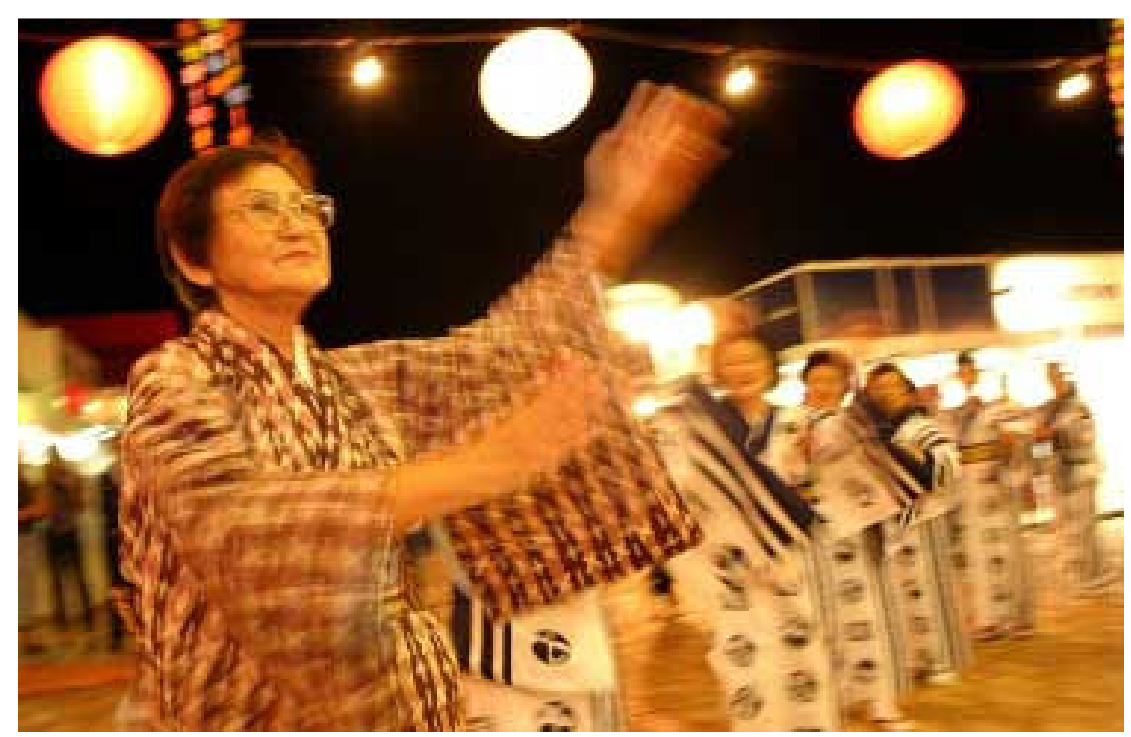

Fig. 29 Apresentação de Bon-odori ${ }^{198}$ na “Nipo”.

\section{“PANELINHAS" E UM ADENDO: DISCURSOS SOBRE RESERVA E TIMIDEZ}

Alguns entrevistados de Maringá, ex-membros da Associação Cultural e Esportiva de Maringá (ACEMA) teceram inúmeras críticas à entidade no que diz respeito, principalmente às disputas por poder e as "panelinhas" formadas nos diferentes departamentos que integram as atividades culturais e esportivas ali promovidas, como o canto, taikō, tênis de mesa, softball, gateball, yakyu ${ }^{199}$. Embora o esforço empreendido todos os anos na organização do Festival Nipo-Brasileiro, ${ }^{200}$ principal evento organizado e sediado na associação, seja reconhecido e elogiado; os diferentes grupos formados no interior dos departamentos foram criticados por serem considerados muito fechados com relação à entrada de novos membros. O entrevistado Leonardo Miyamoto, ${ }^{201}$ que aos doze anos teve interesse em participar do grupo de canto de música japonesa da entidade conta que teve certa dificuldade para se integrar aos demais membros. Segundo sua mãe, Lúcia, Léo teve que mostrar seu talento para ser aceito, “O pessoal

\footnotetext{
${ }^{198}$ Bon: finados; odori: dança. O bon-odori é uma dança de tradição budista voltada para a celebração da alma dos antepassados.

${ }^{199}$ Yakyu: baseball.

${ }^{200}$ O Festival Nipo-Brasileiro acontece todos os anos na ACEMA, geralmente no mês de agosto. No ano de 2009, chegou a sua $20^{\mathrm{a}}$. edição, e atualmente é considerada uma das festas mais tradicionais da cidade, fazendo parte do calendário cultural do município. Tem o mesmo formato dos festivais nipo-brasileiros que acontecem em outros lugares do país: shows com artistas da "comunidade nikkei", apresentação de danças folclóricas japonesas e de outros países, praça de alimentação com comida oriental, expositores de vários segmentos, como concessionárias de automóveis, instituições financeiras e de ensino e um "pavilhão cultural" voltado para a exposição de artes, como ikebana, pinturas, bonsai, cerâmica, origami, etc.

${ }^{201}$ A trajetória de Leonardo Miyamoto e de sua mãe, Lúcia, foi narrada com mais detalhes no capítulo 2 e em outras partes do trabalho. O rapaz foi vítima de bullying na escola, segundo ele, devido à ascendência japonesa, baixa estatura e timidez.
} 
tem que conhecer, porque se não for conhecido, ele não é aceito completamente". Leonardo que permaneceu no grupo dos 12 aos 17 anos, relata:

"Ah, tem muita panelinha ainda. Se aparece uma pessoa diferente, está invadindo o espaço deles. São bem... só eles. Mas depende, tem pessoas e pessoas... Mas a ACEMA é um caso sério... lugarzinho, viu? [risos]. Mas não sobrou nenhum. Do pessoal, que eu mantenho contato, que eu goste de manter contato, não tem ninguém...Você não pode ser mais do que ninguém. Se você for menos, você ainda consegue [risos]. Agora, se você for mais, se você fizer alguma coisinha a mais, eles te ignoram".

Mãe e filho chamam a atenção para a importância do "nome" da família, do "status" e da "tradição" como elementos que têm certo peso na inserção ao grupo, no bom interrelacionamento com outros membros e até mesmo na definição de alguns resultados nos concursos de canto. Leonardo, insatisfeito com o que julgava serem favorecimentos, saiu do grupo. Atualmente é membro do Círculo Católico Estrela da Manhã (CCEM), grupo de jovens ligado à Igreja São Francisco Xavier: "As pessoas te tratam, te recepcionam totalmente diferente. Não tem essa de ciuminho, de gente querendo ser melhor do que ninguém. Lá é todo mundo igual, todo mundo te trata como um igual". ${ }^{202}$

Além das "panelinhas" formadas nos diferentes departamentos de uma entidade, como no exemplo da ACEMA, comentados por Yumi e Leornardo, é possível observar que em cidades com grande concentração de nipo-descendentes ainda se nota em certos espaços frequentados por jovens - como escolas, universidades, shoppings - "grupinhos", "panelinhas" constituídas quase que exclusivamente por descendentes de japoneses. Havia ficado impressionada quando soube que ainda existiam "baladas japas” na cidade de São Paulo, ou seja, baladas cujo público é majoritariamente composto por nikkeis. Em Maringá, é comum encontrarmos grupos de amigos, de quatro até dez pessoas, andando juntas em eventos organizados por entidades nikkeis ou até mesmo nas ruas. Contudo, uma festa aparentemente desvinculada de uma associação e dirigida a esse público era realmente uma novidade para mim.

Tive a oportunidade de conhecer uma festa, a tradicional Apple Music, realizada no Ipê Clube, em agosto de 2009. Era meia noite e poucas pessoas se encontravam no grande salão, cuja decoração em nada lembrava "motivos orientais" ou coisas do tipo. Quando imaginava que a

\footnotetext{
${ }^{202}$ Além de Maringá, o CCEM possui representantes em cidades como Álvares Machado, Presidente Prudente, Mogi das Cruzes, São Paulo, Curitiba e Londrina. Em Maringá, a entidade está atrelada à Missão Católica Nipo-Brasileira, que fundada em 1958 pelo Monsenhor Kimura, era voltada inicialmente para evangelização da comunidade japonesa. Leonardo me convidou para participar da primeira reunião do ano da entidade depois das férias de janeiro, sempre realizada aos sábados das 19:30 às 21:00 horas. Pude notar que a maioria dos membros era descendente de japoneses, com idade entre vinte e vinte e cinco anos. Nesse dia, o objetivo era mostrar aos interessados as atividades promovidas, o conteúdo dos encontros, as orações realizadas. Houve uma espécie de dinâmica para apresentação de todos que ali se encontravam. As canções religiosas tinham ritmo rápido e eram acompanhadas de passos de dança. A dinâmica era um recurso para criar uma maior integração entre os presentes.
} 
festa seria um fracasso, pelo vazio do lugar, percebi uma movimentação do lado de fora do clube. Da sacada, pude observar que aos poucos diferentes grupos de jovens chegavam, permanecendo na entrada da festa. Garrafas de bebidas, latas de cerveja e cigarros se misturavam às várias "rodinhas" que se formavam. Era o "esquenta", ritual de preparação para a festa em que os participantes levam suas próprias bebidas, geralmente destiladas, ou "racham" o valor entre eles. Gradualmente, os grupos entravam no salão e à medida que chegavam entendi o porquê do "ritual": a média de idade dos frequentadores girava em torno dos vinte anos. Havia ainda jovens mais novos que além da pouca idade, com certeza não tinham dinheiro para pagar as bebidas vendidas na festa e, portanto, preparavam-se previamente abastecendo-se de álcool.

A “balada” era como qualquer outra. $D j$ 's, música, bebida, decoração, os ingredientes essenciais em nada diferiam de uma festa convencional. Já o público chamava a atenção: inúmeras "rodinhas" de jovens nikkeis, alguns não-descendentes, formavam-se na pista de dança ao som de músicas que nada lembram o J-Pop. De acordo com o texto de Alex Ogushi do NippoJovem, jornal online do portal Nippo-Brasil, ${ }^{203}$ funk, pagode, música eletrônica são comuns nessas "baladas japas": "o que atrai ou afasta as pessoas é mesmo o público que as frequenta". Em São Paulo, a Mortos Vivos, a Mega Festa, a Apple Music, a Infinity With You e a Friendz são as mais conhecidas.

Ainda segundo a matéria, criados no final da década de 1980, os "bailes da colônia", como eram chamados, buscavam a "manutenção da tradição de união dos nipo-brasileiros", afirma o produtor de "baladas japas" há mais de vinte e dois anos, Eduardo Hioki. O promoter comenta sobre a tendência de redução do público nikkei nesses espaços, pois além da concorrência de outras festas, "hoje está muito difícil de manter a nossa tradição". Mas por que uma balada dirigida aos jovens descendentes de japoneses? O produtor da Apple Music, Fernando Viscaíno responde, questionando: "E porque não? Festas jovens são tradicionais há décadas na colônia, acontecem regularmente em kai kans espalhados pelo país e sempre há um grupinho que reúne uma concentração de japoneses. Não tenho dúvidas de que existem realmente aqueles que curtem estar em eventos desse tipo".

O que motivaria esses jovens, netos e bisnetos de japoneses, a procurar eventos e laços de sociabilidade que tenham relação com a ascendência em comum? Seria a vivência em "colônia", ou seja, em associações nipônicas? Seria afinidade apenas? Seria preconceito contra os "brasileiros"? Amanda Shimizu, 21 anos, sansei, nasceu em Astorga, mas atualmente reside na cidade de Umuarama-PR, onde cursa faculdade de Tecnologia de Alimentos. Amanda

\footnotetext{
203 "Baladas japas: um novo conceito de balada". Conforme: http://www.nj.com.br/especial/especial_20090219.php Acesso: 29/05/10.
} 
completou o Ensino Médio em Maringá e foi nesta cidade que, pela primeira vez, passou a andar em "grupinhos" de nikkeis. Sua turma era conhecida como "Yakuza", em alusão ao nome dado aos membros dos tradicionais grupos de crime organizado no Japão, as máfias. O apelido coletivo não fazia referência a qualquer ação criminosa da turma, mas ao fato do grupo ser numeroso e seus membros andarem juntos.

A estudante participou do seinen-kai da Seicho-No-Ie, do Nishi Honganji ${ }^{204}$ e também colaborava no Festival Nipo-Brasileiro da ACEMA, vendendo cartões para os almoços e jantares, além de ajudar servindo mesas. Ela gostava de ajudar na organização das promoções ofertadas por essas entidades religiosas, cuja renda obtida era voltada para o financiamento de festas e viagens a eventos ou para a doação a entidades beneficentes nikkeis, como asilos e creches $^{205}$. "Então, esse dinheiro era bom para crescer o seinen-kai, melhorar a estrutura. Tudo que puder juntar dinheiro, acho que seria bom. Mesmo trabalhando de graça, era bom arrecadar. Mesmo que fosse para as batchans e os ditchans lá [do asilo], era bom ajudar. Eu gostava... Para se divertir também né?”. Novamente a questão da diversão entra como um motivador para as atividades voluntárias, oportunidade para rever os amigos, conhecer pessoas novas.

"Eu vivia em colônia", diz Amanda. É interessante aqui observar a diferença entre "viver na colônia" e "viver em colônia”, corroborando uma das asserções dessa pesquisa de que essa categoria continua a ser empregada para se referir às associações nipônicas e ao compartilhamento de um conjunto de tradições, práticas, códigos, redes de sociabilidade que tem origem nesses espaços de convivência. "Viver em colônia" denota, portanto, um estilo de vida, uma condição de existência.

Nesses espaços, Amanda desenvolveu laços de amizade. Saindo de um município com poucos nikkeis, Astorga, e entrando em uma cidade com grande concentração deles, Maringá, Amanda analisa essa experiência: “Achei totalmente diferente andar com nihonjin do que com gaijin. Parece que eu me dou mais bem [sic]...”. Ela conta que a maioria de seus amigos em Astorga eram "brasileiros", e na época ela percebia que "ficava muito de lado". Essa "preferência" por "nihonjins" não se restringe ao círculo de amizades, "Para namorar também eu prefiro nihonjin [risos]. Nihonjin, porque... não sei, parece que eu tenho mais confiança. 'Brasileiro', eu acho que.... Eu tentei, mas não deu certo".

\footnotetext{
${ }^{204}$ De acordo com Ronan Alves Pereira (2002), Nishi e Higashi Honganji, grupos "Leste" e "Oeste" da Verdadeira Escola da Terra Pura, foram os principais ramos do movimento de renovação e modernização do budismo, o Shin Bukkyō, "Novo Budismo", que aconteceu no período da Restauração Meiji. Com a emigração para terras estrangeiras, monges, acadêmicos, imigrantes e soldados acabaram atuando como propagadores dessas doutrinas.

${ }^{205}$ Como o asilo Wajunkai e a creche Monsenhor Kimura em Maringá.
} 
Quando a estudante passou no vestibular, teve que se mudar para Umuarama-PR, município que, assim como Astorga, possui poucos descendentes de japoneses. Segundo Amanda, a maioria dos jovens de lá foi embora para o Japão ou mudou-se para Maringá ou outras cidades para fazer faculdade. A primeira coisa que buscou fazer quando se mudou foi andar em "grupinhos" como costumava fazer em Maringá. Por conta própria, procurou algumas entidades, contrariando o caminho mais comum de inserção nesses espaços, ou seja, através dos pais ou do convite de amigos. De acordo com Amanda, há um seinen-kai recém-criado no kai kan da cidade, mas a média da idade dos participantes era de 15 a 18 anos, pessoas mais jovens do que ela. Como ela mesma apontara, os mais velhos acabam se mudando de lá. Amanda quis participar do treino de taikō e de outras atividades da associação, mas não o fez pela falta de tempo. Com a faculdade, ela não poderia se dedicar como gostaria. Pergunto-lhe se a cada mudança de cidade, ela procurava as entidades como uma forma de se aproximar dos "nihonjins":

“Sim, procurava. Lá em Maringá, quando eu fazia o Ensino Médio, dava para contar nos dedos os amigos 'brasileiros' que eu tinha. Tinha dois amigos no máximo. O resto era tudo nihonjin. Lá em Umuarama, não sei se é preconceito, às vezes eu sofro. Tinha uma época no primeiro ano de faculdade, tinha oito meninas morando no pensionato comigo. No total eram trinta e seis. Eu era a única 'japonesa'. Tinha uma época que eu procurava no Orkut, descendentes, mas eu não achava, porque a maioria estava fora de Umuarama. Eu não sei se era preconceito, mas teve uma época que eu não conseguia fazer amizade lá, que eu quase entrei em depressão. Queria largar o curso, um monte de coisa. Só que enfim, vou seguir em frente, porque a vida não é assim. Vou seguir minha carreira, porque vim aqui para estudar. Hoje eu fiz algumas amizades, poucas lá em Umuarama, com pessoas mais jovens. Ainda não ando em grupos como antigamente. As vezes sinto falta, porque eu andava bastante com grupinhos lá em Maringá. Saía para me divertir. Em Umuarama fico mais em casa”.

"Esse preconceito que você menciona é seu com relação aos brasileiros nãodescendentes ou deles com relação a você?” - indago em seguida:

"Eu acho que um pouco dos dois lados. Mas é que minha turma [da faculdade] também não é
muito reunida, em grupos. Mas eu acho que... Eu não sei se é preconceito também da minha
parte, mas eu preferia assim na parte mais nihonjin... de andar, de conversar... Parece que eu
me habituava [sic] mais a conversar, tinha mais facilidade, mais confiança, né? Não era nada
preconceito contra os brasileiros, mas eu achava que eu me dava melhor com os nihonjins...
[Seria afinidade?" - pergunto-lhe] Afinidade mesmo. Mas com os 'brasileiros', eu não tenho
nada contra também. Mas eu percebi assim, comparando, que eu tenho mais afinidade...".

Confiança, afinidade, facilidade na comunicação, preconceito são as palavras-chave do discurso de Amanda. O que explicaria essa aproximação com outros nikkeis? Ela tem dúvidas quanto à resposta. Haveria uma? A julgar pela condição de isolamento dos núcleos coloniais no 
início da imigração, pelas dificuldades de isseis e nisseis em se comunicar em português ou pelos preconceitos recíprocos entre brasileiros e japoneses, havia motivos muito claros para um estreitamento de relações maior com outros descendentes. Mas passados cem anos do início da imigração japonesa para o Brasil? Amanda alega que "se dá melhor" com "nihonjins". Teria alguma relação com a participação nos seinen-kais? Aquelas "panelinhas" de jovens nikkeis que encontramos em lugares de lazer, como "baladas", shoppings, bares ou mesmo na escola e na faculdade seriam majoritariamente formadas por membros de entidades juvenis? Nem sempre.

"Falar com japonês é mais fácil, não me pergunte por quê. Talvez seja a mesma base, educação, história... No meu caso, eu já conhecia meus amigos japoneses desde criança, estudei junto. Nossos pais já se conheciam também" - diz um jovem informante, membro da ACEAST, mas que não atua como voluntário na entidade. O dentista Rodrigo Suzuki, também anda em "grupinho", sendo "80\% de japoneses". Conta que certa vez, ele e seus amigos foram a um aniversário de outro amigo, descendente de italianos, que também fazia parte do grupo. Lá chegando, sentaram todos em uma mesa. Um parente do rapaz brincou: "Nossa, fulano, você só tem yakuza naquela mesa!". Rodrigo conta que o amigo ficou bravo e disse: “Olha, tudo bem, mas qualquer um daquela mesa daria a vida por mim e eu também por eles. Então, você os respeite!", e complementa, "Ele se sentiu mais ofendido do que a gente. A gente não, a gente começou a dar risada [risos]".

Rodrigo, ao contrário de Amanda, não participa e nunca participou como membro de nenhuma entidade nikkei - "não tenho tempo" - mas marca sua presença em festas e eventos da "colônia" em sua cidade, como o Londrina Matsuri ${ }^{206}$. Segundo ele, há uma "tendência natural" dos descendentes de se aproximar de outros descendentes:

\begin{abstract}
"Se você me pedir para explicar, eu não sei o por quê. Mas talvez porque os 'japoneses' sejam... Até a minha geração, são pessoas mais introvertidas, têm alguma falta de conversar, de ser mais aberto, sim. Mas de modo geral eles são mais reservados. E é aquilo lá, né? Eles vão procurar não só 'japoneses', mas qualquer um procura andar com pessoas com quem se sinta a vontade. Um tímido não vai andar com um escandaloso. Ele acha degradante e da mesma forma, o contrário. E eu acho mais fácil, porque eu pelo menos, sempre me aproximei de 'japoneses' não pelo fato de serem 'japoneses', mas pelo fato de estarem na dele. Acredito que em muitos casos, a gente partilha da mesma opinião. Nós também sabemos, entendemos o costume de cada um. Por exemplo, sei lá... Vou visitar minha batchan ou vamos sair pra comer, 'Ah o que você vai cozinhar?'. 'Ah, frango xadrez ou vou fazer um temaki ou alguma coisa assim'. Então acaba aproximando agora se você coloca um descendente de grego neste contexto, ele não vai gostar de um temaki, acredito eu".
\end{abstract}

\footnotetext{
${ }^{206}$ O Londrina Matsuri - Festival da Primavera é organizado nos mesmos moldes que o de muitos festivais nipobrasileiros. Conta com praça de alimentação, programação cultural, área comercial, etc.
} 
Os entrevistados chamaram a atenção para a facilidade em conversar com o "japonês". Facilidade que se verifica nos interesses e gostos comuns, bem como nas semelhanças das histórias de vida e na base educacional recebida. Quando um diz que vai visitar a batchan, o amigo nikkei imediatamente entenderá o significado. Alguns entrevistados como Rodrigo e também Amanda, como se verá adiante, fizeram menção à reserva e à introversão como elementos que ainda encontram-se presentes entre muitos jovens nikkeis. Contudo, enquanto Amanda afirma buscar propositadamente fazer amizades com "nihonjins", por sentir que há uma "diferença"; Rodrigo enfatiza que procura se relacionar com pessoas parecidas com ele e com as quais se sinta à vontade, independentemente da ascendência.

O dentista também pontua que a participação em seinen-kais facilita a aproximação com outros descendentes, pois frequentemente seus membros partilham mais de um espaço em comum. Em outras palavras, além da associação, podem estudar no mesmo colégio, fazer o mesmo curso de línguas ou praticar o mesmo esporte. Tais encontros favorecem o estreitamento de relações. Todavia, pondera:

"O bom de Londrina é que você não precisa ir a esses locais para conhecer 'japoneses' [risos].
Em shopping, mercado, curso de língua, festas, baladas, você sempre acha um ou outro
'japonês' perdido. É fácil você fazer essa amizade... ou você conhece um 'japonês' de
Londrina e ele conhece o resto da 'japonesada'. Aí quando você vê já está com todo mundo
[risos]. É o que aconteceu comigo. Eu estudava com um amigo meu em Londrina e ele falou:
'vou apresentar uns amigos meus'. Putz, daí eu conheci meia Londrina ali! E você acaba
criando esse networking".

O relato de Rodrigo mostra a dinâmica desses encontros que aparentemente fortuitos dizem muito sobre a rede de sociabilidade dessas pessoas e, no limite, também sobre suas identidades. O depoimento de Amanda revela a faceta do preconceito que se esconde nas escolhas das amizades. Um preconceito recíproco sentido por ela e difícil de admitir. A dificuldade em fazer amigos em Umuarama foi por ela associada ao fato de ser a única "japonesa" da sala de aula e do pensionato onde morava. Esse preconceito também se nota no isolamento e fechamento de determinadas "panelinhas" com relação à entrada de novos membros. Rodrigo Suzuki, por exemplo, não considera sua turma "fechada", mas "rígida" e "criteriosa" com possíveis desvios de conduta de seus membros:

“A gente acolhe quem a gente acha que se dá bem... Independente de ser 'brasileiro' ou 'japonês'. [...] Eu acho que é mais fácil os gostos se parecerem entre 'japoneses' do que 'brasileiros'. 'Brasileiro' tem aquele tal do 'jeitinho brasileiro' que me incomoda muito, me incomoda bastante. Se me incomoda, pô, na minha turma quase todos são advogados formados, imagina eles então! Ah, tá, advogado é safado! Não! Depende... [risos]. Eles não, né? Não gosto de quem faz isso ou aquilo. Então, a gente acaba excluindo... Seleciona bem. Se 
o cara tem amante, bebe muito, bateu na esposa... Ah, deixa de lado. Nós somos bem criteriosos. Não é que ninguém entra, ninguém sai. [...] Acredito que 'japonês' é assim, demora para passar confiança, mas quando você tem a confiança dele é para o resto da vida. A partir do momento que conquistou a confiança, beleza, vai embora...”.

Os depoimentos de Rodrigo e Amanda revelam como a rede de sociabilidade também pode se constituir em um indicativo importante para os processos de construção identitária. A partir dos laços de amizade, é possível observar como "marcam a diferença" entre nikkeis e nãonikkeis e como seus sentimentos, preconceitos, dúvidas são desvelados na narrativa. No caso de Amanda, é perceptível como a relação que ela mantém hoje com esses "grupinhos" de amigos nikkeis não é outra, senão a de saudade. A marcação espacial é muito definida em sua fala, pois ela apresenta sua vivência e convivência nos diferentes espaços, Astorga, Maringá e Umuarama, em estreita ligação com a presença ou ausência de nikkeis, ou melhor, "nihonjins". No capítulo 2, vimos como a questão geográfica pode ser um marcador importante na negociação de identidades. Mas a importância atribuída à mesma varia de pessoa a pessoa. $\mathrm{O}$ caso de Rodrigo indica que a inserção em "panelinhas" não necessariamente está relacionada com a participação em entidades.

Seria algo cultivado no seio da família? A maior parte de meus entrevistados quando estabeleciam sua relação, seja de proximidade ou de distanciamento, com a "cultura japonesa", frequentemente fazia alguma menção à influência dos pais ou avós, como na fala de Mariana Yoshida $^{207}$. Se a família cresceu dentro da "colônia", ou seja, se manteve vínculos com uma associação cultural, religiosa ou esportiva, há grandes chances do filho também vir a desenvolver laços com a mesma. Mas isso também não se apresenta como regra geral.

O irmão de Amanda, Guilherme Shimizu, 24 anos, também foi entrevistado junto com ela em minha casa. $\mathrm{O}$ estudante de Engenharia Agroindustrial teve uma trajetória semelhante à da irmã: saiu de Astorga, fez cursinho em Maringá e atualmente faz faculdade na cidade de Campo Mourão, também no Paraná. As semelhanças acabam por aí. Diferentemente de Amanda, Guilherme não tem a mesma relação de proximidade com amigos descendentes, seja andando em grupos, seja na "preferência" dada:

“Até tenho, mas não é da mesma forma que da minha irmã. Para mim, não ligo tanto para a
descendência, tanto para 'japonês' quanto para 'brasileiro', no caso. Em Campo Mourão, eu
tenho uns amigos que são 'japoneses', mas a maioria não frequenta kai kan. São pessoas
mais... reservadas. Não são tanto de fazer reuniões como o pessoal de mais idade. Se tem um
evento no kai kan, eles vão, fazem festa, jantam, mas não participam com o povo. Eu, para
mim é indiferente. Eu tenho mais amizade com 'brasileiro' do que com nihonjin... Para mim é
indiferente. Não tem esse negócio de raça, hoje em dia não importa, todo mundo é igual."

${ }^{207}$ Sansei, 33 anos, engenheira e estudante de Ciências Sociais, de São Paulo. 
Guilherme comenta que os "japoneses não são mais como os de antigamente. Não seguem as mesmas coisas que os avós ou bisavós”, como por exemplo, a exigência de casamento com outro descendente. “A gente está no Brasil... Agora está mais livre para o brasileiro casar com nihonjin. Ainda que os pais aconselhem... os nossos pais [risos]. Mas eu não ligo não! Depende muito da família. Falo para minha mãe, 'Eu é que tenho que decidir o que vai ser bom para mim ou não!'. Ah, mas já falaram muito, hoje eu fico na minha, só escuto”. Os pais de Amanda e Guilherme são os presidentes em exercício da ACEAST do biênio 2010-2012. Entretanto, esse fato não faz parte das preocupações de Guilherme. Ao contrário de sua irmã, assim como seus amigos de Campo Mourão, o rapaz vai aos eventos e jantares, mas não participa como voluntário vendendo cartões ou ajudando a servir as mesas:

\footnotetext{
"Não estou focado em festas. Vou a jantares. Mas penso na minha carreira, não fico pensando em continuidade da colônia, por enquanto. Quero terminar a faculdade, trabalhar. Quem sabe futuramente? Ainda tenho amigos 'japoneses' de outras cidades que a gente conversa. Mas não vou a encontros, esses negócios, de kai kans".
}

É possível observar como as opiniões dos irmãos são bastante divergentes. A conversa aconteceu com os dois ao mesmo tempo, e apesar dos posicionamentos díspares, um escutava o outro sem interferir. Amanda fica em dúvida se a reserva e a timidez permanecem como elementos da "cultura japonesa" que ainda encontram ressonância entre sanseis e yonseis. Embora estejam mais "soltos" e sejam menos "rígidos e sistemáticos" que os isseis, afirma: " $O$ 'brasileiro' é um pouco mais atirado. Já o 'japonês' é bem mais reservado. Às vezes, ele perde no mercado de trabalho e o 'brasileiro' ganha, dependendo de certas coisas. Mas hoje em dia, acho que está meio a meio". Amanda dá o exemplo da comparação feita pela mãe de seu namorado nissei entre as três noras que possui: duas descendentes de japoneses, incluindo Amanda e uma não-descendente. Enquanto esta era, ao ver da sogra, mais "atirada", "conversadora" e "brincalhona", Amanda era mais "tímida" e "reservada". A estudante conclui, “Mas é verdade! 'Japonês' tem um lado negativo, de ser reservado. Às vezes sofre com isso. Tenta se soltar, mas tem dificuldade. Isso vem desde a cultura, em tudo".

Essa questão da timidez e da reserva do nikkei foi brevemente apontada por alguns entrevistados, como Leonardo Miyamoto, Paulo Sasaki, Yumi Kawamura e outros. Assim como Amanda, todos viram como um ponto negativo da "cultura", mas que tende a ser superado com o avançar das gerações. No universo do trabalho, a imagem positiva de honestidade e eficiência soma-se à da inibição, elemento considerado desvantajoso nesse contexto. 
Na reportagem especial já citada da Folha de São Paulo sobre o centenário da imigração japonesa no Brasil, há uma matéria intitulada, "Trabalhadores e estudiosos, mas tímidos" - "Auto-imagem: quando se comparam com os não-orientais, descendentes de japoneses reforçam estereótipo de pessoas reservadas e esforçadas". De acordo com a pesquisa do Datafolha, os nikkeis têm uma imagem clara sobre como se vêem em comparação com a média dos brasileiros. De um lado, dizem acreditar que os descendentes nascidos no Brasil respeitam mais as regras na sociedade (85\%), são mais esforçados nos estudos $(80 \%)$, mais trabalhadores (72\%) e mais confiáveis (64\%). Do outro, consideram-se mais tímidos (87\%), mais fechados $(78 \%)$ e secos $(66 \%)$ e menos afetuosos $(46 \%) .{ }^{208}$ A matéria chama a atenção para os rótulos e estereótipos conferidos aos nikkeis, mas ressalva que “é inegável, porém, que grande parte das características atribuídas aos descendentes de japoneses tenha ligação direta com as origens histórica, social e cultural dos imigrantes", como por exemplo, os valores do confucionismo, como o "gambattê kudasai" (empenhe-se) e as medidas políticas tomadas no período Meiji, como o estímulo à educação.

A matéria do mesmo jornal, "Oriente no trabalho - profissional é visto como analítico e reservado: perfil preconcebido de japoneses pesa a favor ou contra"209, enfatiza que, embora haja descendentes de sexta geração no Brasil, rokusseis, impera no mercado de trabalho uma imagem muito peculiar do profissional nikkei: "analítico, tecnicista e de pouca conversa". A presidente da ABRH-SP (Associação Brasileira de Recursos Humanos, seccional São Paulo), Elaine Saad, afirma: "Não se trata de uma percepção da área de recursos humanos. É uma questão cultural, parte verdade, parte carimbo". A reportagem menciona que os nikkeis são considerados no ambiente de trabalho, "pessoas mais fechadas, bastante capazes individualmente, perspicazes, inteligentes, pouco conflituosas, tímidas e contidas". Tais qualificativos podem significar vantagens ou desvantagens competitivas no mercado de trabalho.

Em uma conversa com meu irmão, César, a respeito de uma possível explicação para suas reprovações nos processos seletivos de programas de trainee, ele desabafou: "Eu não sei o que acontece. Chego na fase final dos processos e não sou aprovado. Só pode ser porque sou 'japonês'! [risos]". Conta que seu amigo que se formou junto com ele e passou em dois processos the dissera uma vez, "Não tem jeito, 'japonês' é mais reservado mesmo". Meu irmão continua a falar:

“É verdade, ‘japonês’ não é ousado! Você já viu algum ‘japonês’ ousado, que se arrisca? 'Japonês' é conservador, tem medo de perder, é submisso, prefere abaixar a cabeça para as

\footnotetext{
${ }^{208}$ Folha de São Paulo, Especial “100 anos da imigração japonesa: Retrato dos nossos japoneses”. 18/06/2008.

${ }^{209}$ Folha de São Paulo, 22/06/2008.
} 
coisas! Na minha entrevista, o gestor falou: 'Percebi que você é um pouco tímido'. Mas eu mal tinha aberto a boca na entrevista e na dinâmica fui um dos candidatos que mais se expressou. Depois ele falou: 'Você não é aquele que toca um instrumento musical?'. Eu respondi: 'Não, aquele é outro japonês'. Ou seja, ele tinha me confundido com outro 'japonês' logo no início, e isso já me deixou apreensivo. Eles já vêem com uma imagem sobre o 'japonês'...".

O desabafo de César pode parecer uma escusa mais fácil na tentativa de atribuir a um fator externo a justificativa para a sua não aprovação nos processos seletivos. Mas ele tematiza duas questões importantes que também foram abordadas pelas reportagens citadas: a imagem e a "cultura". A timidez como mais um qualificativo do imaginário discursivo sobre o nikkei e também como questão cultural. Sobre o último ponto, teria essa inibição alguma relação com a cultura do haji (vergonha) descrita por Ruth Benedict, em Crisântemo e a Espada (1997)? A vergonha em fracassar no cumprimento das obrigações e das regras de conduta é considerada uma virtude no Japão da Era Meiji, o que de algum modo, relaciona-se à obediência, à hierarquia e à "assunção da posição devida". A sensibilidade aos códigos de conduta foi um valor que também acompanhou os primeiros imigrantes no Brasil.

Interessa ressaltar que a fala de César é ilustrativa para a hipótese central desta pesquisa: além dos processos de identificação ou não com as imagens sobre os japoneses e seus descendentes no Brasil, há os momentos de agenciamento de categorias como "cultura" e "valores" e as circunstâncias em que generalizações e essencializações são feitas pelos sujeitos. O discurso de César sobre o "japonês" foi sendo construído de acordo com as ocasiões e condições dadas, ou seja, na apreensão quanto à confusão feita pelo gestor e a partir da confusão, na atribuição à sua pessoa de uma característica, timidez, a qual ele achava ser justificada para o outro "japonês".

Amanda afirma que muita gente diz que seu irmão, Guilherme é tímido, ao que ele nega. $\mathrm{O}$ estudante começou a discorrer sobre as festas que dá em sua república, e contrariando a imagem de "tímido" e "pão-duro" do "japonês", ele seria "festeiro" e "mão-aberta". Disse que os dois primeiros bimestres da faculdade são "só festas", já o segundo semestre é dedicado a "correr atrás do prejuízo". Segundo ele, sua postura seria inversa à imagem associada aos nikkeis. Ouvindo o que o irmão dissera, Amanda comenta, pensativa:

\footnotetext{
"Eu acho que influenciam também as amizades. Como meu irmão morava fora, não tinha muitas amizades com nihonjins, mais com 'brasileiros'... Eu acho que com 'brasileiros', eu acho que também influencia o modo assim de andar... O 'brasileiro' tem aquele jeitinho de conversar, eu acho que influencia um pouco as amizades. A gente acaba se soltando mais, né?".
} 
Guilherme apressa-se em dizer que isso é relativo:

"Eu acho que minha irmã é um pouco reservada. Eu saio muito com 'brasileiros' lá (em Campo Mourão). Saio com 'japoneses' lá também, mas os 'japoneses' não são em nada comparados com o que minha irmã fala, é outro tipo. Festam, não querem saber o dia de amanhã. É igual o meu estilo... [...] Isso vai de cada um. Minha irmã não sabe como é minha imagem lá e como não quero que ela vá para lá para saber como é minha imagem... [risos]”.

Amanda e Guilherme, irmãos com uma diferença de idade de apenas três anos, embora tenham tido a mesma educação e uma trajetória de vida semelhante, têm relações muito diferentes com a "cultura japonesa". É possível notar no discurso de Amanda as recorrentes alusões ao "nihonjin" e ao "gaijin", categorias mais frequentemente empregadas na fala pela primeira e segunda geração de descendentes, enquanto Guilherme prefere utilizar os termos "japonês" e "brasileiro". O último mostra como seu "estilo de vida" corresponde muito pouco ao que se convencionou associar aos nikkeis, regrado e reservado. E Amanda que sente falta do tempo em que fazia parte de uma "panelinha" de "nihonjins" tentar interpretar a mudança de atitude do irmão à sua convivência com "brasileiros", "gaijins", pessoas mais "soltas", com seu “jeitinho de conversar".

O interesse de Amanda em participar de seinen-kais não aconteceu via seus pais, associados da ACEAST, mas de amigos de Maringá que a convidaram a se integrar aos grupos. Amanda e o dentista Rodrigo não foram criados "dentro da colônia", mas ambos têm uma rede de sociabilidade majoritariamente formada por nikkeis, a "panelinha". O caso dos dois mostra que, embora a convivência em associações facilite a amizade entre os membros associados, não se constitui como regra geral para a formação dos "grupinhos". Além disso, o caso dos irmãos Shimizu é mais um exemplo de como são plurais as narrativas e trajetórias quando se fala dos descendentes de japoneses no Brasil.

\section{MADE IN JAPAN}

$\mathrm{Na}$ discussão da ideia de "cultura japonesa" é impossível deixar de mencionar um aspecto fundamental de seu conteúdo: a de produto cultural. Uma cultura pensada também sob a chave da globalização e do consumo. A partir da década de 1970, com o desenvolvimento econômico e tecnológico do Japão, o arquipélago passou da condição de importador de "modelos e tendências", para também a de exportador. Nessa categoria geral de "modelos e tendências" se incluiriam os diversos domínios que compõe esse arranjo híbrido chamado de "cultura japonesa": produtos tecnológicos, culinária, indústria do entretenimento, estilo de vida, religião. 
Nessa década, no contexto do "milagre econômico" brasileiro e do superávit obtido na balança de transações correntes do Japão, observou-se um grande crescimento no fluxo de investimentos diretos japoneses no Brasil (Uehara, 2002: 2). Os brasileiros testemunharam a entrada de inúmeras empresas japonesas em seu território, como Sony, Honda, Yamaha, Toshiba, Canon, etc. Produtos como o walkman da Sony mudaram os hábitos musicais das pessoas do mundo todo ao individualizar a escuta do som. A Nintendo também causou grande alvoroço no universo dos videogames e a popularização da câmera digital com a cybershot da Sony contribuiu para a conformação de uma nova relação com a fotografia.

Definitivamente o país do sol nascente conquistara o mercado mundial e o brasileiro com seus bens tecnológicos. Mas, como assegura Célia Sakurai, “o Japão do pós-guerra entra no mundo do consumo pela porta dos eletrônicos, dos automotores e também pela porta do entretenimento" (Sakurai, 2008: 342). Godzilla, Hello Kitty, National Kid, Cavaleiros do Zodíaco, Jaspion, Sailor Moon, Pokémon, Naruto, Pucca são alguns dos personagens japoneses desenvolvidos para filmes, séries, desenhos, brinquedos desde o pós-guerra até os dias de hoje e que fazem parte do rol de criações do país no ramo da indústria do entretenimento, domínio conhecido como J-Pop, japop ou cultura pop japonesa. Sakurai lembra que no que tange à concepção e produção de brinquedos, os fabricantes japoneses estavam mais próximos dos modelos de criação norte-americanos do que dos europeus, cujos soldadinhos de chumbo reproduziam sua maneira de encarar as crianças, ou seja, como miniaturas de adultos. (id.; ib., 2008: 340). Na conquista do mercado infanto-juvenil, a apelação à fantasia promovida pelo Japão culminou na rivalidade com os Estados Unidos:

Sua rapidez em aproveitar oportunidades para vender para crianças é uma parte fascinante de sua história de ajustamento, e acabou se tornando um elemento significativo na globalização da infância. A mudança promovida pelo Japão tornou mais complexo o retrato da história mundial moderna da infância, antes traduzido em termos estritamente ocidentais (Stearns, 2006 apud Sakurai, 2008: 340).

No mercado de bens de entretenimento, a globalização atinge também os jovens e adultos. Nos últimos anos, assistimos no Brasil e no mundo uma verdadeira febre pelos mangás $^{210}$ e animes japoneses. Com o crescimento no número de usuários de internet e com a

\footnotetext{
${ }^{210}$ Selma Meirelles (2003) aponta algumas características do mangá que em boa medida ajudam a explicar a sua popularização: 1) serialização em periódicos; 2) divisão do público-alvo; 3) sofisticação narrativa. A serialização prende a atenção do leitor ao dividir a história em capítulos. Os mangás também são bastante diversificados e classificados de acordo com seu público-alvo e temáticas abordados, como por exemplo, shounen (garotos), shoujo (garotas), gekigá (adulto), hentai (pornográficos ou eróticos), yuri e yaoi (homossexuais). Além disso, a diagramação das histórias e as técnicas visuais utilizadas como o recurso aos planos e cortes, a cuidadosa caracterização dos personagens e ambientes e a verossimilhança com o universo do leitor aproxima o mangá da linguagem do cinema.
} 
disponibilização de vídeos por esse canal, o fã brasileiro de um desenho animado japonês pode assistir quase que simultaneamente os episódios vistos pelo fã japonês. Inúmeros sites colocam em formato download os animes já traduzidos para o português ou inglês. Atualmente, essa febre não mais se restringe ao universo particularizado do leitor ou telespectador, ou seja, ao mero acompanhamento das histórias em casa, seja em quadrinhos com os mangás, seja na animação televisiva, com os animes. Há aqueles que a estendem à prática de se caracterizar como os personagens favoritos e interpretá-los, os cosplayers, que se reúnem em encontros, concursos, convenções e festas. E aqueles que supostamente "excedem" no fanatismo também ganharam um nome, os otakus ${ }^{211}$.

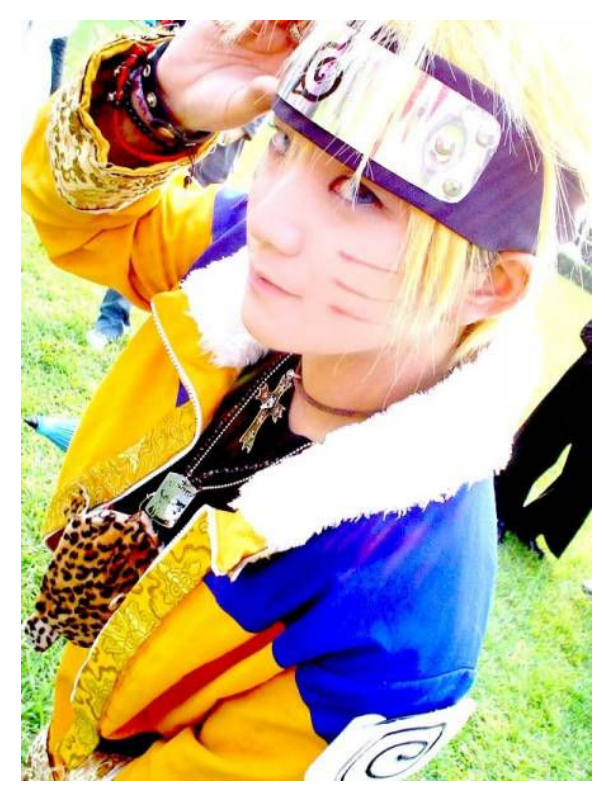

Fig. 30 Cosplay do personagem Naruto

\footnotetext{
${ }^{211}$ No Japão, o termo se refere a fãs de determinado assunto, mas também possui uma conotação pejorativa, estendendo-se àqueles indivíduos obcecados por determinado hobby. Os otakus geralmente são pessoas que, devido à sua incapacidade ou dificuldade de se relacionar socialmente se isolam em seu mundo de fantasia. No Brasil, o termo passou a ser utilizado para aludir aos fanáticos pelos animes e mangás em geral. Um exemplo de como muitos termos japoneses são ressignificados em outros contextos.
} 
Vimos que o entrevistado Henrique Nagata aprecia os desenhos japoneses e embora tenha ajudado a organizar um evento com essa temática em Maringá, o Animeingá, ${ }^{212}$ não se julga um "fanático", pois segundo ele, nunca comprou revistas, bonecos, fantasias, roupas e outros acessórios relacionados aos animes, somente limitando-se a baixá-los pela internet. No Brasil, a quantidade de fãs desses bens culturais que não possuem ascendência japonesa é muito grande $^{213}$. Assim como Henrique, que viu aumentar seu desejo de aprender o idioma japonês depois que passou a acompanhar essas animações, muitos fãs não-nikkeis passam a ter interesse em conhecer a "cultura japonesa" quando mergulham nesse universo, ansiando por aprender dentre outras coisas, o idioma, costumes e valores japoneses.

Henrique também mencionara como esses desenhos vêm carregados de mensagens sobre ética e valores. De acordo com Sakurai, a fórmula desses produtos midiáticos consiste basicamente em mostrar a luta entre o bem contra o mal, sendo a justiça alcançada mediante o enfrentamento de muitos obstáculos, com perseverança e conduta moral reta. A despeito de todo o processo de mercantilização inerente à essa indústria, a autora afirma que existe uma tentativa dos produtores de agregar nesses produtos os valores do bushidō, o código de honra dos samurais. Com o fim da classe dos samurais na Era Meiji, esse código foi sendo resgatado pelas lutas marciais, como o jiu-jitsu e o judō. Um dos principais ensinamentos é o de que o equilíbrio entre força física e espiritual e o respeito à hierarquia constituem o caminho para a evolução do guerreiro/lutador (Sakurai, 2008: 348-49).

A autora aponta que esses valores também estão presentes na composição de personagens como os Pokémons, do famoso desenho animado homônimo, que somente evoluem por merecimento, ou seja, quando gradualmente vencem as provas que surgem no caminho. Naruto, o desenho japonês que conquistou fãs no mundo inteiro e que é veiculado nos canais, SBT e Cartoon Network, também utiliza essa fórmula. Naruto é um jovem persistente, que possui o grande sonho de se tornar o ninja mais forte de sua vila e ser reconhecido como tal. De temperamento forte e bastante atrapalhado no início da série, não desiste do sonho apesar de alguns lançarem dúvidas sobre ele. Mensagens sobre a importância da família, da amizade e do companheirismo aparecem correntemente durante a saga do personagem.

\footnotetext{
${ }^{212}$ Evento organizado nos moldes do Anime Friends, sediado em São Paulo, desde 2003. Considerado o maior evento da América Latina relacionado a animes, mangás e afins, o Anime Friends recebe caravanas do país todo. Conta com a apresentação de bandas de J-music que tocam música pop japonesa, anime songs ou anisongs (trilhas sonoras de animações), shows internacionais, concurso de cosplayers, estandes com vendas de produtos, etc.

${ }^{213}$ O Brasil é o único país bicampeão em um dos maiores campeonatos de cosplay do mundo, o World Cosplay Summit. Os representantes brasileiros vencedores nessas duas edições, 2006 e 2008, não eram descendentes de japoneses.
} 
Sakurai chama a atenção para os conteúdos do desenho Pokémon serem recebidos de maneiras diferentes por crianças japonesas e brasileiras. Suas "raízes profundas na cultura japonesa não podem ser simplesmente transferidas sem referenciais completos e sem filtros culturais. No limite podemos dizer que, em cada contexto, os brinquedos japoneses adquirem significados diferentes" (Sakurai, 2008: 349). Para muitos fãs brasileiros, os animes trazem mensagens sobre o modo de vida, costumes e valores japoneses. Sob a lente de seus referenciais culturais, um Japão vai sendo inventado e imaginado. Como uma porta, esse mundo animado pode despertar o interesse pela "cultura japonesa". Seus conteúdos e sentidos também podem operar como um parâmetro nas reflexões sobre outras realidades, e sobre identidades também, como na já citada fala de Henrique:

\begin{abstract}
"Ás vezes, eu olho os animes e eles passam muitas coisas da cultura japonesa. Os animes de escola, eu leio e penso, 'Nossa, se o Brasil fosse assim, qual seria a qualidade do ensino aqui?'. Toda a disciplina e tal. Mas vendo assim, se eu estudasse em uma escola japonesa, se tivesse tido essa disciplina, eu seria uma pessoa diferente hoje. Mas tem uma coisa também que eu levo em conta, que eu acho que é até melhor do que ser um japonês, por exemplo, o japonês tem muita confiança no outro. Então, chegam aqui no Brasil e acabam quebrando a cara, porque lá no Japão a ingenuidade é muito grande. Você chega aqui no Brasil, o pessoal é mais esperto, tem aquela percepção melhor dessas coisas assim... da ótica da malandragem. Você tem uma percepção... Como você convive nesse meio, você acaba pegando essas coisas $[\ldots] "$.
\end{abstract}

\title{
ESTRANHO É QUEM NÃO APRECIA O PEIXE CRU
}

No arranjo híbrido chamado "cultura japonesa", um importante elemento a ser considerado na investigação é o fenômeno designado vagamente aqui por "positivação do exótico", ou seja, a valorização ou consumo relativamente recentes pelos não-nikkeis de bens culturais tangíveis e intangíveis referentes a um repertório antes considerado "exótico". A apreciação da culinária japonesa é um exemplo. O sashimi, prato a base de peixe cru, que há algumas décadas causava repulsa pela sua "estranheza", atualmente, como afirma Celina Kuniyoshi, “com o Japão em alta na cotação no mercado dos 'modismos', transformou-se na vedete dos paladares sofisticados" (Kuniyoshi, 1998: 21). Estranho é aquele que não sabe apreciar o sashimi. Teria esse fenômeno alguma proximidade com a ideia de japonismo ${ }^{214}$ ? Seria meramente "moda" ou como afirmam alguns entrevistados para essa pesquisa, a apreciação da “cultura japonesa veio para ficar”?

\footnotetext{
${ }^{214}$ Movimento que se traduziu pelo entusiasmo pelas "curiosidades nipônicas", possibilitado pelo fim do isolamento do arquipélago no final no século XIX. Os artefatos japoneses, como porcelanas, gravuras, pinturas, ideogramas, leques, quimonos, chegam até a Europa e seu caráter estético influenciam muitos artistas impressionistas, como Monet, Van Gogh, Tissot, Manet, Degas (Kuniyoshi, 1998).
} 
Se depender da culinária, não há dúvidas quanto à resposta. Em 2003, havia mais de 600 restaurantes japoneses na cidade de São Paulo, números que superam os das churrascarias. ${ }^{215}$ Em sua análise sobre as condições de aceitação da culinária japonesa na capital paulista, Koichi Mori aponta uma série de fatores que conjugados ajudam a iluminar o entendimento da questão. De acordo com o autor, a distribuição geográfica desses restaurantes estivera em estreita relação com a trajetória de deslocamento dos imigrantes japoneses. Concentrando-se inicialmente no bairro da Liberdade, Pinheiros e Mercado, a partir de 1970 esses restaurantes se expandem no atendimento aos funcionários das multinacionais japonesas que se instalam na região da Bela Vista (Mori, 2003b: 10).

Concomitantemente a essa mudança, alguns empresários nisseis e brasileiros nãonikkeis passam a se interessar pelos restaurantes japoneses como um ramo de negócio, o que segundo o autor, acelerou a reestruturação desses espaços, criando um ambiente asseado e sofisticado, além de ter propiciado o próprio "abrasileiramento" da cozinha japonesa, deixando-a mais ao gosto dos brasileiros. A mudança no conceito de alimentação no país, com a preocupação na ingestão de comidas menos gordurosas e saudáveis foi um elemento igualmente importante. Mori aponta que nesse período das décadas de 1970 e 1980, o estreitamento dos laços entre brasileiros nikkeis e não-nikkeis, seja através dos casamentos, seja nas relações de trabalho, negócio e amizades também contribuiu para a aproximação dos não-nikkeis com a culinária japonesa.

O autor mostra como a aceitação do sushi e sashimi ${ }^{216}$ foi gradativamente acontecendo de acordo com um conjunto de contingências histórico-culturais. Se o sabor agridoce do yakissoba, sukiyaki, tempurá e teppanyaki ${ }^{217}$, temperados com shoyu, tinham certa aceitação no paladar do brasileiro na década de 1980, o mesmo não aconteceu imediatamente com o peixe cru, ainda associado à selvageria e ao barbarismo. Mori concluiu que as imagens positivas dos nikkeis no Brasil e do Japão no resto do mundo tiveram um grande peso na transformação dessa visão negativa inicial sobre a cozinha japonesa. "Diligência', 'disciplina', 'ordem', 'alto nível tecnológico', 'automóveis e eletrodomésticos de bom desempenho', 'Sony" foram algumas das imagens sobre os nikkeis e o Japão citadas pelos seus entrevistados. O trabalho de adaptação dos

\footnotetext{
${ }^{215}$ De acordo com um levantamento do Sindicato de Hotéis, Restaurantes, Bares e Similares, na capital paulista há 600 restaurantes de comida japonesa contra 500 churrascarias. O crescimento na oferta do setor na cidade foi superior a $400 \%$ em quinze anos. Conforme matéria, “Ao gosto do brasileiro: Comida japonesa se torna popular como o churrasco nas principais capitais do Brasil”. Revista Veja, edição 1811, 16/07/2003.

${ }^{216}$ Sashimi: peixe cru servido com shoyu, molho de soja. Sushi: arroz temperado com açúcar, sal e vinagre combinado com peixe cru, frutos do mar, vegetais ou frutas. No Brasil, inúmeros ingredientes podem ser utilizados no preparo, até mesmo maionese, cream cheese e morango.

${ }^{217}$ Tempurá: pedaços fritos de vegetais ou mariscos envoltos em polme. Teppanyaki: carne e vegetais preparados em chapa quente.
} 
sushi-men, seja através da "tropicalização" dos sushis ou uso de novos ingredientes nas receitas, seja nas estratégias de inserção de elementos inovadores, como o sistema de rodízio e de combinados de sushi e sashimi, também tiveram um peso significativo no processo de apreciação do peixe cru (Mori, 2003b: 16-17).

A nova onda que toca esse universo da culinária japonesa são as temakerias, locais geralmente pequenos e que dispõe de um cardápio vasto de temakis, ${ }^{218}$ feitos na hora, no estilo fast food. A maior rede de temakerias de São Paulo, a Makis Place, iniciou suas atividades em 2006, expandindo-se anos depois em redes franqueadas dentro da capital e fora dela. Segundo consta no site da empresa, no ano de 2010, a rede já conta com 12 unidades somente na cidade de São Paulo, com inauguração em breve de mais três franquias. ${ }^{219}$ Como uma febre, nos últimos anos, as temakerias espalharam-se rapidamente por todo o Brasil. Bom preço, rapidez no atendimento e alimentação saudável são a combinação ideal para o agitado cotidiano da vida moderna. Fast food com saúde. O Japão é mesmo pop.

\section{“ACHO QUE VIROU MODA SER JAPONÊS”: O JAPÃO É MESMO POP}

Na direção dessa popularização de coisas e símbolos nipônicos, a “cultura japonesa” já não parece tão estranha aos olhos dos brasileiros não-nikkeis. Além da esfera da culinária e do entretenimento, essa "cultura", conjunto híbrido de referências, abrange um domínio que se estende desde a utilização de "motivos japoneses" no design de interiores, na moda ${ }^{220}$, passando pela popularização de esportes e lutas marciais ${ }^{221}$, pela apreciação das artes em geral, como o taikō e ikebana ${ }^{222}$, pelo número crescente de adeptos de religiões e seitas orientais até a incorporação do estilo zen ${ }^{223}$. Um amplo conjunto de referências que conformam um quadro de

\footnotetext{
${ }^{218}$ Temaki: sushi em formato de cone, enrolado no nori (alga) e com recheio que cobre a extremidade da parte mais larga.

${ }_{219}$ Disponível em: http://www.makis.com.br/quemsomos historia.asp?secao=quemsomos. Acesso: 10/06/2010.

${ }^{220}$ No ano do centenário da imigração japonesa para o Brasil, a 25a. edição da São Paulo Fashion Week adotou a temática japonesa para o evento.

${ }^{221}$ Além dos já populares jiu-jitsu, judō e karatê, esportes como sumō, kendō (esgrima japonesa), kyudo (arquearia japonesa) são hoje praticados por muitos não-descendentes de japoneses. Segundo o técnico Gomes, da Associação Kaiko - escola que ensina artes marciais - de Londrina, no Paraná, "Por nossa causa, hoje $80 \%$ dos praticantes brasileiros de sumō já não são descendentes de japoneses". Conforme reportagem, "Tem gosto para tudo - arcos, petecas, bolas pontiagudas: esportes 'diferentes' superam a mesmice das práticas tradicionais e formam atletas em Londrina”, Folha de Londrina, 10/04/2009.

${ }^{222}$ Arte em arranjos florais que tem inspiração em conceitos filosóficos do budismo e visa uma montagem harmônica entre linearidade e cor. $\mathrm{O}$ arranjo expressa o ciclo de crescimento da vida: passado, presente e futuro.

${ }^{223}$ Segundo Sakurai, atualmente o zen é conhecido como um conceito genérico que abrange um conjunto de práticas, manifestações, estados de consciência, ensinamentos que buscam o equilíbrio da mente e o bem estar. Possui uma tradição meditativa e tendo raiz no budismo e na concepção de desapego material, acabou associando-se ao clean (limpo). O estilo zen é muito apropriado em decoração de casas e nos institutos de estética que oferecem massagens shiatsu e banhos de imersão no ofurō (Sakurai, 2008: 351-52).
} 
mercantilização de bens culturais e simbólicos do que antes se encontrava nas "margens" da cultura dominante. Seria um desdobramento do que Hall denomina "proliferação da diferença", essa fascinação da conjuntura pós-moderna global pelo “toque de etnicidade, um 'sabor' do exótico e, como dizemos em inglês, a bit of the other"? (Hall, 2003: 319).

O autor, na tentativa de investigar o significante "negro" na expressão "cultura popular negra”, chega à conclusão de que não existem formas puras. Ao contrário, as formas são híbridas, produtos da confluência de mais de uma tradição cultural, de negociações e estratégias de recodificação e ressignificação a partir de materiais preexistentes. A "cultura japonesa" também é resultado do hibridismo do contato $^{224}$, da transposição das fronteiras, da diáspora. Desterritorializada, segundo Renato Ortiz, "transcende suas origens autóctones" - "Madonna não é norte-americana, na mesma medida em que Doraemon já não é mais japonês" (Ortiz, 2000: 173).

No contexto de globalização dos mercados, esses bens culturais aproximam os gostos dos consumidores num espaço transnacional, contudo defendo que certos objetos, como os animes e mangás, ainda trazem a marca simbólica de suas nações de origem e não perdem sua "cor local" como afirma Ortiz (id.; ib.: 184). Vimos como a partir desses bens, Henrique Nagata desenvolveu sua reflexão a respeito de algumas diferenças culturais entre Brasil e Japão. Além disso, o próprio mercado de eletroeletrônicos incorpora o discurso Made in Japan, ou seja, de garantia de qualidade do produto japonês, como já mostrado no capítulo 1, com a marca Semp Toshiba. Engendrado no contexto de desenvolvimento tecnológico do Japão, esse discurso imprime uma estampa diferencial ao "legítimo" produto nipônico.

Como já reiterado diversas vezes ao longo do trabalho, não faz parte do escopo da pesquisa adentrar com profundidade sobre o que genericamente considerei como "peças" da "cultura japonesa". Nem mesmo uma análise dedicada exclusivamente a esse fim daria conta de cobrir tantos dados e elementos referentes a esse arranjo. O que nos interessa aqui é que essa categoria foi constantemente acionada pelos sujeitos dessa pesquisa nos processos de construção identitária.

Nesse sentido, importa mostrar que a força da difusão e do consumo, relativamente recentes, de imagens e símbolos referentes à “cultura japonesa” nos seus mais variados âmbitos - como por exemplo, culinária, religião, entretenimento, esporte, cinema, teatro, dança, música revela um fenômeno de dimensões globais, mas que possui uma especial ressonância no Brasil,

\footnotetext{
${ }^{224}$ Os olhos grandes que caracterizam os personagens do mangá moderno, por exemplo, assim como outras mudanças nas suas características faciais, estiveram relacionadas com a difusão das histórias em quadrinhos ocidentais no Japão pós-guerra.
} 
país conhecido como a maior "colônia japonesa" fora do Japão. Uma das hipóteses que norteia o trabalho centra-se na ideia de que tais elementos provocam uma inflexão positiva no imaginário discursivo que envolve os nikkeis. Como atesta o entrevistado Pedro Higa, sansei, estudante de Ciências Sociais, residente na cidade de São Paulo:

\begin{abstract}
“Tenho 22 anos. Nasci em 1987. Eu vivi bem essa geração dos anos 80 para os 90 . Eu acho que a sorte minha ou azar até, foi que a gente veio na geração dos chamados 'tokusatsus' ${ }^{225}$, o Jaspion, o Changeman, essas coisas. Então, por mais que tivesse uma piadinha ou outra, aquilo abriu muitos as portas para os orientais. No sentido de que, abriu mais o respeito das pessoas para com os orientais. Também pegaram aquela onda do 'boom' do Japão. Querendo ou não foi uma relação sociológica assim que... Você vê que as pessoas já começaram a olhar os orientais com outros olhos. Depois veio essa nova forma de mídia ${ }^{226}$, de entretenimento e tudo mais. E as pessoas começaram a ver os japoneses como heróis... as criancinhas, no caso".
\end{abstract}

Quando questiono a entrevistada Luciana Nakayama, sansei, 26 anos, técnica de informática e residente na cidade de Maringá, se ela percebe que os "valores" em que foi criada, também podem ser encontrados nas novas gerações, afirma:

\begin{abstract}
"Eu acho que está até mais forte nessas novas gerações. Eu acho que virou moda ser japonês. Virou moda mangá, cabelo liso, estilo japonês, estilo oriental. Eu acho que está mais forte nos mais jovens do que na nossa geração de agora. Porque eu vejo assim... Claro, às vezes é meio fantasioso japonês ficar andando... meninas que não são japonesas andando com blusinhas estilo oriental e quer cabelo igual de japonês, e quer arrumar o cabelo que nem japonês e quer usar 'pulserinha'... Não sei se é por causa da moda que eu estou vendo isso mais forte ou se realmente são valores dessa nova geração. Eu acho que a cultura do Japão está bem divulgada aqui no Brasil agora. Por isso que talvez esteja mais forte. Vejo gente assistindo filme do Japão, desenho do Japão, banda do Japão. Tenho alguns amigos 'brasileiros' que sabem mais do Japão do que eu. Não sei, eu vejo isso mais forte. Agora não sei se é moda, como algo passageiro, ou se é a 'cultura japonesa' mesmo que está prevalecendo".
\end{abstract}

\title{
“ALGUMA COISA ESTÁ ACONTECENDO”: "O RESGATE DA CULTURA”
}

Outro aspecto da tal "cultura japonesa" que o capítulo propõe analisar concerne ao "resgate das tradições", que seria empreendido, sobretudo, pela geração mais jovem, e que se constituiu em uma questão bastante presente nas entrevistas realizadas. Como já discutido, muitos interlocutores afirmaram que existe uma tendência para a "perda de valores" com o avançar das gerações e com os processos de miscigenação. Todavia, alguns notam um fenômeno

\footnotetext{
${ }^{225}$ Abreviação da expressão tokushu satsuei, originalmente referia-se aos gêneros televisivos ou cinematográficos que utilizavam de efeitos especiais. Posteriormente, tornou-se reconhecido pelas séries live-action de super-heróis produzidos no Japão. Além das já citadas por Pedro, havia também as famosas National Kid, Jiraiya, Black Kamen Rider.

${ }^{226}$ Pedro refere-se aqui à expansão da TV por assinatura e da internet como importantes veículos divulgadores das animações japonesas.
} 
de revalorização de práticas culturais, como o aprendizado da língua japonesa, e na música, pelo interesse, por exemplo, no karaoke $\hat{e}^{227}$, taikō, shamisen ${ }^{228}$, yosakoi soran ${ }^{229}$, matsuri dance ${ }^{230}$. Em que medida, esse fenômeno - definido pelos interlocutores sob diversos nomes, como "resgate", "revitalização", "revalorização" de práticas culturais, híbridas por excelência constrói um tropo de identificação para os sujeitos? Conformariam uma "tradição inventada", como na acepção de Eric Hobsbawm e Terence Ranger, ou seja, um conjunto de práticas, de natureza ritual ou simbólica, que visa inculcar certos valores e que implica uma continuidade com relação ao passado? (Hobsbawn, 1984: 9).

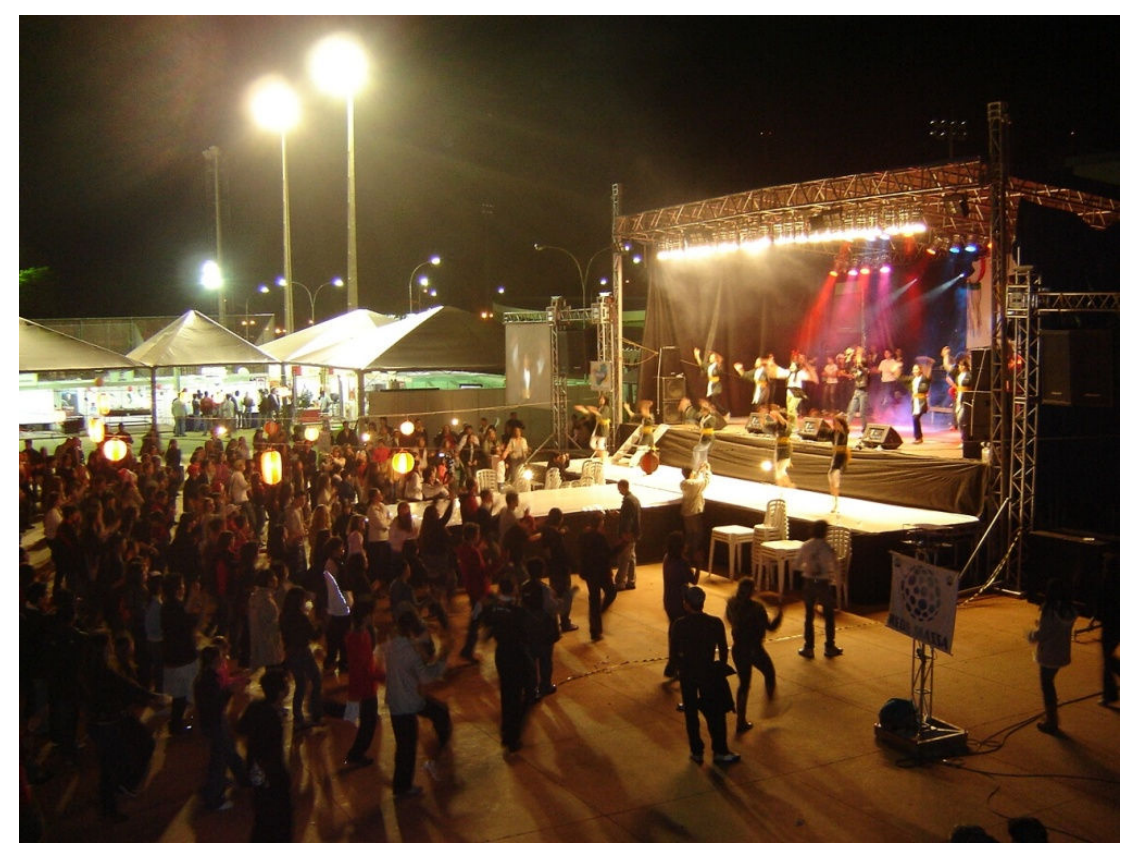

Fig. 31 Jovens dançando o matsuri dance no Hoshi Matsuri ${ }^{231}$ em Maringá. Foto: Camila Ischida (07/09/2008).

\footnotetext{
${ }^{227}$ Atividade em que as pessoas cantam versões instrumentais das músicas. No Brasil, encontra-se presente em estabelecimentos comerciais de entretenimento, mas também é praticado em competições e concursos nas associações espalhadas pelo país.

${ }^{228}$ Instrumento musical japonês de três cordas.

${ }^{229}$ Espécie de dança realizada em grupo, originária no Japão, mas que já conta com vários grupos aqui no Brasil, sobretudo no Estado de São Paulo.

${ }^{230}$ Matsuri: Festa, festival. Expressão criada por jovens das cidades de Maringá e Londrina, no Estado do Paraná, e que se refere a uma coreografia que possui raízes no bon-odori-dança de tradição budista voltada para a celebração da alma dos antepassados - mas que utiliza músicas $J$-pop (pop japonesas).

${ }^{231}$ O Festival Hoshi Matsuri foi idealizado e organizado exclusivamente por jovens integrantes dos seinen-kais de entidades nipo-brasileiras na cidade de Maringá, sobretudo as religiosas, como Seicho-No-Ie, Nishi Honganji, Holiness, CCEM. O evento realizado em homenagem ao centenário da imigração japonesa no Brasil, contou com atrações como shows, concurso da Miss Tanabata, matsuri dance, apresentação de grupos de taikō e yosakoi soran, workshops de kendō, mangás, cosplay, além da venda de pratos japoneses, também preparados pelos jovens.
} 


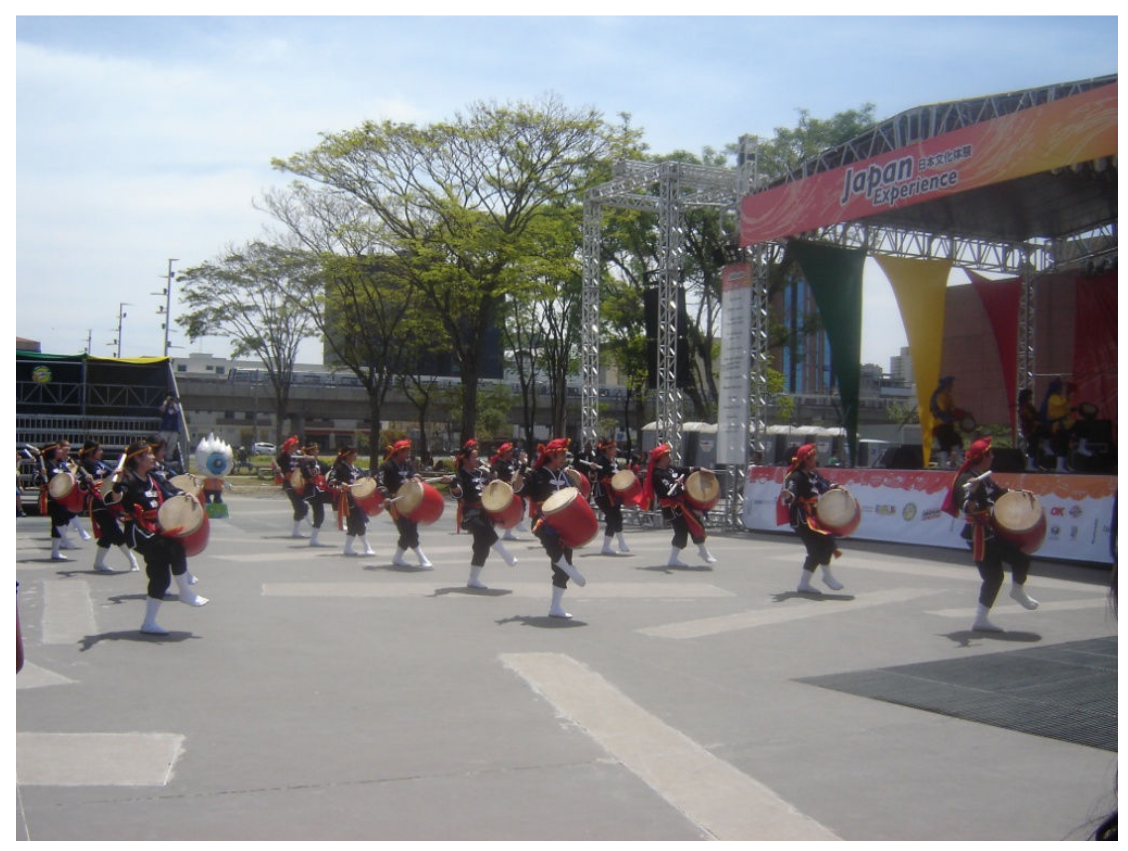

Fig. 32 Apresentação do Ryukyu Koku Matsuri Daiko (taikō de Okinawa) no Japan Experience ${ }^{232}$. Foto Camila Ischida (24/10/2009).

Conheci Pedro Higa, o jovem que se diz pertencente à geração dos tokusatsus, por meio de sua participação em uma comunidade do orkut, já citada neste trabalho, "Arigatô, o c....”. A descrição que consta na página desta é bastante autoexplicativa quanto aos seus propósitos:

\section{"C...(aralho!)}

Esse é um espaço para todos aqueles que já foram vulgarmente tachados de 'japa' só por terem olhos puxados e que se sentem revoltados com as pessoas que não sabem que tem um monte de país na Ásia além do Japão (Laos, Cambodja, Filipinas, Coréia do N, Coréia do S, Mongólia...). E para as garotas que ouvem xavecos na rua e em baladas do tipo 'arigatô' e 'vamo come um sushi' quando o cara provavelmente não sabe responder se sushi vem do Japão ou da China. Afinal, olho puxado não é tudo igual. E aposto que ninguém gosta de ser colocado em um 'saco', nem que os outros fiquem fazendo piadas por causa de uma característica física sua, como se fosse uma coisa para se rir. Espero que com esse espaço a gente não só mande esse pessoal à m..., mas também possa tirar algumas dúvidas e preconceitos e desabafar experiências dessas babaquices que ouvimos por aí. Qualquer um que tenha e entenda as intenções acima pode participar do grupo, tendo ou não olhinhos puxados...”.

Buscava informações nessa comunidade sobre um episódio veiculado no programa humorístico A Diarista, "O Japão nosso de cada dia"233 (2005), quando me deparei com as

\footnotetext{
${ }^{232} \mathrm{O}$ evento Japan Experience é organizado por jovens voluntários da Comissão de Jovens do Bunkyō e chegou à sua $5^{\text {a }}$. edição em 2009. Tem o objetivo de "proporcionar a experimentação prática dos elementos da cultura japonesa a pessoas de todas as idades, raças e culturas, [...] através de palestras, workshops e shows que mantêm as tradições japonesas" (grifos meus) (fonte: www.centenario2008.org.br Acesso:12/06/2010). Conta com oficinas, exposições, shows, apresentações musicais e praça de alimentação com comida japonesa
} 
discussões de alguns membros da comunidade que estavam analisando as possibilidades de processar o programa por racismo, devido a outro episódio da série, “Aquele da academia"234 (2007). A tentativa dos participantes esfriou, mas tive a oportunidade de conversar pessoalmente com Pedro, um dos articulistas do debate, em sua faculdade. Inicialmente pedi a ele que falasse um pouco sobre sua trajetória de vida e, se quisesse, de sua família também.

Pedro conta que a família do pai é de origem okinawana e a da mãe é oriunda da província de Wakayama, "Eu já nasci em um terreno onde tem um certo conflito, né? São dois povos meio que diferentes, um acabou invadindo o outro e assim, a própria família tem um certo... Uma certa briga entre eles, interna. Acho que os orientais brigam muito entre si e isso acaba desestabilizando a própria militância étnica deles". Fiquei bastante curiosa com o fato desse termo estar sendo utilizado com referência aos descendentes de japoneses, já que comumente ele remete à luta de minorias étnicas marginalizadas socialmente. Aos poucos, Pedro foi me explicando os sentidos desse uso. Diz conhecer pouco a história dos antepassados, mas é algo que está pesquisando atualmente,

\begin{abstract}
"Porque na sociedade brasileira, sempre teve aquele forte, uma certa coerção contra os próprios orientais. Então, eles sempre forçam, 'pô, você não é brasileiro, você é japonês'. E não é nem pela sua atitude, mas é pela sua aparência. Desde pequeno, você escuta não só das crianças, mas principalmente da galera mais velha. Inclusive, eu vejo hoje que a juventude é bem menos preconceituosa do que os senhores de 60,70 anos que eu encontro pela rua. Enfim, mas a gente é formado em uma sociedade racista. Eu acho que isso distanciou muito, não só para mim, mas para várias pessoas, da geração nissei, de resgatar a própria cultura. Apesar de estar fazendo no cotidiano, mas eles não têm um olhar histórico sobre isso. Meio difícil você ver alguém com esse olhar. Eu estou resgatando isso mais agora. Nunca participei de nenhum clube, kai kan, nem bunkyō. E eu estou procurando mais agora, para me envolver mais com a cultura que eu acho que eu tenho muita coisa a ver, mesmo não tendo participado. E eu acho importante resgatar isso, mesmo como memória".
\end{abstract}

"Deixe-me ver se entendi, Pedro. Você acha que o preconceito sofrido pelos nikkeis fez com que muitos negassem ou tentassem se afastar da 'cultura' ou de algum tipo de resgate histórico?" - questiono.

\footnotetext{
"Exatamente. Você vê que muita gente inclusive acaba até não andando com orientais, mais por vergonha, não é nem assim por... Porque depois vão falar, 'casalzinho... não sei o quê, é irmão, é parente'. É sempre essa jogada e isso subjetivamente vai causando um certo impasse, né? Acaba desmobilizando as pessoas também. Eu acho que esse é um dos fatores, um dos

${ }^{233}$ Esse episódio, no qual a diarista Marinete, personagem da atriz Cláudia Rodrigues, trabalha na casa de uma família de japoneses, contém uma série de caricaturas do japonês, com alto teor cômico e depreciativo. Apesar das tentativas de contato com a Rede Globo, não consegui a gravação do mesmo.

${ }^{234}$ Nesse episódio a diarista Marinete é contratada para fazer a faxina de uma academia de sumō, mas lá chegando descobre que sua função é lavar as partes íntimas de um lutador.
} 
principais fatores, aliás. Sim, muitas vezes... Eu sempre tentei seguir, 'Ah não estou nem aí para o que os outros falam, o que importa é o que eu realmente acredito'. Mas não tem como, uma vez ou outra você acaba até atravessando a rua para não passar perto de um oriental, porque depois vão falar, 'Ó, seu parente, não sei o quê'. Então você até evita comentários assim dos outros, mesmo que seja brincadeira de algum amigo, você pode xingar o cara, mas se não é seu amigo intimo você... Entendeu? Fica complicado".

O comerciante Cláudio Shimada ${ }^{235}$ de Astorga, também mencionou essa tentativa da criança e do jovem, sobretudo do nissei, em se distanciar ao máximo das "coisas" que estivessem relacionadas ao universo japonês:

"Na realidade, quando a gente é criança e não entende direito, eu penso que a gente queria ao máximo estar integrado com os não-descendentes, sentir-se mais 'brasileiro' do que descendente, do que estar muito com os 'japoneses' [risos]. Uma questão até ao contrário de você querer muito se aproximar do resgate, do que é 'japonês', de fazer parte do nihongako, do teatro japonês, da dança, ou seja, de você talvez querer fazer o possível para estar mais ligado com as coisas que não são orientais. Por isso eu vejo o quanto é importante essa nossa geração conseguir resgatar isso, porque senão muita coisa vai se perder, já que a geração dos avós, dos isseis está indo e a dos nisseis também está envelhecendo. Então, é a dos sanseis que está em uma nova fase e que precisa fazer essa transição para os yonseis. É importante esse resgate $[\ldots] "$.

Cláudio e sua esposa, Maria, como já mencionado no primeiro capítulo, passaram a participar como voluntários da ACEAST, depois que os filhos entraram para o grupo de taikō, Seishun Daiko, da associação. Isabel Nishida ${ }^{236}$, a coordenadora do grupo, também entrevistada para essa pesquisa, havia me relatado, sem citar nomes, o seu contentamento com o fato de que duas famílias associadas à entidade passaram a participar ativamente da mesma, depois que suas crianças entraram para o Seishun Daiko. Falando sobre o grupo, afirma:

"Eu acho que sim, que está dando resultado, porque primeiro estou muito feliz, sabe? Porque
tem duas famílias aqui descendentes de japoneses que não frequentavam, quer dizer eles eram
associados, mas ausentes. Mas como seus filhos estão fazendo taikō, eles estão participando
agora. Quer dizer, os filhos estão trazendo os pais para a associação, então, isso é muito bom!
E são pessoas que, realmente, antes, não participavam de nenhum evento, quer dizer, só
constavam como associados, mas só pagando mensalidade... Não tinham participação. Eu
acho que para nós, só pagar não é interessante. O importante, eu acho, é participar, porque
eu acredito que a 'cultura japonesa' é muito rica e acho que a gente tem que resgatar...
Porque onde a gente for, a gente é sempre 'japonês', por causa dos nossos traços, né? [risos]”.

A fala de Isabel mostra com clareza a diferença entre o mero associado da entidade, pagante das mensalidades e o participante voluntário e atuante nas atividades promovidas. Embora Isabel não tenha feito uma referência direta às famílias que agora participam

\footnotetext{
${ }^{235}$ Sansei, 41 anos, dono de uma loja para presentes e utlidades domésticas.

${ }^{236}$ Nissei, "mestiça", 53 anos, orientadora educacional, de Astorga. Citada no início deste capítulo.
} 
“efetivamente" da ACEAST, há grandes chances de uma delas ser a de Cláudio e Maria. O ponto levantado por Isabel é que neste caso, são os filhos que trouxeram os pais para a associação e não o contrário, como comumente acontece. Cláudio que, quando criança e jovem, na afirmação de sua brasilidade, fazia "o possível para estar mais ligado com as coisas que não eram orientais", vê a aproximação da geração sansei e yonsei com a "cultura japonesa" como algo positivo e necessário para que "muitas coisas não se percam". Afastamento e aproximação/resgate são termos nativos utilizados nessa relação das diferentes gerações com a "cultura".

Júlia Suzuki Bertolli ${ }^{237}$ entende esse "afastamento" como efeito ou até mesmo como estratégia dos imigrantes no processo de adaptação ao país. Ela desenvolve essa reflexão quando lhe pergunto se ela costumava ouvir histórias de preconceitos sofridas pelos seus pais ou avós:

"É o que eu falei para você, de repente eu via muito preconceito por eu ser uma criança, ${ }^{238}$ uma adolescente. De repente, meu pai e minha mãe não sentiam nessa mesma intensidade. Isso eu não vou saber dizer para você. Mas o que posso dizer? Na época deles, eles faziam o maior esforço para se adaptar ao ambiente em que eles vivem hoje, sabe? Esse mundo ocidental. E hoje nós fazemos o maior esforço para resgatar as culturas deles. Então, é assim, no final das contas, enquanto um queria se adaptar... Naquela época eles foram se adaptando até que chegou num ponto em que a gente estava perdendo e começou a voltar resgatando, né? [...] Porque hoje tudo que é oriental está na mídia, está na moda. Então, a gente acaba tendo que resgatar também! E são coisas belíssimas! São coisas que nos dão muito orgulho! Eu penso".

Como foi possível observar ao longo da dissertação, as percepções sobre o preconceito partiram da geração nissei e, sobretudo, sansei e yonsei. De modo geral, a primeira geração mostra-se agradecida pela oportunidade de poder trabalhar e viver com a família no país, não obstante as dificuldades e conflitos que eventualmente surgiram nesse processo de adaptação. Como vimos, essa postura que aliava a resignação e a força no enfrentamento dos obstáculos era inspirada no princípio do "gambarê" (Sakurai, 1993). E um desses obstáculos seguramente foi o preconceito, como mostrado no capítulo 2. Lúcia Miyamoto ${ }^{239}$, nissei, 46 anos, de Maringá, também estabelece uma relação entre "resgate", mudança geracional e preconceito, pois com o sucesso econômico e as conquistas materiais da segunda geração, o jovem da terceira passou a não sentir "vergonha" da descendência, e sim dar valor a ela:

\footnotetext{
"Acho que devido aos que vieram primeiro, levantaram a autoestima mesmo... As pessoas bem sucedidas... fizeram talvez com que os mais jovens tentassem resgatar, porque eles começaram a sentir um pouco de orgulho daquilo lá também. Começaram a valorizar. Porque eu acho que na nossa época mesmo, quando eu ia à escola, 'ah, japonês, calabrês, foi diabo

${ }^{237}$ Sansei, 41 anos, dona de uma relojoaria em Astorga.

${ }^{238}$ Júlia narrou o episódio vivenciado por ela aos 9 anos, citado no capítulo 2, em que a mãe de uma colega sua dissera: "não vá andar com ela, porque ela é japonesa!":

${ }^{239}$ Empresária, mãe de Leonardo Miyamoto.
} 
quem te fez'. Era tanto sarro que a gente sofria... 'Olho rasgado', 'japa', 'Ajinomoto', 'cheiro de missō'. Menina, o que a gente ouvia! Então, a gente tinha até vergonha! Hoje em dia essa geração deles (refere-se à geração do filho), acho que ficou uma geração que financeiramente se tornou melhor, porque antigamente era difícil você ver quem levasse e buscasse o filho na escola de carro! Essas coisinhas que hoje em dia se tornam normais. Mordomias que foram adquiridas graças ao trabalho de todos, de duas, três décadas de trabalho, né... que as pessoas foram conquistando isso. Eles começaram talvez a sentir menos vergonha. A gente tinha mais vergonha, porque o preconceito era bem maior, né?. Os jovens, talvez por resgate mesmo e acho que um pouco é porque a autoestima foi melhorada mesmo. Mas isso tudo graças a um trabalho que vem dos outros! Eu acho que isso serve de estímulo para os jovens para que eles também queiram se dedicar aos estudos, se destacarem naquilo que eles fazem, né?

Já as novas gerações, frequentemente, mostram-se críticas a certos costumes e valores arraigados em algumas famílias de origem nipônica, como a submissão da mulher a certos papéis no interior do grupo familiar, encarada agora sob a ótica do machismo; a inibição, que atrapalha no mercado de trabalho e o preconceito, dirigido tanto contra os brasileiros descendentes de japoneses, como destes contra os não-descendentes.

Júlia percebe uma "força contrária tentando resgatar" o que supostamente estava se perdendo no esforço dos imigrantes e seus descendentes em se integrar à sociedade. Ela aponta que a valorização da "cultura japonesa" e "oriental" e sua inserção no circuito da mídia e da moda também estimulam esse "resgate", corroborando uma das hipóteses do trabalho de que a circulação de imagens positivas sobre esse complexo simbólico relacionado ao Japão/ japoneses/ nikkeis tem efeitos sobre os processos de identificação ou negociação de identidades dos sujeitos. Júlia menciona o "orgulho" que sente nas "belíssimas coisas" associadas à "cultura oriental". "Mas onde você vê esse resgate?" - pergunto-lhe:

"Por exemplo, exemplos práticos da nossa comunidade... o taikō. Eu acho bárbaro! Emocionante! Eu acho arrepiante! Aquela dança, matsuri dance? É muito legal! E onde eles estão pegando os integrantes deles? Na juventude! Na infância e na juventude! Eu acho um resgate bárbaro, acho um resgate que tem tudo para dar certo. Você volta às suas raízes, você volta a sentir... sabe? Que vocêfaz parte de uma coisa diferente só daqui, que vocêfaz parte lá de uma forma direta do Japão! Eu penso que é por aí, é um trabalho. Eu não sei se é um trabalho 'marketeiro', voltado especificamente para isso, mas também tem um resultado, na minha opinião. E eu não vejo a hora do meu filho entrar no taikō! E ele só não vai se ele realmente não quiser. Eu não vejo a hora de ele ir para o karatê, e ele só não vai se ele não quiser, você está entendendo? Eu gostaria de dar essa oportunidade para o meu filho. E se ele se integrar... Minha filha, por exemplo, com os animes. ${ }^{240}$ Nossa senhora! Eu fiquei super empolgada, só que é uma faca de dois gumes esse negócio de animes. Os grupos que se formam! Ela foi naquele encontro lá em São Paulo. Então, ela fez amizades desde Maringá, Londrina, Brasília, até no Rio de Janeiro! De uma certa forma, quando ela quer se expandir, a gente tem que segurar, não adianta, né? Ela fez amigos em tudo quanto é lugar. A respeito disso, de certa forma é legal. Ela teve esse resgate... Meu sobrinho de onze anos passa por esse resgate. Meu sobrinho é 'mestiço' também. Então, eu acho que é um resgate da identidade,

\footnotetext{
${ }^{240}$ Júlia tem uma filha de 18 anos e um filho de 2 anos.
} 
sabe, oriental deles. Ele também está com essa história aí dos cosplayers, sabe,? Eu acho um resgate bem legal, bem interessante. Já faz uns três anos, hein, que eu vejo minha filha muito inspirada assim nos orientais. E eu acho interessante, acho que é um resgate que eu não tive. Eu não tive oportunidade de ter esse resgate. A minha geração foi muito massacrada por causa dos dekasseguis. Foram em massa! Poucos ficaram... A tua já não. Mas a minha geração já foi mais massacrada em relação a isso. Pensa você, você se vê rodeada de amigos orientais e de repente você se vê sem nenhum... Mas eu sinto um resgate bem legal e torço para que isso aumente. E parece que vai aumentar, né? Cada vez um movimento diferente. Eu acho muito interessante!”.

A comerciante que julga sempre ter mantido uma relação de distanciamento com a "cultura japonesa" - casou-se com um descendente de italianos, não fala o nihongo, não participa das atividades da ACEAST, tem poucos amigos nikkeis - fala com grande animação do envolvimento da filha com o mundo dos animes. Júlia, sansei, de 42 anos e Cláudio, sansei, 41 anos fazem parte de uma geração, na qual o sashimi, o shiatsu e o taikō eram vistos como excentricidades. Há poucos anos atrás ainda eram. O próprio testemunho do jovem Pedro, sansei, 21 anos, que inicialmente buscava se afastar de todo esse universo mostra o quão recente é toda essa valorização.

Essa ideia de "resgate", seja da "cultura", das tradições ou das raízes, não é pensada pelos interlocutores como uma tentativa de reproduzir com a maior fidelidade possível hábitos e práticas do Japão trazidos pelos seus ancestrais. Elementos do passado são recriados como, por exemplo, quando jovens de Maringá e Londrina, no Paraná, passam a imprimir mais velocidade e até mesmo ginga ao bon-odori, dança de origem japonesa voltada para reverenciar a alma dos antepassados, ficando conhecido como bon-odori moderno. Coreografada em ritmo lento, a tradicional dança é apreciada nos festivais nipo-brasileiros, sobretudo, pelas mulheres mais idosas. $^{241}$ Depois da iniciativa em acelerar os passos, os jovens introduziram músicas pop japonesas, reinventando completamente o conteúdo e os sentidos da dança e atribuindo outro nome para o resultado: matsuri dance. Os novos passos ainda tem inspiração no bon-odori, e assim como na dança tradicional, todos acompanham a mesma coreografia, contudo o arranjo obtido é totalmente diferente: no emaranhado de influências do Brasil e do Japão, as (re) invenções se dão a cada novo contexto e geração. ${ }^{242}$

Como assegura Júlia, a partir dessas práticas, "Você volta às suas raízes, você volta a sentir que você faz parte de uma coisa diferente só daqui, que você faz parte lá de uma forma direta do Japão!". Desse modo, essa noção de "resgate" tem muito mais a ver com uma

\footnotetext{
${ }^{241}$ Além de reverenciar os antepassados, no bon-odori busca-se agradecê-los pela boa safra. Assim, é coreografada em grupo e em círculo, com passos que reproduzem gestos como semear, ceifar e colher. Ver fig. 29.

${ }^{242} \mathrm{O}$ matsuri dance consiste em uma recriação de uma recriação, pois o bon-odori reproduzido no Brasil nos festivais pode até guardar o propósito de celebrar a alma dos antepassados, mas atualmente é performado e entendido muito mais como um movimento artístico.
} 
"aproximação" da "cultura", em oposição ao "afastamento" experienciado pela geração nissei e sansei mais velha, do que propriamente recuperação de algo reproduzido no Japão e prestes a se perder para sempre. Assim, talvez seja possível afirmar que essa "aproximação" tenha forte relação com a popularização dos bens culturais, tangíveis e intangíveis, ligados ao universo nipônico/nipo-brasileiro. Milena Teruya, sansei, 23 anos, da turma do seinen-kai da Seicho-NoIe de Maringá, ao comentar sobre a participação dos jovens na organização do Festival Hoshi Matsuri, dissera:

\begin{abstract}
"Era uma coisa que eu jamais achei que iria ver, aquela união de 'japoneses'. Mas acho que é isso, pelo menos nessa geração, eu estou vendo que fora essa vontade de querer ajudar, estão buscando um pouco resgatar a identidade, os valores. [...] Além disso, a cultura tem atraído não-descendentes que muitas vezes sabem mais do que os próprios nikkeis. Alguma coisa está acontecendo".
\end{abstract}

Observar a relação de admiração ou de pelo menos respeito dos brasileiros não-nikkeis com esse universo simbólico nipônico/nipo-brasileiro tem significados para os brasileiros nikkeis. Deparar-se com um sujeito fluente em nihongo sem nenhuma descendência quando se é filho ou neto de japoneses e o seu vocabulário se restringe ao arigatō e onegai-shimasu ${ }^{243}$ causa em muitas pessoas certo constrangimento. Com a "cultura japonesa" em alta no mercado de bens simbólicos, esse constrangimento não se limita ao domínio da língua. Existe uma certa cobrança para que os descendentes de japoneses, considerados por eles mesmos e pelo senso comum como "representantes" da "cultura japonesa", detenham um mínimo de conhecimento sobre alguns aspectos da mesma.

Mas certamente no universo da culinária e da língua esta cobrança pode ser maior. No relato que abre este trabalho, narrei a história de uma compra que fiz em uma loja de produtos japoneses. Com tantos "brasileiros" apreciando a "cultura japonesa", como não saber a diferença entre um ajitsuke nori e um yaki nori? Afinal, eu não era uma "japonesa"? Esse acontecimento incitara uma série de questionamentos e um processo reflexivo em mim.

Essa reflexividade que surge em momentos como o que presenciamos atualmente, de positivação, valorização, revitalização da "cultura japonesa" pode ser observada nos vários depoimentos dados. Para Cíntia, "alguma coisa" que envolve o "resgate da identidade e dos valores" está acontecendo e que, possivelmente passa pela atração que a "cultura japonesa" hoje exerce entre os não-descendentes. Para Júlia, o "modismo" incita o resgate, desperta o interesse

\footnotetext{
${ }^{243}$ Arigatō: obrigado; onegai-shimasu: por favor.
} 
para as "belíssimas coisas" da "cultura", acende o "orgulho". O que seria esse sentimento de orgulho se não um catalisador da experiência identitária?

\section{O CENTENÁRIO DA IMIGRAÇÃO JAPONESA NO BRASIL}

As comemorações do centenário da imigração japonesa no Brasil também tiveram força na exploração de imagens positivas sobre a "cultura japonesa" e sobre a presença nikkei no país. Os eventos que pipocaram nos mais diversos cantos da nação, sob a forma de festas, mostras, exposições, durante todo o ano de 2008, fizeram-se sentir como marcos importantes na espetacularização e na visibilidade midiática das "tradições nipônicas" e da "história da imigração japonesa". Um ponto que merece atenção reside na constância de temas e conteúdos presentes na ampla cobertura jornalística e televisiva sobre o evento. De modo geral, consistiu em mostrar primeiramente uma síntese da história da imigração japonesa, seguida das contribuições dos imigrantes e seus descendentes para o desenvolvimento do país, sobretudo na agricultura, a influência da "cultura japonesa", o movimento dekassegui e a explosão mundial da cultura J-Pop. É importante ressaltar que a temática foi explorada sob a perspectiva de uma saga, uma narrativa dramática, quase mítica, com o final feliz: o sucesso da imigração com a integração plena dos descendentes à sociedade brasileira.

A vinda do Príncipe herdeiro do Japão, Naruhito, aqueceu as comemorações e as principais festividades foram as que contaram com sua presença, como a solenidade oficial realizada no Sambódromo do Anhembi, em São Paulo, no dia 21 de junho de $2008 .{ }^{244}$ Os números dados pela $\mathrm{ACCIJB}^{245}$ surpreendem: Cerca de 50 mil pessoas, mais de 19 mil voluntários, estiveram presentes no evento, que foi dividido em três partes, sendo que na primeira, apresentações musicais e artísticas foram realizadas por grupos de até três mil pessoas. A segunda parte foi dedicada ao desfile em carro fechado do Príncipe, ao seu discurso e outras solenidades, como o acendimento da pira da Tocha da Amizade e por fim, houve as apresentações do coral de três mil vozes que entoou canções japonesas e brasileiras e a de taikō com mais de mil tocadores. Na terceira parte da festa, um desfile carnavalesco com cerca de 600 pessoas, integrantes e voluntários da Escola de Samba Unidos de Vila Maria e um show pirotécnico encerraram o megaevento.

\footnotetext{
${ }^{244}$ Do dia 14 ao dia 22 de junho de 2008, o Anhembi Parque que sediou a "Semana Cultural Brasil-Japão", evento com workshops de culinária japonesa, mangás e animes, apresentações artísticas, exposições, teve um público de mais de $200 \quad$ mil pessoas. http://www.anhembi.com.br/anhembi/bin/view/Acontece/AconteceAnhembi1214426780 Acesso: 17/06/2010. 245 Associação para a Comemoração do Centenário da Imigração Japonesa no Brasil. Disponível em: http://www.centenario2008.org.br/ Acesso: 16/06/2010.
} 


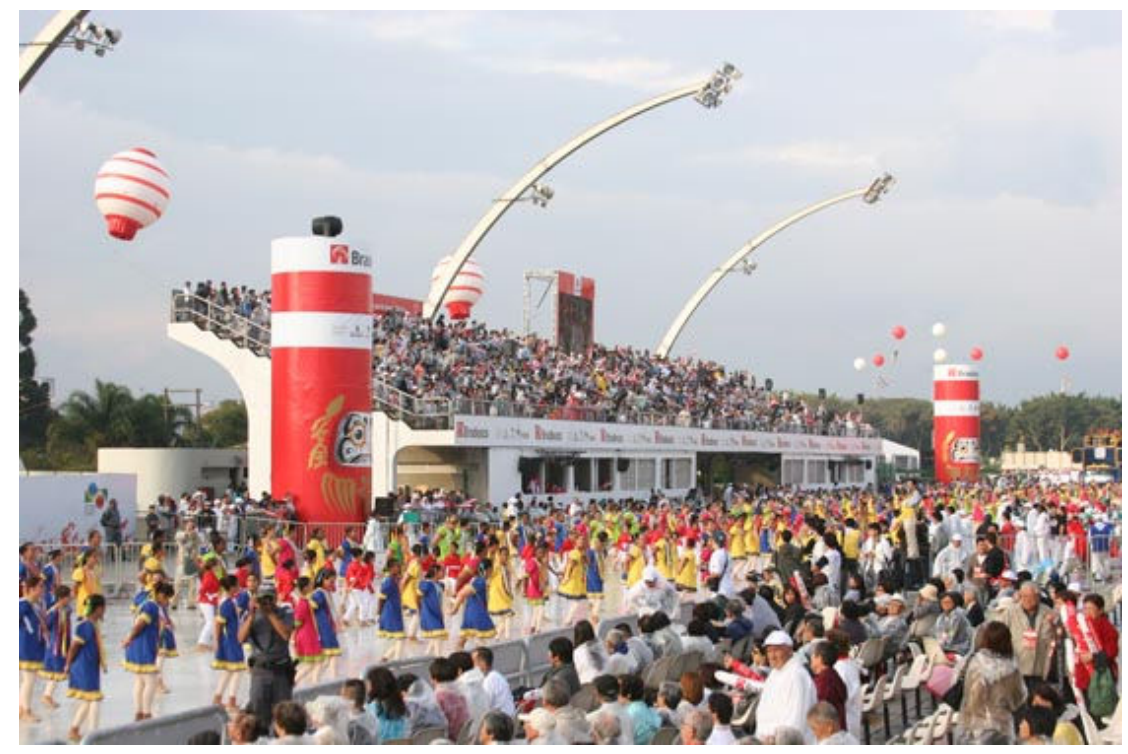

Fig. 33 Vista da comemoração no Sambódromo do Anhembi. Foto: Caio Silveira.

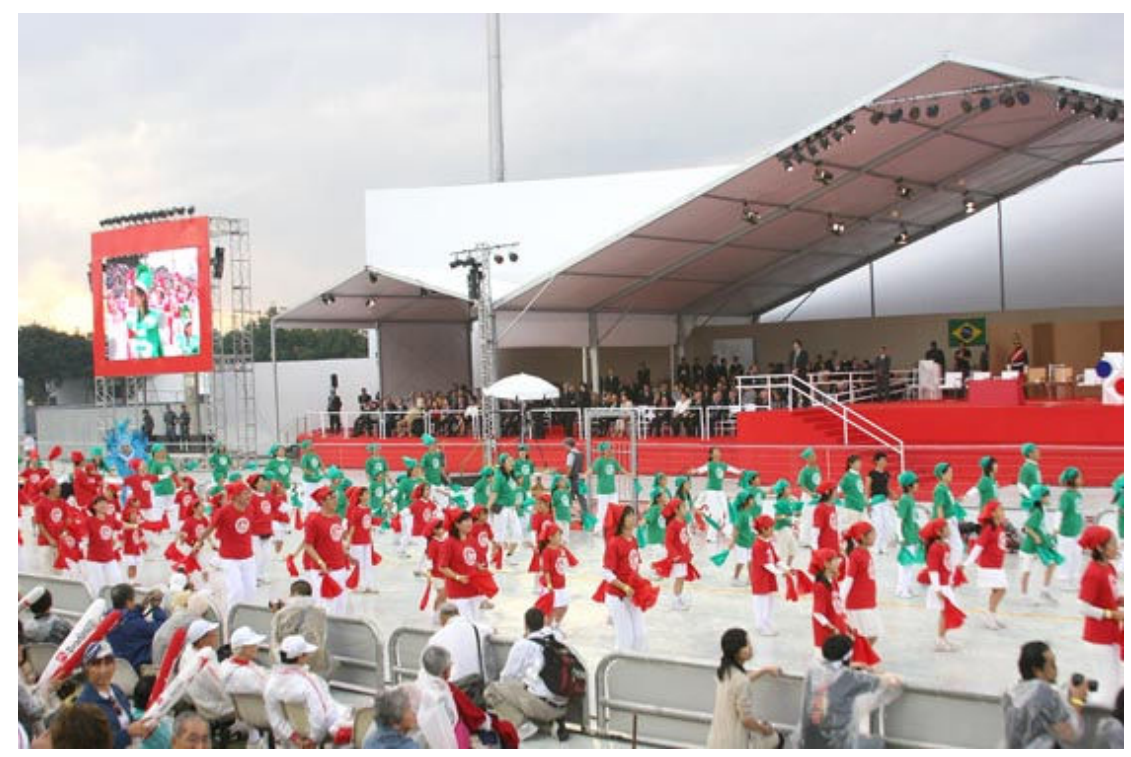

Fig. 34 Apresentação no Sambódromo com autoridades ao fundo. Foto: Caio Silveira.

No Paraná, o Imin Center da cidade de Rolândia, que possuía na época o projeto de construção do Parque Temático Yumê, foi escolhido como local para a solenidade oficial de comemoração do centenário da imigração japonesa no Estado. Milhares de voluntários, grandes atrações e pirotecnia foram também elementos da festividade, além da presença do Príncipe Naruhito. Coral de mil vozes, pirâmide humana, apresentações de bon-odori, taikō, danças 
folclóricas e um grande público, cerca de 75 mil pessoas, marcaram o evento, realizado no dia 22 de junho de 2008 . $^{246}$

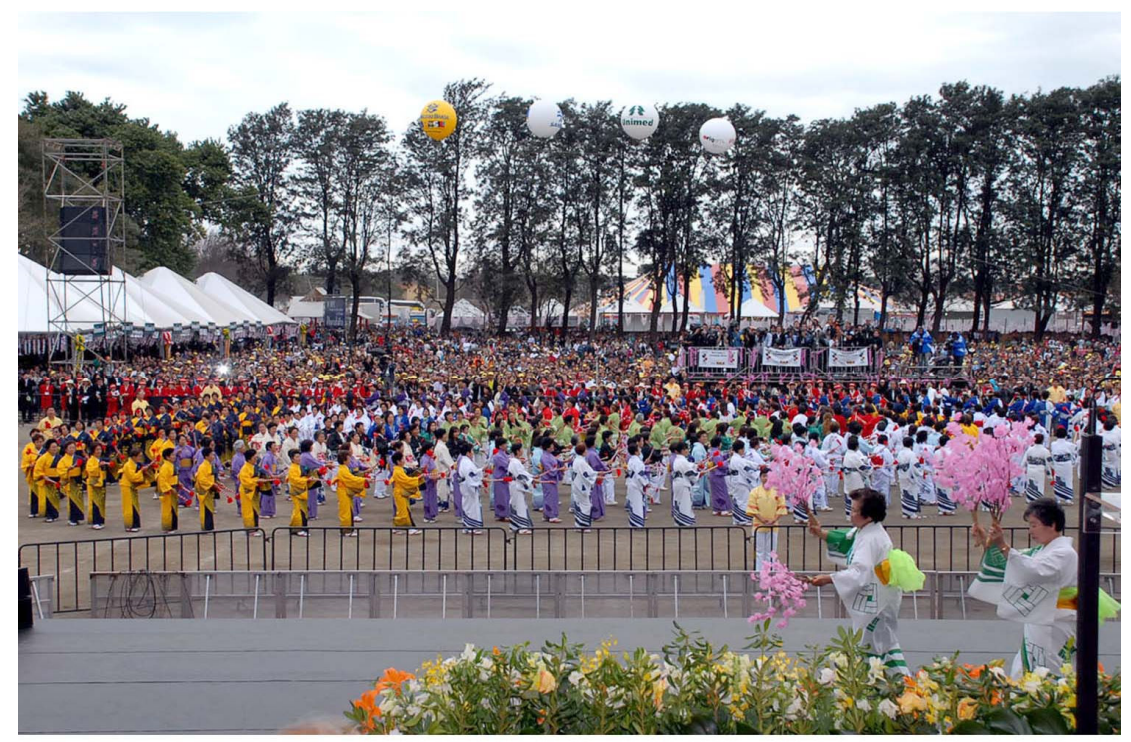

Fig. 35 Apresentação de bon-odori na festa do Imin-100 em Rolândia. Foto: Julio Covello-SECS.

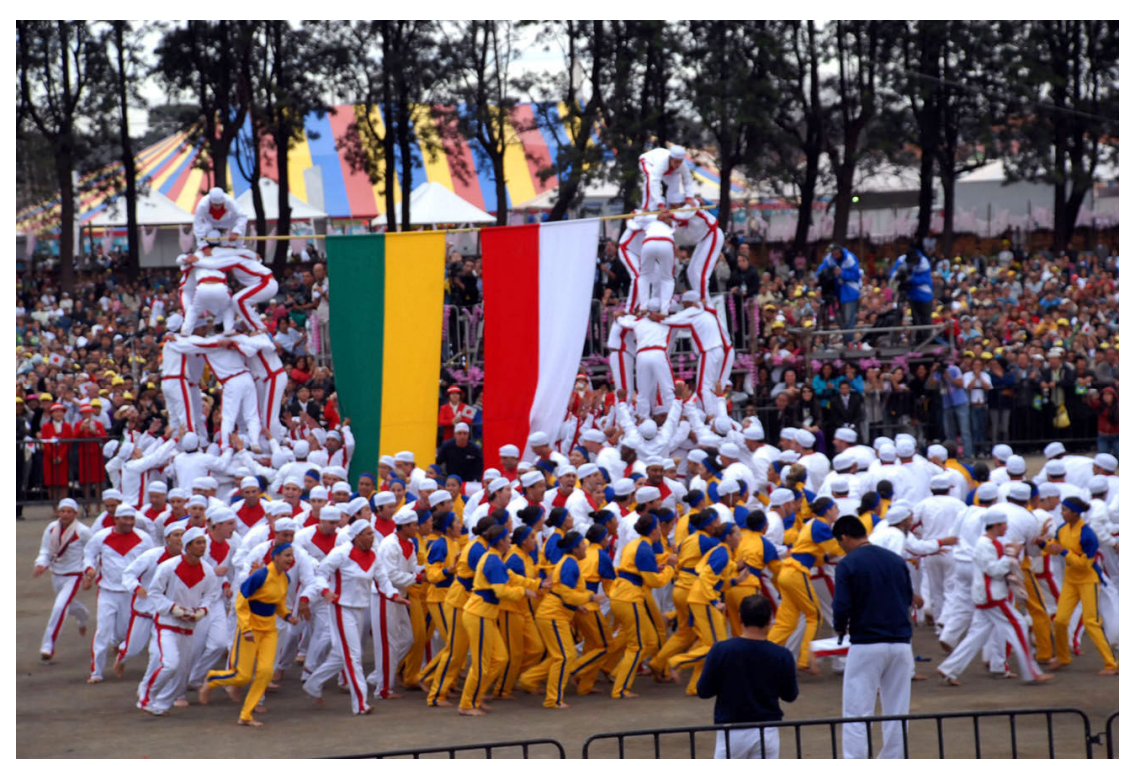

Fig. 36 Pirâmide humana (grupo da Associação Brasil Soka Gakkai Internacional ${ }^{247}$ ). Foto: Julio Covello-SECS.

\footnotetext{
${ }^{246}$ Conforme Agência de Notícias Estado do Paraná, "Rolândia reúne 75 mil pessoas na solenidade de comemoração ao centenário da imigração japonesa”. Disponível em: http://www.aen.pr.gov.br/modules/noticias/article.php?storyid=38722\&tit=Rolandia-reune-75-mil-pessoas-nasolenidade-de-comemoracao-ao-centenario-de-imigracao Acesso: 16/06/2010.

${ }^{247}$ ONG filiada às Nações Unidas, a Soka Gakkai é uma associação, cujo programa é inspirado na filosofia humanista do budismo de Nitiren Daishonin. Baseada no conceito de "revolução humana", a associação prega valores como paz e respeito ao meio-ambiente e aos direitos humanos, desenvolvendo atividades como "exposições, intercâmbios, com universidades e museus, entre outras atividades nas áreas da educação e cultura". Conforme: http://www.bsgi.org.br/sgi.htm Acesso17/06/2010.
} 


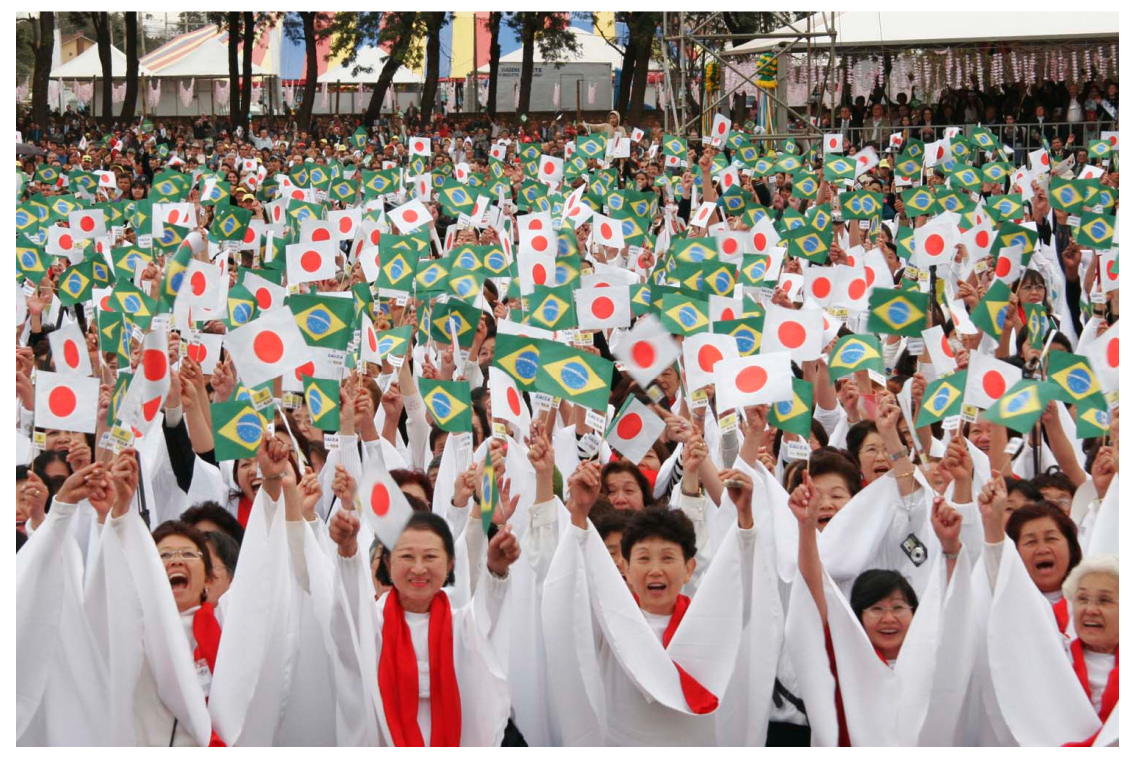

Fig. 37 Coral de mil vozes (Representantes de 26 cidades do Paraná). Foto: Julio Covello- SECS.

Com o objetivo primeiro de prestar uma homenagem aos primeiros imigrantes japoneses que aportaram no país e celebrar a integração dos descendentes junto à sociedade brasileira, além das festas, outros eventos se desenrolaram no país: inúmeras publicações comemorativas, exposições, congressos, encontros, simpósios científicos, produções de documentários e filmes, inaugurações de praças em homenagem aos imigrantes, venda de produtos comerciais os mais diversos explorando a temática, lançamento de selo e moeda comemorativa oficial alusivos ao centenário, propagandas, programas televisivos ${ }^{248}$ e até homenagens em escolas de samba ${ }^{249}$.

\footnotetext{
${ }^{248}$ Além das reportagens produzidas nos telejornais de diversos canais de TV sobre o centenário, quadros especiais foram desenvolvidos em inúmeros programas durante todo o ano de 2008 com o objetivo de divulgar a "cultura japonesa" no Brasil, como por exemplo, o quadro "Passado presente" do Fantástico; o programa "Japão: país de mistérios" do Globo Repórter, na Rede Globo; o programa "OKTV", apresentado por Kendi Yamai e Ikeda na Rede Bandeirantes, e um quadro especial no programa "Amaury Jr. Show", da Rede TV, também apresentado pela dupla de nikkeis. A Band também realizou o concurso Miss Centenário Brasil/Japão e exibiu a minissérie, produzida pelo canal japonês NHK, Haru e Natsu - As cartas que não foram entregues, melodrama de duas irmãs japonesas separadas com a imigração de suas famílias para o Brasil. Uma busca simples sobre o centenário no site de compartilhamentos youtube é indicativa de como a temática foi amplamente divulgada na mídia: cerca de 420 vídeos, entre reportagens, entrevistas e documentários, são disponibilizados http://www.youtube.com/results? search query $=+$ centen $\% \mathrm{C} 3 \% \mathrm{~A} 1$ rio + da + imigra $\% \mathrm{C} 3 \% \mathrm{~A} 7 \% \mathrm{C} 3 \% \mathrm{~A} 3 \mathrm{o}+$ japonesa + no + Brasil\&aq $=$ f Acesso: 16/06/2010.

${ }^{249}$ Em São Paulo, a Unidos de Vila Maria trouxe o enredo "Irashai Masê, milênios de cultura e sabedoria no centenário da imigração japonesa no Brasil". No Rio, o enredo produzido pela Unidos de Porto da Pedra foi "Tem pagode no Maru: 100 anos de imigração japonesa". Ambos os enredos mantiveram a estrutura narrativa de saga dos imigrantes japoneses. Na última escola, a rainha da bateria, a empresária e modelo Ângela Bismarchi, representando Madame Butterfly da ópera de Puccini, fez uma cirurgia plástica para "puxar os olhos" e assim parecer uma japonesa.
} 


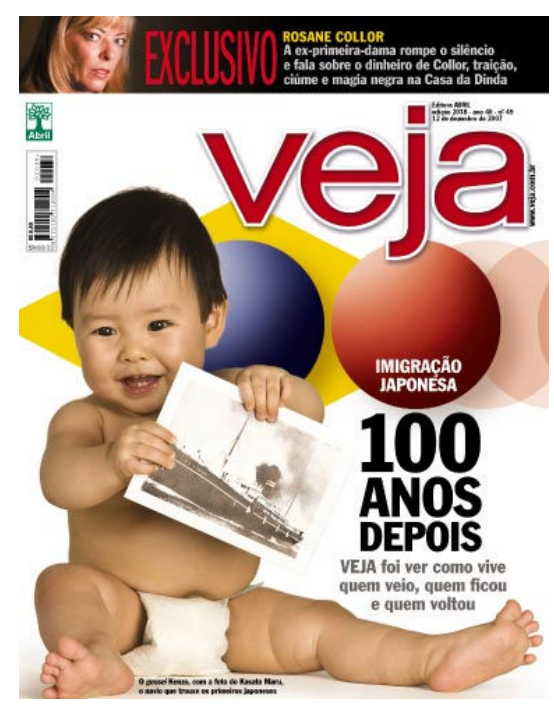

Fig. 38 Capa da Revista Veja, edição 2038

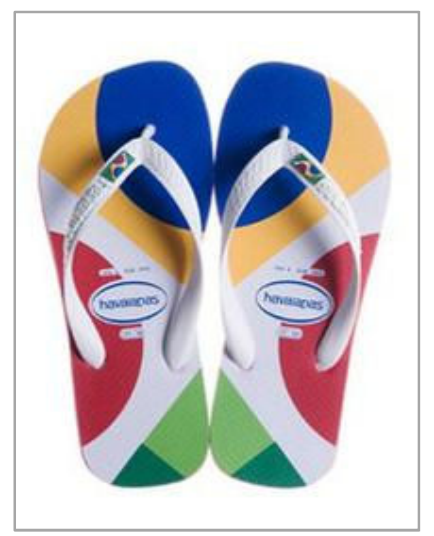

Fig. 39 Edição especial das Havaianas

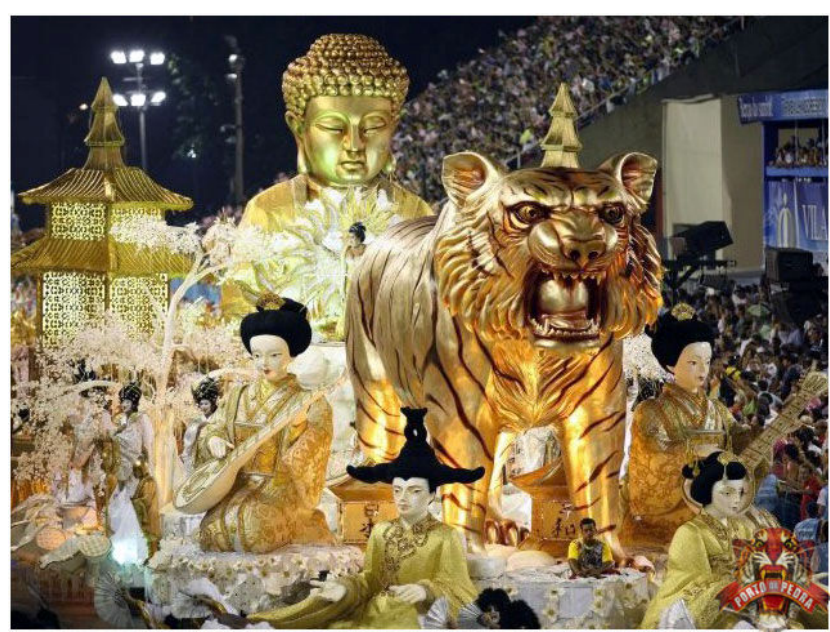

Fig. 40 Desfile da Porto da Pedra com figura de Buda ao fundo

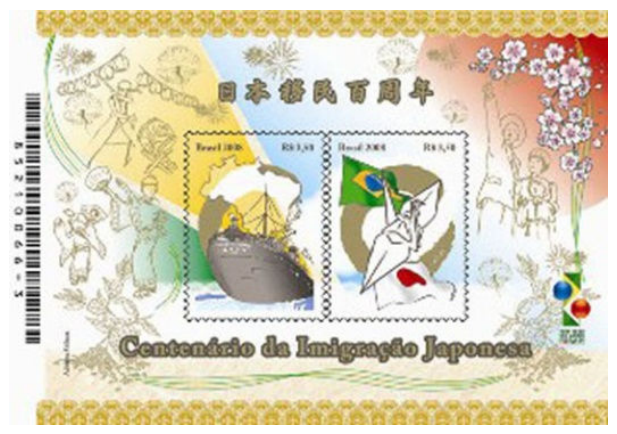

Fig. 41 Selo oficial comemorativo

O planejamento das comemorações do centenário ficou a cargo da Associação para a Comemoração do Centenário da Imigração Japonesa no Brasil (ACCIJB) ${ }^{250}$. Além disso, uma comissão nacional foi oficializada em junho de 2007 pelo Governo Federal com a finalidade de "organizar, elaborar, coordenar e aprovar a programação nacional das atividades oficiais das comemorações do Centenário" 251 . Comissões estaduais e municipais também foram seladas. Todo o conjunto das festividades não seria possível sem a captação de recursos junto aos setores público e privado. Verbas do governo federal foram um grande incentivo para a magnitude que

\footnotetext{
${ }^{250}$ Fundada em 2003, em uma ação conjunta com o Bunkyō, Federação das Associações de Províncias do Japão, Câmara do Comércio e Indústria do Japão no Brasil e Aliança Cultural Brasil-Japão, e reunindo diversos representantes de entidades regionais nipo-brasileiras, a ACCIJB teve um importante papel no estabelecimento de parcerias com capital privado e público, seja japonês ou brasileiro, para a organização dos festejos.

${ }^{251}$ Conforme consta no site oficial da ACCIJB: http://www.centenario2008.org.br/index.php Acesso: 16/06/2010.
} 
os festejos tomaram no país, além do patrocínio de instituições financeiras, como o do Banco Real $^{252}$ e Bradesco ${ }^{253}$. Com o objetivo de homenagear a comunidade nikkei no país e estreitar o intercâmbio comercial Brasil-Japão, grandes somas foram injetadas na comemoração.

A maioria dos entrevistados para essa pesquisa teceu inúmeros elogios e demonstrou satisfação com a amplitude e destaque reservados ao centenário nos festejos e na mídia. A principal questão que se colocavam era por que o centenário da imigração de outros povos, como italianos, alemães e espanhóis, não tiveram a mesma repercussão e magnitude que a dos japoneses. A "união da colônia" era a resposta imediatamente dada. Perguntavam, respondendo logo em seguida a questão que tinham proposto. A organização dos japoneses e seus descendentes em nihonjin-kais, historicamente um artifício para o apoio mútuo, conquistado através da união e do voluntarismo, lançou as bases para a organização das comemorações em larga escala em todo o país. O Sr. Paulo Sasaki, assessor de um deputado estadual, falou com grande entusiasmo:

\begin{abstract}
"Nossa Senhora, foi uma coisa inédita! A forma como a comunidade brasileira recebeu essa organização foi uma coisa fantástica, não só no Paraná, mas no Brasil inteiro. Foi uma coisa inédita! Veja só, onde se viu em uma comunidade até hoje, espanhola, portuguesa, alemã, italiana, que são colônias grandes, quem fez uma homenagem assim, uma comemoração assim?! Você conhece? Não, né? Por quê? Por que conseguiu? Porque a colônia japonesa é unida! A união da colônia japonesa fez isso. Se não tivesse a Aliança Cultural Brasil-Japão do Paraná, o Bunkyō de São Paulo, a ACEMA, teriam acontecido esses eventos? Porque existe a comunidade nipo-brasileira. É a união das entidades. É a força da 'colônia japonesa' que fez isso aí. Infelizmente, nas outras colônias não existe isso. Se eles tivessem esse tipo de associação com certeza fariam alguns eventos comemorando a data deles. [...] Por que Imin100? Porque no Brasil, a comunidade nikkei está unida. Quem mobilizou isso aí? A sociedade brasileira... o governo federal ajudou a pagar. Rolândia, ${ }^{254} 10$ milhões de reais. Maringá, 6
\end{abstract}

\footnotetext{
${ }^{252}$ Como já apontado, o Banco Real foi um dos principais patrocinadores dos eventos promovidos no ano do centenário. No portal do site, é possível observar que o banco oferece um portfólio de serviços e produtos especiais para a "comunidade-nipo-brasileira", de olho nas transações financeiras dos dekasseguis, entre Brasil e Japão.

${ }^{253}$ O Bradesco, assim como o Banco Real, possui uma janela em seu portal na internet, o "Bradesco Nikkei", que oferece serviços nos três momentos da viagem do dekassegui para o Japão: na ida, com o financiamento das passagens; na estadia, com as remessas para o Brasil e com seguros de vida; e na volta, com os investimentos dos recursos. Segundo seu site, a rede de atendimento do banco oferece o "Espaço Nikkei Bradesco", uma área dentro de algumas agências dedicada ao atendimento aos nikkeis que retornaram ou que pensam em viajar ao Japão a trabalho, espaço que conta com gerentes fluentes no idioma japonês.

${ }^{254}$ Para a cidade de Rolândia, R\$ 10 milhões foram empenhados pelo Ministério do Turismo para a construção do parque temático Yumê. Conforme matéria "Japoneses ganharão parque temático em Rolândia: Ministério do Turismo investe R\$ 10 milhões no Paraná para celebrar intercâmbio cultural Brasil-Japão": $\underline{\mathrm{http}}$ ://www.bemparana.com.br/index.php? $\mathrm{n}=51522 \& \mathrm{t}=$ japoneses-ganharao-parque-tematico-em-rolandia Acesso: 16/06/2010. Contudo, ao que consta no site da prefeitura, o projeto do parque, que possui uma área de 9 mil metros quadrados, e que prevê uma espécie de museu interativo, restaurantes e praça ainda não foi viabilizado. O projeto parece ter sido a principal razão para a escolha da pequena cidade de 55 mil habitantes como palco da solenidade oficial no Paraná. Rolândia não tem uma comunidade nipo-brasileira expressiva, já que foi colonizada principalmente por alemães e judeus perseguidos pelo regime nazista.
} 
milhões de reais. ${ }^{255}$ Curitiba não sei quantos milhões. No final das contas, o governo federal injetou dinheiro. Por quê? Porque a força da colônia japonesa é muito grande. Agora se eu fosse um deputado, senador chato, italiano, poderia questionar, não poderia? Por que só para os japoneses? Eles não falam nada, porque reconhecem o trabalho dos japoneses. Porque sabem que os japoneses trabalharam e o que o Brasil é hoje, uma parte deve à colonia japonesa. Todo mundo fala que os japoneses é que realmente levantaram as lavouras. Lá no cerrado, falavam que iam plantar soja, os brasileiros falavam: 'essa 'japonesada' é doida, são loucos, vai dar o que aqui? Vai dar nada!'. E hoje tem fazenda de soja... essas coisas. E hoje eles falam: 'onde japonês planta, dá!'. Quer dizer, esse é o conceito, né?"256.

De fato, essa união de que fala Sr. Sasaki foi um elemento fundamental para explicar a grandiosidade com que o centenário foi comemorado no país. União obtida graças aos milhares de voluntários, nikkeis e não-nikkeis, desejosos de participar de uma forma ou outra do evento histórico. Tive a oportunidade de assistir aos festejos na recepção do Príncipe na cidade de Rolândia, no dia 22 de junho de 2008. Dois ônibus lotados, cem pessoas ao todo, com tocadores de taikō, participantes do coral ou simplesmente interessados em acompanhar a comemoração saíram às 6 horas da manhã da ACEAST em direção à cidade vizinha, distante somente $45 \mathrm{~km}$ de Astorga.

A comissão organizadora do evento, formada por integrantes da Aliança Cultural Brasil-Japão do Paraná, havia requisitado que os participantes do coral chegassem às 7 horas da manhã para o ensaio final. Fiquei bastante surpresa com a disposição dessas pessoas, que das 8 horas da manhã até o final da tarde daquele ensolarado domingo de junho, ficaram em pé, com o sol sob suas cabeças, primeiramente ensaiando, depois esperando a chegada do Príncipe, cuja comitiva estava atrasada com os compromissos pela manhã em Londrina ${ }^{257}$, e por fim, cantando na solenidade. A recomendação era para que a pequena multidão de mil pessoas que compunha o coral não se sentasse e buscasse não sair de suas posições (ver figura 37). No desgastante tempo esperado sob o sol, muitas pessoas, sobretudo senhoras idosas, passaram mal, algumas desmaiaram e tiveram que ser transportadas dali de maca. Um espaço reservado aos idosos

\footnotetext{
${ }^{255}$ A cidade de Maringá também recebeu a visita do Príncipe Naruhito. Boa parte da verba a que se refere Sr. Sasaki está sendo empregada na construção do Parque do Japão, complexo que conta com lago superior, casa de chá, jardim japonês, quiosque, ginásio de esportes e artes marciais, além do Monumento Imin-100.

${ }_{256}$ A contribuição dos imigrantes japoneses e seus descendentes na agricultura brasileira é reconhecida, sobretudo, na prática de diversificação das culturas, na experimentação agrícola, na introdução de inovações técnicas e consequentemente no enriquecimento do mercado interno com variedades na área de hortifrutigranjeiros. A expansão dos agricultores de origem japonesa para as regiões do cerrado e caatinga, mencionada pelo Sr. Paulo, se dá a partir da década de 1960, com o início da modernização do campo, acompanhando os agricultores da região Sul do país que diante da carência de terras agricultáveis em seus Estados, buscavam explorar novas áreas para o cultivo de grãos, como soja, trigo, milho e arroz (CEHIJB, 1993: 461).

${ }^{257}$ Os compromissos assumidos no dia 22 de junho eram vários: pela manhã, o Príncipe Naruhito, acompanhado de sua comitiva, do Vice-Presidente da República, José Alencar e do Governador do Paraná, Roberto Requião, inaugurou a Praça do Centenário da Imigração Japonesa Tomie Nakagawa, em Londrina. No início da tarde, o Príncipe esteve presente na solenidade oficial em Rolândia e no final da tarde, seguiu para a cidade de Maringá, em visita ao Parque do Japão e à Associação Cultural e Esportiva de Maringá.
} 
provenientes das caravanas de diversas cidades do Paraná foi montado próximo ao palco. A maioria deles já se encontrava ali desde o início da manhã, alguns com bengalas, outros em cadeiras de rodas.

Com o avançar da tarde, o público só aumentava e a impaciência na espera do Príncipe também. ${ }^{258} \mathrm{O}$ discurso de Naruhito foi breve, conciso e muito aplaudido pelos presentes. Ao contrário, o de José Alencar e mais ainda o de Roberto Requião arrastaram-se em detalhes, o que deixou o público ainda mais inquieto com a espera. Vaias ecoaram e os discursos encurtaram-se. As apresentações artísticas seguiram por mais três horas e nenhum contratempo se sucedeu. A festa se encerrou no fim da tarde e o Príncipe seguiu para os compromissos em Maringá. De volta ao ônibus, estavam todos muito cansados, mas a satisfação era geral, "Foi cansativo, mas valeu a pena!" - disse a coordenadora do taikō, Isabel Nishida.

A maioria dos entrevistados para essa pesquisa, embora tenha somente acompanhado as comemorações do centenário pela televisão, considerou positiva a cobertura dada ao evento, encarando-a como uma forma de fortalecer e enaltecer a imagem dos japoneses e seus descendentes na sociedade brasileira, além de ter se constituído em uma oportunidade de divulgar a "cultura japonesa". Lúcia Miyamoto, por exemplo, afirma:

\begin{abstract}
"Eu acho que o centenário foi um grande palco na verdade, para mostrar... Não os primam (nikkeis) pelo fato de serem pessoas organizadas e fazerem eventos bonitos? Eu acho que isso ai foi um grande palco para você poder mostrar realmente do que nós fomos capazes ou somos capazes ainda. Eu acho que foi muito bom. Muito positivo, porque eu pelo menos não ouvi ninguém falar que foi feio, humilhante. Todo mundo falando e comemorando e, principalmente os grandes... esse pessoal, bancos, tudo correndo atrás para ajudar na comemoração. Sinal de que alguma força os japoneses tem, né? Porque senão não teriam os grandes patrocinadores. Porque se não tivesse importância... [...] Os orientais são um grande filão, porque nosso nível socioeconômico melhorou muito. Então, se nós éramos insignificantes, meros imigrantes, meros operários da agricultura, hoje já somos um segmento diferente, muito mais amplo, muito mais promissor. Por isso é que tem interesse, porque o capitalismo... O grande termômetro mesmo é você ver o interesse dos patrocinadores. Quem ganha mais dinheiro senão o banco, né?".
\end{abstract}

Lúcia, assim como Sr. Paulo, chama a atenção para a "força dos japoneses”, mas além da união das entidades nipo-brasileiras como componente fundamental para o sucesso dos eventos do centenário, a empresária menciona a ascensão social dos nikkeis e seu poder aquisitivo como motivadores importantes. Os patrocínios dos bancos foram peças-chave nesse processo, um "grande termômetro" na reflexão de Lúcia. Como avaliar esse interesse? Além de buscar atrair uma clientela aqui no Brasil que pertence, em sua maioria, às classes $\mathrm{A}$ e $\mathrm{B}$ e outra

\footnotetext{
${ }^{258}$ De acordo com estimativas da Polícia Militar e Federal, o evento abrigou cerca de 75 mil pessoas, 2 mil veículos e 600 ônibus. Conforme: http://www.aen.pr.gov.br/modules/noticias/article.php?storyid=38722\&tit=Rolandiareune-75-mil-pessoas-na-solenidade-de-comemoracao-ao-centenario-de-imigracao Acesso: 17/06/2010.
} 
que envia bilhões de dólares ao país anualmente ${ }^{259}$, não podemos deixar de esquecer o investimento em marketing cultural, ou seja, a estratégia das empresas em associar suas marcas a projetos culturais. ${ }^{260}$ No lançamento das campanhas publicitárias e no patrocínio aos eventos relacionados ao centenário, esses bancos buscam vincular sua imagem a manifestações artísticas, culturais, marcos históricos e eventos que traduzam valores e ideais corporativos da instituição, como credibilidade, confiança e respeito, qualificativos que como vimos compõe o mosaico de imagens e discursos sobre os japoneses e seus descendentes no Brasil.

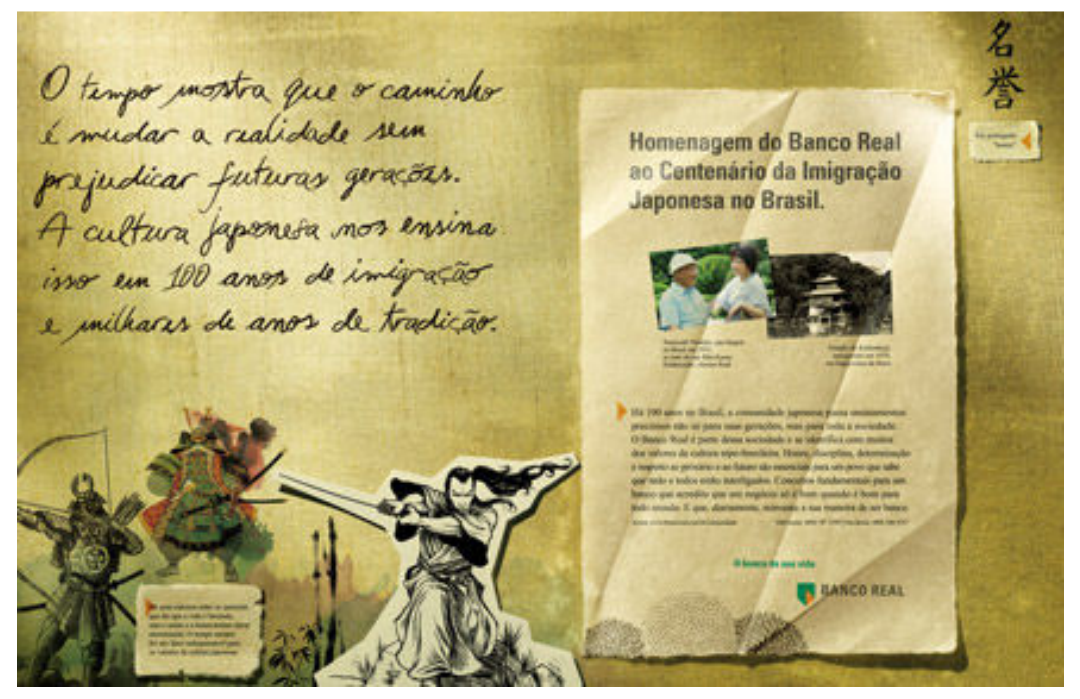

Fig. 42 Anúncio “Homenagem do Banco Real ao centenário da imigração japonesa no Brasil”

\footnotetext{
${ }^{259}$ Em meio à crise financeira de 2009, as remessas anuais dos dekasseguis para o Brasil que já chegaram na casa dos US\$ 5 bilhões diminuíram consideravelmente, ficando entre US\$ 800 milhões e US\$ 1,5 bilhões. Conforme matéria do G1, "Crise diminui remessas dos dekasseguis para o Brasil: Quantia atual fica entre US\$ 800 milhões e US\$ 1,5 bilhão. Na época de 'vacas gordas', valor chegou a US\$ 5 bilhões". Disponível em: http://g1.globo.com/Noticias/Economia Negocios/0,MUL1089381-9356,00.html 18/04/2009. Acesso: 22/06/2010.

${ }^{260}$ Conforme a matéria do Estadão, "Empresas investem em cultura para ter ganho de imagem", 02/03/2009. De acordo com a reportagem, o diretor de marketing do Bradesco, Luca Cavalcanti afirma que quase a metade dos R\$ 500 milhões investidos anualmente em marketing pelo banco é dedicada a eventos, festas, incluindo um músico de taikō do Festival Japão. Para o diretor de marketing do HSBC, Marcello Velloso, "o objetivo é associar a imagem do banco a valores que traduzam sofisticação e exclusividade".
} 


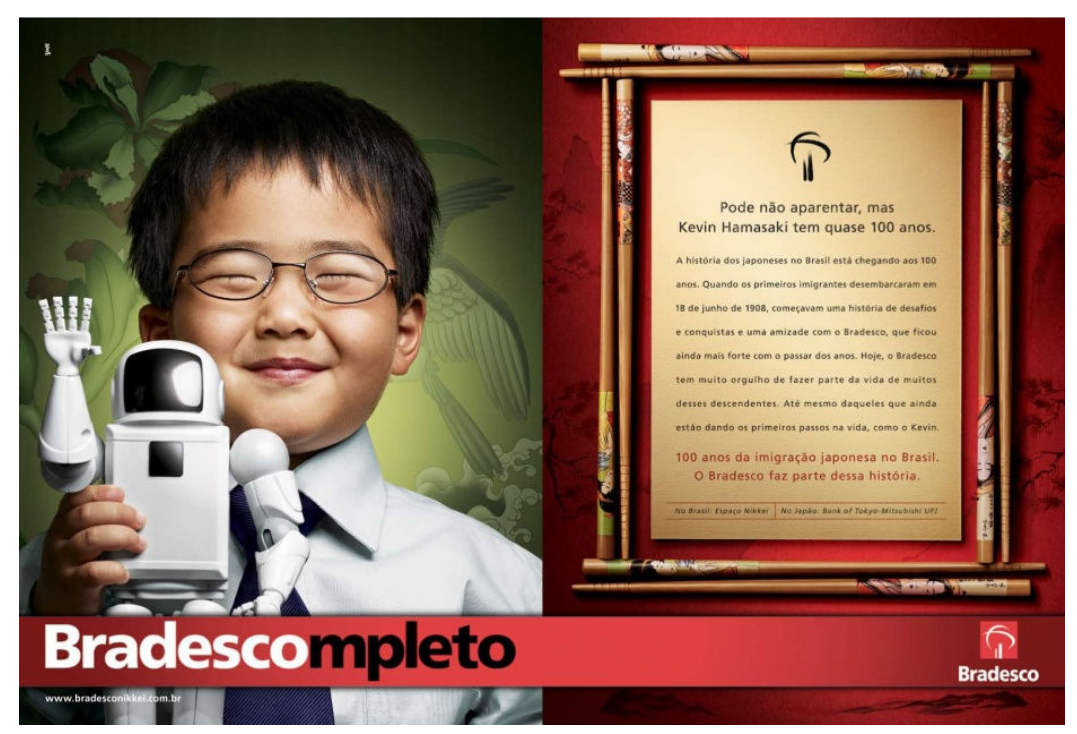

Fig. 43 Anúncio "100 anos da imigração japonesa no Brasil. O Bradesco faz parte dessa história”

O conteúdo semântico dos discursos que envolveram o centenário, ao enfatizar a narrativa de sucesso da imigração, também privilegiou o reconhecimento e o elogio aos valores e às contribuições dos japoneses e seus descendentes. $\mathrm{O}$ discurso do Presidente Lula sobre a comunidade de origem japonesa no Brasil, que abre o capítulo 1 da dissertação, "São pessoas conhecidas por sua determinação, empenho e criatividade. Gente estudiosa e trabalhadora" é um exemplo dessa narrativa. Cito também o discurso do prefeito de São Paulo, Gilberto Kassab, no mega evento comemorativo do centenário no Anhembi:

"Se hoje o Brasil é uma potência agrícola, sem dúvida os japoneses tiveram papel decisivo nessa evolução, enriquecendo o solo brasileiro com seus conhecimentos e técnicas ancestrais. A siderurgia só avançou e atingiu os mais altos níveis de excelência depois que nossas empresas estabeleceram o intercâmbio tecnológico com as siderúrgicas japonesas. Os japoneses nos ensinaram as técnicas de gestão pela qualidade total que ajudam a explicar o sucesso das empresas brasileiras nas últimas décadas. Também no campo das artes e das ciências tem sido marcante a presença de personalidades nipo-brasileiras. E foi em nome dessa relação de amizade e cooperação que a prefeitura iniciou em 2005 os preparativos para que as comemorações do centenário fizessem jus a essa convivência fraterna e produtiva". ${ }^{261}$

Após ressaltar o projeto de restauração da iluminação do bairro da Liberdade, da construção do conjunto esportivo Brasil-Japão e a exposição itinerante Brasil-Japão nas escolas municipais, Kassab conclui:

\footnotetext{
${ }^{261}$ Retirado do DVD “Centenário da Imigração Japonesa - Grande Festividade” (Seiki no Saiten) com o registro oficial dos eventos comemorativos do Centenário da Imigração, realizados em São Paulo. Produzido pela Associação para Comemoração do Centenário da Imigração Japonesa no Brasil (ACCIJB) e Japan Brasil Network (JBNTV).
} 
"Essas foram algumas formas que encontramos para saudar aqueles que deixaram suas terras e vieram enriquecer as nossas. Muito do que São Paulo é hoje se deve a esses imigrantes, que chegaram tímidos, mas repletos de esperanças e sonhos de prosperidade num país de costumes, clima, língua e tradições completamente diferentes e que dividiram conosco sua cultura, serenidade e persistência. A esses imigrantes e seus descendente a cidade de São Paulo demonstra sua admiração e respeito e agradece a oportunidade de convivência tão rica e feliz. Ao saudar calorosamente sua alteza imperial que hoje nos honra com sua visita, faço votos de cooperação sempre crescente e de amizade eterna entre nossos povos".

$\mathrm{Na}$ grande mídia, a estrutura discursiva foi praticamente a mesma. A reportagem " $\mathrm{O}$ centenário de uma saga" na edição especial da Revista Veja sobre o evento, inicia com essas palavras:

À exceção das guerras, as forças propulsoras dos movimentos migratórios são quase sempre
de ordem econômica. Mas o que impele os indivíduos a segui-las é de natureza bastante
humana: a busca pela felicidade pessoal. Foi nessa busca que, há 100 anos, um grupo de
homens e mulheres atravessou oceanos para chegar a um país de língua incompreensível,
comida estranha, clima quente e santos desconhecidos. Lá, trabalhou duro, arou a terra,
capinou o mato, produziu riqueza e gerou descendentes. O Brasil foi o cenário dessa epopéia
moderna. Para reconstituí-la, VEJA fez uma viagem ao passado e visitou o Japão do presente.
Hoje, o que o Brasil comemora não é apenas a chegada das 165 famílias que, a bordo do
Kasato Maru, aqui aportaram em 18 de junho de 1908. É, sobretudo, o que deixaram para os
brasileiros e as cinco gerações de nikkeis (imigrantes e seus descendentes) que hoje vivem no
país: um legado de tenacidade, dedicação ao trabalho e respeito aos padrões éticos. ${ }^{262}$ (grifos
meus).

A tônica geral dos discursos que cobriram o centenário corrobora a hipótese de que esse marco, comemorado e divulgado por todo o país, contribuiu para alimentar e reforçar o imaginário que associa os nikkeis à tríade do trabalho, honestidade e estudo. É importante destacar que alguns jovens com quem conversei viram com certa cautela as grandes proporções que as comemorações tomaram no país. A paulistana, nissei, Clarice Nakashima, de 39 anos, por exemplo, observou:

\begin{abstract}
"Então, esse momento da imigração japonesa (centenário), eu acho que foi legal para repensar algumas coisas. Mas também de alguma forma, isso tudo ainda me incomoda um pouco. Tanta exposição do japonês, porque você acaba criando estereótipos e não consegue nem se identificar, porque você já não sabe mais o que é você, o que é estereótipo, o quê que dizem de você. Mas de qualquer forma, me incomoda muito menos agora do que quando eu era adolescente".
\end{abstract}

Luciana Nakayama, sansei, de 26 anos achou um "exagero", uma "glamourização" e não viu muito sentido em toda essa "auto-homenagem":

\footnotetext{
${ }^{262}$ Edição especial da Revista Veja, "O Brasil do sol nascente: os 100 anos da imigração japonesa”, edição 2038 $(12 / 12 / 07)$. Ver figura 38.
} 
"O japonês, sim, injetou muito dinheiro na economia, ajudou muito. É trabalhador, mas se for ver, os negros trabalharam como escravos. O Brasil começou por causa dos negros. Não existiu uma comemoração desse tamanho, entende? Tinha que pôr uma coisa mais reservada, sabe? Tiveram os monumentos para Zumbi dos Palmares, toda essa questão... e eu não achei que foi uma coisa glamourosa".

A preocupação com o conteúdo mítico e romântico dos discursos sobre o centenário também apareceu na fala desses jovens. Para Luciana Nakayama, Pedro Higa e Henrique Nagata os cem anos da imigração foram um marco histórico que não deveriam ter se resumido somente a festas. Todos reconheceram que o evento ampliou a divulgação da "cultura japonesa" e nesse sentido, teve o ponto positivo de despertar o interesse das pessoas, descendentes e nãodescendentes, contudo, é preciso que haja uma continuidade no projeto de "democratização da cultura" para que cada vez mais pessoas tenham acesso a ela.

A tal "militância étnica" de Pedro, segundo ele, reside justamente na tentativa de reverter a desmobilização da "colônia", dos jovens de modo geral, pouco engajados na "participação crítica em formar uma nova cultura nipo-brasileira". O estudante acredita ser importante as pessoas não acharem que "cultura japonesa" limita-se ao universo pop e critica a visão romanceada da história da imigração japonesa veiculada na mídia e nos festejos do centenário. "Eles não discutem, por exemplo, que caçaram, que o governo caçou vários orientais só por falarem nihongo na rua. Eles não falam que como o Brasil era majoritariamente católico, quem era budista era preso. Então, são coisas assim absurdas que hoje você fala, 'Meu, não é possível que isso aconteceu e ninguém sabe!"”.

Além de Pedro, outros interlocutores como Luciana, Leonardo Miyamoto e Milena Teruya, todos jovens na faixa dos 20 anos, também chamaram a atenção para o fenômeno da "banalização" da "cultura japonesa", sob a qual impera uma visão que a restringe ao universo da culinária, dos animes e mangás. Em linhas gerais, esses jovens disseram que achavam positivas as manifestações de "resgate cultural" pelas novas gerações, mas ponderaram que esse fenômeno também deveria estar acompanhado de um interesse pela história dos antepassados imigrantes.

A entrevistada Milena ${ }^{263}$, sansei, 23 anos, da cidade de Maringá, relatou-me que no início achava o matsuri dance um "absurdo", um "funk", uma "banalização do bon-odori". Atualmente, acredita que "os jovens podem continuar festando, mas devem estar conscientes das origens e raízes da dança". Luciana que utilizou a mesma expressão de Milena para definir o matsuri dance, "funk" e, que ao contrário desta, nunca participou de seinen-kais, acredita que

\footnotetext{
${ }^{263}$ Integrante da diretoria do seinen-kai da Seicho-No-Ie de Maringá.
} 
houve uma "distorção de sentidos" com todo o glamour do centenário: não foram passadas informações corretas, e tampouco, os valores. Sobre as músicas J-Pop, o estudante de Música, Leonardo Miyamoto acha que "aquilo não é cultura japonesa! Aquilo lá é muito importado, muito americanizado" e sobre o matsuri dance, "Não acho que tem tanta raiz japonesa aquilo lá não. Só a tradição de dançar ao lado dos yagurá ${ }^{264}$ e taikō é que se manteve".

Esse ponto de vista mais crítico quanto à ideia de "resgate cultural" e quanto às comemorações do centenário partiu de quase todos os jovens entrevistados para essa pesquisa. Para minha surpresa, enquanto os nisseis e sanseis mais velhos elogiaram o processo de recriação, reinvenção de práticas culturais japonesas/nipo-brasileiras pelos jovens, como o próprio matsuri dance a partir do bon-odori; esses sanseis na faixa dos 20 aos 25 anos, que é importante frisar, não têm o costume de participar da dança coletiva, viram com mais ponderação esse movimento. Consideram uma manifestação positiva, mas disseram achar importantes que os praticantes conheçam a história por trás dessas práticas culturais, tão popularizadas pela mídia e pelos festivais, para que seus significados não se resumam a mera diversão.

\section{CONSIDERAÇÕES FINAIS}

As diferentes reflexões dos sujeitos dessa pesquisa mostram novamente quão plurais estas podem ser quando a questão da "cultura japonesa" é tematizada. Contudo, algumas recorrências podem ser aventadas. No que diz respeito à percepção crítica dos jovens sanseis quanto às comemorações do centenário, uma possível explicação talvez resida na relação de maior distanciamento dos mesmos com a experiência migratória, a qual é mais profundamente marcada para a segunda e sem dúvida mais ainda para a primeira geração, os quais de modo geral, foram bastante elogiosos aos eventos. Como já afirmara Lúcia Miyamoto, as terceiras e quartas gerações não tiveram que passar pelas dificuldades econômicas, barreiras linguísticas e culturais enfrentadas pelos isseis e nisseis.

Assim, a relação de respeito destes com a figura do Príncipe herdeiro do Japão também é de outra ordem e o envolvimento emocional com as comemorações também. $\mathrm{O}$ dentista Rodrigo Suzuki, de Londrina, conta que sua prima cumprimentara o Imperador do Japão quando este visitara o Brasil no Imin-90. O pai da moça tirou uma foto, emoldurou e entregou

\footnotetext{
${ }^{264}$ Yagurá: estrutura de madeira mais elevada como uma espécie de torre, na qual se posicionam os músicos. No bon-odori, a dança acontece em volta do yagurá, mas também pode ser performada somente em círculo, como mostra a figura 35 .
} 
para seu pai, avô de Rodrigo, que "quase teve um troço, ficou muito orgulhoso". Rodrigo que diz não ter acompanhado a visita do Príncipe à Londrina, "porque havia muita gente lá", afirmou:

\begin{abstract}
"A gente acha legal quando um chefe de Estado vem para uma comemoração e não para negócios ou para resolver pendências diplomáticas. Mas não fiquei como meus avós, 'Ah o Imperador vem, o Imperador vem!' (faz gesto de reverência) [risos]. Afinal, tenho orgulho de minhas raizes, mas sou brasileiro. O hino que me faz verter lágrimas, e verte mesmo, pois sou um chorão, que me faz arrepiar é o brasileiro, e não o japonês. Então, apesar de não gostar nem um pouco do Lula, ele é o meu Presidente. Não tive o frisson, como uma tiete, iguais as batchanzinhas....".
\end{abstract}

O discurso de Rodrigo sintetiza inúmeras questões discutidas nessa pesquisa. Sua fala, além de se constituir em uma reflexão sobre como as clivagens geracionais se interpõe na relação do sujeito com as "raízes", mostra que pelo menos para os descendentes de japoneses que não passaram pela experiência migratória, o sentimento de ser brasileiro não é posto em dúvida. Nasceram e cresceram no Brasil e são, portanto, brasileiros. Isso não significa que a brasilidade é dada a priori, mas é construída no contexto. No exemplo citado por Rodrigo, é o hino brasileiro e não o japonês que lhe desperta emoções e sentimentos de pertencimento. No caso de seus avós, a vinda do Príncipe Naruhito nas comemorações do centenário ao Brasil teve um efeito semelhante. O dentista também menciona o "orgulho das raízes", sendo estas entendidas de acordo com suas falas ao longo do trabalho, como o conjunto de valores em que foi criado. Ao falarem em termos como "raízes", "valores", "tradição", "cultura", meus interlocutores anunciam outros modos de identificação para além daqueles forjados por meio do agenciamento de discursos e imagens sobre os nikkeis.

Esta e outras inquietações se inserem no rol da problemática em torno da categoria "cultura japonesa". Explorar o que esse termo sugere, engloba, traduz, tornou-se um imperativo para a compreensão de questões mais amplas perfiladas por essa pesquisa. Buscou-se neste capítulo, investigar algumas "peças", elementos que compõe esse arranjo chamado "cultura japonesa”, a partir da forma como ela é pensada e elaborada pelos sujeitos dessa pesquisa, sendo por isso grafada com aspas. Um exame minucioso sobre essas "peças" seria uma tarefa exaustiva e pouco produtiva. Assim, breves inserções investigativas sobre valores, práticas culturais, língua, associações (kai), redes de sociabilidades, j-pop, centenário da imigração, foram realizadas. O objetivo consistiu em entender como esses elementos "se inscrevem em um regime de etnicidade" (Cunha, 2009), ou seja, como são apropriados nos processos de identificação pelos sujeitos. 
Assim, a relação de distanciamento e/ou aproximação com esses referenciais, seja através da negação, seja através do "resgate", diz muito sobre as identidades dos interlocutores dessa pesquisa. Além disso, outra hipótese defendida é a de que o fenômeno de popularização e positivação de coisas e símbolos relacionados aos Japão e aos nikkeis no Brasil também tem efeitos sobre os discursos e imagens construídos sobre os últimos, e no limite também pode atuar na relação de aproximação do sujeito descendente com esse universo.

O desafio consistiu em pautar a investigação dessas questões a partir de uma concepção híbrida e fluida de cultura, que se estendeu à discussão do compartilhamento de valores, das práticas culturais reinventadas, dos bens simbólicos transculturais, da ideia de comunidade como topos espacial e discursivo. A dinâmica histórica e cultural dos arranjos simbólicos humanos é hoje um pressuposto básico da Antropologia. Em outras palavras, as culturas estão em um fluxo contínuo de mudança. Como afirma Sahlins, inspirado na máxima de Heráclito: "o fluxo é de tal natureza que jamais se pode mergulhar duas vezes na mesma cultura" (Sahlins, 2004: 9).

Neste capítulo, o propósito residiu em mostrar que a "cultura japonesa" é um operador importante da identidade nikkei, acionado também em contexto: como na gratidão de Isabel Nishida aos antepassados pela educação recebida dentro dos "padrões da cultura"; nas panelinhas de amigos nihonjins de Amanda Shimizu; na visão de "diluição/perda da cultura" do médico Luís Yamamoto; na "militância étnica" de Pedro Higa; no contentamento de Júlia Bertolli com o envolvimento da filha com o universo dos animes ou simplesmente no ato de ver um DVD japonês e se emocionar, como nos conta Luísa Sato. Nas diferentes trajetórias e discursos aqui delineados é possível constatar como a categoria "cultura japonesa" se interpõe no processo de construção identitária. Significante que ao passo que se encontra marcadamente presente no imaginário discursivo sobre os nikkeis, é agenciado pelos sujeitos num contexto de enunciação que mescla memória, emoção e redescobertas, como na fala de Yumi Kawamura ${ }^{265}$ :

[...] "Mas era uma coisa que eu não dava assim tanto valor. Quando eu fui ficando mais velha, ai despertou. Hoje eu vejo a cultura assim totalmente diferente de quando eu era jovem. Eu gostava, participava. Mas hoje eu vejo de uma forma diferente. Você vê com outros olhos. Eu acho que é a vida. Eu não sei explicar. Coisas que para mim não tinham significado nenhum, hoje para mim tem significado".

\footnotetext{
${ }^{265}$ Sansei, 39 anos, astorguense.
} 


\section{CAPÍTULO IV - IDENTIDADES NO FLUXO DOS DISCURSOS}

\section{"A GENTE SÓ PERCEBE ISSO QUANDO ALGUÉM FALA"}

O objetivo central deste trabalho consistiu em apresentar uma outra abordagem no tratamento da questão sobre as construções identitárias que envolvem os descendentes de japoneses no Brasil. Mais do que analisar a assunção de identidades definidas a priori como "brasileiro", "japonês", "nikkei", "nipo-brasileiro", "nihonjin" ou "gaijin", visa mostrar, a partir de um olhar etnográfico e na interlocução com o sujeito da pesquisa, como as identidades são múltiplas e construídas em contexto. Por meio de interpelações discursivas, as identificações podem assumir diferentes formas. Vimos ao longo dos capítulos, como um imaginário que associa os nikkeis aos mais variados qualificativos tem efeitos sobre como estes se percebem. Discursos sobre disciplina, honestidade, esforço, feiura, beleza, "raça", e das mais diferentes ordens - sejam veiculados na mídia, nos livros, na propaganda televisiva, no elogio da professora, na fala do político, na piada do amigo - quando interpelam o sujeito, podem gerar processos de identificação ou não. Logo, não nos interessa saber se os descendentes de japoneses no Brasil hoje são mais "brasileiros" ou menos "japoneses", e sim que eles podem ser em contextos diferentes "brasileiros" $e$ até mesmo "japoneses".

O conceito de identificação aqui empregado é baseado nas contribuições do intelectual jamaicano Stuart Hall. Considerado por muitos autores como uma das principais referências dos chamados "cultural studies" ${ }^{266}$, sua obra também se insere no campo da "teoria pós-colonial". ${ }^{267}$ $\mathrm{Na}$ esteira do pós-estruturalismo, movimento que reposicionou a linguagem e o paradigma textual no centro do debate epistemológico das ciências humanas, a crítica pós-colonial independente dos diversos matizes que receberá nos estudos feministas, raciais, étnicos, de imigração - fundamentalmente, endereça uma crítica à concepção de sujeito das ciências sociais, arauto da modernidade enquanto teleologia da história. O sujeito, sob essa perspectiva, já não é mais pensado como ator, agente ou lugar na estrutura social e portador de um conjunto

\footnotetext{
${ }^{266}$ Os "estudos culturais" se desenvolveram inicialmente em meados dos anos de 1960 no Centre for Contemporary Cultural Studies na Birmigham University. A partir de uma leitura marxista, estiveram voltados para a análise de "textos da cultura", às voltas com temas como "sociedade e cultura de massa", televisão e recepção, "cultura da classe trabalhadora", etc. (Hall, 2003).

${ }^{267}$ Os "estudos pós-coloniais" surgiram por volta dos anos de 1970, num contexto político marcado pelos processos de descolonização e independência das antigas colônias da África e da Ásia. A pauta do dia era a "crise de representação" sobre o "outro", ou seja, o que estava em cheque era o poder do "Ocidente" (West) e sua superioridade ontológica e epistemológica de falar em nome do "Oriente" ou do resto do mundo (Rest) (Said, 2007; Hall, 2007).
} 
determinado de ideias, mas considerado como uma posição assumida e construída frente aos discursos.

Sem entrar no mérito das discussões sobre os limites e as críticas a essas correntes (Dirlik, 1997; Sahlins, 1997, 2004; Costa, 2006; Machado, 2004), a presente pesquisa se inspira em alguns aspectos da proposta de Hall, já que suas reflexões sobre questões identitárias não dizem respeito somente ao contexto do fim do colonialismo político. O autor também discute como a fragmentação das paisagens culturais de classe, sexualidade, etnia, nacionalidade nas sociedades modernas perturbou as localizações seguras das identidades pessoais, culminando no deslocamento ou descentramento do sujeito (Hall, 2005). De acordo com Hall, os sujeitos não são meramente produzidos pelos discursos. Estes só ganham sentido na medida em que ensejam um lugar para que o sujeito se posicione frente ao regime de verdade que eles estabelecem. ${ }^{268}$ Isso não significa que o sujeito esteja à espera de um discurso que decifre sua condição comum "sujeitos e discursos se constituem simultaneamente ou de outra maneira: sujeitos só podem se articular a partir de discursos" (Costa, 2006: 104).

Esse posicionamento também não se confunde com a intencionalidade do sujeito, mas tangencia um processo de subjetification, de produção discursiva do self. Cabe ao analista compreender os mecanismos que levam os sujeitos a uma identificação com certas posições no interior da formação discursiva, "bem como a maneira como estes indivíduos as marcam, estilizam, produzem, "performam"” (Hall, 1996 apud Costa, 2006: 103). Hall ao optar pelo uso do conceito de identificação ao invés de identidade, de saída já esclarece que ele não dá "nenhuma garantia contra as dificuldades conceituais que têm assolado o último". O autor o define como um processo de construção sempre incompleto, condicional e contingencial, sujeito ao jogo da differánce ${ }^{269}$ (Hall, 2007: 108).

Vimos como um imaginário sobre os japoneses e seus descendentes que os associa a um conjunto de atributos diversos é entendido pelos interlocutores dessa pesquisa e de como se coloca na experiência de vida e na fala dos mesmos. Um imaginário que tem um efeito de discurso quando interpela o sujeito. Nesse momento, diferentes reações se processam: como a

\footnotetext{
${ }^{268}$ Hall parte da noção de formação discursiva de Foucault para afirmar que o discurso não se confunde com ideologia, entendida como uma representação falseada do mundo. Não cabe ao analista, portanto, a discussão do seu teor de verdade, mas a compreensão do contexto em que o mesmo se produz, ou seja, o "regime de verdade, dentro do qual o discurso adquire significação, se constitui como plausível e assume eficácia prática” (Costa, 2006: 86).

269 Além de Foucault, outra grande inspiração para os autores pós-coloniais é Derrida. O recurso às construções identitárias homogeneizadoras que buscam aprisionar ou reificar a cultura deve ser substituído pela ideia da diferença. Para o autor indiano Homi Bhabha, também referência nesse campo, essa diferença não é uma entidade, pois se desenha no momento de sua manifestação. A diferença não é um dado a priorístico, ou seja, "traços culturais ou étnicos não são preestabelecidos, inscritos na lápide fixa da tradição" (Bhabha, 2007: 20-21). A diferença é representada, performatizada e a tradição, ao ser reencenada, é ao mesmo tempo inventada. Nas palavras de Bhabha, "esse processo afasta qualquer acesso imediato a uma identidade original ou a uma tradição "recebida"” (id.; ib.).
} 
satisfação com que os comerciantes Júlia Suzuki Bertolli e Daniel Kobayashi recebem os elogios sobre a confiabilidade e credibilidade dos nikkeis e de seus estabelecimentos comerciais; o sentimento de "orgulho" que o Sr. Paulo Sasaki e Isabel Nishida evocam quando se discute a "união da colônia" e o sucesso das comemorações do centenário; em minha surpresa quando o caixa da loja de produtos japoneses, diante de minhas dúvidas com relação ao nori, disse: "ué, mas você não é japonesa?!”; no incômodo sentido pelo pequeno Gabriel, filho de Alice e Jorge Ohara $^{270}$, em ser chamado de "japonesinho".

Alice ponderara que se a interpelação fosse algo do tipo "que japonesinho bonitinho!", “não é por maldade, não tem a intenção de ofender". Assim como outros interlocutores, ela comentara sobre o caráter relativo do preconceito, já que a configuração deste depende de uma série de fatores como a intencionalidade do autor, o conteúdo da brincadeira, o tom de voz empregado, o grau de intimidade com a suposta "vítima". Nesse sentido, a forma como o outro é interpelado é definidora do sentimento de constrangimento, de satisfação ou de identificação ou não com o conteúdo da interpelação. Não existem identidades assumidas a priori.

“A gente só percebe isso quando alguém fala, não é verdade? - refletiu Alice num outro dia em que conversávamos. Contou-me que certa vez, estava com dificuldades para tirar o seu carro de uma vaga, pois os veículos estacionados à frente e atrás estavam praticamente colados ao seu. Ela tentou encontrar o dono de um dos carros, entrando em uma loja em frente à vaga utilizada. “Quem está perguntando sobre o carro?” - questionou alguém lá de dentro. “É que aquela japonesa está tentando tirar o carro e não está conseguindo!” - disse uma funcionária. Alice concluiu então:

"Você não pensa que você é diferente. Só quando alguém fala isso. De repente alguém fala, 'ô japonesa!', a gente só percebe isso quando falam, porque a gente se sente igual. Não é verdade?" - ela diz, como se pedisse uma confirmação.

"Quando você diz que não se sente diferente, quer dizer a gente se sente brasileiro..." complemento.

"Isso! A gente se sente igual a qualquer outro! Aí quando falam, 'japonesa não sei o quê', eu penso: 'Nossa é mesmo!!' Ai é que me toco. É... tá falando de mim!" [risos].

Alice mostra como a marcação e a percepção da diferença se constroem no contexto, no momento mesmo de sua manifestação e podem ser forjadas na relação com um discurso. Antes disso, "a gente se sente igual", um brasileiro como qualquer outro. Em sua preciosa reflexão, ela chama a atenção para a nossa ascendência comum, ascendência esta que somente

\footnotetext{
${ }^{270}$ Alice, sansei, 46 anos, orientadora do Kumon em Astorga. Jorge, nissei, 52 anos, feirante.
} 
importa, é percebida, assumida ou "rejeitada" quando discursos que a tematizam interpelam o sujeito ou se cruzam de alguma maneira com sua experiência de vida. Assim, o indivíduo pode assumir diferentes identidades dependendo do contexto e dos discursos envolvidos.

Isso não significa que o sujeito seja "refém" do discurso no processo de construção identitária. A respeito do uso dos postulados foucaultianos sobre o discurso na Antropologia, Sahlins argumenta que as críticas desconstrutivistas ao conceito antropológico de cultura no que concerne ao seu suposto caráter reificado, essencializado, orgânico e coeso caem na mesma armadilha teórica quando supervalorizam o conceito de discurso - "desembocando por vezes em uma narrativa de hegemonia tão totalizadora, que somos retransportados à teoria super-orgânica da cultura promovida por Leslie White nos anos de 1940 e 1950",271 (Sahlins, 2002: 81). Segundo Sahlins, basta substituir "cultura" por "discurso" na seguinte passagem de Foucault, "trata-se de privar o sujeito (ou seu substituto) de seu papel de originador, e de analisá-lo como uma função variável e complexa do discurso" para nos reportarmos à White (id.; ib.).

Como já reiterado diversas vezes ao longo do texto, as identificações por meio de interpelações discursivas ou ressignificações de imaginários ou discursos se constituem em um dos modos de conceber as construções de identidades. A proposta de Hall pode não conter grandes novidades sobre o estudo dessa questão, e diferentemente do autor, não se defende aqui que os sujeitos só se articulam a partir dos discursos. Vimos como as categorias "cultura japonesa" e "colônia/ comunidade" também se constituem em operadores importantes que devem ser considerados. Contudo, a contribuição do autor é válida para o argumento aqui defendido de que não existe uma identidade nikkei aprioristicamente definida e que os discursos sobre os nikkeis tem efeitos na forma como estes são percebidos e se percebem na sociedade.

\section{“ORGULHO E PRECONCEITO”}

O capítulo 3 fecha com a fala emocionada de Yumi Kawamura sobre sua relação com o que ela entende por "cultura japonesa". Percepção que foi mudando ao longo do tempo, uma valorização despertada com o amadurecimento: "Hoje eu vejo a cultura assim totalmente diferente de quando eu era jovem. [...] Eu acho que é a vida. Eu não sei explicar. Coisas que para mim não tinham significado nenhum, hoje para mim tem significado". Vários entrevistados desenharam essa ponte entre juventude e a vida adulta para a explicação das mudanças com

\footnotetext{
${ }^{271}$ Na perspectiva de White, a ação humana era mera expressão da ordem cultural, sendo o indivíduo pensado como uma espécie de "aeronave sem piloto, controlada do solo por ondas de rádio" (Sahlins, 2002: 81).
} 
relação aos novos significados que passaram a atribuir à "cultura". O dentista Rodrigo Suzuki ${ }^{272}$ acredita que o "resgate das raízes" consiste em um processo "natural” do indivíduo:

\begin{abstract}
"Geralmente quando se é criança e a chamam de 'japonês', ela não gosta, fica ofendida, né? 'Ah, mãe queria ter nascido diferente!'. Depois de certa época, quando você começa a andar com 'japoneses' ou quando você fica um pouquinho mais maduro, você acaba percebendo, 'Ah, legal minha cultura!'. Porque são pessoas respeitadas, você acaba vendo empresários, muita gente assim que tem dinheiro e você acaba procurando as raizes, sem querer [...]. O resgate não acontece devido às comemorações (do centenário), mas devido a uma ordem natural do ser humano de olhar para trás e ver. Como sou hoje, 'Pai, como era?' ou o pai fala, 'Na minha época meu pai era assim...'. Você acaba pesquisando, indo atrás de algumas coisas. Antigamente não suportava música japonesa e hoje escuto enka. Meu primo que veio do Japão, falou: 'Cara, você escuta isso? É só batchan e ditchan que escutam isso no Japão!'. Ué, mas eu gosto! Depois que você vê as letras, acaba estudando, você acaba gostando. J-pop não gosto, prefiro as músicas do ditchan e batchan. Tem no meu ipod. Você acaba resgatando as coisas. Hoje compro DVD's, assisto... Assisto com o ditchan da minha namorada... Mas não é só o 'japonês' que olha para trás para ver o que aconteceu, como aconteceu e porque aconteceu. Acaba tendo um resgate, isso é natural de qualquer um".
\end{abstract}

Vimos que esse sentimento de rejeição quanto às origens, surgido principalmente na infância, foi comentado também por Pedro Higa ${ }^{273}$ e outros entrevistados e está sendo vivenciado hoje pelo pequeno Gabriel Ohara. Como espera seu pai, Jorge, "quando crescer, ele vai entender melhor". Rodrigo também acredita que esse entendimento ocorre com a maturidade, num fenômeno comum a todo ser humano de buscar compreender seu passado, suas origens e raízes. Nesse processo, elementos são ressignificados, novos valores e sentidos são conferidos àquilo que se concebia inicialmente.

Lúcia Miyamoto, mãe de Leonardo, ${ }^{274}$ espera que o fillho também passe por esse momento de reflexão. Mais amadurecido, uma nova relação com a história dos antepassados pode ser estabelecida. Ela mencionara diversas vezes em seu depoimento a questão do "orgulho" de ser descendente de japoneses. Disse que achou muito "válida" a comemoração do centenário da imigração japonesa no Brasil e afirma que seu marido que se engajou em comissões para organização de festejos na região de Maringá sentiu muito "orgulho" de ter participado dos eventos. Ao final de nossa conversa, peço-lhe para falar mais a respeito desse sentimento:

"Eu tenho orgulho, com certeza! Porque eu acho que se você não tem orgulho do que você é... O que seria do ser humano se você não tem orgulho do que você é? [...] Dá para ter orgulho do que todos, que até hoje estão aqui, fizeram. E a importância que o próprio Japão deu ao fato dos japoneses terem vindo para cá. Eu acho que foi muito bacana mesmo (comemoração do centenário). Sinto muito orgulho de ser descendente. Por tudo isso, né? Pelas conquistas... Sinto muito orgulho pelos antepassados que sofreram muito, sabe? Porque eu sou muito

\footnotetext{
${ }^{272}$ Sansei, 22 anos, de Londrina.

${ }^{273}$ Sansei, 22 anos, estudante de São Paulo.

${ }^{274}$ Lúcia, nissei, 42 anos, de Maringá, empresária, mãe de Leonardo, sansei, 19 anos, estudante.
} 
curiosa em saber o que nossos avós passaram. Então, eu acho que foi muito válido mesmo. Eu acho que é a mesma coisa que sente meu marido, por ele ter se engajado nisso também. Agora o Leonardo, já não sei se sente tanto. Mas eu creio que, pelo fato de a gente pensar dessa forma, eu acho que na hora em que ele estiver mais amadurecido, ele vai sentir muito orgulho também da história toda que os pais viveram, que os avós e bisavós viveram. Eu acho que tudo acrescenta mesmo. Então, eu acho que a gente planta uma sementinha legal. Um dia vai florescer. Eu acho que é isso que tem que fazer. Nunca se deve esquecer das raízes mesmo".

Rodrigo que também dissera - "Tenho orgulho de minhas raízes, mas sou brasileiro. O hino que me faz verter lágrimas, arrepiar é o brasileiro e não o japonês" - mostra em seu discurso as múltiplas identificações em jogo. Ao mesmo tempo em que tem um vínculo emocional com a história e tradições culturais de seus antepassados, não deixa de ser e de sentirse brasileiro, especialmente quando ouve o hino nacional. Indago-lhe, logo depois, se ser nikkei era motivo de orgulho e se significava alguma coisa para ele:

\begin{abstract}
"Significa muito. Falo que o que sou hoje foi devido à criação de meus pais. Se sou uma pessoa boa ou ruim, foi o que eles passaram. E o que eles passaram para mim foram pontos da 'cultura japonesa', de sempre respeitar os pais, os avós... Não me apego à culinária, valores religiosos, embora não partilhe da mesma opinião de meus pais... católica. O que é orgulho de ser nikkei? É orgulho de estar inserido em uma 'raça', em uma etnia que ainda é admirada, respeitada por grande parte... Vieram como os escravos, mas se sobressaíram. Os negros ainda são marginalizados... japoneses não. Pularam de um nível de escravidão para o topo... É capaz, daqui alguns anos, termos um presidente 'japonês'. Temos o chefe da Aeronáutica Juniti Saito ${ }^{275}$, então, lógico que a gente tem orgulho! Seria hipócrita em falar que não. Falam "é tudo igual". Não é tudo igual... No fundo a gente é um pouco orgulhoso. A partir do momento em que você começa a ver, com outros olhos que você está em uma cultura onde o povo respeita, onde o povo admira, onde muita gente gostaria de ser... Hoje, uma coisa que eu não via há 10 anos e hoje eu vejo, 'ah, você é japonês' ou alguns amigos meus que só gostam de namorar japonesas, né? Então é fato de ser orgulhoso, de ter orgulho. É mais pelas raízes mesmo... Um povo que foi tão discriminado na vida, no Brasil, foi enganado, principalmente na Segunda Guerra... até hoje por brincadeiras ou alguma coisa assim, a gente sabe que tem o respeito. Então, ah, não sei o que falar. Tem orgulho pelo fato de estar em um grupo que era uma minoria no Brasil e hoje está ocupando cadeiras importantes, ou no mínimo mostrando serviço, né?"'.
\end{abstract}

Toca você toda a história e trajetória dos japoneses no Brasil? - pergunto-lhe.

\begin{abstract}
"Todo o sofrimento, o que passaram... Li Corações Sujos ${ }^{276}$... Quando você aprende um pouco da cultura, você passa a respeitar. Não é só o olho puxado. Quando você passa a respeitar, você passa a enxergar de outra forma. Passa a ter orgulho. Não falo que é a única etnia que deveria ter orgulho, longe disso. Mas a que mais sobressaiu, aqui no Brasil, com certeza foi a japonesa. Lógico que é motivo de orgulho esfregar na cara de todo mundo, 'ah, a gente pode,
\end{abstract}

\footnotetext{
${ }^{275}$ Filho de japoneses, o atual Comandante da Aeronáutica é o primeiro nikkei a chegar ao posto máximo da Força Aérea Brasileira.

${ }^{276}$ O livro, escrito pelo jornalista Fernando Morais (2000), reconstitui a história da Shindo Renmei. Ganhador do Prêmio Jabuti, categoria não-fiç̧ão em 2001, está sendo adaptado para o cinema, com lançamento previsto para 2011.
} 
porque a gente veio aqui e tomou a vaga de vocês no vestibular, nos empregos!' [risos]. Assim, de modo mais brincalhão! Mas é isso".

A fala de Rodrigo contém uma série de elementos importantes que foram discutidos ao longo do trabalho. Enfatiza a existência de uma imagem positiva sobre os descendentes de japoneses na sociedade que desperta o respeito e admiração das pessoas, dos próprios nikkeis e do restante dos brasileiros - não é só uma questão de ter os olhos mais puxados, assegura o entrevistado. Essa positivação tem efeitos sobre como o dentista se percebe, pois é motivo de orgulho para ele estar inserido em um grupo que ascendeu socialmente. Quando toca esse assunto, o recurso comparativo com os negros também foi mobilizado. Rodrigo menciona a questão da "raça", do "olho puxado" e o discurso que "os japoneses são todos iguais", complementando que as "brincadeiras" com relação às características físicas do nikkei existem até hoje.

Todavia, chama a atenção para elementos que transcendem a esfera do imaginário tanto positivo, como negativo no que diz respeito aos descendentes: a questão cultural. Assim como vários entrevistados observaram a importância de se conhecer e reconhecer os valores recebidos e o esforço dos antepassados na adaptação ao país, Rodrigo, quando passou por esse processo, diz que passou a enxergar a "cultura" de uma outra maneira, sentindo admiração e orgulho. $\mathrm{O}$ dentista também se refere à hipocrisia daqueles que dizem não o sentir. O sentimento de orgulho, como já comentado, pode servir como um catalisador da experiência identitária. Contudo, pode estar atrelado também a uma postura altiva, sobretudo na marcação da diferença com relação ao outro. Rodrigo buscou enfatizar o seu relativismo quando the perguntei se ele se identificava com o imaginário positivo sobre os nikkeis:

\footnotetext{
"Agora se eu concordo com a imagem de que todo homem trabalhador, honesto e que tenha algum caráter - porque não adianta ter só dinheiro, deve ser respeitado - deve ser espelhado, eu concordo, lógico. Não só pelo fato de ser japonês. Acredito que qualquer pessoa que tenha caráter, que faça algo em prol da sociedade, ou que não atrapalhe, que não lese, deve ser visto dessa forma. Engraçado, não sou nenhum preconceituoso, mas a etnia japonesa se saiu muito bem do que as demais etnias. Não sei dizer o porquê. Talvez seja pelo fato de estudo, estudo, estudo e acabou levando a etnia... concordo sim".
}

O rapaz que, como vimos no capítulo 3, anda em "panelinha" de nikkeis, diz que seu grupo de amigos se conforma, “independentemente (do membro) ser 'brasileiro' ou 'japonês"”, mas acredita ser 'mais fácil os gostos se parecerem entre 'japoneses' do que 'brasileiros', pois “o ‘brasileiro' tem aquele tal do 'jeitinho brasileiro' que me incomoda muito”. Vimos ao longo de todo o texto como as posições de identidade, construídas a partir da alteridade, podem ser estabelecidas por meio do acionamento de preconceitos, estereótipos. A estudante Amanda 
Shimizu, ${ }^{277}$ que também costumava andar "em colônia" não sabia explicar porque o fazia, talvez fosse afinidade, talvez fosse preconceito contra os "brasileiros", talvez os dois.

$\mathrm{Na}$ fala do "militante étnico" Pedro Higa, podemos observar uma abordagem dessas questões. Como já discutido anteriormente, o que chamamos aqui de imaginário discursivo sobre os nikkeis tem efeitos sobre a experiência de vida dos sujeitos dessa pesquisa, podendo ser ressignificados de maneiras diferentes. Em muitos casos, pudemos observar processos de identificação com o mesmo. Já o paulistano Pedro, estudante de Ciências Sociais, não concorda com a atribuição de qualificativos/estereótipos ao nikkei:

"Não, não concordo, porque o estereótipo em si é o senso comum, né? É o que foi veiculado, é o que a galera acha que é assim, ou o que ela viu nos filmes dos Estados Unidos. Então, eu acho totalmente negativo, inclusive os estereótipos positivos do trabalhador. Apesar de que a primeira geração, realmente, tinha essa visão de mundo, tinha uma cultura diferente, e eles prezavam mesmo essa questão de trabalhar, de honrar a família. Inclusive eu queria fazer umas... Contrapor isso com a ética protestante. É muito semelhante assim em algumas coisas, mas você vê que isso começou a se perder e outro problema foi que os próprios orientais começaram a se cobrar, 'Não, porque oriental tem que ser inteligente', 'eu tenho sempre que tirar nota A em tudo, sempre 10 ou as notas mais altas', 'tenho que entrar no vestibular'. E até hoje as maiores, geralmente as maiores pontuações são de orientais né? Sempre tem um oriental no meio".

"Mas você vê isso como negativo então? Não como positivo?" - pergunto-lhe.

"Então, eu vejo como positivo se a pessoa faz isso não pelo estereótipo, não movida pelo estereótipo, movida por interesses pessoais. [ou por valores?]. Ou por valores que foram repassados pela família, os valores que os primeiros imigrantes trouxeram, eu acho isso extremamente importante você manter algumas coisas que eram extremamente positivas, né? O respeito pelos mais velhos, pelo próximo em si, mas eu acho negativo quando isso vira uma cobrança, vira aquela coerção psicológica que, 'se eu não me empenho, se eu não virar um doutor meu tio vai me cobrar, meus primos que estão melhores do que eu em condição material vão começar a rir de mim...'. Você vê que existe uma própria coerção familiar e uma coerção da sociedade, porque eles aprenderam a ser assim, eles aprenderam que 'japonês' é assim. Enfim, eu não tive muitos problemas com isso. Eu repeti de ano, eu era bem esculachado em algumas coisas, na área de exatas, mas tirava notas boas em humanas e geralmente é o contrário, né? E aí você até via as pessoas comentarem, 'Pô, japonês não vai bem em humanas, você é o único que vai bem. Todo mundo tira dez e você tira zero em matemática, como é que consegue? Japonês paraguaio!'. Eu escutei muito isso quando eu era moleque e tudo mais. Até hoje de vez em quando escuto quando estou estudando sociologia e a galera fala, 'Pô, mas sociólogo oriental é dificil, não sei o quê'".

Como muitos jovens entrevistados, Pedro diz se identificar com o valor do respeito à família e demonstra preocupação com a forma com que muitos jovens nikkeis reproduzem os discursos e estereótipos sobre os descendentes sem questionar, como se fosse uma "verdade

\footnotetext{
${ }^{277}$ Sansei, 21 anos, estudante de Umuarama. Sua biografia aparece no capítulo 3.
} 
categórica": "Muitos jovens eu vejo que vestem mesmo a camiseta do estereótipo e falam, 'Não, japonês é assim mesmo, japonês é assim'. Eu falo, 'Pô, mas minha geração não é assim!', então alguma coisa de errado tem". Essa observação também foi feita por Guilherme Shimada, irmão de Amanda ${ }^{278}$ :

"Tem japonês que se acha por causa da 'raça', se acha o bom, o inteligente, o máximo. Tem japonês que se influencia muito por causa da 'raça'. Falam, 'Ah, sou japonês, não sei o quê'. Aí quando enche a cara, fala demais... Tem uns que usam a influência da nacionalidade e tem outros que não. Ficam mais de boa, levam naturalmente e a melhor coisa é assim. O negócio é ficar na dele, no canto e fazer o que cada um tem que fazer, seguir a vida, se esforçar tudo o mais... fazer igual os japoneses, ser esforçado, em outros quesitos, outras coisas mais. Mas tem 'japoneses' que ficam se vangloriando, se achando... Dá vontade de dar porrada num cara desses. Pelo amor de Deus! A pior coisa é a pessoa ficar se achando por causa disso".

Pedro Higa abordou o tema do preconceito com relação a um "conflito" ainda existente no Brasil, a seu ver, entre comunidades de descendentes de japoneses e de okinawanos. Como vimos, ele vivenciou esse drama dentro da própria família: a do pai é de origem okinawana e a da mãe é oriunda da província de Wakayama. O rapaz que sempre teve uma proximidade maior com a família materna - "mais por questão de afinidade mesmo e não cultural" - disse que passou a se interessar e a "resgatar" recentemente a história e a "cultura" dos okinawanos, Uchinanchus, ${ }^{279}$ no país. Quando discutíamos sobre até que ponto a participação menos intensa de nikkeis em domínios como arte, ciências humanas e política tinha relação com uma questão cultural, Pedro disse:

"É nessa questão que eu queria falar dos okinawanos. Em uma palestra que fiz sobre os okinawanos perguntaram por que a maior parte dos nikkeis que está na política, no jornalismo, nos partidos e em outras coisas é de origem okinawana. Estavam falando, porque se fala que os okinawanos são mais expressivos, são mais festeiros. Não sei até onde é verdade e até onde é mentira, mas você acaba até vendo um pouco disso. O primeiro nikkei que acabou escrevendo livros em português no Brasil foi José Yamashiro ${ }^{280}$ que é descendentes de okinawanos. Não sei né, porque eu também tomo cuidado, porque muito okinawano usa isso aí como desculpa para falar que os okinawanos são melhores, entre aspas, que os japoneses, né? Eu também acho um besteirol, porque enfim, não tem uma lógica nessa argumentação. Mas é isso, as pessoas falam que é porque são mais... tem a voz mais ativa, não tem tanta vergonha de se expressar. Pode ter uma certa ligação sim, sociológica, mas a gente não pode afirmar categoricamente que é somente isso".

\footnotetext{
278 Sansei, 24 anos, estudante universitário, nasceu em Astorga, mas mora em Campo Mourão. Foi entrevistado junto com a irmã.

${ }^{279}$ Termos usado pelos okinawanos para se distinguir dos japoneses das ilhas principais (mainland japaneses), os Yamatonchus.

${ }^{280}$ Escritor e jornalista. Atuou nos jornais Nippak, Folha da Manhã, revista Visão e foi editor da revista Mundo Econômico, além de ter escrito diversas obras sobre a história do Japão, de Okinawa e um livro biográfico sobre a imigração japonesa no Brasil.
} 
Pedro acredita que é importante manter as tradições culturais e a identidade dos grupos, mas sem recair na afirmação de uma suposta superioridade com relação ao outro:

\begin{abstract}
"Eu acho importante também, eu acho que os dois lados tiveram um respeito pela família, pelas pessoas, pela hierarquia e tudo mais só que eu não me dava bem com quase ninguém da minha família paterna. Eu fui me aproximar mais agora com 20 e poucos anos, porque eu comecei a me interessar mais pela cultura mesmo, de resgatar. Mas desde pequeno, eu via diferente sim, eu ouvia comentários dos dois lados, não só da minha família, mas assim, nas colônias. Você vai em uma festa okinawana e você acaba sempre escutando alguém falando, fazendo um comentário, seja um só, mas sempre tem um que diz, 'Mas isso é coisa de okinawano, você vai ver coisa de japonês, japonês não sabe dançar assim'. E minha mãe odiava isso, porque ela é filha de japoneses e quando você vai, os japoneses nem tanto tiveram isso aqui de alfinetar os okinawanos, mas em Okinawa e mesmo no Japão me falaram que tem bastante ainda, né? ${ }^{281}$ Eu sempre critiquei os okinawanos nisso, de sempre continuar com esses estereótipos de ficar falando, tentando diminuir moralmente os japoneses, porque é praticamente a mesma coisa que os japoneses fizeram com eles. Como a gente está tudo no mesmo barco, quem olhar para a gente não vai querer saber se você é coreano, chinês, japonês okinawano, taiwanês. Enfim, todo mundo vai falar, 'Você é japonês, você tem o olho puxado, para mim vocês são todos iguais'. Então, eu acho que a gente tem que começar a quebrar alguns preconceitos entre as próprias comunidades mesmo, é claro, mantendo o que cada um tem de melhor, né? A cultura japonesa tem umas coisas diferentes da cultura okinawana, cada um tem que colocar mesmo as diferenças culturais, mas também sabendo conversar entre si, como parceiros, companheiros e não como inimigos. Eu acho que muito dessa coisa de... os orientais de não cobrar os seus direitos vem disso. Eles estão mais preocupados em ganhar status e criticar os outros orientais do que realmente fazer alguma coisa em conjunto, né?".
\end{abstract}

O estudante fala a respeito das diferenças culturais entre os okinawanos e os japoneses da ilha principal e de como essas diferenças foram sentidas por sua família. "Não tem aquela esponja vegetal? Antes de ficar aquela esponja, quando ela ainda não está madura, os okinawanos comem aquilo, né? E minha avó olhou, tipo minha avó materna e falou, "Pô, não vou comer isso aqui, né? Isso aqui eu deixo secar e lavo louça!" ${ }^{282}$, afirma Pedro, dando o exemplo dessas diferenças no âmbito da culinária. Contudo, acrescenta que apesar dos conflitos familiares que surgiram com o casamento de seus pais, a avó "respeitou bem", sendo que a aceitação foi muito maior pelo lado materno, "porque a minha avó e o meu avô (maternos) eram bem mente aberta, né? Mas o outro lado lá não era tão mente aberta assim”. Quais as raízes desse preconceito recíproco?

É importante lembrar que Okinawa é uma província que fazia parte do Reino de Ryukyu, possuindo governo e tradições culturais próprias até ser anexada ao Japão em 1879.

\footnotetext{
${ }^{281}$ A entrevistada Milena Teruya, 23 anos, comentara no capítulo 2 que sofrera preconceito quando era estudante no Japão devido ao seu sobrenome okinawano - "o pessoal considera a gente como se fosse um semi-japonês" (Ver página 151).

${ }_{282}$ Pedro se refere ao naberá, bucha vegetal consumida pelos okinawanos quanto está verde, sob a forma de ensopado ou refogado.
} 
Devido às influências culturais da China, havia forte discriminação por parte dos japoneses (do continente) com relação aos okinawanos, considerados por aqueles como primitivos e bárbaros. De acordo com Koichi Mori (2003a), no início do movimento imigratório para o Brasil, os okinawanos - que respondiam por $41,6 \%$ do total de imigrantes que vieram no Kasato Maru foram acusados pelo governo japonês e pelos imigrantes do continente de serem responsáveis pelas greves e conflitos no trabalho nas fazendas de café. A imigração de okinawanos chegou a ser proibida pelo governo japonês anos mais tarde, e diante do clima reinante nada amistoso entre os dois grupos de emigrados, alguns líderes okinawanos passaram a aconselhar o abandono de certas práticas e costumes da província, ou seja, buscaram recomendar a não afirmação da identidade Ryukyu (Mori, 2003a: 53).

Com o fim da Segunda Guerra Mundial e a fixação definitiva da maior parte dos imigrantes no Brasil, “a divisão entre japonês no Japão e japonês no Brasil se tornou mais significativa do que as diferenças entre okinawanos e os japoneses do continente" (id.; ib.: 55). Por outro lado, depois da derrota do Japão na Guerra, associações de okinawanos foram criadas em prol do auxílio à terra natal, congregadas na Associação Okinawa Kenjin do Brasil, entidade que também exerceu atividade na recepção e apoio aos imigrantes que chegaram ao país depois da Guerra. Com a redução da imigração, a entidade se voltou para a revalorização de costumes e práticas da cultura uchinanchu, como o culto aos ancestrais e os festivais de arte, buscando difundi-las entre os descendentes. De acordo com o autor, "os anos setenta foram os anos em que a construção e administração das barreiras étnicas começavam a ser mais frequentes através das escolhas e a prática dos elementos culturais pelos okinawanos e seus descendentes que exibiam as fronteiras existentes entre os yamatus"283 (Mori, 2007: 279).

Mori também aponta que a ascensão social dos descendentes de okinawanos no país nesse período promoveu novas formas e possibilidades de auto-afirmação. Nas eleições gerais de 1970, ocasião em que a inserção nas carreiras políticas dos mesmos foi maior que a dos yamatonchus, muitos uchinanchus comentavam que os lugares sociais dos dois grupos tinham se revertido, além de passarem a afirmar que possuíam qualidades ou valores, como solidariedade, cooperação e atitudes abertas, que superavam as dos japoneses (mainland) e seus descendentes. O autor conclui: "the culture and the customs that until de 1950 had been considered shortcomings to be thrown aside in attempts to become Japanese, now were reconstructed as

\footnotetext{
${ }^{283}$ Mori também observa que no processo de mudança do campo para a cidade de São Paulo, os descendentes de okinawanos e os da ilha principal se estabeleceram e se concentraram em áreas residenciais distintas, além de terem se dedicado a atividades comerciais diversas. Esse quadro concorreu para a formação de associações autônomas ligadas às províncias de origem e também para o ressurgimento da discriminação continuada para com a segunda geração de descendentes de okinawanos (Mori, 2003a: 56-57).
} 
virtues and strengths that made those of Okinawa descent the 'best' Brazilians" (Mori, 2003a: $60)$.

A afirmação da diferença, portanto, esteve e está articulada a contextos históricos específicos. A crítica de Pedro aos "okinawanos" (descendentes) pode estar relacionada ao fato de ele não ter experienciado uma sociabilidade e vivência em "colônia" com este grupo e também pela sua "militância étnica", traduzida por ele como uma luta pela "democratização da cultura oriental", seja na defesa pela maior acessibilidade a obras artísticas, literárias do Oriente, seja na reivindicação pela mudança na representação estereotipada da "cultura japonesa e/ou oriental" na mídia. Essa luta seria possível através da "união dos orientais", mantendo as diferenças culturais de cada grupo, mas rompendo os preconceitos internos. A crítica do estudante também está direcionada àqueles, sobretudo os integrantes e líderes da "colônia", okinawana ou não, que vêem a preocupação com a "preservação da cultura, num sentido fascista", ou seja, de não admitir que ela seja dinâmica, sofra transformações na inter-relação com outras culturas e com a história.

\begin{abstract}
"Agora dos okinawanos apesar de ter muitas coisas comerciais também que eu critico, você vê que existe uma certa preocupação com a cultura. Mas aí também tem que ver. Eu faço a crítica do porquê que eles mantém algumas questões culturais só para fazer diferença com relação aos japoneses, entendeu? Isso eu acho prejudicial, eu acho que você tem que manter a cultura para manter a identidade, não para manter, 'Ah, porque eu sou melhor que você, porque eu sou diferente'. Você vê até comentários assim, 'A gente é mais parecido com chinês e com brasileiro, porque é mais espontâneo'. Eu acho que esse tipo de comentário não agrega nenhum valor e só prejudica a imagem dos okinawanos".
\end{abstract}

A fala e trajetória de Pedro evidenciam que mesmo dentro desse "grupo" chamado nikkei existem clivagens internas das mais diversas ordens: geracionais, etária, de classe, e também de província de origem. Quando discutíamos a questão do sentimento de orgulho, Pedro chamou atenção para a "carga ideológica do orgulho do japonês ou do okinawano" e disse não saber se partilhava desse sentimento, mas talvez compartilhasse uma "proximidade com essa identidade nikkei":

\footnotetext{
"Eu mesmo me coloco como nikkei, eu tenho essa identidade sim. Como também acho que os bolivianos, aqui de São Paulo, que são descendentes dos Aimarás, né? Eles são bem, são preconceituosos inclusive com os próprios bolivianos que estão melhores de vida aqui. Eu acho que eles têm que ter orgulho mesmo. Orgulho assim, não orgulho que chega a beirar o fascismo, né? Mas um orgulho de respeito mesmo pela sua origem".
}

O rapaz mantém uma postura crítica quanto ao agenciamento de estereótipos e essencialismos nas estratégias de construção identitária, algo que como vimos, permeou as 
narrativas de muitos interlocutores dessa pesquisa. Para Pedro, a afirmação da identidade deveria estar conjugada à valorização de elementos culturais, ao respeito pelas origens e tradições, mas não pautada no estabelecimento de fronteiras entre "eu" e o "outro", quanto mais em critérios de superioridade. Um ponto importante que toda essa discussão levanta gira em torno da seguinte questão: se a identidade é um processo de afirmação dinâmico e dialético em que a relação com o "outro" está em jogo, no qual traços culturais diacríticos são ressignificados e apresentados na simbolização das fronteiras ${ }^{284}$, como podemos definir os limites do que é construção identitária e do que é preconceito?

\section{“ORDINARY PEOPLE REIFY, ALL TIME, EVERYWHERE”}

Como já mencionado diversas vezes, no exame dos processos de construção e negociação de identidades dos sujeitos da pesquisa por meio da ressignificação do imaginário sobre os nikkeis, pudemos observar nas narrativas e depoimentos apresentados ao longo dos capítulos, conteúdos que pareciam escapar das posições de enunciação articuladas a partir de discursos e imagens. Categorias como "cultura", "comunidade", "valores", "raça", "raízes", "orgulho" fizeram parte de um repertório bastante mobilizado pelos interlocutores, e a reboque, essencializações e preconceitos também vieram à tona. Como já anunciado, a leitura de Michael Herzfeld poderá iluminar a reflexão, formando um contraponto à proposta de subjetificação de Stuart Hall, a qual, à primeira vista, parece demasiadamente adstrita ao jogo textual.

O antropólogo britânico, em suas obras, Antropologia do outro lado do espelho: etnografia crítica das margens da Europa (2001) e Cultural Intimacy: the Social Poetics in the Nation-State (2004), debruça-se sobre a questão do agenciamento de "valores" na prática social pelos sujeitos de sociedades "mediterrânicas", mais precisamente, a grega. No primeiro livro, publicado originalmente em 1987, é possível perceber que o autor também busca compreender as estratégias discursivas que subjazem aos processos de criação de identidades. Ao mostrar a tensão existente na Grécia no que diz respeito à negociação entre identidades opostas - a europeia helênica, assim como preconizada pelo discurso oficial nacional e a identidade oriental, turca, experienciada nos contextos cotidianos - Herzfeld anuncia que essa ambivalência desafia os objetivos da disciplina antropológica, que paradoxalmente, ao mesmo tempo em que "rejeita o exoticismo, o sensacionalizar da diferença cultural, persegue o estudo da alteridade cultural" (Herzfeld, 2001: 17).

\footnotetext{
${ }^{284}$ Cf. Barth (1998), Cunha (1986).
} 
$\mathrm{O}$ autor sugere que essa condição de liminaridade entre os polos do "exótico" e do "familiar" tornam a etnografia da Grécia um campo frutífero para se pôr em cheque certas ideias arraigadas na Antropologia. Afirma que o país, na condição de Estado-Nação, não pode ser estudado como um todo uniforme através dos métodos tradicionais da observação participante, pois "tem até agora escapado ao tipo de redução autoritativa que um título genérico como 'os gregos’ poderia sugerir” (Herzfeld, 2001: 19). Por outro lado, seu estudo não deve recair na "etnografia de aldeia", uma mélange de esboços etnográficos sem ligação entre si. Herzfeld mantém o projeto etnográfico, "mas trata-se de uma etnografia de conceitos e identidades em vez de uma etnografia de instituições". O seu foco incide nas "construções discursivas que têm materializado tanto a identidade grega moderna como a antropologia teórica” (id.; ib.).

Essas reflexões do autor, alocadas para esta pesquisa, podem dar bons rendimentos. Quando se toma como objeto de estudo a temática da identidade em uma população tão pluralmente constituída como a dos descendentes de japoneses no Brasil, o receio em imprimirlhes a rubrica "totalizante" "os nikkeis" ainda persiste. Cabe observar, entretanto, que o propósito aqui também não foi o de produzir uma etnografia de "grupos", ou de "aldeia", como dekasseguis, descendentes de origem okinawana ou membros de associações culturais nipônicas. Inspirando-se na obra de Herzfeld, o objetivo consistiu em realizar uma "etnografia de conceitos e identidades".

Assim como alguns gregos, alguns nikkeis também oscilam entre a identidade "brasileira" e a "japonesa". Aqui, também o discurso oficial nacional confere-lhes a marca de "verdadeiros brasileiros", "melhores brasileiros", "autênticos brasileiros", ao mesmo tempo em que um imaginário persiste ao atribuir-lhes certos qualificativos que os diferenciam. Interessa pontuar que nas esferas privadas da vida cotidiana, na "intimidade cultural”, os sujeitos frequentemente agenciam valores, essencialismos, auto-estereótipos que contradizem à retórica da unidade nacional. Como afirma Herzfeld, "ordinary people reify, all time, everywhere" (Herzfeld, 2004: 25).

O depoimento da paulistana Clarice Nakashima, nissei, 39 anos, é bastante rico e elucidativo quando tangencia essa tensão identitária de que fala Herzfeld. Filha de mãe nissei e de pai issei que imigrou depois da Segunda Guerra, ${ }^{285}$ Clarice teve uma educação rígida. O pai não tinha o costume de frequentar os kai kans, mas exigia que os filhos fossem fluentes em

\footnotetext{
${ }^{285}$ O pai de Clarice, engenheiro agrimensor, fazia parte da leva de imigrantes japoneses que aqui chegaram depois da Guerra não para trabalhar na lavoura e sim exercer funções técnicas.
} 
japonês, só tirasssem notas $\operatorname{altas}^{286}$ e que se relacionassem com pessoas de origem japonesa, o que segundo ela:

\begin{abstract}
"me criou uma aversão muito grande com a parte dessa identidade japonesa. Por outro lado, a gente passava na escola por aquela coisa de chamarem a gente de 'olho puxado', 'ô, japonesa'. E eu não conseguia ter essa identidade com os brasileiros direito, porque sempre minha mãe distinguia as amizades, as pessoas, a cultura. E eu sentia mesmo uma diferença. Mas ao mesmo tempo, eu não me sentia brasileira de tudo... Eu ficava no meio disso tudo. Eu não conseguia entender essa parte da identidade e sempre acabei fugindo disso. Sempre acabei tendo ojeriza a japoneses, à língua japonesa, não às pessoas, mas à língua japonesa. De certa forma, eu vivia assim entre dois mundos. Dentro do lar, da esfera doméstica, aceitando a cultura e até o jeito do japonês pensar, de meu pai ser o patriarca da família, de instituir algumas regras, que eu fazia questão ao mesmo tempo de transgredir e obedecer. É meio confuso isso. E só depois que eu fiquei adulta, que eu fui ao Japão como dekassegui em 1989 é que entendi várias coisas do meu 'próprio processo de eu'. Aí consegui entender um pouco essa questão da identidade".
\end{abstract}

Assim como a entrevistada paulistana e também nissei Luísa Sato, Clarice conta que sempre foi muito revoltada durante a adolescência devido à "organização de pensamento japonês" de seus pais. Afirmava que sempre tirava notas baixas, ficava de castigo e apanhava por causa disso, não gostava das "panelinhas" de japoneses, andava com a "turma marginal" da escola, era enfim uma espécie de "ovelha negra" da família. Segundo ela, sua irmã a "dedurava" para a mãe: "Minha mãe achava ruim, e eu apanhava por causa disso! Que absurdo, apanhar da mãe, porque andava com gaijins!" [risos]. Clarice vivia "entre dois mundos" - "Na minha cabeça de criança havia dois mundos. Não misturava os conteúdos, nem japonês, nem português. Não misturava os amigos. Eram sociedades totalmente diferentes. $\mathrm{O}$ jeito de se comportar era diferente". Essa espécie de conflito de identidade, como já discutido, foi mais intensamente vivido pela segunda geração de descendentes.

Clarice dissera que o pai, na exigência de que os filhos fossem "japoneses", tinha uma visão romanceada sobre o país de origem, ele "havia congelado um Japão feudal na cabeça". Quando Clarice sai do Brasil para lá trabalhar como dekassegui por um período de seis anos, afirma que essa experiência foi fundamental para que ela passasse a entender certas atitudes e posturas do pai, por exemplo, nos momentos de manifestação de afeto:

"Sempre fui muito comunicativa e expressiva com meus amigos. ${ }^{287}$ Eu reparava que os pais deles eram diferentes, eram mais liberais, mais abertos, expressavam-se pegando, tendo

\footnotetext{
${ }^{286}$ De acordo com Clarice, o pai amenizou a cobrança de notas altas depois que sua irmã mais nova passou a ter problemas na escola por causa dessa "pressão psicológica".

${ }^{287}$ Clarice é de fato uma pessoa bastante comunicativa. Depois que voltou do Japão, formou-se em produção editorial e atualmente trabalha na área de gestão educacional de uma faculdade em São Paulo. Nos conhecemos quando cursávamos uma disciplina na Escola de Comunicações e Artes da USP. Ela foi bastante receptiva e atenciosa. Conversamos durante horas depois do término de uma das aulas.
} 
contato físico, que é uma coisa que o japonês não tem. Coisas como falar 'eu te amo' dentro da família, meu pai não falava isso. Hoje com meu filho eu tenho uma relação super aberta. Falo 'eu te amo' toda hora, dou beijo, que é uma coisa que não existia nessa relação pai e filho na nossa geração, pelo menos na minha geração. Acho o japonês um pouco travado nisso. Essas coisas eu fui entender quando fui morar no Japão. É um sistema, um código nãoverbal que você... O amor é demonstrado de uma outra forma. Então, o silêncio às vezes fala mais do que você preencher esse silêncio com um monte de palavras. E algumas atitudes do meu pai, eu fui entender só lá. O povo japonês tem uns códigos, um jeito de mostrar amor que você não reconhece como amor, entendeu?[...] Quando eu era pequena, meu pai chegava em casa e a gente estava sentado assistindo televisão. Todo dia ele perguntava: 'Tudo bem?'. E batia na cabeça da gente! Eu pensava: 'mas que coisa! Fica dando croque na cabeça!?'. E depois eu entendi que era o jeito dele de demonstrar amor, de perguntar como foi na escola. Amor para mim é abraçar, beijar, como a gente via com os nossos amigos. E aí, depois no Japão, não é assim. Os códigos são diferentes, né?".

O conflito existia porque ela percebia que seu pai era muito mais autoritário do que os pais de seus amigos, que eram netos de imigrantes japoneses. Ele exigia coisas que os pais destes já não exigiam mais, como o aprendizado da língua japonesa. Mas depois que Clarice viajou ao Japão, passou a entender as dificuldades enfrentadas pelo pai quando imigrou sozinho para o Brasil - "Como ele não teve apoio familiar, ele foi buscar os valores mais tradicionais para ser forte, num mundo difícil, sozinho. Talvez por isso ele tenha sido tão rigoroso". ${ }^{288}$ Clarice afirma que hoje dá valor para a educação que recebeu do pai e se vê, de forma menos radical, reproduzindo esse modelo que ela tanto criticara, com o filho de $7 \operatorname{anos}^{289}$ :

"De qualquer forma, hoje eu agradeço por meu pai ter sido assim, porque quando eu me sinto perdida na educação do meu filho... Eu vejo como é diferente da educação do meu marido, que é descendente de japoneses, mas que não teve uma educação mais rigorosa. Eu consigo ser até mais tradicional do que ele em algumas coisas com meu filho. E eu vejo isso no dia a dia. Falo isso para o meu filho. Quando a gente era pequeno, se a gente tirasse uma nota D ou E, apanhava em casa. Você tremia de medo de falar para o pai que tirou nota baixa". 290

Hoje ela deseja que o filho assimile referências e valores que antes julgava antiquados, e se vê, em suas palavras, "repetindo algumas coisas [que] são latentes dentro de mim, e eu

\footnotetext{
${ }^{288}$ Diferentemente das levas imigratórias antes da Segunda Guerra, uma das características da imigração de japoneses nas décadas de 1960 e 1970 para o Brasil foi a de se constituir em trabalhadores, cuja mão-de-obra era qualificada, e que não estavam inseridos em arranjos familiares previamente formados.

${ }^{289}$ A criança estuda em um colégio de "orientação educacional japonesa", nas palavras de Clarice, e está aprendendo o nihongo. O colégio foi fundado por imigrantes japoneses, mas é aberto e frequentado por muitos alunos nãonikkeis. De acordo com Clarice, o filho está tendo a mesma educação que ela teve. Conta que certa vez, o menino fez uma oração antes da refeição que era a mesma que ela aprendera na escola. Disse que ficou maravilhada, porque isso trouxe uma série de lembranças, de memórias. Ficara contente e afirma ter se surpreendido com seu contentamento e satisfação - "Eu fiquei tão gratificada de saber que ele estava tendo uma educação como a minha!". Quando ela era estudante, não conseguia entender por que o pai a colocara em uma escola japonesa, mas agora compreendia a importância.

${ }^{290}$ Ela conta que quando o filho apareceu com uma nota 6,4, brigou com o menino. Exigira que a nota deveria ser maior que 8 - "menos do que 8 não é nota". Outro dia, a criança disse que queria dar um presente para a mãe: era a nota 10 que tinha tirado. Clarice disse que não se arrependeu pela repreensão, pois agora o filho só tirava notas altas.
} 
acabo pegando algum tipo de... estrutura de pensamento dos meus pais, até mesmo preconceitos. Quando a gente não sabe onde se segurar, a gente acaba se segurando naquilo que nos foi passado quando criança". Quando questiono quais preconceitos ela acha que carrega, Clarice responde, um pouco desconfortavelmente:

\begin{abstract}
"Ah, eu falo para o meu filho, quer dizer, eu não falo, mas eu penso... Ainda bem que eu não falo! Mas eu penso sim que eu gostaria que ele tivesse mais amigos 'japoneses'. Eu discordo, mas é uma coisa que eu passo para ele. Eu não consigo, entendeu? Mas é que eu acho que vai ser mais fácil para ele. Talvez o que a gente chama de preconceito, seja uma outra coisa que a gente não sabe dar o nome. É que eu fico pensando assim, 'Nossa, vai ser muito mais fácil se for...'. Aí eu estaria mais confortável, porque eu sei como a mãe dele (do amigo) é, como o pai dele é, entendeu? É muito mais fácil do que ficar pensando, 'Vai que a mãe dele é uma pessoa hippie, que é 'super pra frente?'... Para mim, eu acho ótimo. Se fosse com relação a mim, eu teria uma experiência diferente. Mas, por ele, não... eu tenho medo. É uma coisa de mãe, uma coisa de querer... Embora, eu saiba que a melhor coisa é você deixar a pessoa viver e ela passar por aquilo e não querer que ela vivencie o que você já viveu. Só que a gente não consegue, porque o amor da gente é muito maior, assim, o amor de proteção é muito maior. Eu acho que isso é um erro de todo pai, não sei. É isso que hoje eu fico perguntando com relação ao meu pai e minha mãe, entendeu? Tudo bem, eu sei que ele é preconceituoso, porque ele queria que a gente casasse com 'japonês'. Eu também sou, porque eu também fico pensando que eu queria que meu filho casasse com 'japonesa'. Eu não sei te posicionar sobre isso, porque eu estou aprendendo agora com o meu filho".
\end{abstract}

Clarice narra, então, um episódio que ela vivenciara e que lhe provocou grandes dúvidas e questionamentos. Chama a atenção como ela detalha as sensações, os diferentes pensamentos que lhe ocorreram no momento em que a cena transcorreu. Como um filme, sua narração é tão viva e clara que optei por transcrevê-la integralmente. Além disso, o assunto, bastante delicado, reconhecido pela própria Clarice, merece que seja abordado também de forma cuidadosa. Pausas, reflexões, dúvidas são aqui apresentadas sem interrupções no desafio de reproduzir o mais fielmente possível a história e as emoções suscitadas em sua pessoa:

"Eu nunca vou buscar meu filho na escola. Mas esse ano, estou tirando um dia da semana para ir buscá-lo. Em uma dessas vezes que eu fui... Meu filho é muito comunicativo e é muito querido pelos amiguinhos. O melhor amigo dele é um menino loiro e outro é negro. Eu não lembro os nomes, porque quase não me encontro com os pais. Eu não sei se eu estou ficando quadrada... Mas para mim, quando você quer conquistar uma pessoa, primeiro você vem, conhece ela... você não pode chegar muito de supetão. Isso assusta um pouco, eu acho. E eu nunca tinha visto a mãe desse menino. Eu já tinha visto uma vez, de vista, porque assim, uma negra em um monte de japonês, você vê, você distingue. Mas eu nunca tinha conversado com ela. Aí ela se apresentou, falou que meu filho era amigo do filho dela e tal. Tudo bem, normal. Mas eu ainda não me sinto íntima da pessoa. Só conhecia, devagarzinho é que você vai conquistando... no dia a dia. E daí ela começou a falar que o filho dela gostava muito do meu filho, que queria que meu filho fosse pousar na casa dela. E meu filho, que é muito sonsinho, ficou falando, 'Ai, mãe deixa!'. 'Não, filho, a gente tem que ver isso direitinho'. 'Mas mãe dá o seu telefone para ela!'. Nossa, eu achei o meu filho tão impertinente aquela hora! Mas enfim, eu conversei, dei uma desculpa. Talvez ela até tenha percebido que eu fiquei desconcertada. Mas eu fui falar com o meu marido, falei para ele assim, 'Será que eu fiquei 
desconcertada, teria tido a mesma reação se ela não fosse uma negra e fosse uma japonesa?'. Se bem que eu achei muito... não é abusado a palavra. Eu fiquei um pouco incomodada, mas por que uma pessoa quer tanto agradar a outra, entendeu? Talvez seja porque ela é uma negra no meio de tanto 'japonês' e ela quer que o filho dela estabeleça contatos. Eu até entendo isso. Mas eu acho que brasileiro é muito afoito nessa coisa de chegar e já ir conquistando, sabe? Vai de pouquinho, vê a pessoa, você tem modos de chegar, entendeu? Que são essas coisas não-verbais que eu acho que japonês já entende, você entendeu? E eu fiquei muito perturbada e chateada, porque eu fiquei me perguntando: 'Será que era porque ela era negra?' ou 'por que ela teve essa atitude?'. Porque ela me assustou, eu não gostei desse tipo de abordagem. No primeiro dia, você acha que eu ia confiar meu filho para pousar na casa dela? E eu não gostei do jeito que ela falou, 'Ah, na minha casa tem um monte de brinquedo, um monte de coisa!'. Quer dizer, para mim isso não tem valor, entendeu? Parece que ela estava querendo dizer assim, 'Eu sou de uma família abastada, eu tenho muitas coisas tecnológicas na minha casa, então você pode deixar o seu filho ali'. Isso me ofendeu, mais do que agradou. Só tinha um amiguinho da escola que eu deixei o meu filho ir brincar um dia! Mas eu fui lá à tarde e busquei ele. Mas para dormir na casa de estranho, eu tomo certo cuidado, não é porque eu desconfio da pessoa, mas é para o meu filho não ser um impertinente e ficar enchendo o saco da pessoa. Porque a mãe tem que se tocar, criança não se toca. Mas ela era japonesa e eu deixei. E eu gostava da amizade, mas não deixei ele pousar entendeu? Ele não vinha na minha casa também. Mas conheci a mãe dele de pouquinho, a gente se conheceu em uma reunião, foi, conversou e tal, foi uma coisa normal. Com essa mulher, eu achei uma coisa meio que agressiva. Eu fiquei encucada comigo mesma, pensando, 'Nossa, eu critiquei tanto os meus pais e estou pior, eu estou igual!?'. Eu fiquei me perguntando, sabe? Mas eu não sei, porque isso ainda está acontecendo. Eu estou vendo ainda minhas reações'.

No depoimento de Clarice e em quase toda a conversa que travamos juntas, foi claro o seu desconforto e aflição em estar reproduzindo no tempo presente, com a educação do filho, tudo aquilo que ela condenara na educação recebida de seus pais: o preconceito contra os "gaijins", o preconceito racial, o desejo de que o filho se relacione com pessoas de origem japonesa. Considera sua postura menos radical, se comparada com a que seus pais tiveram, contudo as preocupações que a cercam não diferem muito da deles. Ela não sabe dizer se a sua reação de condenação à abordagem da mãe do amigo de seu filho aconteceu devido à sua atitude simplesmente ou à sua cor. Talvez ela não tivesse ficado tão desconcertada se o convite para que o filho dormisse na casa do amigo partisse de uma "japonesa".

Uma das coisas que mais incomodou Clarice foi a ênfase que a mãe do menino deu aos brinquedos e bens materiais que havia em sua casa. Não seria possível pensar que essa mãe, mulher, negra, no meio de vários "japoneses", não estivesse de uma forma lutando contra os preconceitos que associam a cor à classe social? Partindo da pré-concepção de que Clarice, descendente de japoneses, classe média, possivelmente com acesso a bens eletrônicos; essa mãe ao afirmar o pertencimento a uma "classe abastada", talvez estivesse tentando tranquilizá-la, na tentativa de quebrar preconceitos - algo como, "Nós somos negros, mas seu filho terá conforto, diversão e segurança em nossa casa". Não teria ela enxergado o preconceito nos olhos de Clarice? Estaria essa mãe combatendo pré-conceitos com relação aos negros, partindo de pré- 
conceitos com relação aos nikkeis? Essa questão do preconceito foi reconhecida por Clarice em outro momento de nossa conversa. Perguntara a ela se o imaginário positivo sobre os descendentes já havia lhe trazido benefícios ou algum tratamento diferenciado:

"Eu acho que sim. Bom, não sei se isso é benefício. Talvez seja mais cobrança, do que benefício. Mas você ser 'japonesa' e as pessoas acharem que você é boa aluna, principalmente os professores. Não sei se isso é bom, porque eles já cobram antes o seu resultado. Mas eu lembro que quando eu trabalhava em uma agência de publicidade, éramos eu, uma moça loira e tinha um coordenador que era negro. A gente ia muito em um café que tinha lá perto e ele falava assim e fazia questão de reforçar essa ideia... Porque ele era tão humilde e tão legal que as meninas não sabiam que ele era o coordenador de lá. E depois que elas descobriram, ele falou, 'Não, eu sou coordenador. Tá vendo? Sou coordenador de uma 'japonesa' e de uma loira!'. Mas quando ele falou japonesa, eu entendi o que ele queria dizer. Que ele era negro, $e$ que apesar de ser negro, tinha uma japonesa subordinada a ele. Para mim isso não interferiu. Toda vez que eu ia lá, falava bem dele e tal. Mas eu senti que ele não queria dizer que eu era menos, mas reforçando a ideia... acho que você entendeu o que eu quis dizer, né? Isso quer dizer que apesar de ser negro, ele tinha conseguido conquistar alguma coisa, enfim, até de uma japonesa. Então, tem isso. Mesmo que inconscientemente, as pessoas tem essa ideia, essa visão".

Imagens, discursos, representações, preconceitos que ainda se fazem sentir e que rebatem a experiência de vida dos diferentes sujeitos, de diferentes formas. Estratégias são mobilizadas no embate com a alteridade. No país em que a cor varia de acordo com a situação sócioeconômica e status social dos indivíduos, um coordenador de uma agência de publicidade, negro, chefe de uma loira e de uma "japonesa", ocupava uma posição que causara estranheza e surpresa nas pessoas.

Outro ponto importante reside na forma como Clarice marca as diferenças entre "japoneses" e "brasileiros": a partir do compartilhamento de códigos. Os primeiros supostamente deteriam ou estariam a par de um repertório comum de "coisas não-verbais", mais imediatamente compreensível ou perceptível entre eles. Essa questão dos “códigos" por ela mencionada aparece em vários momentos de seu testemunho. Clarice, assim como muitos dekasseguis, conheceu o marido no Japão. A partir do relacionamento que teve com um descendente de italianos na juventude, acha a convivência com um nikkei mais fácil, uma vez que este "compartilha dos mesmos códigos", de "regras não-ditas, não-verbais", "sabe de sua história de vida" e "entende coisas que ela não precisa ficar explicando". 291

Tira essa conclusão baseada também nos problemas existentes no casamento do irmão com uma "brasileira": "Eu vejo o tanto de sofrimento que existe ali e penso, 'Poxa, não quero

\footnotetext{
${ }^{291}$ O marido, "apesar de ser 'japonês' (descendente)", tinha uma educação que ela não aprovava, por isso foi um longo caminho até os dois se acertarem. Enfatiza, por isso, que "não foi por que meu marido era japonês que eu comecei a namorar, eu tive afinidade". "Mas a gente se completava. Ele não me deixava ser tão quadrada e eu não o deixava ser tão abrasileirado".
} 
que meu filho passe por isso'. Então, fico pensando que seria mais fácil se ele se casasse com uma 'japonesa'. De acordo com Clarice, sua cunhada não conseguia entender que "brasileiro casa com a pessoa, japonês com a família". Houve preconceito por parte da sua família, sobretudo da mãe, com o casamento, mas quando esta viajou para o Japão, sofreu discriminação lá por ser "gaijin". A mãe escreveu uma carta tentando se reconciliar com a nora, dizendo que sabia agora o que era se sentir estrangeira em um lugar. Porém, mais tarde, os conflitos voltaram. Com base nessas experiências, Clarice declara:

\begin{abstract}
"Eu não tenho preconceito, embora reconheça que é muito mais fácil lidar, digo, ser casada com 'japonês', porque assim, até você lidar com amigo, você não lida intimamente com ele e tem superfícies que você não mexe, você o respeita como ser humano. Agora quando você é casada, a coisa é difícil. Então, aí que fui entender. Eu acho que se a gente (ela e os irmãos) não tivesse ido para o Japão... Porque eu queria namorar, eu namorei 'brasileiros' e eu não queria casar com 'japonês' de jeito nenhum!”. [...]

"As relações estão mudando, os japoneses estão sendo vistos de outra forma. Mas não sei... Ainda continuo a pensar que seria melhor ele se casar com uma 'japonesa' [risos]. Eu fico pensando nisso. Não sei em que códigos dizer isso para você. Eu fico pensando assim, 'Nossa, se já é tão difícil eu e meu marido. A gente se dá bem, tendo vivido na mesma cultura e como é difícil! É uma conquista de todo o dia'. Isso é uma coisa legal, isso que é viver. Imagina quando se é muito diferente? Talvez o diferente seja o legal da vida. Eu achava que o diferente era o legal da vida, mas cansou. Tive um relacionamento com um italiano, ah era muito cansativo! Tudo você tinha que ficar explicando, sabe?”. [...]

"Agora não sei se realmente existe um preconceito por trás, entendeu? Não sei... Porque tem uma coisa de identidade, você ter um netinho que parece com você... Um netinho que não se parece com você eu não sei como é isso! [risos]. Entendeu? Não sei... Então, é meio estranho isso. Eu mesma não entendo. É uma coisa que a gente vai ter que descobrir". [...]

"Não quer dizer que eu goste disso, quando era pequena não gostava. Mas eu fico pensando... Se eu fosse italiana, também não iria querer? Então, não sei se é por ser nikkei. Não sei se é pelo fato de ser nikkei, entendeu? Eu acho que se eu fosse italiana, gostaria que ele namorasse italiana. Não é pela especificidade da 'raça', da etnia".
\end{abstract}

Clarice alega no início de sua fala que não possui preconceito contra "brasileiros". Ajudava a esconder o namoro de uma das irmãs com um, pois a mãe não aprovava o relacionamento. Diz que se não tivesse tido a experiência de trabalho no Japão, provavelmente estaria casada com um não-nikkei: “Porque eu queria namorar, eu namorei 'brasileiros' e eu não queria casar com 'japonês' de jeito nenhum!'”. Agora busca entender se o desejo de que o filho se case com uma "japonesa" configura preconceito contra os "brasileiros", ou seja, "uma outra coisa que a gente não sabe dar o nome". Dúvida que como vimos também afligia a sansei, que vivia em "panelinhas" de nikkeis, Amanda Shimizu. Ambas disseram ser a afinidade e talvez o preconceito os elementos que atuaram na escolha dos companheiros "japoneses".

Não é fácil admiti-lo. No país da "harmonia racial" e da "boa convivência entre os povos" ele ou é negado ou considerado mais brando. Como afirma Lilia Schwarcz, pertence à 
esfera do privado, consistindo em uma prática, cuja existência é reconhecida, porém sempre é atribuída ao outro, a um colega, a um amigo ou parente. Com relação ao preconceito de cor contra negros no Brasil, a autora menciona dados de uma pesquisa da Folha de São Paulo, do ano de 1995, que divulgara que apesar de $89 \%$ dos brasileiros afirmarem que ele existe, só 10\% admitem tê-lo, ainda que $87 \%$ revelem algum preconceito ao concordar com ditos e frases de conteúdo racista. "Todo brasileiro parece se sentir, portanto, como uma ilha de democracia racial, cercado de racistas por todos os lados", conclui a autora (Schwarcz, 1998: 180).

Talvez essa lógica do racismo à brasileira, que não se afirma publicamente, mas é enredado na esfera íntima, se estenda também aos nikkeis. Como vimos, muitos entrevistados para essa pesquisa tiveram dúvidas quanto às possibilidades de existência de preconceito que envolvem o grupo: tanto o direcionado contra os descendentes, como o produzido pelos mesmos. Vale mencionar novamente os dados da pesquisa realizada pela Folha de São Paulo, em 2008, a respeito do centenário da imigração japonesa no Brasil ${ }^{292}$, que revelaram que "após cem anos de convivência, 44\% dos japoneses e descendentes que moram em São Paulo afirmam que há preconceito de nikkeis contra brasileiros" e 36\% afirmam que existe o preconceito inverso, ou seja, o dos brasileiros contra os nikkeis (grifos meus). Números relativamente altos se pensarmos que os primeiros imigrantes japoneses chegaram há mais de cem anos no Brasil, país que já conta inclusive com representantes da sexta geração de descendentes, rokussei. ${ }^{293}$

Sobre o segundo tipo de preconceito, o contra os nikkeis, vimos no capítulo 2 que ele se revela principalmente nas "piadas" com relação ao físico do "japonês". As dúvidas dos interlocutores giravam em torno de pensar se essa atitude configurava preconceito ou discriminação. As respostas foram variadas, mas para muitos deles, as "brincadeiras", embora causem revolta ou incômodo, "não chegam" a configurar uma atitude preconceituosa. Já o preconceito de nikkeis contra "brasileiros", apesar de não declarado, apareceu frequentemente nas narrativas de alguns depoentes nas maneiras de marcar a diferença, num tom de superioridade ao que seja considerado "brasileiro", como o tal do "jeitinho", o comportamento, as atitudes. Yumi Kawamura, nissei, que diz se encaixar "100\% no perfil de nihonjin", o admite, resignadamente:

“Ah, a gente tem, né? Infelizmente... Eu vou falar a verdade, eu tenho. Eu tenho aquilo de falar, 'tem que ser gaijin mesmo!'. O pior é que falo. Porque é diferente, né Camila? Por mais que a gente fale que não, é diferente. Coisas assim que eles fazem, que eu não teria coragem de fazer. São atitudes, comportamentos... é diferente. Aí a gente acaba falando, 'tinha que ser

\footnotetext{
${ }^{292}$ Folha de São Paulo, "100 anos de imigração japonesa: Retrato dos nossos japoneses”, 18/06/2008.

${ }^{293}$ Conforme matéria da Folha de São Paulo, "Menino inicia 6a . geração de descendentes de japoneses", $09 / 02 / 2008$.
} 
gaijin, mesmo!', sabe? Eu não queria ser assim! Mas... acaba. Não sei por que a gente tem ainda. Ainda existe... [tom de resignação]. Acha que tudo o que a gente faz é melhor, sabe? E principalmente...ai, acho que no comportamento, né? 'Brasileiro' é mais... Ah, no modo de vestir, gosta de dançar, de beber. É uma coisa assim que eu não... Aí quando acontece alguma coisa, a gente fala, 'ah, mas tem que ser gaijin'. Infelizmente... Mas hoje em dia, a gente não deveria fazer isso, porque a gente vive aqui no Brasil... Mas é por isso que o 'nihonjin' ainda é bem visto, porque o 'nihonjin' ainda manteve tudo de certo que aprendeu, não é? Se a gente danar a beber e a fazer tudo que eles aprontam, eu acho que a credibilidade do 'nihonjin' vai embora. É a mesma coisa com o preto. Quando você vê, diz 'vixi, cuidado, vai roubar'. Graças a Deus que eu não tenho tanto assim desse jeito, esse preconceito. Mas a maioria, se tiver um nihonjin e um preto e tiver um assalto ali, o policial vem no preto, não vai no nihonjin. Você pode apostar. E a porcentagem de ser o japonês é uma em... bem menor. Infelizmente, não é? Existe isso... Mas japonês é bem visto, porque a gente segue as tradições. Por mais que você fale que não, uma coisinha ainda você... Porque tem descendente que é totalmente rebelde, que não quer ser 'nihonjin' de jeito nenhum. 'Eu não quero comer nem a comida, não quero vestir as roupas, quero ser totalmente brasileiro, não sei o quê mais'. Mas no fundinho tem, puxa alguma coisa".

Yumi narra aqui como ela vê a diferença entre nihonjins e gaijins e como o preconceito atua no julgamento das pessoas a partir de estereótipos e imagens positivas e negativas. É esse preconceito que poderia mover a atitude de um policial diante de dois suspeitos de um crime, um "japonês" e um negro, e é esse mesmo preconceito, admitido por ela, que a faz pensar que a chance do culpado ser o "japonês" é "uma em...", um milhão talvez? É importante lembrar que a maioria dos entrevistados utilizou a discriminação sofrida pelos negros no Brasil como um parâmetro para a avaliação do preconceito contra nikkeis, concluindo que os primeiros efetivamente o sofrem e os segundos não, devido justamente ao imaginário positivo que lhe é atribuído. Em outras palavras, o preconceito de cor foi reconhecido, mas pouco admitido entre os interlocutores. A frase mobilizada por Yumi, "tinha que ser gaijin mesmo!", no julgamento de ações e atitudes que ela desaprova, tem o efeito semelhante para a tão mencionada frase ouvida pelos sujeitos dessa pesquisa, "tinha que ser japonês mesmo!”. Ambas são articuladas em momentos em que estereótipos, discursos e preconceitos vêem à tona na apreciação da atuação do "outro".

A astorguense Yumi Kawamura e a paulistana Clarice Nakashima, ambas de 39 anos, são descendentes de segunda geração, filhas de japoneses. Yumi, por exemplo, assim como Clarice teve uma educação muito rígida, mas hoje agradece aos pais:

“A minha família pelo lado do meu pai não tem muita mistura. Então, meu pai sempre foi muito rígido. Hoje até que nem tanto, mas na época da minha batchan, mãe dele, meu Deus do céu, era o fim do mundo casar com gaijin! Hoje meu pai já está com a cabeça mais aberta, mas assim mesmo ele educou e criou a gente num sistema bem nihonjin. E hoje eu quero... $\mathrm{Na}$ época, eu às vezes até criticava, mas hoje eu acho que foi bom. Hoje eu agradeço muito aos meus pais e é o que eu pretendo... não assim tanto, porque hoje não dá para criar os filhos com a rigidez que eu fui criada". 
A experiência migratória dos pais dos sujeitos dessa pesquisa no Brasil e a relação deles com o universo cultural japonês e brasileiro podem dizer muito sobre como os filhos reagem ou se apegam a essencializações, preconceitos. $\mathrm{Na}$ análise de alguns romances que buscavam resgatar a memória da imigração japonesa no Brasil, Célia Sakurai, mostra como muitos deles retratavam o choque dos imigrantes com a chegada no Brasil e com a precariedade das condições de trabalho, higiene, moradia e alimentação. Não obstante oriundas de pequenas cidades no Japão, essas pessoas estavam acostumadas com alguns confortos da vida moderna. $\mathrm{E}$ quando desembarcavam no país, o chão de terra batido, a água de poço, a matança dos porcos reforçavam a ideia de que tinham chegado ao "fim do mundo". ${ }^{294}$ Assim a possibilidade de que os filhos se tornassem "caboclos brasileiros", gaijins, os atemorizava. Nessa época, estavam motivados em retornar ao Japão, por isso incentivavam os filhos a manterem costumes japoneses, frequentemente incutindo a ideia de superioridade racial defendida pelo regime imperialista (Sakurai, 1993: 65).

Já o pai de Clarice, que imigrou para o Brasil depois da Guerra, tinha uma imagem idealizada do Japão e um forte apego a valores e costumes japoneses, explicada talvez, segundo a filha, pela condição de ter imigrado sozinho para o país. Vimos também com o depoimento de Pedro Higa, como esse apego dos okinawanos e seus descendentes à sua "cultura" sofreu variações conforme determinantes históricas e conjunturais.

Os testemunhos de Clarice e Yumi, com suas dúvidas e aflições, representam essa dimensão que Herzfeld denomina de "intimidade cultural", e que consiste naquela esfera que o antropólogo precisa adentrar com cuidado, pois se refere àqueles "aspectos da identidade cultural que são considerados fontes de embaraço externo, e que, no entanto, oferece aos membros a garantia de uma socialidade comum" (Herzfeld, 2004: 3). É nesse momento que se situa a tarefa da "poética social", a análise dos usos dos estereótipos nas interações cotidianas, na “performance do eu”. Poética, ressalta o autor, que não se refere à versão romântica da poesia, mas que deriva do verbo grego "ação" (poei $\delta$ ) (id.; ib.:142)

Herzfeld objetiva desestabilizar a concepção dominante na Antropologia que se contenta em simplesmente rejeitar os binarismos e essencialismos. Ao reduzi-los a meras ferramentas teóricas, os críticos ignoram a evidência de que os mesmos constituem-se em traços culturais forjadores das ideologias dos regimes políticos ocidentais. O autor também recusa a "necessidade classificatória do essencialismo para o problema da análise e descrição", mas

\footnotetext{
${ }^{294}$ Os dados do censo da colônia de 1958 apontavam que apenas 59,8\% dos imigrantes eram agricultores no Japão e 78,6\% tinham o curso primário completo (CRCJ, 1964 apud Sakurai, 1993).
} 
reconhece que os indivíduos estão submetidos o tempo todo a escolhas binárias, o que o leva a postular o conceito de disemia, que corresponde à "tensão codificada ou formal entre a autoapresentação oficial e a que se dá na privacidade da introspecção coletiva" (Herzfeld, 2004: 14). O antropólogo define sua proposta como uma "recusa de essencializar o essencialismo" (id.; ib.: 218).

Novamente a questão de como podemos definir os limites do que é construção identitária e do que é preconceito se coloca. Estariam ambos atrelados um ao outro? Pudemos observar ao longo dos capítulos como os sujeitos mobilizam estereótipos e essencializações na elaboração das fronteiras identitárias. Como nos posicionar frente a isso? Encarando-as como formas de preconceito meramente? Herzfeld defende uma abordagem do estereótipo não como simples formas de pré-conceitos e reduções simplistas, mas como instrumentos destinados a disfarçar interesses ou estratégias. Em suas palavras, "le recours au stéréotypes est inséparable des situations où des identités sont en jeu" ${ }^{295}$ (Herzfeld, 1992: 67). Através de sua pesquisa etnográfica na Grécia, com exemplos sobre o uso político dos estereótipos nas relações burocráticas e nos jogos de poder, o autor mostra que os estereótipos permitem aos sujeitos desenvolver estratégias de auto-justificação ou auto-identificação. Sua proposta não implica na ausência de uma leitura crítica sobre o estereótipo. Muito pelo contrário:

Tout stéréotype est par définition réducteur. Il souligne toujours l'absence d' une proprieté supposée désirable. Il constitue une arme de pouvoir. Il fait quelque chose, il prive activement l' 'autre' d'un certain attribut sans que celui qui en use se reconaisse coupable: l' attribut en question est à sés yeux purement symbolique, c'est 'simplement' une façon de parler et un 'mot n'a jamais tué personne.'.

O estereótipo, portanto não tem uma mera existência simbólica e discursiva. Na leitura que Herzfeld faz de J. L. Austin, conclui que este gera efeitos e representa uma maneira cruel de "fazer coisas com as palavras, e nesse sentido tem uma existência material" (Herzfeld, 1992: 68). O que Herzfeld busca mostrar é que os estereótipos foram concebidos durante muito tempo pelo pensamento antropológico como pré-conceitos ou meros processos "ordinários", comuns e integrantes ao nosso mundo. Além disso, a visão de que os antropólogos forjam caricaturas da realidade social e cultural é recusada pelos mesmos. Assim, a preocupação da disciplina em rejeitar toda e qualquer forma de preconceito e generalização obscurece revelar aqueles que

\footnotetext{
295 “O recurso ao estereótipo é inseparável das situações, as quais as identidades estão em jogo" (trad. minha).

296 “Todo estereótipo é por definição, redutor. Ele destaca sempre a ausência de uma propriedade supostamente desejável. Constitui uma arma de poder. Ele faz qualquer coisa, priva ativamente o 'outro' de certo atributo sem que aquele que o utiliza se reconhece culpado: o atributo em questão é aos seus olhos puramente simbólico, é 'simplesmente' uma maneira de falar e uma 'palavra jamais matou ninguém”' (trad. minha).
} 
sustentam a sua própria démarche. (id.; ib.). O autor atenta para a importância da investigação do estereótipo e das "generalizações culturais como táticas e estratégias da vida social”: "piadas étnicas", injúrias raciais, as maneiras de evitar ou tocar o "outro" são ações estruturadas em estereótipos (id.; ib: 73).

Nesse sentido, para Herzfeld, o uso dos mesmos nas interações cotidianas é uma prática que se encontra atrelada às estratégias de negociação de identidades. A recorrência aos essencialismos e generalizações na definição de si e de quebra, na definição do "outro", foi um recurso muito empregado pelos interlocutores dessa pesquisa. A discussão a respeito do conjunto de discursos positivos sobre os nikkeis revela sua importância, pois é a partir desse repertório de representações, leia-se estereótipos, que muitos sujeitos dessa pesquisa marcam suas posições de identificação e assim, continuam a nutri-lo nos momentos que o agenciam. Afinal, esse imaginário é criado e recriado sobre os descendentes, mas também por eles próprios.

\section{A VIAGEM- EXPERIÊNCIA}

Vimos como na vida adulta, Clarice Nakashima e Yumi Kawamura passaram a atribuir um novo valor à educação recebida dos pais, o que na infância e juventude fora motivo de discordância e revolta para elas. Afirmei anteriormente que a relação dos pais com o cabedal de valores e costumes japoneses pode dizer muito sobre a própria relação dos filhos com tais elementos. O afastamento ou aproximação com esse conjunto de "códigos", como no dizer de Clarice, é, portanto, inteiramente subjetivo. Contudo, ambas abordaram um ponto muito importante em suas trajetórias, decisivo, precisamente, para a nova postura e entendimento com relação a essas questões: a ida ao Japão.

Ao final da década de 1980, afetados pela crise econômica no Brasil e estimulados pela grande demanda de mão-de-obra nas indústrias proporcionada pelo boom econômico japonês, muitos brasileiros descendentes de japoneses se sentiram atraídos com as oportunidades financeiras que se apresentavam com a imigração para a terra natal de seus pais e avós. Esse movimento que perdura até os dias de hoje ficou popularizado como "fenômeno dekassegui", 297 Segundo dados do Ministério da Justiça do Japão, no ano de 2000, cerca de 265 mil brasileiros viviam no país, remetendo anualmente entre US\$1,5 e US\$ 2 bilhões para o Brasil (Beltrão \& Sugahara, 2006: 62).

\footnotetext{
${ }^{297}$ O termo dekassegui é formado pelos kanjis, deru (sair) e kassegu (trabalhar para ganhar a vida) e se refere a qualquer pessoa que sai da terra natal para trabalhar temporariamente em outra região. Inicialmente aplicado aos trabalhadores sazonais no Japão, é atualmente utilizado para designar os trabalhadores estrangeiros temporários que para lá imigram com o intuito de ganhar dinheiro.
} 
Assim que cheguei à casa de Yumi Kawamura, chamaram-me a atenção as dimensões do domicílio. Um sobrado amplo, com piscina e churrasqueira - "trabalharam muito tempo no Japão" - pensei, já sabendo que ela e o marido eram ex-dekasseguis. A suposição se confirmou em nossa conversa, Yumi aproveitou um período áureo da economia japonesa e da contratação de trabalhadores estrangeiros nas fábricas: a intenção inicial era permanecer por dois anos, ficou doze. Fazia o segundo ano do curso de Direito em Maringá, quando resolveu trancar a faculdade e se aventurar como trabalhadora temporária no Nihon com apenas 19 anos, junto com a amiga da irmã. Mas lá chegando, as duas se separaram e cada uma foi morar e trabalhar em locais diferentes. Em uma das visitas ao Brasil, conheceu seu marido, o qual ficou no Japão por 16 anos. Hoje ele se dedica à agricultura e ambos moram em Astorga. Yumi conta que o namoro se firmou no Japão e diz que só retornou, porque estava grávida. Hoje o filho do casal tem 4 anos.

Yumi nutre uma admiração profunda pelo Japão: “tudo é bom lá no Nihon". Vimos como sua fala foi pontuada durante várias passagens do trabalho a partir do estabelecimento de comparações entre Brasil e Japão e entre "brasileiros" e "nihonjins" (nikkeis). Mas Yumi admite que existe preconceito contra os descendentes de japoneses no país, sentido também, como vimos, pela mãe de Clarice e pela entrevistada Cíntia Teruya:

"Infelizmente... Gaijin é visto como dorobô (ladrão). Você vai nos depatos (lojas de departamento), eles (japoneses) têm medo, porque brasileiro rouba mesmo. Tem depato, shopping que às vezes a gente vai, eles anunciam no alto falante: 'Cuidado, tem brasileiro na loja'. Fazem principalmente na região de Aichi-Ken, que tem muito brasileiro. Eu morava perto de Tóquio, em Saitama. Nunca tinha visto isso. Aí fui visitar minha irmã no feriado. Quando você abre a boca, porque se você não abre, eles acham que você é nihonjin. Mas se você vai num grupo que começa a falar em português, eles já ficam olhando. Lá em AichiKen, eles anunciavam. Eles aprontam, né? Aí sujam todo mundo. [...] A gente é discriminado nessa parte. Eles tem essa imagem que no Brasil não tem nada. Você já deve ter ouvido, eles perguntam se no Brasil tem geladeira, se tem televisão, se tem máquina de lavar roupa. Eles acham que a gente vive na selva. A única coisa que passa do Brasil lá é o Rio de Janeiro, o carnaval, ou quando matou alguém, ou é assalto, samba ou Amazonas. Eles acham que o povo mora em cima da árvore, essas coisas, você acha? Acham mesmo. Isso já perguntaram para mim várias vezes, 'Ah, como é sua cidade? É cidade grande? Como que é? Mora na árvore? Tem talheres?'. Tudo isso eles perguntam. Pelo amor de Deus!’.

De acordo com o antropólogo Takeyuki Tsuda, o status positivo de "minoria étnica" que os nikkeis conservam no Brasil por serem percebidos culturalmente como "japoneses" muda de sinal quando estes imigram para o Japão, ou seja, torna-se negativo, já que ali são considerados culturalmente como "brasileiros" (Tsuda, 2003: 104). Por conta da ideologia de homogeneidade étnica que supõe que todos os japoneses pertencem à mesma "raça", uma concepção racializada de etnicidade e cultura vigora no Japão. Nesse sentido, para muitos 
informantes japoneses de Tsuda, havia uma expectativa de que "a cultura japonesa fosse transmitida através da socialização familiar para os descendentes de japoneses independentemente das fronteiras nacionais" (id.; ib.: 116-17). Quando entram em contato com os dekasseguis nikkeis, a falta de domínio do nihongo e o comportamento "brasileiro" desapontaram muitos deles. A partir da leitura de Goffman, Tsuda conclui: "In this manner, the loss of Japanese culture among the Japanese Brazilians becomes a stigma - an attribute that is discrediting because it is incongruous with social expectations" (id.; ib.).

$\mathrm{O}$ autor aponta, portanto a existência de duas formas de preconceito que atingem os nikkeis ali: o étnico e o de classe. Estes operam a partir das imagens negativas e depreciativas com relação ao comportamento "brasileiro" dos descendentes no primeiro caso e no segundo, com relação ao status ocupacional baixo dos mesmos, decorrente da condição de trabalhadores não-qualificados. Existe também uma percepção negativa e estigmatizada envolvendo a história de migração dos nikkeis que já surgira com a ida de seus pais e avós para o Brasil e se estendeu para os descendentes destes que fizeram o caminho inverso "retornando" para o Japão. Para muitos informantes japoneses de Tsuda, os migrantes são encarados como pessoas sem educação e que não tiveram habilidade para sobreviver economicamente em seu país de origem, necessitando "abandoná-lo" para escapar da pobreza (Tsuda, 2003: 106).

O depoimento de Yumi corrobora essa ideia de que os brasileiros e o Brasil são vistos a partir de imagens negativas, como "atrasados", "subdesenvolvidos", "low-culture" (Tsuda, 2003). É interessante notar que nesta fala específica, Yumi quando diz, "gaijin é visto como dorobô" está se referindo aos brasileiros nikkeis residentes no Japão. Mas vimos também como em várias passagens do texto, ela reporta-se ao termo "nihonjin" para designar os nikkeis no Brasil e "gaijin" para designar os brasileiros não-nikkeis. Categorias, por conseguinte, que têm seus sentidos e conteúdos alterados conforme a situação dada.

Adriana Capuano de Oliveira tece uma interessante reflexão de como certos valores, classificações e símbolos são ressignificados dependendo do contexto. O termo "gaijin" (estrangeiro), por exemplo, utilizado por vários nikkeis, sobretudo os de primeira e segunda geração, para definir o restante dos brasileiros não-descendentes é carregado de um conteúdo pejorativo, que denota certas atribuições vinculadas à identidade brasileira, como a malandragem e o "jeitinho brasileiro" (Oliveira, 1997: 139). Esses nikkeis, quando chegam ao Japão e são chamados pelos japoneses de gaijins sentem na pele a sobrecarga negativa que tal categoria assume, ao mesmo tempo em que resgatam como sendo suas certas características que antes eram imputadas aos brasileiros no Brasil, como o famoso "jeitinho": "aquele que longe dos expedientes oficiais usava da intimidade para seu sucesso" (Schwarcz, 1998: 200). A malícia e a 
criatividade do brasileiro no enfrentamento de situações adversas nas fábricas japonesas, mesmo que burlando regras oficiais, consideradas "irracionais", eram qualificadas positivamente pelos informantes da autora (Oliveira, 1997).

Apesar das dificuldades enfrentadas trabalhando como operária de fábrica e dos preconceitos existentes contra os brasileiros, a experiência foi enriquecedora na opinião de Yumi. Por várias vezes, ela me aconselhou a conhecer o Japão ou pelo menos a permanecer algum tempo fora do país. Percebia que meus entrevistados, quando tomavam conhecimento de que eu nunca tinha ido para o Nihon, passavam a narrar com mais detalhes as experiências vividas lá, os planos, os dramas, as conquistas, as lições de vida. Foi o que fez Yumi, assim que iniciamos nossa conversa.

Quando retornou ao Brasil, entrou na faculdade de pedagogia. $\mathrm{Na}$ época que a entrevista foi realizada, janeiro de 2009, ela não trabalhava, mas pretendia fazer mestrado e prestar concurso público. Sofreu muito quando retornou, principalmente quando voltou a estudar. Afirma que se impressionava como era capaz de falar o português corretamente. "Quando estava no Japão e assistia às fitas do Brasil, eu dizia, 'Nossa, como eu falava o português correto!'. Porque lá parece que a mente vai ficando atrofiada! Porque você começa a fazer só um tipo de serviço. Você só usa a força física e não usa a cabeça. Sabe que fiquei com dificuldade para pensar rápido?”. Ela achava que não ia conseguir acompanhar as disciplinas da faculdade, principalmente no primeiro ano: "Eu quase desisti, tinha perdido totalmente a noção". Também sofreu com a adaptação ao Japão, pois não sabia falar nada de japonês:

\begin{abstract}
"Eu sofri para me adaptar lá quando eu fui. Não sabia falar nada, nada, nada de japonês! Foi terrível, terrível! Porque lá você tem que trabalhar super rápido e eu não dava conta. Fui para uma esteira. Era peça de aparelho eletrônico. Eu não conseguia acompanhar. Aí tinha que parar a esteira. Ih, dava o maior rolo! Ai começavam a falar e eu não entendia nada! Sofri bastante para me adaptar lá. Só que depois, depois você se acostuma. Você tem dificuldade para se adaptar aqui, porque lá é tudo organizado, limpo. Gostei bastante e só voltei mesmo porque estava grávida, porque eu não tinha vontade de voltar".
\end{abstract}

Trabalhou cinco anos na Sony só com brasileiros, até mesmos os chefes o eram. Acha que isso prejudicou o aprendizado do japonês, o nihongo, sabia só o básico. A rotina embrutecedora, monótona e cansativa é comum para aqueles que resolvem ir para o Japão como "peões" de fábrica. Yumi passa a ter uma visão crítica a respeito da exploração do trabalhador depois das leituras de Marx na faculdade, mas conclui que financeiramente foi compensador:

"Porque lá no Japão a gente sofre, sofre mesmo, bastante... E depois eu vi que para tudo eu falava hai e tava bom. E a gente voltando, vê que não, que a gente tem que falar não! E 
nihonjin tem muito de abaixar cabeça, não é? Aí eu me senti, 'nossa fui explorada!' Mas comparando financeiramente, acho que valeu a pena. Para mim foi positivo, apesar de Marx falar da exploração do trabalhador [risos]. E realmente a gente fazia o trabalho que ninguém queria fazer: kitsui, kitanai, os '3K' ${ }^{298}$. Mas eu não tenho do que reclamar. E valeu como experiência também".

Além disso, ao entrar em contato com esse universo, Yumi, quando retornou ao Brasil, passou a rever certos posicionamentos e atitudes que tomava diante das situações que se apresentavam no Japão. Vimos que mesmo atribuindo qualificações positivas aos japoneses e recorrendo diversas vezes a essencializações na caracterização do "brasileiro" e do "nihonjin" (incluindo os brasileiros descendentes de japoneses), Yumi tem uma visão dinâmica da "cultura japonesa": as mudanças fazem parte de um processo "normal" e "necessário". "Porque as pessoas falam que se perderam os valores, mas algumas coisas têm que mudar mesmo. Mas parece que outras ainda ficam...", reflete. Ela deseja educar o filho "ao máximo dentro da cultura, dentro da tradição e preparar o bichinho para o mundo. Esse negócio de dizer só 'hai, hai, hai' já era, não vai a lugar nenhum!".

O próprio imaginário sobre os nikkeis sofreu alterações ao longo do tempo e segundo vários entrevistados, as atribuições positivas já não têm a mesma força como no passado. A ida em massa de descendentes ao Japão afastou muitos deles dos estudos e, consequentemente, da conquista de espaços de prestígio no mercado de trabalho. Quando discutia com Yumi se ela já havia se sentido beneficiada com esse imaginário, ela responde:

"Eu acho que sim. Acho que japonês tem mais crédito, eu acho. Até em termos de
atendimento, eu acho que sim. Já deixaram assim, me atender diferente... Porque eles falam,
'Nossa, japonês vai pagar'. Todo mundo tem uma certa preferência. Quando eu trabalhava,
né? Agora eu estou muito tempo fora do mercado de trabalho. Nessa época sim. Eu acho que
japonês era bem visto. Eu morei em Rondônia por quatro anos. Lá também falavam, só pelo
fato de ser nihonjin era uma outra imagem. É que depois que teve a abertura para o pessoal ir
para o Japão, a maioria não estudou. Meus primos nessa geração que está vindo agora,
ninguém foi para a faculdade. Todo mundo mal terminou o Ensino Médio e foi para o Nihon.
Mas antes quando não tinha isso, os nihonjins tinham os melhores empregos. Pode ver,
engenheiro, dentista, médico. Chega lá, 'Ah, você é japonês, eu confio'. Morei em Rondônia
nesse período e nihonjin era dentista e médico e o pessoal confiava bastante. ${ }^{299}$ Falavam, 'Se é
japonês, pode confiar'. Agora infelizmente essa geração está deixando muito... Até você vê no
vestibular hoje, já não tem tanto nihonjin como antigamente. Porque o pessoal ficou muito

\footnotetext{
${ }^{298}$ Os trabalhadores estrangeiros contratados pelas fábricas japonesas frequentemente tem que se sujeitar aos serviços rejeitados pelos japoneses, conhecidos como "3K": kitanai (sujo), kiken (perigoso) e kitsui (penoso). Os brasileiros ainda acrescentam mais duas características, kibishii (exigente) e kirai (detestável) (Beltrão \& Sugahara, 2006: 62).

${ }^{299}$ Rondônia é um Estado com pouca concentração de japoneses e descendentes. Ver cartograma de distribuição da população nikkei no Brasil na página 30.
} 
naquela ilusão, ‘Ah, eu vou lá (Japão), ganho dinheiro e depois eu volto e estudo, né?'. Então, aconteceu muito isso". 300

O capítulo 3 fecha com a fala de Yumi, na qual ela avalia sua relação com a "cultura" (“japonesa") quando atingira a maturidade, uma nova visão, um outro olhar, uma redescoberta: “Coisas que para mim não tinham significado nenhum, hoje para mim tem significado”. Relação perpassada pela valorização e aproximação que não pode deixar de ser pensada sem levarmos em consideração sua ida para o Japão. Esse aspecto também foi muito discutido pelo comerciante Daniel Kobayashi ${ }^{301}$ que também declarara ter tido uma experiência positiva no país. Diz ter aprendido muitos aspectos da "cultura" que outrora ele ignorava. A própria família foi constituída graças ao Japão, pois foi lá que conheceu sua esposa. Em oito anos, afirma que "aprendeu por osmose, levando pedrada mesmo", não só a se comunicar em japonês, mas também a entender o comportamento e valores que seus avós traziam consigo e que antes ele não compreendia:

"A nivel financeiro não tem o que pague essa bagagem que a gente tem. Entender um pouco do ditchan. Ele tem o jeito dele e às vezes a gente não entendia. 'Mas por que o ditchan é assim?'. Ai deu para encaixar tudo! Nossa, a gente tem mais é que agradecer mesmo! Comecei a aprender lá com o convívio. Mesmo até nas coisas bobas. A gente observava, por exemplo, o ditchan quando ia comer, mastigava com a boca aberta. Eu pensava, 'Nossa, podia comer com mais educação'. Isso vendo o lado ocidental, né? Estando lá no Japão, a gente observava que isso é uma prática normal. Quando as gerações um pouco mais antigas comem, eles comem assim quando está bem gostoso, 'oishii', como eles falam. Eles comem assim com naturalidade, sem aquela etiqueta e tudo mais. É coisa de lá. Então, eu passei a entender. Tem razão, o ditchan é japonês mesmo!".

Assim como Clarice Nakashima passou a compreender certas atitudes do pai japonês depois que fez a viagem ao Japão, Daniel vicenciou processo semelhante com o avô. Da posição inicial de "afastamento" de referenciais desse universo cultural e de "negação das origens", devido às "brincadeiras" sofridas na infância e juventude, comentado também pelos entrevistados Cláudio Shimada e Lúcia Miyamoto, Daniel, a partir do convívio com os japoneses, passa a estabelecer uma nova relação marcada pela valorização, compreensão e gratidão:

\footnotetext{
${ }^{300}$ As primeiras levas imigratórias eram constituídas principalmente por trabalhadores brasileiros escolarizados, com formação superior, oriundos das classes médias, mas que chegavam a obter, como operários de fábrica no Japão, um ganho salarial cinco a dez vezes maior do que no Brasil (Tsuda, 2003).

${ }^{301}$ Sansei, 35 anos, permaneceu oito anos no Japão e atualmente é dono de um mercado em Astorga. No capítulo 1, assim como Cláudio Shimada e Júlia Suzuki Bertolli, Daniel comentou sobre a imagem de credibilidade dos descendentes de japoneses no comércio.
} 


\begin{abstract}
"Dar mais valor, né? Eu acho que foi mais ou menos assim. A príncipio... é que o meu ditchan chamava Saburo. Tinha os documentos e tal. E os moleques de quinta, oitava série, sempre tinham aqueles mais engraçadinhos, pegavam e ficavam fazendo piada. Eu ficava muito nervoso, ficava bravo! Pensava, 'Pô, por que, né? o pessoal ficava tirando sarro?'. Era chato isso, mas foram poucas às vezes que isso aconteceu, mas eu ficava muito chateado, ficava nervoso. Mas depois, a gente indo para lá (Japão) e tendo essa experiência, sempre a gente fala: 'Puxa vida, graças a Deus que eu nasci em um berço de família japonesa, que tive oportunidade, permissão de conhecer outro lugar, viver lá, se libertar fisicamente, financeiramente, graças ao Japão'. Então, eu tenho muito que agradecer mesmo! Essa questão de gratidão ao Japão".
\end{abstract}

A experiência no Nihon também informa a relação de compreensão que Clarice passou a ter com a "cultura", ou melhor, "códigos", que na juventude ela negava ou não entendia: a forma "diferente" do pai de demonstrar amor e afeto, a hierarquia de gênero, a discriminação contra "gaijins", a cobrança de um bom desempenho na escola, o desejo de que o filho fale japonês. Sendo que muitos desses "códigos", Clarice começou a reproduzir quando esteve no Japão e posteriormente com a chegada de seu primeiro filho. Sobre a hierarquia de gênero, ela conta: “Ah, algumas coisas da cultura, talvez eu fale e você entenda. Quando você vai na casa de um parente, as meninas ajudam a lavar a louça e os rapazes vão conversar. ${ }^{302}$ Aquela coisa separada, homem e mulher, que eu até aceitava no âmbito doméstico, mas eu não queria ser dessa forma. Eu criticava isso".

Quando Clarice esteve no Japão, estabeleceu um forte laço de amizade com uma senhora japonesa que a acolheu, "praticamente a adotou como se fosse filha". Clarice casou-se no Japão com um brasileiro, descendente de japoneses, e essa senhora, foi inclusive sua madrinha de casamento. Ensinou-lhe vários "códigos" com relação ao papel da mulher na família, como por exemplo, de como se "portar com o marido", como preparar as refeições e servi-la:

"Reproduzi a típica japonesa lá e não tinha problemas com isso. Comecei a incorporar o jeito de pensar também. Os parentes falavam que eu parecia uma japonesa. Servia comida ao meu marido. Tinha gosto de fazer isso, tinha prazer. De certa forma, vivi a submissão da mulher japonesa no Japão. Não fiquei revoltada com aquilo. Foi uma situação gostosa para mim. Nesse sentido, comecei a entender o que meu pai queria dizer com a família estruturada, porque não é só uma questão de submissão. Mas por trás das cortinas, a mulher manda mais no marido em casa. O que ninguém explica, eu senti na prática. Porque essa senhora me explicou que o poder dentro de uma família está na mão da mulher e a mulher é que tem o poder de levar o homem para frente ou de cair com ele. [...] A mulher fala num tom mais baixo. Ela me ensinou como se portar frente ao chefe do marido, porque sabendo se portar, você dá projeção social para o seu marido. $O$ estrangeiro fica meio perdido com esse emaranhado de relações no Japão. Eu acho delicioso isso. Não é simplesmente machismo, mas comecei a entender meu pai, porque tudo isso vai refletir na educação do seu filho e na

\footnotetext{
${ }^{302}$ Esta fala agrega mais um exemplo da relação de identificação que muitos entrevistados tiveram comigo devido ao fato de eu também ser descendente de japoneses e supostamente entender ou compartilhar esses "códigos".
} 
aceitação dele na sociedade. A mulher quer que o filho consiga um lugar melhor na sociedade".

Clarice é muito agradecida pelos ensinamentos da amiga e conta que foi bem acolhida na comunidade local. A fluência no idioma japonês e o domínio de "códigos" que o pai havia lhe ensinado foram fundamentais para essa boa aceitação. "A gente estranha. O brasileiro tem uma desenvoltura que a gente não está acostumado. Em contrapartida, no Japão, eu era a japonesa que tinha uma desenvoltura que o próprio japonês não tem, só por ser um pouco mais abrasileirada, mais comunicativa. Isso era legal!". Clarice sempre guiava sua conduta a partir dos "códigos" que o pai lhe ensinara, o que resultou em uma postura admirada pelos seus amigos japoneses. A nikkei era em muitos aspectos até mais "quadrada" que os filhos destes e era considerada um exemplo a ser seguido. Seus amigos reconheciam em sua educação, valores e atitudes que acreditavam terem se perdido, ou seja, que não viam mais em seus filhos, somente nos antepassados. "Fazia par com a ideologia de meu pai. Ele congelou o pensamento, para o bem ou para o mal. Isso foi possibilitado 'graças ao acesso ao Japão imaginário de meu pai' esclarece. Seus amigos costumavam dizer que ela era certamente uma japonesa, só havia nascido no Brasil. Clarice buscava mostrar que ser brasileira não era uma ofensa ${ }^{303}$ :

"E as pessoas por uma questão de querer me elogiar, sempre achavam que eu gostaria de ser japonesa lá, de ser considerada japonesa, porque pelo menos na parte burocrática, eu sou japonesa lá, tenho cidadania. Só que para mim, no fundo, no fundo comecei a compreender que não era elogio para mim e eu gostava de ser brasileira".

Depois que Clarice retornou para o Brasil decidiu "retomar toda essa parte da identidade cultural, identidade japonesa e a trabalhar com coisas que antes não gostava ou não conseguia compreender". Acabou se envolvendo em um trabalho de conclusão de curso e um documentário sobre a imigração japonesa. Ela encarou o exercício como um "resgate". Afirma que na preparação do documentário, leu o livro de Tomoo Handa, "Memórias de um imigrante japonês no Brasil’304 e ficou muito emocionada, sensibilizada,

"porque primeiro você se envolve com o seu trabalho e depois tinha que parar, porque ficava chorando. Porque assim, não tem como você separar. Eu ficava vendo o relato daquela

\footnotetext{
${ }^{303}$ A atribuição exógena de uma identidade japonesa e não brasileira à Clarice devido a suas atitudes e maneiras de se comportar - "códigos" que ela dominava, os quais eram condizentes com o que seus amigos japoneses esperavam de uma nihonjin - tem relação com o que já fora discutido anteriormente sobre as imagens negativas que cercam os brasileiros, gaijins, no Japão.

${ }^{304} \mathrm{O}$ livro se constitui em um rico relato de memórias sobre a imigração japonesa no Brasil, sob o ponto de vista do artista plástico japonês, Tomoo Handa. O conjunto de suas obras, incluindo também o livro, "O imigrante japonês História de sua vida no Brasil", compõe um grande esforço de pesquisa que resulta em uma densa narrativa informativa, ao mesmo tempo em que retrata as lembranças das experiências vividas pelo próprio autor.
} 
pessoa, eu ficava imaginando o meu pai quando veio para cá. Então, quando eu lia os relatos, parecia que eu estava lendo a história do meu pai. Não tinha como não me emocionar! E a história dos descendentes de segunda geração, que não é bem a minha história, mas também perpassa por mim (sic), porque de uma certa maneira, eu sou filha de imigrantes. Não sou terceira geração como meus amigos. Então, eu sentia esse negócio de ficar meio em cima do muro, você não sabe se você é japonês ou se você é brasileira. Em casa, você é de um jeito, fora de casa, você é de outro, e era mesmo assim que eu me comportava, entendeu? Então, isso toca um pouco. Essas coisas emocionam a gente".

Essa questão identitária aparece novamente em sua fala quando conversamos a respeito do "orgulho" de ser nikkei, dispositivo muito acionado nas narrativas dos informantes. Devo confessar que após seu longo testemunho, em que teceu várias considerações positivas a respeito dos "códigos" da "cultura" e em que abordou temas como preconceito contra "brasileiros", pensei que ela fosse dizer que compartilhava desse sentimento. Ao contrário, Clarice disse não entender essa questão:

\footnotetext{
"Por que a gente tem que ter orgulho de ser nikkei, e não de ser italiano, de brasileiro? Eu não acho que isso tem muito sentido, porque eu não defendo uma bandeira nikkei, entendeu? De repente, se eu fizesse parte de uma associação ou defendesse isso, fosse um pouco mais ligada a alguma coisa japonesa. Porque se por um lado eu me sinto ligada, por outro, não me sinto. No Japão, eu sentia orgulho de ser brasileira". [...]

"Preciso saber o que significa ser nikkei para mim. Isso eu não sei. É uma condição de existência. Você já nasce assim, você não pode mudar. Assim, não posso dizer que tenha algum fato que eu me orgulhe ou que eu represente alguma coisa de nikkei. Não me sinto assim, por isso que talvez eu não tenha esse sentimento. Quando eu estava no Japão, eu me sentia parte do Brasil. Eu não sei por que, mas eu me sentia muito mais do que agora. Sei lá eu como que explica isso. Engraçado, porque você fez uma pergunta que eu nunca tinha parado para pensar".
}

Adriana Capuano de Oliveira apresenta uma explicação sobre essa aparente contradição comentada por Clarice. Como vimos no capítulo 2, a autora defende que os descendentes de japoneses não se inserem no que ela denomina "padrão de identidade brasileiro", assim como consagra o imaginário "freyriano" da nação: a mistura harmoniosa de suas três raças progenitoras, o branco colonizador, o indígena e o negro (Oliveira, 1997: 17-18). A partir da leitura de Oracy Nogueira, Oliveira sugere que a caracterização racial pautada no fenótipo também se estende aos nikkeis. O "preconceito de marca" atuaria na consideração dos mesmos simplesmente como "japoneses", não importando o grau geracional, nem a distância cultural com relação ao Japão: "E já que a caracterização 'racial' no Brasil é feita através do físico, estas pessoas, mesmo depois de três ou quatro gerações e de fazerem parte de um estilo de vida e de um universo cultural absolutamente brasileiro, estão 'condenadas' à situação de eternos japoneses" (Oliveira, 1997: 24). 
A partir de sua pesquisa com dekasseguis retornados, a autora afirma que esses “japoneses” no Brasil talvez nunca tivessem questionado sua identidade se não passassem pela experiência da migração para o Japão. Lá se sentiram brasileiros como nunca tinham se sentido antes. Oliveira tem uma proposta interessante sobre identidades em contexto, contudo dando bastante ênfase à aparência racial, ou seja, atribuindo ao fenótipo um caráter quase que exclusivo e determinante na definição da identidade "japonesa" no Brasil, já que assume que a apresentação das marcas raciais é um "estigma", uma "condenação à situação de eternos japoneses" (id.; ib.,1997: 23-24). Como discutido no capítulo 2, o fenótipo sem dúvida é um componente fundamental para a elaboração identitária. A partir dele, discursos são erigidos sobre os japoneses e seus descendentes e são também por eles ressignificados. Mas há outros operadores que acionam essa identidade nikkei, como a "cultura japonesa", a "colônia japonesa", a "comunidade nikkei".

Os resultados obtidos por Oliveira talvez residam em parte à realização de sua pesquisa na metade da década de 1990 e com a maioria de entrevistados nisseis, pessoas que como Clarice Nakashima, experienciaram mais intensamente o conflito de identidades - "viviam entre dois mundos". Pude perceber que a maior parte dos meus interlocutores, apesar de agenciarem a categoria "japoneses" para se definirem, não tinham dúvidas quanto à sua "brasilidade". Possuem cara de japoneses, mas nasceram e cresceram no Brasil, falam o português e compartilham muitos valores dessa "cultura brasileira". No entanto, em alguns momentos e contextos específicos, um vínculo com uma comunidade de sentidos se revela, seja através da identificação com o imaginário sobre os japoneses e seus descendentes, seja numa prática de resgate das "raízes” ou um saudosismo de um passado mítico ainda vivo na memória.

A experiência da migração é sempre subjetivamente entendida e sentida de diferentes maneiras. Muitos são os pontos comuns nas trajetórias trilhadas, mas de acordo com cada sujeito, aspectos mais positivos, negativos, recompensadores, agregadores, ou outros, mais traumáticos, conflitivos dessa experiência são enfatizados. De qualquer modo, ela é sempre reveladora de tensões e as identitárias fazem parte do conjunto de vivências daquele que assume a condição de estrangeiro. Daniel, Yumi e Clarice tiveram suas vidas profundamente marcadas por essa experiência, considerada positiva por todos eles, não obstante os obstáculos enfrentados. Reflexões e questionamentos sobre o passado - nas figuras dos pais de Yumi e Clarice ou do ditchan de Daniel - para a compreensão do presente vivido; ou sobre o futuro, nas preocupações com seus filhos, são certamente norteados por essa viagem. 


\section{CONSIDERAÇÕES FINAIS}

Este capítulo buscou mostrar brevemente algumas das inspirações teóricas que compõe o argumento deste trabalho. A proposta de Stuart Hall sobre subjetificação/identificação por meio de interpelações discursivas dá o embasamento para pensarmos sobre outras possibilidades no entendimento da questão identitária que envolve os descendentes de japoneses no Brasil. Sua maior contribuição consiste no destaque que ele dá à inexistência de identidades assumidas a priori, deslocadas de um contexto de enunciação. Como afirmam Bhabha e Hall, a diferença ou différance não é um dado em si, mas é performatizado. Surge no ato de sua manifestação, forjando um lugar de enunciação para o sujeito.

Vimos também que no processo de construção identitária, frequentemente, os sujeitos agenciam essencializações na definição de si, erigindo fronteiras com relação ao "outro". Nessa seara, preconceitos são forjados. A partir da leitura de Herzfeld, é possível pensar sobre os usos dos estereótipos como estratégias na negociação de identidades. Observamos brevemente o uso desse recurso, sob o ponto de vista da narrativa de Pedro Higa sobre os okinawanos e seus descendentes, a qual também deu mostras de como é múltipla a constituição do grupo nikkei no Brasil.

Tal pluralidade também se verifica com relação à condição de dekassegui, na medida em que há interlocutores que o vivenciaram e outros que não. Considerada sob a ótica da "viagem-experiência", percebemos como a permanência a trabalho no Japão marcou profundamente as vidas de Clarice, Yumi e Daniel e, consequentemente, imprimiu uma nova relação desses sujeitos com um arranjo material e simbólico complexo, mas dotado de sentidos, que foi se revelando ao longo de suas narrativas por meio de categorias nativas as mais diversas, como "cultura”, "raízes”, “tradição", “códigos”. 


\section{CONSIDERAÇÕES FINAIS}

Passados cem anos da imigração japonesa no Brasil, em que termos podemos pensar a identidade nikkei na atualidade? Essa foi a questão que abriu este trabalho e que sabemos não ser facilmente respondida. Talvez nem seja. Elegendo o imaginário sobre os japoneses e nipodescendentes como uma porta para acessar as auto-representações de nisseis e sanseis, moradores das cidades de São Paulo, Maringá e Astorga, das mais diferentes idades e "perfis sócioculturais", esta dissertação buscou mostrar como posições múltiplas podem ser construídas por meio de interpelações discursivas e por meio da ressignificação e negociação desse imaginário. Tais posições - "brasileiro", “japonês", "nipo-brasileiro", “nihonjin", "gaijin", "nikkei" - se revelam em momentos e contextos específicos. Não há uma identidade assumida a priori. Nesse sentido, perguntar a um descendente de japoneses: "Você se sente brasileiro ou japonês?" é uma questão que não faz muito sentido para os propósitos deste trabalho.

Nas conversas realizadas com meus interlocutores, esse imaginário foi traduzido como um conjunto de discursos e imagens que qualificava positivamente os nikkeis, através de atributos associados a um "ethos japonês": esforço, honestidade e disciplina foram os mais mencionados. Como um mosaico de discursos que se apresentou aqui na intercalação de narrativas oficiais - midiáticas, políticas, científicas - e narrativas pessoais, ou seja, dos próprios sujeitos dessa pesquisa, pudemos observar no capítulo 1 que essa trama imaginária, como um mito, atualiza-se e reatualiza-se de acordo com as contingências históricas. Ganha novos contornos, sem deixar de revelar certas permanências. Dos jornais e discursos políticos que reportavam ao trabalho dos imigrantes nas fazendas à ampla cobertura do centenário da imigração japonesa no Brasil, foi possível notar recorrências, como a celebração do esforço e do sucesso econômico dos “nossos japoneses".

Vale lembrar que estes mesmos “japoneses" também foram adjetivados negativamente. No capítulo 2, continuando a empregar a metodologia de montagem de discursos, vimos que as construções sobre "raça" forjadas no final do século XIX e início do XX ainda têm efeitos sobre como "brincadeiras" e "piadas" com relação à aparência física são erigidas contra os mesmos. É sobre as marcas fenotípicas que se sustentam as classificações raciais vigentes no país e o corpo torna-se um lócus de produção de diferenças e também subjetividades. No caso dos nikkeis, o "preconceito de marca" atua mobilizando um conjunto de imagens, discursos e estereótipos que dizem respeito a dois repertórios simbólicos diferentes, um que denota zombaria 
e outro, atrelado a um imaginário qualificado positivamente, podendo causar uma valorização do portador, e em alguns casos, até trazendo algumas vantagens no mercado de trabalho.

É importante reiterar que essas discussões foram trazidas à tona à medida que eram problematizadas pelos interlocutores. As várias experiências aqui narradas permitiram entrever como múltiplas posições podem ser definidas em contexto e a partir da ressignificação e negociação do imaginário atribuído aos descendentes. Um imaginário que não simplesmente existe num plano discursivo, mas é alimentado e realimentado pelos agentes envolvidos, nikkeis e não-nikkeis. Afirmado no discurso de uma liderança política, em um programa de televisão ou na fala do indivíduo comum, essa trama de imagens tem repercussões na forma como os sujeitos nikkeis são percebidos e se percebem. Processos de identificação e não-identificação se constróem quando esse conjunto de representações se apresenta na vida dessas pessoas. Esse trabalho trata-se, sobretudo, de uma etnografia sobre diversas experiências narradas que versam a respeito do que ser descendente de japoneses significa para esses sujeitos. Uma abordagem sobre identidades que se revela no discurso dos mesmos.

Entretanto, concluímos também no capítulo 3, que além das posições articuladas por meio de interpelações discursivas, categorias nativas como "cultura japonesa" e "colônia japonesa/comunidade nikkei" se mostraram como operadores significativos no processo de construção identitária. No primeiro caso, a relação de afastamento e/ou aproximação dos sujeitos pesquisados com esse conjunto híbrido de referências, costumes, códigos, práticas e valores, diz muito sobre a forma como pensam e se pensam. Não obstante aparecer frequentemente acompanhada de termos como "preservação", "perda" e "resgate", tal categoria não se revela a partir da concepção de reprodução de uma "cultura originária do Japão" no Brasil.

Os interlocutores entendem que processos históricos e trocas culturais atuam sobre esse arranjo simbólico. A maioria crê que muitos desses atributos positivos que compõe o imaginário sobre os nikkeis sofram alterações e se "enfraqueçam" com o passar das gerações, embora acreditem que alguns elementos se mantenham. Leitura que faz coro à concepção aqui adotada do imaginário como um mito, uma ficção criada sobre e pelos nipo-brasileiros, que se reelabora com as transformações históricas. É importante lembrar que o objetivo não foi o de empreender um exercício de futurologia sobre esse imaginário e nem qualificá-lo como falso ou verdadeiro e sim compreender como ele se interpõe na experiência de vida dos sujeitos.

Adentramos brevemente na discussão do fenômeno de popularização e mercantilização de bens da "cultura japonesa", considerada também a partir da chave da globalização e consumo. A hipótese defendida é a de que esse processo de "positivação do exótico" que envolve a apreciação pelos brasileiros não-descendentes de "peças" desse complexo 
material e simbólico, pode gerar uma relação de (re) aproximação de nikkeis, sobretudo pertencentes às gerações mais novas, com esses referenciais. A comemoração do centenário da imigração japonesa no Brasil em 2008 também se constituiu em um marco histórico que reforçou a difusão de imagens positivas aos descendentes.

Com relação à categoria "colônia japonesa", foi possível acompanhar sua conformação como topos físico e discursivo. De configurações sócioespaciais congregadas em núcleos agrícolas, nihonjin-kais e cooperativas no início da imigração, às teias de sociabilidade que se produzem nas associações culturais, às "panelinhas de japas" e à utilização para se referir ao conjunto dos japoneses e seus descendentes no Brasil, essa categoria também opera como um importante elemento nos processos de construção e negociação de identidades. Categoria, portanto, que só é compreendida em contexto, assim como "gaijin", "nihonjin", "brasileiro" e "japonês".

No capítulo 4, observamos como num contexto diverso, no Japão, por exemplo, tais termos são ressignificados, sendo dotados de outros sentidos e consequentemente tendo outras implicações nas identificações em curso. $\mathrm{Na}$ heterogeneidade que constitui o grupo formado pelos nipo-descendentes no país, abordamos brevemente o caso dos okinawanos no Brasil, os quais também operam com outras categorias nativas, como uchinanchus e yamatonchus. Além disso, pelas diversas experiências narradas pelos interlocutores, vimos como diferenças de idade, gênero, gerações, atividade profissional, classe social e local de residência também se cruzam no estabelecimento desse pluralismo.

No que concerne às clivagens geracionais, o argumento defendido é o de que os "conflitos de identidades", traduzidos por Clarice Nakashima pela condição de "viver entre dois mundos" - o "brasileiro" e o "japonês" - são mais comuns aos que experienciam diretamente os dramas dos deslocamentos transnacionais, como os imigrantes de primeira e segunda geração. De acordo com meus entrevistados, os isseis e nisseis teriam sofrido com mais intensidade os reveses das barreiras culturais, econômicas e linguísticas no processo de adaptação ao país; já os sanseis, não obstante continuarem a relatar experiências em que se viram como vítimas de zombaria ou preconceito devido à descendência japonesa, vivem em uma conjuntura no qual possuem uma relação de mais proximidade, do que a de seus pais, com os referenciais culturais nacionais, e também em um contexto em que elementos do universo cultural "japonês/nikkei" já não causam tanta estranheza entre os brasileiros.

Em que pese o grau de heterogeneidade que marca a constituição do grupo nikkei no Brasil, observamos regularidades. Defende-se aqui o pressuposto de que a assunção e negociação de identidades múltiplas - "brasileiro", “nikkei”, "japonês”, “nihonjin”, "gaijin" - dependem do 
contexto de enunciação, formas e conteúdo da interpelação e agentes envolvidos. Vimos no capítulo 4 que nesses processos de identificação, frequentemente os sujeitos lançam mão de essencialismos e estereótipos não somente sobre si, mas também sobre o "outro". Assim, na esfera da "intimidade cultural", nos domínios da vida privada, os indivíduos muitas vezes acionam preconceitos ou ideias generalizantes quando buscam demarcar as fronteiras identitárias que os separam ou o que os distinguem do "outro".

Contudo, assim como as biografias dos sujeitos dessa pesquisa são várias, as reações também o são. Observamos pessoas como os nisseis Yumi Kawamura que dizia se identificar “100\% no perfil do nihonjin" e o médico Luís Yamamoto que dizia ser esse mesmo "perfil” um "folclore", uma "lenda". Na modulação identitária, o apego dos indivíduos ao que denominam "cultura", "valores”, “tradição", “códigos", raízes”, “origens”, “orgulho”, "herança” é subjetivamente definido, tem relação com os laços que seus antecessores mantiveram ou mantêm com esse repertório simbólico e se apresenta nas narrativas aqui compartilhadas com toda a emoção e singularidade que o tema evoca.

O objetivo deste trabalho consistiu em apresentar reflexões acerca da experiência nikkei no Brasil, tomando como foco as trajetórias de vida de nisseis e sanseis. O ponto de partida para a investigação residiu no imaginário sobre os japoneses e seus descendentes na sociedade, mas abordou também outras questões que tocam o universo cotidiano desses sujeitos. As indagações e as incursões analíticas aqui empreendidas partem da própria fala e experiência de vida dos mesmos.

O grande desafio foi costurar uma narrativa que ao mesmo tempo em que mostrasse as diversidades e divergências das trajetórias e reflexões dos interlocutores, chamasse a atenção para os traços comuns na afirmação da identidade. Sobre essa temática, mais do que tirar grandes lições e contribuições, este trabalho visa mostrar, a partir das múltiplas vozes e discursos que emanam do texto, os vínculos emocionais e imaginados que os sujeitos dessa pesquisa guardam com uma comunidade de sentidos: uma complexa conjunção de imaginários, valores repassados, história dos antepassados, tradições culturais e sentimentos. 


\section{REFERÊNCIAS BIBLIOGRÁFICAS}

ANDERSON, Benedict. Comunidades imaginadas: reflexões sobre a origem e a difusão do nacionalismo (trad. Denise Bottman). São Paulo: Companhia das Letras, 2008.

BAKHTIN, Mikhail. Marxismo e filosofia da linguagem: problemas fundamentais do método sociológico na ciência da linguagem. 9 ${ }^{a}$. edição, São Paulo: Editora Hucitec, AnnaBlume, 2002.

BARCELOS, Luíz C. Educação: um quadro de desigualdades raciais. In: Estudos AfroAsiáticos, no. 23, pp. 37-69, 1992.

BARTH, Fredrik. "Grupos étnicos e suas fronteiras". In: POUTIGNAT, P e STREIFFFENART, J. Teorias da Etnicidade. Seguido de grupos étnicos e suas fronteiras, de Frederik Barth. São Paulo: Fundação Ed Unesp, 1998.

BELTRÃO, K \& SUGAHARA, S. "Permanentemente temporário: dekasseguis brasileiros no Japão". Revista Brasileira de Estudos Populacionais, São Paulo, v. 3, n.1, p. 61-85, jan/jun 2006.

BELTRÃO, K \& SUGAHARA, S et al. "Vivendo no Brasil: características da população de origem japonesa". In: Sakurai \& Coelho (Orgs.). Resistência \& Integração: 100 anos da imigração japonesa no Brasil. IBGE, Rio de janeiro, 2008.

BENEDICT, Ruth. O Crisântemo e a Espada. São Paulo: Perspectivas: 1997

BHABHA, Homi K. O local da cultura. (1998). Belo Horizonte: Editora UFMG, 2006.

BORGES PEREIRA, J. B. Comunicação social e representação étnica. In: Comunicação \& Sociedade. Ano V, no. 9, jun/1983, p. 141.

BUCCI, E; KEHL, M. R. Videologias: ensaios sobre televisão. São Paulo: Boitempo, (Estado de sítio), 2004.

CARDOSO, Ruth C. L. O papel das associações juvenis na aculturação dos japoneses. In: Saito, H \& Maeyama, T. (Org.). Assimilação e Integração dos japoneses no Brasil. Petrópolis, Vozes; São Paulo, 1973.

. Estrutura Familiar e mobilidade social: estudo dos japoneses no Estado de São Paulo. São Paulo: Kaleidos-Primus Consultoria e Comunicação Integrada S/C Ltda, 1998.

CARVALHO, José Murilo de. O motivo edênico no imaginário social brasileiro. In: Revista Brasileira de Ciências Sociais, vol. 13, no. 38, São Paulo, outubro de 1998.

COMISSÃO DE ELABORAÇÃO DA HISTÓRIA DOS 80 ANOS DA IMIGRAÇÃO JAPONESA NO BRASIL (CEHIJB) - Uma Epopéia Moderna: 80 anos da Imigração Japonesa no Brasil Comissão de elaboração da história dos 80 anos da imigração japonesa no Brasil. São Paulo, Hucitec: Sociedade Brasileira de Cultura Japonesa, 1992. 
COSTA, Sérgio. Dois Atlânticos: Teoria social, anti-racismo, cosmopolitismo. Belo Horizonte: Editora UFMG, 2006.

CUNHA, Manuela C. Antropologia do Brasil: mito, história, etnicidade. Ed Brasiliense, 1986. . "Cultura" e cultura: conhecimentos tradicionais e direitos intelectuais. In:

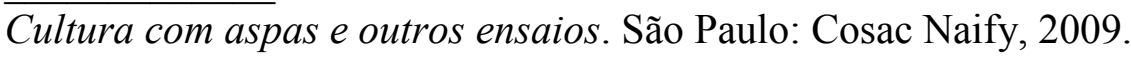

DA MATTA, Roberto. A casa \& rua: espaço, cidadania, mulher e morte no Brasil. Rio de Janeiro, Guanabara Koogan, 4a . Edição, 1991.

DEZEM, Rogério. Matizes do "amarelo": a gênese dos discursos sobre os orientais no Brasil (1878-1908). São Paulo: Associação Editorial Humanitas, 2005.

DIRLIK, Arif. "A aura pós-colonial: a crítica terceiro-mundista na era do capitalismo global”. In: Novos Estudos CEBRAP, no. 49, novembro de 1997.

EDMONDS, Alexander. No universo da beleza: Notas de campo sobre cirurgia plástica no Rio de Janeiro. In: GOLDENBERG, M. (Org.). $\mathrm{Nu} \&$ Vestido: dez antropólogos revelam a cultura do corpo carioca. Rio de Janeiro: Editora Record, 2002.

FAUSTO, Boris. Imigração: cortes e continuidades. In: SCHWARCZ, L. (Org.) História da Vida Privada no Brasil 4: contrastes da intimidade contemporânea. São Paulo. Companhia das Letras: $1^{a}$. edição, 1998.

FERRARI, Florência. "Como pensar nômades com um pensamento nômade? Sugestões para definir um campo em antropologia". Disponível em: http://abaete.wikia.com/wiki/Como_estudar_n $\% \mathrm{C} 3 \% \mathrm{~B} 4$ mades_com_um pensamento_n $\% \mathrm{C} 3$ $\% \mathrm{~B} 4 \mathrm{made} \% 3 \mathrm{~F}$ Sugest $\% \mathrm{C} 3 \% \mathrm{~B} 5 \mathrm{es}$ para definir_um campo em antropologia \%28Florencia Ferrari\%29. Acesso em 05/03/08.

FERREIRA, Y \& ASARI, A. Algumas considerações sobre a atuação do imigrante japonês e seus descendentes na comunidade londrinense. In: $O$ nikkei e sua americanidade. Temas apresentados na III Convenção Panamericana (III Copani), $1^{\text {a }}$.Ed, 1986.

FOUCAULT, Michel. Arqueologia do saber. Forense Universitária: 7ª Edição: 2008a.

$2008 b$. . A ordem do discurso. Leituras Filosóficas. Edições Loyola, 17ª. Ed. São Paulo:

FUKUMOTO, Mary. “Americanidad de los 'nikkei' em las Américas”. In: O nikkei e sua americanidade: temas apresentados na III Convenção Panamericana (III Copani). 1 1a Edição, 1986.

GEERTZ, Clifford. A interpretação das culturas. Rio de Janeiro, LTC: 1989.

GOLDMAN, Marcio. HERZFELD, M. Cultural Intimacy: the Social Poetics in the NationState. New York/London: Routlegde, 2004 (Resenha). MANA 4(2):150-153, Rio de Janeiro, 1998. 
HALL, Stuart. Da Diáspora: identidades e mediações culturais. 2a ${ }^{\mathrm{a}}$ ed. Belo Horizonte: Editora UFMG, 2003. . A identidade cultural na pós-modernidade. Rio de Janeiro: DP\&A, 2005.

. Quem precisa da identidade? In: SILVA (org.) Identidade e Diferença: a perspectiva dos Estudos Culturais. Petrópolis, RJ: Vozes, 2007.

HERZFELD, Michael. “La pratique des stéréotypes". In: L’ Homme, volume 32, numéro 121, p. 67-77, Anné 1992.

Difel: 2001 . Antropologia do outro lado do espelho: etnografia crítica das margens da Europa. Routlegde, 2004

Cultural Intimacy: the Social Poetics in the Nation-State. New York/London:

HIKIJI, Rose Satiko G. Imagem-violência: Mímesis e reflexividade em alguns filmes recentes. Dissertação de mestrado, São Paulo, USP, 1998.

HIKIJI, R. \& KISHIMOTO, A. "Nikkeis no Brasil, dekasseguis no Japão: identidade e memória em filmes sobre migrações". Revista USP, São Paulo, no. 79, p. 144-164, set/nov. 2008.

HOBSBAWN, E \& RANGER, T. A invenção das tradições. Rio de Janeiro: Paz e Terra, 1984.

KIYOTANI, M \& YAMASHIRO, J. "Do Kasato Maru até a década de 20". In: Uma Epopéia Moderna: 80 anos da Imigração Japonesa no Brasil. Comissão de elaboração da história dos 80 anos da imigração japonesa no Brasil. São Paulo: Hucitec: Sociedade Brasileira de Cultura Japonesa, 1992.

KUNIYOSHI, Celina. Imagens do Japão: uma utopia de viajantes. São Paulo: Estação Liberdade. FAPESP, 1998.

KUPER, Adam. Cultura: a visão dos antropólogos. Bauru, SP: EDUSC, 2002.

LEITE, Miriam Moreira. Retratos de Família: leitura da fotografia histórica. São Paulo: Editora da Universidade de São Paulo, 1993.

LESSER, Jeffrey. A negociação da identidade nacional: imigrantes, minorias e a luta pela etnicidade no Brasil. (trad. Patrícia de Queiroz C. Zimbres) São Paulo: Editora UNESP, 2001

- Uma diáspora descontente: os nipo-brasileiros e os significados da militância étnica 1960-1980. (trad. Patrícia de Queiroz C. Zimbres). São Paulo: Paz e Terra, 2008.

. Nascimento da cultura nipo-brasileira: repensando os significados da chegada do Kasato Maru. In: Kasato Maru: uma viagem pela história da Imigração Japonesa. São Paulo: Arquivo Público do Estado de São Paulo, Imprensa Oficial do Estado de São Paulo, 2009. 
LOPES NETO, Aramis. Bullying - comportamento agressivo entre estudantes. In: Jornal de Pediatria - Vol. 81, no. 5 (Supl.), S164 - S172, 2005.

LOURENÇO, Eduardo. Mitologia da Saudade: seguido de Portugal como destino. São Paulo: Companhia das Letras, 1999.

MACHADO, Igor J. "Reflexões sobre o pós-colonialismo". In: Teoria e Pesquisa, no. 44 e 45. Jan/Jul de 2004.

MAEYAMA, Takeshi. Religião, parentesco e as classes médias dos japoneses no Brasil urbano. In: SAITO, H; MAEYAMA, T. (Org.). Assimilação e Integração dos japoneses no Brasil. Petrópolis: Vozes, 1973.

MANFRINATTO, Ana. "Sorry, Liberdade: teoria de Koichi Mori prega a não-existência da cultura japonesa no Brasil". Revista 100 Anos da Imigração japonesa no Brasil. São Paulo: Editora Abril, p. 8-10, 2008.

MAUSS, Marcel. Uma categoria do espírito humano: a noção de pessoa, a de "eu" (1938). In: Sociologia e Antropologia. São Paulo: Cosac Naify, 2003.

MEIRELES, Selma M. "O Ocidente redescobre o Japão: o boom de mangás e animes”. In: Revista de Estudos Orientais. No. 4, pp. 203-211 - 2003.

MIYAO, Sussumu. Posicionamento social da população de origem japonesa. In: SAITO, H (Org.) A presença japonesa no Brasil. São Paulo: T. A Queiroz: Editora da Universidade de São Paulo, 1980.

MORI, Koichi. "Identity transformations among okinawans and their descendants in Brazil". In: LESSER, J. (Org.). Searching for home abroad: japanese brazilians and transnationalism. Duke University Press, 2003a.

. "As condições de aceitação da culinária japonesa na cidade de São Paulo - Por que os brasileiros começaram a apreciar a culinária japonesa?”. In: Estudos Japoneses, no. 23, São Paulo, 2003b.

- "O surgimento do shaman étnico em decorrência da globalização". In: Globalização: Análise compreensiva a partir da perspectiva local e regional. Mita Chioko (Org.) Sophia Aglos Working Papers Series, no. 14, 2007.

MOTTER, M \& MUNGIOLI, M. "Gênero teledramatúrgico: entre a imposição e a criatividade”. In: Revista USP, São Paulo, no. 76, p. 157-166, dez/fev 2007-2008.

MUNANGA, Kabengele. Algumas considerações sobre "raça", ação afirmativa e identidade negra no Brasil: fundamentos antropológicos. In: Revista USP, São Paulo, no. 68, pp. 46-57, dez/fev 2005-2006.

NOGUEIRA, Oracy. Preconceito de marca: as relações raciais em Itapetininga. São Paulo: Editora da Universidade de São Paulo, 1998. 
OLIVEIRA, Adriana Capuano de. Japoneses no Brasil ou brasileiros no Japão: a trajetória de uma identidade em um contexto migratório. Dissertação (mestrado). Departamento de Antropologia. Universidade Estadual de Campinas. Campinas, 1997.

OLIVEIRA, João Pacheco. "Uma etnologia dos 'índios misturados'? Situação colonial, territorialização e fluxos culturais”. In: MANA 4(1):47-77, Rio de Janeiro, 1998

NUCCI, Priscila. Os intelectuais diante do racismo antinipônico no Brasil: textos e silêncios. Dissertação (mestrado). Departamento de História. Universidade Estadual de Campinas, 2000.

ONO, M; WAKISAKA, K. Cultura, Migração e Nissei. In: SAITO, H; MAEYAMA, T. (Org.). Assimilação e Integração dos japoneses no Brasil. Petrópolis: Vozes, 1973.

ORTIZ, Renato. O próximo e o distante: Japão e Modernidade-Mundo. São Paulo: Brasiliense, 2000.

OS NIKKEIS E A SOCIEDADE BRASILEIRA NOS PRÓXIMOS 20 ANOS: JICA. São Paulo, março de 2003.

PAIXÃO, Marcelo J. P. Crítica da razão culturalista: relações raciais e a construção das desigualdades sociais no país. Tese (doutorado). Instituto Universitário de Pesquisas do Rio de Janeiro. Rio de Janeiro, 2005.

PEREIRA, Ronan Alves. "O Budismo japonês: sua história, modernização e transnacionalização". Revista Eletrônica Ponto de Encontro de Ex-Fellow, número 1, Fundação Japão, São Paulo: 2002. Disponível em: http://www.fjsp.org.br/estudos/revista ponto01.html Acesso: 29/05/10.

PINA-CABRAL, João de. "Limiar dos afectos: algumas considerações sobre nomeação e a constituição social de pessoas". Trabalho apresentado na aula inaugural do Programa de PósGraduação em Antropologia Social da Universidade Estadual de Campinas, abril de 2005. Disponível em: www.ceao.ufba.br/fabrica/txts/cabral/limiar.doc Acesso: 09/04/10

RAMOS, Jair de Souza. "Dos males que vem com o sangue: as representações raciais e a categoria do imigrante indesejável nas concepções sobre imigração da década de 20". In: MAIO, M \& SANTOS, R (Orgs.) Raça, ciência e sociedade. Rio de Janeiro: Fiocruz: Centro Cultural Banco do Brasil, 1996.

RIAL, Carmen S. M. "Racial and ethnic stereotypes in brazilian advertising". Antropologia em Primeira Mão. No.44, p.1-23, Florianópolis: 2001.

ROSALDO, Renato. Culture \& truth: the remarking of social analysis. Boston: Beacon Press, 1993.

SAHLINS, Marshall. “O 'pessimismo sentimental' e a experiência etnográfica: por que a cultura não é um “objeto" em via de extinção". MANA (3): 103-105, Rio de Janeiro, 1997.

. Ilhas de História. Rio de Janeiro: Jorge Zahar Ed., 2003.

. Esperando Foucault, ainda. São Paulo: Cosac Naify, 2004. 
SAID, Edward. Orientalismo: o Oriente como invenção do Ocidente. São Paulo: Companhia das Letras, 2007.

SAITO, Hiroshi. O japonês no Brasil: estudo de mobilidade e fixação. São Paulo: Editora "Sociologia e Política", Fundação Escola de Sociologia e Política de São Paulo, 1961.

SAITO, H (Org.) A presença japonesa no Brasil. São Paulo: T. A Queiroz: Editora da Universidade de São Paulo, 1980.

SAITO, H; MAEYAMA, T. (Org.). Assimilação e Integração dos japoneses no Brasil. Petrópolis: Vozes, 1973.

SAITO, Toshiaki. Brasileiros e japoneses, confronto de identidade. In: O Nikkei e sua americanidade: Temas apresentados na III Convenção Panamericana (III Copani), $1^{\mathrm{a}}$.Ed, 1986.

SAKURAI, Célia. Romanceiro da imigração japonesa. Série Imigração (v.4). São Paulo: Editora Sumaré: FAPESP, 1993.

. Imigração japonesa para o Brasil: um exemplo de imigração tutelada (1908 1941). In: FAUSTO, Boris (Org.) Fazer a América: a imigração em Massa para a América Latina. $2^{\mathrm{a}}$. edição. São Paulo: Edusp, 2000.

. A chegada do Kasato Maru e o contexto das imigrações japonesas (1908-1970).

In: Kasato Maru: uma viagem pela história da Imigração Japonesa. São Paulo: Arquivo Público do Estado de São Paulo, Imprensa Oficial do Estado de São Paulo, 2009.

. Os japoneses. $1^{\mathrm{a}}$. ed., $1^{\mathrm{a}}$. reimpressão. São Paulo: Contexto, 2008.

SANT'ANNA, Luiz Carlos R. "Humor Negro". Estudos Afro-asiáticos, n” 26, p.81-98, setembro de 1994.

SASAKI PINHEIRO, Elisa M. Ser ou não ser japonês? A construção da identidade dos brasileiros descendentes de japoneses no contexto das migrações internacionais do Japão contemporâneo. Tese (doutorado). Universidade Estadual de Campinas, Campinas, 2009.

SCHPUN, Mônica R. História de uma invenção identitária (temporalidade migratória, etnia e gênero). Nuevos Mundos Mundos Nuevos, Colóquios, 2007, Puesto em línea el 14 mars 2007, Disponível em URL: http: //nuevomundo.revues.org/índex3685.html> Acesso em janeiro de 2009.

SCHWARCZ, Lilia. O espetáculo das raças: cientistas, instituições e questão racial no Brasil (1870-1930). São Paulo: Companhia das Letras, 1993.

. "Complexo de Zé Carioca: Notas sobre uma identidade mestiça e malandra. In: Revista Brasileira de Ciências Sociais. No. 29, ano 10, outubro de 1995, 1995a.

. "Nomeando as diferenças: a construção da idéia de raça no Brasil". In: VILLAS BÔAS \& GONÇALVES, M. A. (Orgs.). O Brasil na virada do século: o debate dos cientistas sociais. Relume-Dumará: Rio de Janeiro, 1995b. 
. Nem preto, nem branco, muito pelo contrário: cor e raça na intimidade. História da Vida Privada no Brasil. In: SCHWARCZ, L. (Org.) História da Vida Privada no Brasil 4: contrastes da intimidade contemporânea. São Paulo. Companhia das Letras: 1a . edição, 1998.

. No país das cores e nomes. In: ORTIZ, R. O corpo do brasileiro: estudos de estética e beleza. Editora Senac: São Paulo, 2000.

SEYFERTH, Giralda. "Construindo a nação: hierarquias raciais e o papel do racismo na política de imigração e colonização". In: MAIO, M \& SANTOS, R (Orgs.) Raça, ciência e sociedade. Rio de Janeiro: Fiocruz: Centro Cultural Banco do Brasil, 1996.

SILVA, Tomaz Tadeu da. "A produção social da identidade e da diferença". In: SILVA (org.) Identidade e Diferença: a perspectiva dos Estudos Culturais. Petrópolis, RJ: Vozes, 2007.

STOLCKE, Verena. "Sexo está para gênero assim como raça para etnicidade". In: Estudos Afro-Asiáticos, no. 20: 101-119, junho de 1991.

TAKEUCHI, Márcia Y. O perigo amarelo: imagens do mito, realidade do preconceito (19201945). São Paulo: Humanitas, 2008a.

. "A comunidade nipônica e a legitimação de estigmas: o japonês caricaturizado". In: Revista USP, no. 79, nov. 2008 b.

TAUSSIG, Michael. Cultura do terror: espaço da morte na Amazônia. In: Religião e Sociedade, 10, Rio de Janeiro, nov. 1983, p. 49-64.

. Xamanismo, colonialismo e o homem selvagem: um estudo sobre o terror e a cura. Rio de Janeiro: Paz e Terra, 1993.

TOYAMA, Osamu. Cem anos de águas corridas da comunidade japonesa. São Paulo: AGWM, 2009.

TSUDA, Takeyuki. "The benefits of being minority: the ethnic status of the japanese brazilians in Brazil". May, 2000. University of California - San Diego. Working paper no. 21.

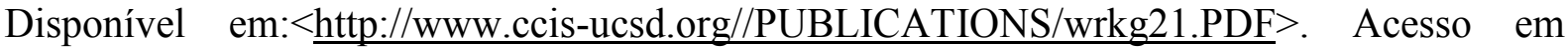
30/10/2005.

Strangers in the ethnic homeland: Japanese Brazilian return migration in transnational perspective. Columbia University Press. New York, 2003.

TSUKAMOTO, Tetsundo. A sociologia do imigrante: algumas considerações sobre o processo imigratório. In: SAITO, H; MAEYAMA, T. (Org.). Assimilação e Integração dos japoneses no Brasil. Petrópolis: Vozes, 1973.

UEHARA, Alexandre R. "O crescimento econômico e os investimentos diretos japoneses no Brasil”. In: Revista Eletrônica Ponto de Encontro de Ex-Fellow, número 1, Fundação Japão, São Paulo: 2002. Disponível em: http://www.fjsp.org.br/estudos/revista ponto.htm Acesso: 08/06/10.

VIVEIROS DE CASTRO, Eduardo. "Sobre a Antropologia hoje: Te(i)ma para discussão". O Ensino da Antropologia no Brasil: temas para uma discussão. Revista da ABA, março 1995. 
WOODWARD, Kathryn. Identidade e diferença: uma introdução teórica e conceitual. In: SILVA (org.) Identidade e Diferença: a perspectiva dos Estudos Culturais. Petrópolis, RJ: Vozes, 2007.

YAMAMOTO, Eriko. A odisseia de uma nissei pioneira. In: In: O nikkei e sua americanidade. Temas apresentados na III Convenção Panamericana (III Copani), $1^{\mathrm{a}}$.Ed, 1986.

\section{SITES CONSULTADOS}

http://www1.folha.uol.com.br/fsp/especial/inde18062008.htm Acesso: 15/12/2008

http://veja.abril.uol.com.br/121207/p 078.shtml Acesso: 15/12/2008

http://www.acbj.com.br/alianca/quemsomos.php?iQuem=historico.htm Acesso : 10/02/2010

http://www.aliancaliga.bunkyonet.org.br/index.php?option=com content\&view=frontpage \&Itemid=1

Acesso : $11 / 02 / 2010$

http://exclusivo.terra.com.br/interna/0,OI1857080-EI1118,00.html Acesso: 23/03/2010

http://exclusivo.terra.com.br/interna/0,OI2742442-EI1118,00.html Acesso: 23/03/2010

http://g1.globo.com/Noticias/Mundo/0,,MUL43863-5602,00.html Acesso: 23/03/2010

http://noticias.bol.uol.com.br/brasil/2007/06/01/ult4469u4700.jhtm Acesso: 23/03/2010

www.sni.org.br Acesso: 23/03/2010

http://www.perfect.com.br/cirurgia.asp?cir=58\&offset Acesso: 23/03/2010

http://rabiscos-da-say.blogspot.com/20090301_archive.html Acesso: 24/03/2010

http://oglobo.globo.com/mundo/mat/2007/06/30/296589906.asp Acesso: 25/03/2010

http://www.plasticahoje.com.br/2010/01/ocidentaliza\%C3\%A7\%C3\%A3o-umapl\%C3\%A1stica-

exclusiva-para-os-orientais.html Acesso: 25/03/2010

http://www.observatoriodaimprensa.com.br/artigos.asp?cod=401TVQ003 Acesso: 25/03/2010

http://www.parana-online.com.br/colunistas/231/71094/?postagem=O+FRACOTE Acesso :

$28 / 03 / 2010$

http://www.fabiocampana.com.br/2009/10/requiao-nao-engole-pesquisador-que-o-criticou-na-

escolinha/comment-page-2/\#comment-143779 Acesso: 28/03/2010

http://jornale.com.br/zebeto/2009/10/06/o-dia-do-gafanhoto-na-escola-do-requiao/

Acesso: $28 / 03 / 2010$

http://www.bonde.com.br/bonde.php?id_bonde=1-3--803-20091027 Acesso: 28/03/2010

http://www.estadao.com.br/noticias/nacional,requiao-atribui-cancer-de-mama-em-homem-a-

gays,457357,0.htm Acesso: 28/03/2010

http://g1.globo.com/Noticias/Politica/0,MUL1357281-5601,00-

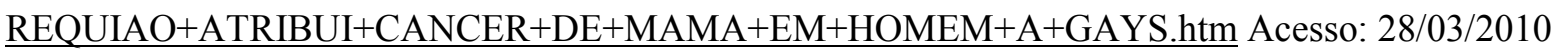


http://jaborando.blogspot.com/ Acesso: 28/03/2010

http://portalimprensa.uol.com.br/portal/ultimas noticias/2009/11/25/imprensa32306.shtml Acesso: $28 / 03 / 2010$

http://veja.abril.com.br/agencias/ae/brasil/detail/2009-11-24-608810.shtml Acesso: 28/03/2010 www.kumon.com.br Acesso: 29/03/2010

http://jornalnacional.globo.com/Telejornais/JN/0,,MUL609085-10406,00-

BRASILEIROS+DE+OLHOS+PUXADOS+E+CORACOES+ABERTOS.html; Acesso: 31/03/2010 http://www.youtube.com/watch?v=81yAFeOas4g Acesso: 01/04/2010

http://www.imdb.com/title/tt0068823/trivia Acesso: 15/04/2010

http://www1.folha.uol.com.br/folha/mundo/ult94u397713.shtml Acesso: 15/04/2010

http://www.popcrunch.com/miley-cyrus-racist-photo-response/ Acesso: 16/04/2010

http://www.tmz.com/2009/02/02/asian-group-not-mad-at-one-of-these-people/ Acesso: 16/04/2010

http://www.tmz.com/2009/02/12/asians-want-4-billion-from-miley/ Acesso: 16/04/2010

http://www.adnews.com.br/publicidade/72809.html Acesso: 29/04/2010

http://www.portaldapropaganda.com/noticias_dia/2005/11/09/0001 Acesso: 29/04/2010

http://www.talent.com.br/blog/?p=1562 Acesso : 29/04/2010

http://www.lourencoelourival.com.br/?pagina=discografia Acesso: 21/05/2010

http://www.missaojovemccem.com.br/index2.php?pg=historia\&cidade=1 Acesso: 29/05/2010

http://bunkyo.bunkyonet.org.br/ Acesso: 07/06/2010.

http://www.makis.com.br/quemsomos_historia.asp?secao=quemsomos Acesso: 10/06/2010.

http://www.centenario2008.org.br/ Acesso:12/06/2010

http://www.youtube.com/results?search_query $=+$ centen $\% \mathrm{C} 3 \% \mathrm{~A} 1$ rio + da + imigra $\% \mathrm{C} 3 \% \mathrm{~A} 7 \% \mathrm{C} 3 \% \mathrm{~A} 3 \mathrm{o}$ +japonesa+no+Brasil\&aq=f Acesso: 16/06/2010.

http://www.bemparana.com.br/index.php? $\mathrm{n}=51522 \& \mathrm{t}=$ japoneses-ganharao-parque-tematico-emrolandia Acesso: 16/06/2010.

http://www.aen.pr.gov.br/modules/noticias/article.php?storyid=38722\&tit=Rolandia-reune-75-milpessoas-na-solenidade-de-comemoracao-ao-centenario-de-imigracao Acesso: 16/06/2010.

http://www.anhembi.com.br/anhembi/bin/view/Acontece/AconteceAnhembi1214426780 Acesso: 17/06/2010.

http://www.bsgi.org.br/sgi.htm Acesso17/06/2010

http://g1.globo.com/Noticias/Economia_Negocios/0,MUL1089381-9356,00.html.

Acesso: $22 / 06 / 2010$.

http://www.messianica.org.br/doutrina.htm Acesso: 27/07/20 


\section{REVISTAS E JORNAIS CONSULTADOS}

Folha de Londrina, 21/06/2008

Folha de Londrina, 10/04/2009

Folha de São Paulo, 19/04/2005

Folha de São Paulo, 24/05/2005

Folha de São Paulo, 09/02/2008

Folha de São Paulo, 18/06/2008.

Folha de São Paulo, 22/06/2008.

O Diário do Norte do Paraná, 09/04/09

O Estado de São Paulo, 02/03/2009

Paraná Shimbum. 21 a 27/11/2009.

Revista Plástica \& Beleza, edição 108, 2010

Revista Veja, edição 1811, 16/07/2003

Revista Veja, edição 2011, 06/03/2007.

Revista Veja, edição 2009, 23/05/2007.

Revista Veja, edição 1683, 17/01/2001.

Revista Veja, edição 1763, 07/08/2002.

Valor Econômico, 24/05/10

\section{FIGURAS}

Fig. 1 Comercial "regresso".

Fonte: http://comercial.redeglobo.com.br/ppa2006/finalistas/classe nacional.php Acesso: 29/04/2010

Fig. 2 Comercial "regresso".

Fonte: http://www.filmbrazil.com/site/produtoras2 pt.php?id=72 acesso: 06/05/2010

Fig. 3 Comercial "tempo".

Fonte: http://www.netpropaganda.com.br/materia/?id=735 Acesso: 29/04/2010

Fig. 4 Comercial "pilha invertida".

Fonte: http://www.nartube.com/bdafbb6695f26a0a50b41413820f4ef97980f513:DIeGV6SNFcw.html Acesso: 29/04/2010

Fig. 5 Anúncio STi.

Fonte: http://www.talent.com.br/blog/?tag=semp-toshiba Acesso: 29/04/2010

Fig.6 Anúncio STi.

Fonte: http://www.propmark.com.br/publique/cgi/cgilua.exe/sys/start.htm?infoid=56295\&sid=3

Acesso: 29/04/2010

Fig. 7 Anúncio Suzuki Motos.

Fonte: http://www.risadaforcada.net/2008/08/volta-s-aulas-2008-b-filosofia.html Acesso: 29/04/2010 
Fig. 8 Fonte: Dezem (2005).

Fig. 9 Atriz Daniele Suzuki e sua personagem Yoko na novela Bang Bang.

Fonte: $\quad$ http://www.parana-online.com.br/colunistas/207/32119/?postagem=NO+VELHO+OESTE

Acesso: 20/03/2010

Fig. 10 Miss Brasil e Miss Universo. Fonte: Revista Veja. Edição 2011.

Fig. 11 Cirurgia de ocidentalização. Fonte: Revista Veja. Edição 1763.

Fig. 12 Cirurgia de ocidentalização.

Fonte: http://rabiscos-da-say.blogspot.com/2009 03 01_archive.html Acesso: 24/03/2010

Fig. 13 Miley Cyrus "puxando os olhos". Fonte: TMZ

Disponível em: http://www.tmz.com/2009/02/02/asian-group-not-mad-at-one-of-these-people/

Acesso: 16/04/2010

Fig. 14 Propaganda do "paritinho".

Fonte: http://www.youtube.com/view_play_list?p=4499ACBFC9363AE5 Acesso: 01/04/2010

Fig. 15 Capa do CD de Lourenço \& Lourival

Fonte: http://www.lourencoelourival.com.br/?pagina=discografia Acesso: 21/05/2010

Fig. 16 Desbravamento das terras. Fonte: Museu Histórico da Imigração Japonesa no Brasil.

Disponível em: http://www.zashi.com.br/zashi_imigracao/289.php Acesso: 08/06/2010.

Fig. 17 Escola nas colônias agrícolas. Fonte: MHIJB.

Disponível em: http://www.zashi.com.br/zashi_imigracao/289.php Acesso: 08/06/2010.

Fig. 18 Nihonjin-kai. Fonte: MHIJB.

Disponível em: http://www.zashi.com.br/zashi imigracao/289.php Acesso: 08/06/2010.

Fig. 19 Hasteamento das bandeiras. Foto: Leandro Monteiro (05/2008).

Fig. 20 Início das atividades no undōkai. Foto: Leandro Monteiro (05/2008).

Fig. 21 Pesca de garrafa no undōkai da ACEAST. Detalhe para participação dos jovens. Foto: Leandro Monteiro (05/2008).

Fig. 22 Corrida de Guetá no undōkai da ACEAST. Foto: Leandro Monteiro (05/2008).

Fig. 23 Voluntários fazendo sukiyaki no "chapão". Foto: Camila Ischida (04/04/2009).

Fig. 24 Apresentação do grupo de taikō da ACEAST, Seishun Daiko, no "Jantar Oriental". Foto: Camila Ischida (04/04/2009).

Fig. 25 Bōnenkai na ACEAST. Foto: Camila Ischida (05/12/2009).

Fig. 26 Nomeação dos cargos de direção e do conselho da associação. Detalhe para a predominância dos homens. Foto: Camila Ischida (05/12/2009).

Fig. 27 Mistura de sabores no bōnenkai da ACEAST: espetinho, strogonoff e nishimê

Foto: Camila Ischida (05/12/2009). 
Fig. 28 Visão panorâmica do Festival Nipo-Brasileiro, conhecido como "Nipo".

Fonte: http://www.festivalnipobrasileiro.com.br/festival/index.php Acesso: 14/06/2010

Fig. 29 Apresentação de Bon-odori na "Nipo".

Fonte: http://www.festivalnipobrasileiro.com.br/festival/index.php Acesso: 14/06/2010.

Fig. 30 Cosplay do personagem Naruto.

Fonte: http://www.naruto.com.br/multimidia/cosplays/ Acesso: 09/06/2010.

Fig. 31 Jovens dançando o matsuri dance no Hoshi Matsuri em Maringá. Foto: Camila Ischida $(07 / 09 / 2008)$.

Fig. 32 Apresentação do Ryukyu Koku Matsuri Daiko (taikō de Okinawa) no Japan Experience. Foto: Camila Ischida (24/10/2009).

Fig. 33 Vista da comemoração no Sambódromo do Anhembi. Foto: Caio Silveira.

Fonte: http://www.spturis.com/eventos/centenarioimigracao-sambodromo/ Acesso: 17/06/2010

Fig. 34 Apresentação no Sambódromo com autoridades ao fundo. Foto: Caio Silveira.

Fonte: $\mathrm{http}: / /$ www.spturis.com/eventos/centenarioimigracao-sambodromo/ Acesso: 17/06/2010

Fig. 35 Apresentação de bon-odori na festa do Imin-100 em Rolândia. Foto: Julio Covello. Fonte: $\mathrm{http}$ ://www.aen.pr.gov.br/modules/galeria/detalhe.php?foto $=66438 \&$ evento $=14336$

Fig. 36 Pirâmide humana (grupo da Associação Brasil Soka Gakkai Internacional). Foto: Julio Covello. Fonte: http://www.aen.pr.gov.br/modules/galeria/detalhe.php?foto=66438\&evento=14336

Fig. 37 Coral de mil vozes (Representantes de 26 cidades do Paraná). Foto: Julio Covello. Fonte: http://www.aen.pr.gov.br/modules/galeria/detalhe.php?foto $=66438 \&$ evento $=14336$

Fig. 38 Capa da Revista Veja, edição 2038 (12/12/2007).

Fig. 39 Edição especial das sandálias Havaianas em comemoração ao Centenário Fonte: $\quad$ http://www.ipcdigital.com/br/Noticias/Brasil/Havaianas-lanca-edicao-especial-para-ocentenario-da-imigracao Acesso: 17/06/2010.

Fig. 40 Desfile da Porto da Pedra com figura de Buda ao fundo.

Fonte: $\quad$ http://www.unidosdoportodapedra.com.br/fotos/carnaval-2008/foto-04.htm $\quad$ Acesso: $17 / 06 / 2010$.

Fig. 41 Selo oficial comemorativo

Fonte: http://www.selosefilatelia.com/PastaLancamentos/017.html Acesso: 17/06/2010.

Fig. 42 Anúncio "Homenagem do Banco Real ao centenário da imigração japonesa no Brasil" Fonte: http://madeinjapan.uol.com.br/2008/02/03/banco-real-e-o-centenario/ Acesso: 22/06/2010.

Fig. 43 Anúncio "100 anos da imigração japonesa no Brasil. O Bradesco faz parte dessa história". Fonte: $\mathrm{http} / / / \mathrm{yrbrasil.com} . \mathrm{br} / 2009 / 2008 / 04 / 11 / 100$-anos-de-imigracao-japonesa/ Acesso: 22/06/2010.

\section{GLOSSÁRIO}

Anime: desenho animado japonês

Batchan: avó 
Bon-odori: dança de tradição budista voltada para a celebração da alma dos antepassados Bōnenkai: confraternização de fim de ano

Burajiru-go: língua "brasileira" (português)

Bushidō: Expressão que significa "caminho do guerreiro" ou "caminho ético dos samurais"

Dekassegui: trabalhador temporário

Ditchan: avô

Fujin-kai: departamento/associação de senhoras

Gaijin: estrangeiro

Gambarê: Esforço, disposição para suportar as adversidades com coragem e resignação

Imin-100: Nome oficial escolhido pelo Paraná para as comemorações do centenário da imigração japonesa

$J-p o p$ : domínio conhecido como cultura pop japonesa

Kai: associação, reunião

Kai-kan: Sede, espaço físico do nihonjin-kai

Mangá: história em quadrinhos japoneses

Matsuri: festa

Matsuri dance: coreografia que tem raízes no bon-odori, mas utiliza música j-pop

Nihon: Japão

Nihongo: língua japonesa

Nihongako: escola de língua japonesa

Nihonjin: japonês

Obassan: senhora

Odissan: senhor

Seinen-kai: associação de jovens

Sensei: professor

Shamisen: instrumento de três cordas

Taikō: tambor japonês

Temaki: espécie de sushi enrolado em formato de cone

Yamato Damashii: espírito japonês

Yakyu: baseball 
